MARIANNE MENDES WEBBER

OS INSTRUMENTOS DE COOPERAÇÃO JURÍDICA
INTERNACIONAL NO DIREITO DA CONCORRÊNCIA

Dissertação de Mestrado

Orientador: Prof. Associado Dr. Wagner Menezes

FACULDADE DE DIREITO DA UNIVERSIDADE DE SÃO PAULO São Paulo 


\section{MARIANNE MENDES WEBBER}

NUSP 7125005

\section{OS INSTRUMENTOS DE COOPERAÇÃO JURÍDICA INTERNACIONAL NO DIREITO DA CONCORRÊNCIA}

Dissertação elaborada no âmbito do Curso de Pós-Graduação Stricto Sensu do Mestrado em Direito Internacional da Faculdade de Direito da Universidade de São Paulo, nos termos da Resolução USP $\mathrm{n}^{\circ}$ 5.473/2008, Resolução FD/POS n ${ }^{\circ}$ 01/2002 e da Portaria CPG FDUSP $n^{\circ}$ 05/2011, como exigência parcial para obtenção do título de Mestre em Direito Internacional.

Orientador: Prof. Associado Dr. Wagner Menezes. 
A Banca Examinadora, abaixo assinada, aprova a Dissertação

\title{
OS INSTRUMENTOS DE COOPERAÇÃO JURÍDICA INTERNACIONAL NO DIREITO DA CONCORRÊNCIA
}

\author{
elaborada por \\ MARIANNE MENDES WEBBER \\ como requisito parcial para a obtenção do grau de \\ MESTRE EM DIREITO INTERNACIONAL
}

BANCA EXAMINADORA:

Prof. Associado Dr. Wagner Menezes, Orientador (FDUSP) 


\section{AGRADECIMENTOS}

Agradeço, primeiramente, ao prof. associado Dr. Wagner Menezes, por ter acreditado neste projeto e por ter me concedido a oportunidade única de compor o seu primeiro grupo de orientandos no Largo São Francisco. Seus constantes estímulos para a construção de uma trajetória acadêmica comprometida, bem como a sua ideologia no desenvolvimento de um Direito Internacional cosmopolita, foram determinantes para o amadurecimento das pesquisas e para lançar a semente do meu desejo de contínuo aprimoramento acadêmico.

A todos os professores do Programa de Pós-Graduação da Universidade de São Paulo, agradeço pela paciência na minha instrução. Em especial, agradeço ao prof. associado Dr. André de Carvalho Ramos, que despretensiosamente inspirou a evolução deste estudo nos bancos da disciplina de Cooperação Jurídica Internacional, sempre se mostrando disponível para orientações pontuais e relevantes comentários, e que, conjuntamente com o prof. associado Dr. Umberto Celli Júnior, trouxe valiosos apontamentos por ocasião da qualificação do projeto de pesquisa, contribuindo imensamente no seu direcionamento.

Agradeço também ao prof. Dr. Augusto Jaeger Júnior, da Universidade Federal do Rio Grande do Sul, não somente por trazer à comunidade de juristas brasileiros substanciais conhecimentos relacionados à temática do Direito Internacional da Concorrência, compartilhando assim o seu extenso saber sobre a matéria, mas também pelas discussões que me motivaram enquanto iniciante pesquisadora.

Aos meus colegas pesquisadores que, no cativante ambiente das Arcadas, com muita amizade me ofereceram essencial suporte e compartilharam comigo as conquistas próprias de um intenso programa de pós-graduação, propiciando sempre relevante troca de informações, conhecimentos e materiais de estudo e de pesquisa. Faço também menção ao apoio recebido dos colegas de escritório, advogados que com maestria aplicam diariamente o Direito e cujas contribuições despertaram um olhar pragmático em torno do objeto desta pesquisa.

Finalmente, agradeço à minha família e aos meus amigos, que não obstante os prolongados períodos de minha ausência, justificados pelo tempo e energia necessários a este estudo, mostraram-se sempre disponíveis para me oferecer ânimo e conforto, sem os quais esta conquista não seria possível. 
Para Dione Kroll,

mãe e modelo de força e virtude. 
"Man is in his actions and practice, as well in his fictions, essentially a story-telling animal. He is not essentially, but becomes through his history, a teller of stories that aspire to truth. But the key question for men is not about their own authorship; I can only answer the question 'What am I to do?' if I can answer the prior question 'Of what story or stories do I find myself a part?' We enter human society, that is, with one or more imputed characters - roles into which we have been drafted - and we have to learn what they are in order to be able to understand how others respond to us and how our responses to them are apt to be construed." 


\section{RESUMO}

O Direito da Concorrência e o Direito Internacional da Concorrência são recentes ramos na história da Ciência Jurídica. A dimensão unilateral do Direito Internacional da Concorrência relaciona-se à aplicação extraterritorial das legislações de defesa da concorrência, o que desencadeia problemas e limitações no plano internacional. Não existe regramento multilateral para a regulação da matéria concorrencial no plano internacional. Na dimensão regional são considerados os acordos regionais (Mercosul, União Europeia e NAFTA). No plano bilateral são encontrados os casos mais concretos de aplicação do Direito Internacional da Concorrência, os quais atualmente relacionam-se a processos de cooperação jurídica internacional. Há um amplo espaço para avanço na regulação da cooperação internacional em sede de atos de concentração multijurisdicionais.

Palavras-chave: Direito Internacional da Concorrência. Cooperação jurídica internacional. Atos de concentração multijurisdicionais. Acordos bilaterais. 


\begin{abstract}
Competition Law and International Competition Law are recently developed branches of the legal sciences. The unilateral dimension of the International Competition Law relates to the extraterritorial enforcement of competition laws, which causes problems and limitations on the international arena. There is a lack of multilateral set of rules for the competition regulation at an international level. The regional agreements shall be considered at regional dimension (Mercosur, European Union and NAFTA). The most concrete cases for the application of the International Competition Law are found at the bilateral level, which are currently related to the international legal cooperation process. There is a wide range for development on the regulation of the international cooperation in relation to the multijurisdictional concentration acts.
\end{abstract}

Key words: International Competition Law. International Antitrust Law. International legal cooperation. Multijurisdictional concentration acts. Bilateral agreements. 


\section{LISTA DAS PRINCIPAIS ABREVIATURAS UTILIZADAS}

ACC

ALADI

ALALC

APRO

CADE

CCMR

CEPAL

$\mathrm{CMC}$

Constituição Federal

DEE

DOJ

Estados Unidos

FTC

GATT

GMC

GTCPC

IAEAA

ICN

Lei da Concorrência

Lei de Acesso à

Informação

Mercosul

NAFTA

OCDE

OEA

OEA-CJI
Acordo em Controle de Concentrações

Associação Latino-americana de Integração

Associação Latino-americana de Livre Comércio

Acordo de Preservação da Reversibilidade das Operações

Conselho Administrativo de Defesa Econômica

Casos de Concentração no Mundo Real - Um Estudo dos Procedimentos de Controle das Concentrações da OCDE

Comissão Econômica para a América Latina

Conselho do Mercado Comum do Mercosul

Constituição Federal da República Federativa do Brasil de 1988

Departamento de Estudos Econômicos do CADE

Departamento de Justiça (Department of Justice) dos Estados Unidos

Estados Unidos da América do Norte

Comissão Federal do Comércio (Federal Trade Commission) dos Estados Unidos

Acordo Geral de Tarifas e Comércio (General Agreement on Tariffs and Trade)

Grupo Mercado Comum do Mercosul

Grupo de Trabalho sobre a Interação entre Comércio e Política de Concorrência da OMC

Lei de Assistência à Execução Internacional (International Enforcement Assistance Act) dos Estados Unidos

Rede Internacional da Concorrência (International Competition Network)

Lei ${ }^{\circ} 8.884$, de 11 de junho de 1994

Lei $n^{\circ} 12.527$, de 18 de novembro de 2011

Mercado Comum do Sul

Acordo de Livre Comércio da América do Norte (North American Free Trade Agreement)

Organização para a Cooperação e Desenvolvimento Econômico Organização dos Estados Americanos

Comissão Jurídica Interamericana da Organização dos Estados Americanos

Organização Mundial do Comércio 
ProCADE

RCMR

RICADE

SBDC

SDE

SEAE

Séries PERs

SG

TFUE

TJUE

Tribunal

Administrativo

TRIMS

TRIPS

TUE

UNCTAD

UNASUL
Procuradoria Federal Especializada junto ao CADE

Recomendações do Conselho para Análise de Concentrações da OCDE

Regimento Interno do CADE

Sistema Brasileiro de Defesa da Concorrência

Secretaria de Defesa Econômica

Secretaria de Acompanhamento Econômico

Acordos Multilaterais de Princípios e Regras Equitativas para o Controle de Práticas Empresariais Restritivas da UNCTAD

Superintendência Geral do CADE

Tratado sobre o Funcionamento da União Europeia

Tribunal de Justiça da União Europeia

Tribunal Administrativo de Defesa Econômica do CADE

Acordo sobre Medidas de Investimento Relacionadas ao Comércio (Agreement on Trade Related Investment Measures)

Acordo sobre Aspectos dos Direitos de Propriedade Intelectual Relacionados ao Comércio (Agreement on Trade Related Aspects of Intellectual Property)

Tratado da União Europeia

Conferência das Nações Unidas para o Comércio e o Desenvolvimento (United Nations Conference on Trade and Development)

União de Nações Sul-Americanas 


\section{SUMÁRIO}

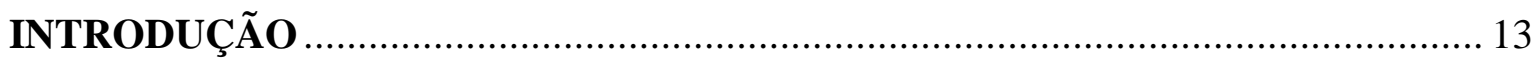

1 DIREITO DA CONCORRÊNCIA: ENFOQUES, CONCEITOS E

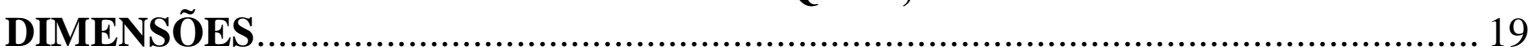

1.1 O DIREITO DA CONCORRÊNCIA …………………................................... 19

1.1.1 A economia e o Direito da Concorrência ............................................................ 19

1.1.2 Influência do Direito norte-americano no desenvolvimento da matéria nos variados sistemas jurídicos nacionais ...................................................................... 26

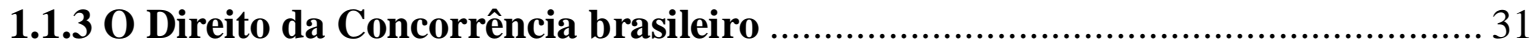

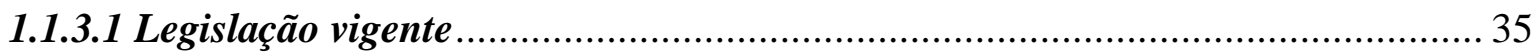

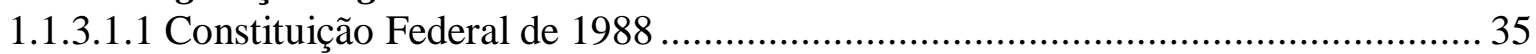

1.1.3.1.2 Lei da Concorrência (Lei $\mathrm{n}^{\circ} 12.529$, de 30 de novembro de 2011)...................... 37

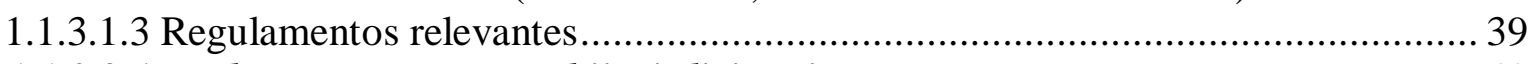

1.1.3.2 Atos de concentração multijurisdicionais ............................................................. 40

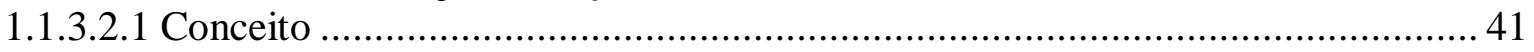

1.1.3.2.2 A análise dos atos de concentração pelo SBDC .................................................. 44

1.1.3.3 Tratamento de informações confidenciais ........................................................5 54

1.2 O DIREITO INTERNACIONAL DA CONCORRÊNCIA: TERMINOLOGIA

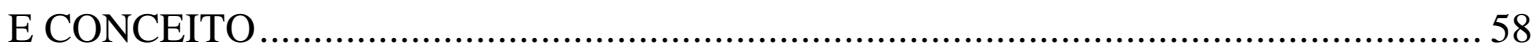

1.3 AS DIMENSÕES DO DIREITO INTERNACIONAL DA CONCORRÊNCIA ..........60

1.3.1 Dimensão unilateral do Direito Internacional da Concorrência ...........................60

1.3.1.1 Evolução da aplicação das legislações nacionais de defesa da concorrência

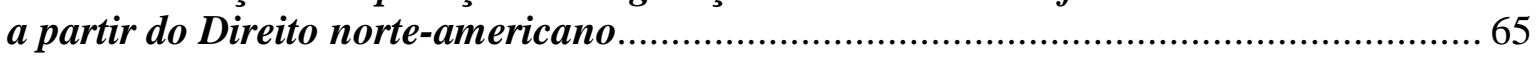

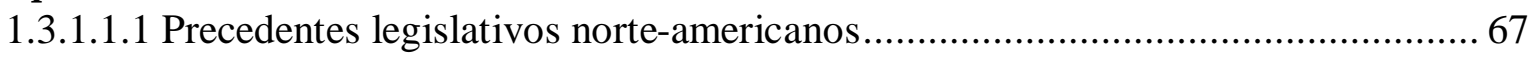

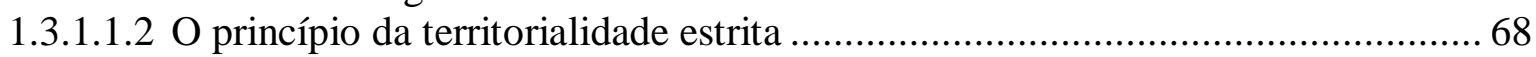

1.3.1.1.3 O princípio da pseudoterritorialidade ……………....................................... 71

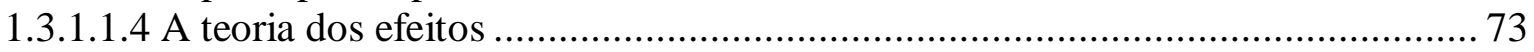

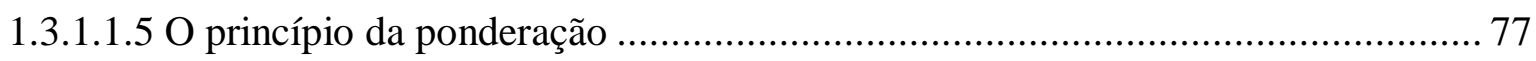

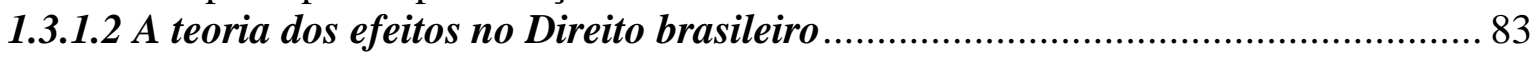

1.3.1.2.1 Art. $2^{\circ}$ da Lei da Concorrência ........................................................................ 83

1.3.1.2.2 Decisões das autoridades brasileiras sobre a aplicação extraterritorial do

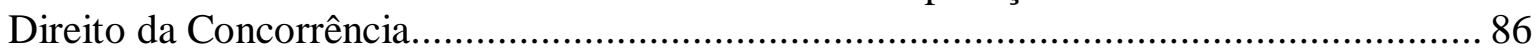

1.3.1.3 Teoria dos efeitos: reflexos, limitações e reação internacional ............................ 91

1.3.1.3.1 Protestos e reclamações diplomáticas ............................................................... 94

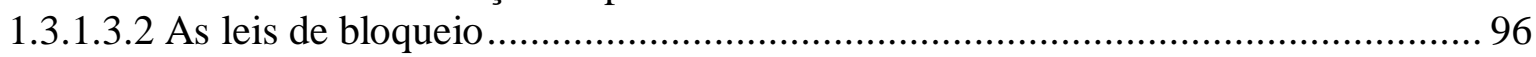

1.3.2 Dimensões multilateral, regional e bilateral: a cooperação em matéria da

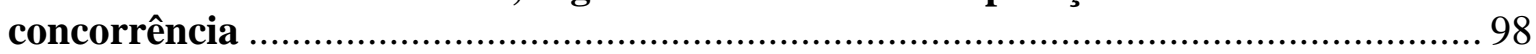

2 COOPERAÇÃO JURÍDICA INTERNACIONAL E O DIREITO DA

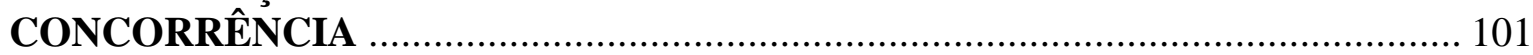

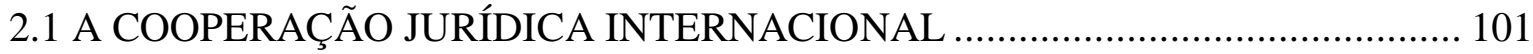

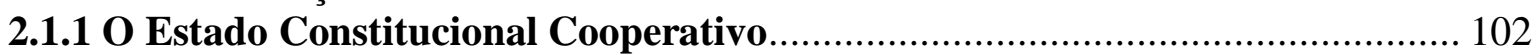

2.1.2 As formas de manifestação da cooperação jurídica internacional...................... 106

2.1.3 Cooperação Jurídica Internacional: definição e espécies.................................... 108

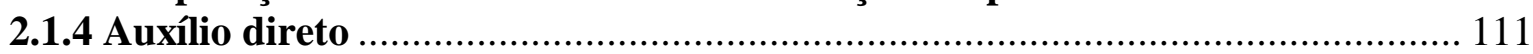

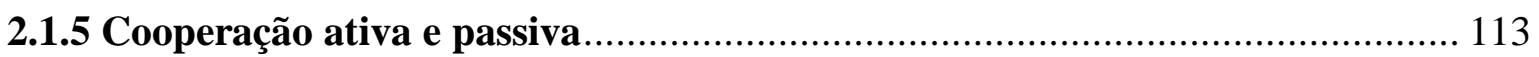

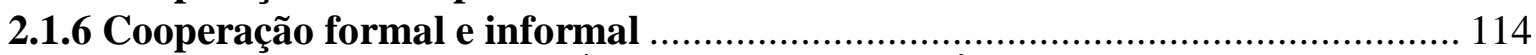

2.2 A COOPERAÇÃO EM MATÉRIA DA CONCORRÊNCIA ……………...................... 116 
2.2.1 Relação entre o Direito Interno e o Direito Internacional e entidades envolvidas

2.2.2 Dimensão multilateral do Direito Internacional da Concorrência .

2.2.2.1 Negociações e iniciativas envolvendo a matéria concorrencial em sentido amplo

2.2.2.1.1 Da Carta de Havana ao GATT e à OMC ......................................................... 124

2.2.2.1.2 Código Concorrencial Internacional ............................................................. 133

2.2.2.1.3 Organização das Nações Unidas (ONU) e Conferência das Nações Unidas

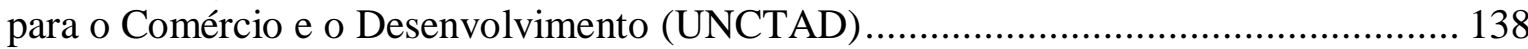

2.2.2.1.4 Organização para a Cooperação e Desenvolvimento Econômico (OCDE)....... 142

2.2.2.1.5 Rede Internacional de Concorrência (ICN) .................................................... 143

2.2.2.2 Os atos de concentração multijurisdicionais e o labor dos foros internacionais em prol da cooperação ............................................................................ 145

2.2.2.2.1 Organização para a Cooperação e Desenvolvimento Econômico (OCDE)....... 146

2.2.2.2.2 Rede Internacional de Concorrência (ICN) .................................................... 149

2.2.3 Dimensão Regional do Direito Internacional da Concorrência ........................ 152

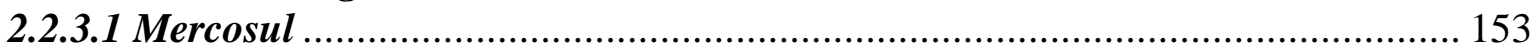

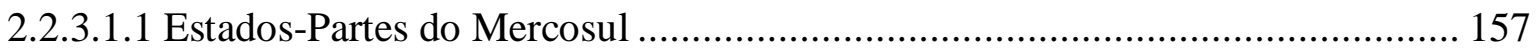

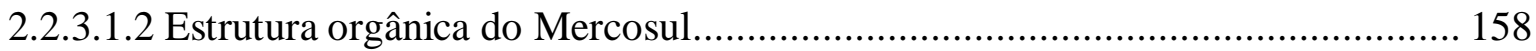

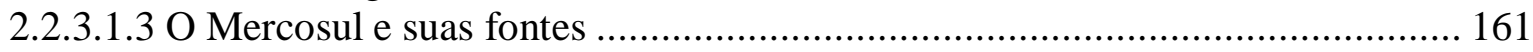

2.2.3.1.4 O Mercosul e a matéria concorrencial ............................................................ 163

2.2.3.1.5 As Decisões do Conselho do Mercado Comum sobre a matéria da

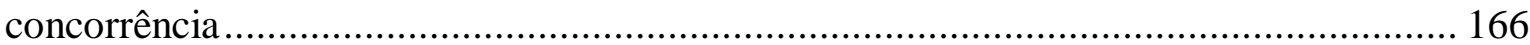

2.2.3.2 Outras Organizações Internacionais e Acordos Regionais ............................. 178

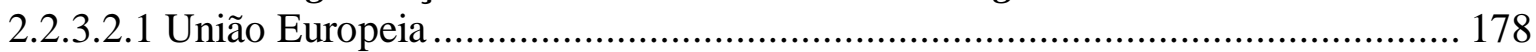

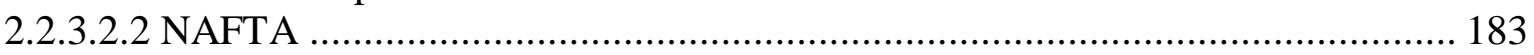

2.2.4 Dimensão bilateral: aspectos gerais dos acordos bilaterais........................... 184

3 OS ACORDOS DE COOPERAÇÃO JURÍDICA INTERNACIONAL ENTRE AS AUTORIDADES DE DEFESA DA CONCORRÊNCIA: análise dos atos de

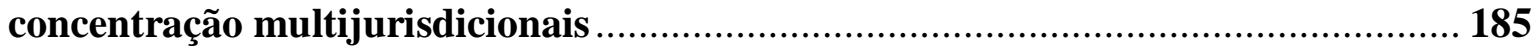

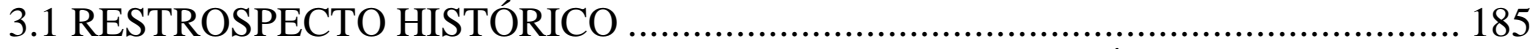

3.2 ACORDOS BILATERAIS: TIPOS, OBJETO E CARACTERÍSTICAS .................. 192

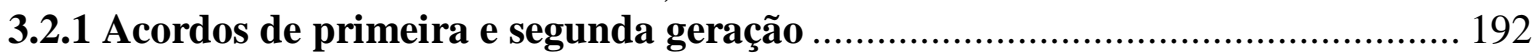

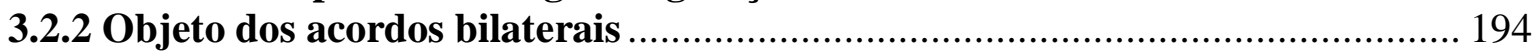

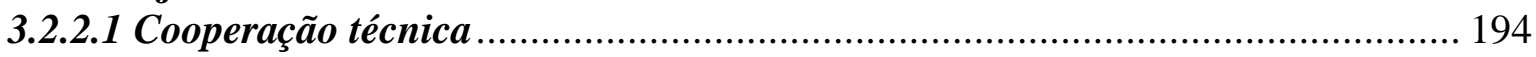

3.2.2.2 Cooperação na aplicação das legislações nacionais de defesa da

concorrência .................................................................................................. 198

3.2.2.2.1 Notificações trocadas entre autoridades.................................................... 199

3.2.2.2.2 Princípios de cortesia negativa e de cortesia positiva...................................... 200

3.2.2.2.3 Busca e compartilhamento de informações.................................................. 206

3.2.2.2.4 Coordenação de atividades entre autoridades: decisões e adoção de restrições concertadas

3.3 ACORDOS DE COOPERAÇÃO CELEBRADOS PELA REPÚBLICA

FEDERATIVA DO BRASIL OU PELO SBDC …..................................................... 217

3.3.1 Recepção dos acordos pelo ordenamento jurídico brasileiro ........................... 219

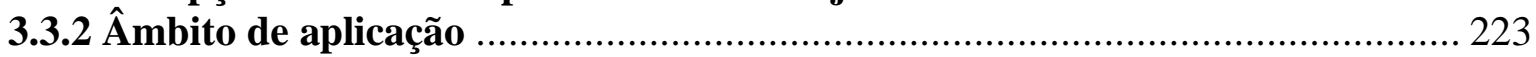

3.3.3 Notificações trocadas entre autoridades ................................................... 225

3.3.4 Princípio de cortesia negativa e positiva ................................................... 226

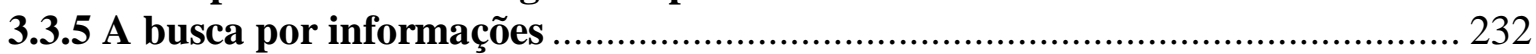




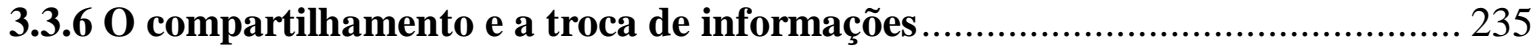

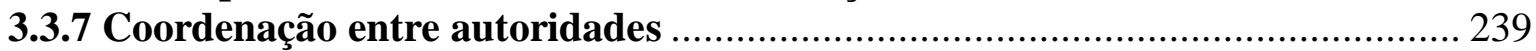

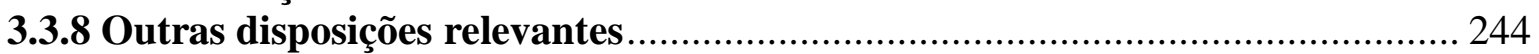

3.3.9 Considerações gerais sobre os acordos firmados pelas autoridades

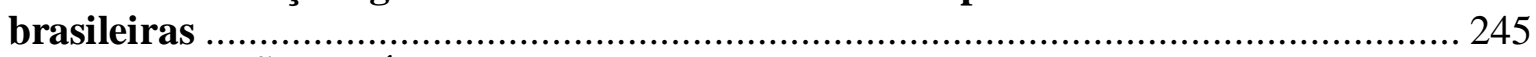

3.4 APLICAÇÃO PRÁTICA DOS ACORDOS EM VIGOR AOS ATOS DE

CONCENTRAÇÃO MULTIJURISDICIONAIS ................................................... 249

3.4.1 Casos envolvendo autoridades brasileiras .................................................... 249

3.4.2 Casos envolvendo a União Europeia e os Estados Unidos............................... 253

3.4.3 Comparação na aplicação de acordos bilaterais por terceiros países e pelas autoridades brasileiras................................................................................ 262

3.5 COOPERAÇÃO BILATERAL EM MATÉRIA DA CONCORRÊNCIA:

PROBLEMAS CONSTATADOS E PERSPECTIVAS .............................................. 264

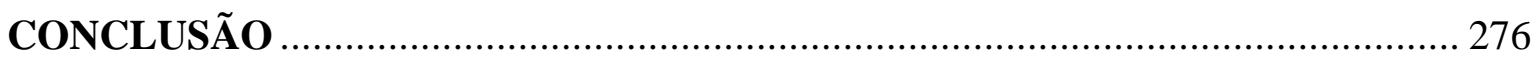

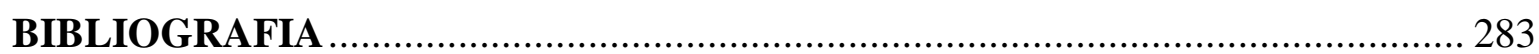

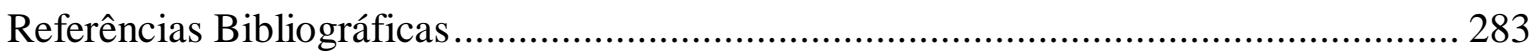

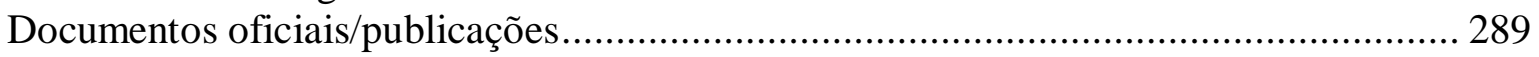

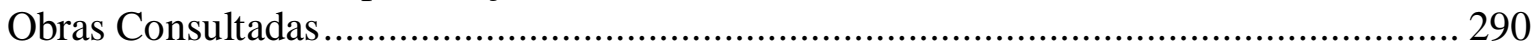

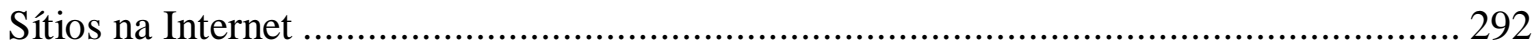

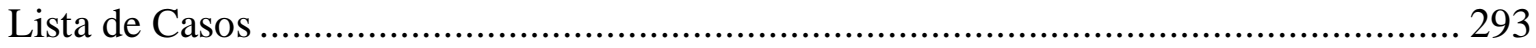

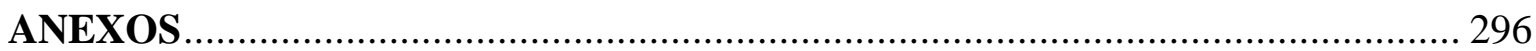

ANEXO A - ACORDOS BILATERAIS CELEBRADOS ENTRE ESTADOS

UNIDOS E A UNIÃO EUROPEIA ....................................................................... 297

ANEXO B - DECISÕES CMC/MERCOSUL RELEVANTES EM MATÉRIA DE COOPERAÇÃ

ANEXO C - SUMÁRIO DOS ACORDOS CELEBRADOS PELO BRASIL E SBDC.

ANEXO D - ACORDOS CELEBRADOS PELO BRASIL E SBDC COM DISPOSIÇÕES DE COOPERAÇÃO TÉCNICA. 305

ANEXO E - ACORDOS CELEBRADOS PELO BRASIL E SBDC COM DISPOSIÇÕES DE COOPERAÇÃO NA APLICAÇÃO DAS LEIS DE DEFESA DA CONCORRÊNCIA. 


\section{INTRODUÇÃO}

Em razão do avultamento do processo de globalização econômica, a comunidade global tem se defrontado com novas e diferentes questões resultantes das relações econômicas e comerciais na plataforma internacional. O comércio internacional assumiu uma nova postura, deixando de centrar as suas preocupações na simples liberalização das fronteiras, passando a abarcar uma abordagem mais ampla e orientada para a concorrência internacional, em especial em relação ao funcionamento eficiente dos mercados internacionais.

De fato, as práticas empresariais com efeitos internacionais e multijurisdicionais assumiram um papel relevante nas relações dos Estados, uma vez que podem afetar diversos mercados nacionais ou regionais. Neste âmbito, destacam-se os atos de concentração multijurisdicionais, processos pelos quais os agentes econômicos concentram esforços econômicos de modo a afetar mais de uma jurisdição.

As transações de concentração envolvendo múltiplas jurisdições possuem, desta forma, a potencialidade de serem reguladas por diferentes autoridades nacionais e regionais, devendo as partes de tais operações dedicar esforços no cumprimento dos diversos requerimentos regulatórios. Tais esforços acarretam custos às partes envolvidas, sejam estes direcionados a taxas e honorários necessários para levar a cabo as operações pretendidas, ou aos custos de oportunidade que as empresas devem despender em prejuízo de outras atividades que poderiam ser desenvolvidas.

Além disso, a notificação de uma mesma operação de concentração multijurisdicional a diversas autoridades de defesa da concorrência pode culminar em uma situação em que decisões desconcertadas ou divergentes sejam alcançadas pelas autoridades envolvidas, prejudicando, assim, a eficiência do sistema global concorrencial e onerando em demasia as partes da operação. Ademais, existe uma dificuldade acrescida de que as decisões de uma dada autoridade nacional da concorrência não cheguem a ser executadas em territórios estrangeiros, tanto em razão de decisões desconcertadas entre as autoridades, como nos casos em que exista lei de bloqueio que dificulte a execução.

A cooperação jurídica internacional trata de instrumento eficaz para endereçar a problemática acima identificada, pelo que a análise da sua extensão e da sua evolução é de especial interesse para a comunidade dos juristas com vocação aos temas do Direito Internacional. 
O objeto deste estudo está na análise dos instrumentos de cooperação jurídica internacional no Direito da Concorrência. Todavia, a pretensão de se descrever todos os instrumentos internacionais de cooperação em matéria da concorrência, dentro de todas as vertentes relevantes, tornaria um trabalho de pós-graduação stricto sensu demasiadamente amplo. Torna-se relevante, desta forma, esclarecer quais as delimitações adotadas.

Por um lado, cumpre clarificar que a perspectiva que se impõe neste estudo parte do sistema jurídico brasileiro. Isso se deve ao fato de o Direito da Concorrência e o Direito Internacional da Concorrência, tal qual concebidos atualmente, possuírem suas raízes nos sistemas jurídicos nacionais. Ao jurista brasileiro cabe, portanto, o estudo dos instrumentos de cooperação internacional a partir do ordenamento jurídico brasileiro, em que pese haver a possibilidade de se analisar o fenômeno tendo como ponto de partida os ordenamentos jurídicos estrangeiros.

Isso não significa que este estudo deixa de lançar mão dos métodos comparativos e de analisar fundamentos e experiências relevantes de outros países na evolução do Direito da Concorrência e do Direito Internacional da Concorrência, mais precisamente sobre aqueles países e organizações cujos ordenamentos e experiências são relevantes e frequentemente considerados pela comunidade internacional em matéria concorrencial: os Estados Unidos e a União Europeia. Contudo, tal análise se dá unicamente com intuito comparativo, buscando manter a perspectiva a partir do ordenamento jurídico brasileiro.

Por outro lado, impõe-se uma segunda delimitação ao trabalho, em relação ao sistema de proteção concorrencial pelas autoridades de defesa da concorrência, o qual é composto pelo controle de condutas (ou comportamentos) e pelo controle de estruturas. Enquanto o controle de condutas objetiva identificar e repreender o abuso do poder econômico, nas mais variadas formas, o controle de estruturas se ocupa com a prevenção de situações que possam ocasionar no mercado um ambiente propício a tal abuso do poder, como é o caso dos atos de concentração econômica e cooperação empresarial.

Desta forma, o presente estudo está delimitado à cooperação jurídica internacional em matéria de concentrações empresariais, excluindo-se, desta forma, as condutas dos seus objetivos - tais como os casos de cartéis, preços predatórios, dentre outros. O foco centrase naqueles atos de concentração que ensejam a cooperação jurídica entre as diferentes autoridades nacionais e regionais de defesa da concorrência, ou seja, os atos de cooperação multijurisdicionais.

O presente estudo apresenta perspectivas interdisciplinares de investigação, o que é característico da análise de normas de concorrência, do Direito Econômico e do Direito 
Internacional. A metodologia utilizada para a sua elaboração fundamentou-se nos métodos histórico, analítico-investigativo e comparativo-dedutivo.

Realizou-se uma ampla pesquisa sobre a doutrina nacional e estrangeira especializada na matéria concorrencial, tanto do ponto de vista da regulação nacional, quanto dos instrumentos e iniciativas internacionais. $O$ foco na pesquisa doutrinária estrangeira esteve naqueles autores provenientes das jurisdições norte-americana e europeia, já que tratam de países reconhecidamente na vanguarda no desenvolvimento da matéria relativa ao Direito da Concorrência.

Ademais, foi realizada uma pesquisa empírico-analítica sobre casos práticos analisados por autoridades judiciárias e administrativas envolvendo a evolução da aplicação extraterritorial das legislações de defesa da concorrência norte-americana e brasileira, bem como a cooperação jurídica entre diferentes autoridades de defesa da concorrência. Procurou-se dar especial ênfase aos casos de cooperação internacional na análise de concentrações multijurisdicionais envolvendo as autoridades norte-americanas e europeias, já que é amplamente conhecido que tais jurisdições se encontram em estado mais avançado de cooperação na matéria objeto deste estudo em relação às demais nações.

Outra vertente de pesquisa relacionou-se ao exame dos instrumentos publicados pelas organizações e outras entidades internacionais, como a Organização Mundial do Comércio (OMC), a Organização para Cooperação e Desenvolvimento Econômico (OCDE) e a Rede Internacional da Concorrência (ICN), dentre outras que desenvolvem estudos expressivos sobre o tema objeto da dissertação. Além disso, foram analisados tratados internacionais de integração regional, outros instrumentos emitidos pelas organizações internacionais regionais e os acordos bilaterais de cooperação jurídica em matéria concorrencial celebrados pelo Brasil e pelo Sistema Brasileiro de Defesa da Concorrência (SBDC), bem como pelos Estados Unidos e União Europeia.

O primeiro capítulo deste estudo dedica-se à análise do Direito da Concorrência e do Direito Internacional da Concorrência nos planos fundamentais, ou seja, englobando questões sobre terminologia, conceito e dimensões.

Para tanto, inicia-se a digressão na correlação entre o Direito da Concorrência e a Economia, tecendo comentários sobre a evolução histórica deste ramo da Ciência Jurídica, pari passu à evolução das teorias econômicas a ele subjacentes. Passa-se, então, a discutir a influência do sistema concorrencial norte-americano no desenvolvimento das legislações de defesa da concorrência de outras jurisdições, destacando as limitações inerentes ao processo de acolhimento de normas estrangeiras em um dado sistema nacional. 
Evoca-se, na sequência, o retrospecto histórico no desenvolvimento da legislação brasileira de defesa da concorrência, seja no nível constitucional como no infraconstitucional, bem como nas resoluções relevantes emitidas pelo SBDC. Nesse âmbito busca-se a determinação terminológica e conceitual dos atos de concentração multijurisdicionais, objeto da pesquisa, bem como das regras vigentes sobre a análise, notificação, caracterização e critérios de submissão das concentrações econômicas às autoridades brasileiras de defesa da concorrência. Ainda neste diapasão, são tecidos comentários a respeito do tratamento de informações confidenciais, consoante a legislação brasileira aplicável.

Passando ao Direito Internacional da Concorrência, o presente estudo propõe-se a discutir a terminologia e o conceito deste recente ramo da Ciência Jurídica, discutindo as opções terminológicas disponíveis vis a vis o alcance pretendido para a expressão. Passase, então, a discutir a dimensão unilateral da matéria, mais propriamente a aplicação extraterritorial das legislações nacionais de defesa da concorrência pelas autoridades competentes.

Para alcançar os objetivos inerentes à dimensão unilateral, conseguintemente são analisados os precedentes legislativos norte-americanos, em especial o Sherman Act, de 1890, bem como o desenvolvimento jurisprudencial daquele país que contribuiu para a evolução da disciplina. Neste âmbito são analisados os princípios da territorialidade, da teoria dos efeitos e da ponderação, pari passu com a jurisprudência relevante que os conceberam. Em seguida são examinados os dispositivos da legislação brasileira sobre a aplicação extraterritorial do Direito da Concorrência, bem como decisões de destaque pelas autoridades judiciárias e administrativas nacionais sobre a aplicação da teoria dos efeitos pelo sistema jurídico nacional.

O primeiro capítulo dedica-se, ainda, à análise das limitações e reações internacionais sobre a aplicação extraterritorial do Direito da Concorrência e os principais problemas identificados na dimensão unilateral do Direito Internacional da Concorrência.

O segundo capítulo foca sua atenção à cooperação jurídica internacional e à sua relação com o Direito da Concorrência. Desta maneira, parte-se da análise dos fundamentos constitucionais e internacionais da cooperação jurídica internacional, passando pela reflexão sobre formas de manifestação do instituto, bem como sobre a sua definição e espécies, com o intuito de iniciar, por conseguinte, a investigação sobre a cooperação jurídica internacional em matéria concorrencial. O estudo dirige, então, sua atenção aos aspectos relacionados à relação entre o Direito Interno e o Direito 
Internacional, em especial ao caráter transnormativo da produção internacional em matéria concorrencial.

No âmbito da cooperação em matéria concorrencial passa-se à análise da dimensão multilateral do Direito Internacional da Concorrência. Neste diapasão, faz-se uma breve incursão nas negociações e discussões multilaterais havidas nos foros internacionais sobre a matéria concorrencial em sentido amplo, incluindo os contornos do Acordo Geral de Tarifas e Comércio (GATT), OMC, Organização das Nações Unidas (ONU), UNCTAD (Conferência das Nações Unidas para o Comércio e o Desenvolvimento), OCDE, ICN e aqueles para a elaboração de um Código Concorrencial Internacional. Especificamente sobre os atos de concentração multijurisdicionais, o segundo capítulo investiga os principais documentos publicados pela OCDE e pela ICN, trazendo considerações sobre as suas disposições mais relevantes ao objeto deste estudo.

Passa-se, então, à descrição dos principais contornos da dimensão regional, com especial ênfase aos tratados e às normativas expedidas no bojo do Mercosul, sem contudo, abster-se de tecer comentários a respeito da União Europeia e do NAFTA.

O principal objetivo do terceiro capítulo é analisar a cooperação jurídica internacional no âmbito da dimensão bilateral do Direito Internacional da Concorrência, mais especificamente sobre os atos de concentração multijurisdicionais, tendo em vista que foi neste escopo que a matéria chegou a ter um desenvolvimento efetivo nas relações entre os Estados em matéria concorrencial. Para tanto, este capítulo inicia com uma digressão histórica a respeito dos acordos bilaterais firmados, passando a discorrer sobre os tipos, o objeto e as principais características dos acordos bilaterais para a aplicação da legislação de defesa da concorrência.

Segue-se uma análise sobre os acordos bilaterais celebrados pelo Governo brasileiro e pelo SBDC, incutindo-se nos aspectos relacionados à recepção dos acordos no ordenamento jurídico nacional, bem como nos dispositivos adotados pelos acordos impostos às autoridades brasileiras de defesa da concorrência. Passa-se, então, a tecer considerações gerais a respeito dos acordos celebrados pelo Brasil e SBDC vis a vis os documentos publicados pela OCDE e ICN, bem como os acordos em vigor entre Estados Unidos e União Europeia.

O estudo passa, então, a discorrer sobre casos práticos em que houve cooperação jurídica internacional pelas autoridades brasileiras e, em outra mão, pelas autoridades norte-americanas e europeias, passando a apresentar conclusões parciais a respeito dos casos analisados. 
Finalmente, o terceiro capítulo dedica-se a tecer considerações a respeito dos problemas identificados na celebração e na execução dos acordos bilaterais para a aplicação das legislações de defesa da concorrência, bem como nos casos em que se procurou uma efetiva cooperação jurídica internacional em matéria concorrencial. Neste estágio de desenvolvimento do estudo são trazidas à baila questões que atualmente constituem o foco da atenção da doutrina nacional e internacional especializada sobre o tema e as perspectivas para o desenvolvimento futuro da cooperação em casos de concentrações multijurisdicionais.

O desenvolvimento do estudo na forma descrita nesta introdução objetiva oferecer uma análise pormenorizada dos instrumentos de cooperação jurídica internacional em matéria da concorrência, em especial em relação à cooperação bilateral entre autoridades de defesa da concorrência no que tange os atos de concentração multijurisdicionais, apresentando considerações acerca da aplicação prática de tais instrumentos cooperativos pelas autoridades competentes. Justifica-se tal objetivo na medida em que, apesar de existir atualmente um segmento da doutrina nacional dedicado ao aprofundamento das questões concorrenciais no âmbito internacional, a cooperação bilateral e os atos de cooperação multijurisdicionais geralmente são transversalmente apresentados, focando-se os doutrinadores em aspectos macros, fundamentais ou multilaterais do Direito Internacional da Concorrência. 


\section{DIREITO DA CONCORRÊNCIA: ENFOQUES, CONCEITOS E DIMENSÕES}

\subsection{O DIREITO DA CONCORRÊNCIA}

O conhecimento histórico moderno sobre a regulação da concorrência retroage até a Antiguidade ${ }^{1}$. No entanto, até que o liberalismo econômico se consolidasse, a regulação da concorrência focava somente na disciplina da conduta dos agentes econômicos, sem abranger um discurso técnico-econômico e a ideia de um mercado liberal ${ }^{2}$.

É possível sustentar, portanto, que a regulação da concorrência tal qual atualmente concebida, no âmbito do liberalismo econômico, é fenômeno recente em comparação aos demais ramos tradicionais da Ciência Jurídica. Ao longo da sua existência, que não é superior a 200 anos, não foi possível verificar um consenso internacional a respeito dos seus fundamentos ${ }^{3}$. Os Estados que possuem legislações nacionais de defesa da concorrência, na maioria das vezes apresentam diferenças em relação às regras materiais aplicáveis.

As teorias econômicas originadas no bojo do modelo liberal tiveram especial função no desenvolvimento do Direito da Concorrência contemporâneo, a partir, principalmente, da interação entre as matérias de Economia e Direito nos Estados Unidos durante o século 20.

\subsubsection{A economia e o Direito da Concorrência}

A primeira legislação conhecida a regular aspectos concorrenciais nas relações entre entidades privadas foi promulgada no Canadá, em 1889. O Act for Prevention and Suppression of Combinations Formed in Restraint of Trade ${ }^{4}$ tratava de regular acordos de fixação de preços ou restrição de produção que visavam de alguma forma restringir o comércio. Foi nos Estados Unidos, no entanto, que o Direito Concorrencial encontrou

\footnotetext{
${ }^{1}$ Para um relato completo sobre a evolução histórica da concorrência, ver FORGIONI, Paula A. Os fundamentos do antitruste. 4. ed. São Paulo: Revista dos Tribunais, 2010, pp. 35-87. A autora descreve que "existe, portanto, diferença fundamental entre a proteção/regulamentação da concorrência, no Estado liberal, e aquela que lhe foi anterior". Ver ainda GABAN, Eduardo Molan; DOMINGUES, Juliana Oliveira. Direito antitruste. 3. ed. São Paulo: Saraiva, 2012, pp. 61-63.

${ }^{2}$ FORGIONI, Paula A. Op. cit., 2010, p. 36.

${ }^{3}$ JAEGER JÚNIOR, Augusto. Direito Internacional da Concorrência - Entre perspectivas unilaterais, multilaterais, bilaterais e regionais. Curitiba: Juruá, 2008, p. 26.

${ }^{4}$ Lei para a Prevenção e Supressão de Cominações Formadas em Restrição ao Comércio (tradução livre).
} 
plena guarida ao seu desenvolvimento, repercutindo nas legislações de defesa da concorrência dos mais variados países.

A Revolução Industrial ${ }^{5}$ causou a modificação do sistema de produção, transitando de um modelo de corporações de ofícios para o de um mercado liberal, na qual a ideia de livre concorrência está inserida ${ }^{6}$. Com o final da Guerra da Secessão, no século 19, a livre atuação dos agentes econômicos nos Estados Unidos ocasionou a concentração de capitais e recursos nas mãos de pequenos grupos. Esse período, marcado pela concentração exercida através dos trusts $^{7}$, refletiu o controle da produção de fixação de preços por parte de pequenos grupos que buscavam a perpetuação de suas atividades mediante acordos concentrados ${ }^{8}$.

Como resposta à concentração econômica, os Estados Unidos promulgaram, em 1890, o Sherman Act, com o objetivo de afastar a distorção econômica verificada. A regulação da concorrência passou, então, a ter papel de destaque na correção do sistema de livre concorrência, conciliando a liberdade econômica individual e o interesse público 9 .

Desde a aprovação do Sherman Act, no entanto, até a década de 1970, o Direito da Concorrência nos Estados Unidos não era dotado de coerência econômica. De fato, desde 1890 até 1960 a Suprema Corte norte-americana não demonstrava ter um conhecimento coerente das questões de natureza concorrencial em função da economia. O Sherman Act era aplicado pelas cortes norte-americanas de forma a ajustar os termos vagos da legislação ${ }^{10}$. A Suprema Corte norte-americana aplicava a legislação de defesa da

\footnotetext{
${ }^{5}$ Kwonka Jr. E White esclarecem que dois períodos sucederam à Revolução Industrial, designadamente o amadurecimento industrial norte-americano e a Revolução da Informação, ocasionando sucessivas modificações nos institutos que permeiam o Direito Concorrencial, bem como a própria política antitruste. (KWONKA JR, John E.; WHITE, Lawrence J. The Antitrust Revolution: economics, competition and policy. 5. ed. New York: Oxford University Press, 2008, p. 1).

${ }^{6}$ FORGIONI, Paula A. Os fundamentos do antitruste. 4. ed. São Paulo: Revista dos Tribunais, 2010, pp. 58-61.

Celli Júnior esclarece que "muitas indústrias abusavam do seu poder econômico, buscando, de maneira concertada, sempre aumentar sua participação acionária e influência em outras indústrias estratégicas, a fim de assegurar a manutenção dos preços altos. Apareceram, assim, os denominados trusts, entre os quais o mais notório talvez tenha sido o composto pelo legendário John Rockfeller. A legislação americana visou exatamente a coibir a ação desses trusts. Daí a expressão legislação antitrust". (CELLI JÚNIOR, Humberto. Regras de concorrência no Direito Internacional moderno. Porto Alegre: Livraria do Advogado, 1999. p. 51). Ver também nesse sentido FORGIONI, Paula A. Op. cit., 2010, pp. 70-77.

${ }^{8} \mathrm{O}$ abuso do poder econômico verificou-se, principalmente, nas redes ferroviárias, as quais detinham o monopólio do transporte de bens e mercadorias e praticavam preços excessivos.

${ }^{9}$ FORGIONI, Paula A. Op. cit., 2010, p. 62.

10 "O Act categoricamente baniu quase todos os contratos que restringiam o comércio, requerendo assim que os juízes desenvolvessem princípios capazes de distinguir uma colaboração eliminadora da rivalidade e uma cooperação com o intuito de promover o crescimento. [...] Entre 1915 até a metade de 1930, as Cortes confiaram seriamente em testes racionais para avaliar as condutas empresariais e até mesmo tratavam comportamentos suspeitos de forma permissiva". (GABAN, Eduardo Molan; DOMINGUES, Juliana Oliveira. Direito antitruste. 3. ed. São Paulo: Saraiva, 2012, p. 66-67).
} 
concorrência com o objetivo de minimizar os efeitos da Grande Depressão de 1930 nos produtores e de proteger os pequenos negócios dos seus rivais maiores e mais eficientes (defesa da descentralização da economia) ${ }^{11}$.

Duas autoridades norte-americanas são responsáveis pela aplicação da legislação de defesa da concorrência, a saber, a Comissão Federal do Comércio (Federal Trade Comission - FTC), criada em 1914, e a Divisão Antitruste do Departamento de Justiça (Department of Justice - DOJ). O FTC empregou seus primeiros economistas nas décadas iniciais da sua existência, enquanto que o DOJ somente empregou um economista no ano de $1936^{12}$. A Ciência Jurídica também passou a buscar na Economia conhecimentos teóricos sobre a concorrência. Em 1939 a Universidade de Chicago passou a empregar economistas na Faculdade de Direito $^{13}$, o que fez com que a partir da década de 1960, juristas passassem a aplicar os princípios econômicos no Direito da Concorrência ${ }^{14}$.

A década de 1970 foi marcada pelas discussões econômicas que deveriam nortear o desenvolvimento do Direito da Concorrência, as quais foram impulsionadas pela Escola Estruturalista de Chicago e pela Escola Neoclássica de Harvard. A Escola de Harvard defendia teorias econômicas de natureza estruturalista, posicionando-se contra a concentração de poder de mercado ${ }^{15}$. Essa visão foi refletida nas conhecidas Diretrizes de Fusão (Merger Guidelines), publicadas pela primeira vez em 1968, pelo DOJ, nos Estados Unidos, as quais trouxeram orientações baseadas em princípios econômicos e não jurídicos. Esse documento, elaborado por uma comissão de juristas e economistas, estabelecia uma regra de classificação do mercado pela proporção da concentração em

\footnotetext{
11 'Pequenas empresas foram favorecidas e protegidas contra a 'opressão do poder econômico' (encroaching economic leverage) dos concorrentes maiores, mesmo que o resultado fosse maior custo para os consumidores". (FARIA, José Ângelo Estrella. O controle de concentrações de empresas estrangeiras e a Lei $\mathrm{n}^{\circ}$ 8.884: a extraterritorialidade revisitada. Juris Síntese, maio/jun. 2009, n. 77, p. 13. Disponível em: http://online.sintese.com. Acesso em: 19 ago. 2012).

12 Atualmente cada uma das entidades emprega cerca de 70 economistas (GINSBURG, Douglas H.; FRASER, Eric M. The Role of Economic Analysis in Competition Law. Getting the balance right: intellectual property, competittion Law and economics in Asia. Hart Publishing. 2010. p. 3. Disponível em: http://www.papers.ssrn.com/sol3/papers.cfm?abstract_id=1610189. Acesso em: 19 ago. 2012).

${ }_{13}^{13}$ Henry Simons, seguido por Aaron Director, em 1948.

${ }^{14}$ Profs. Phillip Areeda, Robert Bork, Ward Bowman, Richard Posner defendiam que a interpretação do Direito da Concorrência deve promover a eficiência econômica na forma de proteção dos consumidores.

${ }^{15}$ Salomão Filho esclarece que "os defensores dessa teoria dão ênfase ao estudo da estrutura de mercados individuais para a aplicação do direito antitruste. Para esses autores a estrutura do setor determina predominantemente a performance da indústria respectiva. Em uma indústria concentrada as empresas estão protegidas da competição por barreiras à entrada, consistentes em economias de escala, exigências maiores de capital, know-how escasso e diferenciação de produtos. Para estes pensadores, existindo apenas alguns vendedores no mercado, diminuem os custos e as dificuldades de uma atuação concertada. Em tais estruturas industriais, através de acordos de atuação concentrada tácita ou explícita, as empresas acabarão por diminuir a produção e aumentar os preços. A preocupação, portanto, não é voltada para a eficiência, mas sim para a existência efetiva de concorrência". (SALOMÃO FILHO, Calixto. Direito Concorrencial - as condutas. São Paulo: Malheiros, 2007, pp. 21-22).
} 
relação às quatro ou oito maiores empresas num dado mercado, utilizando o paradigma da conduta-estrutura-performance.

Já a Escola de Chicago propugnava pela aplicação das teorias econômicas nos casos de concentração econômica com foco na determinação dos efeitos que tais concentrações pudessem causar na concorrência. A principal característica dessa escola estava na ênfase à eficiência produtiva como instrumento para se obter ou manter posição dominante ${ }^{16}$, não devendo presumir-se o dano simplesmente em razão da constatação da existência de concentração no mercado. Nessa esteira, somente as práticas empresariais que levem à ineficiência devem ser repreendidas ${ }^{17}$. A eficiência alocativa do mercado, objetivo nesta vertente do pensamento econômico, serviria ao propósito de beneficiar os consumidores ${ }^{18}$.

Apesar das críticas existentes, do embate das escolas estruturalista e neoclássica parece que a Escola de Chicago prevaleceu, uma vez que os representantes da Escola de Harvard passaram a aceitar os pressupostos defendidos pela outra corrente e as políticas antitruste dos Estados Unidos baseiam-se nos seus ditames até os dias atuais ${ }^{19}$. O grande feito da Escola de Chicago foi a contribuição trazida por juristas e economistas na formação de preceitos operacionais, a partir dos preceitos analíticos, suscetíveis de serem aplicados pelas cortes ${ }^{20}$ e estimuladores da certeza e da segurança jurídica ${ }^{21}$.

$\mathrm{Na}$ esteira deste embate teórico, as autoridades de defesa da concorrência norteamericanas iniciaram, também na década de 1970, um processo de utilização da análise econômica para decidir quais os casos deveriam ser escrutinados, bem como para a efetiva condução do procedimento de análise do caso. Concomitantemente, o FTC passou a

\footnotetext{
${ }^{16}$ SALOMÃO FILHO, Calixto. Direito Concorrencial - as condutas. São Paulo: Malheiros, 2007, p. 21.

${ }^{17}$ Segundo Silva, "a intervenção do governo deve se limitar, outrossim, aos casos em que seja essencial, pois seu poder de correção das imperfeições do mercado é visto com ceticismo por esta doutrina, que confia acima de tudo no poder de autocorreção do mercado". (SILVA, Valéria Guimarães de Lima e. Direito Antitruste: aspectos internacionais. Curitiba: Juruá, 2007, p. 90).

${ }^{18}$ Forgioni esclarece que "sob este prisma, as concentrações (e o poder econômico que delas deriva) não são vistas como mal a ser evitado, os acordos verticais passam a ser explicados em termos de eficiência e ganho para os consumidores". A autora também sustenta essa mesma linha: "a teoria da eficiência desenvolvida pela Escola de Chicago veio a fundamentar teoricamente esse novo direcionamento da política econômica, escondendo-o sob o manto ideologicamente correto da proteção ao consumidor ao afirmar que uma empresa mais eficiente pode reduzir seus custos e, assim, oferecer um produto final mais barato ao consumidor, que se torna, em última instância, o maior beneficiado pelo aumento da eficiência decorrente da concentração econômica". (FORGIONI, Paula A. Os fundamentos do antitruste. 4. ed. São Paulo: Revista dos Tribunais, 2010, p. 91 e pp. 164-165).

${ }^{19}$ SILVA, Valéria Guimarães de Lima e. Op. cit., 2007, p. 93.

${ }^{20}$ GABAN, Eduardo Molan; DOMINGUES, Juliana Oliveira. Direito antitruste. 3. ed. São Paulo: Saraiva, 2012 , p. 81.

${ }^{21}$ Ao reduzir o espectro de valoração da legislação concorrencial somente aos casos de eficiência alocativa, os teóricos pretendiam conferir maior segurança aos agentes econômicos. Há autores, no entanto, que ressaltam que outros pontos envolvidos na análise antitruste também são suscetíveis à valoração pelo Direito. (FORGIONI, Paula A. Op. cit., 2010, pp. 167-170).
} 
empregar no seu Bureau de Economia economistas doutores ${ }^{22}$. O DOJ seguiu a mesma linha evolutiva, o que fez com que a análise econômica realizada passasse a ser cada vez mais sofisticada ${ }^{23}$.

Nesta mesma época, as cortes norte-americanas passaram a utilizar a economia para fundamentar as suas decisões, alterando a jurisprudência precedente ${ }^{24}$ e aplicando a regra da razão em substituição da ilegalidade per se vigente até então. Com tal alteração de metodologia, a Suprema Corte passou a condenar as operações e práticas que, pela análise econômica, contrariassem os interesses dos consumidores ${ }^{25}$.

A partir de então consolidou-se que enquanto nos casos de cartéis as considerações econômicas não são necessariamente obrigatórias ${ }^{26}$, nos casos de atos de concentração, monopólio e abuso de posição dominante a análise econômica ocupa posição de destaque $^{27}$. Quando a análise econômica é invocada pelas autoridades de defesa da concorrência norte-americanas, grande volume de dados é levantado pelas autoridades, de modo a fundamentar as suas decisões ${ }^{28}$. Com a publicação da obra Economic Analysis of

\footnotetext{
${ }^{22}$ Em período anterior a 1983, os economistas empregados pela Divisão Antitruste estavam subordinados a advogados. Tal estruturação das entidades norte-americanas de defesa da concorrência acabou acarretando na tensão interna entre advogados e economistas. Normalmente os advogados, que eram em maior número, acabavam por vencer as discussões. A situação começou a mudar em 1965, quando Donald F. Turner, que era advogado e economista, assumiu a chefia da Divisão Antitruste e criou a posição de Assistente Econômico Espacial (Special Economic Assistant, que respondia diretamente ao Assistant Attorney General), introduzindo a primeira versão das Diretrizes de Fusão. Em 1973, o prof. Tom Kauper criou a Divisão de Política Econômica. Somente em 1981, durante a administração de Ronald Regan, o organograma da Divisão Antitruste foi reorganizado para fazer com que o Economista Chefe passasse a estar no mesmo nível do Deputy Assistant Attorney General, e assim respondesse diretamente ao Assistent Attorney General. Essa estrutura persiste até os dias atuais, sendo que ao menos um economista é designado para cada investigação cível. (GINSBURG, Douglas H.; FRASER, Eric M. The Role of Economic Analysis in Competition Law. Getting the balance right: intellectual property, competittion Law and economics in Asia. Hart Publishing. 2010, pp. 1-6. Disponível em: http://www.papers.ssrn.com/sol3/papers.cfm?abstract_id=1610189. Acesso em: 19 ago. 2012).

${ }^{23}$ KWONKA JR, John E.; WHITE, Lawrence J. The Antitrust Revolution: economics, competition and policy. 5. ed. New York: Oxford University Press, 2008, p. 2.

${ }^{24}$ GINSBURG, Douglas H.; FRASER, Eric M. Op. cit., 2010, pp. 20-22. Casos citados pelos autores: Continental T. V, Inc. v. GTE Sylvania, Inc. (1977 - rule of reason), Reiter v. Sonotone Corp. (1979consumer welfare prescription).

25 "Gone was the concern with the welfare of producers and with small firms that could not compete with large or more efficient rivals". (GINSBURG, Douglas H.; FRASER, Eric M. Op. cit., 2010, p. 22).

${ }^{26}$ Isso se deve ao fato da ilegalidade inerente atribuída pelos sistemas jurídicos aos cartéis. (GINSBURG, Douglas H.; FRASER, Eric M. Op. cit., 2010, pp. 16-17).

27 Neste diapasão a questão é relevante na medida em que envolve a delimitação do mercado, da sua significância, do mercado de produto, dentre outros.

${ }^{28} \mathrm{Na}$ eventualidade de uma dada decisão ser questionada em juízo, os relatórios e informações econômicas são entregues às autoridades judiciais para que possam tomar a decisão final sobre o tema. Tendo em vista que dificilmente as autoridades judiciais contam com economistas, ou juízes com formação em economia, as decisões judiciais geralmente baseiam-se em descobrimentos fáticos e na interpretação jurídica realizada pela autoridade da concorrência. A análise, portanto, geralmente não estará conectada à determinação se uma conduta ou ato é anticoncorrencial, mas se a autoridade da concorrência realizou análise suficientemente adequada sobre a situação.
} 
Law pelo professor Richard Posner, em 1974, a tradição de analisar regras e institutos jurídicos através de um ponto de vista econômico foi consolidada ${ }^{29}$.

A edição de 1982 das Diretrizes de Fusão ${ }^{30}$ substituiu o sistema baseado na proporção de concentração das quatro ou oito maiores empresas do mercado, pelo do Índice Herfindahl-Hirschman $(\mathrm{HHI})^{31}$ e inovou ao empregar o teste do Monopolista Hipotético $^{32}$. Desta forma, as Diretrizes de 1982 não restringiram o seu conteúdo à estrutura de mercado e concentração, havendo incluído considerações teóricas e empíricas, como os prováveis efeitos concorrenciais, a entrada e os ganhos de eficiência associados ao ato de concentração - estando assim, alinhadas com as teorias econômicas da Escola de Chicago $^{33}$.

A análise econômica das questões de natureza concorrencial proporcionou um sistema coerente ao Direito Concorrencial norte-americano, culminando num progressivo aumento da segurança jurídica às partes e na diminuição dos processos judiciais. A evolução da influência econômica na matéria foi tão expressiva, que atualmente a organização industrial tem uma função essencial na construção das políticas de defesa da concorrência $^{34}$, refletindo assim uma dupla instrumentalidade do instituto ${ }^{35}$. E essa

${ }^{29}$ Outras obras que integram a teoria do preço e a microeconomia na análise antitruste foram publicadas na sequência: The Antitrust Paradox (Robert Bork, 1978) e Antitrust Law (Areeda e Turner, 1980).

30 Editadas em 1982 e revisadas em 1984, 1992, 1997 e 2010 - esta última versão foi emanada em 19 de agosto de 2010. GINSBURG, Douglas H.; FRASER, Eric M. The Role of Economic Analysis in Competition Law. Getting the balance right: intellectual property, competittion Law and economics in Asia. Hart Publishing. 2010, pp. 28-29. Disponível em: http://www.papers.ssrn.com/sol3/papers.cfm?abstract_id= 1610189. Acesso em: 19 ago. 2012, esclarece que atualmente estão sendo discutidas alterações às Diretrizes de Fusão. Esse instrumento tem sido de relevada importância nas decisões judiciais sobre o tema, uma vez que as autoridades judiciais buscam nele os fundamentos para as suas decisões. Alterações que se pretendem fazer às Diretrizes, relativas a um novo método de definição de mercados relevantes e de identificação de condutas monopolísticas, deverão alterar o Direito da Concorrência norte-americano atualmente aplicado, segundo o qual qualquer modificação deverá ser precedida de uma análise criteriosa.

31 Este índice mede a concentração, tendo como base o mercado global ao invés de somente as maiores empresas do mercado.

$32 \mathrm{O}$ teste define o mercado relevante ao questionar se um monopolista hipotético poderia obter ganhos ao impor um pequeno, mais significante, não transitório aumento de preço ou se tal aumento de preço seria frustrado em face à alteração da conduta dos consumidores ao mudarem para outros produtos.

33 De acordo com Silva, as Diretrizes de Fusão incorporaram os "argumentos teórico-econômicos desenvolvidos pela Escola de Chicago" e abandonaram "sua origem repressora para tornar-se um instrumento incentivador da fusão empresarial”. (SILVA, Valéria Guimarães de Lima e. Direito antitruste: aspectos internacionais. Curitiba: Juruá, 2007, p. 91).

34 "Economics helps determine what cases the Justice Department and the Federal Trade Commission pursue. Economics frames the central issues for investigation and, based on data analysis and theory, evaluates the likely competitive effects of various practices by companies or of structural changes in industries. And the courts themselves have embraced economic reasoning in their own analyses, a change made possible by the increased economic sophistication of the judiciary”. (KWONKA JR, John E.; WHITE, Lawrence J. The Antitrust Revolution: economics, competition and policy. 5. ed. New York: Oxford University Press, 2008, p. 2).

${ }^{35}$ Além de conciliar a liberdade individual econômica com o interesse público, a concorrência serve como instrumento para que os Estados definam as suas políticas públicas. (FORGIONI, Paula A. Os fundamentos do antitruste. 4. ed. São Paulo: Revista dos Tribunais, 2010, pp. 79-87). 
influência acabou por repercutir em diversas jurisdições ${ }^{36}$, as quais buscaram justamente na experiência norte-americana o embasamento para a promulgação das respectivas legislações internas de defesa da concorrência.

A doutrina neoclássica da Escola de Chicago, que propulsionou o desenvolvimento econômico do Direito da Concorrência, é considerada atualmente ultrapassada em razão das novas teorias desenvolvidas no âmbito da organização industrial ${ }^{37}$. Teorias como a dos mercados contestáveis, dos jogos e dos custos de transação, apesar de não contradizerem o controle de estruturas formulado anteriormente, modificaram o enfoque dos fundamentos estabelecido.

Não obstante a interação verificada entre Direito e Economia, o jurista deve estar sempre atento à função valorativa do Direito, enquanto propulsor das mudanças sociais motivo pelo qual o Direito não se deve limitar a simplesmente instrumentar as teorias econômicas ou tornar-se simples reflexo das políticas ou instituições estabelecidas ${ }^{38}$. Deve sim garantir a própria existência da concorrência, a ordem concorrencial, os interesses dos consumidores e dos concorrentes, cujos objetivos podem ser alcançados com maior eficácia a partir do uso de teorias econômicas na qualidade de elementos analíticos. Como regra, desta forma, deve-se sempre recordar que o Direito é fenômeno complexo e, assim, não deve subsumir-se aos preceitos econômicos ${ }^{39}$. Tais críticas, no entanto, não devem servir para inutilizar a função da Economia na análise concorrencial. Ao contrário, as teorias econômicas são instrumentos essenciais para explicar os fenômenos regulados pelas variadas legislações de defesa da concorrência ${ }^{40}$.

Por fim, ressalta-se que o Direito não deve estar pari passu com as rápidas alterações do pensamento econômico, sob pena de haver insegurança na aplicação do Direito da Concorrência. As autoridades judiciais devem somente passar a utilizar uma

\footnotetext{
${ }^{36}$ Ver item 1.1.2, a seguir.

${ }^{37}$ SALOMÃO FILHO, Calixto. Direito Concorrencial - as condutas. São Paulo: Malheiros, 2007, p. 23.

${ }^{38}$ Salomão Filho descreve que "o Direito vê o conhecimento de maneira diversa das Ciências Sociais. Enquanto para estas o conhecimento é algo eminentemente empírico [...], para os teóricos do Direito o conhecimento é eminentemente valorativo. O momento valorativo, se bem compreendido e utilizado, é exatamente o que dá ao Direito seu caráter distintivo e sua capacidade de mudança social. Daí porque o Direito não pode ser resumido nem a instrumento de positivação de regras e objetivos econômicos, e tampouco à política pura e simples ou ao estudo das instituições políticas. [...] Postular que o conhecimento é valorativo não é nada mais, nada menos, que afirmar que os valores de uma determinada sociedade podem influenciar - e influenciam - de maneira determinante o conhecimento que se tem dela". (SALOMÃO FILHO, Calixto. Op. cit., 2007, pp. 42-49).

39 "Nessa esteira, a busca por segurança e previsibilidade jurídica constitui perigoso incentivo para que o estudioso do antitruste caia na armadilha da análise econômica do direito, que mostra, qual canto de sereia, fórmulas aptas a resolver os casos concretos que se apresentam". (FORGIONI, Paula A. Os fundamentos do antitruste. 4. ed. São Paulo: Revista dos Tribunais, 2010, p. 170).

${ }^{40}$ FORGIONI, Paula A. Op. cit., 2010, p. 171.
} 
nova teoria ou estudo empírico nas suas decisões depois que tal teoria tenha sido aceita ou o estudo tenha sido repetido e os seus resultados aceitos pela comunidade científica ${ }^{41}$.

\subsubsection{Influência do Direito norte-americano no desenvolvimento da matéria nos variados sistemas jurídicos nacionais}

Uma das principais funções do Direito Comparado está no aperfeiçoamento do direito nacional consoante Ciência Jurídica desenvolvida em sistemas normativos estrangeiros, com a finalidade de promover a cooperação internacional ${ }^{42}$. A comparação entre sistemas jurídicos revela-se, assim, não somente como instrumento de estabilização da Ciência Jurídica, mas como um verdadeiro agente transformador da sociedade pela influência de institutos legais inovadores ${ }^{43}$.

É inegável a influência do Direito norte-americano e da evolução da teoria econômica nos Estados Unidos nas legislações nacionais de defesa da concorrência de diversas jurisdições ${ }^{44}$. É amplamente reconhecido que os variados sistemas nacionais sobre o tema valeram-se da experiência norte-americana no desenvolvimento das bases e fundamentos do antitruste para a promulgação das respectivas legislações internas de defesa da concorrência.

É desaconselhável pela técnica legislativa e jurídica, no entanto, que a influência mútua entre sistemas jurídicos se dê de forma absoluta ${ }^{45}$. A influência de regras entre ordenamentos de diferentes países deve ser relativizada pela realidade econômica e

${ }^{41}$ Caso Daubert (Scientific conclusions are subject to perpetual revision). (GINSBURG, Douglas H.; FRASER, Eric M. The Role of Economic Analysis in Competition Law. Getting the balance right: intellectual property, competittion Law and economics in Asia. Hart Publishing, 2010, p. 24. Disponível em: http://www.papers.ssrn.com/sol3/papers.cfm?abstract_id=1610189. Acesso em: 19 ago. 2012).

${ }^{42}$ Interessante notar que David destaca três utilidades do direito comparado, a saber: investigações históricas ou filosóficas referentes ao direito, conhecer melhor e aperfeiçoar o nosso direito nacional e compreender os povos estrangeiros e estabelecer um melhor regime para as relações da vida internacional (DAVID, René. Os grandes sistemas do Direito Contemporâneo. Trad. de Hermínio A. Carvalho3. Ed. São Paulo: Martins Fontes, 1996, p. 3; 7).

${ }^{43}$ David destaca que a influência de normas estrangeiras ocorre não somente no patamar legislativo, como também através da influência da doutrina e jurisprudência estrangeiras, sem qualquer interferência do legislador. Nesse quesito, destaca o autor que "a ciência do direito tem, por sua própria natureza de ciência, um caráter transnacional”. (DAVID, René. Op. cit., 1996, p. 6).

44 "Indubitavelmente, os economistas ofereceram grandes contribuições ao regime antitruste norte-americano, que, por sua vez, irradiou efeitos sobre várias jurisdições antitruste no mundo, dentre as quais a brasileira". (GABAN, Eduardo Molan; DOMINGUES, Juliana Oliveira. Direito antitruste. 3. ed. São Paulo: Saraiva, 2012. p. 69). Ver ainda pp. 81-82 dessa mesma obra sobre influência em outras jurisdições das teorias desenvolvidas pela Escola de Chicago. Nesse sentido ver também SILVA, Valéria Guimarães de Lima e. Direito antitruste: aspectos internacionais. Curitiba: Juruá, 2007, p. 93.

${ }^{45}$ A legislação estrangeira serve, assim, como inspiração ao legislador nacional, que deverá moldar o sistema nacional levando em consideração as particularidades da sua estrutura normativa e tradição. (DAVID, René. Op. cit., 1996, pp. 5-7). 
histórica do ordenamento receptor de tais normas. A simples transposição de determinadas normas para outro sistema, que não aquele de sua concepção, pode acarretar numa distorção dos sistemas envolvidos. Essa assertiva é ainda mais forte se considerado o ramo da matéria concorrencial, que está imbuída de preceitos políticos, verdadeiros ditames sobre como uma dada economia deve evoluir. Sendo esta uma escolha política, nem sempre a opção de uma determinada nação sobre a adoção de regras que devem regular as relações econômicas servirá em território estrangeiro.

Por outro lado, é possível aos variados países buscar inspiração em outras jurisdições sobre regulação de certas matérias. Ao promulgar legislação nacional sobre matéria de inspiração estrangeira, deve o legislador sempre adaptar tais regras à realidade local, adotando aquilo que pode contribuir com a evolução do seu sistema normativo e afastando aquelas regras que possam distorcer o funcionamento jurídico das suas instituições.

O legislador brasileiro parece ter optado por uma forma relativizada de adoção das regras estabelecidas no âmbito da experiência norte-americana para gerar o Direito Concorrencial tal qual existe atualmente no ordenamento jurídico nacional. Certo é que durante o histórico legislativo, por algumas vezes o legislador deixou de procurar a melhor adaptação dos sistemas estrangeiros à realidade brasileira. Mas com a evolução das legislações adotadas, é possível verificar que mesmo que tardio, o legislador seguiu a lógica jurídica do sistema nacional no estabelecimento das regras apropriadas.

Desta forma, apesar da inegável influência da legislação norte-americana, as peculiaridades do desenvolvimento econômico brasileiro fizeram com que a acolhida dos institutos de defesa da concorrência se desse de forma diferenciada em relação à vislumbrada em outras nações ${ }^{46}$. De fato, apesar de a doutrina assinalar que a primeira legislação brasileira de defesa da concorrência, o Decreto-Lei $n^{\circ} 869$, de 18 de novembro de 1938, inspirou-se na legislação e na jurisprudência norte-americana ${ }^{47}$, tal referência não foi absoluta. O Decreto-Lei $n^{\circ} 860 / 1938$ buscava a proteção da "economia popular", ou

\footnotetext{
${ }^{46}$ Forgioni alerta que "o liberalismo, no Brasil, foi introduzido de forma bastante peculiar, pois que depurado pelas especificidades de nosso sistema econômico e político". (FORGIONI, Paula A. Os fundamentos do antitruste. 4. ed. São Paulo: Revista dos Tribunais, 2010, p. 95).

47 Shieber destaca que baseia o seu entendimento nas opiniões externadas por Nelson Hungria, então Consultor-Geral da República, após a promulgação do Decreto-Lei $\mathrm{n}^{\circ}$ 869, que o diploma fora inspirado no projeto do novo Código Penal argentino, nas proposições de reforma do Direito Penal na Alemanha e na legislação e jurisprudência norte-americana - com especial ênfase em relação ao Clayton Act, de 1914. Também cita o Consultor-Geral da República Anibal Freire, por ocasião da consulta feita pela Standard Oil Company of Brazil, de que a jurisprudência e doutrina norte-americana deveriam ser evocadas na aplicação do Decreto-Lei 869. (SHIEBER, Benjamin M. Abusos do poder econômico: direito e experiência antitruste no Brasil e nos EUA. São Paulo: Revista dos Tribunais, 1966, p. 17).
} 
seja, em última instância a preocupação voltava-se ao consumidor, e não às estruturas do liberalismo econômico e à concorrência propriamente dita como ocorreu nos Estados Unidos.

Forgioni ${ }^{48}$ esclarece que "o antitruste não nasce, no Brasil, como fator de ligação entre o liberalismo econômico e (manutenção da) liberdade de concorrência. Nasce como repressão ao abuso do poder econômico e tendo como interesse constitucionalmente protegido o interesse da população, do consumidor". Esta é, na opinião da autora, uma das principais diferenças entre o sistema brasileiro de defesa da concorrência em relação ao norte-americano, que haveria impedido que a sistematização da matéria no ordenamento brasileiro se desse tal qual a norte-americana ${ }^{49}$. Por outro lado, há autores que entendem que a legislação brasileira de defesa da concorrência é um "decalque" da legislação norteamericana.

De outra banda, o Decreto-Lei $n^{\circ} 869 / 1938$ caracterizou os atos contra a economia popular como crimes, bem como estabeleceu a sistemática de delito per se, seguindo assim, a tradição do direito concorrencial norte-americano de criminalizar condutas e descartar os seus efeitos na caracterização do ilícito. Todavia, essa opção legislativa foi revertida com o Decreto-Lei $\mathrm{n}^{\circ} 7.666 / 1945$, que determinou punição administrativa como forma de repressão de condutas anticoncorrenciais ${ }^{50}$ e vinculou a necessidade de constatação dos efeitos como pressuposto de caracterização da conduta como ilícita. Posteriormente, a Constituição de 1946 caracterizou as condutas repreendidas por sua finalidade, e não pelos seus efeitos - conforme ocorria no âmbito do Decreto-Lei $\mathrm{n}^{\mathrm{o}} 7.666 / 1945$.

A influência do Direito norte-americano de defesa da concorrência no sistema brasileiro pode ser identificada também na tramitação do Projeto de Lei n ${ }^{\circ} 122 / 1948^{51}$, que aprovado verteu-se na Lei $n^{\circ} 4.137 / 1962$, apresentado pelo então Deputado Federal

${ }^{48}$ FORGIONI, Paula A. Os fundamentos do antitruste. 4. ed. São Paulo: Revista dos Tribunais, 2010. p. 103.

${ }^{49}$ Para aprofundar esse posicionamento e o seu contraponto, ver Shieber, o qual alerta que "claro que não se cogita ser tôda a experiência norte-americana necessariamente valiosa para o Brasil, país diferente, com problemas econômicos e sociais diversos dos que existem no EUA. Mas, na larga experiência antitruste dos Estados Unidos, certamente existirão muitas coisas que o Brasil pode aproveitar no aperfeiçoamento e execução de um direito antitruste próprio". (SHIEBER, Benjamin M. Abusos do poder econômico: direito e experiência antitruste no Brasil e nos EUA. São Paulo: Revista dos Tribunais, 1966. pp. 15-19).

50 Sistema que seria posteriormente adotado pela Lei $n^{\circ}$ 4.137/1962. Por outro lado, a Lei $n^{\circ}$ 8.137/1990 criminalizou certas condutas anticoncorrenciais, em instrumento apartado da legislação em vigor para defesa da concorrência. A Lei da Concorrência em vigor veio novamente revogar as disposições de natureza penal dos crimes contra a ordem econômica, fazendo com que atualmente a penalização no Brasil se dê somente no âmbito civil e administrativo. 
Agamemnon Magalhães. Em palestra proferida em 22 de junho de 1949, no Clube Militar do Distrito Federal, o deputado esclareceu que o referido Projeto de Lei "adota as diretrizes da legislação dos Estados Unidos com as modificações impostas pelas nossas condições econômicas e políticas" ${ }^{\text {52 }}$. Subsequentemente a Lei $\mathrm{n}^{\mathbf{0}} 4.137 / 1962$ foi gradualmente alterada pela atividade legislativa brasileira, de modo a superar alguns dos problemas identificados quando da sua aprovação. Na opinião de Forgioni, tal evolução foi "fruto da meditação sobre nossa realidade e não mera transposição de institutos alienígenas"53.

O acolhimento da teoria dos efeitos pela legislação brasileira, conforme será descrito adiante, revela uma aderência nacional aos princípios desenvolvidos no ordenamento norte-americano. Nesse sentido, note-se que, diferentemente da legislação brasileira, nem todas as legislações nacionais ou regionais de defesa da concorrência aceitam a teoria dos efeitos de forma ampla. A própria União Europeia é um exemplo de resistência ao acolhimento de tal princípio - mesmo que tenha contornado a questão para que pudesse aplicar a legislação da União extraterritorialmente por outros meios ${ }^{54}$.

Todavia, com o desenvolvimento da matéria concorrencial em diversas jurisdições, é possível identificar que atualmente a legislação norte-americana guarda certas peculiaridades, que destoam das normas adotadas por outros países ${ }^{55}$. Dentre as principais

51 NUSDEO, Ana Maria de Oliveira. Defesa da concorrência e globalização econômica. São Paulo: Malheiros, 2002. p. 219.

52 MAGAlHÃES, Agamemnon. Abuso do poder econômico. Revista Forense, ago. 1949. p. 604 apud FONSECA, João Bosco Leopoldino. Lei de proteção da concorrência. 3. ed. São Paulo: Forense, 2007. pp. 54-55; SHIEBER, Benjamin M. Abusos do poder econômico: direito e experiência antitruste no Brasil e nos EUA. São Paulo: Revista dos Tribunais, 1966. p. 17-18; e FORGIONI, Paula A. Os fundamentos do antitruste. 4. ed. São Paulo: Revista dos Tribunais, 2010. p. 106. A autora destaca que Agamemnon Magalhães foi o pioneiro do antitruste no Brasil.

${ }^{53}$ FORGIONI, Paula A. Op. cit., 2010. p. 119.

${ }^{54}$ Ver GUZMAN, Andrew T. Competition law and cooperation: possible strategies. Cooperation, comity and competition policy. New York: Oxford University Press, 2011, p. 348; PAIS, Sofia Oliveira. O controle das concentrações de empresas no âmbito do Direito Comunitário da Concorrência. Coimbra: Almedina, 1996, pp. 335-340 e 342-343; CARVALHO RAMOS, André de; CUNHA, Ricardo Thomazinho da. A defesa da concorrência em caráter global: utopia ou necessidade. In: CASELLA, Paulo Borba (org.). Guerra comercial ou integração econômic mundial. São Paulo: LTr, 1998, v. 1, p. 825; e CELLI JÚNIOR, Humberto. Regras de concorrência no Direito Internacional moderno. Porto Alegre: Livraria do Advogado, 1999, p. 75. Os autores citam o caso Wood Pulp julgado pelo TJUE em que foi aplicado extraterritorialmente a legislação da União, tendo com base o princípio da territorialidade objetiva do Direito Internacional Público (UNIÃO EUROPEIA. Caso A. Ahlström Oy v Comissão Europeia (Wood Pulp), casos n. C-89, 104, 114, 116, 117 e 125-9/85, Tribunal de Justiça da União Europeia, j. 27 set. 1988.). Pais (1996, p. 336) destaca nesse sentido que "enquanto nos Estados Unidos a jurisprudência parece ter aceite a teoria dos efeitos, na Comunidade Europeia o Tribunal tem-se esquivado a responder a este problema, procurando soluções alternativas menos polêmicas".

${ }^{55}$ Para um relato completo das particularidades identificadas no sistema norte-americano, Valéria Guimarães de Lima e Silva esclarece que tais diferenças decorrem da "ideologia e os valores da nação em que foram promulgadas e são aplicadas, sempre, em defesa dos interesses nacionais. No direito concorrencial norteamericano a possibilidade de conflitos é ainda mais gritante, vez que proporciona, muitas vezes, instrumentos excessivos que podem resultar no abuso da lei e em uma repressão agressiva, que termina por onerar de 
diferenças existentes, destacam-se: (i) a previsão legal de ilegalidades per se, as quais independem da verificação dos efeitos no caso concreto; (ii) a manutenção da concorrência é um fim em si mesma, sendo que a aplicação da legislação concorrencial independe dos interesses dos pequenos competidores ou do bem-estar do consumidor; (iii) a natureza criminal das provisões do Sherman Act, cabendo ações civis e criminais sobre as violações perpetradas (enquanto que em outras jurisdições, como no Brasil, a natureza é civil ou administrativa); (iv) a possibilidade da proposição de ações privadas em matéria concorrencial, que pode deturpar o sistema de proteção governamental; e (v) previsão de indenizações a serem estabelecidas aos agentes que transgredirem a legislação concorrencial, com natureza reparatória e punitiva.

As peculiaridades anteriormente apontadas constituem parte das dificuldades enfrentadas no âmbito das relações internacionais para que as nações cheguem a um acordo amplo de regulação da concorrência no âmbito internacional. Também refletem o descontentamento advindo da aplicação extraterritorial das regras concorrenciais norteamericanas. Não obstante a identificação de tais diferenças entre o sistema antitruste norteamericano, não seria correto afirmar que tal sistema não influenciou e não continua a influenciar as legislações de defesa da concorrência ao redor do globo. É sistemático verificar que a experiência norte-americana serviu e ainda serve de referência a diversas jurisdições na evolução legislativa de natureza concorrencial. Tal razão justifica a relevância do conhecimento dos institutos norte-americanos, incluídas aí a legislação, a doutrina e a jurisprudência, quando o jurista se propõe a dissertar sobre a matéria de defesa da concorrência.

Por fim, deve-se sempre ter em vista que a legislação da concorrência de um dado Estado reflete uma opção ideológica que, na maioria das vezes, extrapola as teorias econômicas adjacentes à matéria. As políticas públicas sobre os respectivos sistemas econômicos das nações irão determinar em última instância a legislação concorrencial a ser adotada. Mesmo considerando essas diferenças de política concorrencial, é possível vislumbrar um ponto comum entre a maioria das nações que compõem a comunidade internacional contemporânea, qual seja o "ethos capitalista" "56.

forma desmedida o concorrente a ponto de retirá-lo do mercado". (SILVA, Valéria Guimarães de Lima e. Direito antitruste: aspectos internacionais. Curitiba: Juruá, 2007. pp. 93-96).

${ }^{56}$ Carvalho Ramos e Cunha destacam que atualmente dois são os modelos adotados pelos países de economia de mercado: (i) o modelo americano (que tem a concorrência como um fim em si mesmo); e (ii) o modelo europeu (em que a defesa da concorrência consiste em um meio para a consecução de políticas do Estado, aceitando algumas práticas restritivas da concorrência em benefício desses objetivos). (CARVALHO RAMOS, André de; CUNHA, Ricardo Thomazinho da. A defesa da concorrência em caráter global: utopia 


\subsubsection{O Direito da Concorrência brasileiro}

Nas palavras de Forgioni ${ }^{57}$, "no Brasil, não é tarefa fácil para o jurista sistematizar a evolução histórica das normas antitruste, perdidas em um cipoal de diplomas, em que se protegem os mais diversos interesses, apenas mediatamente compatíveis" ${ }^{\text {"58 }}$. O certo é que a evolução da matéria no país foi tardia se comparada à experiência norte-americana, principalmente em função da intervenção direta do Estado na economia - o que se contrapõe à liberdade concorrencial e à não intervenção direta do Estado na economia fundamentos da legislação dos Estados Unidos ${ }^{59}$.

Os primeiros períodos da história brasileira, durante o domínio de Portugal, não refletiram um amplo acolhimento do liberalismo econômico, o qual permeava naquele mesmo período as instituições nos mais variados países e, consequentemente, não havia previsões sobre a livre concorrência no ordenamento brasileiro. A ausência de regras concorrenciais justifica-se na medida em que não era possível conceber que houvesse uma concorrência a ser preservada no território brasileiro ${ }^{60}$. Com a transferência da Corte de D. João VI para o Brasil, em 1808, a abertura dos portos brasileiros às nações amigas e o estabelecimento da liberdade de manufatura e indústria ${ }^{61}$, ficou clara a tentativa de acolhimento do liberalismo na economia ${ }^{62}$. No entanto, de igual forma, nesse período não é possível identificar no direito interno nenhuma norma que pretendesse regular a concorrência ${ }^{63}$.

ou necessidade. In: CASELLA, Paulo Borba (org.). Guerra comercial ou integração econômica mundial. São Paulo: LTr, 1998, v. 1. pp. 813-814).

${ }^{57}$ FORGIONI, Paula A. Os fundamentos do antitruste. 4. ed. São Paulo: Revista dos Tribunais, 2010. p. 112.

${ }^{58}$ Para uma completa análise do desenvolvimento das legislações de defesa da concorrência no Brasil, ver FORGIONI, Paula A. Op. cit., 2010, pp. 88-127.

${ }^{59}$ SILVA, Valéria Guimarães de Lima e. Direito antitruste: aspectos internacionais. Curitiba: Juruá, 2007, pp. 293-294.

${ }^{60}$ Id., Ibid., p. 284.

${ }^{61}$ O Alvará de 12 de outubro de 1808 revogou o alvará anterior, emitido em 5 de janeiro de 1785 , a qual proibia, com algumas poucas exceções, todas as atividades que pudessem culminar no desenvolvimento da indústria brasileira e no intercâmbio de bens e serviços com outras nações, além de Portugal. O Príncipe Regente declarava no Alvará de 1808 ser "lícito a qualquer dos meus vassalos, qualquer que seja o País em que habitem, estabelecer todo o gênero de manufaturas, sem exceptuar alguma, fazendo os seus trabalhos em pequeno, ou em grande, como entenderem que mais lhes convém" (PORTUGAL. Alvará de 12 de outubro de 1808).

${ }^{62}$ Essa tentativa, em parte, restou frustrada em razão da elevada concorrência estrangeira, que impediu que a indústria nacional se desenvolvesse e, assim, que fosse possível exercer qualquer pretensão de regulação de uma concorrência inexistente. (FORGIONI, Paula A. Op. cit., 2010, p. 93 e 97). No mesmo sentido ver SILVA, Valéria Guimarães de Lima e. Op. cit., 2007, p. 285.

${ }^{63}$ Há notícias de uma proposição com conteúdo conexo à defesa da concorrência apresentada pelo deputado Brigadeiro Cunha Matos, de 20 de maio de 1826, bem como de norma dessa natureza inclusa no Esboço do 
Com a independência do Brasil, a tendência ideológica do liberalismo econômico refletiu nas Constituições de 1824 e 1891, tratando apenas do dever estatal em garantir as liberdades individuais no mercado ${ }^{64}$. Com o final da I Guerra Mundial e sob a influência da Constituição de Weimar, de 1919, a Constituição brasileira de 1934 foi promulgada, assegurando o direito pleno à propriedade e incluindo em seu texto limitações à liberdade conferida aos agentes econômicos ${ }^{65}$. Não houve, no entanto, sob a égide desta Constituição, a aprovação de lei que regulasse a concorrência.

Na mesma esteira, a Constituição de 1937, outorgada pelo governo de Getúlio Vargas, atribuiu ao Estado o dever de "coordenar os fatores de produção, de maneira a evitar ou resolver os seus conflitos e introduzir no jogo das competições individuais o pensamento dos interesses da Nação, representados pelo Estado”. O art. 141 da Constituição de 1937 também estabelecia regras de fomento à economia popular, inclusive pela determinação da repreensão aos crimes contra a economia popular.

O Decreto-Lei $\mathrm{n}^{\mathrm{o}}$ 869, de 18 de novembro de 1938, veio regulamentar os crimes contra a economia popular, traduzindo pela primeira vez no ordenamento jurídico brasileiro uma lei com regras de defesa da concorrência. Conforme assevera Shieber ${ }^{66}$, no entanto, os dispositivos deste decreto não chegaram a ser executados em questões de natureza concorrencial, principalmente por inexistir uma autoridade incumbida ao exercício de tal competência ${ }^{67}$.

Posteriormente, o Decreto-Lei no 7.666, de 22 de junho de 1945 (Lei Malaia), veio regulamentar os "atos contrários à ordem moral e econômica", criando a Comissão

Código Civil, de Teixeira de Freitas, publicado na década de 1860. Para maiores detalhes, ver FORGIONI, Paula A. Os fundamentos do antitruste. 4. ed. São Paulo: Revista dos Tribunais, 2010, p. 98.

${ }^{64}$ FONSECA, João Bosco Leopoldino. Lei de Proteção da Concorrência. 3. ed. São Paulo: Forense, 2007, p. 48.

${ }^{65}$ Silva aponta que a Constituição de 1934 configura a gênese do Direito da Concorrência no Brasil. (SILVA, Valéria Guimarães de Lima e. Direito antitruste: aspectos internacionais. Curitiba: Juruá, 2007, p. 286).

${ }^{66}$ Shieber esclarece que em sua pesquisa sobre doutrina e jurisprudência somente conseguiu identificar um caso em que os dispositivos do Decreto-Lei $\mathrm{n}^{\circ} 869$ foram executados. Trata-se de um parecer do ConsultorGeral da República, aprovado pelo então Presidente Getúlio Vargas, que apresentava uma resposta à consulta formulada pela Standard Oil Company of Brazil sobre cláusulas contratuais celebradas com proprietários de postos de gasolina. A decisão presidencial foi no sentido de declarar as práticas contratuais da consulente como ilícitas e determinar a modificação dos seus contratos. Nesse sentido, esclarece que "o Decreto-Lei n. 869 teve repercussão no campo de regulamentação dos preços e supressão dos artifícios e fraudes na venda de mercadorias, mas não teve no campo dos abusos de natureza antitruste". (SHIEBER, Benjamin M. Abusos do poder econômico: direito e experiência antitruste no Brasil e nos EUA. São Paulo: Revista dos Tribunais, 1966, p. 6).

${ }^{67}$ Baptista destaca que "a verdade é que a implantação de uma economia em moldes capitalistas modernos é mais tardia, e não havia fatos a serem regulados naquela fase da história econômica". (BAPTISTA, Luiz Olavo. Origens do direito da concorrência. Revista da Faculdade de Direito da USP, v. 91, p. 21, 1996 apud SILVA, Valéria Guimarães de Lima e. Direito antitruste: aspectos internacionais. Curitiba: Juruá, 2007, p. 188). 
Administrativa de Defesa Econômica, na forma de órgão autônomo subordinado à Presidência da República, para dar cumprimento às suas disposições. A Lei Malaia disciplinou o tema de "forma específica, sistemática, voltando-se de forma firme e direta contra o abuso do poder" ${ }^{\prime 68}$. Com o final do governo de Getúlio Vargas, a Lei Malaia foi revogada no mesmo ano da sua promulgação, influenciando, no entanto, o desenvolvimento subsequente da matéria ${ }^{69}$.

A Constituição brasileira de 1946, no seu art. 148, repreendeu pela primeira vez o abuso do poder econômico, que tivesse por finalidade eliminar a concorrência e aumentar arbitrariamente os lucros. O bem juridicamente resguardado deixa, então, de ser simplesmente a defesa da economia popular, para dar especo ao desenvolvimento de uma regulamentação ampla e sistematizada da matéria. Com essa finalidade, a Lei no 4.137, de 10 de setembro de 1962 , foi promulgada ${ }^{70}$, regulando a apuração e a repressão do abuso do poder econômico, descriminalizando as condutas anticoncorrenciais, estabelecendo um mecanismo de controle de atos de concentração e criando o Conselho Administrativo de Defesa Econômica (CADE), o qual foi incumbindo de executar as determinações legalmente estabelecidas.

Durante a vigência da Lei $\mathrm{n}^{\circ} 4.137 / 1962$, o sistema normativo evoluiu de acordo com a realidade econômica específica brasileira, fazendo com que fossem superados alguns dos problemas identificados inicialmente com a promulgação da referida lei. Por outro lado, a aplicação prática das disposições legais era escassa ou ineficaz, em razão principalmente da interferência do Poder Judiciário brasileiro nos processos conduzidos pelo CADE e pela ausência de uma política concorrencial linear ${ }^{71}$. É, portanto, correto

\footnotetext{
${ }^{68}$ Forgioni esclarece ainda que "esse diploma representa, em termos de sistematização da matéria e técnica jurídica, grande avanço, em muitos aspectos semente da regulamentação atual”. (FORGIONI, Paula A. Os fundamentos do antitruste. 4. ed. São Paulo: Revista dos Tribunais, 2010, p. 108).

${ }^{69}$ Nusdeo destaca, nesse sentido, que "apesar da rápida revogação, esse decreto-lei teve uma influência importante na legislação antitruste brasileira, notadamente ao introduzir o conceito de abuso de poder econômico, influenciando o sucessivo tratamento constitucional da proteção à concorrência". (NUSDEO, Ana Maria de Oliveira. Defesa da concorrência e globalização econômica. São Paulo: Malheiros, 2002, p. 219).

${ }^{70}$ Durante a tramitação do projeto de lei que deu azo à Lei $n^{\circ} 4.137 / 1962$, foi promulgada a Lei $n^{\circ} 1.521$, de 26 de dezembro de 1951, para regular o julgamento dos crimes contra a economia popular. Subsequentemente, a Lei $\mathrm{n}^{\mathrm{o}}$ 1.522, de 26 de dezembro de 1951, criou a Comissão Federal de Abastecimento e Preços (COFAP), substituída posteriormente pela Superintendência Nacional de Abastecimento (SUNAB), com o objetivo de efetivar a intervenção política no domínio econômico. "Essas duas leis se colocam em contradição com a evolução conceitual de concorrência, porque a primeira delas volta a definir os atos a ela contrários como crimes e porque a segunda cria órgãos de fixação de controle de preços pelo Estado". (FONSECA, João Bosco Leopoldino. Lei de proteção da concorrência. 3. ed. São Paulo: Forense, 2007, p. 55).

${ }^{71}$ Silva descreve, ainda, em relação a esse diploma legal que teve lugar "a ausência de efetividade da legislação concorrencial, ou, sob outro prisma, na sua aplicação em prol do desenvolvimento nacional, i.e., na defesa das empresas nacionais em detrimento das estrangeiras, resultando, na prática, na ausência de
} 
afirmar que, apesar de alguns períodos não constantes de aplicação da legislação, a Lei no 4.137/1962 não teve muita efetividade no cenário brasileiro ${ }^{72}$.

A Constituição Federal de 1988 elevou pela primeira vez a livre concorrência como princípio econômico constitucional, devendo ser aplicado sob coordenação dos princípios da soberania nacional, função social da propriedade, defesa do consumidor, busca do pleno emprego e defesa do meio ambiente ${ }^{73}$. Para maiores informações sobre o regramento da concorrência na Constituição Federal ver item 1.3.1.1 abaixo.

A Secretaria Nacional de Direito Econômico (SNDE) viria a ser criada somente em 1990, por meio do Decreto $\mathrm{n}^{\mathbf{0}}$ 99.244, de 10 de maio daquele ano. Ato sequente foi promulgada a Lei $\mathrm{n}^{\circ}$ 8.137, de 27 de dezembro de 1990, a qual tratou de criminalizar certas condutas contrárias à ordem econômica. No bojo da abertura do mercado brasileiro e da liberalização da economia, a Lei no 8.158 , de 8 de janeiro de 1991, regulamentou a atuação conjunta da SNDE e do CADE na análise concorrencial, ainda sob os auspícios da Lei $\mathrm{n}^{\circ} 4.137 / 1962$, e estabeleceu um processo administrativo mais célere e eficaz. O reforço pessoal e administrativo da SNDE incrementou quantitativa e qualitativamente as decisões proferidas pelo CADE.

A Lei $n^{\circ} 8.884$, de 11 de junho de 1994, veio regular a matéria da defesa da concorrência por completo, de forma sistematizada, e não fragmentada em diversos diplomas legais ${ }^{74}$, dispondo sobre a prevenção e a repressão às infrações contra a ordem econômica. Esta lei transformou o CADE em autarquia federal, dotando-o, assim, de autonomia administrativa e financeira.

O Sistema Brasileiro de Defesa da Concorrência (SBDC), criado no âmbito da Lei $\mathrm{n}^{\mathrm{o}} 8.884 / 1994^{75}$, era formado pelo CADE, pela Secretaria de Acompanhamento Econômico

aplicação da lei sobre as primeiras”. (SILVA, Valéria Guimarães de Lima e. Direito antitruste: aspectos internacionais. Curitiba: Juruá, 2007, p. 292).

${ }^{72}$ Forgioni destaca que até 1975 o CADE somente havia julgado 11 processos, sendo que em apenas um caso a prática perpetrada pelo agente econômico foi considerada como abuso do poder econômico. (FORGIONI, Paula A. Os fundamentos do antitruste. 4. ed. São Paulo: Revista dos Tribunais, 2010, p. 108). Outros estudiosos indicam que de 1963 a 1990 somente teriam tido lugar 16 condenações por infrações contra a ordem econômica, sendo que dos 337 procedimentos iniciados somente haviam sido instaurados 117 processos. Por tal razão, "o CADE passou a ser visto como um órgão inoperante ou com atuação de pouco relevo". (SILVA, Valéria Guimarães de Lima e. Op. cit., 2007, p. 293; CARVALHO, Leonardo Arquimino de. Direito antitruste \& relações internacionais: extraterritorialidade e cooperação. Curitiba: Juruá, 2003, pp. 122-123).

${ }^{73}$ SILVA, Valéria Guimarães de Lima e. Op. cit., 2007, p. 294.

74 "Naturalmente esse quadro, em que coexistiam fundamentos antagônicos, conceitos novos e outros já ultrapassados, sem que houvesse qualquer ordenação entre eles, proporcionou uma grande confusão na interpretação e implementação da legislação concorrencial e contribuiu para que se buscasse a consolidação, sistematização e a coesão dos avanços alcançados em um único diploma legal." (SILVA, Valéria Guimarães de Lima e. Op. cit., 2007, p. 296).

${ }^{75}$ Sem que, no entanto, tivesse lhe conferido tal designação. 
(SEAE) do Ministério da Fazenda e pela Secretaria de Direito Econômico (SDE) do Ministério da Justiça. No bojo da vigência da Lei nº 8.884/1994 a atuação do CADE se consolidou, de forma a garantir a linearidade da aplicação da legislação de defesa da concorrência. Em consequência, a cultura de respeito aos princípios norteadores da concorrência foi difundida junto aos agentes econômicos, garantindo maior segurança jurídica ao mercado.

Em 30 de novembro de 2011 foi promulgada a Lei nº 12.529 (Lei da Concorrência), que veio estruturar o SBDC e definir as regras de prevenção e repreensão às infrações contra a ordem econômica. Dentre as alterações inseridas no sistema da defesa da concorrência brasileira destacam-se a análise a priori dos atos de concentração e a unificação da SDE e o CADE, em uma única estrutura, a qual se convencionou chamar "Novo CADE". Maiores considerações acerca deste recente regramento legislativo estão consolidadas no item 1.1.3.1.2 deste estudo.

\subsubsection{Legislação vigente}

\subsection{Constituição Federal de 1988}

A análise dos preceitos constitucionais sobre a defesa da concorrência é relevante na medida em que indicam a forma como a concorrência deve ser implementada no Brasil, bem como estabelecem os princípios norteadores da matéria em todas as suas instâncias.

A Constituição Federal de 1988 eleva, pela primeira vez, a livre concorrência à categoria de princípio constitucional, marcando o término do período de intervenção do Estado no domínio econômico ${ }^{76}$. Esta opção do constituinte se deu num sistema amplo de acolhimento da livre iniciativa como fundamento do Estado brasileiro, visando ao bem da coletividade $^{77}$. Ademais, as regras constitucionais indicam que o mercado interno tem natureza de patrimônio nacional, devendo o Estado administrá-lo propriamente ${ }^{78}$.

\footnotetext{
${ }^{76}$ SILVA, Valéria Guimarães de Lima e. Direito antitruste: aspectos internacionais. Curitiba: Juruá, 2007, p. 297.

${ }^{77}$ Em conformidade com o art. $1^{\circ}$ e de seu $\S$ único da Constituição Federal: "Art. $1^{\circ}$. A República Federativa do Brasil, formada pela união indissolúvel dos Estados e Municípios e do Distrito Federal, constitui-se em Estado Democrático de Direito e tem como fundamentos: [...] IV - os valores sociais do trabalho e da livre iniciativa; [...] Parágrafo único. Todo o poder emana do povo, que o exerce por meio de representantes eleitos ou diretamente, nos termos desta Constituição".

78 "Art. 219. O mercado interno integra o patrimônio nacional e será incentivado de modo a viabilizar o desenvolvimento cultural e sócio-econômico, o bem-estar da população e a autonomia tecnológica do País, nos termos de lei federal".
} 
Juntamente ao dever de gerência do mercado, o Estado deve ainda zelar pelos direitos dos consumidores e garantir a posição dos agentes econômicos ${ }^{79}$.

De acordo com o art. 170 da Constituição Federal ${ }^{80}$, o princípio da livre concorrência deve ser conjugado com outros princípios, designadamente o da soberania nacional, da propriedade privada, da função social da propriedade, da defesa do consumidor e do meio ambiente, da busca do pleno emprego e da redução das desigualdades regionais e sociais.

A ordem econômica estabelecida pelo constituinte tem um cunho social, uma vez que apesar da menção a um sistema capitalista fundado na livre iniciativa, o constituinte estabelece também o fundamento na valorização do trabalho humano ${ }^{81}$, com a finalidade de garantir a dignidade da coletividade e em conformidade com os ditames da justiça social $^{82}$. Isso significa que, apesar da adoção de uma economia de mercado, esta deve sempre objetivar o bem coletivo, cumprindo assim o seu papel social. A livre concorrência consiste, assim, em um dos instrumentos previstos pela Constituição Federal para a realização da ordem econômica, guiada, por sua vez, aos fins sociais.

Ainda, de acordo com a análise do art. 170, caput, é possível verificar que, mesmo a livre iniciativa constituindo um dos fundamentos da ordem econômica posta, ela não é absoluta, já que deve guiar-se pela livre concorrência para além de outros princípios. $\mathrm{O}$ princípio da livre concorrência é, pois, o instrumento de que o constituinte lançou mão para assegurar o equilíbrio da livre iniciativa, tratando, portanto, de conceitos complementares ${ }^{83}$.

A Constituição Federal inovou ao admitir a prevenção em matéria concorrencial, ao lado da repressão já prevista nos textos constitucionais anteriormente adotados. De fato, o

\footnotetext{
${ }^{79}$ SILVA, Valéria Guimarães de Lima e. Direito antitruste: aspectos internacionais. Curitiba: Juruá, 2007, p. 305 .

80 "Art. 170. A ordem econômica, fundada na valorização do trabalho humano e na livre iniciativa, tem por fim assegurar a todos existência digna, conforme os ditames da justiça social, observados os seguintes princípios: [...] IV - livre concorrência; [...]".

${ }^{81}$ Silva esclarece que "a Constituição consagra uma economia de mercado, de natureza capitalista, pois a iniciativa privada é um princípio básico da ordem capitalista. Em segundo lugar significa que, embora capitalista, a ordem econômica dá prioridade aos valores do trabalho humano sobre todos os demais valores da economia de mercado". (SILVA, José Afonso da. Curso de Direito Constitucional positivo. 18. ed. São Paulo: Malheiros, 2000, p. 766).

82 "Os princípios da livre iniciativa e da livre concorrência são instrumentais da promoção da dignidade humana. A Constituição do Brasil, em seu todo, persegue objetivos mais amplos e maiores do que, singelamente, o do livre mercado". (FORGIONI, Paula A. Os fundamentos do antitruste. 4. ed. São Paulo: Revista dos Tribunais, 2010, p. 179).

${ }^{83}$ SILVA, Valéria Guimarães de Lima e. Op. cit., 2007, p. 300; SILVA, José Afonso da. Op. cit., 2000, p. 773.
} 
seu art. $173, \S 4^{\mathrm{o}^{84}}$ cuida de estabelecer o caráter repressivo do comando constitucional, imbuindo que certas finalidades devem ser atendidas para que a conduta seja suscetível de repreensão pelas autoridades públicas ${ }^{85}$. Já o caráter preventivo em matéria concorrencial vem consignado no art. 174, caput, da Constituição Federal ${ }^{86}$, determinando que o Estado deve agir preventivamente, controlando as estruturas do mercado, evitando, assim, a materialização de outras situações de domínio econômico.

Note-se que a prevenção e a repressão às condutas anticoncorrenciais estão inseridas em um contexto constitucional amplo, constituindo um fragmento do comando geral da livre concorrência. $\mathrm{O}$ abuso do poder econômico ${ }^{87}$, por sua vez, é considerado um desvio de finalidade do poder econômico - este lícito -, que acaba por gerar prejuízos ou impossibilitar a livre iniciativa. Diferentemente do que ocorre no sistema jurídico norteamericano, a Constituição Federal não adota, portanto, o critério de caracterização de condutas como anticoncorrenciais através do ilícito per se, mas condiciona à verificação do abuso na condução da conduta, nos termos estabelecidos constitucionalmente ${ }^{88}$.

\subsection{Lei da Concorrência (Lei no 12.529 , de 30 de novembro de 2011)}

A Lei da Concorrência, promulgada em 30 de novembro de 2011, entrou em vigor em 29 de maio de $2012^{89}$ e tratou de estruturar o SBDC e definir as regras de prevenção e

\footnotetext{
84 “Art. 173. Ressalvados os casos previstos nesta Constituição, a exploração direta de atividade econômica pelo Estado só será permitida quando necessária aos imperativos da segurança nacional ou a relevante interesse coletivo, conforme definidos em lei. [...]. § $4^{\circ}$ - A lei reprimirá o abuso do poder econômico que vise à dominação dos mercados, à eliminação da concorrência e ao aumento arbitrário dos lucros."

${ }^{85}$ De acordo com Silva, "nem todos os abusos dão ensejo à coibição, devendo para tanto atender às finalidades estabelecidas na Constituição, a saber, a dominação dos mercados, a eliminação da concorrência e o aumento arbitrário dos lucros. Estes, por seu turno, não precisam ser considerados cumulativamente, ao contrário do que se poderia entender pela interpretação literal do texto constitucional, sendo suficiente a presença alternativa de uma dessas finalidades, segundo o entendimento consensual da doutrina nacional". (SILVA, Valéria Guimarães de Lima e. Direito antitruste: aspectos internacionais. Curitiba: Juruá, 2007, pp. 301-302).

86 "Art. 174. Como agente normativo e regulador da atividade econômica, o Estado exercerá, na forma da lei, as funções de fiscalização, incentivo e planejamento, sendo este determinante para o setor público e indicativo para o setor privado".

87 "A doutrina define o poder econômico como a possibilidade de exercício de uma influência notável e em princípio previsível pela empresa dominante sobre o mercado, influindo na conduta das demais concorrentes ou, ainda, subtraindo-se à influência dessas últimas, através de uma conduta indiferente e delas efetivamente independente em alto grau". (NUSDEO, Ana Maria de Oliveira. Defesa da concorrência e globalização econômica. São Paulo: Malheiros, 2002, pp. 240-241).

${ }^{88}$ Silva esclarece que "isso permitiu a manutenção de um grau de concentração considerável entre as empresas brasileiras, necessário para fazer frente à economia de mercado estabelecida constitucionalmente que veio a substituir o dirigismo estatal até então vigente e que culminou na abertura do mercado nacional à concorrência estrangeira”. (SILVA, Valéria Guimarães de Lima e. Op. cit., 2007, pp. 302-303).

${ }^{89}$ Houve discussões a respeito da data de entrada em vigor da Lei da Concorrência, ou seja, se teria ocorrido no dia 29 ou 30 de maio de 2012, em vista da republicação do seu texto no Diário Oficial da União um dia após a sua publicação original - esta ocorrida em $1^{\circ}$ de dezembro de 2011 . Todavia, a republicação da lei não
} 
repreensão às infrações contra a ordem econômica. O Projeto de Lei no 3.937/2004 ${ }^{90}$, que deu azo à Lei da Concorrência, foi influenciado pelas recomendações da OCDE expedidas em 2005, posteriormente revisadas em 2010, conhecida como "revisão pelos pares"91.

Com a entrada em vigor da Lei da Concorrência formalizou-se o SBDC, o qual em período anterior assim era denominado pela doutrina, apesar de não haver previsão legal nesse sentido ${ }^{92}$. O SBDC, anteriormente formado por três órgãos, passou a ser composto por somente dois, a saber o $\mathrm{CADE}^{93}$ e a SEAE. Todavia, apesar da manutenção da SEAE no sistema de defesa da concorrência, as suas antigas funções de instrução processual foram incorporadas ao CADE, que também absorveu todas as demais funções da antiga $\mathrm{SDE}^{94}$.

O CADE passou a ser formado por três órgãos, nomeadamente o Tribunal Administrativo de Defesa Econômica (Tribunal Administrativo), a Superintendência Geral (SG) e o Departamento de Estudos Econômicos (DEE). À SEAE, por sua vez, foi reservada função restrita de advocacia da concorrência ${ }^{95}$. O foco principal da atuação do SBDC passou de um sistema de repreensão para um sistema de prevenção, tanto pela difusão da cultura concorrencial como pela análise prévia dos atos de concentração.

trouxe nenhuma alteração material ao seu texto, pelo que os especialistas defendem que entrou em vigor no dia 29. Nesse sentido, ver ANDERS, Eduardo Caminati; PAGOTTO, Leopoldo; BAGNOLI, Vicente (coords.). Comentários à nova lei de defesa da concorrência. Rio de Janeiro: Forense; São Paulo: Método, 2012, pp. 359-360.

90 Apensado ao Projeto de Lei $n^{\circ} 3.937 / 2004$ correu o Projeto de Lei $n^{\circ} 5.877 / 2005$. Posteriormente, no Senado Federal, o projeto passou a tramitar sobre a numeração 6/2009.

${ }^{91}$ FONSECA, João Bosco Leopoldino. Lei de proteção da concorrência. 3. ed. São Paulo: Forense, 2007 , p. 62.

92 "Para além de uma simples diferença terminológica, acredita-se que a utilização do termo SBDC revele também um reconhecimento formal por parte do legislador de que os órgãos de defesa da concorrência devem formar um sistema coeso, com mecanismos de articulação institucionais bem definidos, de maneira que formem um todo coerente, e não partes desarticuladas entre si”. (ANDERS, Eduardo Caminati; PAGOTTO, Leopoldo; BAGNOLI, Vicente (coords.). Op. cit., 2012, p. 2).

${ }^{93}$ Cf. esclarece Taufick, o CADE passou a contar com uma estrutura semelhante à da FTC norte-americana. (TAUFICK, Roberto Domingos. Nova lei antitruste brasileira. Rio de Janeiro: Forense; São Paulo: Método, 2012, p. 29).

${ }^{94}$ TAUFICK, Roberto Domingos. Op. Cit., p. 27. Ademais, Anders, Pagotto e Bagnoli esclarecem que "a exclusão da SDE do SBDC, e a consequente incorporação de parte de suas funções pelo CADE, é uma tentativa clara do legislador de reduzir a dispersão de centros decisórios em diferentes órgãos, e, assim, procurar dar maior uniformidade e consistência à ideia de sistema”. (ANDERS, Eduardo Caminati; PAGOTTO, Leopoldo; BAGNOLI, Vicente (coords.). Op. cit., 2012, p. 2).

${ }^{95}$ De acordo com o art. 19 da Lei da Concorrência, compete à SEAE "promover a concorrência em órgãos do governo e perante a sociedade". De acordo com Anders, Pagotto e Bagnoli, "a função de advocacia da concorrência pelos órgãos de defesa da concorrência pode ser dividido em dois escopos diferentes. A primeira, de caráter meramente educativo, consiste na divulgação aos Poderes Executivo, Legislativo e Judiciário, agentes econômicos públicos e privados, consumidores, associações de classe e demais integrantes da sociedade, das regras e diretrizes associadas às boas práticas concorrenciais inerentes a uma economia de mercado eficiente. A segunda função, que certamente tem gerado maior controvérsia entre os especialistas [...] refere-se ao relacionamento entre os órgãos de defesa da concorrência e os formuladores/implementadores de políticas públicas”. (ANDERS, Eduardo Caminati; PAGOTTO, Leopoldo; BAGNOLI, Vicente (coords.). Op. cit., 2012, p. 74). 
Dentre as alterações inseridas no sistema da defesa da concorrência brasileira destaca-se a análise dos atos de concentração, a qual passou a ser conduzida a priori, ou seja, em momento anterior à sua concretização - diferentemente do sistema anterior. Não somente o momento de notificação dos atos de concentração foi alterado com a promulgação da Lei da Concorrência, mas os próprios requisitos de notificação, conforme se verá adiante.

\subsection{Regulamentos relevantes}

Com o objetivo de equipar-se com a estrutura e os instrumentos necessários a dar cabo às disposições da Lei da Concorrência, em março de 2012 o CADE colocou em consulta pública proposta de regimento interno e de outras resoluções complementares ao sistema de defesa da concorrência. Após discussões havidas com a sociedade, em 29 de maio de 2012 o Plenário do CADE aprovou quatro resoluções durante a 39a Sessão Extraordinária de Julgamento.

A Resolução CADE nº 1/2012 aprovou o regimento interno do CADE (RICADE). Por sua vez, a Resolução CADE n²/2012 disciplinou a notificação dos atos de concentração, estabelecendo inclusive um procedimento sumário para análise dos mencionados atos.

Já a Resolução CADE n 3/2012 expediu a lista de ramos de atividades para fins de aplicação de penalidades sobre a prática de infração da ordem econômica, e a Resolução CADE nº 4/2012 estabeleceu as recomendações para a apresentação de pareceres técnicos submetidos ao CADE, facilitando assim a interlocução nos processos.

Adicionalmente, em 30 de maio de 2012, os Ministros da Justiça e da Fazenda emitiram a Portaria Interministerial n 994/2012, que veio adequar os valores mínimos de faturamento bruto anual ou volume de negócios no país para efeitos da determinação da necessidade de submissão de atos de concentração para análise do $\mathrm{CADE}^{96}$, conforme se verá a seguir.

\footnotetext{
${ }^{96}$ Em conformidade com o permissivo legal incluído no $§ 1^{\circ}$ do art. 88 da Lei da Concorrência.
} 


\subsubsection{Atos de concentração multijurisdicionais}

A intensificação da globalização ${ }^{97}$ e as mudanças recentes na economia mundial provocaram a necessidade de o Direito da Concorrência ser estudado na sua dimensão internacional. Atos de concentração afetando mais de uma jurisdição tornaram-se recorrentes em setores como fabricação de veículos, produção de alumínio ou empresas de telecomunicação. Esses casos revelam a necessidade de as empresas promoverem a notificação de ditas concentrações multijurisdicionais perante diferentes autoridades de defesa da concorrência ${ }^{98}$.

A cooperação internacional entre autoridades de defesa da concorrência, objeto central deste estudo, é atualmente prática corriqueira nas investigações com dimensões internacionais. Até recentemente o Direito Internacional da Concorrência preocupava-se tão somente em estabelecer se determinadas legislações poderiam, ou não, estender os seus efeitos às condutas conduzidas no exterior, e se seria apropriado haver leis que limitassem de alguma forma a aplicação extraterritorial das legislações nacionais de defesa da concorrência.

Contemporaneamente, as preocupações se voltam à necessidade de uma efetiva cooperação internacional para mitigar os efeitos da extraterritorialidade e o desenvolvimento de um sistema internacional que possa endereçar as questões de política de concorrência atualmente vislumbradas ${ }^{99}$. Para que tal objetivo seja alcançado, relevante se faz uma incursão nas dimensões envolvendo o Direito Internacional da Concorrência, incluindo seus conceitos e regramentos fincados pela legislação brasileira.

\footnotetext{
97 “A globalização é um processo crescente e em contínua aceleração, desencadeado a partir dos anos 90 e facilitado pelo cenário político internacional que oportunizou uma maior inter-relação entre as nações nos campos social, político, econômico e comercial, científico, cultural e tecnológico, desenvolvendo, com isso, um cenário de encontros e desencontros em que correntes transculturais utilizam-se de um linguagem universal e desenvolvem uma mentalidade global em toda a sociedade internacional, antes adstrita aos limites territoriais de seu Estado". (MENEZES, Wagner. Ordem global e transnormatividade. Ijuí, RS: Ed. da Unijuí, 2005, pp. 104-110).

98 "Today, multinational corporations operate in increasingly international markets, yet antitrust laws regulating their competitive conduct remain national. Thus, corporations are subject to divergent antitrust regimes across the vairous jurisdictions in which they operate. This increases ransaction costs, causes unnecessary delays, and raises the likelihood of conflicting decisions". (BRADFORD, Anu. International antitrust cooperation and the preference for nonbinding regimes. Cooperation, Comity and Competition Policy. New York: Oxford University Press, 2011, p. 319).

${ }^{99}$ WHISH, Richard. Competition law. 6. ed. New York: Oxford University Press, 2009, pp. 470-471.
} 


\subsection{Conceito}

Conforme já referido anteriormente, pretende-se no presente estudo analisar a cooperação jurídica internacional em sede de atos de concentração transnacionais a partir do sistema brasileiro. Para realizar essa análise em matéria concorrencial, contudo, deve-se partir dos limites estabelecidos pela legislação nacional sobre o tema. Havendo o tema sido delimitado aos atos de concentração multijurisdicionais, busca-se um conceito do referido instituto jurídico, o qual deverá nortear toda a análise a ser seguida.

A Lei no 8.884/1994 considerava como atos de concentração, e assim deveriam ser submetidos à análise do $\mathrm{CADE}$, aqueles que, sob qualquer forma de manifestação pudessem limitar ou de alguma forma prejudicar a livre concorrência, fosse por intermédio de fusão ou de incorporação de empresas, constituição de sociedade para exercer o controle de empresas ou qualquer forma de agrupamento societário ${ }^{100}$. Tal qual a Lei $n^{\circ} 8.884 / 1994$, a Lei da Concorrência trata de regular os atos de concentração, especialmente no Capítulo I do Título VII, sem, contudo, diferenciar o controle daqueles atos de natureza ou eficácia nacional, daqueles internacionais ou multijurisdicionais.

Somente devem ser considerados atos de concentração os caracterizados pelo art. 90 da Lei da Concorrência, com a exceção trazida pelo seu parágrafo único. Desta forma, realiza-se um ato de concentração quando (i) duas ou mais sociedades anteriormente independentes se fundem; (ii) uma ou mais sociedades adquirem, direta ou indiretamente, por compra ou permuta de ações, quotas, títulos ou valores mobiliários conversíveis em ações, ou ativos, tangíveis ou intangíveis, por via contratual ou por qualquer outro meio ou forma, o controle ou partes de uma ou mais sociedades; (iii) uma ou mais sociedades incorporam outra ou outras sociedades; ou (iv) duas ou mais sociedades celebram contrato associativo, consórcio ou joint venture. São, no entanto, excluídos da definição legal de atos de concentração os contratos associativos, consórcios ou joint venture destinados às licitações promovidas pela administração pública direta e indireta e aos contratos dela decorrentes ${ }^{101}$.

O dispositivo legal mencionado relaciona hipóteses de atos de concentração, sem, contudo, trazer um conceito a que se possa basear. Por outro lado, tais dispositivos parecem indicar que o legislador brasileiro optou por um conceito amplo de atos de

\footnotetext{
${ }^{100}$ De acordo com o caput e $\S 3^{\text {o }}$ do art. 54 da Lei $n^{\circ} 8.884 / 1994$.

${ }^{101}$ De acordo com o $\S$ único do art. 90 da Lei da Concorrência e $\S 3^{\circ}$ do art. 108 do RICADE.
} 
concentração, o qual abrange tanto os atos de concentração em sentido estrito, como os atos de cooperação empresarial ${ }^{102}$.

Nessa leitura, os atos de concentração em sentido estrito abrangem aquelas operações em que ao menos um dos agentes envolvidos deixa de ser independente nas suas atividades. Assim, as sociedades envolvidas passam a ser consideradas como um único agente econômico, submetidas apenas a um centro de decisão ou entidade com poder de controle. Nestes casos há uma alteração estrutural duradoura nas sociedades envolvidas na concentração, passível de se pressupor uma uniformidade econômica ${ }^{103}$. As concentrações empresariais podem ser classificadas em três categorias, a saber, concentrações horizontais, concentrações verticais e conglomerados ${ }^{104}$.

Já os atos de cooperação empresarial englobam formas de uniformização de comportamentos ou realização de atividade conjunta, geralmente materializados por meio de instrumentos contratuais, pelos quais os agentes econômicos não integram totalmente as suas atividades, não interferindo, assim, na autonomia dos agentes. Tratam, exemplificativamente, de casos como contratos de associação de empresas, joint ventures e consórcios. Interessante notar que a Lei da Concorrência trouxe um sistema mais brando em razão dos acordos de cooperação, principalmente em relação aos acordos de exclusividade, que no bojo normativo da antiga legislação de defesa da concorrência deviam ser submetidos à análise do CADE, e que pela nova legislação deixam de ser considerados atos de concentração de notificação obrigatória, passando a ser inseridos no âmbito de controle repressivo da agência no âmbito de condutas anticoncorrenciais ${ }^{105}$.

Note-se que não estão compreendidos na concepção de atos de concentração em sentido amplo aqueles que levam um determinado agente econômico a adquirir poder no mercado em decorrência do crescimento interno, ou seja, a aquisição pelo agente de maior

\footnotetext{
${ }^{102}$ Salomão Filho diferencia os atos de concentração empresarial dos de cooperação, os quais se diferenciam por prejudicar, ou não, a autonomia das partes envolvidas no ato. Nesse sentido, o autor nota que o legislador de 1994 parece ter se inspirado no Direito da U.E. ao incluir entre as formas de operações passíveis de controle pela autoridade da concorrência os atos de cooperação empresarial. (SALOMÃO FILHO, Calixto. Direito Concorrencial - as estruturas. 3. ed. São Paulo: Malheiros, 2007, pp. 267-347).

103 "'A existência dessa 'mudança estrutural duradoura' é bastante evidente nos casos de fusão e incorporação. Nesses dois casos, a união dos empreendimentos, mais do que econômica, é também física e jurídica". (SALOMÃO FILHO, Calixto. Op. cit., 2007, pp. 267-295).

${ }^{104}$ Enquanto a concentração horizontal é aquela que se dá entre agentes econômicos concorrentes (mesmo mercado relevante de produto e geográfico), as concentrações verticais são aquelas que envolvem agentes que exercem atividades em diferentes estágios de uma mesma indústria, mantendo relações de comprador/vendedor ou tomador/prestador de serviço. Já os conglomerados tratam das hipóteses de concentração econômica entre agentes que não atuam numa mesma indústria, não mantendo relação comercial entre si. (SALOMÃO FILHO, Calixto. Op. cit., 2007, p. 300).

${ }^{105}$ TAUFICK, Roberto Domingos. Nova lei antitruste brasileira. Rio de Janeiro: Forense; São Paulo: Método, 2012, p. 460.
} 
eficiência independentemente de repartição dos ganhos de eficiência com os consumidores. Também não devem ser considerados aqueles atos realizados por entidades incluídas num mesmo grupo econômico, conhecidas como operações intragrupo, uma vez que não ocasionam a mudança estrutural do mercado, refletindo apenas a organização das entidades que fazem parte de tal grupo ${ }^{106}$.

Por multijurisdicionais entende-se aqueles atos de concentração que envolvem ou influenciam mais de uma jurisdição, seja pela localização das partes ou grupos econômicos envolvidos na operação em diferentes territórios, seja pelos efeitos que podem ser sentidos nos mercados de mais de um país. Os atos de concentração multijurisdicionais são, portanto, aqueles que evocam a aplicação de mais de um conjunto normativo estatal e, assim, devem ser estruturados e coordenados com diversas autoridades de defesa da concorrência.

A opção pela terminologia "multijurisdicionais", no entanto, não foi de fácil decisão, uma vez que os juristas por vezes adotam outros termos para caracterizar os atos que se pretende descrever - tais como "transnacionais" ou "transfronteiriços". Descarta-se a utilização da terminologia "transnacionais", na medida em que esta parece indicar uma situação de supremacia dos atos em questão em relação às diversas legislações nacionais de defesa da concorrência que regulam a realização de ditos atos. De fato, a alocação de um ato promovido geralmente por entidades de direito privado sobre as normas econômicas, ou seja, de natureza pública e imperativa, das diversas jurisdições mostra-se um contrassenso da razoabilidade que se espera do jurista preocupado com a técnica de caracterização dos institutos legais.

Por outro lado, a definição do termo "transfronteiriço", segundo a língua portuguesa, relaciona-se àqueles atos e fatos transfronteiriços, ou seja, que têm lugar nos territórios imediatamente contíguos de diferentes territórios. A opção por este termo, portanto, acarretaria a restrição da análise do fenômeno que ora se pretende dirigir aos atos de concentração realizados por agentes econômicos sediados em localidades próximas às fronteiras dos respectivos territórios. Estes, por sua vez, deveriam ser contíguos no espaço, ou que fizessem surtir seus efeitos limitadamente a tais localidades ${ }^{107}$.

\footnotetext{
106 ANDERS, Eduardo Caminati; PAGOTTO, Leopoldo; BAGNOLI, Vicente (coords.). Comentários à nova Lei de Defesa da Concorrência. Rio de Janeiro: Forense; São Paulo: Método, 2012, pp. 293-302.

107 O problema enfrentado com o termo "transfronteiriços" na língua portuguesa parece não ser sentido em outros idiomas, como no caso da língua inglesa em que, a terminologia cross borders, adotada por parte da doutrina, atende aos fins pretendidos no conceito em construção, sem a limitação apontada em relação aos espaços de territórios nacionais contíguos.
} 
Opta-se assim, pela terminologia "multijurisdicionais" que parece bem indicar as múltiplas jurisdições envolvidas num único ato de concentração executado ou pretendido por agente econômico privado. Essa tem sido a escolha de parte da doutrina internacional especializada em enfrentar as questões concernentes aos atos de concentrações multijurisdicionais ${ }^{108}$, que coaduna com as vicissitudes do idioma português.

Desta forma, entende-se por atos de concentração multijurisdicionais aqueles em sentido estrito ou de cooperação empresarial, excluídas as hipóteses de obtenção de poder de mercado em função crescimento interno e operações realizadas intragrupo, que sejam realizados por entidades localizadas em diferentes jurisdições ou que façam surtir os seus efeitos em mais de uma jurisdição, mesmo quando sediadas num único território.

\subsection{A análise dos atos de concentração pelo SBDC}

No sistema anterior da Lei $n^{\circ} 8.884 / 1994$, os requerentes nos procedimentos de aprovação de atos de concentração eram instruídos a notificar as autoridades de defesa da concorrência no prazo de 15 dias contados da celebração do primeiro instrumento vinculativo da operação ${ }^{109}$. Isso fazia com que, frequentemente as partes envolvidas numa concentração econômica tratassem de consumar a operação antes de obtida a aprovação do CADE, dificultando a possibilidade de retornar ao status quo ante da concorrência no mercado relevante, nos casos em que a agência decidia finalmente pela não aprovação do ato ou pela aprovação com restrições ${ }^{110}$. Essa situação causava grande insegurança ao

${ }^{108}$ Exemplificativamente, ver BOTTA, Marco. Multi-jurisdiction mergers and acquisitions in an era of globalization: the Telecom Italia-Telefônica case. Global Antitrust Review. Issue 1, 2008, pp. 97-116; BOTTA, Marco. The cooperation between the Competition Authorities of the developing countries: why does it not work? Case study on Argentina and Brazil. The competition law review. Issue 2, jul. 2009, v. V, pp. 153-178; GALLOWAY, Jonathan. Convergence in international merger control. The competition law review. Issue 2, jul. 2009, v. V, pp. 179-192; TOKESHI, Helcio; MONTEIRO, Carmen Diva. Worldwide mergers: a brazilian perpective. Competition law international, out. 2005, bem como diversos dos working papers utilizados no âmbito da OCDE e ICN, como por exemplo, INTERNATIONAL COMPETITION NETWORK. International Competition Network's Framework for Merger Review Cooperation. Japan Fair Trade Commission, mar. 2012. Disponível em: <http://www.jftc.go.jp/en/policy_enforcement/speeches/ pdf/1Framework\%20for\%20Merger\%20Review\%20Cooperation.pdf >. Acesso em: $01 \mathrm{dez} .2012$.

${ }^{109} \mathrm{O} \S 4^{\circ}$ do art. 54 da Lei ${ }^{\circ} 8.884 / 1994$ estabelecia um prazo de 15 dias úteis contados da realização do ato para que as partes apresentassem a notificação ao SDE, o qual a distribuiria dentre o SEAE e o CADE. A interpretação desta disposição pelo CADE era no sentido de contar o prazo legalmente estipulado a partir da data de celebração do primeiro acordo ou contrato vinculativo relativo à concentração pretendida, sendo irrelevante se tal contrato fosse, ou não, o definitivo.

110 A doutrina era unânime ao destacar os benefícios de um modelo de revisão prévio dos atos de concentração. Nesse sentido, ver Tokeshi e Monteiro: "The fact that Brazil has a post-merger review system rather than a pre-merger system has had an important influence on both the procedure and substance of merger control in Brazil, affecting substantive remedies in the merger process. Given that a merger can go through before a final decision has been giving by CADE, the merging parties lack the strong incentive to complete the process quickly that results from a pre-merger review system. It is also more difficult for CADE 
mercado e, muitas vezes, possibilitava que danos à concorrência, aos consumidos ou aos competidores se revelassem irreversíveis ${ }^{111}$.

A Lei da Concorrência veio alterar o momento de submissão dos atos de concentração para análise pelo $\mathrm{CADE}$, transitando para um modelo de análise prévia à consumação do ato ${ }^{112}$. O requerimento para análise de concentração passou a ser exigido preferencialmente após a assinatura do instrumento formal que vincule as partes e antes de consumado qualquer ato relativo à operação. A agência dispõe do prazo legal de 240 dias a contar da submissão da operação para decidir sobre o requerimento apresentado ${ }^{113}$. A alteração do momento de notificação dos atos de concentração ao CADE segue orientação da $\mathrm{OCDE}^{114}$, expressa no bojo do processo de revisão da legislação e da política de concorrência pelos pares.

As partes envolvidas no ato de concentração devem manter as estruturas físicas e as condições competitivas inalteradas até a decisão final do $\mathrm{CADE}^{115}$. Na eventualidade de ser consumado ato de concentração que, nos termos da lei, deveria ter sido submetido ao

to prohibit a transaction entirely, since this would require undoing a merger that has been fully implemented. [...]. A more permanent solution, the adoption of pre-merger control, is one of the main improvements being proposed to Law n. 8.884/94 in the bill that the government finalized and is currently in Congress". (TOKESHI, Helcio; MONTEIRO, Carmen Diva. Worldwide mergers: a brazilian perpective. Competition law international, out. 2005, p. 27).

${ }_{111}$ Em decorrência da opção legislativa adotada pela Lei nº 8.884/1994 de viabilizar o controle da concentração após a sua realização, e ante a possibilidade de um ato não se demonstrar mais reversível à época do julgamento pelo CADE, na hipótese de haver uma decisão negativa, foi editada a Resolução CADE $\mathrm{n}^{\mathbf{0}} 28$, de 24 de junho de 2002, que previa instrumentos que podiam garantir a reversibilidade das operações, nomeadamente as Medidas Cautelares e os Acordos de Preservação da Reversibilidade das Operações (APRO).

${ }^{112}$ De acordo com os $\$ \S 2^{\circ}$ e $3^{\circ}$ do art. 88 da Lei da Concorrência e art. 108 do RICADE.

${ }^{113}$ De acordo com os $\$ \S 2^{\circ}$ e $9^{\circ}$ do art. 88 da Lei da Concorrência, esse prazo poderá ser dilatado (i) por até 60 dias, improrrogáveis, mediante requerimento das partes envolvidas na operação; e (ii) por até 90 dias, não renovável, mediante decisão fundamentada do Tribunal Administrativo. Taufick destaca que "a estipulação de prazos preclusivos e da previsão de não interrupção ou suspensão do art. 63 foi o principal mecanismo criado pelo legislador para evitar que a análise prévia incrementasse o risco Brasil". (TAUFICK, Roberto Domingos. Nova lei antitruste brasileira. Rio de Janeiro: Forense; São Paulo: Método, 2012, p. 428).

114 "A ausência de notificação prévia tem implicações importantes tanto para o procedimento como para a substância da análise de fusões no Brasil. Um efeito procedimental é o aumento do tempo de análise das fusões. [...] Da mesma forma, como as partes de uma fusão são autorizadas a consumar a operação antes que a análise seja concluída (na ausência de uma medida preventiva, discutida mais a frente), falta-lhes incentivo para acelerar o processo. O resultado é que as partes podem ser menos sensíveis às solicitações de informação por parte do SBDC. [...] Substantivamente, a consumação da transação pode afetar os remédios disponíveis ao CADE caso este verifique que o ato de concentração é ilegal. Especificamente, a capacidade do CADE de proibir inteiramente uma operação é, neste caso, dificultada, por ter de determinar o desfazimento de uma fusão consumada, uma tarefa sobremaneira complexa". (ORGANIZAÇÃO PARA A COOPERAÇÃO E DESENVOLVIMENTO ECONÔMICO. IDB - Inter- american Development Bank. Lei e política de concorrência no Brasil: uma revisão pelos pares. Paris: OCDE, 2010, pp. 33-34. Disponível em: 〈http://www.oecd.org/ daf/competition/45154401.pdf〉. Acesso em: 11 ago. 2012).

${ }^{115}$ Consoante o $\S 1^{\circ}$ do art. 108 do RICADE estão "vedadas, inclusive, quaisquer transferências de ativos e qualquer tipo de influência de uma parte sobre a outra, bem como a troca de informações concorrencialmente sensíveis que não seja estritamente necessária para a celebração do instrumento formal que vincule as partes". 
controle pelo CADE, sem que tenha sido obtida a necessária aprovação prévia, os mesmos estarão sujeitos à nulidade e as partes envolvidas poderão sujeitar-se à aplicação de multa pecuniária $^{116}$ - sem prejuízo de ser iniciado procedimento administrativo para apuração do ato. Ademais, até a decisão final do $\mathrm{CADE}$, as partes envolvidas no ato deverão preservar as condições de concorrência no mercado envolvido, sob pena de aplicação das mencionadas sanções.

Os atos de concentração que (i) impliquem na eliminação da concorrência em parte substancial de mercado relevante; (ii) possam criar ou reforçar posição dominante; ou (iii) possam resultar na dominação de mercado relevante de bens ou serviços, serão, em regra, rejeitados durante o procedimento de controle da concentração pelo $\mathrm{CADE}^{117}$.

Dentre os procedimentos administrativos regulados pela Lei da Concorrência estão os de análise e de apuração de atos de concentração econômica ${ }^{118}$, os quais possuem prioridade sobre o julgamento dos procedimentos que versam sobre outras matérias ${ }^{119}$. Enquanto o procedimento de análise de ato de concentração trata dos casos em que as partes submetem, nos termos legais, o ato para aprovação pelo CADE em momento anterior à sua consumação, o procedimento de apuração de ato de contratação trata do procedimento que pode ser iniciado pelo CADE para revelar se determinado ato consumado sem a prévia aprovação da agência, na realidade deveria ter sido objeto do controle prévio $^{120}$.

A Lei da Concorrência previu, ainda, que o CADE deveria regulamentar os procedimentos a serem seguidos para a análise prévia de atos de concentração com o propósito específico de participação de leilões, licitações e operações de aquisição de ações

\footnotetext{
${ }^{116}$ As multas serão fixadas em montante não inferior a $\mathrm{R} \$ 60.000,00$, nem superior a $\mathrm{R} \$ 60.000 .000,00$, de acordo com o $\S 3^{\circ}$ do art. 88 da Lei da Concorrência e art. 112 do RICADE.

${ }^{117}$ A Lei da Concorrência estabelece no $\S 6^{\circ}$ do seu art. 88 algumas exceções à proibição legal descrita, as quais incluem aqueles atos em que seja repassado aos consumidores parte relevante dos benefícios decorrentes da concentração e aqueles que aumentarem a produtividade ou a competitividade; melhorarem a qualidade de bens ou serviços ou propiciarem a eficiência e o desenvolvimento tecnológico ou econômico.

${ }^{118}$ De acordo com o art. 48, incisos IV e V da Lei da Concorrência, respectivamente.

${ }^{119}$ De acordo com o art. 89 do RICADE.

${ }^{120} \mathrm{O} \S 3^{\circ}$ do art. 112 do RICADE estabelece que o procedimento para apuração de ato de concentração será convertido em procedimento para análise de ato de concentração, sem prejuízo de serem aplicadas as multas cabíveis. Para maiores informações sobre o procedimento de apuração, ver art. 113 do RICADE. Para garantir que o CADE tenha acesso a informações das operações societárias consumadas, a Lei da Concorrência, no $\S 8^{\circ}$ do seu art. 88, estabeleceu a obrigação da Comissão de Valores Mobiliários (CVM) e do Departamento Nacional de Registro do Comércio do Ministério do Desenvolvimento, Indústria e Comércio Exterior (DNRC) de lhe comunicar sobre mudanças de controle acionário de companhias abertas e sobre os registros de fusão. Ademais, o $\S 7^{\circ}$ do art. 108 do RICADE estabeleceu a disponibilização de um canal para que quaisquer interessados se manifestem sobre operações que venham a ser consumadas sem a devida autorização prévia do CADE.
} 
por meio de oferta pública ${ }^{121}$. O RICADE veio estabelecer, nesse sentido, que as ofertas públicas de ações podem ser notificadas ao CADE a partir da sua publicação, independendo da aprovação prévia da agência para que sejam consumadas ${ }^{122}$.

Em vista dos objetivos do presente estudo, este se concentra nas regras e procedimentos associados à análise pela agência de defesa da concorrência dos atos de concentração em geral, para o qual a Resolução CADE $n^{\circ}$ 2/2012 estabeleceu dois ritos de análise: o sumário e o não sumário. A regra quanto ao rito a ser seguido na análise dos atos de concentração é o rito não sumário, sendo possível adotar o rito sumário somente nos casos em que, em razão da simplicidade das operações, haja um menor potencial ofensivo à concorrência ${ }^{123}$.

Os requerimentos para análise de atos de concentração são recebidos e instruídos pela $\mathrm{SG}^{124}$, a qual poderá aprovar os atos de concentração que lhe são submetidos (i) nos casos de menor potencial ofensivo à concorrência, previstos na forma de procedimento sumário da Resolução CADE no 2/2012, nos quais a sua decisão é proferida logo após a recepção do requerimento, sem a necessidade de promoção de instrução ${ }^{125}$; ou (ii) após realizada a instrução processual, inclusive nos casos declarados como complexos em que se exija instrução complementar, podendo a aprovação ocorrer sem restrições ${ }^{126}$.

Em relação à instrução do procedimento, note-se que dentre as funções atribuídas ao DEE inclui-se a elaboração de estudos e pareceres econômicos, de ofício ou por

\footnotetext{
${ }^{121}$ De acordo com o $§$ único do art. 89 da Lei da Concorrência.

$122 \mathrm{O}$ assunto está regulado pelo art. 109 do RICADE, em que consta que o exercício dos direitos políticos adquiridos em razão de oferta pública de ações depende da obtenção de decisão favorável do CADE para o ato de concentração.

${ }^{123}$ De acordo com o art. $8^{\circ}$ da Resolução CADE n 2/2012 são enquadráveis nessa hipótese as seguintes operações: (i) joint ventures clássicas ou cooperativas: casos de associação de duas ou mais empresas separadas para a formação de nova empresa, sob controle comum, que visa única e exclusivamente à participação em um mercado cujos produtos/serviços não estejam horizontal ou verticalmente relacionados; (ii) consolidação de controle: as aquisições de participação societária realizadas pelo controlador quando a participação direta ou indiretamente adquirida, de pelo menos um vendedor considerado individualmente, chegue a ser igual ou superior a $20 \%$ do capital social ou votante; (iii) substituição de agente econômico: situações em que a empresa adquirente ou seu grupo não participava, antes do ato, do mercado envolvido, ou dos mercados verticalmente relacionados e, tampouco, de outros mercados nos quais atuava a adquirida ou seu grupo; (iv) baixa participação de mercado com sobreposição horizontal: as situações em que a operação gerar o controle de parcela do mercado relevante comprovadamente abaixo de $20 \%$, a critério da SG, de forma a não deixar dúvidas quanto à irrelevância da operação do ponto de vista concorrencial; (v) baixa participação de mercado com integração vertical: as situações em que a empresa adquirente ou seu grupo não detinham, comprovadamente, participação superior a $20 \%$ nos mercados relevantes verticalmente integrados, antes da operação; e (vi) outros casos em que, apesar de não abrangidos pelas categorias anteriores, forem considerados simples o suficiente, a critério da SG, a ponto de não merecerem uma análise mais aprofundada. ${ }^{124}$ De acordo com os arts. 13, inciso XII, e 53 da Lei da Concorrência e art. 24, XIII do RICADE. Ademais, a SG poderá determinar por uma única vez que os requerentes emendem a petição que não preencha os requisitos estabelecidos por lei ou apresentem defeitos ou irregularidades que possam dificultar o julgamento. ${ }^{125}$ De acordo com o art. 119, inciso I do RICADE e arts. $5^{\circ}$ a $8^{\circ}$ da Resolução CADE nº 2/2012.

${ }^{126}$ De acordo com o art. 121, inciso I do RICADE.
} 
solicitação do Tribunal Administrativo ou $\mathrm{SG}^{127}$. Ademais, nessa esteira, a Procuradoria Federal Especializada que funciona junto ao CADE (ProCADE) possui competência para tomar as medidas judiciais solicitadas pelo Tribunal Administrativo ou pela SG com vistas à obtenção de documentos para instrução de procedimentos administrativos de qualquer natureza $^{128}$.

Da decisão da SG que aprovar o ato de concentração, (i) caberá recurso ao Tribunal Administrativo, a ser interposto por terceiros interessados ou pela agência reguladora do mercado envolvido; ou (ii) o próprio Tribunal Administrativo poderá avocar o procedimento para julgamento, mediante decisão fundamentada de um dos seus Conselheiros $^{129}$. Em relação à decisão da SG que aprovar o ato de concentração, a consumação do ato poderá ter lugar, portanto, somente após decorrido o prazo de recurso ou para a avocação, hipóteses em que a execução do ato restará suspensa. Adicionalmente, nos casos em que a SG entender que o ato deva ser rejeitado, aprovado com restrições ou em que não existam elementos conclusivos quanto aos seus efeitos no mercado, a sua decisão será na forma de impugnação do ato perante o Tribunal Administrativo ${ }^{130}$.

O requerente do procedimento administrativo poderá apresentar ao Tribunal Administrativo as razões de fato e de direito com que se opõe à impugnação da SG ou ao recurso interposto ${ }^{131}$, juntando provas, estudos e pareceres que suportem suas alegações. Após distribuição do procedimento a um Conselheiro-Relator ${ }^{132}$, este poderá (i) autorizar precária e liminarmente a realização do ato, impondo restrições que visem à reversibilidade da operação ${ }^{133}$; (ii) determinar que seja realizada instrução complementar; ou (iii) decidir pela inclusão do procedimento em pauta para julgamento pelo Tribunal Administrativo ${ }^{134}$.

\footnotetext{
${ }^{127}$ De acordo com o art. 17 da Lei da Concorrência e art. 31, inciso I do RICADE.

${ }^{128}$ De acordo com o art. 15, inciso V da Lei da Concorrência e art. 28, inciso V do RICADE.

${ }^{129}$ Enquanto pender o julgamento do recurso perante o Tribunal Administrativo, ou análise do ato em razão da análise do mesmo ter sido avocada, resta suspensa a execução do ato de concentração nos termos do $\S 4^{\circ}$, art. 65 da Lei da Concorrência.

${ }^{130}$ Os arts. 53 a 57 da Lei da Concorrência e arts. 119 a 121 e 123 do RICADE estabelecem o procedimento para a condução da análise de concentração no bojo da SG.

${ }^{131}$ Nos casos de recurso apresentado por terceiro interessado ou agência regulatória, o Conselheiro-Relator poderá simplesmente não conhecer o recurso, determinando o seu arquivamento. Se for configurada litigância de má-fé, poderá ser aplicada multa, nos valores estabelecidos pelo $\S 3^{\circ}$ do art. 65 da Lei da Concorrência, a qual será revertida ao Fundo de Defesa de Direito Difusos.

${ }^{132}$ Nos casos em que o Tribunal Administrativo avocar a análise de caso objeto de decisão favorável da SG, o Conselheiro que provocou a análise do tribunal restará prevento para julgar o ato de concentração, de acordo com o art. 65, inciso II da Lei da Concorrência.

${ }^{133}$ A autorização precária e liminar para a realização de ato de concentração econômica é regulada pelos arts. 115 a 117 do RICADE, o qual determina que tal medida poderá ser concedida somente se não houver perigo de dano irreparável às condições de concorrência do mercado, se as medidas forem integralmente reversíveis e se o requerente demonstrar a iminente ocorrência de prejuízos financeiros substanciais e irreversíveis para a sociedade adquirida, caso a autorização precária não venha a ser concedida. No caso de deferido o pedido de
} 
Ao Plenário do Tribunal Administrativo cabe a apreciação dos processos administrativos de atos de concentração econômica impugnados pela $\mathrm{SG}^{135}$, podendo decidir pela aprovação, rejeição ou aprovação parcial do ato. Nos casos de aprovação parcial, o Tribunal Administrativo deverá determinar as restrições que deverão ser observadas como condição de validade ou eficácia do ato, com o objetivo de mitigar os eventuais efeitos nocivos sobre os mercados relevantes afetados ${ }^{136}$.

Adicionalmente, o CADE poderá celebrar Acordo em Controle de Concentrações $(\mathrm{ACC})^{137}$, por proposição do requerente desde a notificação do ato de concentração até o limite de 30 dias contados da data de impugnação pela SG, sem prejuízo da análise do mérito da operação. Apesar de eventualmente serem negociados pela SG, os ACC devem ser aprovados pelo Tribunal Administrativo.

A decisão do Tribunal Administrativo é definitiva no âmbito do Poder Executivo, cabendo apenas a interposição de embargos declaratórios e pedido de reapreciação nos termos do $\operatorname{RICADE}^{138}$. Da decisão final do CADE, no entanto, não cabe recurso, sendo vedada a nova submissão do ato para sua análise ${ }^{139}$, tampouco a revisão pelo Poder Judiciário $^{140}$. A exceção está nos casos de aprovação do ato de concentração, cuja decisão poderá ser revista pelo Tribunal Administrativo, se a decisão tiver sido baseada em

autorização liminar, o CADE poderá determinar medidas que visem à reversibilidade da operação, as quais deverão ser observadas pela requerente sob pena de multa e demais providências cabíveis.

${ }^{134}$ De acordo com o art. 59 e 60 da Lei da Concorrência e art. 127 do RICADE.

${ }^{135} \mathrm{De}$ acordo com o art. $9^{\circ}$, inciso X da Lei da Concorrência e art. $9^{\circ}$, inciso X do RICADE. A regulação completa do procedimento a ser seguido perante o Tribunal Administrativo consta nos arts. 58 a 63 da Lei da Concorrência.

${ }^{136}$ As restrições, também referidas por vezes como remedies ou remédios, podem, de acordo com o $\S 2^{\circ}$ do art. 61 da Lei da Concorrência, incluir: (i) a venda de ativos ou de conjunto de ativos que constituam uma atividade empresarial; (ii) a cisão da sociedade; (iii) a alienação de controle societário; (iv) a separação contábil ou jurídica de atividades; (v) o licenciamento compulsório de direito de propriedade intelectual; e (vi) qualquer outro ato ou providência que sejam necessários para a eliminação dos efeitos nocivos à ordem econômica. Para um exemplo da aplicação de remédios, ver o caso de concentração Kolynos/Colgate (Ato de Concentração n ${ }^{\circ}$ 27/1995), no qual o CADE determinou a alienação da marca Kolynos. As restrições, ou remédios, tratam, portanto, de hipóteses de reparação em prol da concorrência, que podem ser utilizadas para mitigar os efeitos de atos de concentração, os quais, de outra forma, prejudicariam o mercado, sem, no entanto, inviabilizar a operação econômica pretendida pelas partes.

${ }^{137}$ De acordo com o art. 125 do RICADE.

${ }^{138}$ De acordo com os arts. 100 e 211 a 219 do RICADE. Ademais, os embargos de declaração, propostos com o objetivo de esclarecer pontos obscuros, contraditórios ou omissos da decisão do Tribunal Administrativo, interrompem o prazo para interposição da reapreciação e suspendem a execução do julgado. O pedido de reapreciação, por sua vez, é restrito à hipótese de apresentação de informação ou documento novo, capaz por si só de assegurar pronunciamento mais favorável do CADE e não suspender a execução da decisão atacada.

${ }^{139}$ Um ato de concentração somente poderá ser reapresentado para análise pelo CADE no caso descrito pelo art. 129 do RICADE, ou seja, no caso de recusa, omissão, engano, falsidade ou retardamento injustificado por parte dos requerentes que levarem à rejeição do pedido de aprovação.

${ }^{140}$ De acordo com o $\S 3^{\circ}$ do art. 61 da Lei da Concorrência e $\S$ único do art. 128 do RICADE. 
informações falsas ou enganosas prestadas pelo interessado, se as obrigações assumidas forem descumpridas ou se os benefícios visados não forem alcançados ${ }^{141}$.

a) Caracterização e critérios para submissão

O primeiro elemento a ser considerado na identificação das operações que devem ser submetidas à análise pelo CADE está na caracterização da operação pretendida como um ato de concentração econômica. Conforme já mencionado, a Lei da Concorrência define como ato de concentração as seguintes hipóteses: (i) a fusão de duas ou mais sociedades anteriormente independentes; (ii) a aquisição, direta ou indireta, por uma ou mais sociedades, por compra ou permuta de ações, quotas, títulos ou valores mobiliários conversíveis em ações, ou ativos, tangíveis ou intangíveis, por via contratual ou por qualquer outro meio ou forma, do controle ou partes de uma ou outras sociedades; (iii) a incorporação por uma ou mais sociedades de outra ou outras sociedades; ou (iv) a celebração por duas ou mais sociedades de contrato associativo, consórcio ou joint venture $^{142}$.

Em relação ao item (ii) acima, a Resolução CADE no 2/2012 esclarece que devem ser submetidas a este Conselho as operações que (ii.a) acarretem aquisição de controle; (ii.b) não acarretem aquisição de controle, mas preencham as regras de minimis abaixo descritas; ou (ii.c) sejam realizadas pelo controlador quando a participação direta ou indiretamente adquirida, de pelo menos um vendedor considerado individualmente, chegue a ser igual ou superior a $20 \%$ do capital social ou votante ${ }^{143}$.

As regras de minimis acima mencionadas determinam que são de notificação obrigatória aquelas aquisições de sociedade ou sociedades, no todo ou em parte, que confiram ao adquirente o status de maior investidor individual, ou que (i) no caso de sociedade investida não concorrente que não atue em mercado vertical relacionado ao do adquirente (i.a) o adquirente passe a deter titularidade direta ou indireta de $20 \%$ ou mais do capital social ou votante da sociedade investida; ou (i.b) o adquirente que já possua $20 \%$ ou mais do capital social ou votante adquira participação direta ou indireta de vendedor

\footnotetext{
${ }^{141}$ De acordo com o art. 91 da Lei da Concorrência e art. 134 do RICADE. Ainda, de acordo com o $§$ único do mencionado dispositivo legal, a parte que der causa à falsidade ou engano poderá sujeitar-se à multa pecuniária em valor a ser estabelecido entre $\mathrm{R} \$ 60.000,00$ e $\mathrm{R} \$ 6.000 .000,00$, sem prejuízo de outras medidas cabíveis.

${ }^{142}$ De acordo com o art. 90 da Lei da Concorrência, e $\$ 3^{\circ}$ do art. 108 do RICADE. Ademais, são excluídos da definição legal de atos de concentração os contratos associativos, consórcios ou joint ventures destinados às licitações promovidas pela administração pública direta e indireta e aos contratos dela decorrentes.
} 
individual em proporção igual ou superior a $20 \%$ do capital social ou votante; ou (ii) no caso em que a sociedade investida seja concorrente ou atue em mercado vertical relacionado ao do adquirente (ii.a) o adquirente passe a deter titularidade direta ou indireta de $5 \%$ ou mais do capital social ou votante da sociedade investida; ou (ii.b) o adquirente que já possua $5 \%$ ou mais do capital social ou votante incremente sua participação, individualmente ou somada com aquisições anteriores, em proporção equivalente ou superior a $5 \%$ do capital social ou votante $\mathrm{e}^{144}$.

Além de identificar as espécies de operações que devem ser submetidas à análise prévia pelas autoridades de defesa da concorrência, as legislações de defesa da concorrência usualmente estabelecem outros elementos a serem considerados como critérios balizadores complementares. Nessa esteira, a Lei $n^{\circ}$ 8.884/1994 estabelecia como elementos determinantes da submissão de ato de concentração ao controle do CADE a participação de empresa ou grupo de empresas resultante de $20 \%$ de um mercado relevante, ou em que qualquer dos participantes tivesse registrado faturamento bruto anual no último balanço equivalente a $\mathrm{R} \$ 400.000 .000,00^{145}$.

A Lei da Concorrência, no entanto, eliminou o requesito de participação em mercado relevante previsto na legislação anterior ${ }^{146}$, que muitas vezes se revelava de difícil determinação, garantindo, assim, maior previsibilidade sobre os atos que devem ser submetidos ao controle pelo CADE. Desta forma, os elementos para submissão restringemse, desde a entrada em vigor da nova legislação, à verificação do faturamento bruto ou volume total de negócios no país ${ }^{147}$ das partes envolvidas na concentração pretendida.

\footnotetext{
${ }^{143}$ De acordo com os arts. $9^{\circ}$ e 11 da Resolução CADE nº 2/2012.

144 De acordo com o art. 10 da Resolução CADE $n^{\circ} 2 / 2012$. Ainda, de acordo com o $\S$ único deste dispositivo, para o enquadramento nas hipóteses descritas deve-se considerar as atividades de todas as sociedades do grupo econômico adquirente.

${ }^{145}$ Em relação ao segundo requisito - valor de faturamento bruto anual - note-se que o CADE interpretava em algumas das suas decisões que o faturamento a ser considerado seria o mundial, ou seja, abarcando todas as suas atividades internacionais do grupo econômico. Todavia, a Súmula $n^{\circ} 1 / 2005$ do CADE eliminou a discussão, ao decretar que o critério de $\mathrm{R} \$ 400.000 .000,00$ somente seria aplicável ao faturamento obtido no Brasil.

${ }^{146}$ Anders, Pagotto e Bagnoli esclarecem que a opção pela eliminação do critério de participação de mercado ocorreu com o objetivo de atender às recomendações feitas por pares e estudos da OCDE, que o consideravam o fundamento de incertezas e insegurança jurídica no sistema concorrencial. (ANDERS, Eduardo Caminati; PAGOTTO, Leopoldo; BAGNOLI, Vicente (coords.). Comentários à nova lei de defesa da concorrência. Rio de Janeiro: Forense; São Paulo: Método, 2012, p. 276).

147 "Referida lei introduz nesse artigo o conceito de 'volume de negócios', inexistente na lei anterior. Diante da ausência de uma definição técnica que possa ser atribuída a este termo, cria-se novo grau de incerteza em relação à base de cálculo do critério de submissão de atos de concentração. Poder-se-ia assumir que o legislador pretendeu, com isso, aferir, por exemplo, não somente o faturamento bruto registrado pelas empresas no País, como também o volume de negócios advindos de exportações ao mercado local, ou valores de seus ativos no País". (ANDERS, Eduardo Caminati; PAGOTTO, Leopoldo; BAGNOLI, Vicente (coords.). Op. cit., 2012, p. 279).
} 
Pela nova regulamentação devem ser submetidos para apreciação prévia pelo CADE os atos de concentração econômica em que, cumulativamente (i) pelo menos um dos grupos envolvidos na operação tenha registrado, no último balanço, faturamento bruto anual ou volume de negócios total no território brasileiro, no ano anterior à operação pretendida, igual ou superior a $\mathrm{R} \$ 750.000 .000,00$; e (ii) pelo menos um outro grupo envolvido na operação tenha registrado, no último balanço, faturamento bruto anual ou volume de negócios total no território brasileiro, no ano anterior à operação pretendida, igual ou superior a $\mathrm{R} \$ 75.000 .000,00^{148}$.

A Resolução CADE no 2/2012 estabelece que devem ser consideradas como grupo econômico, para a finalidade de cálculo dos faturamentos previstos na Lei da Concorrência e para a elaboração do requerimento de submissão do ato de contração para análise pela agência, as sociedades (i) que estejam sob controle comum, interno ou externo; e (ii) nas quais qualquer das sociedades sob controle comum seja titular, direta ou indiretamente, de pelo menos $20 \%$ do capital social votante ${ }^{149}$. Já nos casos de fundos de investimento, a mesma regulamentação determina que se deve considerar como parte integrante do grupo econômico (i) os fundos que estejam sob a mesma gestão; (ii) o gestor; (iii) os cotistas que detenham direta ou indiretamente $20 \%$ das cotas de pelo um dos fundos que se encontrem sob a mesma gestão; e (iv) as sociedades integrantes do portfólio dos fundos em que a participação direta ou indiretamente detida pelo fundo seja igual ou superior a $20 \%$ do capital social votante ${ }^{150}$.

Por fim, a Lei da Concorrência estabeleceu a faculdade de o CADE requerer a submissão de atos de concentração consumados, que não se enquadrarem nos critérios de faturamento ou negócios anteriormente mencionados, desde que o faça no prazo de um ano contado da consumação do ato ${ }^{151}$. Essa regra, inovadora em relação ao diploma de 1994, visou suprir uma lacuna que poderia advir do aumento dos valores dos critérios de faturamento bruto e do volume de negócios, a partir do qual operadores envolvendo agentes com menor faturamento não necessitam submeter as operações ao controle do CADE. Assim, nos casos em que o CADE entender que a concorrência pode ter sido de alguma forma afetada por ato de concentração que a princípio não alcançava os critérios de

\footnotetext{
${ }^{148}$ De acordo com o art. 88, incisos I e II da Lei da Concorrência. Os valores inicialmente previstos pela Lei da Concorrência, de $\mathrm{R} \$ 400.000 .000,00$ e de $\mathrm{R} \$ 30.000 .000,00$, foram majorados pela Portaria Interministerial $n^{\circ} 994 / 2012$.

${ }^{149}$ De acordo com o $\$ 1^{\circ}$ do art. $4^{\circ}$ da Resolução CADE $n^{\circ} 2 / 2012$.

${ }^{150}$ De acordo com o $\$ 2^{\circ}$ do art. $4^{\circ}$ da Resolução CADE $n^{\circ} 2 / 2012$.

${ }^{151}$ De acordo com o $\S 7^{\circ}$ do art. 88 da Lei da Concorrência e $\S 7^{\circ}$ do art. 108 do RICADE.
} 
submissão, poderá notificar os agentes envolvidos para que submetam a operação para análise pela autoridade de defasa da concorrência ${ }^{152}$.

b) Requerimento para submissão de Ato de Concentração

O requerimento para análise de ato de concentração pelo CADE deve ser apresentado, sempre que possível, em conjunto pelas partes envolvidas na operação, entendidas como as entidades que participam diretamente no negócio jurídico pretendido e os respectivos grupos econômicos ${ }^{153}$.

A minuta de requerimento que deve ser utilizada pelos requerentes em procedimentos administrativos de análise de ato de concentração consta dos anexos da Resolução CADE no 2/2012. Enquanto o Anexo I trata de estabelecer o formulário para procedimento não sumário de análise, o Anexo II traz o formulário a ser adotado nos casos de procedimentos sumários.

Para os objetivos deste estudo destaca-se que dentre as informações e documentos que devem ser incluídos no requerimento de análise de ato de concentração, tanto para procedimentos no rito sumário, como no não sumário, constam os seguintes: (i) informação sobre os mercados em que a concentração deverá produzir algum impacto e os principais mercados envolvidos; (ii) informação sobre a nacionalidade de origem dos grupos econômicos envolvidos; (iii) informação sobre as demais jurisdições em que a operação em questão foi ou será apresentada, bem como data da notificação; (iv) confirmação sobre a possibilidade de a operação estar sujeita à aprovação de outros órgãos reguladores no Brasil ou no exterior; e (v) apresentação de jurisprudência do CADE e internacional na definição de mercado relevante de produto e geográfico.

Tais informações, juntamente com as outras informações e documentos trazidos pelas partes no procedimento administrativo, poderão eventualmente nortear o trabalho do CADE para a efetivação de cooperação jurídica internacional com autoridades de defesa de concorrência estrangeiras.

\footnotetext{
${ }^{152}$ Anders, Pagotto e Bagnoli destacam alguns problemas que poderão advir da aplicação prática deste dispositivo. (ANDERS, Eduardo Caminati; PAGOTTO, Leopoldo; BAGNOLI, Vicente (coords.). Comentários à nova Lei de Defesa da Concorrência. Rio de Janeiro: Forense; São Paulo: Método, 2012, pp. 284-286).

${ }^{153}$ De acordo com os arts. $3^{\circ}$ e $4^{\circ}$ da Resolução CADE n 2/2012.
} 


\subsubsection{Tratamento de informações confidenciais}

A Lei da Concorrência prevê a obrigação do Tribunal Administrativo, dos seus Conselheiros e da SG assegurarem tratamento sigiloso de documentos, informações e atos processuais, que sejam necessários à elucidação dos fatos ou exigidos pelo interesse da sociedade nos procedimentos administrativos de análise de atos de concentração econômica ${ }^{154}$. Interessante notar que tal dever não se estende aos procedimentos de apuração de atos de concentração econômica. Adicionalmente, podem as partes dos procedimentos administrativos requererem o tratamento sigiloso de documentos e informações, no tempo e modo definidos pelo RICADE ${ }^{155}$.

Nesse tocante, relevante é a análise da Lei $\mathrm{n}^{\circ} 12.527$, de 18 de novembro de 2011 (Lei de Acesso à Informação) e do seu regulamento (Decreto $\mathrm{n}^{\circ} 7.724$, de 16 de maio de 2012), que tratam de assegurar o direito constitucionalmente garantido de acesso às informações mantidas por órgão públicos, da administração direta ou indireta, em razão de interesses de particulares, coletivos ou gerais. A Lei de Acesso à Informação determina que a qualquer parte interessada deverá ser garantido o acesso a informações e documentos mantidos por autoridades públicas federais, incluídas, dentre outras, as agências reguladoras, nos termos legais.

Não estão submetidas à regulação da Lei de Acesso às Informações, no entanto, aquelas informações relacionadas à atividade empresarial de pessoas físicas ou jurídicas de direito privado obtidas pelas agências reguladoras ou por outros órgãos ou entidades no exercício de atividade de controle, regulação e supervisão da atividade econômica, cuja divulgação possa representar vantagem competitiva a outros agentes econômicos ${ }^{156}$. Adicionalmente, não são aplicados os dispositivos de acesso à informação às hipóteses de sigilo previstas na legislação, como fiscal, bancário, de operações e serviços no mercado de capitais, comercial, profissional, industrial e segredo de justiça, dentre outras hipóteses ${ }^{157}$.

De fato, a Lei de Acesso à Informação faculta a possibilidade de existirem outras hipóteses legais de sigilo, de segredo de justiça e de segredo industrial decorrentes da exploração direta de atividade econômica pelo Estado ou por pessoa física ou entidade privada que tenha qualquer vínculo com o poder público ${ }^{158}$.

\footnotetext{
${ }^{154}$ De acordo com o art. 49 da Lei da Concorrência.

${ }^{155}$ De acordo com o $\S$ único do art. 49 da Lei da Concorrência.

${ }^{156}$ De acordo com o $\S 2^{\circ}$ do art. $5^{\circ}$ do regulamento da Lei de Acesso à Informação.

${ }^{157}$ De acordo com o art. $6^{\circ}$, inciso I do regulamento da Lei de Acesso à Informação.

${ }^{158}$ De acordo com o art. 22 da Lei de Acesso à Informação.
} 
Desta forma, a regra definida pela Lei de Acesso à Informação é de que qualquer documento ou informação deve ser de acesso público, cuja regra admite exceções. Exatamente nas exceções previstas pela Lei de Acesso à Informação e seu regulamento, o CADE encontrou legitimidade para regular mediante resolução própria o acesso e o tratamento confidencial conferido às informações relacionadas às atividades empresariais, cuja divulgação possa representar vantagem competitiva a outros agentes econômicos.

Em relação à confidencialidade, portanto, o RICADE estabelece quatro modalidades de tratamento dos autos, informações, dados, correspondências, objetos e documentos de interesse de qualquer das diversas espécies de procedimentos administrativos, a saber: (i) público, quando puderem ser acessados por qualquer pessoa; (ii) acesso restrito, quando o acesso for exclusivo à parte que os apresentou, aos representados e às pessoas autorizadas pelo CADE; (iii) sigiloso, quando o acesso for exclusivo às pessoas autorizadas pelo CADE e às autoridades públicas por proferir parecer ou decisão; e (iv) segredo de justiça, com acesso limitado nos termos de decisão judicial ${ }^{159}$.

O acesso exclusivo aos autos, documentos, objetos, dados e informações, nos termos descritos no item (ii) acima, poderá ser deferido em razão de sigilo decorrente de lei ou por constituir informação relativa à atividade empresarial de pessoas físicas ou jurídicas de direito privado, cuja divulgação possa representar vantagem competitiva a outros agentes econômicos, nas hipóteses descritas no RICADE ${ }^{160}$. Por outro lado, o acesso restrito não será deferido no âmbito de procedimentos de análise de atos de concentração quando tiverem natureza notadamente pública, forem de domínio público ou tiverem sido previamente divulgados pelo interessado ${ }^{161}$, bem como estiverem relacionados a certas categorias de informações ${ }^{162}$.

\footnotetext{
${ }^{159}$ De acordo com os arts. 50 e 51 do RICADE. O Juízo ou autoridade judicial que presidir processo judicial determinará o tratamento a ser dado aos documentos, objetos e informações que forem tomados como prova emprestada dos ditos processos judiciais.

${ }^{160}$ De acordo com o art. 53 do RICADE, as hipóteses em que poderá ser determinado o acesso restrito são as seguintes: (i) escrituração mercantil; (ii) situação econômico-financeira da empresa; (iii) sigilo fiscal ou bancário; (iv) segredos de empresa; (v) processo produtivo e segredos de indústria, notadamente processos industriais e fórmulas relativas à fabricação de produtos; (vi) faturamento do interessado; (vii) data, valor da operação e forma de pagamento; (viii) documentos que formalizam o ato de concentração notificado; (ix) último relatório anual elaborado para os acionistas ou quotistas, exceto quando o documento tiver caráter público; (x) valor e quantidade das vendas e demonstrações financeiras; (xi) clientes e fornecedores; (xii) capacidade instalada; (xiii) custos de produção e despesas com pesquisa e desenvolvimento de novos produtos ou serviços; e (xiv) outras hipóteses, a critério do CADE, desde que respeitados os dispositivos relacionados à Lei de Acesso à Informação e ao seu regulamento.

${ }^{161}$ Note-se que a natureza pública da informação pode ter sido conferida por lei, nacional ou estrangeira, e que o domínio público considerado refere-se tanto ao país, quanto ao exterior.

${ }^{162}$ De acordo com o art. 54 do RICADE. Ademais, incluem-se nas categorias que não são passíveis de terem acesso restrito pelo CADE as seguintes: (i) composição acionária e identificação do respectivo controlador; (ii) organização societária do grupo econômico de que façam parte; (iii) estudos, pesquisas ou dados
} 
Note-se que a regra geral para os procedimentos administrativos de análise de atos de concentração é de que todas as informações e documentos incluídos nos autos são de natureza pública ${ }^{163}$. A parte interessada em manter dados e informações confidenciais possui o ônus de requerer ao CADE que o acesso restrito seja conferido por meio de requerimento fundamentado nos termos do $\mathrm{RICADE}^{164}$. Isso significa que, na eventualidade de uma parte coadunar com o tratamento público de determinada informação ou documento poderá simplesmente deixar de requerer que lhe seja conferido tratamento confidencial. Ademais, como a decisão de deferimento do acesso restrito pode ser revisto pela autoridade a qualquer tempo, de ofício ou a requerimento do interessado, é plenamente possível que a parte interessada renuncie à confidencialidade que tenha sido anteriormente conferida a certas informações e documentos.

Tal constatação é relevante na medida em que grande parte da cooperação jurídica internacional realizada pelas autoridades de defesa da concorrência se dá na troca de informações entre as autoridades das diferentes jurisdições. Todavia, para que o CADE possa contribuir com cooperação ativa em troca de informações, não poderá lhes ser conferido tratamento confidencial. Regra geral, caso o CADE transmitisse para outras autoridades informações sigilosas ou de acesso restrito, estaria transgredindo as disposições legais que determinam o dever da autoridade de manter sigilo.

Destaca-se, no entanto, que a redação do RICADE não esclarece sobre os parâmetros que o CADE deverá utilizar para autorizar o acesso a informações de acesso restrito e sigiloso, tampouco se tais pessoas devem fazer parte do quadro de colaboradores da agência. Em tese, se poderia vislumbrar a possibilidade de o CADE autorizar o acesso a tais informações por pessoas ligadas a autoridades de defesa da concorrência estrangeiras ${ }^{165}$, desde que tal autorização não resulte em vantagem competitiva a outros agentes econômicos e os recipientes estrangeiros de tal informação assumam a obrigação

compilados por instituto, associação, sindicato ou qualquer outra entidade que congregue concorrentes, ressalvados aqueles encomendados individualmente ou com cláusula de sigilo; (iv) linhas de produtos ou serviços ofertados; (v) dados de mercado relativos a terceiros; (vi) quaisquer contratos celebrados por escritura pública ou arquivados perante notário público ou em junta comercial, no País ou no exterior; e (vii) informações que a empresa deve publicar ou divulgar em razão da norma legal ou regulamentar a que esteja sujeita no Brasil ou em outra jurisdição.

${ }^{163}$ De acordo com a Lei de Acesso à Informação e o art. 56 do RICADE.

${ }^{164}$ De acordo com o art. 55 do RICADE.

165 Diversamente, a anterior Resolução CADE $\mathrm{n}^{\circ} 45$, no seu art. 41, estabelecia que informações confidenciais somente poderiam ser acessadas pela parte interessada, seus mandatários, pelo Presidente, Conselheiros, Procuradores e servidores expressamente autorizados, nos termos do art. 12, inciso II, da referida resolução. Não havia, portanto, nenhuma exceção que permitisse a divulgação da informação confidencial, mesmo que mediante a anuência da parte interessada, para colaboradores de autoridades de defesa da concorrência estrangeiras. 
de garantir-lhe a confidencialidade. Por outro lado, o dispositivo em questão poderá ser interpretado restritivamente, exigindo, assim, que a parte detentora da informação de acesso restrito ou sigilosa renuncie à confidencialidade e autorize a divulgação da informação confidencial pelo SBDC à autoridade de defesa da concorrência estrangeira.

Desta forma, e tendo em vista que a Lei da Concorrência e o RICADE entraram em vigor recentemente, não tendo sido possível vislumbrar na prática a interpretação que será acolhida pelo SBDC, adota-se para os fins deste estudo a interpretação mais conservadora, de que será necessário obter a renúncia da parte interessada para o compartilhamento de informações confidenciais pelo SBDC - mantendo assim a sistemática de compartilhamento de informações até então vigente.

Note-se que há legislações nacionais de outros Estados que se encontram em estágio mais avançado de desenvolvimento em relação à troca de informações confidenciais em matéria concorrencial. É o caso, por exemplo, da Lei de Assistência à Execução Internacional $^{166}$ (IAEAA) dos Estados Unidos, que expressamente permite a contínua troca de informações confidenciais com outros países, ampliando assim as possibilidade de cooperação em matéria da concorrência ${ }^{167}$.

Por outro lado, o Plenário do Tribunal Administrativo de Defesa Econômica do CADE, os seus Conselheiros e a SG têm poderes para requisitar informações de quaisquer pessoas, órgãos, autoridades e entidades públicas ou privadas, respeitando e mantendo o sigilo legal quando for o caso, bem como determinar as diligências que se fizerem necessárias ao exercício de suas funções ${ }^{168}$. Note-se que a Lei da Concorrência e o RICADE não restringem os poderes das autoridades brasileiras de defesa da concorrência à solicitação de informações de autoridades nacionais, sendo-lhes lícito interagir com autoridades estrangeiras para obtenção de informações, cabendo-lhes, entretanto, o dever de guardar sigilo das informações a que tenha sido conferido tratamento confidencial.

\footnotetext{
${ }^{166}$ Em inglês, International Enforcement Assistance Act.

${ }^{167}$ LILLA, Paulo Eduardo. A OMC e a interação entre comércio e política antitruste no âmbito da cooperação internacional: perspectivas para a nova rodada e negociações multilaterais. Revista do IBRAC Direito da concorrência, consumo e comércio internacional. São Paulo, jan. 2003, v. 19, pp. 233 e ss; SWAINE, Edward T. Cooperation, Comity and Competition Policy: United State. Cooperation, Comity and Competition Policy. New York: Oxford University Press, 2011, p. 19.

${ }^{168}$ De acordo com os arts. $9^{\circ}$, inciso XVIII; 11, inciso III; e 13, inciso VI da Lei da Concorrência, e arts. $9^{\circ}$, inciso XVIII; 18, inciso III; 24, inciso VI, e 73 do RICADE.
} 


\subsection{O DIREITO INTERNACIONAL DA CONCORRÊNCIA: TERMINOLOGIA E CONCEITO}

O Direito Internacional da Concorrência trata de ramo jurídico de recente desenvolvimento da literatura jurídica internacional e brasileira ${ }^{169}$, que se ocupa primordialmente com o problema advindo da aplicação extraterritorial dos variados ordenamentos jurídicos nacionais de defesa da concorrência ${ }^{170}$. Não se confunde, portanto, com o estudo comparativo dos diversos ordenamentos jurídicos nacionais sobre o Direito da Concorrência.

O Direito da Concorrência também é referido por alguns autores como Direito Concorrencial ou Direito Antitruste. Esta terceira opção de nomenclatura da matéria está conectada ao instituto norte-americano do antitruste. No final do século 19, nos Estados Unidos, as empresas com problemas financeiros passaram a fazer acordos para controlar os preços do mercado. As participações cruzadas de tais empresas, constituídas para que acordos de preços não fossem frustrados, eram denominadas de trusts, um fundamento dos conhecidos cartéis. O combate de tais trusts pelas autoridades norte-americanas deu origem à expressão antitruste ${ }^{171}$.

Desta maneira, parece que as nomenclaturas Direito da Concorrência e Direito Concorrencial sejam mais adequadas, uma vez que abrangem uma maior gama de questões econômicas, para além da regulação das condutas empresariais - como é o caso das estruturas econômicas. De fato, a terminologia "concorrência" deriva do latim medieval concorrentia, que por sua vez relaciona-se ao verbo concurrere, com significado de

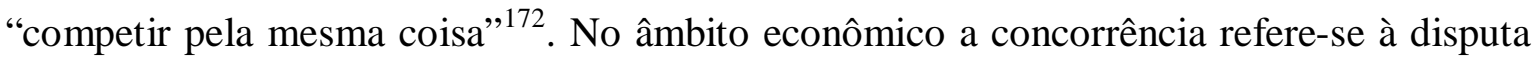

\footnotetext{
169 "Em toda a parte do mundo, a importância do direito da concorrência, como forma de assegurar a abertura e o livre mercado, proteger os consumidores, prever condutas que impeçam a concorrência, tem se tornado mais aparente". (MARQUES, Frederico do Valle Magalhães. Direito Internacional da Concorrência. Rio de Janeiro: Renovar, 2006, p. 3).

170 "Quando um país aplica normas jurídicas de seu ordenamento a situações que se formam total ou parcialmente no estrangeiro, diz-se haver uma aplicação extraterritorial do direito nacional, que é determinada, no caso concreto, por uma norma de colisão. O direito internacional da concorrência compreende, portanto, as normas de colisões espaciais referentes às práticas restritivas da concorrência". (FARIA, José Ângelo Estrella. Aplicação extraterritorial do Direito da Concorrência. Revista de Informação Legislativa. Brasília, jan./mar. 1990, n. 105, p. 19).

${ }^{171}$ Celli Júnior esclarece nesse sentido que "a legislação americana visou [...] coibir a ação desses trusts. Daí a expressão legislação antitrust". (CELLI JÚNIOR. Humberto. Regras de concorrência no Direito Internacional moderno. Porto Alegre: Livraria do Advogado, 1999, p. 51).

172 "A concorrência é o fundamento da economia de mercado e a grande impulsionadora da competição existente entre as empresas que atuam num mesmo mercado, fazendo com que as empresas, fabricantes e fornecedores atuem, de forma sadia, no mercado, na busca pelo consumidor. O direito da concorrência, por sua vez, fornece todo o aparato necessário para manter esta disputa em níveis razoáveis, impedindo, assim, o desenvolvimento da denominada concorrência predatória". (MARQUES, Frederico do Valle Magalhães. Op. cit., 2006, pp. 107-109).
} 
entre agentes econômicos para a conquista de novos mercados para seus produtos - noção mais ampla daquela decorrente do antitrust norte-americano.

A aceleração da globalização econômica ${ }^{173}$ acarretou o amadurecimento da matéria ${ }^{174}$ e a percepção de uma faceta internacional do Direito da Concorrência ${ }^{175}$. Apesar de a vertente internacional da matéria estar intimamente conectada às legislações nacionais sobre o tema, e de atualmente delas depender para a sua existência e desenvolvimento, "problemas internacionais clamam por soluções internacionais"176.

Com esta perspectiva em mente, o jurista deve buscar a melhor terminologia para identificar a matéria em discussão. Dentre as opções disponíveis - Direito Internacional da Concorrência e Direito da Concorrência Internacional - entende-se ser a primeira opção mais acertada ${ }^{177}$. Caso fosse adotada a expressão Direito da Concorrência Internacional, a matéria se limitaria aos aspectos internacionais da concorrência com efeitos num panorama global. Não estariam inclusos, considerando essa terminologia, aqueles efeitos danosos à

\footnotetext{
173 "O movimento de globalização econômica percebido a partir da década de 80 é original, na medida em que não se limita à mera expansão da atividade econômica dos agentes para além de suas fronteiras, mas constrói interações funcionais diferenciadas entre as economias das várias unidades nacionais, ganhando, assim, qualidades próprias. [...] Essas características implicam novos problemas para o Direito, sobretudo para o direito econômico, que se ocupa da ordenação do mercado e da implementação da política econômica do Estado". (NUSDEO, Ana Maria de Oliveira. Defesa da concorrência e globalização econômica. São Paulo: Malheiros, 2002, p. 138). Faria também destaca o "aumento dos fluxos internacionais de capitais e a crescente integração econômica das últimas décadas" como fator que culminou numa "concentração empresarial sem precedentes, da qual resultam cada vez menos competidores independentes". (FARIA, José Ângelo Estrella. $O$ controle de concentrações de empresas estrangeiras e a Lei $n^{\circ}$ 8.884: a extraterritorialidade revisitada. Júris Síntese, maio/jun. 2009, n. 77, p. 1). Ver também nesse sentido Menezes que destaca as alterações sofridas pelo Direito Internacional em razão da aceleração do processo de globalização. (MENEZES, Wagner. Ordem global e transnormatividade. Ijuí, RS: Ed. da Unijuí, 2005, pp. 104-114).

174 "International competition law is not so much a discrete subject but a site where a number of different laws come together, sometimes abruptly. Competition law jurisdictions not infrequently reach different conclusions on the legality of a transaction or some other conduct that has economic effects in more than one jurisdiction; [...] competition laws are not merely sets of substantive rules, but have procedural, institutional and jurisdictional dimensions. The enforcement of competition law in one country might also directly conflict with a variety of laws, industry specific regulations and policies of other jurisdictions." (NOONAN, Chris. Editorial - Globalisation, international enforcement and extraterritoriality. The competition law review. Issue 2, jul. 2009, v. V, p. 147).

${ }^{175}$ Salomão Filho destaca a "internacionalização das preocupações concorrenciais", fundamentando-a no liberalismo comercial verificado a partir da década de 80 e na ascensão da economia japonesa e do crescente poderio tecnológico e concorrencial das empresas daquele país. (SALOMÃO FILHO, Calixto. Direito concorrencial - as estruturas. 3. ed. São Paulo: Malheiros, 2007, p. 39).

${ }^{176} \mathrm{O}$ autor ainda aduz: "É chegado o momento da internacionalização do direito da concorrência. É preciso ser dado o primeiro passo para a superação do crescente conflito entre a manutenção das soberanias estatais como estão, com ordenamentos jurídicos com âmbito de aplicação limitados, e a abertura dos mercados promovida pelas empresas com atuações transfronteiriças". (JAEGER JÚNIOR, Augusto. Direito Internacional da Concorrência - Entre perspectivas unilaterais, multilaterais, bilaterais e regionais. Curitiba: Juruá, 2008, p. 30).

${ }^{177}$ Esta também foi a escolha de outros juristas em obras recentes, como JAEGER JÚNIOR, Augusto. Op. cit., 2008; MARQUES, Frederico do Valle Magalhães. Direito Internacional da Concorrência. Rio de Janeiro: Renovar, 2006; e FARIA, José Ângelo Estrella. Aplicação extraterritorial do Direito da Concorrência. Revista de Informação Legislativa. Brasília, jan./mar. 1990, n. 105.
} 
concorrência de um mercado local, advindos de atos ou fatos de abrangência internacional. A expressão Direito Internacional da Concorrência, por sua vez, designa a delimitação do Direito Internacional em matéria de concorrência.

Assim, como existe uma bipartição no Direito Internacional em privado e público, é possível fazer uma analogia em relação ao Direito Internacional da Concorrência.

No seu âmbito público, identificar-se-iam as ações dos Estados, mais precisamente nos acordos e nos tratados internacionais assinados entre dois ou mais Estados, nos regramentos concorrenciais adotados por ocasião da integração econômica havida em razão de blocos econômicos e nas tentativas de celebração de tratados e convenções internacionais sobre a matéria. Por outro lado, na sua vertente privada, a matéria abrangeria as regras nacionais de defesa da concorrência que tratam de regular os efeitos sentidos nos mercados nacionais advindos das condutas e estruturas de âmbito internacional. É o caso, por exemplo, das normas internas que determinam a aplicação unilateral de um determinado direito nacional da concorrência aos atos e fatos que façam surtir seus efeitos em tal mercado nacional ${ }^{178}$. E é justamente a aplicação unilateral dos Estados de suas regras internas de natureza concorrencial extraterritorialmente que constitui o objeto central do Direito Internacional da Concorrência.

Desta forma, o Direito Internacional da Concorrência constitui ramo da Ciência Jurídica que busca regular e mitigar os problemas advindos da aplicação extraterritorial dos variados direitos nacionais de defesa da concorrência. São revelados, assim, os esforços em âmbito unilateral, bilateral, regional e multilateral da disciplina.

\subsection{AS DIMENSÕES DO DIREITO INTERNACIONAL DA CONCORRÊNCIA}

\subsubsection{Dimensão unilateral do Direito Internacional da Concorrência}

A vocação natural do Direito da Concorrência está na regulação de práticas ocorridas dentro do território dos Estados, sendo, desta forma, de aplicação territorial limitada. Todavia, com a intensificação da globalização econômica, as atividades empresariais apresentam-se cada vez mais em ações multijurisdicionais, que afetam os interesses de várias nações ${ }^{179}$. Em casos desta natureza, geralmente emerge um conflito

\footnotetext{
${ }^{178}$ Neste estudo são melhor analisadas na perspectiva unilateral do Direito Internacional da Concorrência.

179 "Todos os Estados atingidos por essas limitações à concorrência possuem o desejo de regular as atividades que limitam a concorrência e que produzem efeitos em um ou em mais de um Estado. Mas não existe um direito internacional da concorrência que possa ser aplicado às práticas limitadoras da concorrência que
} 
sobre a aplicação dos variados regramentos nacionais envolvidos na defesa da concorrência, o que decorre, na maioria das vezes, da aplicação extraterritorial do Direito da Concorrência nacional dos países envolvidos pelas suas correspondentes autoridades ${ }^{180}$. Ante a natureza das operações transnacionais dos grupos econômicos, a incidência extraterritorial das legislações nacionais de defesa da concorrência torna-se imperativa, sob pena de tronar inócua a proteção dos livres mercados pelos Estados ${ }^{181}$.

Nesse sentido, é interessante notar que no caso do Direito Internacional da Concorrência, especialmente em função do seu caráter de ordem pública ${ }^{182}$, normalmente não são utilizadas as expressões "lei aplicável" e "jurisdição competente", da forma como o jurista está acostumado a encontrar nas diversas manifestações do Direito Internacional Privado - já que estas tratam dos casos de aplicação estrangeira a situações com conexões com mais de uma jurisdição ${ }^{183}$. Na esfera da concorrência, a expressão "lei aplicável" é substituída pelo alcance da jurisdição de determinado país ${ }^{184}$.

produzam efeitos em mais de um Estado. Devido a isso, os Estados são compelidos a aplicar os seus direitos nacionais da concorrência a tais fatos, de forma extraterritorial". (JAEGER JÚNIOR, Augusto. Direito Internacional da Concorrência - Entre perspectivas unilaterais, multilaterais, bilaterais e regionais. Curitiba: Juruá, 2008, pp. 33-34).

${ }^{180}$ Faria esclarece que "quando um país aplica normas jurídicas de seu ordenamento a situações que se formam total ou parcialmente no estrangeiro, diz-se haver uma aplicação extraterritorial do direito nacional, que é determinada, no caso concreto, por uma norma de colisão”. (FARIA, José Ângelo Estrella. Aplicação extraterritorial do Direito da Concorrência. Revista de Informação Legislativa. Brasília, jan./mar. 1990, n. 105, p. 19). No mesmo sentido, Tavares de Araújo Júnior defende que "de acordo com o princípio da extraterritorialidade o âmbito de aplicação da lei não está restrito às fronteiras nacionais, mas inclui também qualquer atividade econômica ocorrida no exterior cujos efeitos alterem as condições de concorrência no mercado doméstico. A utilidade básica desse estatuto é a de prover os fundamentos jurídicos para a ação conjunta das autoridades antitruste no tratamento de casos com dimensão internacional". (TAVARES DE ARAÚJO JR, José. Política de concorrência no Mercosul: uma agenda mínima. Ago. 2001. Disponível em: <http://www.sedi.oas.org/DTTC/TRADE/ PUB/STAFF_ARTICLE/tav01_conc_agenda.asp>. Acesso em: 22 out. 2009, p. 1). Com base em Jean Combacau e Serge, Silva ainda explica que "o exercício da jurisdição extraterritorial traduz a pretensão estatal de aplicar as suas normas para reger condutas, determinar situações ou levar em consideração fatos exteriores a seu território. Ela se refere, portanto, à consideração, por parte das autoridades nacionais, de elementos situados fora dos limites geográficos dos Estados”. (SILVA, Valéria Guimarães de Lima e. Direito antitruste: aspectos internacionais. Curitiba: Juruá, 2007, p. 40).

181 "Na mesma e exata medida em que operam internacionalmente os agentes, há que se coibir, mediante ação das legislações e jurisdições nacionais os efeitos nefastos dessas práticas sobre cada um dos mercados". (CASELLA, Paulo Borba. Extraterritorialidade e proteção da livre-concorrência. Revista da Faculdade de Direito da Universidade de São Paulo. São Paulo: USP, 2001, v. 96, p. 503).

${ }^{182}$ Em vista do caráter público da legislação de defesa da concorrência, não é possível vislumbrar a aplicação de legislação estrangeira. Nesse sentido, ver FARIA, José Ângelo Estrella. O controle de concentrações de empresas estrangeiras e a Lei $n^{\circ}$ 8.884: a extraterritorialidade revisitada. Júris Síntese, maio/jun. 2009, n. 77. Disponível em: <http://online.sintese.com>. Acesso em: 19 ago. 2012, p. 2. Ver também CARVALHO RAMOS, André de; CUNHA, Ricardo Thomazinho da. A defesa da concorrência em caráter global: utopia ou necessidade. In: CASELLA, Paulo Borba (org.). Guerra comercial ou integração econômica mundial. São Paulo: LTr, 1998, v. 1, p. 811.

${ }^{183}$ FARIA, José Ângelo Estrella. Op. cit., jan./mar. 1990, n. 105, p. 20.

${ }^{184}$ Forgioni esclarece ainda que "a Lei 8.884, ao estabelecer, no seu art. $2^{\circ}$, sua aplicabilidade 'às práticas cometidas no todo ou em parte no território nacional ou que nele produzam ou possam produzir efeitos', determina, de fato, que o Brasil terá jurisdição sobre aqueles casos. Em outras palavras, atrai para a competência das autoridades brasileiras (que passam a ter poder - ainda que concorrente - para julgar) todas 
A aplicação extraterritorial do Direito é compartilhada por muitas áreas do conhecimento jurídico, dentre as quais tem-se especial interesse o Direito da Concorrência. Regra geral, cada país tem a faculdade de definir a sua competência internacional, desde que não viole regras do Direito Internacional ${ }^{185}$. A decisão do caso S. S. Lotus ${ }^{186}$, julgado pela Corte Permanente de Justiça Internacional, é tradicionalmente invocado como fundamento para a permissão da aplicação extraterritorial da legislação nacional - o que também é aplicável em matéria de defesa da concorrência ${ }^{187}$. O caso, julgado em 7 de setembro de 1927, discutiu a questão da competência concorrente e/ou exclusiva na aplicação do direito nacional de um dos Estados envolvidos.

Em 1926 ocorreu a colisão em alto mar entre o paquete francês Lotus e o cargueiro turco Boz-Kourt. Devido à colisão das embarcações, o cargueiro Boz-Kourt partiu-se ao meio e afundou, sendo que oito cidadãos turcos faleceram no incidente. O paquete Lotus conseguiu resgatar 10 pessoas após o acidente, dentre os quais o capitão da embarcação turca, o Sr. Hassan Bey. Após o acidente a embarcação Lotus seguiu até Istambul onde, após alguns trâmites locais, foi decretada a prisão preventiva do Sr. Hassan Bey e do oficial francês Sr. Demons - que era o responsável pelo Lotus no momento do acidente -

as condutas que possam vir a afetar os interesses econômicos, sociais ou políticos do país. Jurisdição e lei aplicável, no caso, confundem-se". (FORGIONI, Paula A. Os fundamentos do antitruste. 4. ed. São Paulo: revista dos Tribunais, 2010, pp. 448-449). Nesse sentido, esclarece Silva: "Em direito concorrencial, sempre que o estado opta por exercer sua jurisdição em caráter extraterritorial, ele necessariamente aplica também extraterritorialmente as leis relativas à matéria. A legislação estrangeira não é uma opção, pelo simples fato de tratar-se de uma matéria que envolve questões de política e de direito público". (SILVA, Valéria Guimarães de Lima e. Direito Antitruste: aspectos internacionais. Curitiba: Juruá, 2007, p. 41).

${ }^{185}$ Carvalho Ramos e Cunha destacam ainda a contraposição de duas correntes, sendo que uma defende que a aplicação extraterritorial do direito somente pode ocorrer se o Direito Internacional assim autorizar, enquanto que a outra defende que os Estados são livres para estabelecer a aplicação extraterritorial, desde que não entrem em conflito com o Direito Internacional. (CARVALHO RAMOS, André de; CUNHA, Ricardo Thomazinho da. A defesa da concorrência em caráter global: utopia ou necessidade. In: CASELLA, Paulo Borba (org.). Guerra comercial ou integração econômica mundial. São Paulo: LTr, 1998, v. 1, p. 817).

186 CORTE PERMANENTE DE JUSTIÇA INTERNACIONAL. Caso S. S. Lotus. França v. Turquia, Recueil dês Arrêts, série A, n. 10, 1927. Disponível em: <http://www.worldcourts.com/pcij/eng/decisions/ 1927.09.07_lotus.htm>. Acesso em: 11 jul. 2011.

${ }^{187}$ Ao contrapor a decisão do caso S.S. Lotus com a narrativa de Kelsen, Carvalho esclarece que "os Estados teriam liberdade para legislar sobre qualquer assunto, assim estendendo a sua jurisdição para aplicar a qualquer fato ou ato que entendessem pertinentes. As limitações à atividade legislativa decorrem da própria vontade estatal, que pode se autolimitar com base nos interesses que possui, com base em tratados ou convenções ratificadas, ou mesmo em função da observação pragmática da realidade que limita a atuação legiferante do Estado. A esta pretensa tentativa de editar regrar que valham além dos limites jurisdicionais de atuação do Estado, atribui-se, ocasionalmente, o nome 'extraterritorialidade' ou 'exterritorialidade'. [...] mesmo que um Estado edite norma com determinado intuito, e aplique esta norma, não poderá ultrapassar seu limite territorial para fazer concreta a norma individualizada. [...] como visto, a efetivação das decisões leia-se execução - não se faz facilmente, tornando-se inócuas se ausentes os elementos de cooperação intergovernamental ou supranacional". (CARVALHO, Leonardo Arquimino de. Direito antitruste \& relações internacionais: extraterritorialidade e cooperação. Curitiba: Juruá, 2003, pp. 64-65). Ver ainda CASELLA, Paulo Borba. Extraterritorialidade e proteção da livre-concorrência. Revista da Faculdade de Direito da Universidade de São Paulo. São Paulo: USP, 2001, v. 96, p. 511; e CARVALHO RAMOS, André de; CUNHA, Ricardo Thomazinho da. Op. cit., 1998, v. 1, pp. 819-821. 
com fundamento no homicídio dos oito tripulantes turcos. As autoridades turcas iniciaram procedimentos criminais e cíveis contra os responsáveis, que culminaram na condenação criminal dos Srs. Hassan e Demons. À época do início dos procedimentos perante a Corte Permanente de Justiça Internacional pendia a decisão de um recurso interposto perante as autoridades turcas.

A discussão do caso centrou-se no fato de a colisão ter ocorrido em alto mar entre duas embarcações particulares, cada qual com uma bandeira. $O$ governo francês questionava a possibilidade de a legislação turca pretender impor a competência das suas cortes criminais contra o Sr. Demons sobre fato ocorrido na embarcação francesa em alto mar, ou seja, em território francês ${ }^{188}$. Por outro lado, o governo turco defendia que não havia nenhum princípio no Direito Internacional que restringisse a aplicação extraterritorial da sua legislação sobre o fato ocorrido em alto mar.

Com base na interpretação dos princípios de direito internacional da soberania, da competência e da liberdade, a decisão a que se chegou foi no sentido de que, em vista da soberania dos Estados, é possível que as legislações nacionais tenham eficácia sobre fatos ocorridos no exterior ${ }^{189}$, desde que respeitados os limites das respectivas extensões territoriais e verificado o elemento de conexão com tais fatos e o direito internacional.

De fato, restrições à soberania dos Estados não podem ser presumidas, devendo ser explicitamente inseridas em tratados internacionais ou decorrer do costume ou dos princípios internacionais ${ }^{190}$. Uma das restrições impostas pelo direito internacional é a de que nenhum país pode exercer a sua soberania, de qualquer forma, no território de outro

\footnotetext{
188 "It follows that what occurs on board a vessel on the high seas must be regarded as if it occurred on the territory of the State whose flag the ship flies". (CORTE PERMANENTE DE JUSTIÇA INTERNACIONAL. Caso S. S. Lotus. França v. Turquia. Recueil dês Arrêts. Série A, n. 10, 1927, p. 25. Disponível em: 〈http://www.worldcourts.com/pcij/eng/decisions/1927.09.07_lotus.htm>. Acesso em: 11 jul. 2011).

${ }^{189}$ Em relação a esta questão Faria alerta que "no estágio atual do direito internacional público a soberania dos Estados não é fundamentada por aquele, mas sim pressuposta, isto é, são os Estados soberanos que, através de sua vontade, criam as normas do ius gentium, e não ao contrário. A determinação do âmbito de aplicabilidade das normas de seu próprio ordenamento é uma forma típica do exercício dos direitos de soberania próprios. Existe, portanto, uma presunção em favor da liberdade dos Estados". (FARIA, José Ângelo Estrella. Aplicação extraterritorial do Direito da Concorrência. Revista de Informação Legislativa. Brasília, jan./mar. 1990, n. 105, pp. 22-24). Ver também CASELLA, Paulo Borba. Extraterritorialidade e proteção da livre-concorrência. Revista da Faculdade de Direito da Universidade de São Paulo. São Paulo: USP, 2001, p. 511.

190 "A própria dinâmica da vida internacional passou a desautorizar o entendimento tradicional (esposado pela antiga Corte Permanente de Justiça Internacional (CPJI), no caso S.S. Lotus (1927), de que as relações interestatais se regiam por regras jurídicas emanando inteiramente da livre vontade dos próprios Estados; tal visão deixava de corresponder à realidade jurídica internacional. Se não podiam presumir restrições à soberania ou independência dos Estados (como entendeu a antiga CPJI), tampouco se podia presumir a ausência de restrições, porquanto não cabia deduzir o direito aplicável à determinada situação do 'simples fato' da soberania ou independência estatal". (TRINDADE, Antônio Augusto Cançado. O direito internacional em transformação: ensaios, 1976-2001. Rio de Janeiro: Renovar, 2002, p. 1044).
} 
país. A questão relativa à competência é, assim, eminentemente territorial. Todavia, essa assertiva não significa que o Direito Internacional proíba um Estado de exercer a sua jurisdição no seu próprio território em relação a atos praticados no exterior, desde que respeitados os princípios do Direito Internacional.

A decisão reconheceu, ainda, que não existe nenhuma regra ou princípio do Direito Internacional que impeça um Estado de exercer a sua jurisdição sobre atos ocorridos no exterior, devendo apenas tal Estado garantir que certos limites impostos pela referida área do Direito sejam observados ${ }^{191}$. Na tradição do Direito Criminal, o princípio da territorialidade não deixa de ser a regra para a fixação da competência internacional. Todavia, na maioria dos sistemas existem regras que viabilizam a extensão dessa competência a condutas praticadas no exterior. O princípio da territorialidade não é, portanto, um princípio absoluto.

Interessante notar que a decisão do caso S.S. Lotus dedicou-se a demonstrar um nexo entre as condutas realizadas no exterior que produziam efeitos no território em que se reclamava a competência para julgar a lide. Assim, os efeitos surtidos em razão de tais condutas concretizadas no exterior assumiram um papel relevante na decisão da Corte Permanente de Justiça Internacional ${ }^{192}$.

Conforme será demonstrado adiante, a decisão do caso S.S. Lotus de fato traz discussões relevantes que servem ao Direito Internacional da Concorrência, mais precisamente na formulação das teorias que embasaram a aplicação extraterritorial dos diversos direitos nacionais de defesa da concorrência. Além disso, parece não ter havido mudança sensível no Direito Internacional Público, desde a época em que a sentença do caso S.S. Lotus foi prolatada ${ }^{193}$. Parte da doutrina, no entanto, repudia a utilização do

\footnotetext{
${ }^{191}$ Neste sentido, a decisão é clara: "there is no rule of international law prohibiting the State to which the ship on which the effects of the offence have taken place belongs, from regarding the offence as having been committed in its territory and prosecuting, accordingly, the delinquent". (CORTE PERMANENTE DE JUSTIÇA INTERNACIONAL. Caso S. S. Lotus. França v. Turquia. Recueil dês Arrêts. Série A, n. 10, 1927, p. 25. Disponível em: <http://www.worldcourts.com/pcij/eng/decisions/1927.09.07_lotus.htm>. Acesso em: 11 jul. 2011).

192 A referida decisão esclarece "once it is admitted that the effects of the offence were produced on the Turkish vessel, it becomes impossible to hold that there is a rule in the international law which prohibits Turkey from prosecuting Lieutenant Demons because of the fact that the author of the offence was on board the French ship". Ainda, na p. 30, os julgadores reconhecem que "the offence for which Lieutenant Demons appears to have been prosecuted was an act-of negligence or imprudence-having its origin on board the Lotus, whilst its effects made themselves felt on board the Boz-Kourt". (CORTE PERMANENTE DE JUSTIÇA INTERNACIONAL. Caso S. S. Lotus. França v. Turquia. Recueil dês Arrêts. Série A, n. 10, 1927, p. 23. Disponível em: <http://www.worldcourts.com/pcij/eng/decisions/1927.09.07_lotus.htm>. Acesso em: 11 jul. 2011).

${ }^{193}$ FARIA, José Ângelo Estrella. O controle de concentrações de empresas estrangeiras e a Lei $\mathrm{n}^{\circ}$ 8.884: a extraterritorialidade revisitada. Júris Síntese, maio/jun. 2009, n. 77. Disponível em: <http://online.sintese. com>. Acesso em: 19 ago. 2012, p. 3.
} 
referido caso como fundamento da aplicação extraterritorial das legislações nacionais na matéria em apreço ${ }^{194}$.

Fruto do desenvolvimento jurisprudencial norte-americano, conforme se verá a seguir, a teoria dos efeitos constitui a base da aplicação extraterritorial unilateral do Direito da Concorrência. Para que se possa melhor compreender a teoria dos efeitos e suas implicações far-se-á uma breve incursão sobre o desenvolvimento da legislação norteamericana da concorrência.

\subsubsection{Evolução da aplicação das legislações nacionais de defesa da concorrência a partir do Direito norte-americano}

Os Estados Unidos foram pioneiros, não somente na aplicação extraterritorial da sua legislação de defesa da concorrência, mas também na concepção do Direito da Concorrência da forma como atualmente é conhecido ${ }^{195}$. Até os dias de hoje as mais variadas jurisdições sofrem a influência da legislação e jurisprudência norte-americanas no que tange ao Direito da Concorrência.

A primeira legislação mundialmente reconhecida no âmbito concorrencial é o Sherman Antitrust Act, dos Estados Unidos da América, de 1890 (Sherman Act). Este estatuto buscou proteger o pequeno empresário das grandes empresas que passaram a dominar a economia dos Estados Unidos naquela época ${ }^{196}$. Todavia, mesmo antes da

\footnotetext{
${ }^{194}$ Alguns autores, como Silva contestam a utilização do caso S. S. Lotus como fundamento para a aplicação unilateral extraterritorial da legislação da concorrência pelos Estados, uma vez que este teria versado sobre o princípio da territorialidade objetiva, consoante estabelecido pelos princípios de direito internacional. A citada autora ainda alerta "ademais, o mesmo julgado Lotus fornece a impressão errônea de que os Estados não sofrem qualquer restrição por parte do Direito Internacional para fins de estabelecimento da sua própria jurisdição [...] nesse aspecto, o julgado é considerado como sendo específico em demasia (jurisdição em crimes de alto-mar) para ter seus enunciados tratados como regra geral, devendo ser estes, ainda, tratados dentro do contexto histórico em que se inserem, ou seja, em uma época na qual o poder soberano do Estado era tido como absoluto e incontrastável, conceito este atualmente obsoleto". (SILVA, Valéria Guimarães de Lima e. Direito antitruste: aspectos internacionais. Curitiba: Juruá, 2007, pp. 404-406).

${ }^{195}$ Id., ibid., p. 77.

196 "The court interpreted the Sherman Act in light of a set of changeable social and political goals, such as mitigating the effects on producers of the Great Depression of the 1930s, and protecting small businesses from larger, more efficient rivals". (GINSBURG, Douglas H.; FRASER, Eric M. The role of economic analysis in competition law. Getting the balance right intellectual property, competition law and economics in Asia. Hart Publishing, 2010, pp. 19-20. Disponível em: <http://www.papers.ssrn.com/sol3/papers. cfm?abstract_id=1610189>. Acesso em: 19 ago. 2012). Os autores destacam que com o passar do tempo, os objetivos sociais e políticos consubstanciados na legislação antitruste cederam lugar à análise econômica dos fatores, sempre objetivando o bem-estar do consumidor, o que, em última análise, acabou por alterar toda a estrutura do Direito da Concorrência.
} 
promulgação do Sherman Act foi formada jurisprudência naquele país que tratou de formular e aplicar alguns princípios concorrenciais ${ }^{197}$.

O Sherman Act continha regras rígidas com o objetivo de limitar o poder de mercado e garantir a defesa da livre concorrência. O seu art. $1^{\circ}$ declarou a ilegalidade de qualquer contrato ou combinação, fosse ou não em forma de trust, ou conspiração realizados com o intuito de restringir o comércio entre os estados norte-americanos ou outros países. Já o art. $2^{\circ}$ previu a condenação das pessoas que monopolizassem, tentassem monopolizar ou conspirassem com outra(s) pessoa(s) com o objetivo de monopolizar qualquer parte do comércio realizado entre os estados norte-americanos ou outros países. Para cada conduta, a legislação estabeleceu a aplicação de penas de multa e prisão.

Conforme se depreende da análise das regras anteriormente descritas, o Sherman Act centrou seus esforços na condenação de condutas ilícitas. Este fato, aliado à rigidez das regras deste instrumento legislativo, ocasionou o retardamento da efetividade da legislação durante os seus primeiros anos de vigência ${ }^{198}$.

Com o desenvolvimento da jurisprudência, a interpretação do Sherman Act foi amenizada pela regra da razão ${ }^{199}$, o que acabou por conferir aos Tribunais a responsabilidade pela caracterização de uma prática como ilícita, mediante o caso concreto. Para além disso, verificou-se na economia norte-americana um expressivo número de concentrações empresariais no final do século 19 e início do século 20. Estes fatos, aliados às lacunas consubstanciadas no Sherman Act, fizeram emergir a preocupação de que a legislação então em vigor deixaria de ser efetiva.

Para evitar o enfraquecimento da legislação, em 1914 foi promulgado o Clayton Antitrust Act (Clayton Act), que veio reforçar e regulamentar as disposições mais generalistas do Sherman Act, apresentando alguns conceitos, aumentando algumas das

\footnotetext{
${ }^{197}$ Para maiores explicações sobre a jurisprudência desenvolvida, inclusive a respeito do caso Charles River Bridge $v$. Warren Bridge, julgado pela Suprema Corte norte-americana em 1837, consultar SILVA, Valéria Guimarães de Lima e. Direito antitruste: aspectos internacionais. Curitiba: Juruá, 2007, pp. 77-80.

198 Silva destaca que o retardamento desta efetividade também se deve à falta de clareza e às lacunas do Sherman Act, bem como ao fato de as cortes federais norte-americanas haverem dedicado os seus esforços em interpretar o Sherman Act de acordo com a jurisprudência formada antes da sua vigência - a qual era mais tolerante. (SILVA, Valéria Guimarães de Lima e. Op. cit., 2007, p. 82).

${ }^{199} \mathrm{O}$ caso precursor da regra da razão (rule of reason) foi o Standard Oil Co. of New Jersey $v$. Estados Unidos, 221 U.S. 1 (1911). Ginsburg e Fraser também destacam a relevância da regra da razão no direcionamento da legislação antitruste em prol da proteção do bem-estar do consumidor. (GINSBURG, Douglas H.; FRASER, Eric M. The role of economic analysis in competition law. Getting the balance right intellectual property, competition law and economics in Asia. Hart Publishing, 2010, p. 21. Disponível em: <http://www.papers.ssrn.com/sol3/papers. cfm?abstract_id=1610189>. Acesso em: 19 ago. 2012).
} 
penas anteriormente estabelecidas e regulando o controle das concentrações econômicas ${ }^{200}$. O Clayton Act visou à repressão dos preços discriminatórios, das vendas casadas e de qualquer outra prática relacionada ${ }^{201}$.

O Federal Trade Commission Act, de 1914, criou a Federal Trade Commission (FTC), autoridade administrativa norte-americana de defesa da concorrência. Esta entidade passou a deter poderes de impedir a consecução de atos anticoncorrenciais, de investigação e reunião de informações relativas à matéria concorrencial, para além de celebrar acordos com empresas infratoras com objetivo de impedir o prosseguimento de processos. Todavia, ao FTC não foi atribuído o poder de impor as penalidades estabelecidas aos infratores da legislação de defesa da concorrência, cabendo-lhe tão somente iniciar procedimento perante o judiciário para tal finalidade.

Nem o Clayton Act, nem o Federal Trade Commission Act, no entanto, regularam a questão da aplicação extraterritorial do Direito da Concorrência norte-americano. Todavia, munidos deste conjunto normativo, os tribunais norte-americanos desenvolveram a sua jurisprudência partindo do princípio da territorialidade estrita até a adoção da teoria dos efeitos, a qual é o ponto central da atual política legislativa dos Estados na aplicação extraterritorial das respectivas legislações de defesa da concorrência.

\subsection{Precedentes legislativos norte-americanos}

Jaeger $^{202}$ identifica quatro princípios desenvolvidos pela doutrina para a aplicação do Direito da Concorrência no âmbito internacional. Tais princípios são utilizados de forma conjugada pelas diferentes legislações nacionais de defesa da concorrência e servem como critérios para determinação do alcance das respectivas legislações de defesa da concorrência nos casos em que efeitos são surtidos em diversos mercados.

\footnotetext{
${ }^{200}$ O Robson-Patman Act de 1936 e o Celler-Kefauver Act de 1950 vieram para reforçar as disposições do Clayton Act.

${ }^{201}$ Silva destaca, ainda, os problemas verificados na legislação adotada, dentre as quais se destaca o extenso campo de interpretação conferido pelo Clayton Act e a sua tardia promulgação. (SILVA, Valéria Guimarães de Lima e. Direito antitruste: aspectos internacionais. Curitiba: Juruá, 2007, pp. 85-86).

${ }^{202}$ JAEGER JÚNIOR, Augusto. Direito Internacional da Concorrência - Entre perspectivas unilaterais, multilaterais, bilaterais e regionais. Curitiba: Juruá, 2008, p. 61. Outros autores sugerem diferente classificação, como Forgioni, que propõe a análise do tema através de critérios para determinação da "lei aplicável", os quais seriam (i) a territorialidade; (ii) a nacionalidade dos agentes; e (iii) o local de verificação dos efeitos. (FORGIONI, Paula A. Os fundamentos do antitruste. 4. ed. São Paulo: Revista dos Tribunais, 2010, p. 444). Tavares de Araújo Júnior, por sua vez, refere-se aos princípios da territorialidade e da extraterritorialidade (TAVARES DE ARAÚJO JR, José. Política de concorrência no Mercosul: uma agenda mínima. Ago. 2001, p. 1. Disponível em: <http://www.sedi.oas.org/DTTC/TRADE/PUB/STAFF_ ARTICLE/taI01_conc_agenda.asp >. Acesso em: 22 out. 2009).
} 


\subsection{O princípio da territorialidade estrita}

Segundo o princípio da territorialidade estrita, a legislação de defesa da concorrência de determinado país será aplicada às práticas ocorridas no correspondente território e que nele façam surtir seus efeitos. A atividade negocial dentro do território nacional $^{203}$ é ponto central deste princípio, uma vez que prevê a comunicação dos acordos realizados ao menos por duas sociedades que atuam em um Estado à autoridade de defesa da concorrência local. O princípio da territorialidade está em conformidade com os princípios do Direito Internacional, uma vez que o Estado, enquanto membro de uma comunidade internacional, exerce a sua autoridade dentro do seu próprio território ${ }^{204}$.

O âmbito de aplicação da legislação nacional de defesa da concorrência é muito restringido pela adoção deste princípio, uma vez que não abarca acordos que se relacionem com mercados exteriores - inclusive aqueles realizados no exterior e que fazem surtir seus efeitos no mercado interno. Por outro lado, a opção pela adoção deste modelo está na possibilidade de se evitar protestos de outros países ${ }^{205}$, cumprindo automaticamente com os princípios do Direito Internacional.

O princípio da territorialidade estrita é atualmente adotado em países como a Inglaterra, Paquistão e Índia, além de outros integrantes da commonwealt $^{206}$. Inclusive a Lei de Concorrência brasileira, ao estabelecer no seu art. $2^{\circ}$ que deverá ser aplicada "às práticas cometidas em todo ou em parte no território nacional", em certa medida adota o princípio da territorialidade ${ }^{207}$.

\footnotetext{
${ }^{203}$ Jaeger Júnior esclarece nesse tocante que a atividade negocial em questão constitui "aquela explorada de forma permanente, por empresa nacional, submetida ao seu próprio direito". (JAEGER JÚNIOR, Augusto. Direito Internacional da Concorrência - Entre perspectivas unilaterais, multilaterais, bilaterais e regionais. Curitiba: Juruá, 2008, p. 62).

${ }^{204}$ FORGIONI, Paula A. Os fundamentos do antitruste. 4. ed. São Paulo: Revista dos Tribunais, 2010, p. 444.

${ }^{205}$ Normalmente são emanados em função da aplicação extraterritorial do Direito.

${ }^{206}$ Nesse sentido ver JAEGER JÚNIOR, Augusto. Op. cit., 2008, p. 62.

${ }^{207}$ Autores como Forgioni esclarecem nesse respeito que "é competente a jurisdição brasileira para apreciar as práticas antitruste que sejam cometidas dentro do seu território". (FORGIONI, Paula A. Op. cit., 2010, p. 445). No caso brasileiro, no entanto, esse princípio é conjugado com a teoria dos efeitos, conforme se verá mais adiante.
} 
a) Caso American Banana Co. v. United Fruit Co. (Suprema Corte dos Estados Unidos 1909)

Nos Estados Unidos, outrora, esse princípio já teve aplicação ${ }^{208}$. No caso American Banana Co. v. United Fruit Co. ${ }^{209}$, julgado pela Suprema Corte dos Estados Unidos, em 1909, a aplicação extraterritorial da legislação norte-americana a práticas ocorridas no exterior foi rejeitada com base no princípio da territorialidade e na doutrina de ato do Estado $^{210}$.

A empresa autora American Banana Co. foi constituída no Alabama, em 1904, enquanto que a ré, United Fruit Co. foi constituída em 1899, em Nova Jérsei. A autora alegou no processo em questão que antes mesmo da sua constituição, McConnell começou o cultivo de bananas no Panamá - então parte dos Estados Unidos da Colômbia - e começou a construir uma estrada de ferro com a finalidade de escoar a produção para exportação. Tais iniciativas foram conduzidas de acordo com a legislação local.

McConnel foi então notificado pela ré para celebrar um acordo ou desistir das ações naquele território. Alguns meses depois, o governador do Panamá recomendou ao seu governo a concessão da autorização para que a Costa Rica passasse a administrar o território onde passava a estrada de ferro. O governo da Costa Rica interferiu, então, com as atividades de McConnell, havendo alguns soldados e oficiais costa-riquenhos confiscado parte da plantação e um carregamento de produtos, para além de terem obstado a finalização da construção da estrada de ferro. A autora alegava que as intervenções governamentais tiveram lugar em razão da influência da ré.

A American Banana Co. tentou induzir o governo da Costa Rica a retirar os seus soldados, bem como tentou fazer com que os Estados Unidos interferissem na questão, mas não obteve êxito. Como resultados dos atos da ré, a autora teria sido privada do uso da plantação, da estrada de ferro e dos produtos apreendidos. Para além disso, a ré teria se

\footnotetext{
208 "As principais leis norte-americanas que formam a espinha dorsal do tratamento da concorrência no país, [...], contrariamente do que se possa imaginar, não contêm qualquer dispositivo prevendo a sua extraterritorialidade. Inicialmente, a aplicação dessas leis pelos tribunais foi realizada em observância ao princípio da territorialidade estrita, havendo sido revertida essa situação somente em 1945 [...]". (SILVA, Valéria Guimarães de Lima e. Direito antitruste: aspectos internacionais. Curitiba: Juruá, 2007, p. 97). ${ }^{209}$ ESTADOS UNIDOS DA AMÉRICA DO NORTE. Caso American Banana Co. v. United Fruit Co. Suprema Corte, 213 U.S. 347, 1909. Disponível em: <http://supreme.justia.com/ us/213/347/case.html>. Acesso em: 10 jul. 2011.

${ }^{210}$ Doutrina (Act of State Doctrine) criada em 1897 pela Suprema Corte dos Estados Unidos. Ainda sobre esta decisão consultar CARVALHO, Leonardo Arquimino de. Direito antitruste \& relações internacionais: extraterritorialidade e cooperação. Curitiba: Juruá, 2003, p. 101. Ao comentar a decisão, o autor explica que "a regra geral é de que o caráter de um ato como legal ou ilegal deva ser determinado pela lei do país onde o ato é concluído, sendo toda a legislação prima facie territorial. De modo contrário, seria uma interferência na autoridade soberana de outro Estado".
} 
beneficiado da situação uma vez que acabou por compelir os produtores a aceitarem as suas demandas, impedindo que a autora comprasse produtos para exportação e venda.

A American Banana Co. iniciou então uma ação perante as cortes norte-americanas com o objetivo de ser ressarcida dos prejuízos sofridos. A Suprema Corte norte-americana decidiu em desfavor da autora, fundamentando a sua decisão no fato de que as normas do Sherman Act não devem ser aplicadas a atos produzidos no exterior, mesmo que afetem adversamente o mercado norte-americano ou que tenham sido realizados por pessoas ou entidades norte-americanas ${ }^{211}$. O julgado reconhece, ainda, que a caracterização de um ato como legal ou ilegal deve ser realizada de acordo com a legislação do país onde tal ato foi realizado. A Suprema Corte entendeu, neste diapasão, que qualquer tentativa de aplicação de outra legislação, além de injusta, constituiria uma interferência na autoridade de outro país soberano, contrário à sociedade internacional ${ }^{212}$.

b) Caso Estados Unidos v. Sisal Sales Corp. (Suprema Corte dos Estados Unidos - 1927)

Em 1927, a Suprema Corte norte-americana julgou o caso Estados Unidos v. Sisal Sales Corp. ${ }^{213}$, que "preparou o caminho para a aceitação da extraterritorialidade do direito da concorrência por parte das cortes norte-americanas"214.

O caso em questão envolvia a comercialização do sisal - a fibra de uma planta nativa mexicana utilizada na colheita de milho nos Estados Unidos. A decisão da Suprema

\footnotetext{
${ }^{211}$ A decisão do caso estabeleceu nesta ocasião que "the prohibitions of the Sherman Anti-Trust Law of July 2, 1890, c. 647. 26 Stat. 209, do not extend to acts done in foreign countries even though done by citizens of the United States and injuriously affecting other citizens of the United States [...] Acts of soldiers and officials of a foreign government must be taken to have been done by its order". (ESTADOS UNIDOS DA AMÉRICA DO NORTE. Caso American Banana Co. v. United Fruit Co. Suprema Corte, 213 U.S. 347, 1909, p. 213. Disponível em: http://supreme.justia.com/ us/213/347/case.html. Acesso em: 10 jul. 2011. Swaine comenta a decisão: "the court upheld dismissal of the complaint because the relevant acts - the seizure by the Costa Rican government of property owned by American Banana, allegedly at United Fruit's behest - took place outside the United States". (SWAINE, Edward T. Cooperation, comity and competition policy: United States. Cooperation, comity and competition policy. New York: Oxford University Press, 2011, p. 3).

212 "Under American Banana, geographic borders served to mark the outermost limits of a domestic law's reach, and conduct had to occur within those boundaries in order for domestic laws to apply". (GUZMAN, Andrew T. Competition law and cooperation: possible strategies. Cooperation, comity and competition policy. New York: Oxford University Press, 2011, p. 346).

${ }^{213}$ ESTADOS UNIDOS DA AMÉRICA DO NORTE. Caso Estados Unidos $v$. Sisal Sales Corp, Suprema Corte, 274 U.S. 268 (1927). Disponível em: http://supreme.justia.com/us/274/268/. Acesso em: 10 jul. 2011.

${ }^{214}$ JAEGER JÚNIOR, Augusto. Direito internacional da concorrência - Entre perspectivas unilaterais, multilaterais, bilaterais e regionais. Curitiba: Juruá, 2008, p. 72. Ver também CARVALHO, Leonardo Arquimino de. Direito antitruste \& relações internacionais: extraterritorialidade e cooperação. Curitiba: Juruá, 2003, p. 103, que esclarece que a corte norte-americana baseou a sua decisão na competência dos Estados Unidos de proteger as suas leis no seu próprio território - com fundamento no princípio da territorialidade.
} 
Corte americana versou sobre uma apelação apresentada em nome do governo dos Estados Unidos contra três entidades bancárias, duas sociedades constituídas em Delaware (Eric Co. e Sisal Sales Co.), uma sociedade mexicana (Comision Exportadora de Yucatan) e membros da corretora Hanson \& Orth. O objeto principal da demanda relacionava-se ao controle da importação e comercialização do sisal, bem como o completo monopólio da comercialização do produto nos mercados interno e internacional.

A Suprema Corte esclareceu que o caso em análise diferia em muito do American Banana Co. v. United Fruits Co., uma vez que neste caso a lide versava sobre atos realizados fora do território norte-americano e que não eram considerados ilegais pela legislação local. O caso do sisal, por outro lado, tratava da averiguação de acordo, combinação e conspiração realizadas pelas apeladas em território norte-americano, porém efetivadas no exterior. Houve, desta forma, uma violação das leis norte-americanas por pessoas que estão sujeitas à jurisdição dos Estados Unidos - e não simplesmente a verificação de atos anticoncorrenciais promovidos por outros governos no exterior. Desta forma, decidiu-se pelo reconhecimento da competência das cortes norte-americanas e pela aplicação da legislação norte-americana de defesa da concorrência ${ }^{215}$.

Não obstante as decisões anteriormente descritas, não é possível afirmar que nos Estados Unidos se aplica a teoria da territorialidade estrita, em face da alteração na orientação jurisprudencial, conforme se verá a seguir.

\subsection{O Princípio da Pseudoterritorialidade}

O princípio da pseudoterritorialidade constitui um meio termo entre o princípio da territorialidade estrita e a teoria dos efeitos, melhor descrita a seguir. Trata-se de alternativa intermediária que engloba tanto as práticas que limitam a concorrência nos mercados locais causadas por sociedades situadas neste mesmo mercado, bem como aquelas causadas no exterior por sociedades que possuem alguma atividade negocial dentro

\footnotetext{
${ }^{215}$ A Suprema Corte norte-americanaestabeleceu neste caso que "the United States complain of a violation of their laws within their own territory by parties subject to their jurisdiction, not merely of something done by another government at the instigation of private parties. True, the conspirators were aided by discriminating legislation, but, by their own deliberate acts, here and elsewhere, they brought about forbidden results within the United States. They are within the jurisdiction of our courts, and may be punished for offenses against our laws". (ESTADOS UNIDOS DA AMÉRICA DO NORTE. Caso Estados Unidos $v$. Sisal Sales Corp, Suprema Corte, 274 U.S. 268 (1927), p. 274. Disponível em: <http://supreme.justia.com/us/274/268/.> Acesso em: 10 jul. 2011).
} 
de tais mercados nacionais ${ }^{216}$. Adotam o princípio da pseudoterritorialidade o Canadá e a União Europeia, em sua legislação comunitária.

O desenvolvimento deste princípio ocorreu no âmbito da União Europeia como uma alternativa à teoria dos efeitos, a partir do aprimoramento da teoria da unidade econômica $^{217}$. Esta teoria considera que a empresa matriz estrangeira de sociedade controlada localizada em um dado território submete-se à legislação de defesa da concorrência desse território.

Destaca-se também o vínculo do princípio da pseudoterritorialidade à teoria da implementação do comportamento limitador da concorrência - também concebida no âmbito da União Europeia, com vistas a ultrapassar as limitações da teoria da unidade econômica $^{218}$. Tal teoria busca diferenciar os efeitos do próprio comportamento em si, abarcando as situações em que as práticas limitadoras da concorrência sejam exercidas por sociedades localizadas no exterior, as quais não possuem representação local por meio de sociedades controladas ou, no caso de as possuir, as controladas não participem do comportamento recriminado.

Na opinião de Jaeger Júnior, na prática os limites extraterritoriais da legislação comunitária foram ampliados de forma a alcançar sociedades sem qualquer subordinação no território em questão, ofendendo ou não os princípios do direito internacional ${ }^{219}$.

\footnotetext{
${ }^{216}$ Jaeger Júnior explica que "o desenvolvimento deste princípio permitiu uma válvula escapatória para os Estados que queriam se manter apegados ao princípio da territorialidade estrita e distantes das críticas do outros membros da sociedade internacional, mas que queriam aproximar-se de uma defesa da concorrência baseada em uma legislação que contivesse a teoria dos efeitos e alargar um pouco o âmbito de aplicação de suas legislações". (JAEGER JÚNIOR, Augusto. Direito internacional da concorrência - Entre perspectivas unilaterais, multilaterais, bilaterais e regionais. Curitiba: Juruá, 2008, p. 63).

217 "No acórdão ICI/Comissão <o Tribunal> preferiu recorrer à teoria da unidade económica do grupo, formado pelas filiais comunitárias e empresas-mãe estrangeiras, para justificar a aplicação do direito comunitário - afirmando que as três empresas não comunitárias, Geigy, Sandoz e ICI, participaram num acordo de fixação de preços ilegal através das suas filiais estabelecidas na Comunidade que eram controladas pelas empresas-mãe, apesar de o advogago-geral Henri Mayras the ter sugerido a adopção da teoria dos efeitos limitada aos efeitos 'qualificados', isto é, aos efeitos 'directos', 'imediatos', 'previsíveis' e "substanciais"'. (PAIS, Sofia Oliveira. O controle das concentrações de empresas no âmbito do Direito Comunitário da Concorrência. Coimbra: Almedina, 1996, pp. 336-338). Ver também SILVA, Valéria Guimarães de Lima e. Direito antitruste: aspectos internacionais. Curitiba: Juruá, 2007, pp. 75-76; FORGIONI, Paula A. Os fundamentos do antitruste. 4. ed. São Paulo: Revista dos Tribunais, 2010, pp. 445-446; JAEGER JÚNIOR, Augusto. Op. cit., 2008, pp. 63-64.

${ }^{218}$ Para maiores referências sobre esta teoria, analisar SILVA, Valéria Guimarães de Lima e. Op. cit., 2007, p. 76.

${ }^{219}$ JAEGER JÚNIOR, Augusto. Op. cit., 2008, pp. 64-65.
} 


\subsection{A teoria dos efeitos}

Conforme referido anteriormente, a teoria dos efeitos ${ }^{220}$ é fruto do desenvolvimento jurisprudencial norte-americano ${ }^{221}$, mais especificamente do caso Estados Unidos $v$. Aluminium Corp. of America et al. (Alcoa), julgado em $1945^{222}$, conforme se verá a seguir.

a) Caso Estados Unidos v. Aluminium Corp. of America (Alcoa) (Corte do Segundo Circuito dos Estados Unidos - 1945)

O caso Alcoa trata de uma ação movida pelos Estados Unidos contra a Aluminium Company of America (Alcoa), a Aluminium Limited (Limited) e outros, com o objetivo de obter da corte a declaração de que os réus estavam monopolizando o comércio interestadual e internacional de lingote de alumínio, bem como executando práticas anticoncorrenciais que visavam eliminar seus concorrentes, e que, por tal razão, tais sociedades deveriam ser dissolvidas. Outro pedido relacionava-se à alegada conspiração ilegal dos réus com outras sociedades estrangeiras para restrição de tal comércio $^{223}$.

No bojo do julgamento a Corte do Segundo Circuito chegou à conclusão de que a Alcoa controlava $90 \%$ do mercado de lingote de alumínio ${ }^{224}$. O restante da participação de mercado seria consumido por importações realizadas no mercado norte-americano. Tendo

\footnotetext{
${ }^{220}$ Nusdeo reconhece a teoria dos efeitos como "teoria do impacto territorial", conceituando-a como a teoria pela qual "o Estado é competente para legislar e conhecer de eventos ocorridos fora do seu território, envolvendo participantes não nacionais, desde que tais eventos produzam efeitos dentro do território nacional". (NUSDEO, Ana Maria de Oliveira. Defesa da concorrência e globalização econômica. São Paulo: Malheiros, 2002, p. 162).

${ }^{221}$ SILVA, Valéria Guimarães de Lima e. Direito antitruste: aspectos internacionais. Curitiba: Juruá, 2007, p. 74.

${ }^{222}$ ESTADOS UNIDOS DA AMÉRICA DO NORTE. Caso Estados Unidos $v$. Aluminium Corp. of America et. al. (Alcoa), Corte do Segundo Distrito, n. 144148 F.2d 416 (1945). Disponível em: <http://myweb. clemson.edu/ maloney/424/alcoa.pdf>. Acesso em: 10 jul. 2011.

${ }^{223} \mathrm{O}$ caso envolveu a análise de uma série de condutas dos réus que seriam contrárias à concorrência, dentre as quais se destaca a monopolização do mercado do lingote de alumínio para manipulação de preços, eliminação de concorrentes entrantes no mercado de lingote de alumínio - dominação da matéria prima, price squeeze, dentre outras. Todavia, em consideração aos objetivos deste estudo, a análise exposta deve ser concentrada na alegação de que a Alcoa e/ou a Limited estariam envolvidas numa conspiração ilegal com outras sociedades estrangeiras e que, por tal motivo, deveriam ser condenadas por terem transgredido a legislação aplicável.

${ }^{224}$ Tal percentagem referia-se à participação no mercado de lingote de alumínio virgem - excluindo assim o mercado secundário de lingote de alumínio. É interessante notar que o predomínio da Alcoa no mercado norte-americano de lingote de alumínio foi o resultado do desenvolvimento das suas atividades em período anterior, resguardadas pela exclusividade conferida em razão de duas patentes de sua titularidade. No momento em que tais patentes expiraram, a Alcoa detia substancial participação no mercado em questão, bem como um grande parque de produção. Por tal razão, conseguiu manter a sua posição dominante no mercado nos anos que sucederam.
} 
em vista que as importações do produto constituíam relevante condicionante ao mercado interno norte-americano de lingote de alumínio, o comércio internacional do produto assumiu, assim, relevância nas considerações apresentadas pela corte.

A Alcoa era uma sociedade norte-americana, com sede na Pensilvânia. Já a Limited foi constituída de acordo com a legislação canadense, em 1928, com o objetivo de assumir e administrar as propriedades estrangeiras que outrora pertenciam à Alcoa. Apesar de possuírem personalidades jurídicas distintas, ambas as sociedades tinham como principais acionistas os mesmo indivíduos. A Alcoa e a Limited mantiveram numerosas operações entre si, que os Estados Unidos consideravam não terem sido realizadas de acordo com as condições normais de mercado. Ainda, foram demonstradas algumas situações de cooperação entre as empresas na decisão. Não obstante as ligações detectadas, a Corte do Segundo Circuito decidiu que tratavam de estruturas jurídicas apartadas e, assim, não poderiam ser consideradas como um único agente econômico.

Em relação à alegação de conspiração ilegal, constatou-se durante o julgamento que um cartel denominado "Aliança" havia sido formado. Tal cartel foi estabelecido por meio de uma sociedade constituída na Suíçaa ${ }^{225}$, por seis sociedades estrangeiras, dentre as quais se destaca a Limited. Note-se que a Alcoa jamais chegou a ser um dos acionistas do referido cartel. Haja vista a Corte do Segundo Circuito haver decidido que a Alcoa e a Limited eram entidades distintas, desde logo descartou-se a possibilidade de condenação da Alcoa em razão da formação do cartel. Persistia, no entanto, a dúvida se a Limited poderia de alguma forma ser responsabilizada pela formação do dito cartel, consoante a legislação dos Estados Unidos. Buscava saber, portanto, se uma sociedade canadense poderia ser condenada por uma corte norte-americana, consoante a sua legislação de defesa da concorrência, em razão de cartel estabelecido na Suíça com outras sociedades estrangeiras.

Todos os participantes do dito cartel eram produtores de lingote de alumínio e, através da Aliança, estabeleceram um sistema de quotas e royalties para controle da sua produção num panorama internacional. $\mathrm{O}$ ato constitutivo do cartel fazia, inclusive, expressa referência ao mercado norte-americano, considerando-o, dessa forma, como um dos mercados-alvo da atuação dos seus acionistas 226 .

\footnotetext{
${ }^{225}$ O cartel funcionava por intermédio de uma sociedade constituída na Suíça, que servia de base operacional à alocação das cotas de produção entre os membros e a fixação dos preços internacionais do produto, da qual não participava diretamente a sociedade norte-americana Alcoa.

${ }^{226} \mathrm{O}$ cartel teve dois acordos que regulavam o seu funcionamento, nomeadamente o Ato Constitutivo de 1931 e o Acordo de 1936, que substituiu o primeiro. O Ato Constitutivo de 1931 continha a Cláusula de
} 
A Corte do Segundo Circuito acabou por decidir que a legislação norte-americana deveria ser aplicada ao cartel. Nesse sentido, a corte reconheceu que a questão não dependia do reconhecimento das obrigações previstas na legislação estrangeira como fundamento da responsabilidade das empresas envolvidas. A preocupação era no sentido de saber se o Congresso norte-americano havia escolhido incluir no âmbito de aplicação da legislação de defesa da concorrência dos Estados Unidos as condutas executadas no exterior por pessoas ou entidades que não fossem da nacionalidade norte-americana.

Desta forma, a corte escolheu analisar a legislação consoante as limitações geralmente encontradas em sede de Direito Internacional Privado, mais precisamente no que se refere às normas de conflito ${ }^{227}$. Reconheceu-se que o Congresso norte-americano não pretendia abarcar na legislação aquelas condutas realizadas no exterior que não traziam qualquer consequência dentro do território dos Estados Unidos. Por outro lado, era incontroverso na referida demanda que qualquer Estado poderia impor a sua legislação a qualquer sujeito, mesmo que estrangeiro, em razão de condutas efetivadas fora dos seus limites geográficos e que viessem ocasionar efeitos no seu território. Tal possibilidade seria, inclusive, reconhecida pelos demais Estados.

Para o corpo de julgadores, dois fatores deveriam ser verificados quanto à determinação de se aplicar ou não a legislação norte-americana, a saber (i) a intenção de afetar o mercado norte-americano e (ii) a concreta verificação de tais efeitos neste mercado. No caso Alcoa, a corte entendeu que existia tanto a intenção como a concretização dos efeitos no mercado, pelo que a legislação norte-americana de defesa da concorrência haveria de ser aplicada.

Desta forma, a Limited - sociedade canadense - foi condenada pela Corte do Segundo Circuito, em vista da participação do acordo de cartel estrangeiro, com base no

Conversão que estabelecia que qualquer acionista poderia exceder a sua quota na medida em que tal acionista convertesse em alumínio nos Estados Unidos ou Canadá quaisquer minérios entregues a ele em algum desses países por pessoas situadas nos Estados Unidos. Tal previsão tinha por objetivo permitir que a Limited recebesse bauxita ou alumina da Alcoa para fundir em alumínio e entregar o produto para a Alcoa. O Acordo de 1936 não continha nenhuma previsão expressa em relação à importação do produto nos Estados Unidos. Todavia, durante a preparação dos termos do acordo todos os acionistas concordaram que tais importações deveriam ser incluídas nas quotas.

227 "Na decisão proferida pela Corte, o Juiz habilmente transferiu o enfoque da questão constitucional para um enfoque não menos interessante, contudo, mais facilmente contornável, relacionado a conflito de leis. Concluiu que, sob determinadas situações, poderia um Estado impor obrigações para pessoas além de suas fronteiras por condutas que causassem consequências dentro das fronteiras do Estado". (CARVALHO, Leonardo Arquimino de. Direito antitruste \& relações internacionais: extraterritorialidade e cooperação. Curitiba: Juruá, 2003, pp. 103-106). No mesmo sentido afirmam Oliveira e Rodas: "o Juiz, tendo preferido abordagem de conflito de leis a uma visão constitucionalista, alargou a competência internacional do Estado". (OLIVEIRA, Gesner; RODAS, João Grandino. Direito e economia da concorrência. Rio de Janeiro: Renovar, 2004, p. 377). 
art. $1^{\mathrm{o}}$ do Sherman Act. Houve, portanto, uma extensão da aplicabilidade territorial da legislação, uma vez que o Sherman Act foi aplicado a um acordo celebrado no exterior, que tencionava - e efetivamente produziu - efeitos no território norte-americano ${ }^{228}$. A extensão da jurisdição nacional norte-americana e a consequente aplicação extraterritorial da legislação de defesa da concorrência fez emergir a conhecida teoria dos efeitos ${ }^{229}$.

Segundo a teoria dos efeitos, independentemente de uma dada empresa estar localizada em um país estrangeiro, as práticas limitadoras da concorrência praticadas por ela serão reguladas pelo direito nacional de defesa da concorrência do país cujos efeitos tais práticas fizeram surtir no seu território ${ }^{230}$. Não importa, desta forma, a nacionalidade da empresa, o local da prática ou o fato de o país onde a prática ocorreu não condenar a conduta. A teoria dos efeitos é entendida como resultado de uma interpretação extensiva do princípio da territorialidade objetiva ${ }^{231}$.

A solução do caso Alcoa serviu de base à evolução da jurisprudência norteamericana que seguiu desde então, havendo sido corroborada pela Suprema Corte dos Estados Unidos nos casos Continental Ore Co. v. Union Carbide and Carbon Corp. em $1962^{232}$ e Hartford Fire Insurance Co. v. California em $1993^{233}$. O Foreign Trade Antitrust

\footnotetext{
${ }^{228}$ Jaeger Júnior destaca que os tribunais norte-americanos tentaram em decisões posteriores caracterizar o termo "efeito", havendo destacado três características essenciais: intenção e previsibilidade, substancialidade e caráter direto do efeito e avaliação consoante a capacidade de um homem médio comum. Inclusive, a International Law Association e o Institut de Droit Internacional defendem que tais características devem sem observadas cumulativamente para a boa aplicação da teoria dos efeitos. (JAEGER JÚNIOR, Augusto. Direito Internacional da Concorrência - Entre perspectivas unilaterais, multilaterais, bilaterais e regionais. Curitiba: Juruá, 2008, pp. 74-75). De outra banda, Oliveira e Rodas destacam ainda que "o fato de as cortes federais não terem sido unânimes em seguir tal precedente - Caso Alcoa -, provocou solução legislativa dada pelo Congresso Norte-Americano em 1982, quando emitiu o Foreign Trade Antitrust Improvement Act. Essa lei esclareceu que o Sherman Act não teria jurisdição sobre o comércio exterior, a menos que a conduta tivesse efeito direto, substancial e razoavelmente previsível no mercado do país. Para que pudesse o Act alcançar importação ou exportação, deveria ter havido contratação nos Estados Unidos. Conforme esse diploma legal, a doutrina dos efeitos sofreu forte mutação, não podendo atuar, por exemplo, para impedir cartéis de exportação engendrados no exterior e dirigidos para o território norte-americano". (OLIVEIRA, Gesner; RODAS, João Grandino. Direito e economia da concorrência. Rio de Janeiro: Renovar, 2004, p. 378).

${ }^{229}$ FOX, Eleanor M. Antitrust without borders: from roots to codes to networks. Cooperation, comity and competition policy. New York: Oxford University Press, 2011, p. 265.

${ }^{230}$ A teoria dos efeitos "looked past the location of the conduct alleged to have violated U.S. antitrust law to focus instead on the conduct's consequences", expõe SWAINE, Edward T. Cooperation, comity and competition policy: United States. Cooperation, comity and competition policy. New York: Oxford University Press, 2011, p. 5.

${ }^{231}$ O princípio da territorialidade foi alargado para compreender os efeitos resultantes de uma prática ocorrida em outro território. Nesse sentido ver JAEGER JÚNIOR, Augusto. Op. cit., 2008; e SILVA, Valéria Guimarães de Lima e. Direito antitruste: aspectos internacionais. Curitiba: Juruá, 2007.

${ }^{232}$ ESTADOS UNIDOS DA AMÉRICA DO NORTE. Caso Continental Ore Co. v. Union Carbide and Carbon Corp, Suprema Corte, 370 U.S. 690 (1962).

${ }^{233}$ ESTADOS UNIDOS DA AMÉRICA DO NORTE. Caso Hartford Fire Insurance Co. v. California, Suprema Corte, 113 S.Ct. 2891 (1993). Ver SWAINE, Edward T. Op. cit., 2011, p. 5-6; GUZMAN, Andrew T. Competition law and cooperation: possible strategies. Cooperation, comity and competition policy. New York: Oxford university Press, 2011, p. 347.
} 
Improvement Act, de 1982, codificou a teoria dos efeitos no sistema norte-americano, ao determinar a aplicabilidade do Sherman Act às condutas que tivessem um efeito "direto, substancial e razoavelmente previsível sobre o comércio dos Estados Unidos" ${ }^{\text {„34 }}$.

A teoria dos efeitos também acabou por ser transportada para outros sistemas jurídicos ${ }^{235}$, dentre os quais o direito comunitário, o direito da Alemanha, da Suíça, da Austrália, da Espanha, da Grécia, da Noruega, da Suécia, da Áustria, da Eslováquia, da Polônia, da Rússia, da Eslovênia, da Romênia, da Bulgária, da Argentina e do Brasil, conforme se verá a seguir.

\subsection{O princípio da ponderação}

A teoria dos efeitos sofreu muitas críticas, conforme analisar-se-á adiante, sendo este o principal motivo do desenvolvimento do princípio da ponderação, o qual foi concebido como meio de mitigar os problemas identificados. O princípio da ponderação constitui, desta forma, um desdobramento da teoria dos efeitos, pelo qual se procura conciliar os interesses dos Estados envolvidos ${ }^{236}$. Ou seja, propõe-se a aplicação extraterritorial da legislação de defesa da concorrência do Estado cujo território sofreu com os efeitos da prática anticoncorrencial, mas de forma a preservar os interesses relevantes dos outros Estados envolvidos por ocasião do julgamento da referida prática. A doutrina anota, por tal razão, que este princípio está conectado ao da cortesia internacional ${ }^{237}$.

\footnotetext{
${ }^{234}$ FARIA, José Ângelo Estrella. O controle de concentrações de empresas estrangeiras e a Lei $\mathrm{n}^{\circ}$ 8.884: a extraterritorialidade revisitada. Júris Síntese, maio/jun. 2009, n. 77, p. 7. Disponível em: $<$ http://online.sintese. com>. Acesso em: 19 ago. 2012.

235 "Desde então, a maioria das legislações nacionais e as normas dos processos de integração dispõem sobre a sua aplicação a práticas limitadoras da concorrência que tenham efeitos internos, independentemente de onde elas foram produzidas, ainda que com diferentes intensidades". (JAEGER JÚNIOR, Augusto. Direito Internacional da Concorrência - Entre perspectivas unilaterais, multilaterais, bilaterais e regionais. Curitiba: Juruá, 2008, p. 37). Ver também nesse sentido FARIA, José Ângelo Estrella. Op. cit., maio/jun. 2009, n. 77, pp. 8 e 10. Disponível em: http://online.sintese.com. Acesso em: 19 ago. 2012; e FOX, Eleanor M. Antitrust without borders: from roots to codes to networks. Cooperation, comity and competition policy. New Yortk: Oxford University Press, 2011, p. 266.

${ }^{236}$ Carvalho Ramos e Cunha destacam os princípios do sovereign immunity doctrine, act of state doctrine $\mathrm{e}$ foreign sovereign compulsion doctrine que foram tentativas disseminadas nos Estados Unidos para atenuar os problemas advindos da aplicação extraterritorial do Direito da Concorrência. (CARVALHO RAMOS, André de; CUNHA, Ricardo Thomazinho da. A defesa da concorrência em caráter global: utopia ou necessidade. In: CASELLA, Paulo Borba (org.). Guerra comercial ou integração econômica mundial. São Paulo: LTr, 1998, v. 1, p. 823).

${ }^{237}$ SILVA, Valéria Guimarães de Lima e. Direito antitruste: aspectos internacionais. Curitiba: Juruá, 2007, pp. 141-144; JAEGER JÚNIOR, Augusto. Op. cit., 2008, pp. 67/77-79.
} 
A evolução da jurisprudência norte-americana sobre o princípio da ponderação teve como expoentes os casos Timberlane Lumber Co. v. Bank of America, N.T. and S.A. ${ }^{238}$, Mannington Mills, Inc. v. Congoleum Corp. ${ }^{239}$ e Laker Airways Ltd. v. Sabena, Belgian World Airways $^{240}$.

a) Caso Timberlane Lumber Co. v. Bank of America (Corte do Nono Circuito dos Estados Unidos - 1976)

O caso versa sobre a violação dos arts. $1^{\circ}$ e $2^{\circ}$ do Sherman Act e do Wilson Tariff Act, em especial sobre a aplicação da legislação norte-americana de defesa da concorrência a atividades ocorridas em outro país, incluindo atos de oficiais governamentais estrangeiros. Em suma, a alegação da Timberland era de que colaboradores do Bank of America, bem como outros oficiais localizados nos Estados Unidos e em Honduras, conspiraram para impedir a Timberland de moer madeira em Honduras, através de suas subsidiárias, e exportar o produto para os Estados Unidos. Desta forma, o controle da exportação de madeira haveria sido mantido por alguns indivíduos selecionados, os quais eram financiados e controlados pelo Bank of America ${ }^{241}$.

A corte distrital que analisou a ação a desconsiderou com base na doutrina do ato de Estado e na incompetência das cortes norte-americanas. Nesta ocasião a corte distrital defendeu que estava impedida de analisar o caso, pois versava sobre atos de um Estado

${ }^{238}$ ESTADOS UNIDOS DA AMÉRICA DO NORTE. Caso Timberlane Lumber Co. v. Bank of America, Corte do Nono Distrito, 549 F. 2d 597 (9th Cir. 1976). Disponível em: <http://openjurist.org/749/f2d/1378/ timberlane-lumber-company-v-bank-of-america-national-trust-and-savings -association>. Acesso em: 10 jul. 2011. Neste caso foi aplicada a tripartite jurisdictional rule of reason test, com o objetivo de afastar a competência das cortes dos Estados Unidos em certos casos (cf. CARVALHO, Leonardo Arquimino de. Direito antitruste \& relações internacionais: extraterritorialidade e cooperação. Curitiba: Juruá, 2003, p. 107). Para maiores informações sobre o caso, ver SILVA, Valéria Guimarães de Lima e. Direito antitruste: aspectos internacionais. Curitiba: Juruá, 2007, pp. 146-148.

${ }^{239}$ ESTADOS UNIDOS DA AMÉRICA DO NORTE. Caso Mannington Mills, Inc. v. Congoleum Corp, Corte do Terceiro Distrito, 595 F. 2d 1287 (3rd Circ 1979). Disponível em: <http://law.justia.com/cases/federal/appellate-courts/F2/595/1287/324597/>. Acesso em: 10 jul. 2011.

${ }^{240}$ ESTADOS UNIDOS DA AMÉRICA DO NORTE. Caso Laker Airways Ltd. v. Sabena Belgian World Airways, Corte Distrito de Columbia, 731 F. 2d 909 (DC Cir. 1984). Disponível em: <http://openjurist.org/731/f2d/909/laker-airways-limited-v-sabena-belgian-world-airlines-klm-laker-airwayslimited>. Acesso em: 10 jul. 2011. Este caso revelou uma divergência da jurisprudência em relação ao Timberlane Lumber Co. v. Bank of America, o que denotou a fraqueza do princípio da ponderação no sistema norte-americano. Carvalho inclusive ressalta que o tribunal enfatizou nesse caso que "decisões políticas que procuram equilibrar interesses domésticos e estrangeiros eram da prerrogativa do poder Executivo e não dos tribunais". (CARVALHO, Leonardo Arquimino de. Direito antitruste \& relações internacionais: extraterritorialidade e cooperação. Curitiba: Juruá, 2003, p. 111).

${ }^{241}$ Para maiores detalhes sobre o caso, ver SWAINE, Edward T. Cooperation, comity and competition policy: United States. Cooperation, comity and competition policy. New York: Oxford University Press, 2011, pp. 10-11. 
estrangeiro soberano que não afetavam direta e substancialmente o comércio exterior norte-americano.

A Suprema Corte norte-americana, ao analisar o caso, levantou a questão relacionada à doutrina de ato de Estado ${ }^{242}$. Todavia, tratou de relativizar a aplicação da referida doutrina, de modo que somente fosse eficaz na medida necessária para respeitar o direito internacional das relações exteriores. Desta forma, declarou incorreta a interpretação da corte distrital de aplicar a doutrina de ato de Estado ao caso com base numa diferenciação entre a natureza do ato praticado pelo governo hondurenho ${ }^{243}$.

A decisão também analisou a questão relativa ao alcance extraterritorial das leis norte-americanas de defesa da concorrência, invocando o caso Alcoa, dentre outros, e declarando que não há dúvidas sobre a incidência da legislação norte-americana sobre algumas condutas realizadas em outras nações. Ressaltou, no entanto, que apesar de alcançar algumas condutas, não alcança todas.

O teste sobre os efeitos no território norte-americano das condutas realizadas no exterior não havia sido aperfeiçoado até aquele momento a ponto de considerar os interesses de outros países e de partes estrangeiras. A Suprema Corte então adotou um teste tripartite $^{244}$ para identificar as condutas que seriam substancialmente relevantes, nos termos da teoria dos efeitos. Houve, portanto, uma tentativa de relativização da teoria dos efeitos, considerando os interesses de Estado estrangeiro, de modo que a simples identificação de

\footnotetext{
${ }^{242}$ A decisão reforçou que "Every sovereign State is bound to respect the independence of every other sovereign State, and the courts of one county will not sit in judgment on the acts of the government of another done within its own territory." (ESTADOS UNIDOS DA AMÉRICA DO NORTE. Caso Timberlane Lumber Co. v. Bank of America, Corte do Nono Distrito, 549 F. 2d 597 (9th Cir. 1976). Disponível em: <http://openjurist.org/749/f2d/1378/timberlane-lumber-company-v-bank-of-america-national-trust-andsavings -association>. Acesso em: 10 jul. 2011).

243 "Unlike the Occidental Petroleum plaintiffs, see id. at 110, Timberlane does not seek to name Honduras or any Honduran officer as a defendant or co-conspirator, nor does it challenge Honduran policy or sovereignty in any fashion that appears on its face to hold any threat to relations between Honduras and the United States. In fact, there is no indication that the actions of the Honduran court and authorities reflected a sovereign decision that Timberlane's efforts should be crippled or that trade with the United States should be restrained". (ESTADOS UNIDOS DA AMÉRICA DO NORTE. Caso Timberlane Lumber Co. v. Bank of America, Corte do Nono Distrito, 549 F. 2d 597 (9th Cir. 1976). Disponível em: <http://openjurist.org/749/ f2d/1378/timberlane-lumber-company-v-bank-of-america-national-trust-and-savings -association>. Acesso em: 10 jul. 2011).

244 "The antitrust laws require in the first instance that there be some effect actual or intended on American foreign commerce before the federal courts may legitimately exercise subject matter jurisdiction under those statutes. Second, a greater showing of burden or restraint may be necessary to demonstrate that the effect is sufficiently large to present a cognizable injury to the plaintiffs and, therefore, a civil violation of the antitrust laws. [...] Third, there is the additional question which is unique to the international setting of whether the interests of, and links to, the United States including the magnitude of the effect on American foreign commerce are sufficiently strong, vis-a-vis those of other nations, to justify an assertion of extraterritorial authority". (ESTADOS UNIDOS DA AMÉRICA DO NORTE. Caso Timberlane Lumber Co. v. Bank of America, Corte do Nono Distrito, 549 F. 2d 597 (9th Cir. 1976). Disponível em:
} 
efeitos no território norte-americano deixaria de ser suficiente para considerar uma conduta havida no exterior como passível de ser submetida à legislação norte-americana.

Apesar da relativização da teoria dos efeitos, a doutrina aponta que os esforços da Suprema Corte norte-americana no julgamento do caso em análise foram insuficientes para restabelecer a confiança da comunidade internacional na "moderação do judiciário norteamericano", que estava abalada por alguns $\operatorname{conflitos}^{245}$.

b) Caso Mannington Mills, Inc. v. Congoleum Corp. (Corte de Apelação do Terceiro Circuito dos Estados Unidos - 1979)

O caso versa sobre patentes detidas pela Congoleum Corp. nos Estados Unidos e em outros 26 países para a fabricação de cobertura química em relevo para piso de vinil ${ }^{246}$. A Mannington Mills, Inc. também exercia atividades relacionadas à fabricação de pisos e obteve a licença da Congoleum Corp. para utilização das patentes no território norteamericano. Apesar a Mannington Mills, Inc. alegar possuir licenciamento semelhante em outras jurisdições, a Congoleum Corp. iniciou contencioso contra a Mannington Mills, Inc. na Nova Zelândia, Canadá, Austrália e Japão.

A Mannington Mills, Inc. iniciou ação nos Estados Unidos contra a Congoleum Corp. alegando violação do art. $2^{\circ}$ do Sherman Act, em face da sua política de licenciamento conduzida no exterior ${ }^{247}$. A corte distrital desconsiderou o caso com base na doutrina de ato de Estado, uma vez que as patentes estrangeiras teriam suas validades determinadas pelas cortes dos respectivos Estados e que qualquer tentativa das cortes norte-americanas de influenciar a proteção de tais patentes seria uma transgressão da doutrina dos atos de Estado.

A corte de apelação do terceiro circuito, ao julgar o caso em análise, concluiu que a doutrina de atos de Estado não constitui impedimento ao conhecimento das demandas da

\footnotetext{
<http://openjurist.org/749/f2d/1378/timberlane-lumber-company-v-bank-of-america-national-trust-andsavings -association>. Acesso em: 10 jul. 2011).

${ }^{245}$ FARIA, José Ângelo Estrella. O controle de concentrações de empresas estrangeiras e a Lei $n^{\circ}$ 8.884: a extraterritorialidade revisitada. Juris Sintese, maio/jun. 2009, n. 77, p. 6. Disponível em: <http://online.sintese. com>. Acesso em: 19 ago. 2012.

${ }^{246}$ Ver maiores detalhes em SWAINE, Edward T. Cooperation, comity and competition policy: United States. Cooperation, comity and competition policy. New York: Oxford University Press, 2011, pp. 10-11.

247 "The complaint charges that Congoleum enforced the foreign patents by bringing and threatening the institution of infringements suits in foreign countries. This activity allegedly restrained the export trade of the United States by restricting the foreign business of Mannington and other American competitors in addition to demonstrating an intent to monopolize". (ESTADOS UNIDOS DA AMÉRICA DO NORTE. Caso Mannington Mills, Inc. v. Congoleum Corp, Corte do Terceiro Distrito, 595 F. 2d 1287 (3rd Circ 1979). Disponível em: <http://law.justia.com/cases/federal/appellate-courts/F2/595/1287/324597/>. Acesso em: 10 jul. 2011).
} 
Mannington Mills, Inc., em face da natureza do ato perpetrado e dos efeitos surtidos sobre as partes.

Nesta ocasião a corte invocou o julgamento Timberlane Lumber Co. v. Bank of America para adotar o mesmo processo de balanceamento das questões relevantes ao caso, na determinação da aplicação extraterritorial da legislação norte-americana de defesa da concorrência. Com este propósito, a corte de apelações enumerou 10 questões relevantes que deveriam ser analisadas, concluindo por entender que não havia impedimento para a aplicação extraterritorial às condutas perpetradas pela Congoleum Corp.

c) Caso Laker Airways, Ltd. v. Sabena Belgian World Airways (Corte de Apelação do Circuito do Distrito Federal dos Estados Unidos - 1984)

A Laker Airways começou a operar na rota Nova Iorque-Londres com tarifas substancialmente mais baixas do que os seus competidores. Em reunião dos concorrentes havida no bojo da Associação Internacional de Transporte Aéreo (IATA), em 1977, as empresas que já compunham o mercado teriam acordado em praticar preços predatórios de forma a eliminar a Laker Airways do mercado em questão.

Não obstante tal decisão, a Laker Airways conseguiu manter as suas operações até 1981, mantendo seu lucro. Nesse ano, no entanto, uma variação cambial da libra esterlina acumulada com a competição em preços predatórios de suas concorrentes - teria ocasionado grandes perdas na operação da Laker Airways. Por tal razão, a Laker Airways viu-se obrigada a buscar financiamento para suas atividades. Nesta época, as suas competidoras teriam diminuído ainda mais os preços praticados no mercado relevante. Em reuniões da IATA havidas em 1981 e 1982 (na Suíça e nos Estados Unidos), haveria sido acordado que as competidoras iriam aumentar os seus preços no segundo semestre de 1982, depois que a Laker Airways houvesse sido eliminada do mercado. Em razão dessas práticas, a Laker Airways viu-se obrigada a iniciar procedimento falimentar em fevereiro de 1982.

O caso revelou duas questões relevantes, quais sejam, as grandes diferenças das políticas de defesa da concorrência dos Estados Unidos e do Reino Unido e os problemas advindos da competência concorrente de diferentes jurisdições sobre um mesmo caso. A Laker Airways iniciou dois procedimentos judiciais perante as cortes norte-americanas, que foram posteriormente unificados e relacionam-se à apelação em análise. Depois que a Laker Airways, Ltd. iniciou a ação perante as cortes norte-americanas, os réus - empresas 
norte-americanas, inglesas e de outros países - iniciaram procedimentos sobre o mesmo caso perante as cortes inglesas, com o intuito de obstar a continuação dos processos iniciados nos Estados Unidos ${ }^{248}$.

Apesar de alguns dos atos anticoncorrenciais alegados pela Laker Airways terem tido lugar nos Estados Unidos, a maioria deles ocorreu no exterior. A corte reconheceu que as condutas alegadas pela Laker Airways afetavam diretamente o bem-estar do consumidor norte-americano, bem como o pagamento dos credores da empresa em processo falimentar e, assim, seriam do interesse dos Estados Unidos. Para além disso, a decisão também tratou da questão relativa à cortesia no Direito Internacional e ao respeito à soberania dos países na aplicação extraterritorial do Direito da Concorrência. Ressaltou, no entanto, que cortesia não deve afastar a proteção da competência das cortes norte-americanas.

A corte norte-americana reconheceu que, consoante o Sherman Act e o Clayton Act, a competência das cortes norte-americanas era incontestável - visto que os preços predatórios praticados afetavam diretamente o comércio dos Estados Unidos. O julgamento do caso da Laker Airways revelou o enfraquecimento da doutrina da ponderação, basicamente por não ter contemplado desde a sua formulação a supremacia dos interesses norte-americanos sobre os interesses dos demais países. Nota-se que a jurisprudência posterior sobre o tema revela a perda de força do princípio da ponderação ${ }^{249}$.

\footnotetext{
${ }^{248}$ A situação ficou ainda mais complexa quando o governo britânico invocou as provisões do British Protection of Trading Interests Act (Act). Cf. descrito na decisão em questão, "upon a determination that measures taken to regulate international trade outside the United Kingdom "threaten to damage the trading interests of the United Kingdom," the Act authorizes the English Secretary of State to require that any person conducting business in the United Kingdom disobey all foreign orders and cease all compliance with the foreign judicial or regulatory provisions designated by the Secretary of State. The Act authorizes the Secretary of State to prevent United Kingdom courts from complying with requests for document production issued by foreign tribunals, and forbids enforcement of treble damage awards or antitrust judgments specified by the Secretary of State". (ESTADOS UNIDOS DA AMÉRICA DO NORTE. Caso Laker Airways Ltd. v. Sabena Belgian World Airways, Corte Distrito de Columbia, 731 F. 2d 909 (DC Cir. 1984). Disponível em: <http://openjurist.org/731/f2d/909/laker-airways-limited-v-sabena-belgian-world-airlinesklm-laker-airways-limited>. Acesso em: 10 jul. 2011).

${ }^{249}$ Nesse sentido Silva declarou que "o fracasso da adoção da cortesia resulta não de suas premissas, que em tese são válidas e desejáveis, mas sim, dos meios utilizados para aplicá-la, que tanto carecem de competência como terminam por deturpar sua finalidade". (SILVA, Valéria Guimarães de Lima e. Direito antitruste: aspectos internacionais. Curitiba: Juruá, 2007, p. 165). Ademais, ver Fox, a qual expõe "through all the years from the famous Timberlane case to the present, no tone U.S. court has ever found the interest of another nation outweighted the interest of the United States in cases in which the United States had na antitrust interest at stake". (FOX, Eleanor M. Antitrust without borders: from roots to codes to networks. Cooperation, comity and competition policy. New York: Oxford University Press, 2011, p. 269).
} 


\subsubsection{A teoria dos efeitos no Direito brasileiro}

\subsection{Art. $2^{\circ}$ da Lei da Concorrência}

$\mathrm{O}$ art. $2^{\circ}$ da Lei $n^{\circ} 8.884 / 1994$ foi o primeiro dispositivo da legislação brasileira a ter explicitamente conotação extraterritorial em matéria de concorrência ${ }^{250}$, o que foi reproduzido nos mesmos termos pela Lei da Concorrência ${ }^{251}$, conforme se verá a seguir. Todavia, mesmo antes do advento da Lei $n^{\circ} 8.884 / 1994$, a doutrina nacional $^{252}$ e as decisões do $\mathrm{CADE}^{253}$ já contemplavam a aplicação da teoria dos efeitos no sistema brasileiro.

Para alguns, o fundamento de tal posicionamento estava na natureza penal da lei de defesa da concorrência, o que invocava a aplicação dos princípios do Direito Penal. Nesse sentido, o art. $6^{\circ}$ do Código Penal brasileiro estabelece como parâmetro para estabelecimento da competência das autoridades brasileiras os resultados das condutas, o que transposto para o cenário do Direito Concorrencial era compreendido como "efeitos". Outros entendem que no bojo da Lei $\mathrm{n}^{\circ} 4.137 / 1962$, mais precisamente seu art. $2^{\circ}$, que estatuía no seu inciso I o domínio dos "mercados nacionais" como forma de abuso do poder econômico, a legislação brasileira de defesa da concorrência deveria ser aplicada às práticas e aos atos "que produzirem tais efeitos nos mercados nacionais" 254 .

\footnotetext{
${ }^{250}$ OLIVEIRA, Gesner; RODAS, João Grandino. Direito e economia da concorrência. Rio de Janeiro: Renovar, 2004, p. 381.

251 ANDERS, Eduardo Caminati; PAGOTTO, Leopoldo; BAGNOLI, Vicente (coords.). Comentários à nova Lei de Defesa da Concorrência. Rio de Janeiro: Forense; São Paulo: Método, 2012, p. 7.

${ }^{252}$ Nesse sentido ver CARVALHO, Leonardo Arquimino de. Direito antitruste \& relações internacionais: extraterritorialidade e cooperação. Curitiba: Juruá, 2003, pp. 126 e ss; JAEGER JÚNIOR, Augusto. Direito Internacional da Concorrência - Entre perspectivas unilaterais, multilaterais, bilaterais e regionais. Curitiba: Juruá, 2008, p. 123; FARIA, José Ângelo Estrella. Aplicação extraterritorial do Direito da Concorrência. Revista de Informação Legislativa. Brasília, jan./mar. 1990, n. 105, pp. 20 e 25; FARIA, José Ângelo Estrella. O controle de concentrações de empresas estrangeiras e a Lei $n^{\circ}$ 8.884: a extraterritorialidade revisitada. Juris Sintese, maio/jun. 2009, n. 77, p. 18. Disponível em: <http://online.sintese.com>. Acesso em: 19 ago. 2012.

${ }^{253}$ Dentre as decisões em questão está o Processo Administrativo no $1 / 63$ e o Pedido de Registro $\mathrm{n}^{\circ}$ 1/88. Ambos os procedimentos versavam sobre práticas ocorridas no exterior por sociedades estrangeiras, mas sobre as quais o CADE não se eximiu de analisar os efeitos ocorridos no mercado nacional. Nesse sentido, Faria esclarece que embora o CADE "não tenha tido oportunidade de assentar expressamente esse princípio durante a vigência da Lei $\mathrm{n}^{\circ} 4.137$, algumas decisões permitiam entrever que o órgão considerava evidente a aplicabilidade da lei nacional sob tais circunstâncias, por exemplo, ao considerar sujeito a registro acordo entre empresas estrangeiras sediadas no exterior em virtude de possíveis efeitos sobre a concorrência no mercado nacional, sem que estivessem presentes quaisquer dos elementos que justificassem a aplicação extraterritorial do direito interno segundo as teorias clássicas do direito penal. O elemento de conexão decisivo foi o efeito do ato sobre o mercado interno". (FARIA, José Ângelo Estrella. Op. cit., 2009, p. 18).

254 "A lei não era clara sobre se a jurisdição nacional se estenderia a práticas restritivas cometidas no exterior ou resultantes de atos de empresas estrangeiras que produzissem efeitos restritivos da concorrência no território nacional". (FARIA, José Ângelo Estrella. Op. cit., 1990, n. 105, pp. 20 e 25; FARIA, José Ângelo
} 
Atualmente, o art. $2^{\circ}$ da Lei da Concorrência estabelece que a mesma deverá ser aplicada "sem prejuízo de convenções e tratados de que seja signatário o Brasil, às práticas cometidas no todo ou em parte no território nacional ou que nele produzam ou possam produzir efeitos". Desta forma, o dispositivo do art. $2^{\circ}$ contempla o acolhimento do princípio da territorialidade estrita e da teoria dos efeitos, podendo, portanto, haver a aplicação extraterritorial e unilateral do direito nacional, o que pode acarretar, em última instância, conflitos em matéria de jurisdição estatal.

Com relação ao princípio da territorialidade, deve-se aplicar a legislação brasileira aos atos executados no território nacional. Parte da doutrina entende que o legislador ultrapassou o limite do desejável ao acolher o princípio da territorialidade juntamente com a teoria dos efeitos nas hipóteses do art. $2^{\circ}$. Esta corrente entende que o legislador estaria externando preocupação com os atos praticados no Brasil, cujos efeitos somente são sentidos em países estrangeiros, ultrapassando o permissivo constitucional de proteção à ordem econômica $^{255}$.

Em razão do acolhimento da teoria dos efeitos, independentemente da nacionalidade das partes, a legislação brasileira de defesa da concorrência terá aplicação quando houver possibilidade de dada prática ter efeitos repercutidos no território nacional $^{256}$. A determinação da competência internacional das autoridades brasileiras segue, desta maneira, regra territorial - e não pessoal ${ }^{257}$. Por tal razão, a competência das autoridades antitruste brasileiras deve ser entendida sempre em razão do território, ou seja, levando em consideração o fato de os efeitos haverem ocorrido ou terem potencialidade de

Estrella. O controle de concentrações de empresas estrangeiras e a Lei $\mathrm{n}^{\circ}$ 8.884: a extraterritorialidade revisitada. Juris Sintese, maio/jun. 2009, n. 77, p. 18. Disponível em: 〈http://online.sintese.com>. Acesso em: 19 ago. 2012). Nesse mesmo sentido ver VAZ, Isabel. Legislação de defesa da concorrência e extraterritorialidade. Revista do Instituto Brasileiro de Estudos das Relações de Concorrência e de Consumo - IBRAC. São Paulo, 1997, v. 4, n. 6, p. 265.

${ }^{255}$ Taufick justifica que "além de o órgão de defesa da concorrência brasileiro carecer de legitimidadeinteresse-de-agir (valendo-me da expressão do direito processual civil) para coibir a prática, esta apenas poderá ser coibida por órgão de defesa da concorrência alienígena cuja lei acolha o princípio real. É sempre válido lembrar que, além de o acolhimento do princípio da territorialidade representar afronta à proteção à ordem econômica nacional trazida pela Constituição Federal (art. 173, $\S \S 4^{\circ}$ e $5^{\circ}$ ), ele vai de encontro à sua própria natureza". (TAUFICK, Roberto Domingos. Nova lei antitruste brasileira. Rio de Janeiro: Forense; São Paulo: Método, 2012, pp. 17-18).

256 “Contrario sensu, a extraterritorialidade da Lei 12.529/2011 poderá ser recusada caso se possa comprovar a inocorrência (i) da prática ilícita, total ou parcial, no Brasil e (ii) da produção ou da potencialidade de produção de efeitos no território brasileiro. Essa comprovação deverá ocorrer ao longo dos processos administrativos de investigação". (ANDERS, Eduardo Caminati; PAGOTTO, Leopoldo; BAGNOLI, Vicente (coords.). Comentários à nova Lei de Defesa da Concorrência. Rio de Janeiro: Forense; São Paulo: Método, 2012, p. 7).

${ }^{257}$ Taufick descreve que o dispositivo do art. $2^{\circ}$ tem por referência os efeitos previstos no art. 36 da Lei da Concorrência, tratando assim da aplicação do "princípio real ao direito concorrencial, que leva em consideração os danos concorrenciais causados à ordem econômica brasileira, independentemente do lugar da ocorrência do fato e da nacionalidade do autor". (TAUFICK, Roberto Domingos. Op. cit., 2012, p. 17). 
ocorrer no território nacional. Não importa, neste tocante, se há ou não uma conexão entre a sociedade que executou a prática repreendida e o território nacional ${ }^{258}$.

A influência da teoria dos efeitos norte-americana é claramente percebida no dispositivo do art. $2^{\circ}$ da Lei da Concorrência e seu âmbito de aplicação resta inequívoco na interpretação da legislação em confronto com a Constituição Federal ${ }^{259}$. Destaca-se, no entanto, que a legislação brasileira não condiciona a efetiva concretização dos efeitos à aplicação extraterritorial da lei nacional. Basta, para tanto, que os efeitos tenham potencialidade de ocorrer no mercado brasileiro a fim de se justificar a aplicação da Lei da Concorrência. Nesse sentido têm sido as decisões do CADE e do judiciário ${ }^{260}$.

Por outro lado, diferentemente da legislação antitruste norte-americana, a lei brasileira exclui da proteção legal conferida por meio da teoria dos efeitos, aqueles que venham a repercutir unicamente no comércio exterior brasileiro - pois tais efeitos não seriam sentidos no território nacional ${ }^{261}$.

A Lei da Concorrência não é, todavia, clara sobre que efeitos devem justificar a extensão da competência das autoridades brasileiras. A doutrina aponta que devem ser consideradas para este propósito as infrações e práticas descritas pela própria legislação de defesa da concorrência, devendo as mesmas resultar num efeito sensível, ou ao menos relevante, ao mercado nacional ${ }^{262}$. Ademais, devem ser considerados tanto os efeitos

${ }^{258}$ JAEGER JÚNIOR, Augusto. Direito Internacional da Concorrência - Entre perspectivas unilaterais, multilaterais, bilaterais e regionais. Curitiba: Juruá, 2008, p. 126.

259 "Há de se determinar, ainda, qual o âmbito de aplicação da teoria dos efeitos. A resposta se encontra no art. $2^{\circ}$, caput, da Lei 8.884/94, que, por seu turno, encontra fundamento no art. 219 da Constituição: sendo o mercado interno considerado como patrimônio nacional, os incentivos ao seu desenvolvimento, assim como a sua proteção, constituem um dever constitucional do Estado brasileiro. Tal dispositivo é assimilado pelo art. $2^{\circ}$, caput, da lei de defesa da concorrência, que submete à aplicação desta os atos que produzam efeitos no território nacional”. (SILVA, Valéria Guimarães de Lima e. Direito antitruste: aspectos internacionais. Curitiba: Juruá, 2007, p. 332).

${ }^{260} \mathrm{O}$ rol de casos em que a aplicação extraterritorial da legislação brasileira de defesa da concorrência é farto - principalmente nos procedimentos de aprovação de atos de concentração. As decisões do CADE, no entanto, não chegaram a fixar princípios sobre o tema, apesar de terem tido oportunidades para tanto. No âmbito judiciário, destaca-se o Recurso Especial no 615.628-DF julgado pelo STJ em 21 de junho de 2009, melhor descrito no item 1.3.1.2.2 a seguir. Ver CARVALHO, Leonardo Arquimino de. Direito antitruste \& relações internacionais: extraterritorialidade e cooperação. Curitiba: Juruá, 2003, p. 133; e OLIVEIRA, Gesner; RODAS, João Grandino. Direito e economia da concorrência. Rio de Janeiro: Renovar, 2004, p. 382. Pinski, no entanto, sustenta que a legislação brasileira não deve ser aplicada quando os efeitos forem totalmente imprevisíveis. (PINSKI, Lior. Aplicação extraterritorial da Lei Antitruste. Revista de Direito Mercantil. São Paulo: Revista dos Tribunais, 1999, n. 115, p. 138).

${ }^{261}$ Jaeger Júnior destaca, nesse sentido, que o legislador nacional seguiu o modelo do direito comunitário da concorrência em relação a esta matéria. (JAEGER JUNIOR, Augusto. Op. cit., 2008, p. 126). Nesse sentido também verificar SILVA, Valéria Guimarães de Lima e. Op. cit., 2007, p. 332.

${ }^{262}$ Almeida entende que "em primeiro lugar; deve tratar-se de um efeito sensível, pois efeitos de reduzido impacto não justificam aplicação da lei de defesa da concorrência. Em segundo lugar; pode ser um efeito direto, ou seja, deve resultar imediatamente do comportamento. Caso contrário, uma vez que a mundialização tornou possível que uma atividade econômica tenha efeitos no mundo inteiro, o campo de aplicação da lei brasileira de defesa da concorrência seria vastíssimo". (ALMEIDA, José Gabriel Assis de. A aplicação extra- 
diretos ou imediato dos atos - ou seja, aqueles que imediatamente relacionam-se ao ato analisado -, quanto os indiretos - mais precisamente aqueles de natureza indireta que externam o efeito deturpador da concorrência ${ }^{263}$. Havendo, portanto, a possibilidade de algumas destas infrações ou práticas fazerem surtir algum efeito no mercado nacional, as autoridades brasileiras deverão analisar o ato ${ }^{264}$.

Além disso, a interpretação doutrinária do art. $2^{\circ}$ é no sentido de que devem ser verificadas duas condições para que a aplicação extraterritorial do direito brasileiro de defesa da concorrência tenha lugar: (i) o ato deve afetar o comércio nacional, pois sem tal efeito o país não teria interesse em regular o ato; e (ii) os responsáveis devem estar presentes no Brasil, permitindo, assim, a efetividade da decisão das autoridades nacionais de defesa da concorrência ${ }^{265}$. Note-se que o $\S 2^{\circ}$ do art. $2^{\circ}$ da Lei da Concorrência busca mitigar a questão da presença no Brasil, uma vez que reputa para fins meramente processuais, como situada no território nacional, a sociedade que possua agentes ou representantes, bem como filiais, agências, sucursais, escritórios ou estabelecimentos, no Brasil.

Relevante é, desta forma, a análise sobre o meio pelo qual a autoridade de defesa da concorrência brasileira tem interpretado o acolhimento da teoria dos efeitos pela legislação antitruste e, assim, garantido a aplicação extraterritorial das normas brasileiras dessa natureza ${ }^{266}$.

1.3.1.2.2 Decisões das autoridades brasileiras sobre a aplicação extraterritorial do Direito da Concorrência

O número de casos analisados pelo CADE que envolveram a aplicação extraterritorial do Direito da Concorrência é expressivo, sendo que, em vista da recente

territorial do direito da concorrência brasileira. Arché: Interdisciplinar. Rio de Janeiro, 2001, v. 10, n. 29, pp. 63-79). Ver também PINSKI, Lior. Aplicação extraterritorial da Lei Antitruste. Revista de Direito Mercantil. São Paulo: Revista dos Tribunais, 1999, n. 115, p. 138.

${ }^{263}$ FARIA, José Ângelo Estrella. Aplicação extraterritorial do Direito da Concorrência. Revista de Informação Legislativa. Brasília, jan./mar. 1990, n. 105, p. 25.

${ }^{264}$ Por outro lado, Oliveira e Rodas defendem que "como a lei prevê não só reais efeitos verificados no país, mas também a possibilidade, esta deve ser real e efetiva e não unicamente imaginária. A potencialidade deve ser ancorada por fatos palpáveis, como por exemplo, a atuação no Brasil de representante exclusivo, ou de filial, ou, ainda, a conclusão de acordos de exclusividade em que a importação de produtos cartelizados seja feita unicamente pelos citados entes". (OLIVEIRA, Gesner; RODAS, João Grandino. Direito e economia da concorrência. Rio de Janeiro: Renovar, 2004, p. 382).

${ }_{265}^{265}$ OLIVEIRA, Gesner; RODAS, João Grandino. Op. cit., 2004, p. 381.

266 "A questão da extraterritorialidade da lei de defesa da concorrência é também uma questão de soberania nacional de natureza econômica". (VAZ, Isabel. Legislação de defesa da concorrência e extraterritorialidade. Revista do Instituto Brasileiro de Estudos das Relações de Concorrência e de Consumo - IBRAC. São Paulo, 1997, v. 4, n. 6, p. 269). 
aprovação da Lei da Concorrência, as suas decisões abrangem principalmente o período de vigência da Lei $n^{\circ}$ 8.884/1994. Os casos analisados pelo CADE não versam somente sobre atos de concentração, mas também incluem casos relativos à repressão de condutas anticoncorrenciais pelos variados agentes econômicos.

Talvez o caso mais emblemático ${ }^{267}$ sobre a aplicação extraterritorial do Direito da Concorrência pelo CADE verse justamente sobre a repreensão de condutas anticoncorrenciais pelas autoridades de defesa da concorrência: o Caso do Cartel das Vitaminas $^{268}$. No caso em questão, julgado em 2007, empresas dos grupos Roche, Aventis e Basf foram condenadas pelo CADE em razão da formação de um cartel internacional, baseado nas respectivas matrizes situadas no exterior.

A competência do CADE foi estabelecida com base no art. $2^{\circ}$ da Lei ${ }^{\circ}$ 8.884/1994, mesmo considerando que o caso foi instaurado em 2000 pela SDE justamente em função das notícias veiculadas na imprensa nacional e internacional sobre a condenação das empresas nos Estados Unidos, em razão da formação do dito cartel no período de 1990 a 1999. Inclusive, à época da decisão do CADE, as empresas já haviam sido condenadas na Europa e nos Estados Unidos.

Nesse sentido, o Conselheiro-Relator Ricardo Villas Bôas Cueva bem esclareceu no seu voto proferido no Caso do Cartel das Vitaminas que deve ser aplicada a lei brasileira de defesa da concorrência "ainda que nenhum ato tenha sido praticado em território nacional, e mesmo que nenhum efeito tenha de fato se produzido, bastando que se prove a potencialidade dos danos internamente, dos atos praticados fora do Brasil" ${ }^{269}$.

Note-se que apesar de o centro de decisões sobre os preços praticados pelo cartel estar situado no exterior, de acordo com as provas produzidas nos autos, o mercado brasileiro, fortemente dependente da importação das matérias-primas, não somente tinha potencialidade de ser afetado pelas condutas identificadas, como por reconhecimento do Conselheiro-Relator efetiva e concretamente foi afetado ${ }^{270}$. Isso porque a administração de cada uma das subsidiárias brasileiras estava subordinada hierárquica e economicamente à respectiva matriz estrangeira.

\footnotetext{
${ }^{267}$ ANDERS, Eduardo Caminati; PAGOTTO, Leopoldo; BAGNOLI, Vicente (coords.). Comentários à Nova Lei de Defesa da Concorrência. Rio de Janeiro: Forense; São Paulo: Método, 2012, p. 8.

${ }^{268}$ Processo administrativo CADE $\mathrm{n}^{\circ}$ 08012.004599/1999-18.

${ }^{269}$ Ver voto do Conselheiro-Relator nesse sentido (Processo administrativo CADE $n^{\circ}$ 08012.004599/199918, p. 7).

${ }^{270}$ Id., ibid., p. 18.
} 
Mas não foi somente em relação a condutas anticoncorrenciais que o CADE se manifestou sobre a aplicação extraterritorial do Direito da Concorrência brasileiro. Diversos são os casos em que o entendimento da agência sobre a aplicação do art. $2^{\circ}$ da Lei $\mathrm{n}^{\text {o }} 8.884 / 1994$ esteve relacionado a ato de concentração, razão porque se passa a descrever alguns desses exemplos.

Na concentração econômica realizada em 1994 pela Nalco Chemical Company e a Exxon Corporation ${ }^{271}$, ambas sociedades norte-americanas, houve repercussão em concentrações econômicas locais realizadas em diversos outros países, dentre eles o Brasil. Nesta oportunidade o CADE invocou na sua decisão o art. $2^{\circ}$ da Lei $n^{\circ}$ 8.884/1994 como fundamento para aplicação da teoria dos efeitos na operação realizada no exterior ${ }^{272}$ e, então, apreciada favoravelmente pela agência brasileira.

Já a operação realizada entre a Aticus Corporation e a Texas International Inc. ${ }^{273}$, ambas sociedades norte-americanas, teve lugar nos Estados Unidos em 1997, e seus resultados poderiam afetar, por meio de importações, aproximadamente $15 \%$ do mercado de computadores no Brasil. Mesmo considerando que a operação em questão não ocasionou a transferência de ativos no Brasil, o Conselheiro-Relator Antonio Fonseca reconheceu no tocante à aplicação extraterritorial da lei brasileira pelo CADE, que a mesma deveria ter lugar em função dos efeitos no território nacional.

No caso da concentração havida em razão da aquisição pela Henkel KGaA do controle da subsidiária brasileira da Loctite Corporation ${ }^{274}$, via operação no mercado mobiliário realizada nos Estados Unidos em 1997, a competência do CADE para analisar a questão decorreu da coordenação do comportamento concorrencial de subsidiária brasileira em relação à operação realizada no exterior com efeitos no Brasil.

Já o caso MCI Worldcom Inc. e Sprint Corporation ${ }^{275}$, analisado pelo CADE em 1999, relacionava-se aos efeitos anticoncorrenciais no mercado brasileiro de

\footnotetext{
${ }^{271}$ Ato de Concentração CADE nº $28 / 1995$.

${ }^{272}$ No voto do vogal Antônio Fonseca, ele esclarece que "o art. $2^{\circ}$ da Lei no 8.884/1994 adota a doutrina dos efeitos. Isto é, embora, em princípio, a lei brasileira aplica-se nos limites do território nacional, excepcionalmente a legislação abrange atos ou práticas que, realizados no exterior, produzam os seus efeitos no território nacional. A extraterritorialidade é excepcionalmente aceita por várias jurisdições". (Ato de Concentração CADE nº 28/1995, p. 1).

${ }^{273}$ Ato de Concentração CADE n⿳0 $132 / 1997$.

${ }^{274}$ Ato de Concentração CADE n $^{\circ} 120 / 1997$.

$275 \mathrm{Na}$ União Européia, UNIÃO EUROPEIA. Caso Sprint Corporation/MCI Worldcom (Sprint/MCI), Comissão Europeia, Processo n M.1741, decisão 28 jun 2000, JO L 300, 18 nov 2003; e no Brasil, Ato de Concentração CADE n ${ }^{\circ}$ 53500.005134/1999. Santos contextualiza o caso: "Neste caso, em outubro de 1999, a MCI e a Sprint notificaram o CADE sobre o seu projeto de concentração, que também havia sido proposto na mesma altura perante a FTC norte-americana e a Comissão Europeia. No entanto, no Brasil, quando ocorreu a privatização do setor de telecomunicações, a MCI adquiriu a Embratel, e um consórcio composto
} 
telecomunicações. No caso em questão as empresas MCI Worldcom e da Sprint, que eram controladoras das duas únicas prestadoras de serviços de telefonia fixa comutada a longa distância no Brasil (Embratel e Intelig), pretendiam realizar ato de concentração no exterior por meio da incorporação da Sprint pela MCI Worldcom. O Conselheiro-Relator Celso Campilongo, em seu despacho, descreveu a operação como "incorporação da Sprint pela MCI, ocorrida nos Estados Unidos, com reflexos no Brasil por meio da transferência de $25 \%$ das quotas da Intelig para a MCI”. Não obstante o reconhecimento implícito dos efeitos no território nacional da operação pretendida, o procedimento em questão foi extinto e arquivado em razão da comunicação das partes sobre a não conclusão do negócio ${ }^{276}$.

Já em 2006, o SBDC analisou a concentração advinda da aquisição da Eaton s.a.m, Monaco pela norte-americana Borg Warner Transmissions Systems Inc. (Eaton Monaco/Brog Warner") ocorrida em 17 de setembro de 2006 e notificada ao SBDC em 5 de outubro de $2006^{277}$. As sociedades em questão não estavam sediadas no Brasil e não mantinham nenhuma representação permanente ou atividade no território brasileiro. Neste caso o SBDC manteve interessante discussão sobre a extensão da teoria dos efeitos. Enquanto a SDE sustentava que a operação não deveria ter sido notificada, Luis Fernando Schuartz, do CADE, esclareceu no seu voto que a aplicação da legislação brasileira ao caso era justificada na medida em que a operação poderia impactar ou tinha potencialidade de impactar o território nacional. Não obstante o debate havido, a operação acabou por ser aprovada sem restrições, uma vez que nenhuma preocupação sobre o mercado brasileiro foi vislumbrada.

Os exemplos de concentrações realizadas no exterior e submetidas às autoridades de defesa da concorrência brasileira são múltiplos e constantes. Apesar de em alguns casos o CADE não se pronunciar expressamente sobre a aplicação da teoria dos efeitos e/ou

pela Sprint, National Grid e France Telecom adquiriu a Intelig (empresa espelho). A Embratel e a Intelig eram, portanto, concorrentes no mercado de chamadas de longa distância nacionais e internacionais. Este ato de concentração levantou graves problemas em relação ao mercado brasileiro das telecomunicações, pois era um típico caso de participações cruzadas, uma vez que a Sprint detinha $25 \%$ de participações da Intelig, que era concorrente da Embratel, que por sua vez era controlada pela MCI”. (SANTOS, Maria Cecília de Andrade. A política da concorrência e a Organização Mundial do Comércio. Revista de Direito Constitucional e Internacional, abr./jun. 2001, ano 9, n. 35, p. 250).

${ }^{276}$ Marques destaca que as partes anunciaram o cancelamento da operação após o veto da Comissão Europeia, em 28 de junho de 2000. Ademais, o autor destaca que "casos como este, quase comuns na atualidade, revelam a complexa e intricada estrutura jurídica que permeia esse tipo de relação". (MARQUES, Frederico do Valle Magalhães. Direito Internacional da Concorrência. Rio de Janeiro: Renovar, 2006, pp. 340-341).

${ }^{277}$ Ato de Concentração CADE n ${ }^{\circ} 08012.009358 / 2006-74$. 
aplicação do art. $2^{\circ}$ da Lei $n^{\circ} 8.884 / 1994$ ou Lei da Concorrência ${ }^{278}$, é possível notar que sistematicamente a agência tem exercido a sua competência na aplicação extraterritorial do Direito da Concorrência brasileiro às operações realizadas no exterior com potencialidade de gerar efeitos no território nacional. Há também casos em que, a contrariu sensu, a autoridade brasileira tem rejeitado competência para análise, mediante a confirmação de que certas operações realizadas no exterior não geraram e nem tinham potencial de fazer surtir efeitos no território nacional ${ }^{279}$. Ante o exposto, é pacífico o entendimento de que o CADE adota sistematicamente em suas decisões a teoria dos efeitos.

Finalmente, cumpre destacar dentre as decisões das autoridades judiciárias brasileiras a respeito da matéria concorrencial, o julgamento havido em 2009 pelo Superior Tribunal de Justiça de recurso especial que teve por objeto o ato de concentração decorrente da aquisição pela General Electric Company da divisão de turbinas industriais a gás de grande porte da Alstom France S/A (GE/Alstom) ${ }^{280}$. Apesar do caso apresentado ao Judiciário focar essencialmente o momento em que a apresentação da concentração ao CADE deveria ter ocorrido, o voto do relator e o voto-vista do Min. Mauro Campbell Marques no caso analisaram a questão da aplicação extraterritorial da legislação de defesa da concorrência brasileira.

A extraterritorialidade foi discutida no STJ, principalmente em razão da decisão em primeira instância que desconsiderou as informações inseridas na decisão do $\mathrm{CADE}^{281} \mathrm{de}$

\footnotetext{
${ }^{278}$ Pode-se destacar nesse sentido o caso da concentração havida entre Compagnie de Saint-Gobain e Owens Corning (Ato de Concentração CADE nº 08012.001885/2007-11), a qual foi realizada em 2007 por empresas estrangeiras (uma norte-americana e outra francesa), mas fez surtir efeitos no território nacional em razão do envolvimento da planta localizada em Capivari/SP. Apesar de não fazer referência ao art. $2^{\circ}$ da Lei $n^{\circ}$ 8.884/1994 em sua decisão, o CADE exerceu a sua competência e aplicou a legislação brasileira, decidindo pela reprovação da operação e determinando o desinvestimento realizado pela Saint-Gobain em Capivari/SP. Outros exemplos: Ato de Concentração CADE nº 08012.011733/2008-16 (Toshiba Medical Visualization Systems Europe Limited e Barco NV) e 8012.011065/2008-19 (3M Company e Grafoplast S.p.A.).

${ }^{279}$ Ver casos de concentração econômica Schwinn GT/Corp. e Pacific Cycle, LLC (Ato de Concentração CADE n ${ }^{\circ}$ 08012.006025/2001-89), Carlyle Group Co-Invest GP Limited e Qinetiq Group Plc (Ato de Concentração CADE no 08012.009254/2002-36) e NSK Ltd. e NSK Torrignton Co. Ltd. (Ato de Concentração CADE $n^{\circ}$ 08012.005749/2003-77). Interessante o voto de vista do Conselheiro Celso Fernandes Campilongo no caso Schwinn GT/Corp. e Pacific Cycle, LLC, citado pelos demais, em que esclareceu: "o art. $2^{\circ}$ da Lei Antitruste aplica-se, exclusivamente, às práticas que, mesmo quando cometidas fora do território nacional, nele produzam ou possam produzir efeitos econômicos. De modo singelo: sem efeitos no Brasil, ainda que potenciais, a Lei $n^{\circ}$ 8.884/94 é inaplicável a práticas ocorridas no Exterior. Em resumo: da perspectiva interna, sanciona-se tanto o comportamento que tenha por efeito, quanto aquele que tenha por objeto, independentemente do resultado, uma ameaça à concorrência; já para práticas ocorridas fora do Brasil, a Lei $\mathrm{n}^{\circ}$ 8.884/94 aplica-se apenas a operações que possam gerar resultados econômicos, vale dizer, efeitos, no Território Nacional. Não tendo impactos econômicos de relevo no país e sem que as Requerentes possuam o controle sobre agente ou representante no Brasil, inaplicável à espécie a Lei Antitruste nacional" (Ato de Concentração CADE nº 08012.006025/2001-89).

${ }^{280}$ Caso General Electric Company/Alstom France S.A., Superior Tribunal de Justiça, Recurso Especial $n^{\circ}$ 615.628-DF julgado pelo STJ em 21 de junho de 2009 (rel. Ministro Herman Benjamin).

${ }^{281}$ No bojo do Ato de Concentração CADE n $08012.005572 / 99-99$.
} 
que apesar de as duas empresas envolvidas na transação não estarem sediadas no Brasil, ou aqui manterem subsidiárias, ambas as empresas exploram o mercado nacional de turbinas a gás de grande porte por meio de exportações, com participação no mercado de $8 \%$ e $9 \%$. Além disso, de acordo com parecer técnico apresentado, o mercado mundial do mercado de produto em questão é dominado por quatro empresas, dentre as quais constam as sociedades envolvidas na operação com participações de $40 \%$ no caso da GE e $15 \%$ no caso da Alstom.

No voto do relator ministro Hermand Benjamin fica claro o envolvimento das autoridades europeias e norte-americanas na análise da concentração. Ademais, o relator esclarece que a aquisição das turbinas a gás de grande porte, realizada pelos agentes econômicos, "foi o ato que, nos termos da lei, teve potencial para 'limitar ou prejudicar a livre concorrência' [...] concretizou-se o risco ao bem jurídico tutelado no momento da assinatura do contrato entre a recorrida e a Alston France"282.

Adicionalmente, o ministro Mauro Campbell Marques, no seu voto-vista defende que os argumentos trazidos pela GE de que o fato de o contrato ter sido celebrado por duas sociedades estrangeiras, no exterior, não devem prevalecer. Nos fundamentos exarados, o ministro destaca a aplicação do art. $2^{\circ}$ da Lei $n^{\circ}$ 8.884/1994, enfatizando que o mercado geográfico estabelecido pelo CADE é mundial, incluindo, portanto, o mercado brasileiro. Conclui o ministro que "pouco importa se as empresas envolvidas têm ou não filial no Brasil, se o contrato preliminar foi ou não avençado no Brasil. Basta, que, em tese, o concerto de concentração possa, sob qualquer perspectiva, impactar o mercado nacional" 283 .

Da análise das decisões do CADE e do STJ é possível depreender o amplo reconhecimento sobre a teoria dos efeitos, ou seja, a aplicação extraterritorial da legislação nacional de defesa da concorrência no ordenamento jurídico brasileiro.

\subsubsection{Teoria dos efeitos: reflexos, limitações e reação internacional}

A teoria dos efeitos, cuja aplicação em última instância causa a aplicação extraterritorial das variadas legislações nacionais de defesa da concorrência, revela

\footnotetext{
${ }^{282}$ Ver relatório do Recurso Especial $n^{\circ}$ 615.628-DF, p. 9. Ver ainda nas pp. 12-13 do dito relatório: “a assinatura do contrato de aquisição da divisão de turbinas a gás firmou vínculo que deu origem, inegavelmente, às condições para a negociação surtir efeitos de maneira imediata, até mesmo com potencial limitação ou eliminação da concorrência [...]. Dessa maneira, inegável o fato de que a fusão das empresas é ato de concentração que possui repercussão no Brasil”.
} 
limitações de ordem executória (procedimental) e material. A principal limitação apontada pela doutrina ${ }^{284}$ está na falta de competência das autoridades envolvidas em executar no exterior a sua decisão protetiva da concorrência local. De fato, existem barreiras procedimentais que impedem a aplicação das decisões emanadas por uma autoridade de defesa da concorrência em outro território ${ }^{285}$.

Além disso, na maioria dos países, a solução da aplicação unilateral do Direito da Concorrência acaba por não reprimir a atuação de sociedades nacionais que façam produzir no exterior efeitos danosos à concorrência estrangeira ${ }^{286}$. Exceção a esta regra está na legislação dos Estados Unidos, que prevê em certa medida jurisdição para além das suas fronteiras com base nos efeitos produzidos - abarcando assim tanto o comércio interno como externo.

Ainda, casos em que diversos territórios tenham a concorrência local afetada pela atuação internacional de agentes econômicos localizados em diferentes jurisdições, apontam outra deficiência da teoria dos efeitos. Em tais situações, diversas legislações nacionais têm a pretensão de regular o mesmo ato causador dos efeitos que se pretende repreender, o que pode culminar em decisões divergentes sobre um mesmo fato - em alguns casos até contraditórias ${ }^{287}$. Isso se deve ao fato de cada legislação nacional de defesa da concorrência potencialmente possuir conteúdo diverso em relação às demais envolvidas.

No âmbito específico do controle de concentrações empresariais, o uso da teoria dos efeitos revela uma problemática própria: as sociedades que participam de atos de concentração multijurisdicionais vêm-se compelidas a apresentar um mesmo ato de concentração para o controle de autoridades de defesa da concorrência de diferentes jurisdições. Isso ocorre recorrentemente em razão de muitas legislações nacionais de

\footnotetext{
${ }^{283}$ Ver voto-vista do Recurso Especial n ${ }^{\circ}$ 615.628-DF, p. 23.

${ }^{284}$ WHISH, Richard. Competition Law. 6. ed. New York: Oxford University Press, 2009, p. 472.

285 Tal limitação tem estreita relação com o "princípio da soberania dos Estados e com a proibição fundada no direito internacional de interferência em questões internas dos outros Estados". (JAEGER JÚNIOR, Augusto. Direito Internacional da Concorrência - Entre perspectivas unilaterais, multilaterais, bilaterais e regionais. Curitiba: Juruá, 2008, p. 60). Nesse sentido ver também LAGARES, Eva Valle. International Agreements Regarding Cooperation in the Field of Competition: the new strategy of the European Commission. Journal of European Competition Law \& Practice, jan. 2010, p. 1.

286 Tratam de casos, por exemplo, de cartéis voltados à exportação, cujos efeitos ocorrem somente no exterior. Jaeger Júnior destaca que o Direito Comunitário da Concorrência - arts. 101 e 102 do TFUE igualmente apresenta tal deficiência, constituindo esta uma das principais críticas ao sistema adotado. O autor também defende que essa limitação é inerente à própria teoria dos efeitos, que oferece proteção somente ao mercado nacional. (JAEGER JUNIOR, Augusto. Op. cit., 2008, p. 39).

${ }^{287}$ A cooperação internacional poderia em tese mitigar os efeitos desta pluralidade de autoridades decidindo sobre um mesmo fato. No entanto, o grau de cooperação internacional que atualmente é verificada no âmbito
} 
defesa da concorrência acolherem a teoria dos efeitos como método de estabelecimento das respectivas jurisdições ${ }^{288}$. Nesses casos, a possibilidade das diferentes entidades envolvidas acabarem por proferir decisões antagônicas sobre um mesmo ato de concentração é elevada $^{289}$, dificultando às sociedades envolvidas a conclusão do ato pretendido e também elevando os custos que estas têm de incorrer em razão das múltiplas notificações às autoridades envolvidas $^{290}$.

Note-se que o conflito nos casos de controle de concentrações é bastante elevado, devido, principalmente, à possibilidade das autoridades envolvidas (i) definirem o mercado relevante de forma diferenciada; (ii) avaliarem de forma diversa os efeitos anticoncorrenciais e potenciais ganhos de eficiência; e (iii) apreciarem a concentração mediante métodos e parâmetros diferenciados ${ }^{291}$.

Todavia, as diferenças identificadas nas políticas de defesa da concorrência entre os variados sistemas jurídicos têm sido apontadas como o principal fator das decisões antagônicas das diferentes autoridades de defesa da concorrência. No caso das decisões

do Direito Internacional da Concorrência, a qual se baseia essencialmente na troca de informações e meras notificações, não é suficiente para eliminar este problema.

288 "In the contexto $f$ international trade under the de facto international competition policy regime, firms operating in multiple states are subject to multiple regulatory review". (GUZMAN, Andrew T. Competition law and cooperation: possible strategies. Cooperation, comity and competition policy. New York: Oxford University Press, 2011, p. 347). Ver também FARIA, José Ângelo Estrella. O controle de concentrações de empresas estrangeiras e a Lei $\mathrm{n}^{\circ}$ 8.884: a extraterritorialidade revisitada. Juris Síntese, maio/jun. 2009, n. 77, p. 13. Disponível em: 〈http://online.sintese.com〉. Acesso em: 19 ago. 2012.

${ }^{289}$ Diversos são os casos em que um mesmo ato de concentração obteve decisões antagônicas por diferentes autoridades nacionais de defesa da concorrência, dentre as quais se destacam: (i) a aquisição dos ativos da divisão de Havilland da Boeing Company pela Aerospatiale SNI e pela Alenia-Aeritalia e Selenia SpA (UNIÃO EUROPEIA. Caso Boeing Company/Aerospatiale SNI, Alenia-Aeritalia e Selenia SpA (Aerospatiale-Alenia/de Havilland), Comissão Europeia, Processo n ${ }^{\circ}$ IV/M.053, decisão em 2 out 1991, JO L 334, 05 dez 1991), reprovada pela Comissão Europeia e aprovada pelas autoridades canadenses; (ii) fusão entre Boeing e McDonnell Douglas, aprovada irrestritamente nos Estados Unidos e condicionalmente pela Comissão Europeia (UNIÃO EUROPEIA. Caso Boeing Company/McDonnell Douglas (Boeing/McDonnell Douglas), Comissão Europeia, Decisão no 97/816, de 30 jul 1997, JO L 336, 8 dez 1997); e (iii) fusão da subsidiária integral da General Electric Company com a Honeywell International Inc., aprovada nos Estados Unidos e no Canadá e reprovada pela Comissão Europeia (UNIÃO EUROPEIA. Caso General Electric Company/Honeywell International Inc. (GE/Honeywell), Comissão Europeia, Processo $\mathrm{n}^{\circ}$ M.2220, decisão 03 jul 2001, JO L 48, 18 fev 2004). Maiores considerações sobre os casos Boeing/McDonnell Douglas e GE/Honeywell serão tecidas no terceiro capítulo deste estudo, em razão da cooperação havida entre as autoridades norte-americanas e a União Europeia.

${ }^{290}$ Nesse sentido, ver SANTOS, Maria Cecília de Andrade. A política da concorrência e a Organização Mundial do Comércio. Revista de Direito Constitucional e Internacional, abr./jun. 2001, ano 9, n. 35, p. 229. Além disso, Majoras destaca que "in cases involving mergers in global markets, there are serious externalities associated with one jurisdiction blocking a merger on the basis of theories that other jurisdictions believe risk secrificing important efficiencies to prevent speculative future harm to competition. By doing so, that jurisdiction denies consumers around the world the benefits the merger might have delivered'. (MAJORAS, Deborah Platt. GE-Honeywell: the U.S. decision. Palestra proferida perante a Antitrust Law Section - State Bar of Georgia em 29 de novembro de 2001, p. 15. Disponível em: <http://www.justice.gov/atr/public/speeches/9893.htm〉. Acesso em: 28 ago. 2012. 
proferidas por autoridades norte-americanas e pela União Europeia, a problemática é bastante visível. Enquanto que nos Estados Unidos a política de defesa da concorrência desenvolveu-se em torno da eficiência econômica e do bem-estar do consumidor - o que não traz necessariamente preocupação em relação a mercados altamente concentrados -, a política europeia, que se originou da prevenção ao abuso de posição dominante, leva menos em conta os fatores extraconcorrenciais na avaliação dos atos de concentração e tem foco na proteção dos concorrentes - revelando assim uma característica mais estruturalista da defesa à concorrência ${ }^{292}$.

Contemporaneamente, as diferenças dos sistemas de política de concorrência constituem razão de maior magnitude ao conflito advindo da jurisdição concorrente das autoridades de defesa da concorrência, do que as decisões prolatadas pelas cortes norteamericanas - conforme ocorrera outrora.

\subsection{Protestos e reclamações diplomáticas}

Conflitos têm sido causados entre os Estados desde o momento em que se começou a aplicar as legislações nacionais de defesa da concorrência pelas autoridades competentes extraterritorialmente ${ }^{293}$. Certos Estados afetados, com destaque para o Reino Unido e Japão, vêm apresentando desde então protestos fundamentados no receio de que as respectivas soberanias sejam afetadas por tais iniciativas. Tais protestos assentam

\footnotetext{
${ }^{291}$ FARIA, José Ângelo Estrella. O controle de concentrações de empresas estrangeiras e a Lei $\mathrm{n}^{\text {o }}$ 8.884: a extraterritorialidade revisitada. Juris Sintese, maio/jun. 2009, n. 77, p. 13. Disponível em: <http://online.sintese.com>. Acesso em: 19 ago. 2012.

292 "Sem embargo, embora os tribunais dos Estados Unidos gozem de ampla liberdade para exercer jurisdição sobre uma ampla gama de fusões internacionais, na prática, os tribunais dos Estados Unidos raramente proibiram uma grande fusão internacional. Todavia, essas decisões são na maioria das vezes resultado de uma aceitação da fusão como instrumento para uma melhor eficiência produtiva e de economias de escala, e não de uma limitação espontânea de jurisdição [...]. A situação é outra em relação ao controle de concentrações pela Comissão Europeia [...]". (FARIA, José Ângelo Estrella. Op. cit., 2009, p. 15).

293 Faria destaca que em geral os protestos levantados contra a aplicação da teoria dos efeitos nunca abarcaram objeções fundamentadas, mas tão somente limitaram a contestar a aplicabilidade da dita teoria ao caso concreto. Destaca, entretanto, que o único país a manifestar-se por princípio contra a teoria dos efeitos foi o Reino Unido. Segue o autor defendendo que "não existem, porém, protestos diplomáticos que permitissem concluir pela rejeição geral da effects-doctrine". (FARIA, José Ângelo Estrella. Aplicação extraterritorial do direito da concorrência. Revista de Informação Legislativa. Brasília, jan./mar. 1990, n. 105, pp. 30-31). No mesmo sentido ver CARVALHO RAMOS, André de; CUNHA, Ricardo Thomazinho da. A defesa da concorrência em caráter global: utopia ou necessidade. In: CASELLA, Paulo Borba (org.). Guerra comercial ou integração econômica mundial. São Paulo: LTr, 1998, v. 1, p. 822.
} 
principalmente em relevante interesse público do Estado estrangeiro ou na inexistência de efeitos substanciais no território no qual se pretende fazer valer a jurisdição estatal ${ }^{294}$.

De fato, as limitações à teoria dos efeitos apontadas fizeram emergir críticas ${ }^{295}$ à sua aplicação, fundamentadas principalmente nos princípios do Direito Internacional, dentre os quais se destaca o princípio da cortesia e do equilíbrio das relações internacionais. Em face das críticas ocorreram recusas por parte dos Estados em colaborar, protestos e reclamações diplomáticas, bem como medidas legislativas protetivas ${ }^{296}$.

No bojo do julgamento do caso Estados Unidos $v$. Imperial Chemical Industries et al., em $1951^{297}$, foi possível verificar a hipótese de recusa em colaborar. Nesta ocasião, a corte norte-americana analisou questão relacionada à divisão do mercado internacional de nylon pela empresa norte-americana DuPont de Nemours e a inglesa Imperial Chemical Industries. As cortes inglesas acabaram por recusar a implementação da decisão norteamericana sob alegação de que a empresa inglesa não estaria sujeita à legislação dos Estados Unidos ${ }^{298}$.

Outro caso reiteradamente mencionado pela doutrina é o dos Estados Unidos $v$. The Watchmakers of Switzerland Information Center, julgado em 1955 pelos tribunais norteamericanos $^{299}$. A associação dos relojoeiros suíços, que fora considerada legal pelas cortes suíças, acabou sendo condenada pela justiça norte-americana. A Suíça apresentou então reclamações diplomáticas aos Estados Unidos, que culminaram, após longo período de negociação, numa outra decisão das cortes norte-americanas.

Certo é que durante a formação da jurisprudência norte-americana que buscava a implementação do princípio da ponderação, inexistiram protestos de outros Estados em

\footnotetext{
${ }^{294}$ FARIA, José Ângelo Estrella. O controle de concentrações de empresas estrangeiras e a Lei $n^{\circ}$ 8.884: a extraterritorialidade revisitada. Juris Sintese, maio/jun. 2009, n. 77, p. 4. Disponível em: <http://online. sintese.com>. Acesso em: 19 ago. 2012.

${ }^{295}$ Nesse sentido, ver FORGIONI, Paula A. Os fundamentos do antitruste. 4. ed. São Paulo: Revista dos Tribunais, 2010, p. 447. Jaeger Júnior esclarece que "muitos países não aceitam pacificamente serem vítimas da aplicação extraterritorial de legislações nacionais de direito da concorrência com base na teoria dos efeitos. Esse é o caso, por exemplo, da Inglaterra, muito apegada ao princípio da territorialidade". (JAEGER JÚNIOR, Augusto. Direito Internacional da Concorrência - Entre perspectivas unilaterais, multilaterais, bilaterais e regionais. Curitiba: Juruá, 2008, p. 134). Ver também Oliveira e Rodas para quem as "reclamações se deram quando, em meados do século passado, os Estados Unidos da América passaram a aplicar sua legislação antitruste a contratos concluídos por empresas estrangeiras em território alienígena, sob pressuposto de que eles produziam efeitos no território do Estado". (OLIVEIRA, Gesner; RODAS, João Grandino. Direito e economia da concorrência. Rio de Janeiro: Renovar, 2004, p. 375).

${ }^{296}$ JAEGER JÚNIOR, Augusto. Op. cit., 2008, pp. 41-42/136-141.

${ }^{297}$ ESTADOS UNIDOS DA AMÉRICA DO NORTE. Caso Estados Unidos $v$. Imperial Chemical Industries, Ltd., Corte Distrital de Nova Iorque, 100, F. Supp. 504 (S.D. N.Y. 1951).

${ }^{298}$ OLIVEIRA, Gesner; RODAS, João Grandino. Op. cit., 2004, p. 383.

${ }^{299}$ ESTADOS UNIDOS DA AMÉRICA DO NORTE. Caso Estados Unidos $v$. The Watchmakers of Switzerland Information Center, Corte Distrital de Nova Iorque, 133, F. Supp. 40 (S.D. N.Y. 1955).
} 
relação à aplicação extraterritorial do Direito da Concorrência norte-americano ${ }^{300}$. Todavia, com a reversão do desenvolvimento jurisprudencial constatado e com o retorno à ampla aceitação da teoria dos efeitos, diversos conflitos diplomáticos tiveram lugar, fato que levou algumas nações a adotarem legislação destinada a afastar a aplicação da legislação norte-americana de defesa da concorrência às suas empresas, impedindo a obtenção de provas ou a execução de sentenças baseadas na teoria dos efeitos ${ }^{301}$.

\subsection{As leis de bloqueio}

Face à insatisfação da comunidade internacional e da tensão criada pela aplicação extraterritorial das leis de defesa da concorrência, diversos países editaram leis de bloqueio $^{302}$ com o objetivo de preservar as respectivas soberanias. Tais leis proíbem, de forma geral, que esses países forneçam informações e documentos que possam ser usados contra tal Estado ou suas empresas, limitando assim a aplicação extraterritorial do Direito da Concorrência $^{303}$. De fato, parece não haver estímulo aos países para fornecimento de informações que possam prejudicar as suas próprias empresas - indiretamente as suas próprias economias, mesmo que estejam submetidos a acordo bilateral de cooperação.

São ainda objeto das leis de bloqueio as disposições que proíbem a execução de sentença estrangeira ou que viabilizam que a sociedade requerida recupere os valores de condenação despendidos em função da aplicação extraterritorial da legislação de defesa da

\footnotetext{
300 FARIA, José Ângelo Estrella. Aplicação extraterritorial do Direito da Concorrência. Revista de Informação Legislativa. Brasília, jan./mar. 1990, n. 105, p. 38.

${ }^{301}$ FARIA, José Ângelo Estrella. O controle de concentrações de empresas estrangeiras e a Lei $\mathrm{n}^{\circ}$ 8.884: a extraterritorialidade revisitada. Juris Síntese, maio/jun. 2009, n. 77, p. 6. Disponível em: <http://online. sintese. com>. Acesso em: 19 ago. 2012.

${ }^{302}$ São exemplos de leis de bloqueio o United Kingdom's Protection of Trading Interests Act, de 1980; o regulamento comunitário $\mathrm{n}^{\mathrm{o}} 2271 / 96$, relativo à proteção contra os efeitos da aplicação extraterritorial de legislação adotada por um país terceiro e das medidas nela baseadas ou dela resultantes; ainda, o art. 181 da Constituição Federal brasileira; e o art. $6^{\circ}$ da Resolução no 9/2005 do Superior Tribunal de Justiça. Outros países adotaram leis dessa natureza, tais como a Austrália (Foreign Ntitrust Judgements Restriction of Enforcement Act), o Canadá (Loi sur les mesures extraterritoriales étrangères), a França (Lei 80.538, de 16/07/1980) e a África do Sul. Forgioni destaca que "é constatado empiricamente que 'ondas' de blocking laws coincidem com períodos de instrução de grandes processos antitruste nos Estados Unidos. Por esta razão, ainda que não tenha sido expressamente declarado por ocasião de sua promulgação, a maioria das leis de bloqueio originou-se no desejo de proteção contra a excessiva extraterritorialidade das leis norteamericanas". (FORGIONI, Paula A. Os fundamentos do antitruste. 4. ed. São Paulo: Revista dos Tribunais, 2010, p. 453). Ver ainda OLIVEIRA, Gesner; RODAS, João Grandino. Direito e economia da concorrência. Rio de Janeiro: Renovar, 2004, p. 384; e PINSKI, Lior. Aplicação extraterritorial da Lei Antitruste. Revista de Direito Mercantil. São Paulo: Revista dos Tribunais, 1999, n. 115, pp. 134-135.

${ }^{303}$ Nesse sentido, Forgioni esclarece "os efeitos extraterritoriais das leis antitruste sobre limitações impostas pelas soberanias dos outros países”. (FORGIONI, Paula A. Op. cit., 2010, p. 451). Ver também CARVALHO RAMOS, André de; CUNHA, Ricardo Thomazinho da. A defesa da concorrência em caráter global: utopia
} 
concorrência de outras nações. De fato, parte da doutrina especializada ${ }^{304}$ aponta as questões de execução do direito da concorrência em outras jurisdições como foco central das leis de bloqueio.

Em vista das dificuldades e das reações internacionais verificadas em resposta ao acolhimento da teoria dos efeitos, o sistema legal norte-americano sofreu adaptações para mitigar as deficiências do sistema. Assim, a jurisprudência norte-americana adotou a doutrina da cortesia positiva - mediante o desenvolvimento do princípio da ponderação acima descrito - e promulgou outros instrumentos legislativos com este propósito ${ }^{305}$.

Todavia, tais iniciativas não se demonstraram efetivas, pelo que a problemática identificada ainda pende de medidas que possam efetivamente mitigar os efeitos adversos da aplicação extraterritorial da legislação de defesa da concorrência, tanto em relação à legislação norte-americana, quanto sobre as demais legislações nacionais que, a exemplo da experiência norte-americana, acabaram por acolher a teoria dos efeitos ${ }^{306}$. Em suma, as medidas tomadas pelos Estados Unidos minimizaram o problema advindo da aplicação extraterritorial do Direito da Concorrência com base na teoria dos efeitos, mas não conseguiram eliminar os problemas identificados pelos críticos ao sistema ${ }^{307}$. Parte da doutrina aponta, por outro lado, que "não existe, porém, um número significativo de protestos diplomáticos que permita concluir por uma rejeição universal ou sequer majoritária da effects doctrine ${ }^{\text {"308 }}$.

De todo o modo, justamente em função das críticas acima apontadas, pode-se concluir que a simples aplicação extraterritorial unilateral do Direito da Concorrência nacional pelos Estados não constitui a solução desejada para resolver o problema da ausência de normas efetivas de regulação do Direito Internacional da Concorrência. Pende uma resolução dos problemas apontados por parte da comunidade internacional, seja por

ou necessidade. In: CASELLA, Paulo Borba (org.). Guerra commercial ou integração econômica mundial. São Paulo: LTr, 1998, v. 1, p. 824.

${ }^{304}$ WHISH, Richard. Competition Law. 6. ed. New York: Oxford University Press, 2009, p. 472.

305 Destaca-se nesse sentido o Foreign Trade Antitrust Improvement Act, de 1982, que conferiu características essenciais aos efeitos a serem observados na aplicação da teoria dos efeitos; e o Antitrust Enforcement Guidelines for International Operations, de 1995. Apesar desses instrumentos normativos terem sido concebidos para minimizar os protestos internacionais, acabaram por surtir efeitos adversos, alterando mais uma vez a orientação da jurisprudência.

306 "National competition laws as well as the supranational European Law define the scope of their application according to the so-called effects doctrine. [...] This has now become a global phenomenon". (TERHECHTE, Jörg Philipp. International competition enforcement law: between cooperation and convergence. New York: Springer, 2011, p. 39).

${ }^{307}$ São medidas inadequadas à solução do problema. (CARVALHO, Leonardo Arquimino de. Direito antitruste \& relações internacionais: extraterritorialidade e cooperação. Curitiba: Juruá, 2003, p. 144). 
meio da adoção de sistemas multilaterais ou regionais efetivos de defesa da concorrência, ou mediante uma cooperação bilateral mais ampla e efetiva ${ }^{309}$.

\subsubsection{Dimensões multilateral, regional e bilateral: a cooperação em matéria da concorrência}

Conforme descrito neste primeiro capítulo, o Direito da Concorrência é um ramo precoce no desenvolvimento na Ciência Jurídica, o qual teve no Brasil ampla influência da economia e do desenvolvimento da matéria no sistema legal norte-americano. O sistema de defesa da concorrência brasileiro, que possui fundamentos constitucionais, passou por recente reestruturação por meio do advento da Lei da Concorrência, a qual afetou diretamente o sistema de notificação dos atos de concentração às autoridades antitruste.

O Direito Internacional da Concorrência é a matéria jurídica, cuja evolução também se deu há pouco tempo, e que se ocupa primordialmente com os problemas advindos da aplicação extraterritorial da legislação de defesa da concorrência. Desta forma, a dimensão unilateral do Direito Internacional da Concorrência está consubstanciada na aplicação extraterritorial e unilateral do Direito da Concorrência nacional pelas autoridades respectivamente competentes. Essa perspectiva é a que orienta e justifica todos os demais esforços havidos em sede multilateral, regional e bilateral.

Nesse sentido, e conforme já exposto neste capítulo, a Lei da Concorrência, seguindo o modelo norte-americano, contém dispositivo de acolhimento da teoria dos efeitos, fazendo com que seja possível, portanto, aplicar a legislação brasileira

\footnotetext{
${ }^{308}$ FARIA, José Ângelo Estrella. O controle de concentrações de empresas estrangeiras e a Lei $n^{\circ}$ 8.884: a extraterritorialidade revisitada. Juris Síntese, maio/jun. 2009, n. 77, p. 4. Disponível em: <http://online.sintese. com>. Acesso em: 19 ago. 2012.

${ }^{309}$ Forgioni destaca que "a doutrina dos chamados países desenvolvidos costuma sugerir três ordens de medidas para solucionar conflitos de normas e jurisdição antitruste: (i) a criação de uma autoridade antitruste internacional ou, ainda, seu tratamento no âmbito da Organização Mundial do Comércio; (ii) a harmonização das legislações, para que se evitem grandes disparidades entre os sistemas; e (iii) a celebração de tratados visando à colaboração das autoridades antitruste e à diminuição dos problemas políticos decorrentes da extraterritorialidade". No entanto, a autora adverte, em relação ao item (i), sobre a possibilidade de que a criação de um órgão supranacional sobre o tema poderá ser prejudicial aos países em desenvolvimento, na medida em que poderão ficar vulneráveis nas suas políticas econômicas em face dos interesses dos países desenvolvidos. (FORGIONI, Paula A. Os fundamentos do antitruste. 4. ed. São Paulo: Revista dos Tribunais, 2010, p. 458). Silva também destaca as alternativas oferecidas pelos acordos bilaterais de cooperação e iniciativas multilaterais como formas de superar as questões relativas à aplicação extraterritorial do Direito da Concorrência. (SILVA, Valéria Guimarães de Lima e. Direito antitruste: aspectos internacionais. Curitiba: Juruá, 2007, p. 431). Nesse sentido, Nusdeo sintetiza: "os problemas decorrentes do concurso de jurisdições, o consenso em relação à necessidade de se enfrentar práticas como cartéis internacionais e os atos de concentração transnacionais de maneira cooperativa, assim como a percepção da danosidade para o comércio internacional da utilização de regras antitruste nacionais como mecanismo protecionista têm levado a iniciativas multilaterais e bilaterais de cooperação ou uniformização de leis".
} 
concorrencial a atos praticados no exterior, os quais venham a surtir efeitos no território nacional.

Conforme denotado da experiência norte-americana, a aplicação extraterritorial do Direito da Concorrência pode ocasionar protestos e reclamações diplomáticas, além de já terem causado a promulgação de leis de bloqueio por diversas jurisdições. Este cenário não contribui para que as decisões das autoridades de defesa da concorrência que envolvem a aplicação extraterritorial das respectivas legislações possuam validade e eficácia no exterior, mitigando assim os efeitos que são buscados com tal tutela. Além disso, no cenário descrito neste capítulo pode-se verificar que é plenamente possível haver o envolvimento de mais de uma autoridade na revisão de um determinado ato de concentração multijurisdicional, revelando assim que podem ocorrer decisões sobrepostas e até mesmo antagônicas proferidas pelas autoridades envolvidas em um mesmo ato.

O Direito Internacional da Concorrência aponta a cooperação jurídica internacional como solução disponível aos variados Estados para mitigar as dificuldades encontradas. A cooperação entre os países pode, em tese, ocorrer em três dimensões: multilateral, regional ou bilateral.

A comunidade internacional vem demonstrando esforços para a construção de um conjunto de regras mínimas multilaterais de Direito Internacional da Concorrência, de forma a garantir a proteção do ambiente no qual o processo evolutivo do comércio internacional deverá se desenvolver ${ }^{310}$. Tais iniciativas podem ser observadas desde a Carta de Havana para uma Organização Internacional do Comércio, assinada em 24 de março de 1948. No âmbito internacional, várias entidades trabalham no desenvolvimento do tema. Todavia, conforme se analisará no segundo capítulo deste estudo, apesar dos esforços para o desenvolvimento do Direito Internacional da Concorrência neste âmbito multilateral, não é possível defender que exista atualmente um regramento universal e efetivo sobre o tema.

À parte da perspectiva multilateral existe, ainda, uma perspectiva regional da matéria, traduzida nas normativas emanadas pelas diversas organizações regionais de

(NUSDEO, Ana Maria de Oliveira. Defesa da concorrência e globalização econômica. São Paulo: Malheiros, 2002, p. 165).

310 "O dito comércio internacional não é livre, pois não há proteção à livre concorrência por meio da punição do abuso do poder econômico, e assim a livre iniciativa resta desprotegida, o que possibilita a colocação de barreiras ao acesso ao mercado. Caso o consenso internacional prime pela liberalização do comércio, deverá primar, também, por um fortalecimento da política da concorrência em nível global”. (KLEIN, Vinícius. O direito da concorrência no Mercosul. Núcleo de Pesquisa em Direito Público do Mercosul. Revista da Faculdade de Direito da Universidade Federal do Paraná. 2002, p. 194. Disponível em: <http://ojs.c3sl.ufpr.br/ojs2/index.php/direito/article/view File/1754/1451>. Acesso em: 21 out. 2009). 
integração econômica ${ }^{311}$. A União Europeia traduz o estágio mais avançado de cooperação regional em matéria de concorrência ${ }^{312}$, mas é possível encontrar disposições sobre a matéria em outras organizações. É o caso, por exemplo, do Mercosul, que também buscou a regulação da concorrência no seu bojo normativo. No entanto, não é possível concluir que no âmbito regional do Mercosul exista efetivamente um sistema de defesa da concorrência, já que as normativas emanadas não chegaram a ser implementadas por completo por todos os agentes envolvidos.

Ante a inexistência de tratados multilaterais sobre o tema, acordos bilaterais passaram a ser celebrados por diversos países, traduzindo uma perspectiva bilateral da matéria $^{313}$ - tema que constitui o ponto central deste estudo e será desenvolvido a seguir, no segundo capítulo.

\footnotetext{
${ }^{311}$ No que toca à cooperação regional o Direito Internacional da Concorrência tem especial relevância, uma vez que não há possibilidade de se conceber o desenvolvimento econômico de uma região sem que haja uma correspondente proteção da livre iniciativa, da concorrência e dos direitos dos consumidores. Nesse sentido, Salomão Filho defende que "o passo fundamental para a consolidação de um mercado comum é a coordenação de políticas macroeconômicas [...]. Essa coordenação não pode ocorrer sem que haja, concomitantemente, uma convergência das políticas de regulação da concorrência, sob pena de as condutas anticoncorrenciais facilitadas pela integração colocarem em risco o fim pretendido: o Mercado Comum". (SALOMÃO FILHO. Calixto. O Mercosul como modelo de regulação do mercado. Contratos internacionais. 3. ed. São Paulo: Revista dos Tribunais, 2002, p. 412).

312 "Há quem sustente que o fenômeno da globalização da economia estaria provocando um esvaziamento da função dos sistemas legais de controle ou de defesa da livre concorrência. Isso porque, em uma economia aberta, a competição internacional se encarregaria de substituir esses sistemas. Iniciado bem antes, mas programado para atingir o seu apogeu enquanto ainda estiverem se manifestando as consequências desse fenômeno, o processo de integração da Comunidade revela exatamente o contrário. Em vez de perderem importância, esses sistemas de controle têm-se tornado cada vez mais necessários, pois, para os governos dos Estados-Membros, tem sido difícil sucumbir à tentação de favorecer ou proteger, de alguma forma, suas empresas domésticas, em claro detrimento dos concorrentes de outros Estados-Membros." (CELLI JÚNIOR. Humberto. Regras de concorrência no Direito Internacional Moderno. Porto Alegre: Livraria do Advogado, 1999, p. 239).

313 "If a supranational system of enforcement of competition law is still far from becoming a reality, effective systems of bilateral cooperation seem at the moment to be more realistic alternative. In the recent years a number of bilateral agreements between different competition authorities have been concluded on the basis of the OECD guidelines of 1995". (BOTTA, Marco. The cooperation between the Competition Authorities of the Developing Countries: why does it not Work? Case Study on Argentina and Brazil. The competition law review. Issue 2, jul. 2009, v. V, p. 155).
} 


\section{COOPERAÇÃO JURÍDICA INTERNACIONAL E O DIREITO DA CONCORRÊNCIA}

\subsection{A COOPERAÇÃO JURÍDICA INTERNACIONAL}

A aceleração do processo de globalização acarretou o aumento das interações no plano internacional, seja de ordem pessoal, institucional ou econômica, ultrapassando os limites territoriais dos Estados. Se o Direito segue o fato social, devem os ordenamentos jurídicos se amoldar a essa nova realidade de contatos extraterritoriais, já que consequências jurídicas são esperadas em função da mudança dos padrões de relacionamentos ${ }^{314}$.

A cooperação jurídica internacional passa, então, a desempenhar um papel de destaque no meio jurídico, já que os Estados e as suas autoridades dependem desse instrumento para que as respectivas atuações sejam providas de efetividade no plano internacional $^{315}$. Além disso, cumpre lembrar que o princípio da cooperação internacional não se resume somente à busca da efetividade na atuação internacional dos Estados, mas também se fundamenta na ideia de que a cooperação dos povos é essencial para viabilizar o desenvolvimento da comunidade internacional ${ }^{316}$.

Com esse propósito em mente, o Estado brasileiro tem demonstrado preocupação cada vez maior com o desenvolvimento de mecanismos de interação jurídica internacional, garantindo aos cidadãos e empresas brasileiras uma prestação jurisdicional e administrativa efetiva, ao mesmo tempo assegurando aos demais atores da comunidade internacional a possibilidade de interagir de forma segura com as instituições nacionais.

Todavia, isso não significa que a cooperação jurídica internacional pelas autoridades brasileiras seja recente. O Estado brasileiro, em especial as suas autoridades judiciárias, tem uma tradição histórica de cooperação internacional. Desde a época do

\footnotetext{
${ }^{314}$ Araújo esclarece "a acentuada internacionalização da vida diária contém muitas consequências para a vida jurídica, de ordem positiva e negativa. Na primeira, destacam-se as questões ligadas à pessoa humana, ao direito de família e ao aumento das transações internacionais, tanto entre comerciantes como com os consumidores. Na segunda, desponta o aumento da litigiosidade com características internacionais, ligadas às esferas cível e penal”. (ARAÚJO, Nádia de. Cooperação jurídica internacional no Superior Tribunal de Justiça. Comentários à Resolução n. 9/2005. Rio de Janeiro: Renovar, 2010, p. 1).

${ }^{315}$ Note-se que a cooperação jurídica internacional pode contemplar medidas de natureza civil, comercial ou penal.

316 “La idea de promoverse la cooperación entre los pueblos para lograr el progreso de la humanidad está anclada em la noción del desarrollo de uma comunidad internacional, más solidaria, dirigida a la resolución de problemas comunes que afecten todos los pueblos". (MENEZES, Wagner. Derecho Internacional en América Latina. Brasília: Funag, 2010, p. 236).
} 
Império $^{317}$ as autoridades judiciárias mostram-se disponíveis à cooperação com autoridades estrangeiras, mesmo que dita cooperação não tenha sido requerida no bojo de um tratado internacional de que o país fosse signatário. De todo modo, a cooperação jurídica internacional institucionalizada por meio de tratados internacionais acaba por conferir maior rapidez e eficácia ao cumprimento de medidas requeridas por outros países.

Com passar dos tempos foi sendo modificado o papel dos Estados em um mundo globalizado, dependente da cooperação jurídica internacional para a eficácia na regulação das relações humanas e empresariais. Em razão da alteração dos fundamentos das relações estatais, o próprio conceito de Estado Constitucional teve de evoluir, de modo a responder aos anseios da comunidade internacional e garantir a consistência do sistema jurídico. Desta forma, surge o conceito do Estado Constitucional Cooperativo, o qual se passa a descrever.

\subsubsection{O Estado Constitucional Cooperativo}

O Estado Constitucional iniciou uma nova fase, qual seja, a do entrelaçamento das relações internacionais que acarretarão a designação da cooperação como um dos principais elementos da sua identidade ${ }^{318}$. Para comportar a evolução deste instituto, Häberle $^{319}$ propôs um conceito de Estado Constitucional Cooperativo correspondente à necessidade internacional de política de paz. O conceito proposto tem por finalidade, portanto, abarcar o princípio de cooperação internacional, o qual se relaciona profundamente com a intensificação das relações internacionais dos Estados, não somente pautadas em simples coordenação dos esforços internacionais em torno de determinada matéria, mas vocacionadas a uma ação mais efetiva dos Estados perante a comunidade internacional mediante um profundo processo de cooperação.

\footnotetext{
${ }^{317}$ Mesmo antes da publicação do Aviso Circular $\mathrm{n}^{\circ}$ 1, de 1847, que disciplinou pela primeira vez a cooperação no território brasileiro, já era comum que juízes recebessem pedidos de cooperação estrangeira e lhes dessem o devido cumprimento. Nesse sentido ver ARAÚJO, Nádia de. Cooperação jurídica internacional no Superior Tribunal de Justiça. Comentários à Resolução n. 9/2005. Rio de Janeiro: Renovar, 2010, p. 9.

318 "O Direito Internacional, ao transcender os antigos parâmetros do direito clássico da paz e da guerra, equipou-se para responder às novas demandas e desafios da vida internacional, com maior ênfase na cooperação e na solidariedade". E segue: "Com todos os desenvolvimentos anteriormente relatados, a comunidade internacional tem dado mostras de sua disposição de distanciar-se da tradicional visão hobbesiana - ou 'realista' - da convivência internacional (marcada pela política de poder) e de aproximar-se da visão kantiana de uma comunidade universal caracterizada pela cooperação e pela solidariedade". (TRINDADE, Antônio Augusto Cançado. O direito internacional em transformação: Ensaios, 1976-2001. Rio de Janeiro: Renovar, 2002, pp. 1.054 e 1.075).
} 
O conhecido conceito de Estado Constitucional contempla o Estado "em que o poder público é juridicamente constituído e limitado através de princípios materiais e formais" ${ }^{320}$, dentre os quais se destacam os elementos estatal, democráticos, de direitos fundamentais individuais, sociais e culturais, a separação dos poderes e um Poder Judiciário independente. Já o Estado Constitucional Cooperativo é "o Estado que justamente encontra a sua identidade também no Direito Internacional, no entrelaçamento das relações internacionais e supranacionais, na percepção da cooperação e responsabilidade internacional, assim como no campo da solidariedade" ${ }^{, 321}$.

Assim, são objeto do Estado Constitucional Cooperativo as questões relativas aos outros Estados, das instituições nacionais e supranacionais e dos cidadãos estrangeiros. Há correspondência entre o Estado Constitucional Cooperativo e o desenvolvimento de um Direito Internacional Cooperativo, na medida em que o Estado Constitucional deve se transformar internamente de modo a adequar-se ao Direito Internacional Cooperativo.

A cooperação pode se dar no âmbito processual jurídico-formal (acordos, tratados, dentre outros) e material (justiça social, direitos humanos, dentre outros), sem que o Estado Constitucional Cooperativo deixe de possuir a sua identidade própria, autônoma. A soberania dos Estados não é, portanto, mitigada pela cooperação por estes promovida ${ }^{322}$. Não há primazia entre o Estado Constitucional Cooperativo e o Direito Internacional, sendo ambos integrantes de um conjunto.

Dentre os motivos e pressupostos do desenvolvimento do Estado Constitucional Cooperativo destacam-se os fatores sociológico-econômico (inter-relações econômicas dos Estados) e o ideal-moral (construção relativa aos direitos fundamentais e direitos humanos).

No plano universal, dois documentos internacionais de natureza constitucional destacam-se na organização da comunidade dos Estados visando à cooperação,

\footnotetext{
${ }^{319}$ HÄBERLE, Peter. Estado constitucional cooperativo. Trad. de Marcos Augusto Maliska e Elisete Antoniuk. Rio de Janeiro: Renovar, 2007, p. 2.

${ }^{320}$ Id., ibid., p. 6.

${ }^{321}$ Id., Ibid., p. 4.

322 "A cooperação não importa, de modo algum, limitação da soberania, pois é precisamente com base nesta que ela se realiza. Se não houver a soberania, não haverá cooperação, que pressupõe coordenação de atos próprios; mas subordinação, que pressupõe realização de atos impostos por outro. O que a cooperação restringe e até elimina são os conflitos. Constitui ela forma consensual de harmonia". (SILVA, José Afonso da. Comentário contextual à Constituição. 6. ed. São Paulo: Malheiros, 2009, p. 52). Nesse sentido, Slaughter esclarece sobre a evolução do conceito da soberania, desde a acepção de Westfalen até o atual estágio, o qual possui a capacidade de participar nos regimes, nas redes e nas instituições internacionais e transnacionais, necessárias à viabilização da independência de governo dos Estados nos respectivos territórios. Para que tal conceito resulte, a participação implica na aceitação de algumas responsabilidades
} 
designadamente o Estatuto da Liga das Nações, de 1919, e a Carta da ONU, de $1945^{323}$. O direito de coordenação está previsto nos dois diplomas, nos quais se considera a cooperação como meio de solução de assuntos internacionais, sejam de natureza social, cultural ou humanitária e de fomento do respeito aos direitos fundamentais e aos direitos humanos. A Carta da ONU, diferentemente do Estatuto da Liga das Nações, concebe que a cooperação deve se dar no âmbito social e econômico dos Estados, objetivando a garantia da $\operatorname{paz}^{324}$.

Em função da Resolução da Assembleia Geral da ONU n 2.625, de 1970, a qual reforçou a necessidade de cooperação pelos Estados, é possível depreender que aos Estados cabe um verdadeiro dever de cooperar ${ }^{325}$. À medida que o legislador internacional acolheu o princípio geral de cooperação, definiu-se a obrigação dos Estados de promover a cooperação nos mais variados setores da comunidade internacional ${ }^{326}$. De fato, o dever de cooperar decorre da constatação de que a eficácia da aplicação das legislações nacionais dos Estados depende da cooperação entre as diferentes unidades políticas que se expressam no plano mundial ${ }^{327}$. Desta forma, o princípio da boa-fé nas relações internacionais entre Estados deve sobrepor-se a qualquer resistência ou forma de desconfiança no cumprimento de medidas solicitadas por autoridades estrangeiras.

A União Europeia é um exemplo proeminente de cooperação regional ${ }^{328}$, pela qual os Estados abdicaram parte das respectivas soberanias para se atingir uma integração

básicas por todos os governos sobre os respectivos povos. (SLAUGHTER, Anne-Marie. Sovereignty and power in a Networked World Order. Stanford Journal of International Law, 2004, n. 40, pp. 284-287).

${ }^{323}$ Para tal efeito, consultar os arts. 1.3 e 1.4 da Carta das Nações Unidas. Silva comenta que a cooperação consta em vários documentos internacionais, constituindo um dos propósitos explícitos da Carta das Nações Unidas, destacando como finalidade inerente à mesma a resolução de problemas de caráter econômico, social, cultural ou humanitário. (SILVA, José Afonso da. Comentário contextual à Constituição. 6. ed. São Paulo: Malheiros, 2009, p. 52).

${ }^{324}$ HÄBERLE cita Mosler, que entende que a obrigação de cooperação deveria ser acrescida à obrigação geral pela paz como elemento constitucional material da ordem jurídica internacional. (HÄBERLE, Peter. Estado constitucional cooperativo. Trad. de Marcos Augusto Maliska e Elisete Antoniuk. Rio de Janeiro: Renovar, 2007, p. 27).

${ }^{325}$ A obrigação de cooperar dos Estados consta na interpretação de juristas como José Afonso da Silva e Nádia de Araújo. Nesse sentido, ver SILVA, José Afonso da. Op. cit., 2009, p. 52; e ARAÚJO, Nádia de. Cooperação Jurídica Internacional no Superior Tribunal de Justiça. Comentários à Resolução n. 9/2005. Rio de Janeiro: Renovar, 2010, p. 3. Alguns autores sugerem que o dever de cooperar decorre de uma interpretação do art. 38 do Estatuto da Corte Internacional de Justiça - princípios gerais de Direito Internacional - ou ainda do princípio da boa-fé.

${ }^{326}$ MENEZES, Wagner. Derecho Internacional en América Latina. Brasília: Funag, 2010, p. 237.

327 CASELLA, Paulo Borba; SANCHEZ, Rodrigo Elian. Cooperação judiciária internacional. Rio de Janeiro: Renovar, 2002, p. 25.

${ }^{328}$ Especial referência é feita ao Estatuto do Conselho Europeu (1949) ao qual foi incorporada a convicção de que a "garantia da paz sobre os fundamentos da justiça e da cooperação internacional é de interesse vital para a conservação da sociedade humana e da civilização”. (HÄBERLE, Peter. Op. cit., 2007, p. 32). 
econômica, de política social e regional ${ }^{329}$. Ainda no âmbito da cooperação regional estão o Tratado sobre a OCDE, de 1960, a Conferência sobre Segurança e Cooperação na Europa, de 1975, a Organização dos Estados Americanos (OEA), de 1970, dentre outros. A cooperação internacional, no entanto, não se limita à cooperação entre Estados, podendo ser promovida e fomentada por entidades privadas, com é o caso das empresas multinacionais, da Anistia Internacional, dentre outras.

A tipologia sobre a cooperação dos Estados encontra guarida em regras constitucionais dos diversos Estados ${ }^{330}$. Nessa esteira, o art. $4^{\circ}$, IX, da Constituição Federal brasileira estabelece como princípio das relações internacionais brasileiras a "cooperação entre os povos para o progresso da humanidade”. Silva, em seus comentários a tal dispositivo, define cooperação como o ato de "operar em conjunto, operar com o outro, o que pressupõe harmonia e solidariedade da busca do objetivo que requer o esforço conjunto", o que no caso em apreço é o progresso da humanidade ${ }^{331}$.

O desenvolvimento das ações concertadas para a cooperação internacional implica na doutrina comum das fontes jurídicas, ou seja, as fontes jurídicas deixam de constituir um monopólio do Estado para se integrarem aos procedimentos internacionais ou de Direito Internacional de legislação e a processos de interpretação. Assim, os Estados devem reconhecer a influência recíproca da ordem jurídica nacional e internacional, com especial atenção ao direito comparado. Não somente isso, mas a cooperação internacional também acarreta a formação de um Direito comum de cooperação, cuja experiência da União Europeia é a sua melhor expressão.

\footnotetext{
${ }^{329}$ Häberle esclarece que a "integração como forma de incremento da cooperação pode, com isso, ser vista também como perspectiva de esforços internacionais de cooperação". (HÄBERLE, Peter. Estado constitucional cooperativo. Trad. de Marcos Augusto Maliska e Elisete Antoniuk. Rio de Janeiro: Renovar, 2007, p. 31).

${ }^{330}$ São exemplos das regras constitucionais verificadas nas mais variadas constituições: (i) que reconhecem a inclusão do Estado na comunidade dos povos; (ii) que reconhecem a cooperação; (iii) de parceria ou solidariedade; (iv) de recepção de pactos de direitos humanos; (v) de integração de normas de direito internacional universalmente reconhecidas; (vi) de primazia ou colisão em favor de direito internacional, nos casos de direitos humanos; (vii) de interpretação conforme o direito internacional; (viii) de fontes do direito aberto ao direito internacional; e (ix) de interpretações abertas ao direito estrangeiro. (HÄBERLE, Peter. Op. cit., 2007, pp. 57-58).

${ }^{331}$ SILVA, José Afonso da. Comentário contextual à Constituição. 6. ed. São Paulo: Malheiros, 2009, p. 52.
} 


\subsubsection{As formas de manifestação da cooperação jurídica internacional}

As formas de manifestação da cooperação jurídica internacional podem ser mais rígidas, como no caso de tratados e convenções, ou mais flexíveis - soft law ${ }^{332}$-, podendo variar, inclusive, no âmbito destas ${ }^{333}$. Nessa esteira, é relevante o estudo desenvolvido por Abbot $^{334}$, sob a coordenação da professora Dinah Shelton, sobre o fenômeno da legalização das políticas internacionais.

A legalização inclui uma expressiva gama de arranjos normativos e institucionais, desde normas rígidas de Direito Internacional até as conhecidas soft laws, sendo definida como uma forma de institucionalização com três dimensões, nomeadamente obrigação, precisão e delegação ${ }^{335}$.

A dimensão "obrigação" significa que as normas não são somente vinculantes aos Estados e aos demais atores das políticas internacionais, mas são legalmente vinculantes, incluindo assim nessa acepção todas as normas gerais, procedimentos e discursos do Direito Internacional. "Precisão" refere-se à definitividade, elaboração e densidade das normas legais. Já a "delegação" está relacionada à aceitação da autoridade de terceiras partes na resolução de litígios, na interpretação normativa, na elaboração de normas e em atividades adjacentes. A delegação pode ocorrer para tribunais com atribuições de natureza jurisdicional, como para instituições de resolução de litígios não jurisdicionais ou agências reguladoras e outros organismos políticos.

\footnotetext{
${ }^{332}$ Accioly, Nascimento e Silva e Casella fazem ressalvas quanto à possibilidade de haver vinculação jurídica sobre os conhecidos instrumentos de soft law, estabelecendo que "o acordo geral sobre os princípios é indispensável, na falta do que as mais belas regras jurídicas não passarão de enunciados destituídos de eficácia”. Note-se que, nesse sentido, a soft law não se confunde com as normas de jus cogens, previstas inclusive na Convenção de Viena sobre o Direito dos Tratados, de 1969, as quais tratam de normas imperativas de direito internacional geral, da qual nenhuma derrogação é possível. O jus cogens relaciona-se aos costumes decorrentes da prática reiterada, do costume, enquanto que no caso das soft laws tal prática reiterada não é observada. Nessa esteira os autores alertam que "salvo exceções bastante delimitadas, de atribuir às organizações internacionais o papel de legisladores universais, não é possível atribuir força obrigatória geral às resoluções emanadas das organizações internacionais, sem ir consideravelmente mais além do que pretenderam atribuir a essas organizações os estados que as constituíram”. (ACCIOLY, Hildebrando; NASCIMENTO E SILVA, G. E. do; CASELlA, Paulo Borba. Manual de Direito Internacional Público. 17. ed. São Paulo: Saraiva, 2009, pp. 306-315).

333 HÄBERLE, Peter. Estado constitucional cooperativo. Trad. de Marcos Augusto Maliska e Elisete Antoniuk. Rio de Janeiro: Renovar, 2007, p. 13.

334 Abbot utiliza a terminologia legalization, mas a fim de facilitar o desenvolvimento deste estudo referiremos ao correspondente termo em português: legalização. (ABBOT, Keneth W. The many faces of International Legalization. American Society of International Law, 1998).

${ }^{335}$ Id., ibid., p. 59.
} 
Cada uma das dimensões pode ser escalonada e graduada independentemente, conferindo à legalização o status de contínuo multidimensional. A partir da graduação das dimensões é possível verificar que a legalização pode variar desde uma situação de completa ausência de Direito, na qual nenhuma das três dimensões seja verificada, passando por formas de quase legalização ou leve legalização (soft laws), até a situação de extrema ou rígida legalização (hard laws). Por meio dessa análise é possível determinar que a legalização não constitui um fenômeno binário, ou seja, completa existência ou ausência de Direito. E nessa esteira é necessário reconhecer que qualquer uma das graduações da legalização tem propósitos específicos e finalidades relevantes.

Há correspondência entre o grau de legalização e o processo utilizado para a formação e aplicação do instrumento internacional: enquanto que a diplomacia conduz à cobertura do completo espectro de legalização, contudo muitas vezes com baixa delegação, as conferências sobre matérias específicas - como, por exemplo, em matéria de meio ambiente e direitos humanos - conduzem normalmente à expedição de instrumentos não vinculativos, porém com elevado grau de precisão e elaboração. Os acordos celebrados entre entidades infraestatais, como é o caso da cooperação entre autoridades de defesa da concorrência ou bancárias, poderão ou não ser vinculativos, mas em regra não possuem elevado grau de delegação.

Com a sistematização da legalização é possível traçar estratégias para a formação dos instrumentos internacionais, as quais poderão, ainda, revelar os motivos pela escolha de determinado procedimento de legalização. A escolha por um determinado processo poderá se dar em função dos custos associados à sua conclusão, já que acordos flexíveis geralmente estão associados ao dispêndio de menores valores e esforço pelas partes.

Um ponto relevante a considerar neste diapasão é a posição das entidades governamentais antes e após a assinatura dos instrumentos, já que no momento de celebração não é possível prever todos os efeitos, repercussões e especialmente contingências que deverão advir de tal acordo ${ }^{336}$. Uma forma de lidar com tais incertezas é optando em celebrar acordos de baixa delegação, conferindo poderes a instituições políticas ao invés de entidades com poderes jurisdicionais. Outra forma seria por meio da

\footnotetext{
${ }^{336}$ Outra preocupação das entidades estatais no processo de legalização está relacionada aos "custos de soberania", os quais podem ter fundamento em questões psicológicas ou simbólicas, ou até mesmo questões materiais (quando os interesses nacionais estiverem em jogo). Desta forma, os custos de soberania estão geralmente associados à delegação, restando melhor resguardados nos processos de legalização soft, com baixo grau de delegação. A questão da soberania poderá variar de acordo com a matéria ou Estados, designadamente sobre a sua autonomia. (ABBOT, Keneth W. The many faces of International Legalization. American Society of International Law, 1998, p. 62).
} 
elaboração de regras imprecisas, constituídas por princípios gerais, que comportem interpretação e adequação, ou pela adoção de um sistema não vinculativo de normas que permita aos atores experimentar a execução do acordo.

Com base nos estudos apresentados, é possível vislumbrar que a cooperação jurídica internacional poderá ter forma mais ou menos efetiva, consoante forma de legalização escolhida pelas entidades que concebem tal cooperação.

Em relação ao Direito Internacional da Concorrência, mais precisamente no que diz respeito aos atos de concentração multijurisdicionais, parece que a opção política verificada até o momento seja a da adoção de uma legalização de baixo nível, com baixa delegação, uma vez que não existem tratados ou convenções multilaterais sobre a matéria ${ }^{337}$, mas há predominantemente acordos celebrados entre as autoridades de defesa da concorrência e trabalhos sem força vinculante desenvolvidos por organizações e redes internacionais.

Cogita-se que tal opção se deva ao fato de o fenômeno da internacionalização dos fatores relativos à concorrência ser recente, além de estar intrinsecamente vinculado às políticas públicas econômicas das variadas nações, o que, aliado ao fato de haver insegurança sobre os efeitos e custos de uma efetiva cooperação em matéria de concorrência, torna qualquer opção legislativa vinculante sobre o tema uma opção incerta, insegura e custosa.

\subsubsection{Cooperação Jurídica Internacional: definição e espécies}

A cooperação jurídica internacional insere-se em uma zona de transição entre o Direito Internacional Público e o Direito Internacional Privado, com maior prevalência dos aspectos relacionados ao Direito Internacional Privado, uma vez que se relaciona à questão relativa à aplicação de direito estrangeiro por autoridades nacionais ${ }^{338}$. É reconhecido pela doutrina, neste sentido, que o ensino da matéria de Cooperação Jurídica Internacional no bojo da esfera do Direito Internacional Privado é de maior valia para a efetividade na transmissão dos institutos - os quais, por outra forma, acabariam sendo negligenciados.

\footnotetext{
${ }^{337}$ Excetua-se desta assertiva a experiência única da União Europeia, pela qual os Estados-membros conferiram alto grau de delegação às instituições europeias para que decidissem sobre casos envolvendo o direito da concorrência no âmbito comunitário.

338 VERGUEIRO, Luiz Fabrício Thaumaturgo. Implementação da cooperação jurídica internacional vertical. Doutorado em Direito (Tese) - Faculdade de Direito da Universidade de São Paulo. São Paulo, 2012, p. 17.
} 
Note-se que no Brasil a legislação sobre Cooperação Jurídica Internacional encontra-se fragmentada, não existindo uma lei geral sobre a matéria ${ }^{339}$. Busca-se, desta forma, na doutrina a conceituação do instituto.

Araújo entende que Cooperação Jurídica Internacional significa "o intercâmbio internacional para o cumprimento extraterritorial de medidas processuais do Poder Judiciário de outro Estado". A autora segue defendendo que "além disso, hoje há novas possibilidades de uma atuação administrativa do estado nessa matéria, em modalidades de contato direto entre entes estatais, ${ }^{, 340}$. Vergueiro também se posiciona a respeito, destacando que a "efetivação da jurisdição, nacional ou estrangeira, pode depender do intercâmbio não apenas entre órgãos judiciais, mas também entre órgãos administrativos, ou ainda entre órgãos judiciais e administrativos, de Estados distintos" ${ }^{\circledR 41}$. Nessa esteira, a cooperação entre autoridades de defesa da concorrência de diferentes jurisdições encontraria guarida nesta última espécie, ou seja, no contato direto entre entes estatais.

Do exposto depreende-se que a Cooperação Jurídica Internacional pode ser de espécie jurisdicional ou administrativa ${ }^{342}$. A diferenciação entre as duas modalidades é relevante, na medida em que a Constituição Federal ${ }^{343}$ estabelece que o Supremo Tribunal Federal e o Superior Tribunal de Justiça detêm a competência originária e privativa para a Cooperação Jurisdicional Internacional. A ela reportam-se os atos de natureza jurisdicional, os quais devem ser apresentados ao órgão judicial nacional, constitucionalmente estabelecido, sob pena de ofenderem a soberania nacional e não produzirem efeitos jurisdicionais no território nacional ${ }^{344}$.

339 A legislação encontra-se esparsa na Constituição Federal, na Lei de Introdução ao Código Civil, no Código de Processo Civil, no Código de Processo Penal, na Resolução no 9 do Superior Tribunal de Justiça, nos tratados internacionais, bilaterais ou multilaterais, dentre outros. Araújo destaca os trabalhos desenvolvidos por uma comissão especial designada pela Portaria ${ }^{\circ} 2.199$, de 11/08/2004, nomeada pelo Ministério da Justiça, para a elaboração de um Anteprojeto de Lei de Cooperação Jurídica Internacional. Os trabalhos da referida comissão já foram finalizados e aguardam o encaminhamento ao Congresso Nacional. De todo o modo, tais trabalhos já influenciaram concretamente o labor do Superior Tribunal de Justiça na publicação da sua Resolução $n^{\circ}$ 9, que trata dos procedimentos de cooperação em matéria de homologação e execução de sentenças estrangeiras e concessão de exequatur para cartas rogatórias. (ARAÚJO, Nádia de. Cooperação Jurídica Internacional no Superior Tribunal de Justiça. Comentários à Resolução n. 9/2005. Rio de Janeiro: Renovar, 2010, pp. 6 e 14-15).

${ }^{340}$ Id., ibid., p. 2-3.

341 VERGUEIRO, Luiz Fabrício Thaumaturgo. Implementação da cooperação jurídica internacional vertical. Doutorado em Direito (Tese) - Faculdade da Direito da Universidade de São Paulo. São Paulo, 2012 , p. 19.

${ }^{342}$ Nesse sentido ver SILVA, Ricardo Perlingeiro Mendes da. Cooperação jurídica internacional e auxílio direto. O Direito Internacional contemporâneo - Estudos em homenagem ao professor Jacob Dolinger. Rio de Janeiro: Renovar, 2006, p. 804.

${ }^{343}$ Arts. 102, I, g, e 105, I, i da Constituição Federal.

344 "Seria ofensivo à soberania nacional não conferir a órgão judicial nacional, com função jurisdicional, o poder de aferir a compatibilidade entre os efeitos jurisdicionais de decisão judicial estrangeira e os princípios fundamentais do estado. Refiro-me ao juízo de valor que um tribunal nacional faz quanto à observância da 
A Cooperação Jurídica Internacional de cunho tradicional se coaduna à cooperação judiciária, na medida em que se relaciona ao reconhecimento e à execução de sentenças estrangeiras e à concessão do exequatur a cartas rogatórias. Tais procedimentos são de competência privativa do Superior Tribunal de Justiça, o qual regula o processo da referida cooperação por intermédio da sua Resolução n ${ }^{\circ}$ 9, de 04 de maio de $2005^{345}$.

Em relação à cooperação administrativa internacional, não se encontram regras constitucionais que a regulem diretamente ${ }^{346}$, pelo que a mesma poderá ser regulada pelo legislador infraconstitucional, devendo ser entregue aos órgãos judiciais de primeira instância ou aos entes ou órgãos públicos administrativos, conforme seja o caso. O objeto da cooperação administrativa internacional é o ato de natureza administrativa ou judicial, sem conteúdo jurisdicional. Neste caso os efeitos meramente administrativos ou sem conteúdo jurisdicional, produzidos no território nacional por atos públicos estrangeiros, não oferecem risco de ofensa à soberania, uma vez que tais efeitos não estão aptos a gerar coisa julgada ou exequibilidade.

Os procedimentos de cooperação administrativa internacional não reclamam necessariamente a atuação de órgão judicial nacional, uma vez que não implicam na realização de atos jurisdicionais no território nacional. Todavia, quando em determinado caso se fizer necessária a atuação de órgão judicial nacional, em razão da natureza jurisdicional da cooperação requerida, as autoridades administrativas envolvidas deverão buscar na legislação pátria as regras norteadoras da cooperação jurisdicional internacional e respeitar as competências definidas em lei.

De qualquer forma, os atos das autoridades administrativas nacionais, em sede de cooperação administrativa internacional, estarão sempre sujeitos a controle jurisdicional interno. Assim, a cooperação jurídica internacional não atinge de nenhuma forma a soberania nacional, na medida em que as medidas solicitadas sempre dependem ou podem ser revistas em última instância pela Justiça brasileira - a soberania somente seria sacrificada se fosse vedada a intervenção do poder jurisdicional ${ }^{347}$.

ordem pública. [...] A jurisdição nacional somente será movida em prol da jurisdição estrangeira se esta for compatível com os princípios fundamentais do estado”. (SILVA, Ricardo Perlingeiro Mendes da. Cooperação jurídica internacional e auxílio direto. O Direito Internacional contemporâneo - Estudos em homenagem ao professor Jacob Dolinger. Rio de Janeiro: Renovar, 2006, p. 800).

${ }^{345}$ A única exceção corrente está nas regras do Mercosul, estabelecidas nos Protocolo de Las Leñas.

${ }^{346}$ Caberá ao legislador infraconstitucional, se assim entender, regular esta modalidade de cooperação.

347 Silva defende ainda que não há explicação suficiente que justifique a manutenção da competência do Superior Tribunal de Justiça para julgar a concessão de exequatur às cartas rogatórias e a homologação de sentenças estrangeiras. Nesse sentido citou a PEC $\mathrm{n}^{\circ}$ 152/1999 (arquivada) que pretendia transferir a competência ao juiz de execução. (SILVA, Ricardo Perlingueiro Mendes da. Anotações sobre o anteprojeto de lei de cooperação jurídica internacional. Revista de Processo, nov. 2005, n. 129, pp. 133-160). 
A cooperação administrativa internacional entre autoridades de defesa da concorrência, por não contar com uma autoridade judiciária na parte ativa ou passiva da cooperação, e por não envolver, na maioria dos casos, a atuação de uma autoridade judiciária nacional na execução da cooperação requerida, deve ser entendida como cooperação administrativa de iniciativa da parte ${ }^{348}$.

\subsubsection{Auxílio direto}

É relevante mencionar o auxílio direto, ou assistência direta, que constitui recente modalidade de desenvolvimento para a cooperação jurídica internacional. Esse instrumento, acolhido inicialmente nos países de common law, trata de uma tentativa de se agilizar os procedimentos tradicionais de cooperação jurídica internacional, que são associados à morosidade.

Mediante o auxílio direto, o pedido de cooperação é direcionado por autoridade estrangeira a autoridades nacionais, para que deem cumprimento por meio do exercício normal de suas atribuições, como se fosse um procedimento nacional. Desta forma, o procedimento de execução é inteiramente nacional, possuindo a única particularidade de ser iniciado por um pedido de entidade estrangeira.

Destaca-se o trabalho iniciado no século 20 pela Conferência de Haia de Direito Internacional Privado no intuito de desenvolver instrumentos internacionais facilitadores da cooperação jurídica internacional, principalmente nas áreas do direito processual e direito da família, com a criação de autoridades centrais nacionais responsáveis por dinamizar os pedidos das autoridades estrangeiras. O modelo de autoridades centrais acabou sendo replicado em outros tratados, como no caso das Conferências Interamericanas Especializadas em Direito Internacional Privado (CIDIPs) promovidas pela OEA.

\footnotetext{
${ }^{348}$ Silva difere a cooperação de iniciativa de juiz ou de parte, constituindo a primeira na modalidade de cooperação em que a parte ativa do pedido é um juiz, o qual, no bojo de um processo judicial em curso, solicita medida de cooperação a autoridades estrangeiras. Já a cooperação de parte seria aquela modalidade de cooperação iniciada por entidade pública ou privada que provoque diretamente agentes públicos de outro país para dar efetividade para um procedimento em curso no exterior. Nesse sentido, o autor defende que "é possível imaginar órgãos ministeriais, ou até mesmo judiciais, que tenham função inquisitorial, em fase de investigação para futura ação penal no exterior, necessitando de procedimentos investigatórios, sem conteúdo jurisdicional, perante a ordem pública nacional, o que leva à investigação conjunta de órgãos do Ministério Público ou de autoridades policiais de estados distintos serem exemplos de cooperação passiva administrativa de iniciativa da parte". Analogicamente, pode-se depreender que no tocante à concorrência, tal modalidade de cooperação descrita pelo autor é assemelhada. (SILVA, Ricardo Perlingeiro Mendes da. Cooperação jurídica internacional e auxílio direto. O Direito Internacional contemporâneo - Estudos em homenagem ao professor Jacob Dolinger. Rio de Janeiro: Renovar, 2006, pp. 799-803).
} 
Apesar de na maioria das vezes essa modalidade de cooperação estar prevista em tratados dos quais o país é signatário ${ }^{349}$, ela poderá, no entanto, ser utilizada não obstante a inexistência de tratado neste sentido. A sistemática de transmissão de informações entre autoridades de diferentes países por intermédio de uma autoridade central é amplamente utilizada pelos países até os dias atuais ${ }^{350}$. A organização das autoridades centrais ocorre por meio de redes internacionais, propiciando, assim, o contato direto e facilitado entre os órgãos nacionais congêneres.

No Brasil, a função de autoridade central em matéria de cooperação jurídica internacional em matéria civil e penal é normalmente desempenhada pelo Ministério da Justiça, por meio do Departamento de Recuperação de Ativos e Cooperação Internacional $(\mathrm{DRCI})^{351}$. Em alguns casos específicos, no entanto, outras autoridades nacionais são envolvidas. Desta forma, normalmente os pedidos de auxílio direto são encaminhados ao $\mathrm{DRCI}^{352}$, que assume a responsabilidade de transmiti-lo ao órgão competente consoante o ordenamento nacional.

\footnotetext{
${ }^{349}$ Araújo destaca como exemplos de auxílio direto previstos em tratados internacionais a Convenção de Haia sobre aspectos cíveis do sequestro internacional de menores de 1980, a convenção entre Brasil e Portugal em matéria penal, a Convenção de Nova Iorque sobre prestação de alimentos de 1956, a Convenção sobre prestação de alimentos no estrangeiro de 1965, a Convenção contra o tráfico ilícito de entorpecentes e substâncias psicotrópicas e a Convenção das Nações Unidas contra o crime organizado transnacional. (ARAÚJO, Nádia de. Cooperação Jurídica Internacional no Superior Tribunal de Justiça. Comentários à Resolução n. 9/2005. Rio de Janeiro: Renovar, 2010, pp. 12-13 e 95-96).

${ }^{350}$ Vergueiro destaca que um dos principais atores na seara da cooperação jurídica é a autoridade central, a qual deve assegurar o intercâmbio de informações entre os interlocutores. (VERGUEIRO, Luiz Fabricio Thaumaturgo. Implementação da cooperação jurídica internacional vertical. Doutorado em Direito (Tese) - Faculdade de Direito da Universidade de São Paulo. São Paulo, 2012, p. 20).

${ }^{351}$ Criado pelo Decreto $\mathrm{n}^{\circ} 4.991$, de 18/02/2004 e atualmente regido pelo Decreto $\mathrm{n}^{\circ} 6.061 / 2007$, cujo art. 11 dispõe que ao DRCI compete: “(i) articular, integrar e propor ações do Governo nos aspectos relacionados com o combate à lavagem de dinheiro, ao crime organizado transnacional, à recuperação de ativos e à cooperação jurídica internacional [...]; (iii) negociar acordos e coordenar a execução da cooperação jurídica internacional; (iv) exercer a função de autoridade central para tramitação de pedidos de cooperação jurídica internacional; (v) coordenar a atuação do Estado brasileiro em foros internacionais sobre prevenção e combate à lavagem de dinheiro e ao crime organizado transnacional, recuperação de ativos e cooperação jurídica internacional; (vi) instruir, opinar e coordenar a execução da cooperação jurídica internacional ativa e passiva, inclusive cartas rogatórias; e (vii) promover a difusão de informações sobre recuperação de ativos e cooperação jurídica internacional, prevenção e combate à lavagem de dinheiro e ao crime organizado transnacional no País".

${ }^{352} \mathrm{O}$ art. $7^{\circ}, \S$ único da Resolução $n^{\circ} 9$ do Superior Tribunal de Justiça prevê, inclusive, nesse sentido que "os pedidos de cooperação jurídica internacional que tiverem por objeto atos que não ensejem juízo de delibação pelo Superior Tribunal de Justiça, ainda que denominados como carta rogatória, serão encaminhados ou devolvidos ao Ministério de Justiça para as providências necessárias ao cumprimento do auxílio direto". Araújo destaca a decisão proferida por ocasião da Carta Rogatória 3.462, STJ, 2009, pela qual o Presidente César Asfor Rocha acabou por remeter o pedido proveniente da promotoria de Frankfurt ao Ministério de Justiça para as providências cabíveis, em vista do seu entendimento de que o pedido tratava de uma notícia de crime, sem elementos suficientes para delibação. Na maioria das vezes esse tipo de encaminhamento tem sido verificado nos pedidos provenientes de autoridades não judiciárias estrangeiras. (ARAÚJO, Nádia de. Op. cit., 2010, p. 86).
} 
No caso de uma medida judicial ser necessária para garantir o cumprimento do pedido estrangeiro no Brasil, a autoridade central brasileira encaminhará o pedido de cooperação ao órgão nacional competente, o qual iniciará os procedimentos judiciais cabíveis perante a Justiça Federal para alcançar a finalidade pretendida. Em geral, a Advocacia Geral da União e o Ministério Público Federal são as instituições com legitimidade para proposição da ação civil e penal, respectivamente, perante a Justiça Federal. Todavia, nos casos em que medidas judiciais não sejam necessárias, como no caso de prestação de informações públicas ou sobre legislação brasileira aplicável, o cumprimento dos pedidos de auxílio direto pode ser realizado diretamente pela autoridade administrativa central.

Note-se, desta maneira, que o auxílio direto trata de modalidade de cooperação jurídica internacional que poderá assumir tanto características de cooperação judiciária internacional, como de cooperação administrativa internacional. Ante o exposto, o auxílio direto pode também ser compreendido na modalidade de cooperação administrativa internacional, inclusive em matéria concorrencial.

\subsubsection{Cooperação ativa e passiva}

A cooperação jurídica internacional poderá ser ativa ou passiva, consoante o pedido de cooperação seja direcionado para autoridades estrangeiras ou recepcionado por autoridades nacionais ${ }^{353}$. Enquanto que na cooperação ativa são as autoridades nacionais que emitem um pedido de cooperação a ser cumprido por autoridades de outros países, na modalidade de cooperação passiva as autoridades brasileiras recebem das autoridades estrangeiras o pedido de cooperação para o cumprimento no território nacional.

A diferença entre as modalidades de cooperação é relevante na medida em que na cooperação passiva certos procedimentos prévios consubstanciados no ordenamento jurídico nacional deverão ser observados pelas autoridades competentes para o cumprimento. E tais procedimentos prévios variam de acordo com a natureza da cooperação, se judiciária ou administrativa.

Já na cooperação ativa, as autoridades brasileiras devem procurar o cumprimento dos procedimentos e formalidades previstos na legislação estrangeira em questão, bem

\footnotetext{
${ }^{353}$ Isso significa que essa classificação é definida de acordo com o sujeito de onde se origina o pedido ou a quem é demandado. (Cf. VERGUEIRO, Luiz Fabrício Thaumaturgo. Implementação da cooperação jurídica internacional vertical. Doutorado em Direito (Tese) - Faculdade de Direito da Universidade de São Paulo. São Paulo, 2012, p. 23).
} 
como nos tratados e convenções celebrados com os respectivos países envolvidos na cooperação. Quando a cooperação ativa é solicitada por autoridade judiciária brasileira, normalmente o pedido é encaminhado pela autoridade central brasileira à autoridade central estrangeira.

\subsubsection{Cooperação formal e informal}

A cooperação jurídica internacional poderá ser classificada como formal ou informal, consoante os procedimentos e as regras para a sua execução estejam ou não institucionalizados mediante tratado internacional vinculativo ${ }^{354}$.

Conforme discutido no item 2.1.1 deste estudo, aos Estados cabe um dever geral de cooperação, principalmente em razão dos documentos aprovados no âmbito da ONU. Em especial o Brasil assumiu por intermédio de dispositivos constitucionais um dever geral de cooperação. Nesta ótica, não caberá às autoridades brasileiras a decisão sobre se devem ou não cooperar, mas tão somente exercer a sua discricionariedade no estabelecimento dos limites e dos procedimentos a serem seguidos na referida cooperação. Os contornos relativos à extensão, à modalidade e aos procedimentos a adotar em sede de cooperação jurídica internacional poderão, desta forma, estar previstos em legislação nacional ou tratados consubstanciados no sistema jurídico correspondente.

Desta forma, ocorrerá cooperação formal, nos casos em que as autoridades envolvidas na cooperação, seja ativa ou passiva, devam promover todos os procedimentos e contatos necessários para tal finalidade de acordo com as regras estabelecidas em tratados internacionais bilaterais, regionais ou multilaterais que o Estado esteja vinculado. A atuação das autoridades fica, nestes casos, delimitada às regras aplicáveis em razão do tratado em vigor.

Já nos casos em que não haja uma regra vinculante diretamente aplicável à cooperação pretendida, em razão da inexistência de tratado internacional, haverá um

\footnotetext{
354 "La acción de los Estados para promover la cooperación há sido emprendida de varias maneras, em algunos casos de forma libre [...] otras veces, ante la firma previa de tratados que regulamentan el comprometimiento de los Estados em el sentido de promover auxilio mutuo, o aún, por la creación de organizaciones internacionales com la finalidad especifica de buscar objetivos conjuntos y enfrentar problemas comunes em las más variadas áreas que afectan la vida de los Estados, como: salud, educación, alimentación, cultura, entre otros temas". (MENEZES, Wagner. Derecho Internacional en América Latina. Brasília: Funag. 2010, p. 236). Ademais, segundo Dabbah, "this cooperation can be achieved with or without a formal mechanism for cooperation, meaning with or without a formal agreement between the jurisdictions concerned". (DABBAH, Maher M. Future directions in bilateral cooperation: a policy perspective. Cooperation, comity and competition policy. New York: Oxford University Press, 2011, p. 289).
} 
grande espaço de discricionariedade das autoridades envolvidas, sobre a extensão e a forma de conduzir os pedidos de cooperação. A cooperação informal, trata, desta forma, dos esforços de cooperação entre autoridades de diferentes países, sem que haja uma obrigatoriedade institucionalizada através de tratado internacional, restando, portanto, as autoridades livres para definir os contornos da cooperação prestada ${ }^{355}$.

Note-se, no entanto, que apesar de haver um grande espaço para a discricionariedade às autoridades envolvidas na cooperação informal, há de se haver cautela na identificação de regras nacionais que eventualmente venham a se impor no processo cooperativo em razão da natureza da cooperação pretendida. Especial referência se faz aos casos em que não havendo nenhum tratado internacional vinculativo regulando a cooperação entre duas nações, as suas autoridades nacionais busquem uma cooperação que, todavia, em função de legislação nacional aplicável, dependa de especial rito ou procedimento para ser concretizada.

Seria o caso, por exemplo, de um país com o qual o Brasil não tenha um tratado internacional firmado em matéria de defesa da concorrência, solicitar às autoridades brasileiras a busca de provas e informações no território nacional sobre um ato de concentração multijurisdicional submetido à sua análise ${ }^{356}$. O vácuo da inexistência de tratado internacional sobre o tema não seria suficiente para que a autoridade brasileira passasse a cooperar informalmente com a autoridade requerente, realizando todas e quaisquer buscas de provas e informações no território nacional, simplesmente entregandoas às autoridades estrangeiras. Neste caso, haveria a imposição da legislação brasileira aplicável sobre a busca de provas no território nacional, que haveria de ser respeitada pelas autoridades brasileiras no atendimento da cooperação solicitada. Uma alternativa seria o

\footnotetext{
${ }^{355}$ Normalmente a cooperação informal ocorre por intermédio de contatos telefônicos e troca de mensagens eletrônicas, conforme descrito pela Organização para a Cooperação e Desenvolvimento Econômico, no qual o SBDC descreve que "besides the formal cooperation mechanisms listed above, the BCPS sometimes maintains informal contacts with agencies during investigations of international cartels cases. This informal cooperation takes place by e-mails and phone calls in which we exchange experiences and general views with regards to case investigations and also on how to try to solve practical problems in the course of these investigations, such as service of process of foreign companies and individuals". (ORGANIZAÇÃO PARA A COOPERAÇÃO E DESENVOLVIMENTO ECONÔMICO. Global Forum on Competition - Improving International cooperation in Cartel Investigations: contribution from Brazil. Session 2, DAF/COMP/ GF/WD(2012)32. Jan. 2012, pp. 2-3. Disponível em: <http://search.oecd.org/officialdocuments/publicdisplay documentpdf/ ?cote=DAF/COMP/GF/WD(2012)32\&docLanguage=En>. Acesso em: 18 nov. 2012. No mesmo sentido ver CONSIDERA, Cláudio Monteiro; TEIXEIRA, Cleveland Prates. Brazil's recent experience in International Cooperation, 1996. Disponível em: <http://www.seae.fazenda.gov.br/ central_documentos/textos_artigos/1996-1/3-international-cooperation>. Acesso em: 01 dez. 2012, no qual os autores esclarecem "the most valuable source of international cooperation continues being informal".

${ }^{356}$ De fato, a cooperação informal em matéria concorrencial é bastante comum. De acordo com Swaine, "the vast majority of cooperation in competition-related matters occurs through informal channels". (SWAINE,
} 
SBDC iniciar processo administrativo próprio para apurar se tal ato de concentração multijurisdicional estaria também submetido à jurisdição brasileira e, sendo este o caso, compartilhar com a autoridade estrangeira somente as informações públicas a que tivesse acesso.

Um ponto relevante a ser considerado em sede de cooperação informal em matéria concorrencial relaciona-se àqueles acordos de cooperação celebrados pelas autoridades brasileiras de defesa da concorrência que não seguiram o rito constitucional para transposição das suas regras no sistema jurídico nacional e que não possuem, desta forma, natureza vinculativa. Esse tema será mais profundamente desenvolvido no item 3.2.1 infra, mas no entanto, já se adianta que qualquer acordo de cooperação, instrumento de soft law ou de outra natureza que, consoante a legislação aplicável, não tenha caráter vinculativo no plano nacional e internacional, deve ser entendido no âmbito da cooperação informal entre os países relacionados.

A consequência imediata desta classificação está na constatação da ampla discricionariedade das autoridades envolvidas na cooperação, bem como na necessidade de se auferir especial atenção às leis nacionais que eventualmente venham a ser aplicáveis à cooperação pretendida no caso concreto. A partir do momento em que se constate que determinado pedido de cooperação internacional, solicitado no bojo de acordo não vinculante entre os Estados, está submetido à legislação nacional que regule tal modalidade de cooperação, as autoridades brasileiras deverão respeitar o direito nacional aplicável, promovendo todas as ações necessárias para o cumprimento da cooperação pretendida, todavia, com respeito ao sistema jurídico nacional.

\subsection{A COOPERAÇÃO EM MATÉRIA DA CONCORRÊNCIA}

Ao longo deste estudo, e em especial no seu item 1.3.1.3, foram exploradas as consequências advindas do acolhimento da teoria dos efeitos pelos sistemas jurídicos nacionais de defesa da concorrência, que implicou na aplicação extraterritorial das legislações nacionais em matéria da concorrência. Dentre os entraves identificados nesse processo destaca-se o conflito de jurisdição e a possibilidade de diferentes autoridades de defesa da concorrência chegarem a resultados divergentes quanto a um mesmo ato com implicações concorrenciais.

Edward T. Cooperation, comity and competition policy: United States. Cooperation, comity and competition policy. New York: Oxford University Press, 2011, p. 20). 
Especificamente em relação aos atos de concentração multijurisdicionais, as transações econômicas que acabem por afetar mais de um mercado nacional devem, na maioria das vezes ${ }^{357}$, ser notificadas a diferentes autoridades de defesa da concorrência, o que implica, muitas vezes, em decisões divergentes quanto à possibilidade de se executar a transação pretendida ou a respeito dos remédios delineados pelas autoridades com o intuito de se aprovar o ato ${ }^{358}$. Além disso, as sociedades envolvidas nos atos de concentração multijurisdicionais acabam por incorrer em custos expressivos para a promoção das notificações legalmente exigidas, em razão da contratação de especialistas jurídicos e econômicos em diversas jurisdições, além de taxas governamentais e outros custos associados aos procedimentos administrativos.

Em contraponto aos mencionados dissabores do processo de múltiplas notificações está o objetivo de preservação da soberania e da economia das nações envolvidas no processo, bem como o respeito às respectivas jurisdições nacionais.

A Cooperação Jurídica Internacional surge, desta forma, como instrumento que os países podem lançar mão para minimizar os efeitos negativos do atual cenário de revisão de atos com efeitos concorrenciais, sem, contudo, abrir mão das respectivas soberanias e liberdade de regulação. O processo cooperativo garante maior segurança jurídica ${ }^{359}$, tanto aos particulares que praticam atos sujeitos às legislações nacionais de defesa da concorrência, quanto aos Estados que desejam resguardar a autonomia sobre a política de concorrência e as instituições jurídicas existentes.

Além disso, há uma grande expectativa da comunidade internacional de que a cooperação jurídica internacional em matéria concorrencial venha facilitar a convergência das decisões das autoridades de defesa da concorrência envolvidas na análise de certos atos concorrenciais com implicações multijurisdicionais, bem como facilitar a execução de uma dada autoridade em outros territórios, garantindo, assim, a eficácia do seu processo decisivo.

\footnotetext{
357 "Isto porque, nem sempre os interesses que são relevantes para um ordenamento jurídico o são para outros, como facilmente se verificam as diferenças entre os objetivos perseguidos pelos Estados Unidos e pela União Europeia na aplicação das respectivas regras de concorrência. Com efeito, enquanto que nos Estados Unidos os objetivos seriam a proteção do comércio interno e exterior, a proteção do consumidor e o desenvolvimento das possibilidades de exportação das empresas americanas, na União Europeia, o objetivo mais importante seria a construção e a consolidação do mercado comum, que ultrapassa a perspectiva unicamente econômica". (SANTOS, Maria Cecília de Andrade. Sobre a cooperação em matéria de concorrência entre a União Europeia e o Mercosul. Revista do IBRAC - Direito da Concorrência, Consumo e Comércio Internacional. São Paulo, jan. 2001, v. 8, p. 177).

${ }^{358}$ FORGIONI, Paula A. Os fundamentos do antitruste. 4. ed. São Paulo: Revista dos Tribunais, 2010, p. 458.

${ }^{359}$ SANTOS, Maria Cecília de Andrade. Op. cit., 2001, p. 177.
} 
Conforme analisado no primeiro capítulo deste estudo, por influência da legislação norte-americana, o art. $2^{\circ}$ da Lei da Concorrência adota a teoria dos efeitos, fazendo com que seja possível a aplicação extraterritorial do Direito da Concorrência brasileiro. Interessante notar que tal dispositivo legal prevê exceções à aplicação da legislação brasileira, qual sejam "as convenções e os tratados de que seja signatário o Brasil".

Desta forma, há uma precedência na aplicação de eventuais tratados e convenções internacionais em matéria da concorrência em relação às normas internas que lhe sejam contrárias $^{360}$. Note-se, por outro lado, que a Lei da Concorrência não faz menção ao direito costumeiro internacional, o qual, a priori, possui a mesma hierarquia normativa dos tratados e convenções.

Cabe, portanto, a indagação a respeito da possibilidade de existirem normas de direito internacional, tanto costumeiras como codificadas, que definam regras de natureza concorrencial, as quais devam, em última análise, possuir preferência na aplicação pelas autoridades de defesa da concorrência, bem como a determinação sobre a forma de relação entre tais normas internacionais e o ordenamento jurídico interno.

\subsubsection{Relação entre o Direito Interno e o Direito Internacional e entidades envolvidas}

Este item assim como o próximo, se dedicam à análise do trabalho que vem sendo desenvolvido no âmbito internacional para a resolução dos problemas advindos da aplicação extraterritorial da legislação nacional de defesa da concorrência. Mais precisamente, a análise que se pretende realizar engloba instrumentos viabilizadores da Cooperação Jurídica Internacional, os quais possuem relação intrínseca com os métodos adotados pelas variadas nações para conjugar o Direito Interno com o Direito Internacional.

A doutrina clássica do Direito Internacional aponta duas teorias que buscam resolver a questão da relação entre o Direito Internacional e o Direito Interno, a saber: as teorias dualista e monista ${ }^{361}$.

A teoria dualista, fruto da concepção westfaliana, concebida em 1899 por Carl Heinrich Triepel, preconiza que o Direito Internacional e o Direito Interno tratam de dois

\footnotetext{
${ }^{360}$ FARIA, José Ângelo Estrella. O controle de concentrações de empresas estrangeiras e a Lei $\mathrm{n}^{\circ}$ 8.884: a extraterritorialidade revisitada. Juris Síntese, maio/jun. 2009, n. 77, p. 2. Disponível em: <http://online. sintese.com>. Acesso em: 19 ago. 2012.

361 ACCIOLY, Hildebrando; NASCIMENTO E SILVA, G. E. do; CASELLA, Paulo Borba. Manual de Direito Internacional Público. 17. ed. São Paulo: Saraiva, 2009, pp. 211 e ss.
} 
sistemas jurídicos distintos, sem qualquer inter-relação, tampouco subordinação. Nessa ótica, não seria possível conceber conflito na aplicação entre fontes de origem nacional ou internacional, pois são provenientes de sistemas apartados. O ordenamento jurídico interno dos Estados seria, portanto, domínio exclusivo do legislador nacional e, por tal motivo, para que uma norma internacional viesse a ser inserida neste ordenamento, ela deveria ser incorporada por ato do legislativo.

A teoria monista, por sua vez, defendida por Hans Kelsen, defende que as ordens nacional e internacional são partes de um único sistema jurídico, com compartilhamento de fontes e sujeitos, havendo uma hierarquia entre as normas produzidas nos dois foros ${ }^{362}$. Nesta concepção, o Direito Internacional deve ser aplicado automaticamente em uma dada ordem interna, em razão dos seus efeitos imediatos.

Em virtude das críticas e deficiências apontadas aos dois sistemas, surgiram, ainda, teorias que procuram conciliar os entendimentos sobre o tema, refletindo em geral um entendimento de coordenação entre Direito Internacional e Direito Interno.

Das discussões havidas na doutrina é possível concluir que, não obstante ainda pendam algumas divergências, tanto o Direito Interno como o Internacional fazem parte de um único sistema normativo, formado por dois ordenamentos que se inter-relacionam constantemente. Nesse sentido, relevante é a Convenção de Viena sobre o Direito dos Tratados de 1969, que expressamente estabelece nos seus arts. 27 e 46 que um Estado não poderá se furtar à aplicação de um tratado sob a alegação de estar cumprindo com uma norma nacional - com exceção das normas de importância fundamental ${ }^{363}$. Para garantir a segurança deste entendimento e praticidade na sua aplicação, é aconselhável que os Estados possuam normas internas que esclareçam sobre a relação entre os diferentes $\operatorname{ordenamentos}^{364}$.

Ocorre que, como aponta Menezes, o Direito Internacional Clássico, fundado na soberania absoluta e indivisível dos Estados, foi gradualmente substituído após a II Guerra

\footnotetext{
${ }^{362}$ Existem duas correntes dentro da teoria monista, uma que defende que o Direito Internacional teria primazia na aplicação em relação ao Direito Interno e a outra com entendimento diametralmente oposto. Nesse sentido, ver ACCIOLY, Hildebrando; NASCIMENTO E SILVA, G. E. do; CASELLA, Paulo Borba. Manual de Direito Internacional Público. 17. ed. São Paulo: Saraiva, 2009, p. 211.

${ }^{363}$ No mesmo sentido está o parecer da Corte Internacional de Justiça do ano de 1930 em que estabeleceu ser princípio reconhecido no direito internacional, que disposições de lei interna não podem prevalescer, nas relações entre nações, sobre as do tratado.

364 Accioly, Nascimento e Silva, e Casella destacam que a legislação brasileira nada esclarece nesse sentido, pelo que a determinação dos limites relativos à relação entre Direito Internacional e ordenamento interno brasileiro coube aos tribunais. (ACCIOLY, Hildebrando; NASCIMENTO E SILVA, G. E. do; CASELLA, Paulo Borba. Op. cit., 2009, p. 212).
} 
Mundial em função dos seus desdobramentos no plano internacional ${ }^{365}$ e da aceleração da globalização econômica, por um Direito Internacional Contemporâneo, revelando diferentes problemáticas de interação entre Estados e entre indivíduos no plano mundial. A mudança dos paradigmas da sociedade internacional acabou por causar outras transformações na relação entre o Direito Interno e o Direito Internacional ${ }^{366}$.

Parte das modificações no cenário internacional relaciona-se à criação de uma ordem econômica internacional, com instituições consolidadas e mecanismos de interação comercial, como empresas transnacionais, arbitragem comercial internacional e a nova lex mercatoria $^{367}$. Interessante notar que nessa nova ordem econômica internacional, enquanto políticas econômicas internacionais passam a influenciar políticas internas dos Estados, indivíduos e empresas, por meio de mecanismos de pressão, passam a influenciar as relações internacionais dos Estados de modo que venham a atender os seus interesses econômicos e de mercado.

Desta forma, a transnacionalização do capital advinda da crescente atuação direta dos agentes econômicos na esfera internacional também acaba por contribuir para a modificação das concepções jurídicas da relação entre Direito Internacional e Direito Interno, revelando uma "relação de localismo globalizado e de globalismo localizado"368.

Um exemplo da mudança de paradigmas apontada está na atividade de produção normativa dos foros internacionais, cujos resultados são conhecidos como soft law ${ }^{369}$, as

\footnotetext{
365 "Por Direito Internacional Clássico deve-se entender o sistema jurídico assentado sobre a soberania absoluta e indivisível dos Estados que se substancia na sua vontade de contrair ou não, livremente, obrigações no plano internacional, não reconhecendo nenhuma autoridade superior à sua, imprimindo, em razão disso, uma relação de coordenação horizontal com outras soberanias". Ademais, dentre os fatores que contribuíram para a alteração dos paradigmas da sociedade internacional, Menezes destaca a criação da ONU em 1945, a evolução das organizações internacionais, estando ou não subordinados à ONU, a integração econômica regional por meio de blocos econômicos, a atuação de ONGs, a internacionalização dos direitos humanos, a adoção da Declaração universal dos Direitos Humanos pela Assembleia Geral da ONU e o surgimento de uma ordem econômica internacionalizada. (MENEZES, Wagner. Ordem global e transnormatividade. Ijuí, RS: Ed. da Unijuí, 2005, pp. 38 e ss).

366 “A percepção das mutações, em curso no contexto pós-moderno, deverá ensejar visões simultaneamente mais abrangentes e mais flexíveis a respeito do direito internacional e do papel deste como regulador do contexto internacional. Mudou o mundo; resta adaptar de modo consequente seus instrumentos reguladores". (ACCIOLY, Hildebrando; NASCIMENTO E SILVA, G. E. do; CASELLA, Paulo Borba. Manual de Direito Internacional Público. 17. ed. São Paulo: Saraiva, 2009, p. 225).

367 TRINDADE, Antônio Augusto Cançado. O direito internacional em transformação: Ensaios, 19762001. Rio de Janeiro: Renovar, 2002, pp. 1063-1066.

${ }^{368}$ MENEZES, Wagner. Op. cit., 2005, p. 106.

${ }^{369}$ Há quem defenda que a soft law constitui não somente fonte do Direito Internacional Contemporâneo, ao lado das fontes clássicas previstas pelo art. 38 do Estatuto da Corte Internacional de Justiça, a saber, os tratados, o costume, os princípios gerais do Direito, a jurisprudência, a doutrina e a analogia e a equidade, como do próprio Direito Interno. Nesse sentido, ver MENEZES, Wagner. Op. cit., 2005, pp. 123-147 e 155159. O autor ainda proporciona na p. 147 da citada obra um conceito do instituto da soft law: "documentos solenes derivados de foros internacionais, que têm fundamento no princípio da boa-fé, com conteúdo variável e não obrigatório, que não vinculam os seus signatários a sua observância mas que, por seu caráter e
} 
quais, mesmo desprovidas de força vinculativa e, assim, sem obrigatoriedade no plano internacional $^{370}$, acabam por ser consideradas pelo legislador nacional na promulgação de leis nacionais em vista do seu caráter declarativo, fruto dos debates havidos nos foros internacionais. Há de se notar que, nesses casos, apesar da produção legislativa ser genuinamente nacional, a sua gênese está nos trabalhos desenvolvidos nos foros internacionais $^{371}$.

A influência do fenômeno ora descrito em matéria da defesa da concorrência, ou seja, da influência da soft law na promulgação de legislações nacionais ou nas análises realizadas pelas autoridades de defesa da concorrência, é reconhecida pela doutrina, que destaca a mudança havida na opção de um processo de formação de regras vinculativas por um processo não vinculativo nos foros internacionais ${ }^{372}$.

Interessante notar que os trabalhos de soft law relacionados à cooperação jurídica internacional em matéria da concorrência não são desenvolvidos unicamente por organizações internacionais. Parte deste trabalho é desenvolvida por redes governamentais, as quais se diferenciam das organizações internacionais, principalmente na medida em que não são os Estados diretamente representados em tais entidades, mas órgãos de sua administração $^{373}$. Estas redes caracterizam-se pela atuação além-fronteiras com o objetivo de regular as atividades de indivíduos e sociedades em uma economia global, combater o crime mundial e dar respostas a problemas comuns em uma escala mundial ${ }^{374}$, com grande ênfase nas áreas ambiental, concorrencial e do mercado de ações.

importância para o ordenamento da sociedade global, por refletirem princípios e concepções éticas e ideais, acabam por produzir repercussões no campo do Direito Internacional e também para o Direito Interno dos Estados". De acordo com o autor, consideram-se dentre os instrumentos de soft law as resoluções, recomendações e pareceres das organizações internacionais, conferências entre representantes dos Estados e os tratados não ratificados e os tratados-modelo.

370 TRINDADE, Antônio Augusto Cançado. O direito internacional em transformação: Ensaios, 19762001. Rio de Janeiro: Renovar, 2002, p. 1073.

371 "As instituições legislativas dos Estados se obrigam a cumprir, sem dúvida, diretivas originadas de compromissos de governo no exercício das relações internacionais". Todavia, Menezes esclarece que a soft law não repercute somente nas legislações nacionais, já que também opera para construir uma sociedade internacional. Nesse sentido, discute-se quem seria o destinatário final de tais normativas, se os Estados, os indivíduos ou a sociedade internacional. "Essas normas são aplicadas e direcionadas aos seus cidadãos como normas nacionais - e realmente acabam sendo, por causa de processos legislativos nacionais - apesar de terem sido criadas em foros internacionais". (MENEZES, Wagner. Ordem global e transnormatividade. Ijuí, RS: Ed. da Unijuí, 2005, pp. 55, 154 e 199-202).

372 JAEGER JÚNIOR, Augusto. Direito Internacional da Concorrência - Entre perspectivas unilaterais, multilaterais, bilaterais e regionais. Curitiba: Juruá, 2008, p. 192.

${ }^{373}$ Destaca-se também que as redes internacionais, contrariamente às organizações internacionais, são desprovidas de personalidade jurídica no plano internacional.

374 São exemplos destas instituições o G8, o G20, o International Network for Environmental Compliance and Enforcement, a Conferência sobre o Direito e a Política Internacional da Concorrência da Fordham Law School, ICN, dentre outros. 
Nesse sentido, Raustiala ${ }^{375}$ defende que o exercício da soberania requer cooperação e intervenção institucionalizadas, sendo que a melhor ilustração da nova soberania pode ser encontrada na operação das redes governamentais ${ }^{376}$. Enquanto que o poder exercido por tais redes não é vinculante, o resultado das suas ações poderá sê-lo na medida em que os membros que participam dessas redes detêm competências internas que viabilizam a vinculação às iniciativas que promoverem ${ }^{377}$. Na mesma esteira, Slaughter defende que no mundo contemporâneo, no qual a soberania significa a capacidade de participar em regimes cooperativos, no interesse coletivo de todos os Estados, a expansão da capacidade formal das instituições estatais para interagir nas redes governamentais implica na expansão do poder dos Estados ${ }^{378}$.

Não há nos casos de criação de soft law, portanto, a habitual utilização pelos Estados da recepção formal do Direito Internacional clássico para que tais instrumentos sejam acolhidos pela legislação vigente e passem, assim, a ter força vinculativa no sistema jurídico. Desta forma, o Direito Interno e o Direito Internacional passam a ter uma relação "transnormativa" 379 , ou seja, interagem em um mesmo plano, tanto na produção, quanto sobre os efeitos e a aplicação das normas criadas. Essa inter-relação do global e do local repercute em uma internacionalização dos direitos, atribuindo características de uniformidade aos ordenamentos nacionais.

Uma vez compreendida a forma pela qual as fontes internacionais inter-relacionamse com a ordem jurídica interna, e vice-versa, resta a análise dos documentos e tratados internacionais - multilaterais e regionais - que regulam ou consubstanciam normas idealizadas para regular a concorrência. Somente assim será possível delinear a pedra basilar da cooperação jurídica internacional em matéria concorrencial, tal qual existente na

\footnotetext{
375 RAUSTIALA, Kal. Rethinking the sovereignty debate in International Economic Law, 6 Journal of International Economics Law 841, 843, 2003 apud SLAUGHTER, Anne-Marie. Sovereignty and power in a Networked World Order. Stanford Journal of International Law, 2004, n. 40, p. 288.

${ }^{376}$ As quais seriam as organizações internacionais, constituídas ou não, formadas pelos Estados, mas que não receberam poderes especiais para emitir resoluções ou outros instrumentos de natureza vinculativa. É o caso, por exemplo, da Rede Internacional da Concorrência (International Competition Network - ICN).

${ }^{377}$ Considerando que os membros das redes governamentais são representantes dos governos e que possuem o poder de exercer internamente as decisões e medidas definidas pelas redes governamentais internacionais, a coercibilidade de tais medidas resta garantida pelo engajamento e pela participação de tais membros nessas instituições.

${ }^{378}$ SLAUGHTER, Anne-Marie. Op. cit., 2004, pp. 326-327.

379 "As regras internacionais passam ora por um processo de transnacionalização, atravessando fronteiras e emergindo nos ordenamentos nacionais, ora por um processo de modelação em foros internacionais, onde essas normas são reproduzidas pelos Estados, alterando, com isso, substancialmente, a relação do Direito Internacional com o Direito Interno. A relação deixa, portando, de ser dualista ou distante para adquirir cada vez mais uma dimensão transnormativa". (MENEZES, Wagner. Ordem global e transnormatividade. Ijuí, RS: ed. da Unijuí, 2005, pp. 201-202).
} 
contemporaneidade e entender as questões de interesse dos Estados no desenvolvimento da cooperação no contexto bilateral.

\subsubsection{Dimensão multilateral do Direito Internacional da Concorrência}

A comunidade internacional tem se dedicado à negociação de instrumentos normativos em matéria da concorrência com potencial de serem adotados mediante um sistema multilateral. Para essa atividade, os Estados têm lançado mão do uso de foros internacionais, dentre os quais se destacam as organizações internacionais ${ }^{380}$, como a Organização Mundial do Comércio (OMC), a Organização para a Cooperação e Desenvolvimento Econômico (OCDE) e a Organização das Nações Unidas (ONU) - por intermédio da Conferência das Nações Unidas para o Comércio e o Desenvolvimento (UNCTAD) - e outras entidades de atuação global, como a Rede Internacional da Concorrência (International Competition Network - ICN).

Interessante notar que os trabalhos produzidos em tais foros internacionais nem sempre contam com força legal e vinculativa, atribuída normalmente aos tratados e convenções internacionais. Tais instrumentos, amplamente difundidos como soft law, são desprovidos de força vinculativa e refletem a transferência pelos Estados das discussões sobre políticas normativas do âmbito local para o global, consoante descrito no item 2.2.1 supra. Conforme já referido anteriormente, mesmo desprovidos de força obrigacional no plano internacional, os documentos de soft law são relevantes na medida em que, por meio do método transnormativo, são considerados pelos Estados na adoção de legislação interna sobre os temas discutidos no plano internacional ${ }^{381}$.

Desta forma, o labor das organizações internacionais e outras entidades é relevante para o bom desenvolvimento do objeto deste estudo, bem como para, num sentido macro, impulsionar as discussões imprescindíveis para o desenvolvimento da regulação da concorrência no âmbito mundial. Pretende-se, assim, apresentar brevemente a evolução do Direito Internacional da Concorrência, na sua perspectiva multilateral, passando

\footnotetext{
380 "Sem dúvida as organizações internacionais representam um dos fatores de avanço do Direito Internacional e dinamização das relações internacionais contemporâneas, a ponto de terem sido inseridas mais recentemente como sujeitos do Direito Internacional, condição só atribuída aos Estados pelo Direito Internacional Clássico, fato que por si só já mereceria registro pela influência na mudança dos elementos do Direito Internacional". (MENEZES, Wagner. Ordem global e transnormatividade. Ijuí, RS: ed. da Unijuí, 2005, p. 52).

${ }^{381}$ Menezes esclarece que "as organizações internacionais passam a desempenhar o papel de legisladoras globais, propondo normas e regras que passam a ser adotadas pelos Estados e, transcendendo a eles, a outros
} 
posteriormente a descrever os principais estudos desenvolvidos por organizações e outras entidades internacionais sobre a matéria, incluindo as recomendações e outros instrumentos de soft law emanadas por tais entidades.

\subsubsection{Negociações e iniciativas envolvendo a matéria concorrencial em sentido amplo}

Sem exaurir o tema, pretende-se discorrer sobre as principais iniciativas tomadas no plano internacional envolvendo a matéria de defesa da concorrência, as quais influenciam materialmente as relações bilaterais entre os Estados nos aspectos concorrenciais da Cooperação Jurídica Internacional.

Neste retrospecto deixa-se de discorrer, entretanto, sobre certas iniciativas que, por um motivo ou outro, revelaram-se infrutíferas ou foram substituídas pela atuação internacional em outros foros. É o caso, por exemplo, da proposta do Conselho Europeu de 1951 para uma Convenção Europeia de controle de cartéis internacionais, a qual previa a criação de uma autoridade internacional de defesa da concorrência, mas que, no entanto, acabou por ser rejeitada ${ }^{382}$. Ainda nesse sentido, estão as Conferências de Haia para o Direito Internacional, que de uma forma ou de outra, alcançam os temas do Direito Internacional da Concorrência.

\subsection{Da Carta de Havana ao GATT e à OMC}

Em julho de 1944, em New Hampshire, nos Estados Unidos, teve lugar a Conferência Monetária e Financeira de Bretton Woods ${ }^{383}$. Em razão dessa conferência foram estabelecidos os pilares da ordem econômica internacional após a II Guerra Mundial, os quais incluíram a criação do Fundo Monetário Internacional e do Banco

sujeitos do Direito Internacional e até mesmo aos indivíduos". (MENEZES, Wagner. Ordem global e transnormatividade. Ijuí, RS: Ed. da Unijuí, 2005, pp. 52-55).

382 JAEGER JÚNIOR, Augusto. Direito Internacional da Concorrência - Entre perspectivas unilaterais, multilaterais, bilaterais e regionais. Curitiba: Juruá, 2008, p. 175.

383 "Foi a tendência de universalismo e cooperação entre os Estados que motivou a celebração dos acordos de Bretton Woods, ao final da Segunda Guerra Mundial, que reformularam e reordenaram o sistema financeiro internacional, em crises sucessivas desde o início do século”. (MAGALHÃES, José Carlos de. Direito econômico internacional: tendências e perspectivas. Curitiba: Juruá, 2009, p. 65). Ademais, Menezes destaca que o sistema estabelecido em Bretton Woods consistiu na "sistematização, também no plano internacional, de uma ordem econômica administrada a partir de instituições internacionais que gerenciariam todo o sistema". Com esse sistema, os Estados deixaram de ser independentes no exercício dos poderes sobre definição de medidas comerciais internas e externas, estabelecimento do valor de suas respectivas moedas e condução da economia. (MENEZES, Wagner. Op. cit., 2005, pp. 77 e 98-101). 
Internacional para a Reconstrução e o Desenvolvimento - atualmente denominado Banco Mundial.

O terceiro pilar concebido durante Bretton Woods relacionava-se à criação de uma Organização Internacional do Comércio, na forma de uma organização internacional que institucionalizasse o princípio da não discriminação das relações comerciais. Para concretização deste ideal, em 24 de março de 1948 foi assinada a Carta de Havana, a qual previa, no seu Capítulo V, a regulação da matéria de defesa da concorrência ${ }^{384}$. As regras desta natureza centravam-se nas práticas comerciais restritivas e nas medidas governamentais que pudessem distorcer o comércio internacional, restringir a concorrência, limitar o acesso a mercados ou favorecer o controle monopolístico. Acolheuse o princípio do abuso de posição dominante, de modo que a detenção de um mercado relevante não seria prática coibida. Nesse sentido, a Carta de Havana previa procedimentos de consulta e de investigação para a apuração das práticas coibidas, as quais se encontravam elencadas $^{385}$.

A doutrina especializada destaca que a Carta de Havana constituiu a primeira iniciativa multilateral para a regulação da concorrência em âmbito internacional ${ }^{386}$. Todavia, este documento não chegou a ter vigência, uma vez que o Senado norteamericano se recusou a ratificar o acordo por receio de que ele comprometesse a soberania dos Estados Unidos nas suas relações comerciais ${ }^{387}$.

\footnotetext{
${ }^{384}$ Marques oferece uma tradução para o dispositivo do art. 46 (1) da Carta de Havana: "cada Membro deve tomar as medidas apropriadas e deve cooperar com a Organização para prevenir, das partes das empresas públicas ou privadas, práticas comerciais afetando o comércio internacional que restrinjam a concorrência, limitem o acesso aos mercados, ou imponham controle monopolista, sempre que tais práticas tenham efeitos nocivos na expanção da produção do comércio e interfira no alcance de quaisquer dos objetivos do artigo $1^{\text {"” }}$ (MARQUES, Frederico do Valle Magalhães. Direito Internacional da Concorrência. Rio de Janeiro: Renovar, 2006, p. 201).

${ }^{385}$ Thorstensen enumera quais práticas seriam consideradas como restritivas pela Carta de Havana: "fixar preço e condições na compra, venda ou leasing de qualquer produto; excluir empresas ou dividir mercados, ou alocar clientes, ou determinar quotas; discriminar contra empresas; impor limites de produção; impedir, através de acordo, o desenvolvimento ou aplicação de tecnologia patenteada ou não; e, estender o uso do direito da patente, marca ou direito do autor concedidos a um membro, a condições que estejam fora do escopo da concessão". (THORSTENSEN, Vera. A OMC - Organização Mundial do Comércio e as negociações sobre investimentos e concorrência. Revista Brasileira Política Internacional, 1998, v. 41 (1), p 75).

386 JAEGER JÚNIOR, Augusto. Direito Internacional da Concorrência - Entre perspectivas cnilaterais, multilaterais, bilaterais e regionais. Curitiba: Juruá, 2008, p. 173; SANTOS, Maria Cecília de Andrade. A Política da Concorrência e a Organização Mundial do Comércio. Revista de Direito Constitucional e Internacional, abr./jun. 2001, ano 9, n. 35, p. 230.

387 "Objetivos ambiciosos para a época, dificuldades econômicas do pós-guerra e a não ratificação por parte de alguns negociadores, mormente dos Estados Unidos da América, contribuíram para que a Carta de Havana, instituidora da Organização Internacional do Comércio - OIC, nunca entrasse em vigor, permanecendo o GATT, versão imperfeita e incompleta daquela, funcionando até 1995". (OLIVEIRA, Gesner; RODAS, João Grandino. Direito e economia da concorrência. Rio de Janeiro: Renovar, 2004, p. 407). Nesse mesmo sentido, ver MAGALHÃES, José Carlos de. Direito econômico internacional:
} 
Em 1947, 23 países envolvidos nas negociações comerciais acabaram celebrando um acordo com o conteúdo do Capítulo IV da Carta de Havana, o qual foi denominado Acordo Geral de Tarifas e Comércio (GATT) ${ }^{388}$. Este acordo tinha por objetivo estimular o comércio por meio da redução e eliminação das tarifas ${ }^{389}$, sem, no entanto, criar uma organização internacional. Entretanto, apesar da intenção inicial de incluir regras relativas à defesa da concorrência ${ }^{390}$, o GATT não trouxe nenhuma disposição relativa a esta matéria.

Após diversas rodadas de negociação comercial iniciadas em 1986, em 15 de abril de 1994 foi criada a OMC como resultado da Rodada do Uruguai, por meio de Acordo de Marraquesh. Atualmente 157 países são membros da OMC, os quais concentram cerca de 97\% do comércio internacional. A OMC é uma organização internacional, com personalidade jurídica própria, que visa à regulação do comércio internacional, sem contar, entretanto, com regulação específica em matéria concorrencial ${ }^{391}$.

Alguns autores defendem que certos acordos adotados durante a Rodada do Uruguai contêm disposições relativas à defesa da concorrência no âmbito internacional, incluindo especialmente regras sobre monopólio, serviços exclusivos de fornecedores e proibição de medidas governamentais que venham distorcer ou afetar a concorrência ${ }^{392}$. Por outro lado, reconhecem que a regulação existente é insuficiente para regular todos os aspectos relacionados ao Direito Internacional da Concorrência, uma vez que não contemplam normas que obriguem os Estados a promover e manter a competitividade no

tendências e perspectivas. Curitiba: Juruá, 2009, p. 66; THORSTENSEN, Vera. A OMC - Organização Mundial do Comércio e as negociações sobre investimentos e concorrência. Revista Brasileira Política Internacional, 1998, v. 41 (1), p. 75; e MARQUES, Frederico do Valle Magalhães. Direito Internacional da Concorrência. Rio de Janeiro: Renovar, 2006, pp. 202-212.

388 "É de se destacar que o GATT não é uma organização internacional, mas um foro de negociações comerciais e de liberalização de tarifas alfandegárias, pelo qual os Estados, usando desse foro conjunto, negociariam por meio de rodadas realizadas periodicamente". (MENEZES, Wagner. Ordem global e transnormatividade. Ijuí, RS: Ed. da Unijuí, 2005, p. 80).

389 AMARAL JÚNIOR, Alberto. Introdução ao Direito Internacional Público. São Paulo: Atlas, 2008, p. 370.

${ }^{390}$ SANTOS, Maria Cecília de Andrade. A Política da Concorrência e a Organização Mundial do Comércio. Revista de Direito Constitucional e Internacional, abr./jun. 2001, ano 9, n. 35, p. 230.

391 “A OMC, como entidade dotada de personalidade jurídica internacional, o que não ocorria com o GATT simples acordo intergovernamental, que, com o passar do tempo adquiriu certa estrutura administrativa regula o comércio internacional de bens e serviços". (MAGALHÃES, José Carlos de. Direito econômico internacional: tendências e perspectivas. Curitiba: Juruá, 2009, p. 105).

392 Nesse sentido ver JAEGER JÚNIOR, Augusto. Direito Internacional da Concorrência - Entre perspectivas unilaterais, multilaterais, bilaterais e regionais. Curitiba: Juruá, 2008, p. 183; MARQUES, Frederico do Valle Magalhães. Op. cit., 2006, pp. 206-207; e THORSTENSEN, Vera. Op. cit., 1998, v. 41 (1), p. 80. Thorstensen descreve algumas características dos acordos TRIPS, TRIMS, Acordo sobre Comércio de Serviços, Acordo sobre Salvaguardas, art. XVII do GATT/94, Acordo sobre Barreiras Técnicas, Acordo sobre a Aplicação de Medidas Sanitárias e Fitossanitárias, Acordo sobre Inspeção Pré-Embarque e art. VI do 
mercado interno, tampouco que tomem medidas necessárias contra agentes econômicos que pratiquem atos restritivos e afetem o comércio entre os demais membros da organização.

Juntamente com a criação da OMC inaugurou-se um sistema de resolução de controvérsias dentro da sua estrutura institucional, para que disputas relacionadas ao comércio internacional pudessem ser resolvidas. Todavia, o sistema de solução de controvérsias estabelecido neste foro não considera questões de natureza concorrencial nos casos que lhe são adjudicados. Um exemplo da recusa do sistema estabelecido no âmbito da OMC para julgar questões de natureza concorrencial está no painel proposto pelos Estados Unidos contra o Japão em $1996^{393}$, em função de conduta executada pela sociedade japonesa Fuji que limitava o acesso de empresas norte-americanas, em especial a Kodak, na distribuição de filmes no Japão. Como os Estados Unidos não conseguiram enquadrar as condutas identificadas no caso aos tratados do GATT/OMC, o painel não teve possibilidade de tomar qualquer medida em relação ao caso apresentado.

Apesar da resistência de certas correntes, um crescente número de doutrinadores defende a criação no âmbito da OMC de um sistema de proteção da concorrência ${ }^{394}$. Por outro lado, há dificuldades que devem ser consideradas, como o fato de que mais da metade dos países integrantes da OMC não possuírem uma legislação nacional de defesa da concorrência.

Durante a Conferência Ministerial de OMC em Singapura, havida em dezembro de 1996, foi criado um órgão auxiliar ao Conselho Geral denominado Grupo de Trabalho sobre a Interação entre Comércio e Política de Concorrência (GTCPC) ${ }^{395}$, com o objetivo de analisar e explorar questões de natureza anticoncorrencial e a interação com o comércio

GATT/94, juntamente com o Acordo Anti-Dumping, que teria disposições relacionadas à matéria concorrencial.

393 Ver ORGANIZAÇÃO MUNDIAL DO COMÉRCIO. Caso Japan - Measures Affecting Consumer Photographic Film and Paper, Estados Unidos v. Japão, Relatório do painel, WR/DS44/R, 31 de março de 1998; e MARSDEN, Philip. The curious incident of positive comity - The dog that didn't bark (and the trade dogs that just might bite). Cooperation, comity and Competition policy. New York: Oxford University Press, 2011, pp. 306-307. Marques descreve que "a Kodak apresentou uma petição de acordo com a seção 301 do Trade Act de 1974, alegando que o governo japonês havia encorajado e/ou tolerado uma série de práticas anticompetitivas, no mercado japonês de filmes fotográficos. O resultado alcançado no processo foi o de que não havia qualquer ação do governo japonês que estivesse contrária às normas da OMC e que qualquer conduta anticompetitiva era produto de uma prática privada não objeto das normas da OMC". (MARQUES, Frederico do Valle Magalhães. Direito Internacional da Concorrência. Rio de Janeiro: Renovar, 2006, p. 335).

${ }^{394}$ JAEGER JÚNIOR, Augusto. Direito Internacional da Concorrência - Entre perspectivas nnilaterais, multilaterais, bilaterais e regionais. Curitiba: Juruá, 2008, p. 183.

${ }^{395}$ Para maiores informações a respeito das discussões havidas no âmbito da OMC com relação à política da concorrência, sugere-se o acesso a <http://www.wto.org/english/tratop_e/comp_e/comp_e.htm>. Acesso em: 17 jul. 2011. 
internacional, com vistas a futuras negociações sobre a matéria no âmbito da OMC. O objetivo do grupo, portanto, não consistia na negociação de normas e compromissos, mas somente na realização dos trabalhos e pesquisas preparatórias, de modo que, no futuro, havendo um consenso entre os membros da organização, um acordo multilateral pudesse ser negociado. Apesar de os poderes atribuídos ao GTCPC terem sido limitados no ato da sua criação, a partir da criação deste órgão a defesa da concorrência passou a ser tema da agenda da $\mathrm{OMC}^{396}$.

As atividades do GTCPC, iniciadas em 1997, focaram-se principalmente em torno de três pontos de discussão, a saber (i) a relevância dos princípios fundamentais da OMC em relação à matéria concorrencial (tratamento nacional, transparência e cláusula da não mais favorecida ${ }^{397}$; (ii) relevância da assistência técnica e cooperação entre as autoridades de defesa da concorrência; e (iii) formas pelas quais a defesa da concorrência poderia contribuir para alcançar os objetivos da OMC e a promoção do comércio internacional, ou seja, a interação da concorrência com o comércio internacional.

Durante a atuação do GTCPC os Estados-membros da OMC contribuíram por meio da apresentação de comentários, sugestões e debates, tanto orais nas reuniões havidas, como escritas, mediante documentos oficiais ${ }^{398}$. Da confluência dos discursos nacionais no foro da OMC, o GTCPC tomou algumas decisões relevantes sobre pontos específicos da matéria concorrencial, nomeadamente: (i) estabelecimento de um vocabulário comum sobre a matéria (como por exemplo, mercado relevante, barreiras à entrada, estrutura de

\footnotetext{
${ }^{396}$ Oliveira e Rodas destacam as matérias que foram objeto das discussões do GTCPC nos primeiros anos da sua existência. (OLIVEIRA, Gesner; RODAS, João Grandino. Direito e economia da concorrência. Rio de Janeiro: Renovar, 2004, pp. 408-410). Ver ainda JAEGER JÚNIOR, Augusto. Direito Internacional da Concorrência - Entre perspectivas unilaterais, multilaterais, bilaterais e regionais. Curitiba: Juruá, 2008, p. 184.

${ }^{397}$ Marques destaca que a maioria das propostas apresentadas pelos Estados membros ao GTCPC possui como denominador comum o estabelecimento e a utilização dos princípios da OMC na matéria concorrencial: "os princípios sobre os quais é fundada a OMC devem ser utilizados e adaptados à política $\mathrm{e}$ ao direito da concorrência a serem implementados, no âmbito da OMC, como já ocorreu em outras áreas antes não abrangidas pela $\mathrm{OMC}$, e.g., ao regular serviços e propriedade intelectual. [...] algumas propostas partem da identificação dos princípios já existentes para então aplicar ao direito da concorrência, outras partem da identificação direta dos princípios do direito da concorrência em esfera global". O autor destaca, ainda, que a partir de 2000 os princípios de flexibilidade e progressividade, due process, proibição de cartéis hardcore e tratamento especial e diferenciado foram inclú́dos no rol de princípios a serem estudados no âmbito da OMC, sendo que o último relaciona-se aos países com menor grau de desenvolvimento e que não possuem legislação nacional de defesa da concorrência ou estão em fase inicial de implementação. (MARQUES, Frederico do Valle Magalhães. Direito Internacional da Concorrência. Rio de Janeiro: Renovar, 2006, pp. 217-218).

398 "Essas contribuições dos membros da OMC são de fundamental importância para a discussão, elaboração de normas e desenvolvimento do direito da concorrência na OMC, constituindo tais manifestações importantes fontes para a construção de um direito internacional da concorrência em perspectiva internacional, fomentando a formação de um incipiente customary law da $\mathrm{OMC}$ no que diz respeito à política
} 
mercado, poder de mercado, dano concorrencial, concentração vertical e horizontal e fusões); (ii) definição dos elementos essenciais em um acordo internacional (princípios da transparência e não discriminação, identificação das práticas anticoncorrenciais, cooperação e sistema de solução de controvérsias); (iii) outros elementos relevantes em um acordo internacional (princípios do direito nacional da concorrência, cooperação entre autoridades, criação de um comitê, medidas para países em menor grau de desenvolvimento); (iv) desenvolvimento de mecanismos de cooperação nos âmbitos nacional, regional e internacional; e (v) necessidades específicas a serem consideradas na cooperação regional e internacional (assistência técnica, promoção da cultura de cooperação, identificação de áreas prioritárias para a cooperação e divulgação de informações sobre melhores práticas).

Da análise das posições exaradas pelos membros da OMC, foi possível, ainda, verificar uma contraposição de interesses, vislumbradas em maior magnitude em relação ao posicionamento norte-americano e europeu em torno da forma pela qual a matéria concorrencial deveria ser negociada ${ }^{399}$. Enquanto os europeus defendiam um sistema de cooperação entre as autoridades de defesa da concorrência, com adoção de normas mínimas para a harmonização das normas nacionais sobre a matéria, os Estados Unidos opunham-se à discussão do tema no âmbito da OMC.

De fato, a União Europeia centrou seu discurso na cooperação das autoridades, de forma a reforçar a necessidade de aplicar a legislação concorrencial e mitigar os conflitos decorrentes da aplicação extraterritorial dos variados direitos nacionais. O objetivo de tais medidas era conferir maior segurança nas trocas comerciais e diminuir os custos relacionados à proposição de procedimentos perante diversas jurisdições. Dentre as condutas anticompetitivas inseridas na proposta europeia constavam as práticas com impacto em diversos mercados, como no caso de cartéis e atos de concentração multijurisdicionais.

concorrencial". (MARQUES, Frederico do Valle Magalhães. Direito Internacional da Concorrência. Rio de Janeiro: Renovar, 2006, p. 209).

${ }^{399}$ Sobre o posicionamento dos Estados Unidos e da União Europeia perante a OMC, ver SANTOS, Maria Cecília de Andrade. A política da concorrência e a Organização Mundial do Comércio. Revista de Direito Constitucional e Internacional, abr./jun. 2001, ano 9, n. 35, pp. 234 e ss. Ademais, interessante notar a divergência vislumbrada nas negociações havidas sobre o sistema de soluções de controvérsias em matéria da concorrência, mais precisamente se deveria ou não o sistema da OMC ser aproveitado nessa matéria. Nesse sentido, ver JAEGER JÚNIOR, Augusto. Direito Internacional da Concorrência - Entre perspectivas unilaterais, multilaterais, bilaterais e regionais. Curitiba: Juruá, 2008, pp. 187-188; MARQUES, Frederico do Valle Magalhães. Direito Internacional da Concorrência. Rio de Janeiro: Renovar, 2006, pp. 223-239; BRADFORD, Anu. International antitrust negotiations and the false hope of WTO. Harvard International Law Journal. Verão 2007, v. 48, n. 2, pp. 383-439. 
Vislumbrava-se, assim, uma cooperação na análise das condutas anticoncorrenciais com efeitos disseminados em diversos territórios mediante acordo multilateral, que contasse com um sistema básico, incluídos princípios e regras comuns de cooperação. A proposta europeia de um acordo em matéria da concorrência incluía um conjunto mínimo de princípios e regras para adoção das leis nacionais da concorrência, garantindo uma confluência global na regulação do tema, bem como o estabelecimento de disposições comuns de cooperação internacional, inclusive no que se refere ao intercâmbio de informações não confidenciais e cortesia positiva e negativa.

Esse posicionamento trouxe para a OMC a experiência da União Europeia na regulação da concorrência no âmbito regional ${ }^{400}$. Mais ainda, a União Europeia defendia em suas manifestações que a OMC seria o foro adequado para a negociação de regras em matéria da concorrência, destacando a importância dos princípios adotados para o comércio internacional e também para a matéria concorrencial ${ }^{401}$.

No tocante à resolução de conflitos, a União Europeia propôs que fosse adotado um procedimento capaz de dar a resposta necessária às obrigações assumidas no âmbito multilateral, podendo ser incorporado aos já existentes na $\mathrm{OMC}$ - com a ressalva de que fossem adaptados às características específicas do direito da concorrência e que não permitissem o reexame de decisões nacionais. Por fim, a proposta europeia esclarecia que se pretendia que somente os Estados estivessem submetidos às obrigações assumidas pelo acordo multilateral - e não os indivíduos ou as empresas.

Os Estados Unidos, por sua vez, defendem que a política concorrencial possui objetivos diversos da política comercial, estando a primeira centrada em práticas privadas e a segunda em governamentais, e, assim, a OMC não seria o local adequado para hospedar as discussões internacionais em torno da concorrência ${ }^{402}$. Além disso, os Estados Unidos

\footnotetext{
${ }^{400}$ MARQUES, Frederico do Valle Magalhães. Direito Internacional da Concorrência. Rio de Janeiro: Renovar, 2006, p. 224.

${ }^{401}$ Os motivos desse posicionamento são discutidos em MARQUES, Frederico do Valle Magalhães. Op. cit., pp. 225-232.

402 Nesse sentido é interessante o artigo de Bradford, professora norte-americana da Universidade de Chicago, no qual utiliza teorias e exercícios econômicos, em especial a teoria dos jogos, para justificar os fundamentos do fracasso e da importunidade de se negociar o tema concorrencial no foro da OMC. A autora conclui em seu artigo que os Estados não chegaram a um consenso sobre um acordo multilateral vinculante de regulação da concorrência no âmbito global, basicamente por dois motivos consubstanciados nas estratégias utilizadas por cada Estado: (i) a cooperação em matéria concorrencial muitas vezes falha em razão de os Estados terem percebido que os custos políticos e econômicos são maiores que os benefícios esperados da cooperação, significando que os custos de oportunidade relacionados à negociação sobre concorrência numa plataforma global são menores em relação a outros itens da agenda de negociação comercial; e (ii) nas situações em que as partes concluíram que a cooperação em matéria concorrencial é hipótese de Pareto, ou seja, superior à não cooperação, a cooperação acabou por ser obstruída em função de problemas distributivos e informacionais. Nas hipóteses contempladas de impasse nas negociações (deadlock) resta claro que há
} 
justificam seu posicionamento na heterogeneidade dos Estados que participam na OMC e no reflexo dessas discrepâncias nos respectivos sistemas nacionais de defesa da concorrência ${ }^{403}$.

A postura norte-americana declina pela assinatura de acordos bilaterais para assistência técnica e cooperação, consoante o grau de confiança que as autoridades norteamericanas possuem em relação às suas contrapartes estrangeiras, bem como o grau de desenvolvimento e independência de cada uma destas autoridades. De fato, a assistência técnica promovida pelos Estados Unidos tem servido de instrumento suficiente para difusão da sua política de concorrência para terceiros países. Por tal razão, as autoridades norte-americanas consideram prematuro iniciar negociações para adoção de regras multilaterais de concorrência pela OMC.

Não obstante tal posicionamento, os Estados Unidos muito contribuíram com as atividades do GTCPC, o que pode ser comprovado nos inúmeros documentos de trabalho, em que consta a sua experiência no desenvolvimento do tema concorrencial no sistema jurídico norte-americano, bem como na explicitação da conformidade das suas normas com os princípios gerais adotados pelos países no âmbito da OMC. De acordo com a doutrina, o

contestação sobre a própria conveniência em se alcançar um acordo vinculativo multilateral sobre o tema pelo que negociações no âmbito da OMC tendem a não surtir efeitos, já que negociações nesse foro somente tendem a obter resultados favoráveis quando há interesses comuns dos Estados. Já nas hipóteses de um jogo de coordenação com consequências distributivas, a autora conclui que a cooperação internacional nas políticas concorrenciais, quando desejável, provavelmente não necessite de regras para execução e oponibilidade de grande magnitude em relação à maioria das questões concorrenciais. Desta forma, a incorporação da matéria concorrencial à OMC parece menos atraente, uma vez que a capacidade da organização em promover conexões entre os Estados é contestada e a sua capacidade para assegurar o cumprimento das regras concorrenciais não é necessária. Bradford defende que, não obstante tais conclusões, a busca dos Estados pelo desenvolvimento de mecanismos de cooperação informal em relação às políticas concorrenciais nacionais segue intocada. Assim, é plausível que as nações continuem a desenvolver instrumentos que garantam a governança não vinculante e a cooperação voluntária e informal, sem, no entanto, sentirem-se obrigadas a adotar um regime vinculante nesta matéria. Em suma, os Estados assumem como aceitáveis os custos inerentes ao regime de não cooperação formal em matéria concorrencial, fazendo com que um acordo vinculante multilateral sobre o tema não seja plausível nesse ponto de desenvolvimento das relações econômicas entre os Estados. Nessa esteira de pensamento, qualquer acordo multilateral que fosse alcançado no âmbito da OMC, na atual fase de desenvolvimento das políticas concorrenciais dos Estados, seria de fraca legalização, contendo somente disposições gerais, com inúmeras cláusulas de escape e exceções. Para a autora, na medida em que haja disseminação das teorias econômicas que fundamentam as normas concorrenciais e a cooperação informal entre os países torne as assimetrias do direito e política da concorrência dos países diminutas, é possível conceber que mudem as recompensas esperadas da adoção de um acordo multilateral vinculativo em matéria da concorrência, viabilizando, assim, um regime global em matéria concorrencial. (BRADFORD, Anu. International antitrust negotiations and the false hope of WTO. Hardvard International Law Journal. Verão 2007, v. 48, n. 2, pp. 383-439).

403 Jaeger Júnior destaca que "os Estados Unidos da América possuem posição divergente, baseados na heterogeneidade dos países representados na $\mathrm{OMC}$, no fato de que um acordo na organização não poderia abranger mais que o menor denominador comum (le plus petit commun dénominateur) e nas suas reservas quanto à troca de informações em um contexto multilateral e ao controle de suas decisões pela organização". (JAEGER JÚNIOR, Augusto. Direito Internacional da Concorrência - Entre perspectivas unilaterais, multilaterais, bilaterais e regionais. Curitiba: Juruá, 2008, p. 186). 
posicionamento norte-americano é bastante técnico, mais reservado e menos em prol de uma negociação internacional multilateral em matéria concorrencial ${ }^{404}$.

O Brasil chegou a apresentar duas manifestações escritas ao GTCPC $^{405}$, nas quais reconheceu a OMC como foro adequado para regular a matéria concorrencial no âmbito internacional, em razão do aproveitamento da infraestrutura já existente, da experiência na condução das negociações e do fato que a OMC compreende um conjunto de normas e princípios já consolidados e aceitos pela comunidade internacional. Além disso, o Brasil destacou a importância dos princípios do comércio internacional aplicados à concorrência e da cooperação em matéria concorrencial, tanto em relação às condutas anticompetitivas com impactos internacionais, como sobre os atos de concentração.

Em paralelo a estas discussões, a Declaração da IV Conferência Ministerial havida em Doha, em 2001, estabeleceu como objetivo da OMC o estabelecimento de uma estrutura multilateral em política da concorrência, propondo que o GTCPC promovesse o aprofundamento de pesquisas e análises sobre questões relativas à concorrência em torno do comércio internacional. Em 2003, o GTCPC publicou um relatório no qual esclareceu o posicionamento majoritário dos países de que uma estrutura de regulação da concorrência no âmbito na OMC não deveria ter por objetivo a harmonização das legislações nacionais de defesa da concorrência, mas somente estabelecer princípios que refletissem os valores comuns dos Estados e promovessem a cooperação, respeitando, assim, as diferenças econômicas e jurídicas vislumbradas ${ }^{406}$.

Todavia, os temas de Cingapura, dentre os quais encontrava-se a questão da política da concorrência, acabaram por ser apontados como motivo do colapso da Conferência Ministerial de Cancun, de $2003^{407}$. Em julho de 2004 o Conselho Geral da OMC decidiu, por meio do conhecido Pacote de 2004, que a interação entre comércio e concorrência não comporia mais o programa de trabalho da organização, conforme havia sido determinado na Declaração Ministerial de Doha. Desta forma, nenhuma outra discussão sobre o tema teve lugar no âmbito da OMC e assim deverá permanecer até o final da Rodada de Doha. Até o momento, portanto, não há nenhum instrumento que vincule os membros da

\footnotetext{
${ }^{404}$ MARQUES, Frederico do Valle Magalhães. Direito Internacional da Concorrência. Rio de Janeiro: Renovar, 2006, pp. 234-235.

${ }^{405}$ Id., ibid., pp. 219-223, em que o autor cita e descreve o comunicado de 24 de julho de 1998 e de 18 de setembro de 1998.

${ }^{406}$ JAEGER JÚNIOR, Augusto. Direito Internacional da Concorrência - Entre perspectivas unilaterais, multilaterais, bilaterais e regionais. Curitiba: Juruá, 2008, p. 187.

${ }^{407}$ FOX, Eleanor M. Antitrust without borders: from roots to codes to networks. Cooperation, comity and competition policy. New York: Oxford University Press, 2011, p. 272.
} 
organização a qualquer regra de defesa da concorrência e as negociações e pesquisas que estavam em curso foram suspensas ${ }^{408}$.

A falta do tema concorrencial na regulação do comércio internacional é sentida pela doutrina, que entende que o Direito da Concorrência é fundamental para evitar o protecionismo nas relações comerciais internacionais, garantindo um ambiente livre de restrições não tarifárias a produtos estrangeiros ${ }^{409}$. Por outro lado, alguns entendem que, para além da discordância entre Estados Unidos e União Europeia, existem questões que atualmente dificultam a negociação e a adoção do tema concorrencial no âmbito da OMC, como, por exemplo, o fato de quantidade expressiva dos membros da OMC não possuírem uma legislação de defesa da concorrência ou apresentarem déficit na aplicação das legislações nacionais desta natureza ${ }^{410}$.

\subsection{Código Concorrencial Internacional}

Em julho de 1993, durante a Rodada do Uruguai, um grupo de acadêmicos, conhecido como Grupo de Munique, propôs um Código Concorrencial Internacional ${ }^{411}$ a ser adotado a partir de um tratado multilateral dentro do sistema GATT. O documento propositivo foi elaborado num período de dois anos por um grupo de 12 especialistas na matéria, provenientes de diversos países ${ }^{412}$, cujo objetivo não incluía somente a elaboração de um código que contemplasse critérios científicos, mas também a constituição de uma autoridade internacional de defesa da concorrência no âmbito do então existente GATT.

O texto do Código Concorrencial Internacional consistia de 21 artigos, organizado em oito partes, direcionadas principalmente ao comércio internacional, ou seja, sem a

\footnotetext{
${ }^{408}$ As atividades do GTCPC foram suspensas. Todavia os pedidos de assistência técnica em matéria da concorrência continuam a ser conduzidos pela Secretaria da OMC.

${ }^{409}$ CARVALHO RAMOS, André de; CUNHA, Ricardo Thomazinho da. A defesa da concorrência em caráter global: utopia ou necessidade. In: CASELLA, Paulo Borba (org.). Guerra comercial ou integração econômica mundial. São Paulo: LTr, v. 1, pp. 833-834.

410 CARVALHO, Leonardo Arquimino de. Direito antitruste \& relações internacionais: extraterritorialidade e cooperação. Curitiba: Juruá, 2003, pp. 187-188.

${ }^{411}$ Em inglês, International Antitrust Code. Parte da doutrina utiliza a terminologia Código Antitruste Internacional. Todavia, em razão das premissas expostas no primeiro capítulo deste estudo, preferiu-se acatar a denominação Código Concorrencial Internacional.

${ }^{412}$ De acordo com Marques, o grupo, reunido desde 1991, intitulava-se International Antitrust Code Working Group, e tinha como objetivo elaborar um código internacional sobre a matéria, bem como criar uma autoridade internacional no âmbito do GATT, "de forma a assegurar que as práticas restritivas ao comércio internacional fossem eliminadas, proporcionando, assim, o desenvolvimento do comércio internacional e assegurando o livre acesso aos mercados". (MARQUES, Frederico do Valle Magalhães. Direito Internacional da Concorrência. Rio de Janeiro: Renovar, 2006, pp. 252-253) Ver também TERHECHTE, Jörg Philipp. International Competition Enforcement Law: between cooperation and convergence. New York: Springer, 2011, pp. 70-72.
} 
adoção de nenhum modelo de concorrência específico - seja de concorrência perfeita ou nacional.

Assentava-se em cinco princípios basilares, nomeadamente (i) aplicação aos casos com relações multijurisdicionais; (ii) inaplicabilidade imediata e harmonização mediante regras mínimas; (iii) princípio da não discriminação (tratamento nacional); (iv) princípio da proteção mínima; e (v) internacionalização do processo de análise concorrencial. Os especialistas envolvidos na elaboração do texto se inspiraram na Convenção da União de Paris para a Proteção da Propriedade Industrial de 1883 para o acolhimento de três dos mencionados princípios.

Em relação ao princípio (i) supra, o Código Concorrencial Internacional foi estruturado para abarcar somente casos com implicações multijurisdicionais, ou seja, em que os efeitos das condutas fossem sentidos em duas ou mais jurisdições ${ }^{413}$. Isso significa que casos puramente nacionais deveriam continuar a ser analisados pelas respectivas autoridades nacionais de defesa da concorrência.

O princípio (ii), por sua vez, reconhecia a relevância das variadas legislações nacionais de defesa da concorrência, garantindo aos Estados a liberdade de promulgar a regulamentação que achassem mais apropriada nos respectivos sistemas jurídicos. O Código Concorrencial Internacional estabeleceu, por outro lado, padrões mínimos de harmonização que os Estados deveriam considerar ao aprovar as suas legislações. $\mathrm{O}$ modelo proposto, portanto, trata da adoção de um tratado-contrato - em oposição ao modelo de tratado-lei - semelhante à opção acolhida por ocasião da adoção do TRIPS.

Enquanto isso, o princípio da não discriminação citado no item (iii) relacionava-se à cláusula do tratamento nacional inserida nos tratados da $\mathrm{OMC}$. O princípio, se aplicado à matéria concorrencial, impossibilitaria que as legislações nacionais de defesa da concorrência conferissem tratamento diferenciado aos efeitos surtidos no território nacional em relação aos do exterior. Em consequência da adoção deste princípio, os conhecidos cartéis de exportação, autorizados por certas legislações nacionais, deveriam passar a ser combatidos.

\footnotetext{
${ }^{413}$ Correspondente à cláusula da interestatalidade do direito comunitário da concorrência cf. JAEGER JÚNIOR, Augusto. Direito Internacional da Concorrência - Entre perspectivas unilaterais, multilaterais, bilaterais e regionais. Curitiba: Juruá, 2008, p. 195. Ver também p. 200 dessa mesma obra, em que o autor esclarece sobre o âmbito de aplicação do Código Concorrencial Internacional, que deveria "ser aplicado a todas as restrições à concorrência que afetem ao menos dois Estados signatários e que, no seu âmbito de aplicação, um Estado signatário pode regular e aplicar seu direito àquelas restrições que produzam efeitos econômicos em seu território ou que afetem de outro modo o seu comércio, inclusive se na prática tenha se iniciado fora do seu território".
} 
O princípio da proteção mínima, acima referido no item (iv), refletiu os objetivos do Código Concorrencial Internacional de promover uma harmonização pelos padrões mínimos, afastando, assim, a completa harmonização em matéria concorrencial. A opção por um padrão mínimo de harmonização visava, de modo geral, conciliar as posições dos Estados, as quais foram reveladas nos processos de negociação na OMC. Além disso, a adoção de regras mínimas abriria espaço para que as nações que não estão dotadas de sistemas nacionais de proteção da concorrência pudessem desenvolver as respectivas legislações e, assim, estar pari passu com as práticas globais sobre o tema.

Finalmente, o princípio consubstanciado no item (v) tratava da internacionalização do processo de análise concorrencial, o que não significaria que a análise dos processos concorrenciais seria analisada imediatamente por uma autoridade internacional. $\mathrm{O}$ texto do Código Concorrencial Internacional previa que a análise dos casos com implicações multijurisdicionais continuasse a ser de competência das autoridades nacionais de defesa da concorrência, mas sob a intervenção de uma Autoridade Concorrencial Internacional. Nos casos em que as autoridades nacionais deixassem de dar a devida aplicação ao Código Concorrencial Internacional, descumprindo assim as suas obrigações internacionais, a questão poderia ser submetida a um Tribunal Concorrencial Internacional.

Para além dos cinco princípios basilares acima descritos, o Código Concorrencial Internacional determinava a adoção de outros 15 princípios complementares ${ }^{414}$, com aplicação às operações multijurisdicionais e a promoção da transparência, da cooperação e da convergência entre os Estados-Partes do tratado relativo à adoção do código. Para além disso, o Código Concorrencial Internacional propunha a adoção de certas regras de natureza material ${ }^{415}$.

No tocante aos atos de concentração multijurisdicionais, o Código Concorrencial Internacional trazia disposições sobre o conceito de concentração, o âmbito de aplicação, a adoção de um sistema de notificação prévia, a suspensão das concentrações empresariais, a forma para avaliação das operações, as exceções aplicáveis aos casos de interesse público

\footnotetext{
${ }^{414}$ MARQUES, Frederico do Valle Magalhães. Direito Internacional da Concorrência. Rio de Janeiro: Renovar, 2006, pp. 257-261.

${ }^{415}$ Jaeger Júnior destaca que tais regras previam substancialmente "a obrigatoriedade de criação de instituições nacionais, a previsão de procedimentos de investigação, a previsão de cominação de multas, bem como três âmbitos de proibições de acordos, quais sejam: o vertical e o horizontal e os acordos restritivos relacionados ao direito de propriedade intelectual e à indução de práticas restritivas ilegais; o controle de concentrações; e o abuso de posição dominante". (JAEGER JÚNIOR, Augusto. Direito Internacional da Concorrência - Entre perspectivas unilaterais, multilaterais, bilaterais e regionais. Curitiba: Juruá, 2008, pp. 199-200).
} 
relevante e as reestruturações de empresas que atuam em mercados não competitivos, mas com elevado grau de concentração.

De acordo com o Código haveria concentração quando, mediante contrato ou por qualquer outro meio, ocorresse a aquisição de uma parte de ações ou ativos, que implicasse no controle, direto ou indireto, total ou parcial, desde que relativo à parcela substancial de uma ou mais partes. O conceito proposto era bastante vago, uma vez que não trazia uma delimitação precisa do que seria incluído na acepção de controle direto ou indireto e parcela substancial. O mesmo problema de definição ocorria com relação ao momento em que as partes de uma notificação devessem promover a notificação prévia. O texto do Código Concorrencial Internacional determinava que a notificação deveria se dar antes que a operação se tornasse "effective". A doutrina aponta que esse termo poderia ser interpretado tanto como o momento da vigência da operação, quanto o da sua realização ${ }^{416}$.

Em relação ao âmbito de aplicação, interessante notar que o Código adotava uma técnica de exclusão para a caracterização de uma concentração multijurisdicional - a qual acarretaria na aplicação do Código Concorrencial Internacional. Desta forma, uma concentração não seria considerada multijurisdicional quando o valor agregado anual mundial de faturamento das partes fosse menor do que $1 \%$ do PIB do Estado afetado pela operação pretendida ou quando mais de $90 \%$ do valor agregado anual mundial sobre o faturamento das partes envolvidas na operação fosse proveniente do exterior (em relação ao Estado afetado pela operação pretendida).

À Autoridade Concorrencial Internacional, cuja criação era prevista pelo Código, seriam conferidos instrumentos para controlar o cumprimento das suas disposições e iniciar medidas eventualmente cabíveis contra as autoridades nacionais perante o Tribunal Concorrencial Internacional - também previsto no Código. Não obstante a criação de tal autoridade internacional, a doutrina entende que a soberania dos Estados seria preservada $^{417}$, uma vez que a aplicação das legislações nacionais de defesa da concorrência e a jurisdição nacional de suas autoridades seria mantida em casos específicos, e nos demais haveria um compartilhamento de jurisdição entre as autoridades nacionais e a Autoridade Concorrencial Internacional, com primazia da segunda em relação à

\footnotetext{
${ }^{416}$ MARQUES, Frederico do Valle Magalhães. Direito Internacional da Concorrência. Rio de Janeiro: Renovar, 2006, p. 268.

${ }^{417}$ JAEGER JUNIOR, Augusto. Direito Internacional da Concorrência - Entre perspectivas unilaterais, multilaterais, bilaterais e regionais. Curitiba: Juruá, 2008, p. 205.
} 
primeira $^{418}$. No tocante ao Tribunal Concorrencial Internacional, este seria um tribunal internacional especializado e permanente, que operaria em sede própria, estando, contudo, sujeito às regras do sistema de solução de controvérsias da OMC.

De acordo com Código, no tocante ao tema da concentração multijurisdicional, a Autoridade Concorrencial Internacional deveria realizar a sua avaliação sobre a operação econômica pretendida, levando em consideração fatores concorrenciais materiais, como a estrutura competitiva de todos os mercados relevantes envolvidos, a posição no mercado e o poder econômico-financeiro das empresas envolvidas na transação, bem como as alternativas que restariam aos demais participantes do mercado, as barreiras à entrada e a tendência de oferta e procura pelos bens e serviços relacionados. Já nos casos em que somente autoridades nacionais de defesa da concorrência estivessem envolvidas, o Código Concorrencial Internacional determinava que as autoridades deveriam chegar a um consenso, sob pena de terem de se submeter à orientação da Autoridade Concorrencial Internacional. Esta, por sua vez, levaria em consideração o interesse público dos Estados que tiverem sido declarados no bojo da transação e dos efeitos econômicos no mercado internacional $^{419}$.

Havendo sido apresentado aos países-membros da OMC durante a Rodada do Uruguai sob o caráter de acordo plurilateral, de adesão não obrigatória, o Código Concorrencial Internacional acabou por não ser considerado naquela reunião e, assim, jamais chegou a ser aprovado ${ }^{420}$.

Nesse sentido, é importante relevar que à época da proposição do Código Concorrencial Internacional, a adoção de regras concorrenciais pela maioria dos Estados era ainda bastante incipiente, fazendo com que a iniciativa proposta fosse considerada por muitos como ousada, tendo em vista a realidade interna da maioria das partes do GATT $^{421}$.

${ }^{418}$ MARQUES, Frederico do Valle Magalhães. Direito Internacional da Concorrência. Rio de Janeiro: Renovar, 2006, p. 263.

${ }^{419}$ MARQUES, Frederico do Valle Magalhães. Op. cit., 2006, pp. 269-270. Ver ainda TERHECHTE, Jörg Philipp. International competition enforcement law: between cooperation and convergence. New York: Springer, 2011, p. 58, em que o autor expõe que "Indeed, the development of cooperation networks seems to have undermined the idea of a world antitrust authority".

${ }^{420}$ Santos destaca que "houve também outras tentativas de se criar um sistema internacional de regras de concorrência, como, por exemplo, o International Antitrust Code, mas sem muito sucesso". (SANTOS, Maria Cecília de Andrade. A política da concorrência e a Organização Mundial do Comércio. Revista de Direito Constitucional e Internacional, abr./jun. 2001, ano 9, n. 35, p. 230).

421 "De fato, o Código veio regular uma área diversa da normalmente regulada no âmbito do GATT [restrições governamentais], qual seja a das restrições privadas ao comércio. Essa característica do Código, atrelada às mudanças que estavam para ser implementadas em virtude dos acordos negociados durante a Rodada Uruguai e das discussões sobre a necessidade de constituição de uma organização internacional, constitui a razão pela qual esse grupo de estudiosos entendeu por bem elaborar e apresentar uma proposta de um acordo sobre direito da concorrência no âmbito da OMC, na época ainda GATT". (MARQUES, 
Existem temas incluídos no texto do Código que até nos dias atuais são de difícil negociação, como no caso da divisão, compartilhamento e exercício de jurisdição pelos Estados. Marques ${ }^{422}$ destaca ainda que a pretensão de se redigir e adotar de uma só vez um conjunto de normas de defesa da concorrência no âmbito multilateral é inconcebível, sendo necessário primeiramente estabelecer algumas diretrizes básicas para que os Estados adotem uma política congruente da concorrência, perseguindo objetivos análogos e promovendo o comércio internacional, com respeito as suas diferenças ${ }^{423}$.

Além disso, muitas críticas foram direcionadas ao texto proposto, seja em razão da falta de clareza e detalhes de muitas das suas proposições, ou pelo detalhamento excessivo para um texto que pretendida estabelecer diretrizes e princípios gerais. Não obstante a não adoção do Código Concorrencial Internacional pelos Estados, pelo fato de não serem atendidas as suas variadas necessidades, o seu texto permanece como grande fonte de estudo sobre o tema, com vistas ao desenvolvimento futuro sobre a matéria.

2.2.2.1.3 Organização das Nações Unidas (ONU) e Conferência das Nações Unidas para o Comércio e o Desenvolvimento (UNCTAD)

A UNCTAD, criada em 1964, é um órgão de caráter intergovernamental que compõe o sistema da ONU e que abarca nas suas atividades as discussões relacionadas ao comércio e ao desenvolvimento ${ }^{424}$. O principal objetivo da UNCTAD é colaborar com os países em desenvolvimento na sua integração com a economia mundial.

Frederico do Valle Magalhães. Direito Internacional da Concorrência. Rio de Janeiro: Renovar, 2006, pp. 255 e 263).

${ }_{422}$ Id., ibid., p. 345.

423 "O fato é que nem todos os membros da OMC possuem legislação antitruste, sendo que não há convergência entre os sistemas de concorrência, devido à cultura inerente a cada país nessa área e aos diferentes níveis de desenvolvimento econômico, formas distintas de aplicação das leis nacionais, todo eles fatores que podem gerar conflitos internacionais, principalmente quando há aplicação extraterritorial de normas antitruste. Dessa forma, seria ilógica a criação de um código internacional ou legislação comum sobre concorrência, sem antes haver uma progressiva harmonização e convergência dos sistemas de concorrência dos diversos membros da OMC". (LILLA, Paulo Eduardo. A OMC e a interação entre comércio e política antitruste no âmbito da cooperação internacional: perspectivas para a nova rodada e negociações multilaterais. Revista do IBRAC - Direito da Concorrência, Consumo e Comércio Internacional. São Paulo, jan. 2003, v. 10, pp. 233 e ss).

424 "Foi aprovada, já em 1963, a moção que provocou a criação da CNUCD <UNCTAD>, como órgão permanente da Assembleia Geral da ONU. A decisão foi tomada em dezembro de 1964, por meio da Resolução 1.995 (XIX), e para ele contribuíram 90 países subdesenvolvidos ou em vias de desenvolvimento, segundo classificação corrente, dentre 120 membros que, àquela época integravam a Organização". (MAGALHÃES, José Carlos de. Direito econômico internacional: tendências e perspectivas. Curitiba: Juruá, 2009, p. 80). 
Em 1980 a UNCTAD elaborou o único instrumento multilateral sobre política e legislação de concorrência, o qual, apesar de não ter força vinculativa ${ }^{425}$, representa um indício da vontade da comunidade internacional em matéria da defesa da concorrência. $\mathrm{O}$ instrumento acabou por converter-se na Recomendação no 35/63 da Assembleia das Nações Unidas sobre uma série de Acordos Multilaterais de Princípios e Regras Equitativas para o Controle de Práticas Empresariais Restritivas (Série PERs) ${ }^{426}$. Tal instrumento foi formulado com a intenção de se tornar uma lei-modelo a ser adotada pelos Estados, todavia nunca chegou a ser considerada em um processo legislativo ${ }^{427}$.

Em geral, a Série PERs objetiva assegurar que as práticas comerciais não dificultem a concretização dos benefícios que podem advir da liberalização de tarifas e da eliminação de barreiras não tarifárias. Além disso, objetiva-se que, com a regulamentação das práticas comerciais restritivas, maior eficiência ao comércio internacional seja atribuída e haja uma aproximação dos agentes internacionais em prol da negociação de um acordo multilateral para a promoção da concorrência.

A doutrina entende que o texto da Série PERs acolheu a teoria dos efeitos como elemento de conexão para a aplicação do direito nacional, ao definir práticas comerciais restritivas a exemplo daquelas que limitam o acesso ao mercado ou que restringem a concorrência - revelando, assim, a tendência na aceitação desta doutrina para tal finalidade $^{428}$. Essa também tem sido a percepção generalizada dos Estados quanto ao texto aprovado nessa ocasião, com exceção do Reino Unido e do Canadá ${ }^{429}$.

\footnotetext{
${ }^{425}$ As resoluções e recomendações das organizações internacionais constituem espécie de soft law e, assim, não são vinculativas. (MENEZES, Wagner. Ordem global e transnormatividade. Ijuí, RS: Ed. da Unijuí, 2005, pp. 149-150). No mesmo sentido, ver FOX, Eleanor M.; CRANE, Daniel A. Global issues in antitrust and competition law. St. Paul: West, 2010, p. 493.

${ }^{426}$ Aprovado por consenso pela Assembleia Geral das Nações Unidas em 16 de dezembro de 1980.

427 JAEGER JÚNIOR, Augusto. Direito Internacional da Concorrência - Entre perspectivas unilaterais, multilaterais, bilaterais e regionais. Curitiba: Juruá, 2008, p. 192.

${ }^{428}$ Carvalho Ramos e Cunha destacam que "na parte aplicável às empresas, por exemplo, o acordo declara como proibidas as práticas concertadas e o abuso de posição dominante nos mercados, dentro da sistemática adotada pela maioria das nações, que dispõem da legislação de defesa da competição". (CARVALHO RAMOS, André de; CUNHA, Ricardo Thomazinho da. A defesa da concorrência em caráter global: utopia ou necessidade. In: CASELLA, Paulo Borba (org.). Guerra comercial ou integração econômica mundial. São Paulo: LTr, 1998, v. 1, p. 831). Ainda nesse sentido, ver FARIA, José Ângelo Estrella. Aplicação extraterritorial do Direito da Concorrência. Revista de Informação Legislativa. Brasília, jan./mar. 1990, n. 105, p. 31; FARIA, José Ângelo Estrella. O controle de concentrações de empresas estrangeiras e a Lei $n^{\circ}$ 8.884: a extraterritorialidade revisitada. Juris Síntese, maio/jun. 2009, n. 77, pp. 10-11; THORSTENSEN, Vera. A OMC - Organização Mundial do Comércio e as negociações sobre investimentos e concorrência. Revista Brasileira Política Internacional, 1998, v. 41 (1), p. 76.

429 "States should base their legislation primarily on the principles of eliminating or effectively dealing with acts or behaviors of enterprises which, through an abuse or acquisition and abuse of a dominant position of market power, limit access to markets or otherwise unduly restrain competition, having or being likely to have adverse effects on their trade or economic development, or which through formal, informal, written or unwritten agreements among enterprises have the same impact” - Seção E, $\mathrm{n}^{\circ} 2$ da Série PERs (UNCTAD.
} 
No que se refere aos atos de concentração, a Série PERs estabelece que os agentes econômicos devem abster-se de realizar concentrações, seja mediante fusões, joint ventures ou por outra forma de aquisição de controle (horizontal, vertical ou conglomerado), quando tais operações consubstanciarem um abuso de posição dominante ou culminarem na aquisição e no abuso de posição dominante, de forma a limitar o acesso ao mercado ou por outro meio limitar a concorrência, causando ou tendo potencialidade de causar efeitos materiais relevantes ao comércio internacional ou economia dos países, em especial sobre os países em desenvolvimento ${ }^{430}$.

Interessante notar que, dentre os princípios estabelecidos pela Série PERs, há destaque para a visada cooperação bilateral, regional e multilateral entre os Estados, juntamente com a adoção de mecanismos internacionais, a melhoria da troca de informações relativas às práticas comerciais restritivas entre os Estados e a viabilização eficaz de consultas multilaterais sobre políticas relacionadas ao controle das práticas comerciais restritivas. Além disso, a Série PERs estabelece que os Estados devem promover a troca de informações públicas e, de acordo com as respectivas legislações nacionais, a troca de outras informações que possam viabilizar o controle efetivo sobre práticas negociais restritivas ${ }^{431}$.

As regras da Série PERs foram concebidas para que pudessem ser revisadas periodicamente pela UNCTAD e seu grupo de especialistas. Para tal propósito, nos anos de 1985, 1990 e 1995 foram realizadas conferências diplomáticas, sem que, entretanto, fosse aprovada qualquer alteração em seu texto. Já durante a conferência havida no ano de 2000, em Genebra, os Estados reiteraram o relevante papel que uma legislação e a política da concorrência possuem para o desenvolvimento ${ }^{432}$.

A conferência de novembro de 2005, havida na Turquia, acabou por alargar o papel da UNCTAD como foro internacional para consultas sobre política e direito concorrencial e cooperação jurídica internacional em matéria da concorrência, além de reiterar o seu

Report of the Sixth United Nations Conference to Review All Aspects of the Set of Multilaterally Agreed Equitable Principles and Rules for the Control of Restrictive Business Practices. Disponível em: <http://unctad.org/en/docs/ tdrbpconf7d11_en.pdf>. Acesso em: 04 nov. 2012).

${ }^{430}$ De acordo com a Seção D, $\mathrm{n}^{\mathbf{0}} 4$ da Série PERs (UNCTAD. Report of the Sixth United Nations Conference to Review All Aspects of the Set of Multilaterally Agreed Equitable Principles and Rules for the Control of Restrictive Business Practices. Disponível em: <http://unctad.org/en/docs/ tdrbpconf7d11_en.pdf>. Acesso em: 04 nov. 2012).

${ }^{431}$ De acordo com a Seção E, nºs 6, 7 e 9 da Série PERs (UNCTAD. Report of the Sixth United Nations Conference to Review All Aspects of the Set of Multilaterally Agreed Equitable Principles and Rules for the Control of Restrictive Business Practices. Disponível em: <http://unctad.org/en/docs/ tdrbpconf7d11_en.pdf>. Acesso em: 04 nov. 2012).

432 JAEGER JÚNIOR, Augusto. Direito Internacional da Concorrência - Entre perspectivas unilaterais, multilaterais, bilaterais e regionais. Curitiba: Juruá, 2008, pp. 178-179. 
papel na promoção de assistência técnica para países em desenvolvimento e organizar revisões pelos pares ad hoc das legislações nacionais de defesa da concorrência.

A última conferência havida para revisar a Série PERs teve lugar em Genebra, em novembro de $2010^{433}$. Neste encontro ficou decidido que as futuras reuniões deveriam contemplar a questão da Cooperação Jurídica Internacional e as redes existentes em matéria concorrencial, o recebimento de contribuições com vistas à revisão da lei modelo concorrencial da UNCTAD, o aprimoramento das formas de cooperação técnica aos países em desenvolvimento e a discussão sobre o design e sistemas de execução ideais em relação à política e direito concorrencial. Além disso, os países se engajaram na tarefa de identificar os pontos de convergência das respectivas leis nacionais, regionais e internacionais em matéria concorrencial, com vistas a identificar as condutas anticoncorrenciais que podem afetar as economias dos países em desenvolvimento.

Outra área relevante de atuação da UNCTAD relacionada à concorrência, e por vezes discutida nas conferências para revisão da Série PERs, trata da cooperação técnica que disponibiliza aos países em desenvolvimento o fomento das suas estruturas nacionais de política e legislação concorrencial. Existem dois órgãos institucionais da UNCTAD aos quais cabe a revisão e a implementação dos trabalhos em matéria da concorrência: o Grupo Intergovernamental de Especialistas em Política e Legislação de Concorrência ${ }^{434}$ e as Conferências de Revisão das Nações Unidas ${ }^{435}$.

Em que pese a adoção da Série PERs, não é possível concluir que exista um regramento multilateral no âmbito da UNCTAD que vise a regular as questões de defesa da concorrência internacionalmente. Todavia, as negociações e discussões no âmbito da UNCTAD continuam em curso, com objetivo de que tal regramento multilateral seja em algum estágio adotado pelos países.

\footnotetext{
${ }^{433}$ A próxima reunião deverá ocorrer nos auspícios da UNCTAD, em Genebra, no ano de 2015.

${ }^{434}$ A primeira sessão da reunião do Grupo Intergovernamental de Especialistas em Política e Legislação de Concorrência, havida em 1998, teve como fruto a publicação do Handbook on competition Legislation and a Directory of Competition Authorities - que concentra informações sobre legislações e sistemas de defesa da concorrência de diversas nações. Disponível para consulta em: <http://www.unctad.org/Templates/ Download.asp?docID=9999\&intItemID=1932\&lang=1>. Acesso em: 17 jul. 2011.

435 Dentre as conclusões apresentadas em sede das Conferências destaca-se o estímulo e a cooperação entre os países em prol da defesa da concorrência.
} 


\subsection{Organização para a Cooperação e Desenvolvimento Econômico (OCDE)}

A OCDE é uma organização internacional criada em $1961^{436}$, com sede em Paris, formada atualmente por 34 países compromissados com governos democráticos e economia de mercado. A entidade possui um alcance global, na medida em que se relaciona com mais de 70 países não membros, dentre os quais o Brasil, além de organizações não governamentais e sociedades civis. Instrumentos, decisões e recomendações ${ }^{437}$ são publicados pela organização com a finalidade de auxiliar os seus membros na definição de suas políticas econômicas e facilitar as negociações multilaterais de instrumentos internacionais.

Dentre seus diversos comitês, a OCDE mantém um grupo de estudo, denominado Comitê de Concorrência, que constitui uma das principais fontes mundiais utilizadas pelas autoridades governamentais para a análise, o aconselhamento e a definição das melhores práticas de eficiência econômica concorrencial global ${ }^{438}$. Os seus trabalhos são divididos de acordo com os diversos temas relacionados à concorrência, designadamente às questões relacionadas ao abuso de poder dominante, monopólio, combate a cartéis e controle de atos de concentração ${ }^{439}$. A OCDE tem se dedicado primordialmente ao auxílio na implementação da cooperação entre as autoridades de defesa da concorrência.

O Comitê de Concorrência publicou diversas recomendações relevantes ${ }^{440}$ nas matérias abrangidas pelas suas divisões ${ }^{441}$, atividade esta amplamente reconhecida no

\footnotetext{
${ }^{436}$ De acordo com Jaeger Júnior, a OCDE é sucessora da Organização de Cooperação Econômica para a Europa, a qual, por sua vez, foi criada como parte do Plano Marshall para auxílio na reconstrução da Europa. (JAEGER JÚNIOR, Augusto. Direito Internacional da Concorrência - Entre perspectivas unilaterais, multilaterais, bilaterais e regionais. Curitiba: Juruá, 2008, p. 176).

${ }_{437}$ As recomendações da OCDE não são vinculantes e assumem uma característica de soft law.

${ }^{438}$ Para maiores informações a respeito das atividades do Comitê, recomenda-se o acesso ao sítio da Internet: <www.oecd.org/competition>. Acesso em: 08 jul. 2010. O Brasil participa das reuniões do Comitê na qualidade de ouvinte não membro. Oliveira e Rodas destacam que "o trabalho da OCDE em política e legislação de concorrência encoraja os governos a combaterem práticas anticoncorrenciais e a promover reformas econômicas orientadas para o mercado". (OLIVEIRA, Gesner; RODAS, João Grandino. Direito e economia da concorrência. Rio de Janeiro: Renovar, 2004, p. 404).

${ }^{439}$ Em relação a estes últimos, a análise centra-se na determinação e no estudo dos mercados relevantes, dos efeitos concorrenciais das transações, dos casos mais relevantes e complexos no cenário internacional e dos métodos para a eficiente análise dos atos complexos de concentração.

${ }^{440}$ Em matéria da concorrência cumpre destacar a Recomendação do Conselho referente à cooperação entre os Estados-membros sobre as práticas restritivas ao comércio que afetem o comércio internacional (1967), a Recommendation Concerning a Consultation and Conciliation Procedure on Restrictive Business Practices Affecting International Trade (1973) e as Diretrizes comportamentais para as empresas internacionais (1976), para além dos outros instrumentos descritos nessa seção (SANTOS, Maria Cecília de Andrade. A política da concorrência e a Organização Mundial do Comércio. Revista de Direito Constitucional e Internacional, abr./jun. 2001, ano 9, n. 35, pp. 230-231).
} 
âmbito internacional. Uma das principais características das recomendações da OCDE é a promoção das formas de cooperação. Até o momento, no entanto, os trabalhos da OCDE não abrangeram a negociação de um tratado multilateral a respeito da defesa da concorrência. Para detalhes acerca das recomendações relativas aos atos de concentração multijurisdicionais ver item 2.2.2.2.1 neste estudo.

\subsection{Rede Internacional de Concorrência (ICN)}

A ICN é uma rede governamental, criada em outubro de 2001 por autoridades de defesa da concorrência de diversos Estados ${ }^{442}$, como um fórum independente em forma de rede virtual. A criação da ICN é um desdobramento do apoio auferido pelo Relatório do Comitê de Aconselhamento de Política de Concorrência Internacional dos Estados Unidos para a formação de uma entidade adequada às negociações multilaterais em matéria da concorrência, concebida como uma alternativa aos trabalhos desenvolvidos no âmbito da OMC. A Direção Geral para a Concorrência da Comissão Europeia endossou a criação da entidade, sendo também apoiada pela International Bar Association e por um grupo de profissionais especializados de diversos países.

Atualmente, a ICN é composta por 319 autoridades governamentais ${ }^{443}$, nacionais ou multilaterais, as quais trabalham no âmbito da concorrência. Além disso conta ainda com a colaboração de organizações internacionais, como a OCDE, a OMC e a UNCTAD, de organizações não governamentais, de comunidades acadêmicas e de setores privados relacionados à concorrência ${ }^{444}$. A alta concentração de entidades envolvidas na ICN corrobora com a expressiva aceitação da entidade no cenário internacional e com a relevância das suas atividades ${ }^{445}$. A informalidade do método de trabalho da ICN

${ }^{441}$ Para além disso promove anualmente o Fórum Global sobre a Concorrência, que constitui importante foro de discussões entre os diversos países sobre política e normas da concorrência. Ademais, publica regularmente o Jornal de Legislação e Política de Concorrência, com trabalhos relevantes sobre a matéria.

${ }^{442}$ Jaeger Júnior esclarece que o ICN foi constituído por 14 autoridades nacionais de defesa da concorrência, a saber, África do Sul, Alemanha, Austrália, Canadá, Estados Unidos, França, Japão, Itália, Israel, Coréia, México, Reino Unido, União Europeia e Zâmbia. (JAEGER JÚNIOR, Augusto. Direito Internacional da Concorrência - Entre perspectivas unilaterais, multilaterais, bilaterais e regionais. Curitiba: Juruá, 2008, p. 190).

${ }^{443}$ Dentre as quais se incluem os órgãos do SBDC.

444 OLIVEIRA, Gesner; RODAS, João Grandino. Direito e economia da concorrência. Rio de Janeiro: Renovar, 2004, p. 415.

${ }^{445}$ JAEGER JÚNIOR, Augusto. Direito Internacional da Concorrência - Entre perspectivas unilaterais, multilaterais, bilaterais e regionais. Curitiba: Juruá, 2008, p. 189. Ver também BRADFORD, Anu. International antitrust cooperation and the preference for nonbinding regimes. Cooperation, comity and competition policy. New York: Oxford University Press, 2011, p. 324, no qual a autora defende que 
diferencia-se das demais organizações internacionais, revelando uma maneira especial e não convencional de trabalho ${ }^{446}$.

O principal objetivo da entidade é a promoção da convergência mundial em matéria da concorrência, mediante a manutenção de um foro independente e especializado no assunto. Para tanto, a entidade conta com quatro grupos especializados, cujos resultados são anualmente divulgados e acabam por ser adotados pela entidade em forma de recomendações. A ICN realiza conferências anuais, nas quais os membros discutem os principais temas que envolvem a concorrência, analisam os avanços na regulação da matéria e emitem as suas recomendações.

Apesar de a ICN não possuir legitimidade para elaborar leis ou instrumentos vinculativos, a entidade trabalha na edição de documentos que refletem as melhores práticas de concorrência, as quais poderão ser adotadas pelos seus membros na forma como entenderem mais adequada ${ }^{447}$. Nesse sentido, as recomendações da ICN já chegaram a ser citadas em julgados havidos pelo CADE, como suporte às decisões proferidas em casos envolvendo aspectos concorrenciais internacionais ${ }^{448}$. Os instrumentos de recomendação da ICN, quando envolvem atos de concentração multijurisdicionais, são melhor descritos no item 2.2.2.2.2 do presente estudo.

Apesar de haver inúmeros esforços para a harmonização e a sistematização de um Direito Internacional da Concorrência, não é possível concluir que exista um regramento global e universal sobre a matéria ${ }^{449}$. Isso não significa dizer que as atividades até então desenvolvidas tenham sido em vão, uma vez que a publicação de recomendações e melhores práticas por estas instituições, mesmo não sendo vinculativas, têm se

"following the collapse of the WTO antitrust negotiations in 2003, the ICN remains the most influential international regime facilitating multilateral antitrust cooperation today".

446 "Meanwhile, one should not overestimate the capabilities of this informal network. Giving its informality, it will be difficult to reach consensus in the future". (TERHECHTE, Jörg Philipp. International competition enforcement law: between cooperation and convergence. New York: Springer, 2011, p. 69).

${ }^{447}$ Para maiores informações sobre a ICN, suas atividades e publicações, recomenda-se o acesso ao sítio na Internet: <www.internationalcompetitionnetwork.org>.

${ }^{448}$ Nesse sentido, ver Ato de Concentração no 08012.002992/02004-14 (ADC Telecommunications, Inc. e Krone International Holding Inc.), cuja decisão do Conselheiro-Relator foi fundamentada no documento do ICN intitulado "Práticas Recomendadas para Procedimentos de Notificação de Atos de Concentração" (cf. SILVA, Valéria Guimarães de Lima e. Direito antitruste: aspectos internacionais. Curitiba: Juruá, 2007, pp. 368-371).

449 "Apesar dos avanços alcançados no estudo e regulamentação do direito e política da concorrência, em âmbito nacional e regional, ainda não existe um tratamento geral equânime, por meio de normas de aplicação geral, que permitam a convergência das normas e políticas públicas nacionais e regionais de direito da concorrência e a sua regulamentação em âmbito internacional, aplicável a todos os agentes econômicos". (MARQUES, Frederico do Valle Magalhães. Direito Internacional da Concorrência. Rio de Janeiro: Renovar, 2006, p. 12). No mesmo sentido, ver CARVALHO RAMOS, André de; CUNHA, Ricardo Thomazinho da. A defesa da concorrência em caráter global: utopia ou necessidade. In: CASELLA, Paulo Borba (org.). Guerra comercial ou integração econômica mundial. São Paulo: LTr, 1998, v. 1, p. 830. 
demonstrado relevantes, na medida em que influenciam os legisladores nacionais a regulamentar o tema ${ }^{450}$.

Por outro lado, parte da doutrina enxerga que a falta de um foro multilateral para resolução de controvérsias em matéria da concorrência, que poderia vir a ser estabelecido em sede de tratado internacional sobre o tema, constitui um dos óbices para um mais amplo desenvolvimento do Direito Internacional da Concorrência ${ }^{451}$. Já para alguns países, como o caso do Estado Unidos, a criação de um foro de resolução de controvérsias ou a utilização de foro já existente - como no caso da $\mathrm{OMC}$ - não seria adequado ${ }^{452}$.

\subsubsection{Os atos de concentração multijurisdicionais e o labor dos foros internacionais em prol da cooperação}

Dentre o conjunto de trabalhos desenvolvidos nos foros internacionais, destaca-se, em relação à matéria do controle de concentrações multijurisdicionais, o labor de duas instituições - a OCDE e a ICN - que muito influenciaram o desenvolvimento das relações bilaterais $^{453}$ entre as autoridades de defesa da concorrência, principalmente por meio da publicação de recomendações e sugestões de melhores práticas a serem adotadas pelos $\operatorname{Estados}^{454}$.

De fato, a atuação de redes governamentais é relevante na medida em que podem influenciar - e influenciam -, direta ou indiretamente, nas legislações nacionais para a

\footnotetext{
450 "The OECD, UNCTAD and ICN recommendations and suggested best practices regarding merger notifications, cartels and other rules and procedures are not easy to adopt or to adapt to some nations' specific institutional environments. However, it has been recognized that those recommendations and suggested best practices can improve the efficiency of competition enforcement and assist in coping with cross-border strategies." (FARINA, Elizabeth M. M. Q.; ARAÚJO, Patrícia Agra. Brazilian competition policy in a global perspective. Competition Law international, out. 2005, p. 4.3).

${ }^{451}$ SANTOS, Maria Cecília de Andrade. A política da concorrência e a Organização Mundial do Comércio. Revista de Direito Constitucional e Internacional, abr./jun. 2001, ano 9, n. 35, p. 232.

${ }^{452} \mathrm{O}$ entendimento dos Estados Unidos tem sido no sentido de que a utilização do foro da OMC não seria adequado em virtude de o mesmo ter atuação sobre as atividades de comércio exterior dos Estados, não lhe cabendo a análise da conduta de entidades privadas. Todavia, a orientação parece estar se transformando nos últimos tempos, para a condição de que, se criado um foro para resolução de controvérsias, o mesmo não deverá atingir condutas individuais. (SANTOS, Maria Cecília de Andrade. Op. cit., abr./jun. 2001, p. 232).

453 "If a supranational system of enforcement of competition law is still far from becoming a reality, effective systems of bilateral cooperation seem at the moment to be more realistic alternative. In the recent years a number of bilateral agreements between different competition authorities have been concluded on the basis of the OECD guidelines of 1995". (BOTTA, Marco. The cooperation between the Competition Authorities of the Developing Countries: why does it not work? Case study on Argentina and Brazil. The competition law review. Issue 2, jul. 2009, v. V, p. 155).

454 "The OECD, UNCTAD and ICN recommendations and suggested best practices regarding merger notifications, cartels and other rules and procedures are not easy to adopt or to adapt to some nations' specific institutional environments. However, it has been recognized that those recommendations and suggested best practices can improve the efficiency of competition enforcement and assist in coping with cross-border strategies." (FARINA, Elizabeth M. M. Q.; ARAÚJO, Patricia Agra. Op. cit., out. 2005, p. 4.3).
} 
defesa da concorrência e na formação de tratados bilaterais e multilaterais sobre a matéria, a serem ratificados pelos Estados. É justamente nessa instância que se centra a análise sobre o desenvolvimento da cooperação bilateral internacional quanto aos atos de concentração multijurisdicionais.

\subsection{Organização para a Cooperação e Desenvolvimento Econômico (OCDE)}

Em 1994, a OCDE publicou um relatório intitulado "Casos de Concentração no Mundo Real - Um Estudo dos Procedimentos de Controle das Concentrações"455 (CCMR), elaborado pelos professores Richard Whish e Diane Wood ${ }^{456}$, no qual apresentaram um estudo sobre casos de concentração de relevo, bem como um sumário das questões constatadas e sua recomendações.

A recomendação $n^{\circ} 1$ do CCMR fundamenta-se no desejável estímulo à cooperação em geral, bem como no encorajamento das negociações de acordos bilaterais e multilaterais.

Em relação às informações confidenciais, a recomendação $n^{\circ} 2$ do CCMR indica que a renúncia das partes aos direitos que detêm sobre a confidencialidade das informações que instruem a revisão do ato de concentração poderá ser benéfica à análise das concentrações, devendo, desta forma, ser encorajada. A recomendação $\mathrm{n}^{\circ} 3$ destaca a necessidade de maior clarificação sobre que informações devem ser consideradas como confidenciais pelas autoridades de defesa da concorrência. Já a recomendação $\mathrm{n}^{\circ} 5$ do CCMR propõe que as informações que já se encontram no domínio público sejam distribuídas de forma mais eficiente.

Em relação às notificações sobre concentração, o CCMR, na sua recomendação $n^{\circ}$ 4, estabelece que deveria haver algum dispositivo legal inserido nas legislações nacionais de defesa da concorrência obrigando que as partes notificantes informassem, em algum momento durante o procedimento de análise da concentração, se elas notificaram alguma outra autoridade de defesa da concorrência sobre o mesmo ato. A recomendação $n^{\circ} 6$, por sua vez, indica que seria benéfica a elaboração de ao menos uma minuta de formulário de notificação de concentração, a qual solicitaria informações comuns em um formato único, mas que contemplasse a possibilidade de haver anexos nacionais, consoante fosse

${ }^{455}$ ORGANIZAÇÃO PARA A COOPERAÇÃO E DESENVOLVIMENTO ECONÔMICO. Merger cases in the real world - A study of merger control procedures. Paris: OCDE, 1994. Disponível em: 〈http://www.oecd.org/dataoecd/4/40/31587583.pdf>. Acesso em: 09 jul. 2010.

${ }^{456}$ Da Universidade de Londres e Universidade de Chicago, respectivamente. 
adequado. Por fim, a recomendação $\mathrm{n}^{\circ} 7$ do CCMR constata que o setor privado em muito se beneficiaria se houvesse convergência entre os requerimentos de notificação, no entanto, tal somente seria possível mediante alteração das legislações nacionais.

A OCDE também editou, em 1995, o documento intitulado "Recomendações Relacionadas à Cooperação entre Estados-Membros sobre Práticas Anticoncorrenciais que

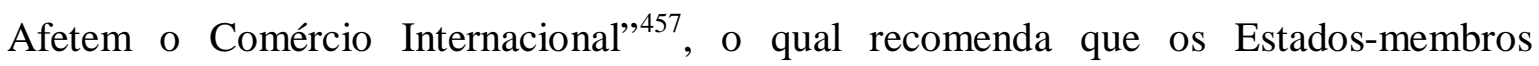
coordenem investigações de concorrência de interesse mútuo, desde que tal seja permitido pelas leis nacionais, bem como procedam às solicitações de uns aos outros para compartilhamento de informações. As Recomendações da OCDE de 1995 tratam de uma revisão de documento semelhante ao editado pela instituição em 1967, inovando pela consagração da cortesia positiva, melhor examinada no terceiro capítulo deste estudo.

A entidade publicou, ainda, outros instrumentos relevantes sobre o tema, dentre os quais destaca-se o de 2005 - "Recomendações do Conselho para Análise de Concentrações" ${ }^{458}$ (RCMR), o qual oferece recomendações divididas em quatro categorias, a saber: procedimentos de notificação e análise; coordenação e cooperação; recursos e poderes das autoridades da concorrência; e revisão periódica.

Em relação aos procedimentos de notificação e análise, o RCMR destaca que a análise de concentração deve ser efetiva, eficiente e oportuna ${ }^{459}$, devendo os paísesmembros assegurar que as regras, políticas, práticas e procedimentos relacionados à análise da concentração sejam transparentes e disponíveis ao público. Conforme as recomendações

457 ORGANIZAÇÃO PARA A COOPERAÇÃO E DESENVOLVIMENTO ECONÔMICO. Recommendation concerning co-operation between member countries on anticompetitive practices affecting international trade. Paris: OCDE, 1995. Disponível em: <http://www.oecd.org/dataoecd/ 60/42/21570317.pdf>. Acesso em: 09 jul. 2010.

458 ORGANIZAÇÃO PARA A COOPERAÇÃO E DESENVOLVIMENTO ECONÔMICO. Recommendations \& best practices. Recommendation of the Council on Merger Review. Paris: OCDE, 2005. Disponível em: <http://www.oecd.org/document/44/ 0,3343,en_2649_34715_44940780_1_1_1_1,00. html $>$. Acesso em: 09 jul. 2010.

459 "1. Member countries should ensure that the review process enables competition authorities to obtain sufficient information to assess the competitive effects of a merger. 2. Member countries should, without limiting the effectiveness of merger review, seek to ensure that their merger laws avoid imposing unnecessary costs and burdens on merging parties and third parties. In this respect, Member countries should in particular: (i) assert jurisdiction only over those mergers that have an appropriate nexus with their jurisdiction; (ii) use clear and objective criteria to determine whether and when a merger must be notified or, in countries without mandatory notification requirements, whether and when a merger will qualify for review; (iii) set reasonable information requirements consistent with effective merger review; (iv) provide procedures that seek to ensure that mergers that do not raise material competitive concerns are subject to expedited review and clearance; and $(v)$ provide, without compromising effective and timely review, merging parties with a reasonable degree of flexibility in determining when they can notify a proposed merger. 3. The review of mergers should be conducted, and decisions should be made, within a reasonable and determinable time frame." (ORGANIZAÇÃO PARA A COOPERAÇÃO E DESENVOLVIMENTO ECONÔMICO. Recommendations \& best practices. Recommendation of the Council on Merger Review. Paris: OCDE, 
do RCMR, o procedimento de análise da concentração deve proteger os segredos industriais e comerciais, bem como de qualquer outra informação que seja considerada confidencial pela legislação aplicável. Ainda, neste âmbito, as legislações nacionais devem assegurar que os procedimentos sejam justos às partes envolvidas na concentração, facultando a possibilidade de recurso sobre a decisão final a um órgão apartado da autoridade da concorrência ${ }^{460}$.

No que tange à coordenação e à cooperação, o RCMR recomenda que os Estadosmembros procurem cooperar e coordenar as respectivas análises de concentrações transnacionais, sem que seja prejudicado o cumprimento da legislação nacional aplicável $^{461}$. O RCMR propõe, também, que as autoridades da concorrência evitem inconsistências em relação às reparações (remédios) determinadas por outras jurisdições sobre a mesma concentração.

Mais precisamente em relação ao recebimento de informações confidenciais de outras jurisdições, o RCMR recomenda que as autoridades de defesa da concorrência estabeleçam medidas de proteção em relação ao tratamento e manuseio de tais informações. Por fim, a OCDE recomenda que os Estados-membros encorajem as partes da concentração a facilitar a coordenação entre as autoridades envolvidas, em especial no tocante às notificações e à outorga de termos de renúncia de direito sobre informações confidenciais.

No tocante aos recursos e poderes das autoridades da concorrência o RCMR recomenda que os Estados confiram às respectivas autoridades de defesa da concorrência os poderes necessários para conduzir de forma eficiente e efetiva a análise da concentração, bem como para coordenar e cooperar efetivamente com outras autoridades de defesa da concorrência a análise de concentrações multijurisdicionais. Já em relação à revisão periódica, o RCMR propugna que os Estados-membros procedam com

2005, p. 1-2. Disponível em: <http://www.oecd.org/document/44/ 0,3343,en_2649_34715_44940780_1_1_ 1_1,00. html>. Acesso em: 09 jul. 2010).

${ }^{4 \overline{0}}$ Recomenda-se, ainda, que às partes da concentração deve ser possibilitado consultar, a qualquer tempo, as autoridades da concorrência a respeito do objeto da análise, bem como deve ser facultado às terceiras partes a possibilidade de se manifestarem durante o curso do procedimento. Ademais, as leis sobre concorrência não devem diferenciar as sociedade estrangeiras das nacionais. (ORGANIZAÇÃO PARA A COOPERAÇÃO E DESENVOLVIMENTO ECONÔMICO. Recommendations \& best practices. Recommendation of the Council on Merger Review. Paris: OCDE, 2005, p. 2. Disponível em: <http://www.oecd.org/document/44/ 0,3343,en_2649_34715_44940780_1_1_1_1,00. html>. Acesso em: 09 jul. 2010).

461 "Member countries are encouraged to facilitate effective cooperation and coordination of merger reviews, and to consider actions, including national legislation as well as bilateral and multilateral agreements or other instruments, by which they can eliminate or reduce impediments to cooperation and coordination". (Id., ibid., 2005, p. 2). 
periodicidade à revisão das respectivas legislações nacionais sobre concorrência, buscando o melhoramento das mesmas e a convergência com respeito às melhores práticas.

Por fim, cabe ressaltar que o RCMR convida os Estados que não sejam membros da OCDE, como é o caso do Brasil, a implementar as recomendações contidas no documento. Além disso, é de se notar que por intermédio dos documentos emitidos e com a finalidade de se reduzir a potencialidade de conflitos, a OCDE tem insistido na importância de se incrementar a cooperação internacional nos procedimentos de análise concorrencial, principalmente na celebração de acordos bilaterais de cooperação ${ }^{462}$.

\subsection{Rede Internacional de Concorrência (ICN)}

Conferências anuais são organizadas pela ICN desde 2002, para a apresentação dos resultados dos grupos de trabalho ${ }^{463}$ e para a análise, recomendações e desenvolvimento de projetos. Já na primeira conferência, havida em Nápoles, Itália, um dos grupos de trabalho formados foi o relativo às concentrações. Esse grupo promove a adoção de melhores práticas na elaboração e instrumentação dos regimes de análise dos atos de concentração, com o objetivo de aumentar a efetividade dos mecanismos de análise de cada jurisdição, facilitar a convergência procedimental e material, e reduzir o tempo e as despesas privadas e públicas na análise das concentrações transnacionais.

Dentre os objetivos traçados pelo grupo de trabalhos no seu planejamento para o quinquênio $2010-2014^{464}$, reiterado no plano de trabalho para o biênio 2010-2011 ${ }^{465}$, está a promoção de maior cooperação internacional e convergência nos padrões para análise dos atos de concentração, bem como a assistência aos membros para encontrar soluções que evitem encargos desnecessários às empresas e às autoridades de defesa da concorrência

\footnotetext{
${ }^{462}$ FARIA, José Ângelo Estrella. O controle de concentrações de empresas estrangeiras e a Lei $\mathrm{n}^{\circ}$ 8.884: a extraterritorialidade revisitada. Juris Síntese, maio/jun. 2009, n. 77, p. 11. Disponível em: <http://online. sintese.com>. Acesso em: 19 ago. 2012.

${ }^{463}$ A INC já formou 12 grupos de trabalho, cada um com objetivo de discutir um assunto específico relacionado à concorrência. Atualmente cinco grupos mantêm suas atividades, a saber: grupo de advocacy (uma espécie de lobby), grupo de agency efictiveness (efetividade das autoridades de defesa da concorrência, anteriormente nomeado "implementação de políticas da concorrência"), grupo sobre cartéis, grupo sobre concentrações e grupo sobre condutas unilaterais.

${ }^{464}$ Planejamento de longo prazo do grupo de trabalho sobre concentrações para o quinquênio 2010-2014, disponível para acesso em: 〈http://www.internationalcompetitionnetwork.org/uploads/library/doc622.pdf〉. Acesso em: 08 jul. 2010.

${ }^{465}$ Plano de trabalho do grupo sobre concentrações para o biênio 2010-2011, disponível para acesso em: <http://www.internationalcompetitionnetwork.org/uploads/library/doc623.pdf>. Acesso em: 08 jul. 2010.
} 
neste âmbito ${ }^{466}$. As atividades do grupo de trabalho dividem-se basicamente em duas frentes, a saber: (i) análise e a investigação de concentrações; e (ii) notificações e procedimentos de concentrações.

Mediante a adoção do princípio da extraterritorialidade, os atos de concentração que possam surtir efeitos em mais de uma jurisdição são suscetíveis de análise por diferentes autoridades de defesa da concorrência. Por tal motivo, as partes envolvidas devem promover a notificação sobre tais concentrações em mais de um território. Nesse âmbito, o trabalho da ICN centra-se na análise dos aspectos procedimentais das notificações de concentração e na revisão das questões relacionadas à jurisdição, ao tempo, aos requerimentos sobre o escopo da notificação de concentração e às informações a serem prestadas, bem como ao tempo de análise das concentrações.

Dentre os Princípios Orientadores para a Notificação e Análise de Concentrações (Princípios Orientadores) $^{467}$, editados pela ICN, são relevantes para a análise dos acordos bilaterais de cooperação os princípios $n^{\circ} 6$ (coordenação) e $n^{\circ} 8$ (proteção de informações confidenciais). Desde logo ressalta-se que a ICN, ao elaborar os Princípios Orientadores, preferiu a expressão "coordenação", ao invés de "cooperação".

De acordo com os Princípios Orientadores, o princípio da coordenação determina que as jurisdições que estejam a analisar uma mesma operação devem se engajar na cooperação necessária ao aumento da eficiência e efetividade dos processos de análise e na redução das despesas, sem, entretanto, comprometer as disposições da legislação nacional aplicável. Já o princípio da proteção de informações confidenciais determina que o processo de análise de concentração deve proteger as informações confidenciais.

O Capítulo $\mathrm{X}^{468}$ das Práticas Recomendadas para os Procedimentos de Notificação de Concentração (Práticas Recomendadas), elaboradas pela ICN, também dispõe sobre a coordenação entre as autoridades de defesa da concorrência. O item X.A estabelece que as

\footnotetext{
${ }^{466}$ Os outros dois objetivos são: a viabilização de que os seus membros melhorem a qualidade das respectivas análises de concentração e o aumento da transparência na prática das autoridades de defesa da concorrência, de modo a minimizar as incertezas e aumentar a previsibilidade na análise de concentrações.

${ }^{467}$ Os princípios são: (i) soberania; (ii) transparência; (iii) não discriminação em função da nacionalidade; (iv) procedimento justo; (v) análise eficiente, pontual e efetiva; (vi) coordenação; (vii) convergência; e (viii) proteção de informação confidencial. (Ver INTERNATIONAL COMPETITION NETWORK. Guiding principles for merger notification and review. Disponível em: <http://www.internationalcompetition network.org/uploads/library/doc591.pdf>. Acesso em: 08 jul. 2010).

${ }^{468}$ Faz-se especial nota para o Capítulo X das Práticas Recomendadas as quais têm correspondência com o princípio da coordenação dos Princípios Orientadores, assim como os demais capítulos deste documento.
} 
autoridades da concorrência devem procurar a coordenação das respectivas análises de concentrações que possam levantar questões de competitividade de preocupação mútua ${ }^{469}$.

As Práticas Recomendadas também determinam, no item X.B, que a coordenação entre as autoridades de defesa da concorrência deve ser conduzida de acordo com a legislação e demais instrumentos e doutrinas legais aplicáveis ${ }^{470}$. Neste diapasão, são de especial relevo as disposições legais relacionadas ao tratamento de informações confidenciais e de comunicações privilegiadas. Ainda, nos seus comentários ao item X.B, a ICN recomenda, quando duas ou mais autoridades de defesa da concorrência realizam análises de concentrações coordenadas recorrentemente, que celebrem acordos formais, memorandos de entendimentos ou outros protocolos para a análise das concentrações e troca de informações.

O item X.C das Práticas Recomendadas determina que a coordenação entre as autoridades da concorrência deve ser concebida caso a caso, bem como consoante às necessidades das autoridades envolvidas.

Consoante o dispositivo do item X.D, durante o procedimento de coordenação da concentração, as autoridades de defesa da concorrência devem incitar e facilitar a cooperação das partes do ato de concentração ${ }^{471}$. Constituem exemplos sobre como as partes podem colaborar nesse procedimento: comunicações sobre notificação entregues às autoridades em coordenação e a outorga voluntária de termos de renúncia dos direitos de confidencialidade. Para tal propósito, a ICN editou um documento intitulado Renúncia de Confidencialidade em Investigações de Concentrações, com o intuito de promover a outorga voluntária de termos de renúncia do direito de confidencialidade pelas partes, bem como fornecer minutas padronizadas que poderão ser utilizadas para tal propósito.

Finalmente, de acordo com o item X.E das Práticas Recomendadas, as autoridades envolvidas na análise da concentração devem procurar estabelecer nas suas decisões as restrições (remédios) que considerem as preocupações relativas à concorrência doméstica,

\footnotetext{
${ }^{469} \mathrm{O}$ objetivo desta disposição é incentivar a eficiente análise de concentrações, o cumprimento efetivo de legislação sobre concentração e o resultado consistente, ou ao menos não conflitante, entre as análises operadas pelas diferentes autoridades de defesa da concorrência, bem como reduzir a duplicação de trabalho $\mathrm{e}$ os encargos desnecessários para as partes e as autoridades. (INTERNATIONAL COMPETITION NETWORK. Recommended practices for merger notification procedures. Jun. 2005, p. 29. Disponível em: 〈http://www.internationalcompetitionnetwork.org/uploads/library/doc588.pdf>. Acesso em: 08 jul. 2010).

${ }^{470}$ Aqui se incluem os acordos e contratos de cooperação. (Id., ibid., p. 29).

${ }^{471}$ As autoridades de defesa da concorrência deverão, para tal finalidade, promover a transparência sobre o procedimento de coordenação, informando as partes sobre os benefícios de tal coordenação, inclusive através da publicação das suas práticas e políticas de coordenação. (Id., ibid., pp. 30-31).
} 
evitando eventuais inconsistências em relação às restrições porventura exigidas em outras jurisdições para o mesmo ato de concentração ${ }^{472}$.

Finda a análise dos documentos da OCDE e da ICN que versam sobre os atos de concentração multijurisdicionais, e identificados os principais pontos de preocupação destas entidades internacionais, importante ater-se às recomendações relevantes para que se possa conduzir aos apontamentos finais relacionados aos acordos bilaterais de cooperação em matéria concorrencial - o que se pretende fazer no terceiro capítulo deste estudo. Antes, porém, resta analisar os aspectos relacionados à dimensão regional do Direito Internacional da Concorrência.

\subsubsection{Dimensão Regional do Direito Internacional da Concorrência}

No final do século 20, o fenômeno da integração econômica tomou posição de destaque, servindo de instrumento ao avultamento da globalização econômica, acarretando a formação de blocos regionais. Com essa alteração no cenário econômico mundial, os países integrantes de tais blocos econômicos passaram a cada vez mais construir um fluxo comercial entre as suas fronteiras, com o objetivo de promover o desenvolvimento das respectivas economias mediante o incremento dos estímulos advindos da majoração do mercado consumidor disponível aos seus agentes comerciais. Com a estruturação regional das economias, os Estados esperam, portanto, atingir um maior grau de facilidades na comercialização de bens e serviços. De fato, em vista da globalização da economia não é mais possível vislumbrar a existência de nações cujas economias estejam isoladas do fluxo internacional econômico ${ }^{473}$.

Desta forma, cabe ao presente estudo explorar os aspectos concorrenciais englobados nas ações regionais de cooperação internacional. A perspectiva regional do Direito Internacional da Concorrência traduz-se nas diversas regras estabelecidas no âmbito de organizações ou acordos regionais de integração econômica.

\footnotetext{
${ }^{472}$ Isso não significa que todas as autoridades de defesa da concorrência devam chegar a um mesmo resultado, mas somente que devem considerar o impacto que a sua decisão poderá surtir nas outras jurisdições envolvidas. Por tal motivo é conveniente que as partes envolvidas no ato de concentração coordenem a apresentação das suas propostas para reparar a concorrência junto aos diferentes territórios. Por outro lado, as autoridades envolvidas devem manter constante comunicação sobre as vias de reparação da concorrência que estão sendo cogitadas, de modo que possam, na medida do possível, conciliar os objetivos pretendidos. (INTERNATIONAL COMPETITION NETWORK. Recommended practices for merger notification procedures. Jun. 2005, p. 31. Disponível em: <http://www.internationalcompetitionnetwork. org/uploads/library/doc588. pdf>. Acesso em: 08 jul. 2010).

${ }^{473}$ JAEGER JÚNIOR, Augusto. Liberdade de concorrência na União Europeia e no Mercosul. São Paulo: LTr, 2006, p. 537.
} 
No que toca à cooperação regional, o Direito Internacional da Concorrência tem especial relevância, uma vez que não há possibilidade de se conceber o desenvolvimento econômico de uma região sem que haja uma correspondente proteção da livre iniciativa, da concorrência e dos direitos dos consumidores ${ }^{474}$. Assim, é recorrente a regulação da concorrência por meio de organizações e acordos regionais, tendo como exemplos mais expressivos os casos da União Europeia, do Mercado Comum do Sul (Mercosul) e do Acordo de Livre Comércio da América do Norte (NAFTA).

Não obstante o caso da União Europeia constituir-se no mais emblemático em matéria de integração regional, em especial em relação à matéria concorrencial, este estudo centra o foco de atenção ao Mercosul. Tal escolha é justificada na medida em que os objetivos do presente estudo centram-se na perspectiva da cooperação jurídica internacional sobre atos de concentração multijurisdicionais a partir do direito brasileiro e, assim, a importância da análise do bloco regional do qual o Brasil faz parte torna-se de maior relevância aos objetivos delineados. Este estudo não se furta, no entanto, de tecer breves considerações acerca de alguns dos outros acordos e organizações regionais que regulam a matéria concorrencial, as quais estão inseridas no item 2.2.3.2, infra ${ }^{475}$.

\subsubsection{Mercosul}

As iniciativas para a integração dos países latino-americanos não são recentes. Alguns autores destacam que desde o descobrimento das Américas já existiam iniciativas

\footnotetext{
${ }^{474}$ Nesse sentido, Salomão Filho defende que "o passo fundamental para a consolidação de um mercado comum é a coordenação de políticas macroeconômicas [...]. Essa coordenação, não pode ocorrer sem que haja, concomitantemente, uma convergência das políticas de regulação da concorrência, sob pena de as condutas anticoncorrenciais facilitadas pela integração colocarem em risco o fim pretendido: o Mercado Comum". (SALOMÃO FILHO. Calixto. O Mercosul como modelo de regulação do mercado. Contratos internacionais. 3. ed. São Paulo: Revista dos Tribunais, 2002, p. 412). Ver também Marques: "na exata medida e proporção em que se removem as barreiras nacionais ao livre fluxo dos agentes e fatores de produção econômica, visando à configuração de mercado comum [...], inexoravelmente, será obrigatório assegurar a existência e operação de um regime mínimo harmonizado das regras da concorrência" (MARQUES, Frederico do Valle Magalhães. Direito Internacional da Concorrência. Rio de Janeiro: Renovar, 2006, pp. 287-288); Jaeger Júnior: "sem normas de proteção da livre concorrência e da ordem econômica que impeçam as ações anticoncorrenciais das empresas, não é possível alcançar os benefícios do mercado comum" (JAEGER JÚNIOR, Augusto. Liberdade de concorrência na União Europeia e no Mercosul. São Paulo: LTr, 2006, p. 536); e MORAIS, Luís Domingos Silva. Empresas comuns (Joint Ventures) no Direito Comunitário da Concorrência. Coimbra: Almedina, 1996, pp. 494-499.

${ }^{475}$ Para além das organizações e acordos regionais descritos neste estudo existem outros que possuem dispositivos sobre a matéria concorrencial, como é o caso da Comunidade Andina de Nações, a Comunidade do Caribe (CARICOM), a União Econômica e Monetária do Oeste Africano, o Mercado Comum da África Oriental e Astral e o acordo entre Australia e Nova Zelândia. Para maiores informações, ver FOX, Eleanor M.; CRANE, Daniel A. Global issues in antitrust and competition law. St Paul: West, 2010, p. 521.
} 
tendentes à integração da América Latina ${ }^{476}$. Já em 1935, durante o governo de Getúlio Vargas, houve negociações para integrar os três países mais expressivos da América do Sul: a Argentina, o Brasil e o Chile (Bloco ABC). Tais iniciativas foram frustradas, em parte pelo desestímulo do governo dos Estados Unidos ${ }^{477}$.

Ainda no final da década de $1940^{478}$ foi constituída a Comissão Econômica para a América Latina (CEPAL) no âmbito do Conselho Econômico e Social das Nações Unidas, constituindo o grande ato inicial da integração da América Latina. A Organização dos Estados Americanos (OEA), por meio da Resolução no 57/1954, menciona pela primeira vez o projeto de integração regional firmado a partir da cooperação regional dos países americanos.

Em 18 de fevereiro de 1960 foi criada a Associação Latino-americana de Livre Comércio (ALALC), substituída em 12 de agosto de $1980^{479}$, com a assinatura do Tratado de Montevidéu, pela Associação Latino-americana de Integração (ALADI) ${ }^{480}$. Adicionalmente, em 26 de maio de 1969, o Acordo de Cartagena foi firmado, constituindo assim a Comunidade Andina de Nações ${ }^{481}$. Mais recentemente, no ano de 2007, a União de Nações Sul-Americanas (UNASUL) foi formada.

Não obstante as numerosas e valorosas iniciativas da região, o processo de integração regional do Mercosul é considerado como um dos mais relevantes da América Latina $^{482}$. A intensificação das relações bilaterais econômicas entre Brasil e Argentina

\footnotetext{
${ }^{476}$ CUNHA, Ricardo Thomazino da. Direito de defesa da concorrência: Mercosul e União Europeia. Barueri, SP: Manoler, 2003, pp. 165 e ss.

${ }^{477}$ ACCIOLY, Elizabeth. Mercosul e União Europeia: estrutura jurídico-institucional. 4. ed. Curitiba: Juruá, 2010, p. 63.

${ }_{478}$ Mais precisamente em 25 de fevereiro de 1948.

479 "Os motivos do fracasso da ALALC são diversos. [...] a partir da metade dos anos 60 até a década de 80, pelo menos, a integração dos países latino-americanos foi dificultada pela tomada do poder nestas nações por regimes militares ditatoriais, que impuseram sistemas fechados de economia, buscando a autossuficiência interna. Adota-se política de desenvolvimento interno baseada na substituição de importações, por meio de altas tarifas alfandegárias e inúmeras restrições não-tarifárias, isolando-se, cada vez mais, os países latinoamericanos entre si". (CUNHA, Ricardo Thomazino da. Op. cit., p. 169). Ver também Magalhães, para quem o resultado positivo da ALAC foi o Pacto Andino, "que sobreviveu à própria extinção da organização e convive com a sua sucessora", a ALADI. (MAGALHÃES, José Carlos de. Direito Econômico Internacional: tendências e perspectivas. Curitiba: Juruá, 2009, p. 69).

${ }^{480}$ Os objetivos da ALADI eram mais modestos do que os da ALAC, mas ainda contemplavam uma integração com última finalidade de se atingir um mercado comum; todavia, sem o estabelecimento de prazos para a formação de uma zona de livre comércio. Por outro lado, a falta de instrumentos capazes de consolidar a união pretendida constitui o motivo do fracasso do modelo trazido pela ALADI. Para uma análise completa sobre a ALADI, ver ARAÚJO, Leandro Rocha de. Associação Latino-Americana de Integração (ALADI). Blocos econômicos e integração na América Latina, África e Ásia. Curitiba: Juruá, 2008, pp. 111-136.

${ }^{481} \mathrm{O}$ Acordo de Cartagena é o fruto de uma cisão entre os países latino-americanos tidos como comercialistas e desenvolvimentistas, tendo sido firmado por estes últimos.

${ }^{482}$ SANTOS, Maria Cecília de Andrade. Sobre a Cooperação em Matéria de Concorrência entre a União Europeia e o Mercosul. Revista da IBRAC - Direito da Concorrência, Consumo e Comércio Internacional. São Paulo, jan. 2001, v. 8, pp. 177 e ss.
} 
iniciada na metade da década de 1980 é tida como o impulso que culminou na formação do Mercosul. Com o desenvolvimento do quadro de cooperação bilateral, Brasil e Argentina subscreveram a Ata de Buenos Aires em 6 de julho de 1990, por meio da qual decidiram que os dois países concluiriam um mercado comum até dezembro de 1994, dentre outras disposições. Subsequentemente, em 20 de dezembro de 1990, os dois países celebraram junto à ALADI, o Acordo de Complementação Econômica $\mathrm{n}^{\circ} 14$, de modo a colocar em prática os objetivos estabelecidos pela Ata de Buenos Aires ${ }^{483}$.

Com receio do isolamento econômico, os países vizinhos, Paraguai e Uruguai, começaram a negociar com o Brasil e a Argentina a formação de um bloco econômico comum. Destas negociações chegou-se à assinatura, em 26 de março de $1991,{ }^{484}$ do Tratado de Assunção. Interessante notar que o Mercosul foi negociado no âmbito do ALADI, por meio do Acordo de Complementação Econômica $n^{\circ} 18^{485}$, sendo que o próprio preâmbulo do Tratado de Assunção deixa aberta a possibilidade de adesão aos demais membros da ALADI. O Mercosul foi, então, criado e assumiu a forma de organização internacional, tendo como objetivo a formação de um mercado comum ${ }^{486}$.

A natureza das regras contidas no Tratado de Assunção é programática, ou seja, não se constitui de normas autoaplicáveis ou autoexecutáveis ${ }^{487}$. O Tratado de Assunção previu em seus dispositivos um período de transição para preparar a formação de uma zona de livre comércio e da união aduaneira, a qual deveria ser finalizada em 31 de dezembro de

${ }^{483}$ Para um relato pormenorizado da evolução da cooperação entre Brasil e Argentina neste período, ver CUNHA, Ricardo Thomazino da. Direito de defesa da concorrência: Mercosul e União Europeia. Barueri, SP: Manole, 2003, pp. 171-175.

${ }^{484}$ Internalizado no ordenamento jurídico brasileiro por intermédio do Decreto $\mathrm{n}^{\circ} 350$, de 21 de novembro de 1991, em vigor internacional e para o Brasil a partir de 29 de novembro de 1991. (CASELLA, Paulo Borba. Direito da concorrência na EU e no Mercosul. In: BAPTISTA, Luiz Olavo; MERCADANTE, Araminta de Azevedo; CASELLA, Paulo Borba (orgs.). Mercosul: das negociações à implantação. 2. ed. São Paulo: LTr, 1998, p. 347).

485 "A propósito, o próprio Mercosul surgiu no âmbito da ALADI, e, diferentemente do que apregoaram alguns, na época foi complemento daquele projeto integracionista". (MENEZES, Wagner. Mercado Comum do Sul (Mercosul). Blocos econômicos e integração na América Latina, África e Ásia. Curitiba: Juruá, 2008, p. 139). Ver também MENEZES, Wagner. Derecho Internacional en América Latina. Brasília: Funag, 2010, p. 185; e ARAÚJO, Leandro Rocha de. Associação Latino-Americana de Integração (ALADI). Blocos econômicos e integração na América Latina, África e Ásia. Curitiba: Juruá, 2008, p. 114, em que o autor destaca que este acordo foi recepcionado pelo ordenamento brasileiro por intermédio do Decreto $\mathrm{n}^{\circ}$ 550 , de 27 de maio de 1992.

486 "Atingidas as cinco liberdades, forma-se o mercado comum [...] no qual mercadorias, serviços, capitais e pessoas fluem livremente em um espaço único, sem fronteiras. O processo é lento, estando apenas nos seus movimentos iniciais. O Tratado de Assunção não estipulava prazos para o surgimento deste mercado, determinando apenas para a constituição da zona de livre comércio e da união aduaneira". (CUNHA, Ricardo Thomazino da. Direito de defesa da concorrência: Mercosul e União Europeia. Barueri, SP: Manole, 2003, p. 182).

${ }^{487}$ MENEZES, Wagner. Op. cit., 2008, p. 141. 
$1994^{488}$. Durante este período de transição, o sistema de solução de controvérsias e a estrutura institucional do Mercosul eram provisórios.

A estruturação em definitivo do Mercosul se deu com a assinatura do Protocolo de Ouro Preto, em 17 de dezembro de 1994, por meio do qual se manteve o aspecto intergovernamental da organização, isto é, sem o acolhimento de organismos supranacionais. O item 2.2.3.1.2, infra, descreve com maior detalhamento a estrutura orgânica atualmente existente no Mercosul.

O Protocolo de Ouro Preto veio também reiterar os objetivos do Mercosul em alcançar um mercado comum e, por intermédio dos seus arts. 34 e 35, proveu o Mercosul com capacidade internacional, possibilitando que se tornasse sujeito de direitos e obrigações no plano internacional. Isso significa que somente após o Protocolo de Ouro Preto o Mercosul passou a ter personalidade jurídica internacional ${ }^{489}$, podendo a partir de então tomar todas as medidas necessárias para atingir os objetivos estabelecidos pelos Estados-Partes $^{490}$.

Após a adoção do Protocolo de Ouro Preto, seguiu-se a assinatura de outros acordos e protocolos no âmbito do Mercosul (como por exemplo: o Protocolo de Brasília e o Protocolo de Olivos ${ }^{491}$, bem como o Protocolo de Las Leñas, o Protocolo de Buenos Aires, o Protocolo de São Luis, o Protocolo de Santa Maria e o Protocolo de Medidas Cautelares, celebrado também em Ouro Preto). Este estudo, porém, ater-se-á aos trabalhos daqueles que são mais relevantes ao seu objeto tal qual delimitado anteriormente.

Apesar de o objetivo estabelecido pelo Tratado de Assunção ser o de atingir o mercado comum, pode-se considerar no seu atual estágio de evolução, que a integração alcançada é de uma união aduaneira imperfeita. Devido às instabilidades econômicas da

\footnotetext{
488 Somente em $1^{\circ}$ de janeiro de 1995 atingiu-se entre os Estados-Partes a zona de livre comércio e união aduaneira (imperfeita), com a criação da Tarifa Externa Comum (TEC).

${ }^{489}$ Montgomery descreve que dentre os critérios de aferição da característica de organização internacional a dada entidade, está a averiguação de que a entidade possui personalidade jurídica própria, com capacidades de sujeito de direito internacional, isto é, de firmar tratados e de reclamar seus direitos em foros internacionais. (MONTGOMERY, Neil. As organizações internacionais como sujeitos de Direito Internacional. Blocos econômicos e integração na América Latina, África e Ásia. Curitiba: Juruá, 2008, pp. 48 e 73-76).

${ }^{490}$ Jaeger Júnior descreve que a partir da vigência do Protocolo de Ouro Preto o Mercosul passou a deter capacidade para "firmar tratados, alienar e comprar bens imóveis e móveis, ser parte em tribunais, bem como possuir e transferir patrimônio”. (JAEGER JÚNIOR, Augusto. Liberdade de concorrência na União Europeia e no Mercosul. São Paulo: LTr, 2006, p. 545).

491 Tais Protocolos estabeleceram as normas para o sistema de solução de controvérsias no Mercosul. Importante destacar que o Protocolo de Olivos constituiu o Tribunal Permanente de Revisão do Mercosul, o qual foi instalado em 13 de agosto de 2004, com sede na cidade de Assunção no Paraguai. Já o Protocolo de Brasília, anterior na sua adoção em relação ao Protocolo de Olivos, estabeleceu um sistema de solução de controvérsias através de arbitragem ad hoc, e vigente até 2002.
} 
região o objetivo de formação de um mercado comum encontra-se adiada, dependente, pois, da vontade política dos seus Estados-Partes ${ }^{492}$.

Desta forma, de acordo com Menezes, pode-se definir o Mercosul como "uma organização regional (a partir da adesão da Venezuela) de integração, de natureza intergovernamental, que se encontra entre uma zona de livre comércio incompleta e uma união aduaneira imperfeita, cujo objetivo central é chegar a um mercado comum"493.

\subsection{Estados-Partes do Mercosul}

O bloco foi formado originalmente pela Argentina, Brasil, Paraguai e Uruguai. Posteriormente, a Bolívia ${ }^{494}$, o Chile, o Peru, o Equador e a Colômbia aderiram ao processo de integração regional, na condição de Estados Associados. Em 4 de julho de 2006 os Ministros das Relações Exteriores dos Estados-Partes autorizaram, em Buenos Aires, a incorporação da Venezuela como membro pleno do Mercosul. Nos dias 20 e 21 de julho de 2006 os presidentes dos Estados-Partes confirmaram o entendimento na Cúpula do Mercosul, havida na cidade de Córdoba, com a assinatura do Protocolo de Adesão da Venezuela ao Mercosul.

Até meados de 2012 a adesão da Venezuela já havia obtido a necessária ratificação por parte da Argentina, do Brasil e do Uruguai. Pendia naquele momento a aprovação por parte do poder legislativo paraguaio para que a sua adesão ao Mercosul fosse concretizada. Em 29 de junho de 2012, Argentina, Brasil e Uruguai decidiram pela suspensão do Paraguai no bloco, com fundamento no Protocolo de Ushuaia sobre Compromisso Democrático no Mercosul ${ }^{495}$. Posteriormente, a Decisão do Conselho Mercado Comum $(\mathrm{CMC}) \mathrm{n}^{\circ}$ 28/2012 incumbiu o Grupo Mercado Comum à regulamentação dos aspectos operacionais relativos a essa suspensão. Em função disso, em 30 de julho de 2012 a

\footnotetext{
492 ACCIOLY, Elizabeth. Mercosul e União Europeia: estrutura jurídico-institucional. 4. ed. Curitiba: Juruá, 2010, p. 78).

${ }^{493}$ MENEZES, Wagner. Mercado Comum do Sul (Mercosul). Blocos econômicos e integração na América Latina, África e Ásia. Curitiba: Juruá, 2008, p. 151.

${ }^{494}$ Em 7 de dezembro de 2012, durante a Cúpula de Chefes de Estado do Mercosul e Estados Associados, havida em Brasília, a Bolívia assinou o Protocolo de Adesão ao Mercosul, sendo este o primeiro passo com vistas à aderência da Bolívia ao Mercosul na qualidade de membro pleno.

495 Accioly destaca que este protocolo é um daqueles de maior relevância para os Estados-Partes devido à instabilidade democrática marcada no continente latino-americano. "Nesse documento os seis Estados reconhecem a vigência das instituições democráticas como condição indispensável para a existência e o desenvolvimento do Mercosul, admitindo que toda alteração da ordem democrática será inaceitável para a continuidade do processo de integração regional". (ACCIOLY, Elizabeth. Op. cit., 2010, p. 73).
} 
Argentina, o Brasil e o Uruguai decidiram pela incorporação da Venezuela ao Mercosul na condição de Estado-Parte, com efeitos a partir de 12 de agosto de $2012^{496}$.

Em que pesem as recentes discussões por parte da comunidade latino-americana sobre os efeitos concretos da incorporação da Venezuela ao bloco e sobre a validade da decisão tomada pelos Estados-Partes sem a participação do Paraguai, o que por si só poderia constituir objeto de estudo específico, certo é que nos documentos oficiais e demais iniciativas do Mercosul a Venezuela tem obtido tratamento equivalente aos demais Estados-Partes da organização. Além disso, parte da doutrina especializada já consagra a Venezuela como parte efetiva do Mercosul ${ }^{497}$.

Desta maneira, considera-se para as finalidades deste estudo, que no atual estágio da evolução das discussões, o Mercosul é formado hoje pela Argentina, Brasil, Paraguai, Uruguai e Venezuela, em que pese a atual posição de suspensão do Paraguai.

\subsection{Estrutura orgânica do Mercosul}

São órgãos do Mercosul, de acordo com o Protocolo de Ouro Preto, o Conselho Mercado Comum (CMC), o Grupo Mercado Comum (GMC), a Comissão de Comércio do Mercosul, o Parlamento do Mercosul ${ }^{498}$, o Foro Consultivo Econômico Social e a Secretaria Administrativa ${ }^{499}$. A estrutura orgânica formada pelo Protocolo de Ouro Preto tem como objetivo manter o processo de integração, com escopo final de alcançar o mercado comum. Desde logo se destaca que os órgãos em questão não são supranacionais, tratando-se apenas de órgãos diplomáticos das relações externas dos Estados-Partes, portanto, com natureza intergovernamental ${ }^{500}$.

\footnotetext{
${ }^{496}$ Ver decisão do CMC n ${ }^{\circ}$ 27/2012.

${ }^{497}$ Nesse sentido, Menezes defende que "a adesão de um novo membro fortalece sim, o bloco. Trata-se de um componente importante no jogo do cenário econômico internacional, pois constitui um conjunto de consumidores em potencial e resulta em um espaço geográfico relevante. O bloco passa a ter uma economia que se diversifica das demais e oferece outros elementos na dinâmica comercial, o que lhe confere uma dimensão continental". (MENEZES, Wagner. Mercado Comum do Sul (Mercosul). Blocos econômicos e integração na América Latina, África e Ásia. Curitiba: Juruá, 2008, pp. 154 e 158); e também MENEZES, Wagner. Derecho Internacional en América Latina. Brasília: Funag, 2010, p. 182.

${ }^{498}$ Em relação a este órgão deve-se considerar a Decisão CMC n ${ }^{\circ}$ 49/2004, que decidiu pela sua criação, que, no entanto, foi instalado somente em 14 de dezembro de 2006.

499 Para um detalhamento completo dos órgãos que compõem o Mercosul, ver ACCIOLY, Elizabeth. Mercosul e União Europeia: estrutura jurídico-institucional. 4. ed. Curitiba: Juruá, 2010, pp. 81-104.

500 "Todo o processo fica sob jugo dos governos nacionais, os quais impõem o ritmo que desejarem à integração. Enquanto os parceiros têm os mesmos objetivos, a união das economias caminha rapidamente. Qualquer crise de consenso entre os governos dos Estados Partes pode levar à estagnação, ou mesmo ao seu retrocesso [...]. Esta situação gera problemas no estabelecimento e na aplicação do direito de defesa da concorrência". (CUNHA, Ricardo Thomazino da. Direito de defesa da concorrência: Mercosul e União Europeia. Barueri, SP: Manole, 2003, p. 200).
} 
O CMC é o órgão hierarquicamente superior do Mercosul, ao qual cabe a condução política e as decisões tendentes ao cumprimento dos objetivos do bloco ${ }^{501}$. Dentre as funções e competências do CMC, se destacam aquelas relacionadas à conformidade no cumprimento do Tratado de Assunção, seus protocolos e demais acordos firmados no seu âmbito e o exercício da titularidade da personalidade jurídica do Mercosul, negociando e firmando acordos em seu nome. O CMC é integrado pelos Ministros de Relações Exteriores e de Economia dos Estados-Partes, ou equivalentes, que se reúnem ao menos uma vez por semestre. A forma de manifestação do CMC está na tomada de "decisões" por consenso $^{502}$ dos seus membros, as quais, apesar de não serem autoaplicáveis, são vinculativas aos Estados-Partes ${ }^{503}$.

O GMC é o órgão executivo do Mercosul, sendo composto por 16 membros, quatro titulares e quatro suplentes por país, os quais são coordenados em última instância pelos Ministérios das Relações Exteriores dos Estados-Partes. Os membros do GMC são designados pelos respectivos governos, devendo necessariamente constar representantes dos Ministérios das Relações Exteriores e da Economia, ou equivalentes, e dos Bancos Centrais dos Estados-Partes. Dentre as atribuições do GMC está a proposição de projetos de decisão ao CMC e a criação ou extinção de órgãos, como os subgrupos de trabalho e reuniões especializadas. O GMC manifesta-se por intermédio de "resoluções", as quais são tomadas pelo consenso e vinculam os Estados-Partes.

Já a Comissão de Comércio do Mercosul tem a função de prestar assistência ao GMC em sua função executiva, velando pela aplicação e cumprimento da tarifa externa comum e dos demais instrumentos de política comercial comum, tanto em relação ao comércio interno do Mercosul, quanto sobre o comércio com terceiros países. Quatro membros titulares e quatro membros suplentes por Estado-Parte compõem a sua estrutura, os quais também são coordenados pelos Ministérios das Relações Exteriores dos EstadosPartes. As manifestações da Comissão de Comércio do Mercosul se dão mediante “diretrizes" ou "propostas", sendo somente as diretrizes obrigatórias aos Estados-Partes ${ }^{504}$.

\footnotetext{
501 "Na realidade, este papel não é o mero emprego mecânico das regras do Tratado de Assunção, mas sim a formação do direito secundário, por meio da tomada de decisões. O Conselho dispõe, então, de funções 'legislativas' e políticas com o fim de atingir os fins da integração'. (CUNHA, Ricardo Thomazino da. Direito de defesa da concorrência: Mercosul e União Europeia. Barueri, SP: Manole, 2003, p. 201).

${ }^{502}$ Esse método de decisão pode tornar o avanço da integração impraticável. (Id., ibid., p. 201).

503 Os Estados-Partes têm a obrigação, portanto, de promover a recepção das decisões nos respectivos ordenamentos jurídicos. (MENEZES, Wagner. Mercado Comum do Sul (Mercosul). Blocos econômicos e integração na América Latina, África e Âsia. Curitiba: Juruá, 2008, p. 145).

${ }^{504}$ Id., ibid., p. 147.
} 
O Parlamento do Mercosul ${ }^{505}$, formado inicialmente como Comissão Parlamentar Conjunta, trata do foro do bloco no qual os povos do Mercosul são representados, respeitadas as suas pluralidades ideológica e política. Além disso, ao Parlamento cabe a promoção e a defesa permanente da democracia, da liberdade, da paz e do desenvolvimento sustentável da região, com justiça social e respeito à diversidade cultural da população. Ademais, dentre os objetivos estabelecidos, cabe ao Parlamento a promoção da solidariedade e da cooperação regional e internacional. Os parlamentares são eleitos por sufrágio universal direto, com mandato de quatro anos e a composição do Parlamento é formada pelo critério da proporcionalidade. Note-se que apesar de os pareceres emitidos pelo Parlamento não possuírem caráter vinculativo, o órgão detém a competência de agilizar o processo de internalização das suas normas nos ordenamentos jurídicos internos dos Estados-Partes.

O Foro Consultivo Econômico Social é um órgão auxiliar, representativo dos setores econômicos e sociais dos Estados-Partes, formado por igual número de representantes de cada um dos Estados-Partes com o objetivo de aproximar a sociedade civil ao bloco. O Foro possui função consultiva e manifesta-se por meio de "recomendações" ao GMC, as quais não são vinculativas.

Por fim, a Secretaria Administrativa é um órgão de apoio operacional às atividades do Mercosul, responsável pela prestação de serviços administrativos aos demais órgãos que compõem a organização, possuindo sede permanente em Montevidéu, no Uruguai. As atividades da Secretaria são gerenciadas por um Diretor, que necessariamente deve ser nacional de um dos Estados-Partes do Mercosul, o qual é escolhido pelo GMC e aprovado pelo CMC para mandato de dois anos.

O CMC, o GMC e a Comissão de Comércio possuem atribuições relevantes no que se refere às políticas e ao direito da concorrência. Para além da estrutura institucional básica do Mercosul anteriormente mencionada, existem ainda órgãos temáticos, dentre os quais destacam-se os subgrupos de trabalho ${ }^{506}$, mais especificamente o Subgrupo de Coordenação de Políticas Econômicas, que engloba em seus trabalhos a harmonização de legislações de defesa do consumidor e da concorrência. Ademais, o Comitê Técnico no 5

\footnotetext{
${ }^{505}$ Aprovado inicialmente pela Decisão do CMC no 49/2004, a qual investiu a anterior Comissão Parlamentar Conjunta na condição de Comissão Preparatória de um Parlamento do Mercosul. A Decisão do CMC $\mathrm{n}^{\circ}$ 23/2005 veio aprovar o Protocolo Constitutivo do Parlamento do Mercosul.

${ }^{506}$ Existem ainda as Reuniões de Ministros de áreas específicas, os Grupos ad hoc de assessoria técnica ao Grupo do Mercado Comum e o Comitê de Cooperação Técnica.
} 
foi constituído dentro do bojo da Comissão do Comércio, como subórgão com a principal função de discussão do tema da defesa da concorrência ${ }^{507}$.

Importante salientar, conforme denota Jaeger Júnior, que "os membros das instituições são representantes dos governos dos Estados-partes e estão sujeitos à autoridade e direcionamento deles. Em função disso, possuem poderes limitados" ${ }^{\text {, }}$.

\subsection{O Mercosul e suas fontes}

De acordo com o art. 41 do Protocolo de Ouro Preto, constituem fontes do Mercosul: o Tratado de Assunção ${ }^{509}$, seus protocolos e instrumentos adicionais ou complementares; outros acordos celebrados no âmbito do Tratado de Assunção; as decisões do CMC; as resoluções do GMC; e as diretrizes da Comissão de Comércio do Mercosul. Constituem ainda fontes acessórias e complementares os princípios gerais de direito e os laudos do Tribunal Arbitral (conforme Protocolo de Brasília) ${ }^{510}$.

O processo de formação de normas do Mercosul é simples ${ }^{511}$. Normalmente a constituição de normas no Mercosul inicia no GMC, o qual tem poder de iniciativa, o que lhe confere participação ativa no processo legislativo. As proposições do GMC são remetidas ao CMC para que possa deliberar sobre a tomada ou não de uma decisão. Não há previsão nos instrumentos normativos do Mercosul sobre potencial colaboração entre seus órgãos.

Interessante notar que em 1994 o Protocolo de Ouro Preto veio esclarecer quanto à vinculação das manifestações do CMC, do GMC e da Comissão de Comércio do Mercosul, matéria que não estava esclarecida no Tratado de Assunção. As decisões, resoluções e diretrizes são, desta forma, obrigatórias para os Estados-Partes, tal qual o são o Tratado de Assunção, o Protocolo de Brasília e o Protocolo de Ouro Preto.

\footnotetext{
507 Jaeger Júnior sintetiza que "os órgãos aplicadores das normas da concorrência são a Comissão e o Comitê". (JAEGER JÚNIOR, Augusto. Liberdade de concorrência na União Europeia e no Mercosul. São Paulo: LTr, 2006, p. 550).

${ }^{508}$ Id., ibid., p. 572.

${ }^{509}$ O Tratado de Assunção é composto por 24 artigos e quatro anexos. Cunha esclarece que "seu tamanho é relativamente modesto se comparado com o Tratado de Roma, de 1975, instituidor da então Comunidade Econômica Europeia, mas isso se deve ao fato de o impulso inicial da União Europeia ter sido muito mais forte do que no Mercosul". (CUNHA, Ricardo Thomazino da. Direito de defesa da concorrência: Mercosul e União Europeia. Barueri, SP: Manole, 2003, p. 175).

510 ACCIOLY, Elizabeth. Mercosul e União Europeia: estrutura jurídico-institucional. 4. ed. Curitiba: Juruá, 2010, p. 77.

${ }^{511}$ JAEGER JÚNIOR, Augusto. Op. cit., 2006, p. 550.
} 
Ademais, de acordo com o art. 37 do Protocolo de Ouro Preto, as normas expedidas pelo CMC, GMC e Comissão do Comércio devem ser por consenso, sendo necessária a presença de todos os Estados-Partes na respectiva reunião ${ }^{512}$. Desta forma, não é possível que sejam tomadas decisões por maioria, a exemplo do que ocorre na União Europeia, culminando no fato de que decisões não tomadas unanimemente não são acatadas ${ }^{513}$.

De acordo com os arts. 38 e 42 do Protocolo de Ouro Preto as normas de caráter obrigatório emanadas pelos órgãos do Mercosul devem ser incorporadas aos ordenamentos jurídicos nacionais mediante os procedimentos previstos pelas respectivas legislações nacionais, devendo os Estados-Partes tomar todas as medidas necessárias para assegurar o cumprimento de tais normas. Disto se depreende que tais normas não são autoaplicáveis, assumindo caráter intergovernamental e devendo ser incorporadas pelos ordenamentos jurídicos dos Estados-Partes ${ }^{514}$.

Considerado o ordenamento jurídico brasileiro, Baptista classifica a internalização das decisões do Mercosul por meio de duas categorias diferenciadas, a saber, (i) quando a normativa do bloco tratar de matéria de natureza e hierarquia de lei, dependerá dos trâmites previstos no direito interno; e (ii) quando a matéria relacionar-se a questões de natureza meramente regulamentar, as normativas poderão ser internalizadas pelo Poder Executivo, através de decretos e portarias, em cumprimento de uma obrigação internacional ao qual o Brasil está vinculado ${ }^{515}$.

Diferentemente da União Europeia, portanto, o modelo institucional do Mercosul não contempla a criação de agências supranacionais e, assim, não há prevalência das

\footnotetext{
512 JAEGER JÚNIOR, Augusto. Liberdade de concorrência na União Europeia e no Mercosul. São Paulo: LTr, 2006, p. 546.

513 "A isso também está ligado o problema da uniformidade de peso na votação, uma vez que cada Estado, independentemente de sua importância, tem o mesmo poder. Pelo fato de um Estado discordante poder atrapalhar o processo, é possível referir que a ele é conferido um direito de veto. Atribui-se essa característica ao fato de que se não fosse assim, Paraguai e Uruguai não teriam aderido ao projeto de integração. Críticas a esse sistema de consenso observam que essa não foi a melhor solução possível e que isso pode conduzir o processo a uma paralização". (Id., ibid., p. 551).

514 "O Protocolo de Ouro Preto, em seu art. $2^{\circ}$, firma o caráter intergovernamental das decisões tomadas no bloco. Esse dispositivo é importante, pois por meio dele é que se podem orientar juridicamente os traços e fundamentos jurídico-institucionais e do bloco, sobretudo visualizar sua disparidade em relação à União Europeia [...]. Outro aspecto relevante do Protocolo de Ouro Preto foi o dispositivo do art. 38, que trata da aplicação interna das normas emanadas dos órgãos do Mercosul, estabelecendo o compromisso dos Estados de incorporar essas normas mediante procedimento específico para garantir a vigência simultânea". (MENEZES, Wagner. Mercado Comum do Sul (Mercosul). Blocos econômicos e integração na América Latina, África e Ásia. Curitiba: Juruá, 2008, pp. 144-150).

515 "Com efeito, o tratado dá a essas decisões um caráter obrigatório, mas estabelece, também, que a implementação se fará de forma prevista pela legislação dos Estados-membros. A obrigatoriedade para todos é a sua implementação. Trata-se de obrigação de meios: em preexistindo os instrumentos legislativos que o permitam, a sua aplicação é imediata. O Poder Executivo tem o dever legal e obrigacional, decorrentes do tratado, de implementá-las imediatamente, mediante decretos". (BAPTISTA, Luiz Olavo. Inserção dos Tratados no Direito brasileiro. Revista de Informação Legislativa. Brasília, out./dez. 1996, n. 132, p. 79).
} 
normas emanadas pelos seus órgãos em relação às legislações nacionais. Por outro lado, os Estados-Partes possuem a obrigação internacional de cumprir os tratados e demais regras emanadas pelos órgãos do Mercosul ou suas instituições ${ }^{516}$.

Enquanto isso, a escolha por parte dos Estados-Partes do Mercosul de um regime de intergovernabilidade, o qual contempla a transferência do poder decisório dos EstadosPartes aos órgãos do Mercosul em caráter precário, culmina em uma situação em que as decisões do bloco, as quais já são dependentes de consenso para aprovação, somente avançam quando há efetivo interesse político interno dos Estados-Partes para tanto. Os interesses do bloco ficam, desta maneira, enfraquecidos e aumenta a dificuldade na implementação dos objetivos institucionais e econômicos perseguidos ${ }^{517}$.

\subsection{O Mercosul e a matéria concorrencial}

Interessante ressaltar que umas das matérias reguladas no âmbito do Mercosul é a concorrência, sendo o seu acordo constitutivo, o Tratado de Assunção, considerado o primeiro instrumento a trazer regras sobre o Direito Internacional da Concorrência. Os Estados-Partes do Mercosul não somente buscaram a regulação da temática da concorrência, conforme orienta Menezes, mas também a incluíram na agenda do relançamento do Mercosul dentre os temas prioritários com o objetivo de "aprofundar o caminho em direção à conformação dos objetivos do bloco" ${ }^{\text {,518. }}$.

Dentre as implicações dos objetivos pretendidos pelos Estados-Partes ${ }^{519}$, o art. $1^{\circ}$ do Tratado de Assunção prevê a criação de um mercado comum fundado na livre

\footnotetext{
516 “O Mercosul, todavia, não caminha na via rápida comunitária, para a internalização ou aplicação das suas normas, pela sua própria conformação intergovernamental. Aqui a política por vezes se sobrepõe ao direito, e por não haver prazo para que a legislação mercosulina seja transposta, pode-se antever a demora na sua transposição, a depender do maior ou menor interesse dos Estados". (ACCIOLY, Elizabeth. Mercosul e União Europeia: estrutura jurídico-institucional. 4. ed. Curitiba: Juruá, 2010, p. 114).

517 Jaeger Junior que enfatiza a "proposta que faz eco na maioria dos autores que tratam do Mercosul, anunciada especialmente durante as situações de crise, é a criação de entidades supranacionais para assegurar o cumprimento das normas". (JAEGER JÚNIOR, Augusto. Liberdade de concorrência na União Europeia e no Mercosul. São Paulo: LTr, 2006, p. 572).

${ }^{518}$ MENEZES, Wagner. Mercado Comum do Sul (Mercosul). Blocos econômicos e integração na América Latina, África e Ásia. Curitiba: Juruá, 2008, p. 157.

${ }^{519}$ Cunha destaca que "estas metas são importantes para entendermos os objetivos da integração, aos quais devem estar atreladas todas as políticas e legislações comuns, inclusive de defesa da competição". (CUNHA, Ricardo Thomazino da. Direito de defesa da concorrência: Mercosul e União Europeia. Barueri, SP: Manole, 2003, pp. 175-176). Ademais, Accioly esclarece que "no Capítulo I do Tratado de Assunção, estão presentes os propósitos, princípios e instrumentos, prevendo o seu art. $1^{\text {o }}$ os seus objetivos. Dentre eles destaque-se o respeito à livre circulação de bens, de serviços e de fatores produtivos, através, dentre outros, da eliminação dos direitos alfandegários e restrições não tarifárias à circulação de mercadorias e de qualquer outra medida de efeito equivalente; o estabelecimento de uma tarifa externa comum e a adoção de uma política comercial comum com relação a terceiros Estados ou agrupamentos de Estados; a coordenação de
} 
circulação de bens, serviços e fatores produtivos, e estabelece a necessidade de coordenação de políticas macroeconômicas e setoriais entre os Estados-Partes, as quais incluem comércio exterior, agrícola, industrial, fiscal, monetária, cambial e de capitais, bem como de outras que se acordem, a fim de assegurar condições adequadas de concorrência entre os Estados-Partes ${ }^{520}$.

Desta forma, a consecução da defesa da concorrência no âmbito do Mercosul deve considerar os demais objetivos previstos no Tratado de Assunção, dentre os quais estão o desenvolvimento econômico com justiça social, a melhor utilização dos recursos disponíveis, a preservação do meio ambiente, a coordenação de políticas macroeconômicas e a coordenação de diferentes setores da economia.

Ademais, o art. $4^{\circ}$ estabelece que nas relações com terceiros países, os EstadosPartes devem assegurar condições equitativas de comércio. Com essa finalidade, os Estados-Partes devem aplicar as suas legislações nacionais para inibir importações cujos preços estejam influenciados por subsídios, dumping ou qualquer outra prática desleal. Além disso, paralelamente, os Estados-Partes devem coordenar suas respectivas políticas nacionais com o objetivo de elaborar normas comuns sobre a concorrência comercial.

Dentre os princípios consagrados no Tratado de Assunção estão o princípio da reciprocidade de direitos e obrigações entre os Estados-Partes, o princípio da não discriminação, o princípio do tratamento nacional e o princípio do pacta sunt servanda. Além disso, o tratado traz regras sobre transparência na coordenação de políticas nacionais para assegurar condições equitativas de comércio com terceiros e estabelece métodos para combater as diferenças pontuais sobre a liberação comercial do Paraguai e Uruguai ${ }^{521}$.

Note-se que o Tratado de Assunção falhou em trazer princípios gerais sobre concorrência, linhas gerais da política e direito da concorrência do bloco ${ }^{522}$. Limitou-se a

políticas macroeconômicas e setoriais entre Estados-Partes, para assegurar condições adequadas de concorrência entre eles, e o compromisso destes de harmonizar suas legislações nas áreas pertinentes, para lograr o fortalecimento do processo de integração". (ACCIOLY, Elizabeth. Mercosul e União Europeia: estrutura jurídico-institucional. 4. ed. Curitiba: Juruá, 2010, p. 74).

520 “Além da política da concorrência, todas as outras mencionadas podem afetar a competição no mercado. Sendo assim, além do ato de harmonizar, a coordenação das políticas entre si é de grande relevo para evitar conflitos entre elas. Exemplo comum de controvérsia ocorre entre a política de concorrência e a industrial, quando a primeira fomenta a competição e a outra incentiva o crescimento industrial pela concentração econômica". (CUNHA, Ricardo Thomazino da. Direito de defesa da concorrência: Mercosul e União Europeia. Barueri, SP: Manole, 2003, pp. 175-177).

${ }^{521}$ ACCIOLY, Elizabeth. Op. cit., 2010, p. 73.

522 "O Tratado funciona como instrumento gerador do processo de integração; baseado na importância do direito da concorrência para a integração, deveria trazer, ao menos, os princípios a serem seguidos neste campo do direito. Não o faz, deixando o problema a ser discutido, posteriormente, pelos Estados Partes". (CUNHA, Ricardo Thomazino da. Op. cit., 2003, p. 182). No mesmo sentido, ver JAEGER JÚNIOR, Augusto. Liberdade de concorrência na União Europeia e no Mercosul. São Paulo: LTr, 2006, p. 640. 
estabelecer a necessidade de coordenação das políticas nacionais, com o intuito de elaborar normas comuns. A falta de uma regulamentação completa sobre o tema concorrencial no tratado que constitui o alicerce fundamental do Mercosul e que define as diretrizes gerais da integração econômica, acarreta uma certa insegurança jurídica.

Adicionalmente, os Estados-Partes do Mercosul não possuem uma expressiva tradição de regulação da concorrência nos respectivos ordenamentos nacionais ${ }^{523}$. Note-se que os países envolvidos na integração do Mercosul possuem como característica marcante o elevado grau de distorção do mercado em função das políticas econômicas adotadas pelo governos, que refletem na disparidade normativa entre os Estados-Partes ${ }^{524}$.

À época da integração econômica entre Argentina, Brasil, Paraguai e Uruguai, apenas os dois primeiros países possuíam legislações internas de defesa da concorrência. Somente após a assinatura do Tratado de Assunção, o Uruguai e o Paraguai começaram a se preocupar com a promulgação de uma legislação dessa natureza. Atualmente, dentre os atuais Estados-Partes do Mercosul, apenas Brasil, Argentina, Uruguai e Venezuela possuem legislação específica sobre o tema, enquanto que o Paraguai conta somente com disposições constitucionais a respeito da defesa da concorrência ${ }^{525}$.

Essa disparidade normativa em matéria da concorrência entre os Estados-Partes, temporal e em relação ao conteúdo, traduz um dos motivos do atraso da evolução da matéria no Mercosul. De fato, a política concorrencial depende de uma uniformidade na evolução de outras matérias relevantes ao comércio internacional. A falta de harmonização, verificada entre as legislações nacionais dos Estados-Partes do Mercosul,

\footnotetext{
523 “A inexistência do correto emprego das leis de defesa da concorrência está relacionada ao estágio de desenvolvimento e à política de crescimento econômico adotada na região. Todos os Estados desta área desenvolveram-se tardiamente, se comparados com os países desenvolvidos do hemisfério norte, denominando-se, como se convencionou chamar, de capitalismo tardio". (CUNHA, Ricardo Thomazino da. Direito de defesa da concorrência: Mercosul e União Europeia. Barueri, SP: Manole, 2003, p. 127). Nesse mesmo sentido, ver JAEGER JÚNIOR, Augusto. Liberdade de concorrência na União Europeia e no Mercosul. São Paulo: LTr, 2006, p. 602).

${ }^{524}$ Inclusive, por tal motivo, o CMC do Mercosul adotou a Decisão no 20/1994, com o objetivo de eliminar as políticas públicas que distorcem a competitividade.

${ }^{525}$ No Brasil, destacam-se a Lei da Concorrência, a Lei $n^{\circ}$ 9.021, de 30 de março de 1995 e a Lei ${ }^{\circ} 10.149$, de 21 de dezembro de 2000. A legislação da Argentina compreende a Lei $\mathrm{n}^{\circ} 25.156$, de 20 de setembro de 1999, conforme alterada (anteriormente já vigia a Lei $\mathrm{n}^{\circ} 22.262 / 1980$ sobre a matéria). A legislação do Uruguai traduz-se na Lei $n^{\circ} 18.159$, de 20 de julho de 2007 (anteriormente vigia a Lei $n^{\circ} 17.243 / 2000$ e a Lei $n^{\circ}$ 17.296/2011). Em relação ao Paraguai, a disposição sobre a defesa da concorrência é encontrada no art. 107: "da liberdade da concorrência" da sua Constituição Nacional - sem, portanto, haver uma legislação específica sobre o tema. Já em relação à Venezuela, vigora a "Ley para promover y proteger el ejercicio de la libre competencia" (LPPLC), que foi promulgada em 13 de dezembro de 1991, em vigor desde 13 de janeiro de 1992. De acordo com Marques, o Brasil é, atualmente, o membro do Mercosul mais avançado em matéria de política da concorrência. (MARQUES, Frederico do Valle Magalhães. Direito Internacional da Concorrência. Rio de Janeiro: Renovar, 2006, p. 292).
} 
atrapalha o desenvolvimento do tema concorrencial no âmbito regional e das instituições necessárias a sua evolução ${ }^{526}$.

Não é possível dizer, todavia, que inexiste uma política nacional de cada um dos Estados-Partes do Mercosul. O fato de a maioria dos países envolvidos já possuírem uma legislação de defesa da concorrência é indicativo de que seus sistemas acatam as diretrizes públicas sobre política concorrencial. E a existência de tais políticas nacionais dificulta a aceitação de normas sobre concorrência no âmbito regional, uma vez que os sistemas já existentes deverão adaptar-se para funcionar de acordo com as diretrizes do bloco econômico $^{527}$. Por outro lado, o desenvolvimento do sistema normativo da União Europeia em matéria concorrencial, e a sua coexistência com as legislações nacionais dos EstadosMembros que a compõem, é um forte indicativo de que é possível superar eventuais barreiras existentes ao acolhimento de regramento regional efetivo em matéria da concorrência.

2.2.3.1.5 As Decisões do Conselho do Mercado Comum sobre a matéria da concorrência

O CMC tomou uma série de Decisões, que complementam e regulamentam as regras encontradas no Tratado de Assunção, no Protocolo de Brasília e no Protocolo de Ouro Preto, dentre as quais se destaca as $n^{\circ} 21 / 1994, n^{\circ} 18 / 1996, n^{\circ}$ 04/2004, no 15/2005 e $n^{\circ} 43 / 2010$, todas com regulamentação específica relacionada à concorrência no Mercosul $^{528}$, e sobre as quais se passa a descrever. Para informação mais completa sobre as Decisões do CMC relacionadas à cooperação entre os Estados-Partes em matéria concorrencial, ver o Anexo B deste estudo.

\footnotetext{
526 “Assim, um dos grandes motivos da lentidão desse processo de harmonização das legislações, em áreas intimamente relacionadas ao direito da concorrência, é que os parceiros do Brasil, no Mercosul, encontramse, ainda, relativamente atrasados em áreas como direito da concorrência, direitos dos consumidores, marcas e patentes, dentre outras" (MARQUES, Frederico do Valle Magalhães. Direito Internacional da Concorrência. Rio de Janeiro: Renovar, 2006, p. 290).

${ }^{527}$ Id., ibid., p. 295.

${ }^{528}$ São exemplos de outras decisões adotadas pelo CMC relacionadas à matéria concorrencial: $\mathrm{n}^{\circ}$ 03/1992 (procedimento de queixas e consultas sobre práticas desleais de comércio, revogado pela Decisão 10/2011),
} 
a) Decisão do Conselho do Mercado Comum n ${ }^{\circ}$ 21/1994

Marco regulatório do Mercosul em matéria concorrencial ${ }^{529}$, a Decisão do CMC $\mathrm{n}^{\circ}$ 21/1994 foi tomada em dezembro de 2004 durante a VII Reunião do CMC, realizada em Ouro Preto. Esta decisão aprovou as pautas gerais de harmonização da defesa da concorrência nos Estados-Partes do Mercosul, prevendo um sistema provisório de colaboração dos Estados-Partes para a elaboração de um Estatuto da Concorrência do Mercosul. Acolheu, para tal efeito, um procedimento de tramitação das denúncias apresentadas durante o período de transição até que o estatuto definitivo fosse adotado.

Concomitantemente com a Decisão $n^{\circ}$ 21/1994 foi aprovado um documento denominado "Elementos Básicos de Defesa da Concorrência no Mercosul" (também referido como "Pautas Gerais de Harmonização"). As Pautas Gerais de Harmonização propostas tratavam de um patamar mínimo que deveria ser incorporado pelos EstadosPartes nas respectivas legislações nacionais de defesa da concorrência ${ }^{530}$. Com a adoção de regras mínimas harmonizadas, os ordenamentos jurídicos nacionais estariam, assim, aptos a avançar na cooperação em matéria concorrencial. Desta forma, as regras desta decisão não podem ser consideradas como supranacionais, já que tratam somente de um parâmetro a ser considerado pelos países na aprovação das respectivas legislações.

A decisão trazia disposições relacionadas tanto às práticas restritivas, quanto aos atos de concentração. No que se refere ao controle dos atos de concentração no âmbito do Mercosul, que constitui o objeto deste estudo, as Pautas Gerais de Harmonização estabeleceram na sua Terceira Seção que os Estados deverão submeter ao seu controle as operações de qualquer natureza que impliquem em um controle de ao menos $20 \%$ do mercado relevante, e que possam produzir efeitos em todo ou em parte do Mercosul.

Adicionalmente, dentre as suas disposições, a Decisão nº 21/1994 implementou um sistema provisório de resolução de controvérsias em matéria concorrencial, até que o Estatuto Concorrencial do Mercosul fosse adotado. O sistema provisório contemplava três fases, designadamente uma fase de resolução voluntária, outra de tentativa de composição junto à Comissão de Comércio e, finalmente, uma fase dentro do sistema aprovado pelo

$\mathrm{n}^{\text {o }}$ 07/1993 (regulamento relativo à defesa contra as importações objeto de dumping ou de subsídios), $\mathrm{n}^{\circ}$ 20/1994 (diretrizes para eliminar políticas públicas que distorcem a competitividade).

529 A partir dela, começou a ser desenhado o sistema de defesa da concorrência do Mercosul. (CUNHA, Ricardo Thomazino da. Direito de defesa da concorrência: Mercosul e União Europeia. Barueri, SP: Manole, 2003, p. 187).

530 JAEGER JÚNIOR, Augusto. Liberdade de concorrência na União Europeia e no Mercosul. São Paulo: LTr, 2006, p. 648. 
Protocolo de Brasília ${ }^{531}$. Por outro lado, a decisão falhou em trazer consequências às práticas anticompetitivas, não havendo contemplado hipóteses de sanções ou nulidades no âmbito do Mercosul, somente remetendo-as à aplicação das sanções previstas pelos ordenamentos jurídicos internos dos Estados-Partes.

Casella informa, no entanto, que a Decisão no 21/1994 "não foi feliz em nenhum dos objetivos, já que não foi realmente aplicada e não conseguiu a harmonização legislativa pretendida" ${ }^{532}$. Por outro lado, em conformidade com o art. $3^{\circ}$ da Decisão $n^{\circ}$ 21/1994, os Estados-Partes do Mercosul se reuniram em Fortaleza para a celebração de um protocolo em matéria da concorrência, sobre o qual se discorrerá a seguir.

b) Decisão do Conselho do Mercado Comum no 18/1996 - Protocolo de Defesa da Concorrência do Mercosul

A Decisão do CMC no 18/1996, adotada em Fortaleza, em dezembro de 1996, aprovou o Protocolo de Defesa da Concorrência no Mercosul (Protocolo de Fortaleza), o qual tinha por objeto a defesa da concorrência no âmbito do Mercosul ${ }^{533}$. O Protocolo de Fortaleza nunca chegou a entrar em vigor e acabou por ser revogado pela Decisão do Conselho do Mercado Comum n ${ }^{\circ} 43 / 2010$, conforme se verá a seguir. No entanto, o seu estudo é relevante da medida em que constituiu o primeiro instrumento no âmbito do Mercosul aprovado com a pretensão de abarcar a matéria concorrencial de forma completa e poderá, no futuro, ser o instrumento de referência para a evolução do tema no âmbito regional.

${ }^{531}$ JAEGER JÚNIOR, Augusto. Liberdade de concorrência na União Europeia e no Mercosul. São Paulo: LTr, 2006, p. 650.

${ }^{532}$ CASELLA, Paulo Borba. Direito da Concorrência na UE e no Mercosul. In: BAPTISTA, Luiz Olavo; MERCADANTE, Araminta de Azevedo; CASELLA, Paulo Borba (orgs.). Mercosul: das negociações à implantação. 2. ed. São Paulo: LTr, 1998, p. 349. Nesse sentido, Cunha também reconhece que os objetivos da Decisão no 21/1994 não prosperaram, justificando tal desfecho na falta de estrutura do Mercosul: "o subgrupo ${ }^{\circ} 10$ do GMC, por meio da Comissão ad hoc de Defesa da Concorrência, havia optado por estabelecer sistema similar ao modelo europeu, porém, devido à deficiência da estrutura institucional do Mercosul, chegou-se ao possível no momento, ou seja, a normas provisórias com apenas pautas de harmonização". (CUNHA, Ricardo Thomazino da. Direito de defesa da concorrência: Mercosul e União Europeia. Barueri, SP: Manole, 2003, p. 187). No mesmo rumo, ver JAEGER JÚNIOR, Augusto. Liberdade de Concorrência na União Europeia e no Mercosul. São Paulo: LTr, 2006, pp. 640 e 651).

533 "Dentre os pontos tratados pelo PDC destacam-se: os subsídios e medidas antidumping em relação às ações governamentais; e em relação ao setor privado, instrumentos para reprimir práticas anticompetitivas de âmbito regional e para controlar fusões e aquisições que alterem condições de concorrência em mais de um país, e a cooperação entre as agências nacionais de defesa da concorrência". (OLIVEIRA, Gesner; RODAS, João Grandino. Direito e Economia da concorrência. Rio de Janeiro: Renovar, 2004, p. 393). Já Jaeger Júnior destaca que "o Protocolo não incluiu a cláusula de proibição às ajudas dos Estados, que era a proposta da Argentina. [...] Por tal fato é dito que o Protocolo não satisfez totalmente as expectativas jurídicas e políticas. Possui, sim, grande similitude com a lei brasileira e com as diferentes fontes comunitárias". 
Em geral, o Protocolo trazia disposições genéricas que dependiam de maior especificação para serem aplicadas. Dentre elas constava a competência dos órgãos comuns de defesa da concorrência, a determinação das práticas anticoncorrenciais ilícitas a ser combatidas, o procedimento a ser seguido na apuração e repreensão das referidas práticas, as penas aplicáveis, a cooperação entre as autoridades de defesa da concorrência, a celebração de compromissos de cessação de prática anticompetitiva, a solução de controvérsias, dentre outros.

$\mathrm{O}$ art. $2^{\circ}$ do Protocolo regulava o seu âmbito de aplicação mediante adoção da teoria dos efeitos ${ }^{534}$. Nesse sentido, estabelecia que as suas regras deveriam ser aplicadas aos atos praticados por pessoas físicas ou jurídicas de direito público ou privado ou outras entidades ${ }^{535}$ que tenham por objeto produzir ou que produzam efeitos sobre a concorrência no âmbito do Mercosul e que afetem o comércio entre os Estados-Partes ${ }^{536}$. O mercado geográfico relevante a ser considerado era, portanto, o Mercosul, não importando se o ato fosse executado fora do território. Destaca-se que o Protocolo limitava a sua aplicação aos atos que efetivamente afetassem o mercado do Mercosul, descartando aqueles que somente teriam potencialidade de afetar o bloco.

Em relação ao controle de atos e contratos, o Protocolo limitou-se a fixar um prazo de dois anos para que os Estados-Partes estabelecessem normas comuns para o controle dos atos que pudessem limitar ou de qualquer forma prejudicar a livre concorrência, resultar na dominação do mercado regional, inclusive aqueles de concentração econômica - o que nunca chegou a ser concretizado ${ }^{537}$.

(JAEGER JUNIOR, Augusto. Liberdade de concorrência na União Europeia e no Mercosul. São Paulo: LTr, 2006, p. 654).

534 "Este é um caso típico de aplicação extraterritorial da lei. No caso em questão tem-se como território o Mercosul e a aplicação do Protocolo para os atos que tenham por objeto produzir ou que produzam efeitos sobre a concorrência em seu território, não importando, assim, se o ato foi concretizado/realizado fora das fronteiras do Mercosul, bastando, para que seja passível a aplicação do Protocolo, que tal ato afete o comércio intrabloco". (MARQUES, Frederico do Valle Magalhães. Direito Internacional da Concorrência. Rio de Janeiro: Renovar, 2006, p. 299). No mesmo sentido, ver JAEGER JÚNIOR, Augusto. Liberdade de concorrência na União Europeia e no Mercosul. São Paulo: LTr, 2006, p. 658.

535 "Com o uso da expressão "outras entidades", o legislador deu a entender que o agente econômico não precisa estar revestido de personalidade jurídica, bem como não necessita ter fins lucrativos [...]. De fato, o Conselho do Mercosul adotou em seus pronunciamentos um conceito amplo de empresa, que desempenha para a delimitação do âmbito de aplicação da legislação um papel decisivo”. (Id., ibid., p. 657).

536 Dentre as entidades afetadas pelo Protocolo, incluem-se as empresas públicas que desempenham monopólio estatal. Ademais, o art. $3^{\circ}$ do Protocolo reserva à competência exclusiva dos Estados-Partes a regulação dos atos praticados nos respectivos territórios e cujos efeitos a eles se restrinjam.

537 Casella esclarece que o Protocolo de Fortaleza não continha nenhuma regra relativa aos atos de concentração, autorizando-os ou desautorizando-os, não havendo necessidade de submissão dos atos à autoridade comum. (CASELLA, Paulo Borba. Direito da Concorrência na UE e no Mercosul. In: BAPTISTA, Luiz Olavo; MERCADANTE, Araminta de Azevedo; CASELLA, Paulo Borba (orgs.). Mercosul: das negociações à implantação. 2. ed. São Paulo: LTr, 1998, p. 350). 
Desta forma, pode-se dizer que com o Protocolo de Fortaleza o Mercosul não foi dotado de um sistema de defesa da concorrência completo e suficiente, uma vez que não regulou o controle de atos de concentração ${ }^{538}$. Esta situação é ainda de maior relevância se considerado que os mercados brasileiro e argentino são extremamente concentrados. Jaeger Júnior alerta, no entanto, que apesar de a lacuna legislativa no âmbito do Mercosul sobre os atos de concentrações culminar em dificuldades no controle das fusões e aquisições, as quais transformam o mercado substancialmente pela remoção de barreiras internas, é conhecida a prática internacional de se adotar regras sobre atos de concentração somente após a implementação de uma legislação da concorrência ${ }^{539}$.

O Protocolo previu, ainda, a criação do Comitê de Defesa da Concorrência, o qual deveria ser formado pelos órgãos nacionais de aplicação do Protocolo em cada EstadoParte. Ademais, o Protocolo estabeleceu em seu Capítulo V o procedimento que deveria ser observado para a submissão dos atos de controle do Comitê ${ }^{540}$. O Capítulo VIII previa, ainda, regras de cooperação técnica entre os Estados-Partes, com o objetivo de assegurar a implementação do Protocolo. Ademais, por meio do art. 32, os Estados-Partes se comprometeram, no prazo de dois anos a contar da sua vigência, e com o objetivo de incorporar o protocolo nos respectivos territórios, a elaborar regras de aplicação em relação às ajudas de Estado.

Por fim, o Protocolo previa um sistema de cooperação entre as autoridades nacionais de defesa da concorrência, do qual dependida o sucesso do sistema que se pretendia implementar. De fato, toda a apuração das práticas anticoncorrenciais pelo Protocolo dependia da atuação de ao menos uma autoridade de defesa da concorrência, fazendo surgir a necessidade de cooperação entre autoridades nacionais nos casos em que determinada prática afetasse outros países do Mercosul. Para o propósito de fomento da cooperação, o Protocolo previa um programa de troca de informações e experiências, além

\footnotetext{
${ }^{538}$ CUNHA, Ricardo Thomazino da. Direito de defesa da concorrência: Mercosul e União Europeia. Barueri, SP: Manole, 2003, p. 221.

539 JAEGER JÚNIOR, Augusto. Liberdade de concorrência na União Europeia e no Mercosul. São Paulo: LTr, 2006, p. 667.

540 "Realce-se o fato de caber ao órgão concorrencial de cada Estado-parte a responsabilidade pela instauração do procedimento, pela investigação da prática restritiva da concorrência e pela elaboração de parecer sobre a prática a ser submetida à análise do Comitê, cuja decisão - imposição de medida preventiva ou multa - depende do referendo da Comissão do Comércio do Mercosul, que por ser órgão intergovernamental, depõe, segundo alguns, contra a independência das suas decisões". (OLIVEIRA, Gesner; RODAS, João Grandino. Direito e economia da concorrência. Rio de Janeiro: Renovar, 2004, p. 393 ).
} 
de treinamento técnico ${ }^{541}$, compilação de decisões e investigação conjunta de práticas anticoncorrenciais.

A doutrina é unânime em defender que o Protocolo nunca chegou a surtir seus efeitos para os Estados-Partes do Mercosul, uma vez que não foi internalizado por todos os países $^{542}$. Havendo sido revogado em 2010, a menção a este instrumento é relevante no sentido de conhecer o histórico de formação das regras de integração sobre a matéria.

c) Decisões do Conselho do Mercado Comum nº 04/2004 e 15/2006

O Entendimento sobre cooperação para a aplicação de suas leis nacionais de concorrência (Decisão do CMC no 4, de 07 de julho de 2004) e o Entendimento sobre cooperação para o controle de concentrações econômicas de âmbito regional (Decisão do CMC $\mathrm{n}^{\circ} 15$, de 20 de julho de 2006) estabelecem regras de cooperação entre as autoridades de defesa da concorrência dos Estados-Partes do Mercosul ${ }^{543}$.

Note-se que em 2009 ambas as decisões foram internalizadas no ordenamento jurídico brasileiro pelo SBDC, por meio de portaria conjunta entre o CADE, a SDE e o $\mathrm{SEAE}^{544}$. Neste tocante faz-se especial referência aos comentários inseridos no item 2.2.3.1.3, supra, sobre opções facultadas pelo ordenamento jurídico brasileiro na internalização de normas emanadas no Mercosul. Conforme referido anteriormente, nos casos em que o conteúdo da norma mercosulina seja de natureza essencialmente regulamentar, é possível que seu acolhimento no ordenamento nacional se dê por intermédio de ato do Poder Executivo, dentro das competências auferidas pelo sistema. Tendo em vista que as decisões em comento tratam da matéria concorrencial, entende-se aceitável que sejam acolhidas por ato do SBDC.

\footnotetext{
541 "No Protocolo, além da cooperação na troca de informações, prevê-se também a cooperação interinstitucional, ou seja, entre órgãos nacionais de defesa da concorrência". (CUNHA, Ricardo Thomazino da. Direito de defesa da concorrência: Mercosul e União Europeia. Barueri, SP: Manole, 2003, p. 233).

${ }^{542}$ Ratificado pelo Paraguai em 30 de outubro de 1997 e promulgado no Brasil por meio do Decreto $\mathrm{n}^{\circ} 3.602$, de 18 de setembro de 2000. Pendia a internalização pelo Uruguai e pela Argentina. Ver OLIVEIRA, Gesner; RODAS, João Grandino. Direito e economia da concorrência. Rio de Janeiro: Renovar, 2004, p. 393; e CUNHA, Ricardo Thomazino da. Op. cit., 2003, p. 199. Note-se, ainda, que em 2002 os Estados-Partes adotaram Acordo sobre o Regulamento do Protocolo da Concorrência (disponível em: <http://www.sice.oas.org/trade/MRCSR/ agcompop.asp>. Acesso em: 17 jul. 2011). Carvalho Ramos e Cunha também defendem que o sistema regional do Mercosul não chegou a solucionar a questão de proteção da concorrência em relação ao Direito Internacional. (CARVALHO RAMOS, André de; CUNHA, Ricardo Thomazinho da. A defesa da concorrência em caráter global: utopia ou necessidade. In: CASELLA, Paulo Borba (org.). Guerra comercial ou integração econômica mundial. São Paulo: LTr, 1998, p. 829).

${ }^{543}$ Para informação mais completa sobre as Decisões do CMC relacionadas à cooperação entre os EstadosPartes em matéria concorrencial, ver o Anexo B deste estudo.
} 
A Decisão $n^{\circ}$ 04/2004 trata da cooperação entre as autoridades de defesa da concorrência dos Estados-Partes do Mercosul, tanto na vertente da aplicação das respectivas legislações nacionais de defesa da concorrência, quanto sobre a cooperação técnica. Tal decisão prevê um sistema de notificações diretas entre as autoridades nacionais de defesa da concorrência ${ }^{545}$ sobre as "atividades de aplicação", as quais compreendem quaisquer investigações ou procedimento conduzido por uma autoridade no marco da sua legislação de defesa da concorrência, inclusive aquelas que envolvam fusões ou aquisições em uma ou mais partes da transação, ou uma empresa que controle uma ou mais partes da transação, seja ela constituída ou organizada segundo as leis da outra parte, bem como no caso de busca de informações localizadas no território de outra parte - dentre outras hipóteses $^{546}$.

Note-se que a Decisão no 04/2004 é direcionada à cooperação entre as autoridades de defesa da concorrência na análise de atos de concentração apresentados perante uma das autoridades em que estejam envolvidas empresas constituídas e organizadas no território de outra parte. Não abrange, a princípio, preocupação em relação aos atos de concentração que possam afetar o mercado nacional dos outros Estados-Partes, quando promovidos por empresas que não tenham sido lá constituídas ou organizadas, tampouco o mercado do Mercosul como um todo.

Ainda de acordo com esta a Decisão $n^{\circ}$ 04/2004, o SBDC deve promover a notificação sobre operações de concentração no prazo de 15 dias a partir da publicação que noticia o recebimento pelo SBDC de operação contracionista para análise. Ademais, de acordo com o art. $\mathrm{V}$ da decisão, as autoridades nacionais de defesa da concorrência poderão coordenar as respectivas atividades de aplicação com relação a matérias interrelacionadas ou conexas, quando assim julgarem conveniente.

\footnotetext{
${ }^{544}$ Ambos os instrumentos foram internalizados por intermédio da Portaria Conjunta CADE/SDE/SEAE ${ }^{\circ}$ 148, de 13 de novembro de 2009.

${ }^{545}$ De acordo com o art. XI da Decisão $\mathrm{n}^{\circ}$ 04/2004 qualquer das autoridades de defesa da concorrência poderá requerer que as solicitações, as informações e os documentos requeridos sejam remetidos pelos canais diplomáticos habituais.

${ }^{546}$ De acordo com o art. II.2, são atividades de aplicação da Decisão no 04/2004: (i) forem relevantes para as atividades de outra Parte na aplicação de suas respectivas leis; (ii) envolvam Práticas Anticompetitivas, diferentes de fusões e aquisições, realizadas em todo ou em parte substancial do território de outra Parte; (iii) envolvam fusões ou aquisições em que uma ou mais partes da transação, ou uma empresa que controle uma ou mais partes da transação, seja uma empresa constituída ou organizada segundo as leis de outra Parte; (iv) envolvam condutas supostamente exigidas, recomendadas ou aprovadas por outra Parte; (v) envolvam medidas legais que explicitamente exijam ou proíbam determinada conduta no território de outra Parte ou sejam, de alguma maneira, aplicadas à conduta em território de outra Parte; ou (vi) envolvam a busca de informações localizadas no território de outra Parte.
} 
Adicionalmente, o art. VI da Decisão no 04/2004 prevê que os Estados-Partes deverão, na medida em que seja admissível pela sua respectiva legislação nacional e compatível com seus interesses fundamentais, assegurar a consideração dos interesses fundamentais das outras partes. Tal disposição parece acolher de uma forma bastante incipiente o princípio da cortesia negativa, melhor analisado no item 3.2.1 deste estudo.

De acordo com o art. IX da Decisão no 04/2004, há o reconhecimento de que nenhuma parte está obrigada a fornecer informações às demais, se o provimento de tal informação for proibido de acordo com a sua lei nacional ou for incompatível com seus interesses fundamentais. Todavia, as partes têm o dever de manter a confidencialidade com respeito às informações fornecidas dessa forma por outra parte, não podendo concedê-la a terceiros.

Já a Decisão $n^{\circ} 15 / 2006$, por sua vez, trata especificamente da cooperação entre as autoridades de defesa da concorrência dos Estados-Partes em relação ao controle de concentrações econômicas de âmbito regional. Igualmente à Decisão nº 04/2004, esta Decisão regula a cooperação tanto em relação à aplicação das legislações nacionais de defesa da concorrência dos Estados-Partes, quanto sobre cooperação técnica. As atividades de aplicação previstas por esta decisão estão restritas ao controle de concentrações econômicas conduzidas por qualquer dos Estados-Partes ${ }^{547}$, englobando não somente as concentrações que surtam efeitos nos territórios de mais de um Estado-Parte, individualmente considerados, mas também aquelas que afetam o território do Mercosul como um todo 548 .

Note-se que diferentemente da Decisão $n^{\circ}$ 04/2004, a Decisão $n^{\circ}$ 15/2006 inclui como atividade de aplicação não somente as concentrações que envolvem empresas

\footnotetext{
${ }^{547}$ De acordo com o art. II.2 da Decisão $\mathrm{n}^{\circ}$ 15/2006, devem ser notificadas as seguintes atividades de aplicação: (i) forem relevantes para as atividades de outro Estado-Parte na aplicação de suas respectivas leis de defesa da concorrência; (ii) envolvam operações de concentração econômica que surtam efeitos, no todo ou em parte, no território de mais de um Estado-Parte; (iii) envolvam operações de concentração econômica em que uma ou mais partes da transação, ou uma empresa que controle uma ou mais partes envolvidas na transação, seja uma empresa constituída ou organizada segundo as leis de outro Estado-Parte; (iv) envolvam medidas legais que explicitamente exijam ou pró́bam determinada operação de concentração econômica no território de outro Estado-Parte ou sejam, de alguma maneira, aplicadas à operação de concentração econômica em território de outro Estado-Parte; ou (v) envolvam a busca de informações para a análise de atos de concentração econômica localizadas no território de outro Estado-Parte.

${ }^{548}$ Nesse sentido, ver definições propostas pela Decisão no 15/2006 no art. I: "Controle de concentração econômica é um procedimento de natureza preventiva que requer a apreciação de operações, sob qualquer forma manifestada, que possam limitar ou de qualquer forma prejudicar a livre concorrência, ou resultar no domínio de mercados relevantes de bens ou serviços, por uma Autoridade de Defesa da Concorrência, a qual pode aprovar a operação em sua integralidade, aprová-la com restrições ou reprová-la", e "Controle de concentração econômica de âmbito regional é o controle de concentração econômica reconhecido por duas ou mais Autoridades de Defesa da Concorrência dos Estados Partes do Mercosul como um controle de interesse
} 
constituídas e organizadas em outros Estados-Partes, mas também aquelas que surtem efeitos nos territórios dos outros Estados-Partes. Esta alteração no âmbito de aplicação das regras de cooperação, em relação à decisão anterior, parece, desta forma, estar acertada com a teoria dos efeitos.

À semelhança da decisão de 2004, a Decisão nº 15/2006 estabelece um sistema de notificações diretas entre autoridades de defesa de concorrência dos Estados-Partes ${ }^{549}$, pelo qual devem ser transmitidas informações sobre a natureza da operação de concentração econômica e os instrumentos legais pertinentes. De acordo com o art. II da decisão, o SBDC deverá promover a notificação no prazo de 15 dias contados da publicação que informa a notificação de uma operação ao SBDC. Além disso, é previsto que as autoridades nacionais de defesa da concorrência poderão autorizar a visita de funcionários dos outros Estados-Partes durante o curso da análise da concentração econômica.

A Decisão $n^{\circ} 15 / 2006$ acolheu, ainda, o princípio da cortesia negativa, tal qual o fez a Decisão no 04/2004 - ou seja, cada Estado-Parte deverá, na medida do permitido pela respectiva legislação nacional e que seja compatível com seus interesses fundamentais, assegurar a consideração dos interesses fundamentais dos demais Estados-Partes em todas as atividades de aplicação, inclusive na apreciação do mérito ${ }^{550}$.

$\mathrm{O}$ art. IV da decisão de 2006 acolhe o princípio da cortesia positiva. Assim, na eventualidade de um Estado-Parte entender que estão sendo levadas a cabo atividades de aplicação em outro Estado-Parte, ele poderá solicitar que as autoridades de defesa da concorrência do Estado requerido iniciem os procedimentos de cooperação previstos na decisão. A notificação, neste caso, deverá indicar os possíveis efeitos adversos de tal concentração econômica em relação a seus interesses fundamentais e incluir o oferecimento de informação e cooperação que tiver condições de fornecer. Uma vez recebida a solicitação de cooperação de outro Estado-Parte, a autoridade de defesa da concorrência deverá avaliar se iniciará o procedimento de cooperação e informar prontamente o Estado solicitante sobre a sua decisão, bem como sobre o andamento e

de dois ou mais Estados-Partes, por avaliar uma operação de concentração econômica que pode ter efeitos em um mercado geográfico relevante que abranja o território de mais de um Estado-Parte".

${ }^{549}$ De acordo com o art. XI da Decisão $\mathrm{n}^{\circ}$ 15/2006 qualquer das autoridades de defesa da concorrência poderá requerer que as solicitações, as informações e os documentos requeridos sejam remetidos pelos canais diplomáticos habituais.

${ }^{550}$ De acordo com o art. VI da Decisão n ${ }^{\circ}$ 15/2006. 
eventuais medidas tomadas no decorrer da atividade de aplicação que se relacionem com o mérito da operação ${ }^{551}$.

$\mathrm{O}$ art. V da Decisão $n^{\circ}$ 15/2006 prevê ainda que quando autoridades de defesa da concorrência de dois ou mais Estados-Partes estiverem realizando atividades de aplicação sobre concentrações econômicas inter-relacionadas ou conexas, deverão considerar a conveniência de promover a coordenação das respectivas atividades, levando em consideração os interesses dos demais Estados-Partes.

Finalmente, a Decisão no 15/2006 estabelece por meio do seu art. IX que nenhum Estado-Parte está obrigado a fornecer informações a outro Estado, caso a entrega de tal informação seja proibida de acordo com a legislação nacional ou for incompatível com seus interesses fundamentais. Por outro lado, cada Estado-Parte deve manter a confidencialidade sobre as informações que lhe forem fornecidas nesta qualidade, não lhe sendo possível disponibilizar tal informação confidencial a terceiros, sem que antes seja obtida anuência prévia do Estado ofertante.

Interessante notar que o CADE vem notificando aos países do Mercosul os casos de concentração econômica que possam de alguma forma causar efeitos no mercado comum ou no território nacional dos demais Estados-Partes. Um exemplo dessa situação está na concentração havida entre Compagnie de Saint-Gobain e Owens Corning ${ }^{552}$, na qual o Conselheiro-Relator Fernando de Magalhães Furlan recomendou, em vista de grande parte do mercado latino-americano ser abastecido pela Owens Corning, a comunicação da decisão às autoridades de defesa da concorrência dos Estados-Partes do Mercosul.

d) Decisão do Conselho do Mercado Comum n ${ }^{\circ}$ 43/2010 - Acordo de Defesa da Concorrência do Mercosul

A Decisão do CMC n 43/2010, tomada em Foz do Iguaçu em 2010, aprovou o Acordo de Defesa da Concorrência do Mercosul (Acordo de Foz do Iguaçu) e revogou o Protocolo de Fortaleza ${ }^{553}$. De fato, muitas eram as críticas direcionadas ao Protocolo ${ }^{554}$, o

\footnotetext{
${ }^{551}$ Note-se, no entanto, que de acordo com o art. IV.5 da Decisão $n^{\circ}$ 15/2006 as regras de cortesia negativa estabelecidas não visam limitar a discricionariedade das autoridades nacionais de defesa da concorrência na condução das atividades de aplicação.

${ }^{552}$ Ato de Concentração CADE ${ }^{\circ}$ 08012.001885/2007-11, realizada em 2007 por empresas estrangeiras (uma norte-americana e outra francesa), fez surtir efeitos no território nacional em razão do envolvimento da planta localizada em Capivari/SP. O CADE exerceu a sua competência com base na teoria dos efeitos e aplicou a legislação brasileira, decidindo pela reprovação da operação e determinando o desinvestimento realizado pela Saint-Gobain em Capivari/SP.

${ }^{553}$ Note-se que o Acordo ainda não foi incorporado pelos ordenamentos jurídicos dos Estados-Partes. Não foi possível localizar a proposição legislativa do Acordo de Defesa da Concorrência do Mercosul de 2010 junto
} 
que, aliado ao fato de o Protocolo nunca haver sido internalizado por todos os EstadosPartes, e assim nunca ter tido qualquer eficácia prática, fez com que o Conselho buscasse regular a matéria por meio de outro instrumento.

O Acordo de Foz do Iguaçu difere do Protocolo de Fortaleza na medida em que procurou dar um caráter de cooperação às regras de integração regional do Mercosul, sem a criação de qualquer órgão especializado, tampouco supranacional ${ }^{555}$. O Comitê Técnico de Defesa da Concorrência $n^{\circ} 5$ assumiu, por meio do Acordo de Foz do Iguaçu, as funções de órgão competente no bojo do Mercosul pela defesa da concorrência. Aos EstadosPartes, no entanto, remanesce a competência exclusiva para a regulação dos atos praticados, total ou parcialmente, nos respectivos territórios ou daqueles originados em outros Estados-Partes e que neles produzam efeitos sobre a concorrência ${ }^{556}$.

A importância da cooperação e colaboração na aplicação da legislação de defesa da concorrência dos Estados-Partes foi reforçada por meio do Acordo de Foz do Iguaçu. Nesse sentido, o art. $1^{\circ}$ desse acordo estabelece como objetivos (i) a promoção da cooperação e da coordenação entre os Estados-Partes no tocante à aplicação das leis nacionais de concorrência no âmbito do Mercosul; (ii) prover assistência mútua em qualquer matéria relativa à política de concorrência que considerem necessária; (iii) assegurar a consideração cuidadosa pelos Estados-Partes de seus relevantes interesses recíprocos na aplicação das respectivas leis de concorrência; e (iv) eliminar práticas anticompetitivas por meio da aplicação das respectivas leis de concorrência.

O Acordo estabeleceu um mecanismo formal de consulta e troca de informações a ser adotado pelos Estados-Partes, o que reflete em verdade a adoção da cortesia positiva. As consultas podem tomar lugar quando uma parte acredita que práticas ou concentrações econômicas ocorridas no território de outra parte afetem seus interesses. As autoridades

ao Congresso Nacional. Tendo em vista que esta decisão do CMC revogou o Protocolo de Fortaleza, o qual havia sido incorporado no Brasil por meio do Decreto $\mathrm{n}^{\circ} 3.602$, de 18 de setembro de 2000, entende-se necessária a proposição legislativa para que surta os devidos efeitos no território nacional. Para informação mais completa sobre as Decisões do CMC relacionadas à cooperação entre os Estados-Partes em matéria concorrencial, ver o Anexo B deste estudo.

554 “As limitações mais comumente apontadas ao PDC são: a falta de uma cultura da concorrência; o desaparelhamento dos setores públicos e privados para aplicar as determinações legais; a possibilidade de demora na tomada de decisão; as fortes assimetrias no Mercosul com relação ao grau de desenvolvimento institucional da defesa da concorrência, que impõe um papel crucial para cooperação e assistência técnica; a ausência de delimitação clara e vigorosa das áreas de competência dos órgãos nacionais de cada país e das instâncias do Mercosul; a ausência de uma jurisprudência prévia a respeito da concorrência; a ausência de instâncias deliberativas técnicas e independentes; e a ausência de regras sobre fusões". (OLIVEIRA, Gesner; RODAS, João Grandino. Direito e economia da concorrência. Rio de Janeiro: Renovar, 2004, p. 393).

555 SEAE. Relatório de Atividades, 2010, p. 30. Disponível em: <http://www.seae.fazenda.gov.br/ conheca_seae/relatorios_atividades/copy_of_relativ2009_v180510_final.pdf>. Acesso em: 17 jul. 2011.

${ }^{556} \mathrm{Cf}$. arts. $3^{\circ}$ e $4^{\circ}$ do Acordo de Foz do Iguaçu. 
permanecem livres, no entanto, para conduzir suas atividades consoante as respectivas legislações nacionais. Como dispõe o Acordo, a autoridade consultada poderá iniciar ou ampliar atividades de aplicação consoante consulta recebida, devendo comunicar a autoridade solicitante sobre medidas que venham a ser iniciadas, bem como sobre o andamento de eventuais procedimentos relacionados à consulta.

Já o princípio da cortesia negativa foi acolhido pelo Acordo ao estabelecer a obrigação de cada Estado-Parte dentro das suas possibilidades em notificar os demais Estados-Partes a respeito de qualquer ação de aplicação ou execução que verse sobre matéria da concorrência, que de uma forma ou outra seja do interesse da outra parte. Tal notificação deve se dar na fase inicial dos processos e deverá ser submetida por intermédio do Comitê Técnico $n^{\circ} 5$.

De acordo com o art. $6^{\circ}$ e 13 do Acordo de Foz do Iguaçu, as consultas a serem analisadas por autoridades de defesa da concorrência de outro Estado-Parte devem ser submetidas ao Comitê Técnico $\mathrm{n}^{\circ}$ 5, para que este as redirecione, independente de notificação prévia. Contudo, as respostas a tais consultas não são vinculativas ${ }^{557}$, restando os Estados-Membros livres para emitir a sua decisão final sobre o objeto da consulta ${ }^{558}$. Todavia, a autoridade que emitir tal decisão tem a obrigação de informar a autoridade consultada sobre o teor da sua decisão final, uma vez prolatada, acompanhada das razões técnicas que a embasaram.

O Capítulo IV do Acordo estabelece um procedimento para coordenação das atividades das autoridades de defesa da concorrência nacionais na aplicação das respectivas legislações de concorrência aos casos que envolvam mais de uma jurisdição. Apesar da necessidade de os Estados-Partes envidarem os seus melhores esforços para não proferirem decisões contraditórias por meio da coordenação das suas atividades, cada autoridade da concorrência permanece livre para emitir a decisão que considere mais adequada, de acordo com a respectiva legislação ${ }^{559}$.

$\mathrm{O}$ art. 24 do mesmo Acordo ainda expressa que nenhum Estado-Parte está obrigado a fornecer aos demais ou ao Comitê Técnico informações ou dados confidenciais em razão das respectivas legislações nacionais da concorrência, ou por incompatibilidade com seus interesses relevantes ou políticas governamentais.

\footnotetext{
${ }^{557}$ Salvo disposição em contrário, as opiniões emitidas em face das consultas são consideradas confidenciais, por força do art. 25 do Acordo de Foz do Iguaçu.

${ }_{558} \mathrm{Cf}$. art. $8^{\circ}$ do Acordo de Foz do Iguaçu.

${ }^{559} \mathrm{Cf}$. art. $14^{\circ}, \S \S 1^{\circ} \mathrm{e} 2^{\circ}$ do Acordo de Foz do Iguaçu.
} 
Pela análise do Tratado de Assunção e das Decisões do CMC anteriormente descritas, não é possível concluir que no âmbito regional do Mercosul exista um sistema efetivo de defesa da concorrência ${ }^{560}$. As únicas normas que possuem alguma aplicabilidade no âmbito do Mercosul referem-se tão somente a hipóteses de cooperação entre as autoridades de defesa da concorrência nacionais. Pelos motivos expostos é possível concluir que o grau de desenvolvimento da matéria concorrencial no Mercosul é bastante incipiente $^{561}$, não sendo possível verificar uma completa defesa da concorrência na região ${ }^{562}$.

\subsubsection{Outras Organizações Internacionais e Acordos Regionais}

\subsection{União Europeia}

O exemplo mais proeminente de regulação da defesa da concorrência em âmbito regional está na União Europeia ${ }^{563}$, lugar onde o tema foi inicialmente regulamentado pelo Tratado de Roma, de 1957 - o tratado constitutivo da então denominada Comunidade Econômica Europeia, que sucedeu o Tratado constitutivo da Comunidade Europeia do Carvão e Aço, de 1951, o qual também contava com regras de livre concorrência ${ }^{564}$. O art. $2^{\circ}$ do Tratado de Roma definiu como objetivo da integração vislumbrada a aproximação progressiva das políticas econômicas, significando que se pretendia a criação de políticas comuns em detrimento das nacionais, operando verdadeiro abandono por parte dos Estados-Membros de parcela das respectivas soberanias em determinadas matérias. Sob a égide do Tratado de Roma surgiram políticas comuns de competência comunitária,

\footnotetext{
560 JAEGER JÚNIOR, Augusto. Liberdade de concorrência na União Europeia e no Mercosul. São Paulo: LTr, 2006, p. 676.

${ }^{561}$ OLIVEIRA, Gesner; RODAS, João Grandino. Direito e economia da concorrência. Rio de Janeiro: Renovar, 2004, p. 391.

${ }^{562}$ CASELLA, Paulo Borba. Direito da Concorrência na UE e no Mercosul. In: BAPTISTA, Luiz Olavo; MERCADANTE, Araminta de Azevedo; CASELLA, Paulo Borba (orgs.). Mercosul: das negociações à implantação. 2. ed. São Paulo: LTr, 1998, p. 307.

${ }^{563}$ De acordo com Forgioni, "a União Europeia, tal qual como hoje existe, não teria sido alcançada sem a implementação de política concorrencial consistente". (FORGIONI, Paula A. Os fundamentos do antitruste. 4. ed. São Paulo: Revista dos Tribunais, 2010, p. 87).

${ }^{564}$ GABAN, Eduardo Molan; DOMINGUES, Juliana Oliveira. Direito antitruste. 3. ed. São Paulo: Saraiva, 2013, p. 70; CELLI JÚNIOR, Humberto. Regras de concorrência no Direito Internacional Moderno. Porto Alegre: Livraria do Advogado, 1999, p. 25; e MARQUES, Frederico do Valle Magalhães. Direito Internacional da Concorrência. Rio de Janeiro: Renovar, 2006, p. 277.
} 
incluindo a política agrícola comum, a política comercial comum e a política da concorrência $^{565}$.

Desta forma, desde os seus primórdios, a União Europeia teve regulação da concorrência como um dos elementos essenciais do seu processo de integração, já que desta forma poderia garantir a preservação dos negócios e o desenvolvimento das atividades comerciais ${ }^{566}$. O direito da união evoluiu com o passar dos anos, com a adesão de novos países na qualidade de Estados-Membros e com a adoção de novos tratados que desenvolveram o quadro institucional e regulamentar do bloco ${ }^{567}$. Regras relativas à preservação da concorrência são atualmente encontradas nos principais instrumentos da União Europeia - o Tratado da União Europeia (TUE) e o Tratado sobre o Funcionamento da União Europeia (TFUE) -, para além de numerosos outros regulamentos, diretivas, decisões, recomendações e pareceres da União Europeia ${ }^{568}$.

Os arts. 101 e 102 do TFUE $^{569}$ versam especificamente sobre as regras da concorrência aplicáveis às empresas e, dentre outros dispositivos, determinam que

são incompatíveis com o mercado interno e proibidos todos os acordos entre empresas, todas as decisões de associações de empresas e todas as práticas concertadas que sejam suscetíveis de afetar o comércio entre os EstadosMembros e que tenham por objetivo ou efeito impedir, restringir ou falsear a concorrência no mercado interno.

Não importa, desta forma, o local onde as práticas contrárias à concorrência foram cometidas $^{570}$.

565 ACCIOLY, Elizabeth. Mercosul e União Europeia: estrutura jurídico-institucional. 4. ed. Curitiba: Juruá, 2010, pp. 56-57.

${ }^{566}$ MARQUES, Frederico do Valle Magalhães. Direito Internacional da Concorrência. Rio de Janeiro: Renovar, 2006, p. 274.

${ }^{567}$ O processo de revisão do tratado constitutivo da União Europeia começou com o Ato Único Europeu, em vigor desde $1^{\circ}$ de julho de 1987. Seguiu-se com a adoção do Tratado de Maastricht, assinado em 7 de fevereiro de 1992, do Tratado de Amsterdã, de 2 de fevereiro de 1997, do Tratado de Nice, de 26 de fevereiro de 2001 e do Tratado de Lisboa, de 13 de dezembro de 2007. (ACCIOLY, Elizabeth. Op. cit., 2010, pp. 4649).

568 "O regulamento tem caráter geral, sendo obrigatório em todos os elementos e diretamente aplicável em todos os Estados-Membros. Já a diretiva vincula o Estado-Membro destinatário quanto ao resultado a alcançar, deixando, no entanto, às instâncias nacionais a competência quanto à forma e aos meios ou, como explica Maristela Basso, permite 'aos Estados-Membros escolherem a sua forma de aplicação'. A decisão é obrigatória em todos os seus elementos para os destinatários que designar. Por fim, as recomendações e os pareceres não são vinculantes". (CELLI JÚNIOR. Humberto. Regras de concorrência no Direito Internacional moderno. Porto Alegre: Livraria do Advogado, 1999, p. 33).

${ }^{569}$ Correspondentes aos antigos arts. 81 e 82 do Tratado que institui a Comunidade Europeia, o qual foi reformado pelo Tratado de Lisboa, passando então a adotar a nova nomenclatura e a apresentar numeração dos artigos diversa.

${ }^{570}$ Casella esclarece que "as normas de concorrência tanto podem ter sua aplicação estendida à pessoas jurídicas sediadas em terceiros Estados, porém atuantes no território do Mercado Comum, quanto à liberação das pessoas físicas ou jurídicas comunitárias, cujas práticas concertadas (ou ententes) produzam efeitos em 
O Regulamento $\mathrm{n}^{\mathrm{o}} 139 / 2004$ do Conselho ${ }^{571}$, por sua vez, regula o controle de concentrações, atribuindo a competência de examinar os atos de concentração de "dimensão comunitária" à Comissão Europeia. Este organismo é o órgão executivo da União Europeia com função de implementar a legislação europeia, o orçamento da união e os programas adotados pelo Parlamento e pelo Conselho.

A União Europeia é composta por um sistema complexo de instituições que gozam de poderes autônomos para a implementação dos objetivos definidos nos seus tratados. Dentre esta estrutura destaca-se o Conselho, a Comissão, o Parlamento Europeu e o Tribunal de Justiça da União Europeia (TJUE). Enquanto o Conselho trata do órgão representativo dos interesses individuais de cada Estado-Membro com competência para definir as principais políticas do bloco, a Comissão é o órgão representativo dos interesses da União Europeia, cabendo-lhe a administração diária e a correta aplicação dos $\operatorname{tratados}^{572}$.

No âmbito do direito da concorrência, compõem as atribuições da Comissão Europeia o controle de concentrações econômicas, a repressão aos acordos restritivos da concorrência e aos abusos de posição dominante, a liberalização dos setores econômicos sujeitos a monopólio e o controle dos subsídios governamentais discriminatórios ${ }^{573}$. A Comissão possui, ainda, poderes de investigar supostas infrações às normas da união ${ }^{574} \mathrm{em}$ matéria de concorrência e de sancionar as pessoas envolvidas mediante aplicação de multas e restrição às práticas dos agentes econômicos.

atividades desenvolvidas parcial ou totalmente fora do Mercado Comum”. (CASELLA, Paulo Borba. Direito da Concorrência na UE e no Mercosul. In: BAPTISTA, Luiz Olavo; MERCADANTE, Araminta de Azevedo; CASELLA, Paulo Borba (orgs.). Mercosul: das negociações à implantação. 2. ed. São Paulo: LTr, 1998, pp. 321-322).

${ }^{571}$ Este reformou o anterior Regulamento no 4.064/1989 sobre a matéria, o qual já havia sofrido uma reforma em 1997. Note-se que, apesar de a regulamentação da concorrência ter sido incluída na agenda comunitária desde os primórdios da integração regional, a regulação da concentração empresarial ocorreu somente em 1989, portanto, tardiamente. Nesse sentido, ver MORAIS, Luís Domingos Silva. Empresas comuns (Joint Ventures) no Direito Comunitário da Concorrência. Coimbra: Almedina, 1996, pp. 605 e 706-720; e PAIS, Sofia Oliveira. O controle das concentrações de empresas no âmbito do Direito Comunitário da Concorrência. Coimbra: Almedina, 1996, pp. 171-188.

572 CELLI JÚNIOR, Humberto. Regras de concorrência no Direito Internacional moderno. Porto Alegre: Livraria do Advogado, 1999, pp. 28-29.

${ }^{573}$ MARQUES, Frederico do Valle Magalhães. Direito Internacional da Concorrência. Rio de Janeiro: Renovar, 2006, pp. 279-280; e OLIVEIRA, Gesner; RODAS, João Grandino. Direito e economia da concorrência. Rio de Janeiro: Renovar, 2004, pp. 398-399. Os autores esclarecem em relação ao sistema de defesa da concorrência europeu: "enquanto o sistema europeu baseia-se no conceito de abuso de dominação, preocupando-se, consequentemente, com concentrações geradoras de práticas anticoncorrenciais, o sistema dos EUA, fulcrado no conceito de poder do mercado, tem em mira a concentração em geral".

${ }^{574}$ As investigações podem ocorrer por iniciativa da própria Comissão, de um dos Estados-Membros ou de parte privada. 
A Comissão é dividida administrativamente em Direções Gerais, cabendo à Direção Geral IV a coordenação das atividades relacionadas à concorrência, nomeadamente a coibição de condutas anticoncorrenciais, o controle de concentrações e a liberalização e controle dos subsídios governamentais. À Direção Geral IV cabe também a coordenação dos esforços da União Europeia em dimensão internacional junto a países desenvolvidos e em desenvolvimento ${ }^{575}$.

As decisões da Comissão são recorríveis ao $\mathrm{TJUE}^{576}$, mais especificamente em primeira instância ao Tribunal Geral ${ }^{577}$ que o compõe. Desta forma, o TJUE desempenha relevante foro de discussão e desenvolvimento das regras de defesa da concorrência, uma vez que sua jurisprudência norteia todas as autoridades judiciais dos diversos EstadosMembros na aplicação do direito da união. A jurisprudência do TJUE revela uma evolução do tratamento da matéria desde a adoção do critério da territorialidade objetiva, passando pelo princípio da unidade do grupo econômico e pelo princípio da implementação, até o princípio do efeito ${ }^{578}$.

As autoridades nacionais de defesa da concorrência dos Estados-Membros, bem como as autoridades da própria União Europeia, cooperam na aplicação das legislações nacionais e do direito da união, com fundamento no art. $4^{\circ}, n^{\circ} 3$ do TUE ${ }^{579}$. Nesse sentido, o considerando $n^{\circ} 14$ do Regulamento $n^{\circ} 139 / 2004$ reitera a estreita cooperação que a Comissão Europeia e as autoridades competentes dos Estados-Membros devem lançar mão na aplicação das respectivas competências relativas ao controle de concentrações econômicas $^{580}$.

${ }^{575}$ De acordo com Oliveira e Rodas, a Direção Geral IV “coopera com organizações internacionais, como a OMC, a OCDE e a UNCTAD. Foi a Comissão Europeia a primeira a sugerir a inclusão do direito concorrencial nas negociações da OMC, além de sugerir que tal organismo assumisse a liderança na elaboração de um acordo multilateral". (OLIVEIRA, Gesner; RODAS, João Grandino. Direito e economia da concorrência. Rio de Janeiro: Renovar, 2004, p. 401).

576 O TJUE é formado pelo Tribunal de Justiça, pelo Tribunal Geral e pelos tribunais especializados. Atualmente somente há um tribunal especializado, o Tribunal da Função Pública.

577 Nomenclatura conforme alteração operada pelo Tratado de Lisboa - antigamente designado Tribunal de Primeira Instância, criado em 1989 por força das determinações do Ato Único Europeu.

${ }^{578}$ Para uma retrospectiva sobre os principais casos julgados pela TJUE, ver OLIVEIRA, Gesner; RODAS, João Grandino. Op. cit., 2004, pp. 380-381, no qual são abordados os casos Béguelin (1971), Imperial Chemical Industries $v$. Comission - Dyestuffs (1972), Viho $v$. Commission (1996), Ahlström Osakeytio and Others $v$. Comission - Woodpulp I (1985) e Gencor Ltd v. Commission (1999). Maiores informações podem ser ainda encontradas em GERADIN, Damien; REYSEN, Marc; HENRY, David. Extraterritoriality, comity and cooperation in EU Competition Law. Cooperation, comity and competition policy. New York: Oxford University Press, 2011, pp. 25-29.

${ }^{579}$ Para Whish esse dispositivo trata do princípio de cooperação entre os Estados-Membros e as instituições da UE. (WHISH, Richard. Competition law. 6. ed. New York: Oxford University Press, 2009, p. 885).

${ }^{580} \mathrm{O}$ art. 19 do Regulamento 139/2004 contém disposições detalhadas sobre o relacionamento da Comissão Europeia e as autoridades nacionais de defesa da concorrência dos Estados Membros. O art. 24, por sua vez, traz regras sobre a reciprocidade no tratamento de concentrações econômicas com países terceiros. Segundo Whish, "some systems of law make it difficult, if not impossible, for foreign firms to take over local ones. Not 
Note-se, porém, que as autoridades nacionais devem considerar as regras estabelecidas pela Comissão. Na eventualidade de haver conflito entre a aplicação das regras nacionais e as normas da união, devem os Estados-Membros respeitar a primazia do direito da união sobre os temas da sua competência ${ }^{581}$. De fato, um dos princípios mais expressivos da organização adotada pela União Europeia é o da uniformidade, do qual se depreende que as regras comuns da União devem ser adotadas por todos os EstadosMembros. Para que tal uniformidade seja acalcada, é necessária a existência de um direito comum e, para tanto, caberá o primado do direito da união sobre o direito nacional ${ }^{582}$.

Por outro lado, o princípio da subsidiariedade norteia o método de aplicação das legislações, cabendo a aplicação do direito da união quando for mais benéfica do que a legislação nacional ${ }^{583}$, evitando, assim, a apresentação de notificações múltiplas de uma determinada concentração. De acordo com o art. $5^{\circ}, n^{\circ} 3$ do TUE, o princípio da subsidiariedade tem aplicação nos domínios da competência não exclusiva da União Europeia $^{584}$. De todo o modo, o princípio da subsidiariedade está limitado por dois outros princípios, quais sejam, o princípio da atribuição - pelo qual a União deve limitar a sua atuação somente dentro dos limites das competências atribuídas pelos Estados-Membros mediante os tratados - e do princípio da proporcionalidade - pelo qual a União Europeia deve ater-se à forma e ao conteúdo que sejam necessários para que os objetivos dos tratados sejam alcançados.

Outra preocupação externada no ambiente europeu está na harmonização das legislações nacionais de defesa da concorrência em relação às regras da união ${ }^{585}$. Ademais,

surprisingly resentment is felt where, for example, a British firm is prevented from taking over a foreign one in circumstances in which, were the roles reversed, there would be no obstacle to the merger under UK law." (WHISH, Richard. Competition law. 6. ed. New York: Oxford University Press, 2009, p. 886).

${ }^{581}$ MARQUES, Frederico do Valle Magalhães. Direito Internacional da Concorrência. Rio de Janeiro: Renovar, 2006, p. 284.

582 "Só pode haver uniformidade quando as normas de Direito da União prevalecerem sobre as normas de direito nacional”. (ACCIOLY, Elizabeth. Mercosul e União Europeia: estrutura jurídico-institucional. 4. ed. Curitiba: Juruá, 2010, p. 53). Interessante notar os apontamentos da autora na p. 59 da referida obra, em que esclarece que apesar de o art. I- $6^{\circ}$ do Tratado Constitucional, que conferia a primazia do direito da união sobre o direito nacional, haver sido suprimido do Tratado de Lisboa, a adoção do princípio do primado não foi afetado, já que "enraizado no seio da Europa, quanto mais pelo incansável trabalho realizado pelos juízes comunitários, desde o início desta construção”.

583 OLIVEIRA, Gesner; RODAS, João Grandino. Direito e economia da concorrência. Rio de Janeiro: Renovar, 2004, p. 399.

584 "O art. 50, 3, do TUE afirma que a União Europeia intervirá se e na medida em que os Estados não puderem realizar a ação em causa de modo suficiente, ou se de acordo com a sua dimensão ou seus efeitos puder ser realizado melhor ao nível da União". (ACCIOLY, Elizabeth. Mercosul e União Europeia: estrutura jurídico-institucional. 4. ed. Curitiba: Juruá, 2010, p. 54).

${ }_{585}$ MARQUES, Frederico do Valle Magalhães. Direito Internacional da Concorrência. Rio de Janeiro: Renovar, 2006, p. 284. 
há uma proibição de discriminação em termos de nacionalidade na aplicação das variadas legislações nacionais da concorrência.

O fato de a União Europeia se encontrar em estágio avançado da regulação regional da matéria da concorrência talvez constitua um dos principais motivos da sua posição favorável à negociação multilateral do tema da concorrência em um foro estabelecido e consistente, como é o caso da $\mathrm{OMC}^{586}$. Nesse sentido, destacam-se os apontamentos realizados no item 2.2.2.1.1, supra.

\subsection{NAFTA}

Um dos exemplos de destaque de acordos regionais de integração econômica que possuem normas relativas à defesa da concorrência no âmbito regional é o NAFTA, da qual fazem parte o México, os Estados Unidos e o Canadá, em vigor desde $1994^{587}$. Tratase de uma zona de livre comércio - sem previsão de uma tarifa externa comum a ser adotada pelos Estados-Partes do Acordo ou previsão de circulação de trabalhadores. Notese que o NAFTA não constitui uma organização internacional, uma vez que não lhe foi conferida personalidade jurídica de direito internacional pelos Estados-Partes.

O tratado constitutivo do NAFTA ${ }^{588}$ estabelece como um dos seus objetivos a promoção da concorrência equânime na região. O Capítulo XV do tratado, denominado Política de Concorrência, Monopólios e Empresas Públicas, traz regras específicas sobre a matéria concorrencial, dentre as quais está a obrigação dos países em adotar e manter medidas com vistas a proibir condutas comerciais anticoncorrenciais e estimular a cooperação e a coordenação entre as autoridades de defesa da concorrência correspondente $^{589}$. Destaca-se, no entanto, que o mecanismo de solução de controvérsias estatuído pelo NAFTA não é aplicável aos casos de concorrência.

\footnotetext{
${ }^{586}$ MARQUES, Frederico do Valle Magalhães. Direito Internacional da Concorrência. Rio de Janeiro: Renovar, 2006, p. 287.

587 “Os Estados Unidos que já possuíam um acordo bilateral de livre comércio com o Canadá, desde 1989, no ano subsequente, iniciaram conversações no mesmo sentido com o México. Do consenso entre estes três países, surgiu, em 1992, um acordo trilateral o [...] NAFTA, que foi assinado em 1993, passando a vigorar em $1^{\circ}$ de janeiro do ano seguinte". (OLIVEIRA, Gesner; RODAS, João Grandino. Direito e economia da concorrência. Rio de Janeiro: Renovar, 2004, p. 394).

${ }^{588}$ Disponível em: http://www.sice.oas.org/trade/nafta/naftatce.asp. Acesso em: 17 jul. 2011.

589 Oliveira e Rodas expressam que "apesar do NAFTA não possuir regras comuns de concorrência, muito menos instâncias deliberativas supranacionais, estabelece medidas e procedimentos para promover a cooperação e a aplicação do direito antitruste". (OLIVEIRA, Gesner; RODAS, João Grandino. Direito e economia da concorrência. Rio de Janeiro: Renovar, 2004, p. 396). No mesmo sentido ver WHISH, Richard. Competition law. 6. ed. New York: Oxford University Press, 2009, pp. 492-493; e FOX, Eleanor M.; CRANE, Daniel A. Global issues in antitrust and competition law. St. Paul: West, 2010, pp. 528-530.
} 
Nota-se, desta forma, que as regras de defesa da concorrência no âmbito do NAFTA restringem-se à cooperação, cada Estado permanecendo soberano para adotar e aplicar a respectiva legislação de defesa da concorrência ${ }^{590}$. Ainda no âmbito do NAFTA, foi constituído o Grupo de Trabalho sobre Comércio e Concorrência, com funções de análise e preparo de estudos relacionados à defesa da concorrência na região.

Ante o exposto, é possível concluir que o único bloco econômico que contempla regras efetivas relacionadas à defesa regional da concorrência é a União Europeia. As regras adotadas pelo Mercosul e por outros acordos de integração econômica, como é o caso do NAFTA, resumem-se a tentativas de harmonização, cooperação e coordenação das atividades independentes das autoridades competentes pela análise das práticas anticoncorrenciais dos países que as integram.

\subsubsection{Dimensão bilateral: aspectos gerais dos acordos bilaterais}

A perspectiva bilateral do Direito Internacional da Concorrência resume-se aos acordos bilaterais celebrados com o intuito de eliminar ou mitigar os problemas advindos da aplicação extraterritorial da legislação de defesa da concorrência pelas variadas autoridades de defesa da concorrência. De fato, tendo em vista a ausência de tratados multilaterais sobre o tema - e havendo a perspectiva regional alcançado desenvolvimento efetivo em poucas entidades de integração econômica -, acordos bilaterais passaram a ser celebrados por diversos países ${ }^{591}$.

O terceiro capítulo deste estudo dedicar-se-á, portanto, com maior afinco ao conteúdo de tais acordos bilaterais celebrados pelo Brasil e por suas autoridades de defesa da concorrência, com especial ênfase à regulação dos atos de concentração multijurisdicionais.

\footnotetext{
590 THORSTENSEN, Vera. A OMC - Organização Mundial do Comércio e as negociações sobre investimentos e concorrência. Revista Brasileira Política Internacional, 1998, v. 41 (1), p. 78; e CARVALHO, Leonardo Arquimino de. Direito antitruste \& relações internacionais: extraterritorialidade e cooperação. Curitiba: Juruá, 2003, p. 195.

591 "If a supranational system of enforcement of competition law is still far from becoming a reality, effective systems of bilateral cooperation seem at the moment to be more realistic alternative. In the recent years a number of bilateral agreements between different competition authorities have been concluded on the basis of the OECD guidelines of 1995". (BOTTA, Marco. The cooperation between the Competition Authorities of the Developing Countries: why does it not work? Case study on Argentina and Brazil. The competition Law review. Issue 2, jul. 2009, v. V, p. 155).
} 


\section{OS ACORDOS DE COOPERAÇÃO JURÍDICA INTERNACIONAL ENTRE AS AUTORIDADES DE DEFESA DA CONCORRÊNCIA: A Análise dos Atos de Concentração Multijurisdicionais}

\subsection{RESTROSPECTO HISTÓRICO}

Uma das tendências do desenvolvimento do Direito Internacional da Concorrência, que objetiva contornar o problema da multiplicidade de jurisdições competentes em razão de regras de aplicação extraterritorial de suas normas encontra-se na cooperação bilateral dos Estados por meio da celebração de acordos de cooperação antitruste ${ }^{592}$. Alguns casos práticos relacionados à concentração multijurisdicional empresarial, descritos neste capítulo, traduzem a relevância dos acordos bilaterais na Cooperação Jurídica Internacional entre as autoridades de defesa da concorrência.

Os precursores da tendência de celebração de acordos bilaterais são os Estados Unidos e a União Europeia, os quais firmaram grande quantidade de acordos com outros países ${ }^{593}$, sendo que as nações em desenvolvimento, como Brasil e Argentina, também firmaram alguns outros tantos. Em geral, os acordos bilaterais beneficiam a instrução e a tomada de decisões nos procedimentos de controle de atos de concentração multijurisdicionais e os relativos às condutas anticoncorrenciais. A utilização dos acordos bilaterais de cooperação pelos Estados Unidos e pela União Europeia, principalmente, tem

592 "Competition law authorities need to be persuaded of the need to engage in greater cooperation". (GALLOWAY, Jonathan. Convergence in international merger control. The competition law review. Issue 2, jul 2009, v. V, p. 192). Ver também SILVA, Valéria Guimarães de Lima e. Direito antitruste: aspectos internacionais. Curitiba: Juruá, 2007, p. 465; e LAGARES, Eva Valle. International agreements regarding cooperation in the field of competition: the new strategy of the European Commission. Journal of European competition law \& practice, jan. 2010, p. 1.

${ }^{593}$ SANTOS, Maria Cecília de Andrade. A Política da Concorrência e a Organização Mundial do Comércio. Revista de Direito Constitucional e Internacional, abr./jun. 2001, ano 9, n. 35, p. 230; SANTOS, Maria Cecília de Andrade. Sobre a cooperação em matéria de concorrência entre a União Europeia e o Mercosul. Revista do IBRAC - Direito da Concorrência, Consumo e Comércio Internacional. São Paulo: jan. 2001, v. 8, pp. 177 e ss; e LILLA, Paulo Eduardo. A OMC e a interação entre comércio e política antitruste no âmbito da Cooperação Internacional: perspectivas para a Nova Rodada e negociações multilaterais. Revista do IBRAC - Direito da Concorrência, Consumo e Comércio Internacional. São Paulo, jan. 2003, v. 10, p. 233 e ss. Os autores destacam que a União Europeia possui acordos bilaterais firmados com os Estados Unidos, o Canadá e o Japão e acordo multilateral firmado em julho de 1995 com os países membros da OCDE no âmbito das práticas anticoncorrenciais que afetam o comércio internacional, e os Estados Unidos com os seus principais parceiros comerciais, como por exemplo, Austrália, Brasil, Canadá, Alemanha, Israel e Japão, com graus de comprometimento variados. WHISH, Richard. Competition Law. 6. ed. New York: Oxford University Press, 2009, pp. 492-493 destaca ainda acordos bilaterais desta natureza firmados entre Austrália e Nova Zelândia; e multilaterais entre Dinamarca, Finlândia, Noruega e Suécia. Lagares também destaca que o DG Competition da União Europeia tem levado em consideração o tamanho do país e da sua economia, a intensidade da relação de comércio e investimento com o país em questão e a maturidade do regime de defesa da concorrência quando da celebração destes acordos (LAGARES, Eva Valle. International agreements 
revelado ser de grande valia para a eficiência do controle das concentrações multijurisdicionais por mais de uma autoridade.

Do ponto de vista material, o principal objetivo de tais acordos é promover a cooperação e a coordenação entre as autoridades de defesa da concorrência, com o objetivo de evitar a divergência e mitigar o impacto das suas decisões ${ }^{594}$, bem como de reduzir os custos das sociedades envolvidas nos atos de concentração multijurisdicionais ${ }^{595}$. Além disso, sob a perspectiva formal ou procedimental, a cooperação bilateral entre as autoridades de defesa da concorrência é necessária na medida em que muitas diligências e medidas necessárias à análise de determinado caso envolvendo prática concorrencial com efeitos multijurisdicionais dependem de atos executórios a se realizar no exterior. Desta forma, a própria efetividade da análise ou investigação realizada por autoridade de defesa da concorrência poderá depender da cooperação com autoridades estrangeiras, cujos ordenamentos jurídicos restrinjam a consecução de certas atividades por autoridades estrangeiras nos respectivos territórios com fundamentação na soberania de tais países $^{596,597}$.

regarding cooperation in the field of competition: the new strategy of the European Commission. Journal of European Competition Law \& Practice, jan. 2010, p. 2).

594 "Cooperation, including the sharing of information, permits more complete communication among the reviewing agencies and the coordination of their respective investigations, with the aim of improving the analysis and achieving consistent results, where appropriate". (ORGANIZAÇÃO PARA A COOPERAÇÃO E DESENVOLVIMENTO ECONÔMICO. Global Forum on Competition - Roundtable on Cross-Border Merger Control: Challenges for Developing and Emerging Economies: Contribution from United States. DAF/COMP/GF/WD(2011)29. Session 1. Fev. 2011, p. 6. Disponível em: <http://www.ftc.gov/bc/ international/docs/1102crossbordermergercontrol.pdf $>$. Acesso em: 01 dez. 2012). Nesse sentido, ver também FORGIONI, Paula A. Os fundamentos do antitruste. 4. ed. São Paulo: Revista dos Tribunais, 2010, p. 458; e TOKESHI, Helcio; MONTEIRO, Carmen Diva. Worldwide mergers: a brazilian perpective. Competition Law international, out. 2005, p. 27.

595“"Como a maioria dos países mantém a sua própria lei concorrencial, com obrigações específicas quanto à notificação da operação, muitas vezes as empresas são obrigadas a submeter pedidos de aprovação em várias jurisdições [...]. É claro que às empresas interessaria que houvesse apenas um 'balcão', somente uma autoridade a ser municiada de informações e convencida dos benefícios da prática. Trata-se do ideal do 'one sto shop', almejado por muitos, que traria a vantagem da eliminação da possibilidade de decisões conflitantes". (FORGIONI, Paula A. Op. cit., 2010, p. 456).

596 "A aplicação de medidas a casos que envolvam estas situações geralmente depende de informações também vindas do estrangeiro, de documentos e depoimentos de pessoas. A obtenção desse material todo envolve questões de soberania interna dos outros Estados e depende da autorização dos mesmos. Raramente a empresa auscultada no exterior coloca, por livre e espontânea vontade, as informações à disposição das autoridades de defesa da concorrência [...]. A decisão de um determinado Estado dificilmente poderá ser executada em um outro Estado sem que exista por parte desse uma colaboração na atividade executiva". (JAEGER JÚNIOR, Augusto. Direito Internacional da Concorrência - Entre perspectivas unilaterais, multilaterais, bilaterais e regionais. Curitiba: Juruá, 2008, p. 244).

597 "The domestic nature of merger control presents significant challenges for enforcement on cross-border transactions, particularly for developing countries and emerging economies". (ORGANIZAÇÃO PARA A COOPERAÇÃO E DESENVOLVIMENTO ECONÔMICO. Global forum on competition - Roundtable on Cross-Border merger control: challenges for developing and emerging economies: contribution from UNCTAD. DAF/COMP/GF/WD(2011)8. Jan. 2011, p. 2. Disponível em: <http://search.oecd.org/official 
Os esforços e as recomendações para a celebração de acordos bilaterais em matéria concorrencial datam da década de 1960, sendo que os Estados passaram a firmá-los a partir da década de 1970. De fato, em 1967 a OCDE publicou a sua primeira recomendação no sentido de serem celebrados acordos de cooperação em matéria concorrencial, com o objetivo de se evitar conflitos de políticas concorrenciais e comerciais nacionais mediante o uso de mecanismos de consulta e notificação pelas autoridades competentes ${ }^{598}$.

Já em 1976 os Estados Unidos e a Alemanha firmaram o primeiro acordo bilateral em matéria concorrencial, com ênfase na troca de informações e no acolhimento de procedimentos para solução de questões concorrenciais entre as partes ${ }^{599}$. Adicionalmente, na década de 1980 os Estados Unidos firmaram acordos com o Canadá e a Austrália.

A proliferação na celebração deste tipo de acordo, no entanto, ocorreu somente na década de 1990, paralelamente ao acolhimento generalizado de legislações de defesa da concorrência pelas mais variadas nações ${ }^{600}$. Nesta mesma época o mundo assistiu às chamadas megafusões, que resultaram em empresas de porte internacional, com atividades em diversas jurisdições e lucros que ultrapassam o produto interno bruto de muitos Estados. Em 1998, metade das concentrações econômicas submetidas às autoridades norteamericanas envolvia empresas estrangeiras, criando dificuldades para as autoridades na obtenção de informações no exterior, bem como na execução das decisões proferidas ${ }^{601}$.

A doutrina aponta que a iniciativa para a celebração de acordos bilaterais em matéria concorrencial foi impulsionada pelos Estados Unidos, que viram nessa modalidade de cooperação a alternativa mais eficaz na mitigação das dificuldades advindas da aplicação extraterritorial da legislação de defesa da concorrência e no melhor

docum ents/displaydocumentpdf/?cote=DAF/COMP/GF/WD(2011)8\&docLanguage=En>. Acesso em: 01 dez. 2012).

${ }^{598}$ Jaeger Júnior e Silva destacam as recomendações de 1973, as quais foram objeto de sucessivas revisões. No entanto, Silva ressalta que os procedimentos da OCDE com vistas à conciliação dos Estados membros da OCDE em matéria concorrencial não foram utilizados até o momento (JAEGER JÚNIOR, Augusto. Direito Internacional da Concorrência - Entre perspectivas unilaterais, multilaterais, bilaterais e regionais. Curitiba: Juruá, 2008, pp. 244-246; e SILVA, Valéria Guimarães de Lima e. Direito antitruste: aspectos internacionais. Curitiba: Juruá, 2007, pp. 433-435).

599 "Though the pratical relevance of this covenant remained marginal". (TERHECHTE, Jörg Philipp. International competition enforcement law: between cooperation and convergence. New York: Springer, 2011, p. 10).

600 "Embora estejam se intensificando, acordos desse tipo não são propriamente mecanismos novos. Existiam há algum tempo envolvendo certos países da OCDE. Recentemente, porém, eles têm aumentado não somente em número, envolvendo países que anteriormente não dispunham de legislações antitruste, mas também em escopo. Quando a legislação das duas partes permite, dispõem sobre a possibilidade de troca de informações sigilosas. Além disso, tem-se difundido o uso da chamada cláusula de cortesia positiva [...]". (NUSDEO, Ana Maria de Oliveira. Defesa da concorrência e globalização econômica. São Paulo: Malheiros, 2002, pp. 170-171).

${ }^{601}$ SILVA, Valéria Guimarães de Lima e. Direito antitruste: aspectos internacionais. Curitiba: Juruá, 2007, p. 464. 
desenvolvimento dos seus interesses no plano internacional por meio da manutenção do controle sobre os casos submetidos à sua jurisdição, contrapondo-se à opção multilateral já discutida na época ${ }^{602}$. De fato, por intermédio de negociações apartadas em segmentação bilateral, os Estados Unidos conseguem manter melhor controle sobre as negociações, tendo maior sucesso na consecução dos seus interesses - os quais, se discutidos em foros internacionais, poderiam restar em situação de fragilidade se confrontados com os interesses dos demais Estados ${ }^{603}$. Nesse tocante destaca-se a oposição dos Estados Unidos na inclusão do tema concorrencial no âmbito da $\mathrm{OMC}$, conforme discutido no item 2.2.2.1.1 supra.

O grande marco na evolução desse tipo de acordo está no celebrado em 23 de setembro de 1991 pelos Estados Unidos e União Europeia (Acordo EUA/UE 1991), relativo à aplicação dos respectivos Direitos da Concorrência, servindo até hoje de base para a assinatura da grande maioria dos acordos bilaterais nesta matéria, mesmo que entre terceiros países ${ }^{604}$. O acordo objetiva a promoção da cooperação e da coordenação entre as atividades das respectivas autoridades de defesa da concorrência, acarretando a diminuição das possibilidades de divergências na aplicação dos respectivos ordenamentos jurídicos.

Para além do princípio da cortesia negativa, o Acordo EUA/UE 1991 acolheu, pela primeira vez, o princípio da cortesia positiva, melhor descrito no item 3.2.2.2.2 infra, estabelecendo a obrigação das partes em promover a notificação, uma em relação à outra, sobre a aplicação na prática da correspondente legislação nacional de defesa da

\footnotetext{
602 "Como já indicado, a cooperação ou assistência têm envolvido muito intercâmbio entre os funcionários das agências encarregadas e, nesse sentido, contribuído ao aumento do espectro de influência norteamericana na aplicação das leis antitruste nesses países". (NUSDEO, Ana Maria de Oliveira. Defesa da concorrência e globalização econômica. São Paulo: Malheiros, 2002, p. 171).

603 "Como essa opção retiraria o controle dos Estados Unidos sobre as causas até então por ele julgadas, o país concluiu que a alternativa que melhor se adequaria a seus interesses seria a assinatura de acordos bilaterais de cooperação. Bilaterais, pois assim o país teria maior poder de negociação, sendo mais fácil fazer prevalecer seu ponto de vista ao negociar isoladamente com cada nação as regras que deveriam ser prevista em tais acordos". (SILVA, Valéria Guimarães de Lima e. Direito antitruste: aspectos internacionais. Curitiba: Juruá, 2007, pp. 432 e 467).

604 "Agreement between the Government of the United States of America and the Commission of the European Communities regarding the Application of their Compatition Laws", assinado em 23 de setembro de 1991 (WHISH, Richard. Competition Law. 6. ed. New York: Oxford University Press, 2009, p. 493) Whish destaca que no âmbito europeu o acordo foi aprovado por Decisão Conjunta do Conselho de Ministros e Comissão Europeia datada de 10 de abril de 1995. Ver também OLIVEIRA, Gesner; RODAS, João Grandino. Direito e economia da concorrência. Rio de Janeiro: Renovar, 2004, p. 386; e JAEGER JÚNIOR, Augusto. Direito Internacional da Concorrência - Entre perspectivas unilaterais, multilaterais, bilaterais e regionais. Curitiba: Juruá, 2008, p. 245, cujo autor destaca que possivelmente os Estados Unidos foram precursores na celebração deste tipo de acordo em razão das críticas sofridas pelo desenvolvimento e pela adoção da teoria dos efeitos.
} 
concorrência, bem como a realização de reuniões periódicas a fim de promover maior convergência na aplicação das legislações correspondentes ${ }^{605}$.

Em 4 de junho de 1998 os Estados Unidos e a União Europeia celebraram novo acordo de cooperação bilateral em matéria da concorrência (Acordo EUA/UE 1998) ${ }^{606}$, que veio complementar o acordo de 1991, sem revogá-lo. Um quadro comparativo sobre as disposições ao Acordo EUA/UE 1991 e o Acordo EUA/UE 1998 consta no Anexo A deste estudo.

O novo acordo de 1998 veio reforçar e ampliar o princípio de cortesia positiva previsto no documento de 1991, detalhando as responsabilidades das partes, estando a sua aplicação, no entanto, restrita às práticas anticoncorrenciais ${ }^{607}$. Note-se que o art. $4^{\circ}$ deste acordo implicitamente reconhece o acolhimento da teoria dos efeitos e a possibilidade de haver decisões concorrentes das autoridades de defesa da concorrência envolvidas ${ }^{608}$.

Além dos acordos de 1991 e 1998, os Estados Unidos e a União Europeia assinaram outros protocolos que visaram regular a cooperação entre as suas autoridades de defesa da concorrência, dentre os quais se destaca o Arranjo Administrativo de Comparecimento (AAA) ${ }^{609}$, adotado em 31 de março de 1999, e as Melhores Práticas na

605 LILLA, Paulo Eduardo. A OMC e a interação entre comércio e política antitruste no âmbito da cooperação internacional: perspectivas para a nova rodada e negociações multilaterais. Revista do IBRAC Direito da Concorrência, Consumo e Comércio Internacional. São Paulo, jan. 2003, v. 10, pp. 233 e ss.

606 "Agreement between the Government of the United States of America and the European Communities on the Application of Positive Comity Principles in the Enforcement of their Competition Laws", assinado em 04 de junho de 1998.

${ }^{607}$ RIVERS, Ricky D. General Electric/Honeywell Merger: European Commission Antitrust Decision Strikes a Sour Note. ILSA Journal of International and Comparative Law, 2002/2003, v. 9, p. 531. Ver também DRAETTA, Ugo. Need for better trans-atlantic co-operation in the field of merger control. International Business Law Journal, 2002, p. 562; MARTINEZ, Maria Beatriz. A cooperação internacional na defesa da concorrência: acordos bilaterais e aplicação do princípio da cortesia positiva. Revista do IBRAC - Direito da Concorrência, Consumo e Comércio Internacional. São Paulo, jan. 2004, v. 11, pp.177 e ss, cuja autora descreve que "com uma regulamentação pormenorizada, o acordo de 1998 visa a tornar funcional o quanto previsto pelo acordo de 1991 no tocante à cortesia positiva. Suas previsões foram pensadas, entre outros fatores, diante das necessidades que surgiram quando da primeira situação em que o princípio da cortesia positiva foi invocado pelos EUA perante a Comunidade Europeia, em 1997, no caso envolvendo o sistema de reservas Amadeus"; e JAEGER JÚNIOR, Augusto. Direito Internacional da Concorrência - Entre perspectivas unilaterais, multilaterais, bilaterais e regionais. Curitiba: Juruá, 2008, p. 252, que ao discorrer sobre as limitações da cortesia positiva descreve: "quando foi utilizada pera primeira vez, em 1997, gerou tantos problemas, que as partes acabaram por negociar um novo e detalhado acordo em 1998".

${ }^{608}$ FARIA, José Ângelo Estrella. O controle de concentrações de empresas estrangeiras e a Lei $\mathrm{n}^{\circ}$ 8.884: a extraterritorialidade revisitada. Juris Síntese, maio/jun. 2009, n. 77, p. 11. Disponível em: <http://online. sintese.com>. Acesso em: 19 ago. 2012.

${ }^{609}$ Em inglês Administrative Arrangements on Attendance. Para maiores informações a respeito, consultar GERADIN, Damien; REYSEN, Marc; HENRY, David. Extraterritoriality, comity and cooperation in EU Competition Law. Cooperation, comity and competition policy. New York: Oxford University Press, 2011, p. 39 e DABBAH, Maher M. Future directions in bilateral cooperation: a policy perspective. Cooperation, comity and competition policy. New York: Oxford University Press, 2011, p. 291, no qual o autor descreve que "such attendance has happened in a number of important merger cases, including Air Liquide/BOC, in which the officials of the Federal Trade Commission attended an oral hearing within the European 
Cooperação de Investigações sobre Atos de Concentração (Melhores Práticas EUA/UE) ${ }^{610}$, adotado em 30 de outubro de 2002 e revisado em 14 de outubro de 2011. Enquanto o AAA regula a possibilidade de comparecimento de representantes das autoridades da concorrência em certos estágios da análise concorrencial, em casos específicos (no controle de condutas e estruturas), as Melhores Práticas EUA/UE estabelecem as linhas mestras da cooperação entre as autoridades de defesa da concorrência envolvidas em relação aos atos de concentração multijurisdicionais apresentados perante as duas jurisdições ${ }^{611}$.

Em 17 de junho de 1999 a União Europeia celebrou acordo semelhante ao firmado pelos Estados Unidos com o Canadá ${ }^{612}$, em que as partes reconheceram a possibilidade de ocorrerem atividades anticoncorrenciais no território de uma das partes que também podem afetar os interesses da outra parte. À semelhança do acordo celebrado entre Estados Unidos e União Europeia, o art. $5^{\circ}$, parágrafo $4^{\circ}$ do acordo com o Canadá reconhece implicitamente a teoria dos efeitos e o eventual e consequente conflito de jurisdições. Este dispositivo reforça a liberdade das partes em tomar medida de execução em relação à conduta anticoncorrencial que seja objeto de requerimento de uma das partes.

Apesar de os Estados Unidos e a União Europeia terem firmado após 1998 uma série de outros acordos bilaterais de cooperação com terceiros países, algumas vezes diretamente por meio das respectivas autoridades de defesa da concorrência, não é possível depreender automaticamente que tais acordos possuem os mesmos instrumentos para efetividade da cortesia positiva do acordo de cooperação bilateral firmado em 1998. Tendo em vista que os Estados, em especial os países em desenvolvimento, encontram-se em graus diferenciados de evolução das respectivas legislações nacionais de defesa da concorrência, a maior parte dos acordos firmados pelos Estados Unidos e União Europeia

Commission, and MCI WorldCom/Sprint, in which officials of the European Commission attended the 'pitch' meeting between the Antitrust Division of the U.S. Department of Justice and the merging parties".

${ }^{610}$ Em inglês Best Practices on Cooperation in Merger Investigations (US-EU MERGER WORKING GROUP. Best practices on cooperation in merger investigations, 2011. Disponível em: <http://ec.europa. eu/competition/international/ bilateral/eu_us.pdf>. Acesso em: 17 nov. 2012).

611 "As principais previsões dizem respeito à coordenação temporal da análise dos casos entre essas autoridades e à necessidade de que ambas as partes sejam mantidas informadas acerca do prosseguimento das investigações. Ademais, caso seja necessário reprovar parcialmente um determinado ato de concentração, isso deve ser feito de maneira consistente entre as autoridades. Visou-se, mais uma vez, ao fortalecimento da cooperação bilateral entre as partes". (MARTINEZ, Maria Beatriz. A cooperação internacional na defesa da concorrência: acordos bilaterais e aplicação do princípio da cortesia positiva. Revista do IBRAC - Direito da Concorrência, Consumo e Comércio Internacional. São Paulo, jan. 2004, v. 11, pp. 177 ss). Nesse sentido, ver também DABBAH, Maher M. Future directions in bilateral cooperation: a policy perspective. Cooperation, comity and competition policy. New York: Oxford University Press, 2011, p. 292.

${ }^{612}$ Agreement between the European Communities and the Government of Canada regarding the Application of their Competition Laws, assinado em 04 de junho de 1999. 
com terceiros países não possui o mesmo grau de desenvolvimento do princípio da cortesia do Acordo EUA/UE $1998^{613}$.

Seguindo o exemplo trazido pelos Estados Unidos e a União Europeia, desde 1999, quando foi celebrado o acordo entre Brasil e os Estados Unidos, o Brasil e o SBDC também vêm celebrando acordos de cooperação em matéria concorrencial com outros Estados e outras nacionais de defesa da concorrência. Atualmente o Brasil possui 10 acordos bilaterais em vigor com diversos países, que visam a cooperação em matéria concorrencial tanto no que se refere à cooperação na aplicação das respectivas legislações nacionais de defesa da concorrência, quanto em relação à cooperação técnica. Os acordos celebrados pelo Brasil/SBDC serão analisados posteriormente, no item 3.3 deste estudo.

Em geral a experiência advinda da adoção de acordos bilaterais em matéria concorrencial tem servido aos países como instrumento de se evitar conflitos de jurisdição em matéria concorrencial, potencialmente existente em razão da aplicação extraterritorial das legislações nacionais da concorrência, bem como para garantir um conhecimento mais profundo das questões envolvidas no processo de cooperação em matéria da concorrência, de modo que no futuro seja eventualmente viável a adoção de um tratado multilateral pela comunidade internacional $^{614}$.

Especialmente no que se refere aos atos de concentração multijurisdicionais, a cooperação bilateral tem sido de especial relevância, em razão do aumento no número de concentrações com dimensões internacionais, que acabam por afetar diversas jurisdições $^{615}$. Nesses casos, mais relevante do que a simples obtenção de informações relacionadas à operação de concentração pretendida pelas partes, está a coordenação das atividades das autoridades de defesa da concorrência envolvidas na análise de um mesmo ato, com vistas à compatibilidade das suas decisões e restrições definidas na operação de concentração econômica ${ }^{616}$. Por outro lado, através da experiência havida entre os Estados Unidos e a União Europeia, é possível depreender que problemas poderão ser enfrentados quando da efetivação da cooperação bilateral, conforme se analisará adiante.

\footnotetext{
${ }^{613}$ É o caso, por exemplo, do acordo firmado entre Brasil e Estados Unidos. (LILLA, Paulo Eduardo. A OMC e a interação entre comércio e política antitruste no âmbito da cooperação internacional: perspectivas para a nova rodada e negociações multilaterais. Revista do IBRAC - Direito da Concorrência, Consumo e Comércio Internacional. São Paulo, jan. 2003,v. 10, pp. 233 e ss).

${ }^{614}$ Id., ibid.

${ }^{615}$, Nusdeo destaca a aquisição da American Home Products, que detinha a marca brasileira de creme dental Kolynos pela Colgate (NUSDEO, Ana Maria de Oliveira. Defesa da concorrência e globalização econômica. São Paulo: Malheiros, 2002, p. 171).

616 "Nesse sentido, as autoridades buscam harmonizar os 'remédios' acordados com as partes para minorar os efeitos anticoncorrenciais das operações e possibilitar a sua aprovação”. (Id., ibid., p. 172).
} 


\subsection{ACORDOS BILATERAIS: TIPOS, OBJETO E CARACTERÍSTICAS}

Os acordos bilaterais de Cooperação Jurídica Internacional em matéria concorrencial, celebrados pelo mais variados Estados, possuem certas características recorrentes, que refletem o grau corrente de evolução na celebração deste tipo de acordos pela comunidade internacional. A equivalência da maior parte das disposições destes acordos faz com que a comunidade internacional de juristas trabalhe com sistematização convergente sobre os acordos, pelo que se torna relevante compreender o entendimento generalizado sobre cada um dos temas relevantes.

Neste item pretende-se, portanto, discorrer sobre o objeto, os tipos e as características dos acordos bilaterais firmados pelas variadas nações em sede de cooperação jurídica em matéria concorrencial, sem necessariamente apresentar a perspectiva do sistema jurídico brasileiro. Tal análise está reservada para o item 3.3 deste estudo.

\subsubsection{Acordos de primeira e segunda geração}

Os acordos bilaterais para cooperação em matéria concorrencial de segunda geração diferenciam-se dos acordos de primeira geração na medida em que preveem a possibilidade de contínuo compartilhamento de informações confidenciais entre as autoridades de defesa da concorrência envolvidas ${ }^{617}$.

Em geral, os acordos bilaterais de primeira geração preveem a troca de informações não confidenciais entre as autoridades de defesa da concorrência. Isso não significa, no entanto, que os acordos de primeira geração não prevejam, em alguma medida, a troca de informações confidenciais entre as autoridades envolvidas. Todavia, para a troca de informações sob os auspícios deste tipo de acordo, as autoridades de defesa da concorrência devem obter o consentimento prévio da fonte da informação antes de submeterem a informação à outra autoridade envolvida na cooperação. Obtido o

\footnotetext{
617 "Os acordos de cooperação bilaterais podem ser divididos em acordos de primeira e de segunda geração [...] a distinção desses acordos é feita com base na possibilidade de troca de informações confidenciais entre os países". (MARTINEZ, Maria Beatriz. A cooperação internacional na defesa da concorrência: acordos bilaterais e aplicação do princípio da cortesia positiva. Revista do IBRAC - Direito da Concorrência, Consumo e Comércio Internacional. São Paulo, jan. 2004, v. 11, pp. 177 ss). Também nesse sentido ver JAEGER JÚNIOR, Augusto. Direito Internacional da Concorrência - Entre perspectivas unilaterais, multilaterais, bilaterais e regionais. Curitiba: Juruá, 2008, p. 248; e OLIVEIRA, Gesner; RODAS, João Grandino. Direito e economia da concorrência. Rio de Janeiro: Renovar, 2004, p. 385.
} 
consentimento, o compartilhamento das informações estará submetido a condições e limitações ${ }^{618}$.

Já os acordos de segunda geração têm por objetivo agilizar os procedimentos de cooperação e garantir a efetividade dos resultados pretendidos pela cooperação, tornando o compartilhamento de informações confidenciais um fluxo contínuo entre as autoridades, sem que seja necessária a intervenção ou o consentimento da fonte da informação. $O$ primeiro acordo de segunda geração foi celebrado pelos Estados Unidos e Austrália em $1999^{619}$.

A maior parte dos acordos bilaterais celebrados pelos países, no entanto, é de primeira geração, como é o caso de todos os acordos celebrados pelo Brasil e pelo SBDC. Isso ocorre principalmente por dois fatores, nomeadamente (i) a legislação da grande maioria dos países não admite a troca de informações confidenciais por autoridades governamentais sem que seja obtida autorização prévia da fonte da informação, e (ii) a necessidade de haver um alto grau de comprometimento e de confiança mútua entre as autoridades de defesa da concorrência engajadas na cooperação que implique a troca de informações confidenciais ${ }^{620}$. Tal confiança somente existe nas situações em que há elevada maturidade institucional das partes do acordo, o que não traduz a realidade de muitos países ${ }^{621}$.

Por outro lado, a inserção de dispositivos que permitam o contínuo compartilhamento de informações confidenciais nos acordos bilaterais em matéria concorrencial pode garantir a efetividade da cooperação pretendida, pelo que, conforme informa a doutrina ${ }^{622}$, muitos dos Estados passaram a manifestar interesse em celebrar acordos de segunda geração com países que possuem reconhecida maturidade institucional, como é o caso dos Estados Unidos e da União Europeia. Em paralelo, entretanto, há uma expressiva cautela na adoção de acordos dessa natureza em função da relevância econômica dos interesses protegidos pela legislação de defesa da concorrência - caso da

\footnotetext{
${ }^{618}$ MARTINEZ, Maria Beatriz. A cooperação internacional na defesa da concorrência: acordos bilaterais e aplicação do princípio da cortesia positiva. Revista do IBRAC - Direito da Concorrência, Consumo e Comércio Internacional. São Paulo, jan. 2004, v. 11, pp. 177 ss.

${ }^{619}$ US/Australia Agreement on mutual antitrust enforcement assistance, firmado em Washington em $27 \mathrm{de}$ abril de 1999.

${ }^{620}$ OLIVEIRA, Gesner; RODAS, João Grandino. Direito e economia da concorrência. Rio de Janeiro: Renovar, 2004, p. 385.

${ }^{621}$ MARTINEZ, Maria Beatriz. A cooperação internacional na defesa da concorrência: acordos bilaterais e aplicação do princípio da cortesia positiva. Revista do IBRAC - Direito da Concorrência, Consumo e Comércio Internacional. São Paulo: jan. 2004, v. 11, p. 177 ss; e JAEGER JÚNIOR, Augusto. Direito Internacional da Concorrência - Entre perspectivas unilaterais, multilaterais, bilaterais e regionais. Curitiba: Juruá, 2008, p. 248.

${ }^{622}$ MARTINEZ, Maria Beatriz. Op. cit., 2004.
} 
União Europeia, que tem resistido aos convites dos Estados Unidos em firmar acordo de segunda geração em matéria concorrencial. Maiores detalhes a respeito do compartilhamento de informações constam no item 3.2.2.2.3, infra.

\subsubsection{Objeto dos acordos bilaterais}

Os acordos bilaterais de cooperação em matéria da concorrência poderão ter por objeto a cooperação em relação à aplicação das legislações de defesa da concorrência das partes envolvidas, a cooperação técnica entre autoridades de defesa da concorrência ou ambos.

Conforme exposto na Introdução deste estudo, pretende-se delimitar as tratativas à análise pelas autoridades de defesa da concorrência dos atos de concentração multijurisdicionais, razão porque interessa analisar os acordos que tenham por objeto a aplicação das legislações nacionais de defesa da concorrência, mesmo que na maioria das vezes tais acordos também tenham dispositivos relacionados à cooperação técnica entre as autoridades envolvidas. Excluem-se, assim, do âmbito da análise os acordos de cooperação que tenham como único objetivo a promoção da cooperação técnica entre as autoridades envolvidas na cooperação. Apesar de não constituir tema central deste estudo, entretanto, não é possível tratar das características dos acordos de cooperação em matéria da concorrência sem fazer breve referência à cooperação técnica, conforme texto a seguir.

\subsubsection{Cooperação técnica}

Em geral, a cooperação técnica tem por objetivo promover a disseminação da cultura da concorrência entre a comunidade internacional, bem como o desenvolvimento e o fortalecimento institucional dos sistemas nacionais de defesa da concorrência ${ }^{623}$. Interessante notar que a cooperação técnica em matéria concorrencial não somente tem lugar em sede dos acordos bilaterais de cooperação, que preveem cláusulas desta natureza, mas também por meio das atividades de entidades internacionais, como o Banco Mundial, a OCDE, a ICN e a UNCTAD ${ }^{624}$.

\footnotetext{
${ }^{623}$ LILLA, Paulo Eduardo. A OMC e a interação entre comércio e política antitruste no âmbito da cooperação internacional: perspectivas para a nova rodada de negociações multilaterais. Revista do IBRAC - Direito da Concorrência, Consumo e Comércio Internacional. São Pulo: jan. 2003, v. 10, pp. 233 e ss.

624 "In this context one has to refer to the Technical Assistance of the competition authorities and the Outreach-programs of OECD, which are in particular entrusted with training and educating administrative
} 
Normalmente, os acordos que preveem a assistência técnica são voltados aos países com menor desenvolvimento na área concorrencial, os quais dependem do conhecimento e da experiência das autoridades mais desenvolvidas na adoção e consolidação dos respectivos sistemas nacionais ${ }^{625}$. A cooperação provida nesses casos está no apoio para a elaboração e adoção de novas legislações de defesa da concorrência e na instituição e treinamento de autoridades de defesa da concorrência por países que não as possuem, ou no auxílio ao desenvolvimento e capacitação das legislações e das autoridades já existentes, nos casos em que o grau de maturidade de dado sistema nacional ainda seja muito incipiente.

A capacitação técnica e profissional dos agentes que atuam nas autoridades de defesa da concorrência receptoras da cooperação é um dos pontos fundamentais desta modalidade de cooperação. Além disso, as partes provedoras da cooperação buscam disseminar junto às comunidades assistidas informações relativas ao tratamento de casos com implicações concorrenciais no panorama internacional, os quais na maioria das vezes são dotados de grande complexidade.

A assistência técnica pode se dar em curto ou longo prazo, consoante os objetivos delineados para cada caso de cooperação ${ }^{626}$. Normalmente, a cooperação a longo prazo é direcionada aos casos em que há uma preocupação com a criação de uma cultura de defesa à concorrência, naqueles países que não possuem uma legislação apropriada a tal

authority employees. These measures also harmonize the legal views, economic principles and investigative techniques on which the system is based, and have a direct influence on the convergence process of national antitrust laws". (TERHECHTE, Jörg Philipp. International competition enforcement law: between cooperation and convergence. New York: Springer, 2011, p. 68). Ainda, "existe uma preocupação em relação aos seguintes temas: relações entre as autoridades da concorrência e agências reguladoras de setores específicos da economia, especialmente no que se refere aos processos de privatização e desmonopolização, controle de operações de concentração de empresas internacionais, em especial quando estas vêm a produzir efeitos nos mercados dos países em desenvolvimento e, por último, com a criação de uma cultura da concorrência”. (SANTOS, Maria Cecília de Andrade. A política da concorrência e a Organização Mundial do Comércio. Revista de Direito Constitucional e Internacional, abr./jun. 2001, ano 9, n. 35, p. 243).

625 "Developing countries should also seek capacity building an technical assistance from competition authorities of developed countries and international organizations in order to access the likely impact of individual mergers on the market structure in their countries. It is also in the interests of developed countries to make efforts to cooperate with competition authorities in developing countries and countries in transition giving the changing dynamics of cross-border merger activities". (ORGANIZAÇÃO PARA A COOPERAÇÃO E DESENVOLVIMENTO ECONÔMICO. Global forum on competition - Roundtable on Cross-Border Merger Control: Challenges for Developing and Emerging Economies: Contribution from UNCTAD. DAF/COMP/GF/WD(2011)8. Jan. 2011, p. 6. Disponível em: <http://search.oecd.org/official documents/displaydocumentpdf/?cote=DAF/COMP/GF/WD(2011)8\&docLanguage=En>. Acesso em: 01 dez. 2012).

${ }^{626}$ Ver manifestação da UNCTAD junto à OMC, WTO - WT/WGTCP/W/197, de 15 de agosto de 2002 Grupo de Trabalho sobre Interação entre Comércio e Política de Concorrência (cf. LILLA, Paulo Eduardo. A OMC e a interação entre comércio e política antitruste no âmbito da cooperação internacional: perspectivas para a nova rodada e negociações multilaterais. Revista do IBRAC - Direito da Concorrência, Consumo e Comércio Internacional. São Paulo, jan. 2003, v. 10, pp. 233 e ss). 
finalidade ou em relação àqueles em que a respectiva legislação não é dotada dos instrumentos eficazes para a garantia da concorrência. Nestes casos, às autoridades de defesa da concorrência é disponibilizado um programa de capacitação, o qual inclui o treinamento dos agentes, estágios, troca de funcionários, criação de grupos de estudos, promoção de seminários e revisão das legislações nacionais já existentes.

Já os casos de cooperação técnica a curto prazo incluem a adoção de um programa de capacitação aos países em desenvolvimento, que já possuem um arcabouço legislativo em conformidade com as melhores práticas internacionais, mas que dependem do aprimoramento das habilidades dos seus agentes e das suas instituições para estar preparados a lidar com casos de maior complexidade.

Note-se que a cooperação técnica não necessariamente ocorre entre países desenvolvidos e em desenvolvimento. É perfeitamente plausível se conceber o que na prática tem se concretizado, que é a cooperação existente entre países em desenvolvimento e entre países em menor grau de desenvolvimento. Aliás, a segunda relação descrita parece trazer benefícios às autoridades receptoras da cooperação, uma vez que os países em desenvolvimento têm a possibilidade de compartilhar a sua experiência mais recente na adequação do sistema normativo nacional às práticas de defesa da concorrência, possuindo amplo conhecimento sobre as dificuldades que podem advir do processo de adoção ou aprimoramento de tais conjuntos normativos. Além disso, os países em desenvolvimento e os países menos desenvolvidos em matéria concorrencial, na maior parte das vezes, compartilham uma realidade econômica assemelhada, o que facilita o desenvolvimento do programa de capacitação e a adoção de legislações eficazes para garantia da concorrência.

Conforme descrito no primeiro capítulo deste estudo, o aprimoramento e a consolidação do sistema normativo brasileiro em matéria da concorrência ocorreu com a Lei $\mathrm{n}^{\mathrm{o}} 8.884 / 1994$, portanto, muito recentemente. O Brasil, inclusive, já foi receptor da assistência técnica em matéria concorrencial por meio da cooperação promovida pelas autoridades norte-americanas. O Brasil ocupa, desta maneira, posição favorável à missão de compartilhamento e auxílio a países em desenvolvimento ou em menor desenvolvimento relativo, que não contem com a experiência já adquirida pelas autoridades brasileiras ${ }^{627}$.

\footnotetext{
${ }^{627}$ Santos destaca nesse sentido a assistência técnica promovida pelo CADE na criação da autoridade de defesa da concorrência do Egito. (SANTOS, Maria Cecília de Andrade. A política da concorrência e a Organização Mundial do Comércio. Revista de Direito Constitucional e Internacional, abr./jun. 2001, ano 9 , n. 35, p. 243).
} 
A prática tem revelado que o Brasil de fato tem utilizado este posicionamento para cooperar com outras nações, transmitindo-lhes conhecimentos técnicos relevantes em matéria da defesa da concorrência ${ }^{628}$. Ademais, o SBDC mantém um programa internacional de estágio (PinCADE Internacional), que tem lugar duas vezes ao ano e faculta a representantes das autoridades de defesa da concorrência estrangeiras, em especial da América Latina, a possibilidade de participarem de cursos de formação e condução de atividades de aplicação da legislação brasileira de defesa da concorrência ${ }^{629}$.

Atualmente encontram-se em vigor no Brasil oito acordos que contemplam a cooperação técnica entre autoridades ${ }^{630}$, sendo que destes, quatro a possuem como objeto único entre as autoridades de defesa da concorrência ${ }^{631}$. Um sumário dos acordos celebrados pelo Brasil e pelo SBDC pode se encontrado no Anexo C deste estudo, enquanto que um descritivo pormenorizado dos dispositivos relativos à cooperação técnica nos acordos celebrados pelo Brasil e SBDC pode ser analisado no Anexo D.

É interessante notar que os Estados Unidos e a União Europeia têm sido agentes da promoção da cooperação técnica com o duplo objetivo de auxiliar os países que não possuem uma legislação de defesa da concorrência efetiva e uma estrutura institucional concorrencial consolidada, bem como instrumento para difusão das respectivas políticas da

\footnotetext{
628 "Em 2006, a SDE e o CADE forneceram consultoria a El Salvador, que acabara de promulgar a sua primeira lei da concorrência, sobre técnicas de combate a cartéis. Além disso, tem compartilhado sua experiência no combate a cartéis com o Chile e a Argentina. O SBDC contribuiu com a autoridade da concorrência chilena, a Fiscalía Nacional Econômica (FNE), em seu esforço para convencer os legisladores a aprovar um programa de leniência no Chile. Em junho de 2009, dois Conselheiros do CADE aceitaram convites para visitar o Paraguai e participar de uma série de discussões públicas sobre um projeto de lei de defesa da concorrência atualmente em trâmite junto ao Congresso do Paraguai, que configuraria a primeira lei de concorrência do país. O SBDC também está trabalhando em conjunto com a UNCTAD para a prestação de assistência técnica a outras autoridades de concorrência da América Latina. Por fim, o SBDC está trabalhando com o governo de Angola em um acordo de cooperação informal no qual o SBDC iria ajudar o país na elaboração da sua legislação de concorrência e na formação de capacitação técnica". (ORGANIZAÇÃO PARA A COOPERAÇẪO E DESENVOLVIMENTO ECONÔMICO; IDB - Interamerican Development Bank. Lei e política de concorrência no Brasil: uma revisão pelos pares. Paris: OCDE, 2010, pp. 55-56. Disponível em: <http://www.oecd.org/daf/competition/45154401.pdf>. Acesso em: 11. ago. 2012).

${ }_{629}$ "In 2010, this program gave rise to great interest among competition authorities in Latin America, as evidenced by the increase in the number of interested authorities (from four in 2009 to eight in 2010). In December 2011, CADE executed an agreement with the Brazilian Cooperation agency (ABC) from the Ministry of Foreign Affairs to foster better conditions to this program, including funding". (ORGANIZAÇÃO PARA A COOPERAÇÃO E DESENVOLVIMENTO ECONÔMICO. Global Forum on Competition - Improving International Co-operation in Cartel Investigations: Contribution from Brazil. Session 2. DAF/COMP/GF/WD(2012)32. Jan. 2012, p. 4. Disponível em: <http://search.oecd.org/official documents/publicdisplaydocumentpdf/ ?cote $=\mathrm{DAF} / \mathrm{COMP} / \mathrm{GF} / \mathrm{WD}(2012) 32 \&$ docLanguage $=\mathrm{En}>$. Acesso em: 18 nov. 2012). Nesse sentido, ver também ORGANIZAÇÃO PARA A COOPERAÇÃO E DESENVOLVIMENTO ECONÔMICO; IDB - Inter-american Development Bank. Op. cit., 2010, p. 56.

${ }^{630}$ Acordos firmados com Estados Unidos, Rússia, Argentina, Portugal, União Europeia, França, Peru e China.

${ }^{631}$ Acordos firmados com Rússia, Portugal, França e China.
} 
concorrência ao nível global ${ }^{632}$. Com isso, as duas grandes potências em matéria de desenvolvimento da legislação e política concorrenciais concorrem na disseminação das respectivas estruturas de regulação, buscando, assim, garantir maior força nas negociações multilaterais sobre a matéria.

\subsubsection{Cooperação na aplicação das legislações nacionais de defesa da concorrência}

A cooperação bilateral na aplicação das legislações nacionais de defesa da concorrência pode acarretar diversos benefícios, dentre os quais se destaca a maior efetividade nos mecanismos para aplicação da legislação de defesa da concorrência, maior eficiência na condução das análises e investigações, menor necessidade de se compartilhar informações, mitigação do conflito de competência, proteção dos interesses legítimos das partes em cooperação e alívio para as partes das operações, que não precisam se submeter a diversas autoridades, tampouco à possibilidade de obterem decisões inconsistentes sobre a mesma operação ${ }^{633}$.

Os acordos bilaterais de cooperação na aplicação das legislações nacionais de defesa da concorrência possuem, em geral, disposições semelhantes que afetam os procedimentos de controle de atos de concentrações multijurisdicionais, designadamente: (i) notificação sobre as investigações iniciadas de possível interesse da outra autoridade; (ii) princípio da cortesia positiva, ou seja, o requerimento de abertura de investigações junto à outra autoridade; (iii) coordenação de atividades, ou seja, assistência ou participação em investigações junto à outra autoridade; (iv) coleta de provas e troca de informações na outra jurisdição, incluindo a realização de reuniões periódicas para troca de informações e experiências; e (v) cooperação técnica ${ }^{634}$.

Desta forma, cabe num primeiro momento a análise dos contornos gerais dessas características, de modo que, em momento posterior seja possível realizar a análise dos dispositivos relevantes, partindo da perspectiva do ordenamento jurídico brasileiro. Seguem, portanto, apontamentos gerais sobre as principais e mais recorrentes

\footnotetext{
${ }^{632}$ SANTOS, Maria Cecília de Andrade. A política da concorrência e a Organização Mundial do Comércio. Revista de Direito Constitucional e Internacional, abr./jun. 2001, ano 9, n. 35, p. 239.

${ }^{63}$ DABBAH, Maher M. Future directions in bilateral cooperation: a policy perspective. Cooperation, comity and competition policy. New York: Oxford University Press, 2011, p. 289.

${ }^{634}$ OLIVEIRA, Gesner; RODAS, João Grandino. Direito e economia da concorrência. Rio de Janeiro: Renovar, 2004, p. 385; LILLA, Paulo Eduardo. A OMC e a interação entre comércio e política antitruste no âmbito da cooperação internacional: perspectivas para a nova rodada de negociações multilaterais. Revista do IBRAC - Direito da Concorrência, Consumo e Comércio Internacional. São Paulo, jan. 2003, v. 10, pp.
} 
características dos acordos bilaterais de cooperação sobre a aplicação das legislações de defesa da concorrência pelas diferentes autoridades correspondentes, exceto em relação à cooperação técnica, que foi supracitada no item 3.2.2.1, supra.

\subsection{Notificações trocadas entre autoridades}

Os acordos bilaterais de cooperação em matéria concorrencial estabelecem regras para a realização das notificações entre as autoridades de defesa da concorrência sobre as atividades de aplicação das respectivas legislações de defesa da concorrência e para a troca de informações. Em geral, referidas regras visam instrumentalizar os objetivos dos acordos, pelo que são essenciais para a consecução da cooperação e da coordenação pretendidas.

Conforme aponta a doutrina ${ }^{635}$, os termos dos acordos bilaterais de cooperação apresentam algumas lacunas nas regras para notificações entre as autoridades. Um exemplo está no Acordo EUA/UE 1991, que ao regular a forma de comunicação sobre atividades de sua aplicação, não especificou as hipóteses em que uma autoridade deve notificar a outra, quando da prestação de informações sobre a ocorrência de atividades que podem violar a legislação de defesa da concorrência da parte notificada, solicitando-lhe providências. Desta forma, há dificuldade em se identificar os interesses relevantes que justificam o procedimento de notificação, ampliando demasiadamente o campo de interpretação e hipóteses em que possa ser aplicado tal dispositivo ${ }^{636}$.

Outra lacuna recorrente verificada está no tempo e nos prazos em que tais notificações devem ser promovidas e respondidas pelas autoridades envolvidas. Apesar de em alguns casos os acordos terem uma previsão concreta sobre o momento em que uma autoridade deve promover a notificação à outra sobre determinada matéria, certo é que muitos dos acordos adotados não possuem disposição desta natureza. A falta de dispositivo sobre a matéria pode mitigar a cooperação e tornar ineficiente os esforços das autoridades,

233 e ss; e JAEGER JÚNIOR, Augusto. Direito Internacional da Concorrência - Entre perspectivas unilaterais, multilaterais, bilaterais e regionais. Curitiba: Juruá, 2008, pp. 246-247.

${ }^{635}$ JAEGER JUNIOR, Augusto. Op. cit., 2008, p. 252; e SILVA, Valéria Guimarães de Lima e. Direito antitruste: aspectos internacionais. Curitiba: Juruá, 2007, p. 441.

636 "Ademais, a possibilidade de que a parte solicitante realize tal notificação, ainda que as condutas anticoncorrenciais não sejam proibidas em seu próprio território, colocam em dúvida a importância, a legitimidade ou mesmo a existência de interesses relevantes por parte dela. Ainda, o fato de caber à parte solicitada a realização desta avaliação abre espaço, na prática, para o surgimento de atrito entre ambas no caso de entendimentos divergentes acerca da existência ou não, de referidos interesses relevantes". (SILVA, Valéria Guimarães de Lima e. Direito antitruste: aspectos internacionais. Curitiba: Juruá, 2007, p. 441). 
sendo, portanto, benéfico que os acordos adotem regras claras sobre o momento e os prazos para a promoção das notificações.

Os acordos bilaterais de cooperação em matéria da concorrência normalmente acolhem dispositivo que esclarece sobre a possibilidade de as notificações trocadas pelas partes ocorrerem por meio de contato direto entre as partes do acordo ou seguirem os trâmites da comunicação diplomática. Quando estabelecido que as comunicações e notificações se farão diretamente entre as autoridades de defesa da concorrência, normalmente os acordos preveem a necessidade de as partes indicarem uma pessoa ou um setor de contato que ficará responsável pela centralização de todas as comunicações - em alguns casos o próprio presidente da autoridade de defesa da concorrência assume essa posição.

\subsection{Princípios de cortesia negativa e de cortesia positiva}

Os acordos bilaterais poderão acolher princípios de cortesia negativa e/ou positiva $^{637}$, consoante a cooperação entre as autoridades de defesa da concorrência seja promovida por iniciativa própria ou mediante solicitação da outra parte envolvida nos acordos. Em geral, os princípios da cortesia, positiva ou negativa, são indicativos do reconhecimento mútuo da legislação de defesa da concorrência e da maturidade institucional das partes dos acordos bilaterais ${ }^{638}$. Por meio desses dispositivos, cada Estado se propõe a cooperar e coordenar com o outro Estado na aplicação de normas que a princípio não estariam abrangidas pela sua jurisdição.

\footnotetext{
${ }^{637}$ Em inglês, negative comity e positive comity, respectivamente. Ver OLIVEIRA, Gesner; RODAS, João Grandino. Direito e economia da concorrência. Rio de Janeiro: Renovar, 2004, p. 385, no qual os autores esclarecem que "cortesia significa que um país, ao aplicar suas próprias leis antitruste, leva, de maneira voluntária, em consideração os interesses de outros países, muito embora não necessite dar-lhes, obrigatoriamente, um determinado peso".

638 "Cortesia significa que um país, ao aplicar a própria legislação de defesa da concorrência, leva, de maneira voluntária, em consideração os interesses relevantes de outros países. Isso não implica, todavia, que necessite dar-lhes, obrigatoriamente, uma determinada valoração". (JAEGER JÚNIOR, Augusto. Direito Internacional da Concorrência - Entre perspectivas unilaterais, multilaterais, bilaterais e regionais. Curitiba: Juruá, 2008, p. 248). Ademais, ver DRAETTA, Ugo. Need for better trans-atlantic co-operation in the field of merger control. International Business Law Journal, 2002, p. 558, que define "comity, in the international antitrust law, is defined as a general principle aiming at balancing the exercise of extraterritorial jurisdiction with a readinedd of the country enforcing its competition laws to take into account the important interests of another country (interest balancing rule)"; e FOX, Eleanor M. Antitrust without borders: from roots to codes to networks. Cooperation, comity and competition policy. New York: Oxford University Press, 2011, p. 268, "comity is a concept of discretionary reciprocal deference, It holds that one nation should defer to the law and rules (or dispute resolution) of another because, and where, the other has a greater interest; thus, a greater claim of right'.
} 


\section{a) Cortesia Negativa}

Por intermédio do princípio da cortesia negativa ${ }^{639}$, as autoridades de defesa da concorrência devem levar em consideração os interesses do outro Estado quando estiverem conduzindo internamente qualquer atividade de aplicação do seu respectivo Direito da Concorrência, não exigindo a tomada de medidas específicas ou determinadas ${ }^{640}$. Mais especificamente, uma parte deverá levar em consideração os interesses da outra parte do acordo durante a aplicação da legislação concorrencial, podendo implicar na decisão de não se iniciar uma investigação, deixando, desta forma, a cargo do outro Estado a investigação em questão ${ }^{641}$.

Normalmente, o princípio da cortesia negativa trata de cooperação por iniciativa da parte que está a conduzir a atividade de aplicação, sem a necessidade de haver qualquer estímulo pela parte cujos interesses estejam sendo afetados por tal atividade. Alguns acordos trazem, por outro lado, a possibilidade de uma parte notificar a outra para informála sobre seus interesses relacionados a uma atividade de aplicação em curso na jurisdição da parte requerida. Nestes casos poderá a cortesia negativa ser aplicada em razão de estímulo da parte afetada pelo procedimento de aplicação da legislação em questão.

De todo o modo, note-se que a cortesia negativa configura mero compromisso de observância dos interesses da outra parte do acordo bilateral de cooperação, não exigindo qualquer ação específica da autoridade cujo território tenha eventualmente sido afetado pela prática em questão. Trata-se, portanto, de uma forma superficial de cooperação, uma vez que não acolhe procedimentos claros e diretos a serem observados pelos Estados-partes dos acordos de cooperação. Há apenas um compromisso, que é levar em consideração os

\footnotetext{
${ }^{639}$ Ou cortesia tradicional, como indica MARTINEZ, Maria Beatriz. A cooperação internacional na defesa da concorrência: acordos bilaterais e aplicação do princípio da cortesia positiva. Revista do IBRAC - Direito da Concorrência, Consumo e Comércio Internacional. São Paulo, jan. 2004, v. 11, pp. 177 ss.

640 THORSTENSEN, Vera. A OMC - Organização Mundial do Comércio e as negociações sobre investimentos e concorrência. Revista Brasileira Política Internacional, 1998, v. 41 (1), p. 78. Ver também GERADIN, Damien; REYSEN, Marc; HENRY, David. Extraterritoriality, comity and cooperation in EU Competition Law. Cooperation, comity and competition policy. New York: Oxford University Press, 2011, p. 30; JAEGER JÚNIOR, Augusto. Direito Internacional da Concorrência - Entre perspectivas unilaterais, multilaterais, bilaterais e regionais. Curitiba: Juruá, 2008, p. 248; OLIVEIRA, Gesner; RODAS, João Grandino. Direito e economia da concorrência. Rio de Janeiro: Renovar, 2004, p. 386; MARTINEZ, Maria Beatriz. Op. cit., 2004, cuja autora destaca que "a cortesia tradicional ou negativa foi definida pela primeira vez pelas cortes norte-americanas, em 1895, no julgamento do caso Hilton v. Guyot <159 U.S., 113,164 (1895)>: 'the recognition which one nation allows within it territory to the legislative, executive, or judicial acts of another nation, having due regard both to international duty and convenience and to the rights of its own citizens or of other persons who are under the protection of its laws'.".

641 LILLA, Paulo Eduardo. A OMC e a interação entre comércio e política antitruste no âmbito da cooperação internacional: perspectivas para a nova rodada de negociações multilaterais. Revista do IBRAC - Direito da Concorrência, Consumo e Comércio Internacional. São Paulo, jan. 2003, v. 10, pp. 233 e ss.
} 
interesses da outra parte do acordo, na medida em que tal observância não prejudique os interesses da própria parte em cooperação. $\mathrm{O}$ fato abre espaço para uma decisão subjetiva por parte das autoridades sobre promover ou não a cooperação acordada.

Resumidamente, a cortesia negativa falha ao deixar de exigir das partes um comprometimento com a cooperação em matéria concorrencial, o qual é elemento essencial às exigências econômicas da economia globalizada contemporânea ${ }^{642}$. A adoção do princípio de cortesia negativa nos acordos bilaterais de cooperação concorrencial é bastante comum, variando basicamente em função do seu detalhamento.

\section{b) Cortesia Positiva}

A ideia da cortesia positiva foi amplamente discutida nos foros multilaterais, antes da sua adoção efetiva pelos Estados ${ }^{643}$. Em 1960, ainda no âmbito do GATT, um grupo de especialistas recomendou que os Estados levassem em consideração os requerimentos e consultas realizados por outros Estados e averiguassem se os efeitos indicados pelo país requerente efetivamente existiam e, em caso positivo, tomassem as medidas necessárias para eliminação de tais efeitos ${ }^{644}$.

A OCDE, organização com longa tradição na análise do tema concorrencial, em 1973 publicou pela primeira vez recomendação em prol da adoção do princípio da cortesia positiva, com a publicação do Recommendation Concerning a Consultation and Conciliation Procedure on Restrictive Business Practices Affecting International Trade. Para maiores informações a respeito da atuação da OCDE e suas publicações posteriores em matéria concorrencial, ver item 2.2.2.1.4 supra.

Durante a década de 1990 o princípio da cortesia positiva começou a se desenvolver, principalmente em função da multiplicação dos atos de concentração multijurisdicionais e das práticas anticoncorrenciais, afetando diversas jurisdições. De fato, com a percepção da ocorrência de tais práticas com incidência internacional, as autoridades de defesa da concorrência sentiram a necessidade de desenvolver instrumentos que

\footnotetext{
${ }^{642}$ MARTINEZ, Maria Beatriz. A cooperação internacional na defesa da concorrência: acordos bilaterais e aplicação do princípio da cortesia positiva. Revista do IBRAC - Direito da Concorrência, Consumo e Comércio Internacional. São Paulo, jan. 2004, v. 11, p. 177 ss.

643 Oliveira e Rodas destacam que a cortesia positiva foi primeiramente estabelecida no Friendship, Commerce and Navigation Treaty, celebrado pelos Estados Unidos e Alemanha em 1954, havendo sido posteriormente recomendada pelo GATT e OCDE. (OLIVEIRA, Gesner; RODAS, João Grandino. Direito e economia da concorrência. Rio de Janeiro: Renovar, 2004, p. 386).

${ }^{644}$ MARTINEZ, Maria Beatriz. Op. cit., jan. 2004.
} 
permitissem maior efetividade nas análises e investigações, envolvendo mais do que uma jurisdição $^{645}$.

O primeiro acordo a acolher o princípio da cortesia positiva foi o Acordo EUA/UE $1991^{646}$, sendo refletido em diversos acordos posteriores, como no acordo celebrado entre Estados Unidos e Japão ${ }^{647}$, Estados Unidos e Canadá6 ${ }^{648}$, Estados Unidos e Israel $^{649}$, União Europeia e Canadá, Brasil e Estados Unidos e Brasil e Argentina ${ }^{650}$. Desta forma, passouse a recorrentemente adotar o princípio de cortesia positiva nos acordos de cooperação bilaterais, o qual implica basicamente em atos positivos de cooperação que possibilitam à autoridade requerente solicitar à outra que aja dentro dos poderes conferidos pelo seu próprio ordenamento jurídico, a fim de investigar atividades que afetem o mercado do Estado requerente ${ }^{651}$.

Ou seja, pela cortesia positiva cada parte do acordo de cooperação poderá solicitar à outra parte que sejam iniciadas ou ampliadas atividades de aplicação ${ }^{652}$, no caso de a parte requente acreditar que práticas anticoncorrenciais estejam sendo executadas no território da

645 "Aliado a essa situação, inexistiam instrumentos multilaterais capazes de lidar com a problemática da concorrência, o que obrigou os países líderes do comércio mundial a introduzir uma inovação em suas relações bilaterais. Surge o princípio da cortesia positiva”. (MARTINEZ, Maria Beatriz. A cooperação internacional na defesa da concorrência: acordos bilaterais e aplicação do princípio da cortesia positiva. Revista do IBRAC - Direito da Concorrência, Consumo e Comércio Internacional. São Paulo, jan. 2004, v. 11$, p. $177 \mathrm{ss})$.

646 "A inclusão de tal previsão no acordo gerou muita expectativa para ambas as partes, tendo sido considerado um importante primeiro passo rumo à efetiva cooperação em matéria de defesa da concorrência. Seus autores foram enfáticos ao afirmar que suas previsões levariam à redução das disputas decorrentes da aplicação extraterritorial das leis antitruste". (MARTINEZ, Maria Beatriz. A cooperação internacional na defesa da concorrência: acordos bilaterais e aplicação do princípio da cortesia positiva. Revista do IBRAC Direito da Concorrência, Consumo e Comércio Internacional. São Paulo, jan. 2004, v. 11, p. 177 ss). ). Nesse sentido, ver também GERADIN, Damien; REYSEN, Marc; HENRY, David. Extraterritoriality, comity and cooperation in EU competition law. Cooperation, comity and competition policy. New York: Oxford University Press, 2011, p. 30; JAEGER JÚNIOR, Augusto. Direito Internacional da Concorrência - Entre perspectivas unilaterais, multilaterais, bilaterais e regionais. Curitiba: Juruá, 2008, p. 248; e OLIVEIRA, Gesner; RODAS, João Grandino. Direito e economia da concorrência. Rio de Janeiro: Renovar, 2004, p. 386.

${ }^{647}$ Agreement between the Government of the United States of America and the Government of Japan concerning Cooperation on Anticompetitive Activites, assinado em 07 de novembro de 1999.

${ }^{648}$ Agreement between the Government of United States of America and the Government of Canada regarding the Application of their Competition and Deceptive Marketing Practice Laws, assinado em 03 de agosto de 1995.

${ }^{649}$ Agreement between the Government of United States of America and the Government of the State of Israel regarding the Application of their Competition Laws, assinado em 15 de março de 1999.

${ }^{650} \mathrm{Cf}$. se pode constatar no item 3.3.4 deste estudo, em relação ao Brasil, os acordos subsequentes seguiram o modelo do acordo entre Estados Unidos e União Europeia firmado em 1991, ou seja, com menor detalhamento sobre o mecanismo de cortesia positiva.

${ }^{651}$ TAVARES DE ARAÚJO JR, José. Política de concorrência no Mercosul: uma agenda mínima. Ago. 2001. Disponível em: http://www.sedi.oas.org/DTTC/TRADE/PUB/STAFF_ARTICLE/tav01_conc_agenda. asp. Acesso em: 22 out. 2009; JAEGER JÚNIOR, Augusto. Op. cit., 2008, p. 248; THORSTENSEN, Vera. A OMC - Organização Mundial do Comércio e as negociações sobre investimentos e concorrência. Revista Brasileira Política Internacional, 1998, v. 41 (1), p. 78; e MARTINEZ, Maria Beatriz. Op. cit., jan. 2004. 
parte requerida, ou que nele estejam localizados os subsídios necessários para a análise das práticas anticoncorrenciais pela parte requerente, cujas práticas em última análise, afetem interesses relevantes da parte requerente ${ }^{653}$. Apesar de em geral a parte requerida não estar obrigada a agir da maneira e forma solicitadas ${ }^{654}$, caso tome alguma medida, normalmente terá o dever de manter a parte requerente informada.

O princípio da cortesia positiva adotado nos acordos bilaterais de cooperação diferencia-se da tradicional cortesia norte-americana, na medida em que esta se limita à consideração dos interesses dos outros países na aplicação da legislação de defesa da concorrência norte-americana. Enquanto isso, aquele viabiliza aos Estados cujos interesses estejam sendo ou possam vir a ser afetados por determinada prática ocorrida em outro Estado, vindo a requerer o início das medidas necessárias para satisfação destes interesses, levando efetivamente em consideração os interesses da parte requerente e o mantendo informado sobre o desenvolvimento dos procedimentos relativos à aplicação de tais medidas $^{655}$.

Em geral, sob o manto da cortesia positiva, a expectativa de que a parte requerida efetivamente analise e investigue a prática objeto da solicitação de cooperação somente se justifica na medida em que tal conduta seja recriminada no território da parte requerida, revelando, assim, uma variação do princípio da dupla-incriminação ${ }^{656}$. Exceção a esta regra

${ }^{652}$ RIVERS, Ricky D. General Electric/Honeywell Merger: European Commission Antitrust Decision Strikes a Sour Note. ILSA Journal of International and Comparative law, 2002/2003, v. 9, p. 531.

653 Santos esclarece que a "aplicação deste conceito implica que, quando ocorrerem restrições da concorrência no território de uma das partes que afeta desfavoravelmente a outra, poderá ser possível solicitar que esta parte inicie um procedimento, sempre que tais restrições estejam proibidas pelas normas que se aplicam no território em que as mesmas venham a ocorrer. Assim, reduz-se não apenas o número de casos que vêm a ser examinados por mais de uma autoridade de concorrência, mas também os custos e o risco da existência de decisões em conflitos. Evitam-se igualmente os conflitos políticos que poderiam decorrer de uma aplicação extraterritorial das leis". (SANTOS, Maria Cecília de Andrade. A política da concorrência e a Organização Mundial do Comércio. Revista de Direito Constitucional e Internacional, abr./jun 2001, ano 9, n. 35, p. 231). No mesmo sentido, ver NUSDEO, Ana Maria de Oliveira. Defesa da concorrência e globalização econômica. São Paulo: Malheiros, 2002, p. 171, cuja autora descreve que pela cortesia positiva há a "presunção de deferimento por uma das partes, na aplicação de suas regras da concorrência, ao interesse da outra, quando as atividades anticompetitivas forem direcionadas principalmente ao território desta última". 654 "É importante frisar que as disposições do acordo, principalmente no que concerne aos princípios de cortesia, não têm caráter vinculativo para as partes, ou seja, trata-se de mecanismos de aplicação voluntária com o intuito de dirimir os conflitos e tensões causados por aplicações unilaterais de leis antitruste nacionais". (cf. LILLA, Paulo Eduardo. A OMC e a tnteração entre comércio e política antitruste no âmbito da cooperação internacional: perspectivas para a nova rodada de negociações multilaterais. Revista do IBRAC - Direito da Concorrência, Consumo e Comércio Internacional. São Paulo, jan. 2003, v. 10, pp. 233 e ss).

${ }^{655}$ SILVA, Valéria Guimarães de Lima e. Direito antitruste: aspectos internacionais. Curitiba: Juruá, 2007, p. 439.

${ }^{656} \mathrm{O}$ princípio da dupla-incriminação, muito invocado no âmbito das extradições, refere-se à necessidade de se verificar a incriminação do fato nas duas jurisdições envolvidas na cooperação, para que esta seja viabilizada. Contemporaneamente tem-se verificado que em jurisdições de elevado grau de confiança mútua, 
está no Acordo EUA/UE 1998 que admite que a prática objeto de requerimento de cortesia positiva não seja condenada pelo ordenamento jurídico do Estado requerente, exigindo tão somente que seja repreendida no território do Estado requerido ${ }^{657}$.

Nesse sentido, o art. $3^{\circ}$ do Acordo EUA/UE 1998 prevê que as respectivas autoridades de defesa da concorrência podem solicitar, umas às outras, que seja iniciada investigação sobre atividades anticoncorrenciais e, se necessário, que seja aplicado o Direito da Concorrência da autoridade requerida com a finalidade de repreender eventuais condutas identificadas. Note-se, no entanto, que apesar de prever a possibilidade de solicitação de aplicação do princípio da cortesia positiva e de apresentar pedidos de cooperação, nenhuma das partes está, ao menos nos termos do acordo celebrado pelos Estados Unidos e União Europeia, em 1991 e 1998, obrigada a agir desta maneira ${ }^{658}$.

O objetivo do princípio da cortesia positiva está, pois, em diminuir os conflitos existentes entre os Estados em função da aplicação extraterritorial das respectivas legislações de defesa da concorrência por meio da realocação da responsabilidade de se conduzir a análise e as investigações da prática anticoncorrencial entre as partes signatárias do acordo bilateral de cooperação. O Estado prejudicado pela prática poderá, assim, afastar a necessidade de aplicar extraterritorialmente a sua legislação de defesa da concorrência, caso o Estado correspondente ao local onde a conduta foi executada conseguir promover no seu território de forma eficaz as medidas necessárias ao combate das práticas que afetam o interesse da parte prejudicada ${ }^{659}$.

o princípio da dupla-incriminação tem sido afastado em algumas ocasiões - como é o caso da União Europeia e do Mandado de Detenção Europeu.

${ }^{657}$ SILVA, Valéria Guimarães de Lima e. Direito antitruste: aspectos internacionais. Curitiba: Juruá, 2007, p. 439, no qual a autora fundamenta tal entendimento no art. $3^{\circ}$ do Acordo EUA/UE 1998.

${ }^{658}$ RIVERS, Ricky D. General Electric/Honeywell Merger: European Commission Antitrust Decision Strikes a Sour Note. ILSA Journal of nternational and comparative Lasw, 2002/2003, v. 9, p. 533.

659 "O princípio da cortesia positiva configura importante instrumento de enaltecimento da cooperação internacional no combate às práticas anticompetitivas, permitindo que sejam minimizados os conflitos que possam surgir em decorrência da necessidade de investigações transfronteiriças de condutas prejudiciais aos mais diversos mercados [...] desta forma, a aplicação da cortesia positiva evita dúvidas e, até mesmo, conflitos políticos, que possam advir no tocante à determinação de direito aplicável às condutas, evitando, também, o risco de existirem decisões conflitantes a respeito da mesma infração". (MARTINEZ, Maria Beatriz. A cooperação internacional na defesa da concorrência: acordos bilaterais e aplicação do princípio da cortesia positiva. Revista do IBRAC - Direito da Concorrência, Consumo e Comércio Internacional. São Paulo, jan. 2004, v. 11, p. 177 ss). A autora ainda destaca que "nesse sentido, um país que recebe fundamentadas reclamações acerca da ocorrência de violações à concorrência verificadas em outro país possui, geralmente, três opções: (i) sugerir que o reclamante demande perante o país em que se verifica a conduta; (ii) utilizar-se da aplicação do seu próprio sistema de defesa da concorrência, ainda que a conduta não viole as suas regras ou esteja claramente fora de sua jurisdição; ou (iii) efetuar uma notificação do outro país com base no princípio da cortesia positiva, desde que exista prévio acordo prevendo a utilização desta cláusula". 
No momento da concepção e adoção inicial do princípio da cortesia positiva havia grande expectativa no sentido de que o mesmo viesse a suprir a lacuna legislativa existente, a qual tumultuava os casos com implicações concorrenciais multijurisdicionais em razão da aplicação extraterritorial das legislações de defesa da concorrência.

A efetividade da adoção da cortesia positiva em acordos bilaterais de cooperação em matéria concorrencial, porém, somente ocorrerá nos casos em que houver um elevado grau de confiança entre as autoridades envolvidas e a efetiva voluntariedade na sua implementação ${ }^{660}$. Os dispositivos de cortesia positiva inseridos nos acordos bilaterais não são conjugados com previsões sobre ônus ou penalidades no caso de descumprimento pelas partes do acordo, tampouco com instrumentos de coerção e sistema de resolução de controvérsias $^{661}$. Desta forma, conforme descrito posteriormente no item 3.5 deste estudo, o princípio da cortesia positiva não pode ser considerado suficiente para resolver a problemática advinda da aplicação extraterritorial das variadas legislações de defesa da concorrência $^{662}$.

\subsection{Busca e compartilhamento de informações}

Os acordos bilaterais de cooperação em matéria concorrencial preveem em alguma medida a busca e o compartilhamento de informações entre as autoridades de defesa da concorrência. Nesse sentido, é importante ter em mente que os procedimentos de análise e investigação de práticas anticoncorrenciais possuem índole eminentemente econômica, pelo que o acesso às informações por parte das autoridades que analisam ou investigam tais práticas é essencial para um bom desenvolvimento dos procedimentos.

\footnotetext{
660 “Ainda que prevista em outros acordos bilaterais de cooperação, a implementação do princípio da cortesia positiva se sujeita, acima de tudo, à vontade das partes envolvidas [...], a discricionariedade que as autoridades nacionais competentes possuem na esfera do controle de concentrações é extremamente limitada, além de que os interesses antagônicos dos Estados envolvidos muitas vezes obstam a coordenação de suas atividades". (SILVA, Valéria Guimarães de Lima e. Direito antitruste: aspectos Internacionais. Curitiba: Juruá, 2007, p. 440).

661 JAEGER JÚNIOR, Augusto. Direito Internacional da Concorrência - Entre perspectivas unilaterais, multilaterais, bilaterais e regionais. Curitiba: Juruá, 2008, p. 252; e SILVA, Valéria Guimarães de Lima e. Op. cit., 2007, p. 466, cuja autora esclarece que a União Europeia chegou a propor que os dispositivos sobre cortesia positiva fossem vinculantes às partes do acordo, mas que tal sugestão foi afastada pelos Estados Unidos, sob o fundamento de que o Congresso norte-americano vetaria compromisso internacional desta natureza, em função da limitação que acarretaria nos poderes antitruste nacionais, previstos em lei - "o que demonstra a ausência de disposição do país em abrir mão da regulação das práticas concorrenciais que extrapolem seus limites territoriais".

${ }^{662}$ Fox e Crane alertam, ademais, que até o ano de 2010 a cortesia positiva prevista no Acordo EUA/UE 1998 não havia sido formalmente invocada. Em relação ao Acordo EUA/UE 1991, os autores informam a respeito do caso Amadeus, segundo o qual as autoridades norte-americanas derrogaram a análise do caso à União
} 


\section{a) Busca de informações}

A jurisdição nacional está limitada aos princípios de Direito Internacional Público, dentre os quais se destaca o princípio da não interferência de um Estado em assuntos internos dos outros Estados ${ }^{663}$. Desta forma, a condução de procedimentos para apuração de práticas comerciais restritivas que exijam, por exemplo, diligências a serem realizadas no território de outros Estados, depende da colaboração de tais Estados na condução das diligências ${ }^{664}$. Assim, o Direito Internacional Público garante que um Estado não poderá exercer sua jurisdição no território de outro Estado, sem que o Estado receptor de alguma forma aprove a medida pretendida.

Note-se que conforme discutido no primeiro capítulo deste estudo, no âmbito do Direito Internacional da Concorrência, o Direito Internacional Público permite, por falta de limitações expressas nesse sentido, a aplicação extraterritorial do Direito da Concorrência, refletindo verdadeira extensão da jurisdição nacional a atos praticados no estrangeiro. Tal prerrogativa, no entanto, relaciona-se somente às normas de natureza de direito material concorrencial, não abarcando aquelas normas de direito adjetivo ou procedimental (como seriam os casos da execução das decisões de uma autoridade em outro território). Para estas, a execução da jurisdição nacional em território estrangeiro dependerá sempre da cooperação de tal Estado.

Deve-se sempre ter em mente que para além dos acordos que porventura sejam firmados para a cooperação em matéria concorrencial, os Estados possuem firmados tratados de assistência judiciária ${ }^{665}$, os quais podem ter aplicabilidade no que se refere à busca de informações confidenciais e não confidenciais, levantamento de sigilo bancário, telefônico e sobre comunicações, obtenção de provas, buscas e apreensões, confisco e

Europeia (FOX, Eleanor M.; CRANE, Daniel A. Global issues in antitrust and competition law. St. Paul: West, 2010, p. 517).

663 Inclusive questões relacionadas aos direitos humanos e fundamentais poderão ser levantadas. Nesse sentido, ver TERHECHTE, Jörg Philipp. International competition enforcement law: between cooperation and convergence. New York: Springer, 2011, pp. 19-20, no qual o autor esclarece "the differences in national Standards regarding fundamental and human rights can constitute a not-to-be-underestimated hindrance to the cooperation of authorities or courts. One, for example, hás to consider the consequences of information Exchange in the ECN or between authorities at the international level. Is evidence that hás been obtained through ways which fail to abide by German Standards (i.e., violating a prohibition on the taking of evidence) nevertheless admissible, provided foreign authorities supplied it? The disclosure of such information is explicitly forbidden by the majority of legal systems, at least in the international context showcasing its role as a manifestation of individual fundamental rights positions [...]. Another basic question that affects fundamental rights is the role of the so-called Legal Professional Privilege, which shall protect legal correspondence between lawyers and their clients".

664 FARIA, José Ângelo Estrella. Aplicação extraterritorial do direito da concorrência. Revista de Informação Legislativa. Brasília, jan./mar. 1990, n. 105, p. 32. 
repatriamento de bens em territórios estrangeiros ${ }^{666}$. Apesar da relevância desses tratados, a sua utilização em matérias relacionadas ao tema concorrencial parece ter maior relevância nos casos de cartéis internacionais do que nos atos de concentração multijurisdicionais.

No âmbito dos atos de concentração multijurisdicionais, a busca por informações normalmente ocorre quando representantes ou colaboradores de uma autoridade de defesa da concorrência se deslocam para o território de competência de outra autoridade para participar em reuniões, investigações e procedimentos realizados neste território, a fim de obter informações relacionadas à operação sob análise ou investigação em comum entre ditas autoridades.

Pode também ocorrer a busca de informações quando a autoridade de defesa da concorrência de uma jurisdição mantém contatos diretos com partes da operação ou terceiros situados em outro território, com o objeto de recebimento de informações sobre a operação pretendida, podendo tal busca ter lugar pela apresentação de questionários para preenchimento ou por contatos telefônicos ou pessoais. Ademais, enquadram-se na hipótese de busca de informações os casos em que uma autoridade solicita à outra que realize em seu território procedimentos de busca de informações sobre questões do interesse da parte requerente.

Nestas hipóteses, a autoridade detentora da informação não age como simples remetente da informação, cujo acesso lhe está disponível para a autoridade requerente, pelo que não é possível enquadrá-las como simples troca de informações. De fato, há um envolvimento efetivo entre a autoridade interessada e a fonte das informações localizada no território da autoridade consultada, ou a promoção de procedimentos pela autoridade

\footnotetext{
${ }^{665}$ Mutual Legal Assistance Treaty (MLAT), em inglês.

${ }^{666}$ De fato, ao comentar sobre os instrumentos disponíveis para a cooperação concorrencial nos casos de cartéis internacionais as autoridades de defesa da concorrência comentam: "on a broader cooperation level (i.e., cooperation between countries), MLATs signed with Canada, China, Colombia, Cuba, Italy, France, Mercosur, Peru, Portugal, Spain, South Korea, Suriname, Switzerland, Ukraine, the U.S., and Uruguay are also in force [...]. We are also part of the Inter-American Convention on Mutual Assistance in Criminal Matters, the Inter-American Convention against Corruption, the United Nations Convention against Illicit Traffic in Narcotic Drugs and Psychotropic Substances of 1998, the OECD Anti-Bribery Convention, United Nations Convention against Transnational Organized Crime, and the United Nations Convention against Corruption". (ORGANIZAÇÃO PARA A COOPERAÇÃO E DESENVOLVIMENTO ECONÔMICO. Global forum on competition - Improving International Co-operation in Cartel Investigations: Contribution from Brazil. Session 2. DAF/COMP/GF/WD(2012)32. Jan. 2012, p. 2. Disponível em: <http://search. oecd.org/officialdocuments/publicdisplaydocumentpdf/?cote=DAF/COMP/GF/WD(2012)32\&docLanguage $=$ En>. Acesso em: 18 nov. 2012). No mesmo sentido, ver SWAINE, Edward T. Cooperation, comity and competition policy: United States. Cooperation, comity and competition policy. New York: Oxford University Press, 2011, pp. 18-19: "some os this cooperation is facilitaded by instruments with broader application, like mutual legal assistance treaties (MLATs) and extradition treaties".
} 
notificada em seu território, os quais são executados em vista da solicitação enviada pela parte interessada.

Conforme referido anteriormente, tais procedimentos poderão esbarrar em regras de ordem pública e soberania do Estado requerido, pelo que qualquer pedido de busca de informações deverá ser precedido de uma análise cautelosa sobre os procedimentos disponíveis em cada ordenamento envolvido, para a execução de procedimentos em territórios não abarcados pela jurisdição da autoridade interessada. Nesse tocante devem sempre ser considerados eventuais tratados assinados pelos Estados envolvidos em matéria de cooperação jurisdicional internacional, bem como as regras dos ordenamentos correspondentes sobre limitações das autoridades administrativas na condução de procedimentos cooperativos com autoridades estrangeiras - as quais são limitadas, em algumas hipóteses, ao envolvimento de autoridades judiciárias competentes.

\section{b) Compartilhamento de informações}

Já nos casos de compartilhamento ou troca de informações ${ }^{667}$, as autoridades envolvidas simplesmente comprometem-se a promover a transmissão das informações umas às outras, seja por meio das vias diplomáticas, ou por contato direto entre as autoridades envolvidas $^{668}$. O compartilhamento de informações trata do nível mais baixo de cooperação, pela qual os Estados mantêm a sua soberania, independência e autoridade na condução dos negócios internacionais ${ }^{669}$.

Neste tocante torna-se relevante a diferenciação entre as informações não confidenciais, ou seja, aquelas de acesso público, e as informações confidenciais, que em

\footnotetext{
667 “Os principais deveres assumidos pelas partes referem-se à informação recíproca a respeito de atividades potencialmente anticompetitivas realizadas em seu território de que tenham conhecimento e sejam do interesse da contraparte; à informação sobre investigações ou medidas tomadas que possam afetar os interesses da outra parte; ao oferecimento de assistência na obtenção de provas necessárias às atividades da parte, podendo requisitar documentos, inquirir testemunhas, realizar buscas etc." (NUSDEO, Ana Maria de Oliveira. Defesa da concorrência e globalização econômica. São Paulo: Malheiros, 2002, p. 170).

${ }^{668}$ Note-se que as autoridades norte-americanas destacam que o contato direto entre autoridades é uma das formas aprimoradas de troca de informações entre autoridades de defesa da concorrência no âmbito dos acordos bilaterais: "some of our arrangements, e.g., the Brazil and Mexico bilateral agreements, have enhanced communication by providing for direct contacts between antitrust agencies". (ORGANIZAÇÃO PARA A COOPERAÇÃO E DESENVOLVIMENTO ECONÔMICO. Global Forum on Competition Roundtable on Cross-Border Merger Control: Challenges for Developing and Emerging Economies: Contribution from United States. DAF/COMP/GF/WD(2011)29. Session 1. Fev. 2011, p. 6. Disponível em: $<\mathrm{http}: / / \mathrm{www} . \mathrm{ftc} . \mathrm{gov} / \mathrm{bc} /$ international/docs/1102crossbordermergercontrol.pdf $>$. Acesso em: $01 \mathrm{dez}$. 2012). 669 "Without agreements to facilitate the sharing of information, firms could reside abroad, conduct meetings abroad, and store certain documents regarding prohibited activity offshore and out of the hands of prosecutors. Cooperation regarding information, then, is essencial, at a minimum, for the purposes of
} 
razão de lei ou acordo são para uso exclusivo do detentor da informação. Conforme analisado no item 3.2.1 supra, os acordos bilaterais de cooperação dividem-se entre acordos de primeira e segunda geração, consoante prevejam ou não o contínuo compartilhamento de informações confidenciais entre as autoridades de defesa da concorrência. Tais tipos de acordos têm em comum a possibilidade de compartilhamento de informações não confidenciais, enquanto que o tratamento das informações confidenciais possui regulação diferenciada. Enquanto que nos acordos de primeira geração poderá haver dispositivo que permita a troca de informações confidenciais depois de obtido o consentimento prévio da fonte da informação, os acordos de segunda geração prescindem de qualquer procedimento de anuência da fonte da informação para a troca de informações confidenciais entre as autoridades envolvidas.

Note-se, no entanto, que para que uma dada autoridade de defesa da concorrência possa compartilhar informações confidenciais com outra autoridade geralmente é necessário que haja permissivo legal no seu sistema jurídico para que aja desta forma ${ }^{670}$. A falta de permissivo legal poderá tornar ineficaz e inócua a celebração de acordo de segunda geração. Por tal motivo, os Estados que decidirem celebrar acordos de segunda geração, devem buscar dotar os respectivos ordenamentos jurídicos internos com as regras necessárias para a efetivação dos dispositivos relacionados à troca de informações confidenciais entre as autoridades.

Nesse sentido foi a manifestação da UNCTAD na última conferência havida para revisar a Série PERs, em Genebra, em novembro de $2010^{671}$, quando concluiu que a troca

enforcement'. (GUZMAN, Andrew T. Competition law and cooperation: possible strategies. Cooperation, comity and competition policy. New York: Oxford University Press, 2011, p. 356).

670 "As informações confidenciais são em regra protegidas por leis nacionais e somente poderão ser compartilhadas com o outro país integrante do acordo se houver concordância por parte da empresa da qual elas provêm, o que dificilmente irá acontecer - a menos que haja o comprometimento do Estado que julga a causa em reduzir uma eventual punição à empresa - prejudicando, consequentemente, o desenvolvimento das investigações conjuntas, sobretudo nos casos de formação de cartéis internacionais". (SILVA, Valéria Guimarães de Lima e. Direito antitruste: aspectos internacionais. Curitiba: Juruá, 2007, p. 441). Ver também CARVALHO, Leonardo Arquimino de. Direito antitruste \& relações internacionais: extraterritorialidade e cooperação. Curitiba: Juruá, 2003, p. 200, cujo autor destaca que "o fornecimento de informações representa outro elemento dificultador da aplicação da legislação antitruste a fatos ocorridos fora da jurisdição ordinária. $O$ interessante neste tópico é considerar que as informações não são necessariamente sonegadas por falta de vontade ou mesmo para dificultar o trabalho das autoridades antitruste de um determinado país. As informações requeridas, de modo geral, transpassam um grau normal de informações que poderiam ser divulgadas pelo agente econômico sem prejuízos para suas estratégias comerciais".

671 "There were ongoing efforts towards building formal and informal networks to promote cooperation among agencies. However, while significant progress was being made by those types of networks, there were still important challenges, for example, limits imposed in the exchange of confidential information. In that regard, there was an insistence on the importance of protecting confidentiality of information to be shared with other competition authorities. Exchanges should focus on non-confidential information and experience. It was emphasized that exchange of information should only take place in line with the respective national legislation; and in the absence of existing domestic rules or necessary regional guarantees, it would be 
de informações entre autoridades de defesa da concorrência deve ocorrer com base nas legislações nacionais que sejam aplicáveis à hipótese, sendo que caso inexista uma permissão legislativa para a troca de informações confidenciais, seria prematuro promover o compartilhamento de tais informações.

Exatamente com o intuito de tornar possível a troca de informações confidenciais por suas autoridades de defesa da concorrência, os Estados Unidos adotaram, em 1994, uma legislação denominada Lei de Assistência à Execução Internacional (IAEAA) ${ }^{672}$, que ampliou as suas possibilidades de cooperação no que se refere aos acordos de segunda geração, permitindo que fossem assinados documentos que estabelecessem mecanismos para troca de informações confidenciais entre autoridades, desde que preservados os interesses americanos ${ }^{673}$. Em geral, o IAEAA confere às autoridades norte-americanas de defesa da concorrência os poderes necessários para celebrar acordos de cooperação que envolvam a troca de informações confidenciais, inclusive informações comerciais obtidas no curso de atividades de aplicação da legislação concorrencial ${ }^{674}$.

premature to exchange confidential information. It was highlighted that more advanced jurisdictions were at the stage of exchanging confidential information under specific circumstances and there was a call for further discussion to explore the modalities of establishing a framework on this matter". (UNCTAD. Report of the sixth United Nations Conference to review all aspects of the set of multilaterally agreed equitable principles and rules for the control of restrictive business practices. Disponível em: <http://unctad.org/en/docs/tdrbpconf7d11_en.pdf>. Acesso em: 04 nov. 2012, p. 11).

${ }^{672}$ Em inglês, International Antitrust Enforcement Assistance Act.

${ }^{673}$ Não obstante essa faculdade, as autoridades norte-americanas devem observar a legislação aplicável que proíbe a troca de informações comerciais recebidas: "U.S. law generally prohibits the agencies from sharing confidential business information obtained during a merger investigation unless the submitter voluntarily waives its confidentiality rights". (ORGANIZAÇÃO PARA A COOPERAÇÃO E DESENVOLVIMENTO ECONÔMICO. Global forum on competition - Roundtable on Cross-Border Merger Control: Challenges for Developing and Emerging Economies: Contribution from United States. DAF/COMP/GF/WD(2011)29. Session 1. Fev. 2011, p. 7. Disponível em: <http://www.ftc.gov/bc/international/docs/1102crossbordermerger control.pdf>. Acesso em: 01 dez. 2012). Para maiores informações sobre o IAEAA, ver também NUSDEO, Ana Maria de Oliveira. Defesa da concorrência e globalização econômica São Paulo: Malheiros, 2002, p. 171; OLIVEIRA, Gesner; RODAS, João Grandino. Direito e economia da concorrência. Rio de Janeiro: Renovar, 2004, p. 385; e MARTINEZ, Maria Beatriz. A cooperação internacional na defesa da concorrência: acordos bilaterais e aplicação do princípio da cortesia positiva. Revista do IBRAC - Direito da Concorrência, Consumo e Comércio Internacional. São Paulo: jan. 2004, v. 11, p. 177 ss, cuja autora destaca que o primeiro dos acordos sob o bojo do IAEAA foi o firmado pelos Estados Unidos com a Austrália, em 1999.

674 "In theory, this permits countries to conduct joint or at least coordinated antitrust investigations without the need to seek waivers from the parties supplying the information. But the benefits are largely theoretical, since only such agreement - with Australia - has been entered into under IAEAA". (SWAINE, Edward T. Cooperation, comity and competition policy: United States. Cooperation, comity and competition policy. New York: Oxford University Press, 2011, p. 19). Ver também DABBAH, Maher M. Future directions in bilateral cooperation: a policy perspective. Cooperation, comity and competition policy. New York: Oxford University Press, 2011, p. 295; e LILLA, Paulo Eduardo. A OMC e a interação entre comércio e política antitruste no âmbito da cooperação internacional: perspectivas para a nova rodada de negociações multilaterais. Revista do IBRAC - Direito da Concorrência, Consumo e Comércio Internacional. São Paulo, jan. 2003, pp. 233 e ss. 
Por outro lado, alguns países continuam reticentes em outorgar poderes de troca de informações confidenciais pelas respectivas autoridades de defesa da concorrência, uma vez que tais trocas poderiam comprometer os interesses econômicos nacionais/regionais ${ }^{675}$. A União Europeia é um exemplo dessa situação, cuja autoridade, com alto grau de maturidade institucional e desenvolvimento, não possui os poderes necessários para troca de informações confidenciais sem que seja previamente obtida a anuência da fonte da informação e, por tal razão, não possui acordos de segunda geração celebrados com suas congêneres. O Brasil também não possui permissivo legal para troca de informações confidenciais sem que seja obtida a anuência prévia da fonte da informação, conforme se analisará posteriormente no item 3.3.6, infra.

Em suma, nos países em que não há permissivo legal para celebrar acordos de segunda geração, somente são celebrados acordos de primeira geração. Nestes casos, o escopo da cooperação concorrencial poderá ser, portanto, limitada. Conforme mencionado, para que informações confidenciais sejam compartilhadas entre autoridades de defesa da concorrência no bojo de acordo de primeira geração, será necessário obter a anuência prévia da fonte da informação ${ }^{676}$.

Todavia, nos casos de sérias violações da legislação concorrencial (como nos casos de cartel, abuso de posição dominante, dentre outros), os sujeitos "fonte" da informação não terão, a princípio, o estímulo e a boa vontade necessária para conferir sua anuência para a troca de informações confidenciais entre as autoridades competentes - com exceção dos casos em que tais sujeitos queiram cooperar com as autoridades em razão de eventual tratamento privilegiado que lhes venha a ser concedido (como em casos de celebração de acordos de leniência) ${ }^{677}$. Por outro lado, se considerados os casos de ato de concentração

\footnotetext{
675 "Vale esclarecer a problemática vivenciada pela maioria dos Estados quanto à assinatura de acordos de segunda geração. Tendo em vista a necessidade de proteção dos interesses nacionais, diversos países possuem previsão legal que proíbe a troca ou a divulgação de informações confidenciais sem a expressa autorização da parte detentora da informação. Os acordos de cooperação ficam, portanto, subordinados a esse tipo de limitação, sendo muitas vezes denominados de 'soft agreements'." (MARTINEZ, Maria Beatriz. A cooperação internacional na defesa da concorrência: acordos bilaterais e aplicação do princípio da cortesia positiva. Revista do IBRAC - Direito da Concorrência, Consumo e Comércio Internacional. São Paulo; jan. 2004, v. 11, pp. 177 e ss). Nesse sentido ver também UNIÃO EUROPEIA. International co-operation in antitrust matters: making the point in the wake of the Boeing/MDD proceedings. Disponível em: <http://ec.europa.eu/competition/speeches/text/sp1998_004_en.html>. Acesso em: 04 nov. 2012.

676 "The sharing of confidential business information pursuant to a waiver facilitates the identification of competitive concerns in each reviewing jurisdiction and thus reduces the risk of inconsistent outcomes". (ORGANIZAÇÃO PARA A COOPERAÇÃO E DESENVOLVIMENTO ECONÔMICO. Global forum on competition - Roundtable on Cross-Border Merger Control: Challenges for Developing and Emerging Economies: Contribution from United States. DAF/COMP/GF/WD(2011)29. Session 1. Fev. 2011, p. 7. Disponível em: 〈http://www.ftc.gov/bc/international/docs/1102crossbordermerger control.pdf >. Acesso em: 01 dez. 2012).

${ }^{677}$ UNIÃ̃ EUROPEIA. Op. cit., 2012.
} 
multijurisdicional, pode-se conceber a hipótese que sob o bojo de um acordo de primeira geração a fonte da informação esteja disposta a prestar a necessária anuência ao compartilhamento de informações confidenciais, mas que haja, entretanto, incidência de lei de bloqueio que proíba tal prática ${ }^{678}$.

É possível concluir que as restrições existentes nas legislações nacionais/regionais quanto ao compartilhamento de informações confidenciais pelas autoridades de defesa da concorrência tratam de empecilho para a eficaz cooperação das autoridades que analisam uma mesma operação de concentração multijurisdicional, já que exigem que as autoridades empreendam esforços no convencimento das partes da operação e de terceiros na outorga de instrumentos de renúncia à confidencialidade das informações que tiverem sido prestadas em dada jurisdição, antes que possam efetivamente direcionar os seus esforços para concretizar a cooperação e coordenação almejadas.

3.2.2.2.4 Coordenação de atividades entre autoridades: decisões e adoção de restrições concertadas

Os acordos bilaterais de cooperação poderão prever, em maior ou menor medida, a coordenação das atividades das autoridades de defesa da concorrência envolvidas na cooperação durante a condução das atividades de aplicação do acordo. Nesse sentido é relevante destacar os trabalhos de entidades internacionais na promoção da coordenação entre as autoridades de defesa da concorrência, como o caso da $\mathrm{ICN}^{679}$.

No que se refere aos atos de concentração multijurisdicionais, as análises das autoridades poderão conduzir a resultado de reprovação ou aprovação da operação pretendida pelas partes e, no caso da aprovação, a mesma poderá ser condicionada à

\footnotetext{
${ }^{678}$ De acordo com Jaeger Júnior, essa situação traduz uma das limitações dos acordos bilaterais de cooperação, destacando que em certos casos, mesmo quando a fonte da informação estiver disposta a anuir com o compartilhamento de informação confidencial, poderá haver lei de bloqueio que impeça tal autorização. (JAEGER JÚNIOR, Augusto. Direito Internacional da Concorrência - Entre perspectivas unilaterais, multilaterais, bilaterais e regionais. Curitiba: Juruá, 2008, p. 252). Ver também DABBAH, Maher M. Future directions in bilateral cooperation: a policy perspective. Cooperation, comity and competition policy. New York: Oxford University Press, 2011, p. 295.

${ }^{679}$ Exemplificativamente, ver INTERNATIONAL COMPETITION NETWORK. Recommended practices for merger notification procedures. Jun. 2005, pp. 29-31. Disponível em: <http://internationalcompetition network.org/uploads/library/doc588.pdf>. Acesso em: 8 jul. 2010, no qual a entidade destaca que as autoridades de defesa da concorrência devem procurar a coordenação das análises sobre concentrações que possam compreender questões de interesse comum. Além disso, a ICN determina no referido documento que a coordenação entre autoridades deve (i) ser conduzida em conformidade com as leis e demais instrumentos que sejam aplicáveis; (ii) ser ajustada para cada operação em particular; (iii) contemplar a facilitação e encorajamento da cooperação das partes da operação no processo cooperativo; e (iv) procurar a adoção das restrições que sejam necessárias para garantir as procurações concorrenciais domésticas e que sejam consistentes com as restrições estabelecidas em outras jurisdições.
} 
satisfação de determinadas condições - as chamadas restrições (ou remédios) ${ }^{680}$. Isso significa que nos casos em que haja coincidência ou conexão entre as análises conduzidas por uma e outra autoridade (chamadas recorrentemente de "matérias relacionadas" ou “inter-relacionadas"), é do interesse de todos os envolvidos que as autoridades de defesa da concorrência envidem os seus melhores esforços na condução das suas atividades de forma coordenada, com o objetivo de, conforme seja possível, possam chegar a conclusões consistentes, ou ao menos não conflitantes no tocante aos resultados das análises realizadas $^{681}$.

Mas não é somente em relação ao processo de tomada da decisão final sobre a operação pretendida que a coordenação entre as autoridades poderá ter lugar. As autoridades de defesa da concorrência poderão coordenar toda a sua atividade de aplicação das respectivas leis de concorrência, tanto na fase de instrução, com o recebimento de documentos e informações das partes da operação e de terceiros, a realização de reuniões e conferências telefônicas com as partes da operação, quanto na fase de análise econômica, com a determinação dos mercados relevantes de produto e geográfico, aplicação de teorias econômicas, prognósticos sobre efeitos competitivos e eficiências estimadas na implementação da operação, organização de dados e provas empíricas necessárias ao teste de tais teorias ${ }^{682}$.

Tendo acompanhado todo o processo de análise da sua contraparte estrangeira, incluídas as discussões internas sobre preocupações sobre a forma como a operação poderá afetar o correspondente mercado e as restrições contempladas para mitigar os efeitos da operação, a autoridade de defesa da concorrência estará em melhor posicionamento para discutir com a outra autoridade envolvida na análise da concentração econômica sobre as restrições a serem aplicadas ao caso, bem como sobre a decisão final a ser tomada ${ }^{683}$.

\footnotetext{
680 "Domestic antitrust laws strive to advance domestic consumer welfare, not global welfare [...]. This, however, can lead to a situation whereby a merger that would enhance global welfare is prohibited because the consumer harm it creates in a particular jurisdiction is not offset by efficiencies in that same jurisdiction". (BRADFORD, Anu. International antitrust cooperation and the preference for nonbinding regimes. Cooperation, comity and competition policy. New York: Oxford University Press, 2011, p. 320).

681 "Cooperating on remedies is important for a variety of reasons. From a practical standpoint compatibility is crucial so that merging parties can satisfy the concerns of both jurisdictions at the same time". (GALLOWAY, Jonathan. Convergence in international merger control. The competitionlaw review. Issue 2, jul. 2009, v. V, p. 188).

682 "Collaborations provide transparency and cross-fertilization". (FOX, Eleanor M. Antitrust without borders: from roots to codes to networks. Cooperation, comity and competition policy. New York: Oxford University Press, 2011, p. 266).

683 "Diante da necessidade de harmonizar suas decisões nessas operações internacionais, as autoridades antitruste procuram agir em cooperação, buscando harmonizar os 'remédios' acordados com as partes para minorar os efeitos anticompetitivos das operações e possibilitar sua aprovação. Um exemplo ilustrativo dessa cooperação é o das autoridades norte-americanas com a Comissão da Comunidade Europeia, cujo relativo
} 
No tocante às restrições a serem prescritas às partes da operação no caso de aprovação da operação, as autoridades devem se preocupar em chegar a restrições coincidentes ou que não afetem as restrições a serem impostas pela outra autoridade. Quando ambas as autoridades definirem o mercado relevante geográfico como internacional, os envolvidos na operação se beneficiarão caso as restrições estabelecidas sejam as mesmas. Já nos casos em que o mercado relevante geográfico for estabelecido como nacional ou regional, ou quando o mercado relevante de produto estabelecido não for idêntico na análise das autoridades envolvidas, as restrições definidas em uma jurisdição poderão se relacionar, depender ou afetar as restrições definidas na outra jurisdição. Se conduzida propriamente, a coordenação das autoridades poderá culminar em um conjunto de restrições que atendem as expectativas de todas as jurisdições envolvidas na análise da concentração multijurisdicional.

Para alcançar o sucesso na coordenação das suas atividades, as autoridades dependem imensamente na voluntariedade e colaboração das partes da operação e de terceiros na condução dos seus esforços. Isso porque as legislações nacionais normalmente impõem restrições às iniciativas das autoridades de defesa da concorrência, especialmente no que se refere à troca de informações entre as autoridades e a busca de informações em outras jurisdições.

De modo a garantir a celeridade e a organização na coordenação das atividades é recomendável que as autoridades envolvidas indiquem uma pessoa central para concentrar o envio e recebimento de informações e coordenar internamente as atividades necessárias para a efetiva coordenação entre as autoridades.

Além disso, é conveniente que as autoridades trabalhem conjuntamente na elaboração de um cronograma da análise a ser conduzido consoante as respectivas legislações nacionais de defesa da concorrência, assegurando, desta forma, a harmonia e a concomitância do processo decisório e a possibilidade de haver discussões efetivas e eficazes no que toca aos pontos de contato entre as análises conduzidas por cada autoridade $^{684}$. A preocupação em conduzir os procedimentos de análise e controle dos atos

sucesso decorre da frequência com que operações de concentração envolvem as duas jurisdições". (NUSDEO, Ana Maria de Oliveira. Defesa da concorrência e globalização econômica. São Paulo: Malheiros, 2002, p. 215).

684 Caso o tempo das análises não seja coordenado haverá o risco de uma autoridade avançar no procedimento mais rapidamente do que a outra, e chegar a uma conclusão independente, sem a participação e coordenação da outra autoridade. "With regard to transnational mergers, the timing and procedures for negotiating merger remedies typically differ among the reviewing jurisdictions. As a result, cooperation and communication among reviewing agencies help to avoid inconsistent obligations and manage different timetables for decision, e.g., with regard to divestiture packages or upfront byers". (ORGANIZAÇÃO 
de concentração multijurisdicionais deve também ser compartilhada pelas partes da operação, as quais devem sempre que possível viabilizar notificações simultâneas às autoridades de defesa da concorrência e outorgar termos de renúncia de confidencialidade, viabilizando que estejam constantemente informadas sobre todos os aspectos relevantes às respectivas análises ${ }^{685}$.

Note-se que há iniciativas em outras jurisdições que defendem que uma efetiva cooperação no processo decisório pelas autoridades de defesa da concorrência somente será alcançada se houver harmonização das regras de controle de concentrações econômicas envolvendo mais de uma jurisdição ${ }^{686}$. No início da década de 1990, a American Bar Association, por meio de um dos seus comitês, publicou estudo no qual enfatizou a necessidade de se uniformizar os procedimentos de apresentação das operações de concentração multijurisdicionais para tal propósito ${ }^{687}$. Para tanto, as legislações nacionais ou regionais de defesa da concorrência deveriam prever duas fases de análise, a saber (i) a primeira, pela qual as operações de menor potencial anticoncorrencial pudessem ser aprovadas diretamente; e (ii) nos casos de operações com maior potencial ofensivo, uma segunda fase pela qual a operação passasse por um escrutínio mais profundo. Além disso, tais legislações deveriam harmonizar prazos e tipos de informações e documentos a serem apresentados pelas partes da operação em cada uma das fases.

Com a harmonização dos procedimentos, as autoridades de defesa da concorrência deveriam consultar-se mutuamente logo após notificadas sobre a operação de concentração multijurisdicional, possibilitando às autoridades que identificassem menor grau de impacto concorrencial na sua jurisdição, a faculdade de renunciar à análise em prol das outras autoridades que identificassem aspectos mais sensíveis sobre o caso em apreço. No caso de persistirem mais de uma autoridade na condução da análise da concentração, somente então deveriam as autoridades se engajar em processos cooperativos, com a finalidade de

PARA A COOPERAÇÃO E DESENVOLVIMENTO ECONÔMICO. Global forum on competition Roundtable on cross-border merger control: challenges for developing and emerging economies: contribution from United States. DAF/COMP/GF/WD(2011)29. Session 1. Fev. 2011, p. 8. Disponível em: <http://www.ftc.gov/bc/international/docs/1102crossbordermerger control.pdf>. Acesso em: 01 dez. 2012).

685 “O funcionamento desses acordos de cooperação em atos de concentração depende da concordância das partes, das autoridades nacionais e da uniformidade de seus interesses com relação à concentração". (NUSDEO, Ana Maria de Oliveira. Defesa da concorrência e globalização econômica. São Paulo: Malheiros, 2002, p. 172).

686 "Ultimately, a well-functioning system of international antitrust law requires harmonization in the strong sense - some international institution must interpret and implement the procedural and substantive competition policy norms". (CRANE, Daniel A. Substance, procedure and institutions in the International Harmonization of Competition Policy. Chicago Journal of International Law, 2009-2010, v. 10, n. 1, p. 157).

${ }^{687}$ NUSDEO, Ana Maria de Oliveira. Op. cit., 2002, p. 215. 
harmonizar suas decisões e restrições a serem estabelecidas à operação no caso de aprovação.

Como se sabe, não é possível, no entanto, defender que os Estados gozem de um mesmo grau de evolução das legislações nacionais de defesa da concorrência, quanto mais de procedimentos harmonizados de análise de concentrações econômicas. Não se descarta, nesse sentido, o trabalho realizado por entidades internacionais, como no caso da OCDE e ICN para a harmonização das legislações. Contudo, a coordenação de esforços nos moldes sugeridos pela American Bar Association, apesar de parecer uma solução que beneficia a todos os envolvidos, ainda não é medida que possa ser generalizadamente adotada. Os países devem analisar, caso a caso, a possibilidade de conjugação do modelo apresentado em contraposição às legislações de defesa da concorrência que regerão uma dada relação bilateral cooperativa.

\subsection{ACORDOS DE COOPERAÇÃO CELEBRADOS PELA REPÚBLICA FEDERATIVA DO BRASIL OU PELO SBDC}

O Brasil e o SBDC possuem atualmente em vigor 10 acordos bilaterais de cooperação em matéria de concorrência, celebrados com os Estados Unidos (1999) ${ }^{688}$, a Rússia (2001) $)^{689}$, a Argentina (2003) ${ }^{690}$, Portugal (2005 e 2010) $)^{691}$, Canadá (2008) ${ }^{692}$, Chile $(2008)^{693}$, a União Europeia (2009) $)^{694}$, a França $(2011)^{695}$, o Peru $(2012)^{696}$ e a China

\footnotetext{
${ }^{688}$ Acordo entre o Governo da República Federativa do Brasil e o Governo dos Estados Unidos da América relativo à cooperação entre suas autoridades de defesa da concorrência na aplicação de suas leis de defesa da concorrência, assinado em 26 de outubro de 1999 e ratificado pelo Brasil em 21 de maio de 2003 por intermédio do Decreto ${ }^{\circ}$ 4.702. Cf. MARTINEZ, Maria Beatriz. A cooperação internacional na defesa da concorrência: acordos bilaterais e aplicação do princípio da cortesia positiva. Revista do IBRAC - Direito da Concorrência, Consumo e Comércio Internacional. São Paulo, jan. 2004, v. 11, p. 177 ss, o acordo firmado com o Brasil foi o primeiro celebrado pelos Estados Unidos com um país em desenvolvimento "apesar de suas tímidas disposições, representou o primeiro e importante passo do Brasil no campo da cooperação com autoridades antitruste dos demais países".

${ }^{689}$ Acordo sobre cooperação na área da política de concorrência, assinado em 12 de dezembro de 2001. Nos termos do acordo, em 21 de setembro de 2009, foi assinado o Programa de Cooperação para o biênio 20102011.

${ }^{690}$ Acordo de cooperação entre a República Federativa do Brasil e a República Argentina relativo à cooperação entre as suas autoridades de defesa da concorrência na aplicação das leis de concorrência, assinado em 16 de outubro de 2003, e ratificado pelo Brasil em 18 de setembro de 2008 por meio do Decreto legislativo $\mathrm{n}^{\circ} 264$.

${ }^{691}$ Protocolo de Cooperação Técnica assinado em $1^{\circ}$ de setembro de 2005 e Protocolo de Cooperação Técnica assinado em 14 de janeiro de 2010.

${ }^{692}$ Acordo de cooperação sobre a aplicação das respectivas leis de concorrência, assinado em maio de 2008.

${ }^{693}$ Acordo de Cooperação sobre a aplicação das respectivas leis de concorrência, assinado em outubro de 2008.

${ }^{694}$ Memorando de entendimentos de cooperação, assinado em 08 de outubro de 2009. A União Europeia, por intermédio do DG Competition, tinha interesse em cooperar com o Brasil de forma mais intensa, especialmente pelo fato de o Brasil ser uma economia importante e um dos principais parceiros comerciais da União Europeia. (LAGARES, Eva Valle. International agreements regarding cooperation in the field of
} 
$(2012)^{697,698}$, ou suas respectivas autoridades de defesa da concorrência, conforme aplicável $^{699}$. Tais instrumentos dividem-se em três categorias, a saber, (i) aqueles que têm por objetivo único a cooperação técnica; (ii) aqueles que pretendem unicamente a promoção de uma cooperação mais efetiva na aplicação das leis de defesa de concorrência; e (iii) aqueles mistos, com dispositivos tanto de cooperação técnica, quanto sobre aplicação das leis de defesa da concorrência das partes dos acordos.

Dentre os acordos do tipo (i) acima, somam-se quatro acordos, a saber, aqueles celebrados com Rússia, Portugal, França e China; dentre os do tipo (ii), totalizam dois acordos, a saber aqueles celebrados com Canadá e Chile; já em relação ao tipo (iii) supra, foram celebrados quatro acordos, nomeadamente aqueles celebrados com Estados Unidos, Argentina, União Europeia e Peru. Um sumário com as principais características dos acordos bilaterais celebrados pelo Brasil e o SBDC em matéria concorrencial se encontram no Anexo C deste estudo.

Conforme descrito anteriormente, o foco central deste estudo está na análise dos acordos bilaterais firmados para promover a cooperação bilateral na aplicação das variadas legislações de defesa da concorrência, mais especificamente durante os procedimentos de análise das concentrações multijurisdicionais. Por tal razão, não serão considerados na presente análise aqueles acordos que tratam exclusivamente da cooperação técnica entre autoridades de defesa da concorrência, tampouco os dispositivos relacionados à cooperação técnica que porventura constem dos acordos sobre aplicação da legislação da concorrência - os quais já foram descritos no item 3.2.2.1 supracitado. Um quadro comparativo das principais características e dispositivos relacionados aos atos de concentração multijurisdicionais inseridos nos acordos objeto deste estudo encontra-se no Anexo E.

competition: the new strategy of the European Commission. Journal of European Competition Law \& Practice, jan. 2010, p. 2). A autora esclarece ainda que "Brazil has a sophisticated and trusted competition regime in place".

${ }^{695}$ Acordo de Cooperação Técnica que entre si celebram o CADE e a Autorité de La Concurrence, assinado em 16 de dezembro de 2011.

${ }^{696}$ Acordo de Cooperação entre o Instituto Nacional de Defesa da Concorrência e da Proteção da Propriedade Intelectual (INDECOPI) e o Conselho Administrativo de Defesa Econômica, assinado em 24 de julho de 2012.

${ }^{697}$ Memorando de Entendimento de Cooperação sobre Concorrência entre o Ministério da Indústria e Comércio do Governo da República Popular da China e o CADE, assinado em 13 de setembro de 2012.

${ }^{698}$ Adicionalmente, em 2009, o SBDC internalizou, por meio de portaria conjunta entre o CADE, a SDE e o SEAE, dois memorandos de entendimento que preveem a cooperação técnica no âmbito do Mercosul, já descritos anteriormente no capítulo 2 deste estudo (p. 171).

${ }^{699}$ Optou-se neste estudo por fazer referência direta ao país envolvido no acordo celebrado ao invés da parte que efetivamente o celebrou. Por exemplo, em relação ao acordo celebrado com a União Europeia, na 
Na medida do possível, ao discorrer sobre os acordos celebrados pelas autoridades brasileiras, procurar-se-á direcionar a análise aos atos de concentração multijurisdicionais e traçar um paralelo com os instrumentos publicados por diferentes entidades internacionais, como no caso da OCDE (CCMR e RCMR) e ICN (Princípios Orientadores e Práticas Recomendadas) ${ }^{700}$, descritos no item 2.2.2.2.1 supra, bem como com os acordos de $1991 \mathrm{e}$ 1998, celebrados pelos Estados Unidos e União Europeia ${ }^{701}$.

\subsubsection{Recepção dos acordos pelo ordenamento jurídico brasileiro}

A questão da recepção dos acordos bilaterais de cooperação em matéria concorrencial pelo ordenamento jurídico brasileiro é relevante, uma vez que é indicativa do grau de vinculação que tais acordos irão gozar no sistema jurídico pátrio. Desta forma, os acordos poderão ter caráter vinculativo e força de lei, ou não, consoante modelo de internalização adotado pelas autoridades competentes. Enquanto os acordos aprovados pelo procedimento relativo à recepção de tratados internacionais pelo ordenamento interno terão força vinculativa, os demais não o terão, conforme segue.

De fato, os tratados internacionais dependem de um rito constitucionalmente estabelecido para que sejam acolhidos no ordenamento jurídico nacional ${ }^{702}$ - a ratificação do tratado com intervenção do Congresso Nacional, passando então, a possuir força de lei

realidade o acordo bilateral foi celebrado entre o SBDC e o DG Competition. No entanto, todas as referências feitas a tal acordo estão dirigidas à União Europeia, em detrimento do DG Competition.

${ }^{700}$ Sobre o papel das instituições multilaterais no desenvolvimento da cooperação bilateral, ver BRADFORD, Anu. International Antitrust Cooperation and the preference for nonbinding regimes. Cooperation, comity and competition policy. New York: Oxford University Press, 2011, p. 324.

701 Tal cuidado se deve ao fato da relevância dos acordos entre Estados Unidos e União Europeia para o cenário concorrencial internacional. De acordo com Silva, a importância dos acordos entre Estados Unidos e União Europeia "decorre tanto do papel relevante exercido pelas Partes no comércio internacional - e consequentemente do impacto decorrente da aplicação extraterritorial das suas legislações antitruste sobre agente econômicos internacionais e sobre o outro Estado signatário - quanto ao fato de haverem sido esses Acordos inovadores ao desenvolverem em profundidade determinados tópicos até então tratados de forma genérica em acordos anteriores (tais como a troca de informações), ao aprofundarem a cooperação das autoridades antitrustes a um nível até então inexistente ou, ainda, ao introduzirem novos princípios e conceitos - notadamente o princípio da cortesia positiva - que posteriormente vieram a ser adotados em outros acordos bilaterais do mesmo gênero". (SILVA, Valéria Guimarães de Lima e. Direito antitruste: aspectos internacionais. Curitiba: Juruá, 2007, p. 436).

${ }^{702}$ De acordo com o art. 11 da Convenção sobre o Direito dos Tratados, "o consentimento de um estado em obrigar-se por um tratado pode manifestar-se pela assinatura, troca dos instrumentos constitutivos do tratado, ratificação, aceitação, aprovação ou adesão, ou por quaisquer outros meios, se assim for acordado". De acordo com ACCIOLY, Hildebrando; NASCIMENTO E SILVA, G. E. do; CASELLA, Paulo Borba. Manual de Direito Internacional Público. 17. ed. São Paulo: Saraiva, 2009, p. 141, "geralmente, só ocorre a ratificação depois que o tratado foi aprovado pelo Parlamento, a exemplo do que ocorre no Brasil, onde esta faculdade é do Congresso Nacional [...] embora o tratado só entre em vigor após a sua ratificação, todo o estado deve abster-se da prática de qualquer ato capaz de frustrar o seu objeto e finalidade”. 
e, assim, serem aplicados pela sociedade brasileira nas suas relações diárias ${ }^{703}$. Aqueles tratados, portanto, que mesmo após celebrados por representantes do governo devidamente empossados dos poderes suficientes para a referida celebração do tratado, não tiverem sido recepcionados no ordenamento jurídico mediante ratificação intermediada pelo Congresso Nacional, não possuirão força vinculativa aos jurisdicionados.

Há de se considerar, ainda, aqueles acordos celebrados fora dos parâmetros e das condições de validade de tratados internacionais ${ }^{704}$, incluindo os celebrados por pessoas sem personalidade jurídica internacional ${ }^{705}$ - como no caso de órgãos da administração pública - ou a quem não tenham sido conferidos os poderes de plenipotenciário de representação do Estado ${ }^{706}$. Tais acordos, muitas vezes designados "memorandos de entendimento" ou "protocolos", trazem disposições que mais se assemelham a contratos do que a tratados internacionais, como, por exemplo, quando se referem à "rescisão" ou "resolução" do acordos e não à sua "denúncia". Além disso, alguns desses acordos fazem expressa referência ao fato de não criarem obrigações ou direitos sob o Direito Internacional $^{707}$. Estes acordos, portanto, não são suscetíveis de ser objeto dos procedimentos de ratificação e recepção pelo ordenamento jurídico brasileiro e, portanto, não possuem força vinculativa ${ }^{708}$.

\footnotetext{
703 "No caso Brasileiro, o artigo 84 da Constituição Federal atribui, privativamente, ao Presidente da República, o poder de celebrar tratados, convenções e atos internacionais, sujeitos a referendos do Congresso Nacional (inciso VIII). No mesmo sentido, conforme o artigo 49 da Constituição Federal, é de competência exclusiva do Congresso Nacional resolver definitivamente sobre tratados, acordos ou atos internacionais que acarretem encargos ou compromissos gravosos aos patrimônio nacional (inciso I)". (SEITENFUS, Ricardo; VENTURA, Deisy. Introdução ao Direito Internacional Público. 2. ed. Porto Alegre: Livraria do Advogado, 2001, p. 44).

704 "Para que um tratado seja considerado válido, é necessário que as partes (estados ou organizações internacionais) tenham capacidade para tal, que os agentes estejam habilitados, que haja consentimento mútuo, e o que o objeto do tratado seja lícito e possível". (ACCIOLY, Hildebrando; NASCIMENTO E SILVA, G. E. do; CASELLA, Paulo Borba. Manual de Direito Internacional Público. 17 ed. São Paulo: Saraiva, 2009, p. 135). No mesmo sentido, ver SEITENFUS, Ricardo; VENTURA, Deisy. Introdução ao Direito Internacional Público. 2. ed. Porto Alegre: Livraria do Advogado, 2001, pp. 48-50.

705 "Acordos concluídos entre dois ou mais sujeitos de direito internacional, os tratados destinam-se a produzir efeitos jurídicos e são regidos pelo direito internacional. [...] tal acordo é firmado entre Estados [...]. A nova Convenção de Viena sobre o Direito dos Tratados, de 1986, altera o dispositivo supramencionado para reconhecer plenamente a capacidade de celebrar tratados da organização internacional, seja com Estados, seja com uma outra organização". (SEITENFUS, Ricardo; VENTURA, Deisy. Op. cit., 2001, p. 39).

706 "Os representantes de um estado, para a adoção ou autenticação do texto de um tratado, ou para expressar o consentimento do estado em obrigar-se a suas disposições demonstram a sua capacidade mediante a apresentação dos plenos poderes [...]. Hoje em dia, a apresentação de plenos poderes é dispensada nos casos dos chefes de estado ou de governo e dos ministros das relações exteriores. A carta de plenos poderes deverá ser firmada pelo chefe de estado ou pelo ministro das relações exteriores". (ACCIOLY, Hildebrando; NASCIMENTO E SILVA, G. E. do; CASELLA, Paulo Borba. Op. cit., 2009, p. 137).

${ }^{707}$ É o caso, por exemplo, do art. $4^{\circ}$ do Programa de Cooperação para o biênio 2012-2013, celebrado com a Rússia, e do art. 8.20 do Memorando de Entendimentos firmado com a União Europeia.

${ }^{708}$ SWAINE, Edward T. Cooperation, comity and competition policy: United States. Cooperation, comity and competition policy. New York: Oxford University Press, 2011, p. 20.
} 
Dentre os 10 acordos de cooperação celebrados por autoridades brasileiras, somente três foram celebrados por sujeitos de Direito Internacional, ou seja, pelo Governo brasileiro, designadamente os acordos celebrados com os Estados Unidos, a Rússia e a Argentina. Somente os acordos celebrados com os Estados Unidos e a Argentina, no entanto, chegaram a ser ratificados com participação do Congresso $\mathrm{Nacional}^{709}$ e, assim, possuem força vinculante de lei no ordenamento jurídico brasileiro. No que se refere aos outros oito acordos, a saber, aquele celebrado com a Rússia ${ }^{710}$, e aos outros sete acordos celebrados pelo SBDC com Portugal, Canadá, Chile, União Europeia, França, Peru e China para a aplicação das respectivas leis da concorrência, não é possível concluir que possuam a força vinculativa de lei conferida aos tratados internacionais devidamente ratificados.

Não obstante os oito acordos bilaterais anteriormente indicados serem desprovidos da força legal conferida aos tratados internacionais, não significa que o fenômeno da sua celebração seja irrelevante às relações entre o SBDC e as suas respectivas congêneres estrangeiras. Na realidade tais acordos devem ser incluídos na classificação de soft law ${ }^{711}$, descrita no item 2.2.1 supra, e poderão surtir seus efeitos nas relações internacionais estabelecidas pelo SBDC em sede de cooperação em matéria concorrencial.

De fato, conforme explorado no item 2.2.1 deste estudo, os instrumentos de soft law não utilizam os tradicionais mecanismos de recepção formal do Direito Internacional clássico para acolhimento no sistema jurídico nacional. Mesmo assim acabam por ser considerados pelas autoridades nacionais e pelo legislador na promulgação de regulamentos e de leis nacionais em vista do seu caráter declarativo. No âmbito da concorrência, a própria doutrina reconhece a mudança havida na opção de um processo de formação de regras vinculativas por outro não vinculativo no que se refere à matéria concorrencial $^{712}$. Assim, o Direito Interno e o Direito Internacional possuem uma relação

\footnotetext{
${ }^{709} \mathrm{O}$ acordo com os Estados Unidos foi ratificado pelo Brasil em 21 de maio de 2003 por meio do Decreto $\mathrm{n}^{\mathbf{o}}$ 4.702 e o acordo com a Argentina foi ratificado pelo Brasil em 18 de setembro de 2008 por intermédio do Decreto Legislativo $\mathrm{n}^{\circ} 264$.

${ }^{710} \mathrm{O}$ procedimento de ratificação pelo Congresso Nacional não foi localizado. Em relação a este acordo, considera-se que o mesmo depende de ser ratificado com a intervenção do Congresso Nacional para que seja considerado vinculativo.

711 "Duas são as correntes com relação à utilidade real de tais acordos. Para alguns o adensamento crescente de acordos bilaterais significa estágio prévio ao consenso multilateral, que levará à harmonização do direito substantive; segundo outros, servirá unicamente para aumentar, ainda mais, a força dos países com maior poder de barganha, que preferem negociar isoladamente". (OLIVEIRA, Gesner; RODAS, João Grandino. Direito e economia da concorrência. Rio de Janeiro: Renovar, 2004, p. 384).

712 "It is undoubtful that numerous recommendations, model laws and comparative accounts from international organizations, such as for example the OECD or UNCTAD, have an enormous influence in countries whose competition legislature is still in the process of development". (TERHECHTE, Jörg Philipp. International competition enforcement law: between cooperation and convergence. New York: Springer,
} 
"transnormativa" 713 , ou seja, interagem em um mesmo plano, tanto na produção quanto sobre os efeitos e a aplicação das normas criadas.

Os acordos bilaterais de cooperação em matéria concorrencial celebrados pelo Brasil e o SBDC, com exceção daqueles firmados com os Estados Unidos e a Argentina, que possuem força vinculativa, são acordos de soft law que influenciam efetivamente as atividades do SBDC, dentro do campo da discricionariedade conferida pela legislação brasileira. Isso significa que a margem de discricionariedade conferida pelo ordenamento jurídico nacional para a atuação do SBDC trata do permissivo legal para que a autoridade nacional de defesa da concorrência atue em conformidade com os acordos celebrados na medida em que não forem contrários ao restante da legislação aplicável à sua atuação.

De acordo com o item 2.1.6 supracitado, a cooperação jurídica internacional pode ser do tipo formal ou informal. Entende-se, assim, que no tocante aos acordos celebrados com Estados Unidos e Argentina, o SBDC conta com instrumentos formais de cooperação, enquanto que no âmbito dos demais acordos, a cooperação vislumbrada é realizada informalmente ${ }^{714}$, sem qualquer vinculação das partes dos acordos no plano internacional. Deverá, desta forma, haver voluntariedade do SBDC no cumprimento das disposições do acordo, já que as mesmas não vinculam o Estado brasileiro ou o próprio SBDC ao campo internacional.

Dentre os acordos firmados pelas autoridades brasileiras, os mais relevantes são os celebrados com os Estados Unidos e a Argentina, não somente por constarem entre os primeiros acordos celebrados, tendo servido como modelo àqueles celebrados posteriormente, mas também por terem sido os únicos a serem ratificados pelo Congresso Nacional. Além disso, tais acordos seguiram, em linhas gerais, as recomendações da OCDE, incluídas no RCMR descrito no segundo capítulo deste estudo e as disposições do Acordo EUA/UE 1991, marco na relação bilateral em matéria concorrencial. Assim, a análise que segue basear-se-á principalmente nas disposições desses acordos, sem, no entanto, se furtar a fazer considerações sobre os outros quatro acordos celebrados para a regulação da cooperação em matéria da aplicação da lei da concorrência.

2011, p. 31). Ver também JAEGER JÚNIOR, Augusto. Direito Internacional da Concorrência - Entre perspectivas unilaterais, multilaterais, bilaterais e regionais. Curitiba: Muruá, 2008, p. 192.

${ }_{713}^{13}$ MENEZES, Wagner. Ordem global e transnormatividade. Ijuí, RS: Ed. da Unijuí, 1005, pp. 201-202.

714 "A cooperação internacional é estabelecida através de acordos bilaterais firmados entre governos nacionais, os quais desenvolvem mecanismos mais informais do que o tratado internacional, até porque não exigem compromissos de alteração legislativa, limitando-se a proposições de cooperação na aplicação das leis existentes. Dada sua limitação aos assuntos relativos à aplicação das leis, são denominados por alguns de acordos executivos." (NUSDEO, Ana Maria de Oliveira. Defesa da concorrência e globalização econômica. São Paulo: Malheiros, 2002, p. 170). 


\subsection{2 Âmbito de aplicação}

Os acordos bilaterais de cooperação geralmente definem as "atividades de aplicação" do acordo ${ }^{715}$ como qualquer investigação ou procedimento conduzido por uma parte do acordo no amparo da respectiva legislação de defesa da concorrência ${ }^{716}$. Especificam ainda, o âmbito de tais atividades de aplicação, descrevendo as atividades que devem ser consideradas pelas autoridades de defesa da concorrência para a promoção da cooperação jurídica internacional. A análise e o controle de atos de concentração constam em todos os acordos celebrados pelo Brasil e pelo SBDC como uma das atividades de aplicação previstas.

Os acordos firmados pelo Brasil com os Estados Unidos e Argentina, por exemplo, ao esclarecerem as atividades de aplicação que devem ser notificadas por uma autoridade da concorrência à outra, incluem as atividades que envolvam fusões ou aquisições/atos de concentração nas quais uma ou mais partes da transação, ou empresa que controle uma ou mais partes da transação, for constituída ou organizada sob as leis da outra parte, ou de um de seus estados/unidades subnacionais ${ }^{717}$.

Note-se que o acordo firmado com os Estados Unidos, diferentemente do acordo firmado com a Argentina, refere-se a "fusões e aquisições" e não a "atos de concentração". Tal escolha terminológica parece inadequada, uma vez que não contempla outros atos de concentração como, por exemplo, as incorporações e demais instrumentos de cooperação empresarial, como os contratos de joint venture.

Ademais, é relevante notar que a obrigação de notificação sobre concentrações econômicas entre as partes dos acordos firmados com os Estados Unidos e a Argentina está restrita às situações em que haja um vínculo societário entre as partes da concentração ou suas controladoras e o território da outra parte. Excluem-se, portanto, as hipóteses em que, apesar de as sociedades envolvidas na operação, ou suas controladoras, não terem qualquer vínculo societário com o território da outra jurisdição, lá explorem o mercado (mediante parcerias locais ou importação e exportação, por exemplo). Neste diapasão, reitera-se que

\footnotetext{
${ }^{715}$ Em inglês, são as enforcement activities. No acordo com a União Europeia referem-se às "medidas de implementação".

${ }^{716}$ Ver art. 1.2 dos acordos firmados com os Estados Unidos, a Argentina e o Peru, e art. 1.2.b dos acordos firmados com o Canadá e Chile. O acordo celebrado com a União Europeia não prevê expressamente que os atos de concentração estão incluídos entre as medidas de implementação. Entende-se, no entanto, que os atos de concentração devem ser considerados como contemplados no acordo, já que suas disposições são generalistas, incluindo a cooperação sobre todas as áreas das legislações, implementações e políticas da concorrência.

${ }^{717}$ Ver art. 2.2 dos acordos firmados com os Estados Unidos e a Argentina.
} 
de acordo com a teoria dos efeitos adotada pela Lei da Concorrência brasileira, uma operação de concentração econômica pode fazer surtir efeitos no território do outro Estado, mesmo quando as suas partes ou as suas controladoras não possuírem estabelecimento permanente em tal território ${ }^{718}$. Desta forma, entende-se que os acordos celebrados com os Estados Unidos e a Argentina falham por não acolherem outras hipóteses de notificações sobre atos de concentrações que possam afetar os mercados das partes envolvidas no acordo.

Já os acordos firmados com o Chile e o Canadá ${ }^{719}$ esclarecem que as notificações trocadas entre as partes devem incluir as atividades que envolvam concentrações econômicas nas quais uma ou mais partes da operação mantenham atividade econômica no território da outra parte ou esteja sob controle de entidade constituída ou organizada de acordo com as leis do território da outra parte, bem como aquelas que envolvam penalidades ou restrições que expressamente requeiram ou proíbam conduta naquele território. Assim, os acordos firmados com o Chile e o Canadá parecem estar mais alinhados com a teoria dos efeitos, ao incluir dentre os atos de concentração que deverão ser objeto de notificações entre as autoridades de defesa da concorrência aqueles realizados por entidades que mantenham atividades econômicas no território da outra parte do acordo.

O acordo celebrado pelo SBDC com o Peru ${ }^{720}$ estabelece que devem ser consideradas como atividades de aplicação suscetíveis de afetar os interesses das partes as operações de concentração que tenham sido ou que venham a ser realizadas total ou parcialmente no território da outra parte, que possam ter efeitos total ou parcialmente no território da outra parte ou que possam estar sujeitas à aplicação da lei de defesa da concorrência da outra parte. Ainda, aquelas atividades que envolvam um ou mais agentes econômicos que realizem alguma atividade econômica no território da outra parte ou que são vinculados a um ou mais agentes econômicos que realizem alguma atividade econômica no território da outra parte. Desta forma, parece que o acordo com o Peru segue a construção utilizada nos acordos firmados com o Canadá e o Chile, englobando a lógica da teoria dos efeitos na delimitação dos atos de concentração que devem ser objeto da cooperação e coordenação entre as autoridades de defesa da concorrência.

\footnotetext{
${ }^{718}$ O Superior Tribunal de Justiça, inclusive, já expressou o seu entendimento nesse mesmo sentido - ver Recurso Especial no 615.628-DF julgado pelo STJ em 21 de junho de 2009 (rel. Ministro Herman Benjamin). Para maiores informações a este respeito ver item 1.3.1.2.2 deste estudo.

${ }^{719}$ Cf. os arts. 2.1 dos acordos firmados com o Canadá e o Chile.

${ }^{720}$ Cf. o art. $6^{\circ}$ do acordo celebrado com o Peru.
} 
O acordo celebrado com a União Europeia, por outro lado, absteve-se de trazer disposição que delimite os atos de concentração que devem ser objeto das atividades de aplicação do acordo. Suas previsões são mais generalistas no que toca aos atos de concentração multijurisdicionais $^{721}$.

Por fim, é importante consignar que dentre as atividades de aplicação que são relevantes a este estudo constam ainda a troca e a busca de informações, as quais serão detalhadas ao longo deste item 3.3.

\subsubsection{Notificações trocadas entre autoridades}

Conforme descrito no item 3.2.2.2.1 supra, a cooperação e a coordenação em matéria concorrencial no âmbito de acordos bilaterais são executadas por meio de um sistema de notificações entre as autoridades de defesa da concorrência. Todos os acordos celebrados pelo Brasil e pelo SBDC contêm regras sobre a forma como as notificações entre as autoridades deverão ser realizadas.

Com exceção do acordo celebrado com a União Europeia, que não contém detalhamento sobre o conteúdo das notificações a serem trocadas pelas autoridades, os acordos celebrados pelo Brasil e o SBDC estabelecem que devem constar das notificações o detalhamento sobre a prática anticoncorrencial objeto da cooperação pretendida, sua natureza e as disposições legais aplicáveis. Os acordos com o Canadá, Chile e Peru determinam, quanto ao grau do detalhamento das notificações, que as partes requerentes deverão proporcionar à parte notificada uma avaliação inicial sobre os efeitos da atividade nos seus interesses de aplicação da legislação de defesa da concorrência.

Os acordos celebrados pelo Brasil e pelo SBDC preveem que as notificações devem ser realizadas tão logo seja possível ou se torne evidente que as circunstâncias a serem informadas estão presentes. O acordo com a Argentina estabelece prazos determinados para que as partes promovam as notificações, sendo que no caso do Brasil, a notificação sobre atos de concentração deverá ser promovida em 15 dias a contar da publicação que informa a notificação do ato ao SBDC. De modo geral, parece que o acordo com a Argentina trouxe regra relevante para garantir a eficácia das notificações a serem

\footnotetext{
721 "The purpose of the MoU is to promote cooperation and coordination between the Brazilian competition authorities and DG Competition and to increase understanding and awareness of policy approaches, legislation, and enforcement". (LAGARES, Eva Valle. International agreements regarding cooperation in the field of competition: the new strategy of the European Commission. Journal of European Competition Law \& Practice, jan. 2010, p. 2).
} 
conduzidas pelas partes, da qual beneficiariam os demais acordos, se tivessem adotado regra semelhante. No entanto, nenhum dos acordos prevê prazos específicos para as respostas das autoridades notificadas, o que poderá mitigar a eficácia da cooperação ao reduzir a velocidade do fluxo das comunicações entre as partes.

Ademais, os acordos em análise estabelecem que em regra todas as notificações e comunicações serão realizadas diretamente entre as autoridades de defesa da concorrência envolvidas. No caso dos acordos com os Estados Unidos e Argentina, no entanto, há previsão que certas notificações e os pedidos de consultas ${ }^{722}$ trocados diretamente pelas autoridades deverão ser confirmados prontamente por escrito por meio dos canais diplomáticos costumeiros. Ainda, os acordos com o Canadá, Chile, União Europeia e Peru preveem a existência de um ponto de contato central para a troca das notificações, o qual, no caso do Peru, deverá ser o Presidente/Secretário Técnico da autoridade correspondente.

\subsubsection{Princípio de cortesia negativa e positiva}

\section{a) Cortesia negativa}

Todos os seis acordos celebrados pelo Brasil e pelo SBDC para a aplicação das respectivas legislações nacionais de defesa da concorrência acolhem o princípio da cortesia negativa, prevendo a obrigação das autoridades de defesa da concorrência de considerar os importantes interesses das demais autoridades na execução de atividades de aplicação. De forma geral, no entanto, os acordos preveem exceções a tal consideração nos casos em que isso possa acarretar em conflitos com as legislações nacionais de defesa da concorrência que sejam aplicáveis ou com relevantes interesses da autoridade que esteja a conduzir as atividades de aplicação.

O acordo celebrado com os Estados Unidos traz maiores detalhes sobre a cortesia negativa ao estabelecer que tal consideração deve ocorrer, inclusive, nas decisões sobre a iniciação de investigação ou procedimento, amplitude de investigação ou procedimento e natureza das medidas legais ou penalidades propostas em cada caso ${ }^{723}$.

\footnotetext{
722 Tratam das notificações e pedidos de consulta previstos nos arts. 2, 4.2 e 6.2 do acordo com os Estados Unidos e nos arts. 5.2 e 7.2 do acordo com a Argentina.

${ }^{723}$ Cf. o art. 6.1 do acordo celebrado com os Estados Unidos.
} 
Os acordos celebrados pelo SBDC com o Canadá, Chile e União Europeia ${ }^{724}$, preveem ainda a possibilidade que uma autoridade de defesa da concorrência notifique a outra a respeito da possibilidade de as atividades de aplicação da parte requerida virem a afetar os importantes interesses da parte requerente. Nesses casos a parte requerida deverá se esforçar para oferecer oportunidade de discussão sobre as atividades de aplicação e atualizar a requerente sobre desenvolvimentos significativos relacionados a tais interesses. Note-se que tal notificação não se enquadra na hipótese de cortesia positiva, na medida em que não conterá a solicitação para que a parte requerida inicie ou amplie atividades de aplicação, mas tão somente leve em consideração os interesses importantes da parte requerente na aplicação já em curso.

Inovador no conjunto de acordos celebrado pelo Brasil e o SBDC é o documento firmado com o Peru, o qual inclui, no seu art. $6^{\circ}$, maior detalhamento sobre as atividades de aplicação que poderão afetar os interesses da outra parte. Dentre as hipóteses contempladas nesse dispositivo, destaca-se (i) as operações de concentração que tenham sido ou que venham a ser realizadas total ou parcialmente no território da outra parte, que possam ter efeitos total ou parcialmente no território da outra parte ou que possam estar sujeitas à aplicação da lei de defesa da concorrência da outra parte; e (ii) que envolvam um ou mais agentes econômicos que realizem alguma atividade econômica no território da outra parte ou que são vinculados a um ou mais agentes econômicos que executem alguma atividade econômica no território da outra parte. O detalhamento da cortesia negativa conferido pelo acordo celebrado com o Peru foi bastante feliz, tendo abarcado redação em consonância com a teoria dos efeitos e conferido, assim, maior segurança às atividades de defesa da concorrência.

\section{b) Cortesia positiva}

Dos seis acordos bilaterais de cooperação celebrados pelo Brasil e SBDC para a aplicação das respectivas legislações de defesa da concorrência, somente três contêm disposições relativas à cortesia positiva, nomeadamente aqueles firmados com os Estados Unidos, a Argentina e a União Europeia. As regras de cortesia positiva adotadas nos acordos celebrados com os Estados Unidos e a Argentina são idênticas, enquanto que as

\footnotetext{
${ }^{724}$ Cf. os arts. 4.2 dos acordos celebrados com o Canadá e o Chile e o art. 4.10 do acordo celebrado com a União Europeia.
} 
adotadas pelo acordo da União Europeia diferem na sua estruturação, mas possuem o conteúdo coincidente.

Os acordos celebrados pelo Brasil e SBDC com adoção da cortesia positiva estabelecem, de forma geral, que se uma parte acreditar que práticas anticompetitivas realizadas no território da outra parte afetam adversamente seus importantes interesses poderá solicitar que as autoridades de defesa da concorrência daquela outra parte iniciem atividades de aplicação apropriadas ${ }^{725}$. Os acordos firmados com os Estados Unidos e a Argentina estabelecem ainda que a notificação enviada deverá conter pedido detalhado, indicando a natureza da prática e os efeitos nos interesses relevantes da parte requerente, bem como a oferta de informações e cooperações adicionais que forem possíveis.

A parte requerida, por sua vez, deverá decidir se, em função do pedido de cooperação recebido, iniciará ou ampliará atividades de aplicação em curso, devendo informar a parte requerente a respeito da sua decisão ${ }^{726}$. Adicionalmente, os acordos celebrados com os Estados Unidos e a Argentina estabelecem que no caso de atividades de aplicação serem iniciadas ou ampliadas pela parte requerida, esta deverá comunicar a requerente os seus resultados e progressos parciais significativos.

É relevante notar que os acordos em análise não obrigam as partes de nenhuma forma a acatar o pedido de cortesia positiva que seja endereçado por uma autoridade à outra, tampouco traz critérios que as autoridades de defesa da concorrência devem levar em consideração quando forem decidir sobre acatar a cooperação requerida ou não. A falta de obrigatoriedade das partes em acordos bilaterais de cooperação em matéria concorrencial em acatar os pedidos de cortesia positiva é um dos pontos de deficiência do sistema estabelecido por este tipo de acordo, conforme se verá posteriormente, no item 3.5 deste estudo.

Note-se que os acordos em análise são bastante claros ao estabelecer que nenhuma das suas disposições deve limitar a discricionariedade das autoridades de defesa da concorrência, as quais permanecem livres para, de acordo com as respectivas atribuições legais ${ }^{727}$, conduzir suas atividades livremente ${ }^{728}$. As autoridades mantêm, portanto, as

\footnotetext{
${ }^{725}$ Cf. arts. 4.2 e 5.2 dos acordos celebrados os Estados Unidos e Argentina, respectivamente, e art. 3.6 do acordo firmado com a União Europeia.

${ }^{726}$ Cf. arts. 4.3 e 5.3 dos acordos celebrados os Estados Unidos e Argentina, respectivamente, e art. 3.7 do acordo firmado com a União Europeia.

${ }^{727}$ Nesse sentido deve-se considerar a legislação de defesa da concorrência e demais normas nacionais que regem as atividades e estabelecem as funções das autoridades nacionais de defesa da concorrência. De fato, não tendo as partes estabelecido disposição que efetivamente obrigue as autoridades envolvidas a cooperar uma com as outras, mesmo que dito acordo tenha natureza de tratado internacional vinculativo, as partes
} 
respectivas autonomias para conduzir as atividades de aplicação que considerarem adequadas e, se bem entenderem, retirarem a sua solicitação de cortesia positiva a qualquer momento.

Conforme discutido anteriormente, o Acordo EUA/UE 1998 tratou o princípio de cortesia positiva de forma mais efetiva do que o acordo anterior de 1991. Se contraposto com o acordo celebrado entre Estados Unidos e Brasil, é fácil perceber as diferenças no que se refere ao nível de cooperação pretendida, especialmente em relação à extensão da cortesia positiva adotada em cada um dos acordos ${ }^{729}$.

Todavia, o Acordo EUA/UE 1998 aplica-se tão somente às práticas anticoncorrenciais, excluindo expressamente do seu âmbito de aplicação os procedimentos de controle de atos de concentração ${ }^{730}$. O Acordo EUA/UE 1991 continua, assim, a ser o documento considerado pelas autoridades norte-americanas e europeias nas iniciativas cooperativas relacionadas às concentrações econômicas multijurisdicionais. Note-se que as regras de cortesia positiva adotadas pelo Acordo EUA/UE 1991 são equivalentes às normas acolhidas nos acordos celebrados pelo Brasil e SBDC anteriormente descritas.

Não obstante, entretanto, a sua não aplicabilidade aos atos de concentração multijurisdicionais envolvendo as duas jurisdições, a análise do princípio da cortesia positiva estabelecido pelo Acordo EUA/UE 1998 é relevante para que se possa compreender a extensão atualmente disponível à comunidade internacional para o acolhimento da cortesia positiva nas suas relações bilaterais de promoção da cooperação jurídica internacional em matéria concorrencial.

O próprio conceito de cortesia positiva é mais extenso no Acordo EUA/UE 1998. O art. $3^{\circ}$ deste acordo prevê que qualquer parte pode requerer às autoridades de defesa da concorrência da outra o início das investigações a fim de dar resolução às atividades

permanecem livres para atuar e exercer as suas funções dentro dos limites determinados pela legislação nacional que eventualmente seja aplicável ao caso.

${ }^{728}$ Cf. arts. 4.4 e 5.4 dos acordos celebrados os Estados Unidos e Argentina, respectivamente, e art. 3.8 do acordo firmado com a União Europeia.

729 "Se compararmos este acordo com outros do tipo firmados pelos EUA, veremos o quão tímido e contido ele foi em suas disposições, omitindo regras comuns a quase todos os outros acordos bilaterais". (MARTINEZ, Maria Beatriz. A cooperação internacional na defesa da concorrência: acordos bilaterais e aplicação do princípio da cortesia positiva. Revista do IBRAC - Direito da Concorrência, Consumo e Comércio Internacional. São Paulo, jan. 2004, v. 11, pp. 177 ss).

${ }^{730}$ De acordo com o art. $2^{\circ}, n^{\circ} 4$ do acordo de 1998. No mesmo sentido, ver DRAETTA, Ugo. Need for better trans-atlantic co-operation in the field of merger control. International Business Law Journal, 2002, p. 562; e SILVA, Valéria Guimarães de Lima e. Direito antitruste: aspectos internacionais. Curitiba: Juruá, 2007, p. 440, cuja autora esclarece que o acordo de 1998, "que suplementa o primeiro, não trata em seu texto das práticas concentracionistas, abrangendo tão-somente as atividades anticoncorrenciais, exatamente em decorrência do fato de as respectivas legislações daqueles países não deixarem na esfera do controle de 
anticoncorrenciais, de acordo com a legislação de defesa da concorrência da parte requerida. Tal solicitação pode ocorrer mesmo que a prática objeto do requerimento não seja repreendida pela legislação de defesa da concorrência da parte requerente ou no caso de as autoridades da parte requerente não tenham iniciado ainda procedimentos para repreender tal prática, nos auspícios da sua respectiva legislação.

Ademais, o art. $4^{\circ}$ do Acordo EUA/UE 1998 estabelece a possibilidade de as autoridades de defesa da concorrência acordarem sobre a suspensão ou deferimento das atividades de aplicação da parte requerente durante o período em que a parte requerida estiver em processo de execução das atividades de aplicação requeridas pelo pedido de cooperação $^{731}$. Este dispositivo estabelece critérios objetivos a serem observados pelas partes na hipótese de suspensão ou deferimento das atividades de aplicação. Note-se que nenhum dos acordos celebrados pelo Brasil ou SBDC contém disposição relacionada à suspensão ou deferimento das atividades de aplicação por parte da autoridade requerente.

Os critérios adotados pelos Estados Unidos e União Europeia em 1998 incluem a suspensão ou o deferimento nos casos em que (i) as atividades de natureza potencialmente anticoncorrencial não possuam impacto direto, substancial e razoavelmente previsível aos consumidores do território da parte requerente ou, quando possuírem tal impacto, as práticas anticoncorrenciais tenham lugar e sejam direcionadas principalmente ao território da parte requerida; (ii) os efeitos adversos nos interesses da parte requerente possam ser investigados, eliminados ou adequadamente sanados pela aplicação da legislação de defesa da concorrência da parte requerida ${ }^{732}$; e (iii) quando as autoridades da parte requerida assumirem o compromisso de promover determinadas ações ${ }^{733}$ na condução das respectivas atividades de aplicação da legislação de defesa da concorrência.

concentrações praticamente nenhum espaço para o exercício da discricionariedade que a deferência ao princípio da cortesia positiva exige".

731 "Tal dispositivo demonstra que as partes concordam com dois pontos fundamentais: inicialmente, que a jurisdição deve ser exercida preferencialmente pelo Estado que possui o nexo causal mais estreito com o ilícito cometido; em segundo lugar, que deve ser evitado ao máximo o exercício extraterritorial da jurisdição, substituindo-o por um mecanismo de cooperação interestatal tal qual preconizado pelo princípio da cortesia positiva". (SILVA, Valéria Guimarães de Lima e. Direito antitruste: aspectos internacionais. Curitiba: Juruá, 2007, pp. 439-440). Para maiores informações sobre procedimentos de suspensão ou deferimento, ver GERADIN, Damien; REYSEN, Marc; HENRY, David. Extraterritoriality, comity and cooperation in EU Competition Law. Cooperation, comity and competition policy. New York: Oxford University Press, 2011, pp. 31-32.

${ }^{32}$ Todavia, o acordo excepciona as situações em que em razão de prática anticoncorrencial afetando os territórios das duas partes, possam ser aplicadas penalidades nas duas jurisdições.

733 As ações previstas no art. $4^{\circ}$ do Acordo EUA/UE 1998 são os seguintes: (i) disponibilizar recursos adequados para investigar as atividades anticoncorrenciais e, quando necessário, tomar prontamente as medidas de execução adequadas; (ii) usar os seus melhores esforços para acessar todas as fontes de informação razoavelmente disponíveis, incluindo as fontes de informação conforme possam ser sugeridas pelas autoridades de concorrência da parte requerente; (iii) informar as autoridades de concorrência da parte 
O parágrafo $4^{\circ}$ do art. $4^{\circ}$ do Acordo EUA/UE 1998, por outro lado, expressamente prevê que as autoridades de defesa da concorrência que tiverem optado por diferir ou suspender as suas medidas de execução poderão tomar ou retomar posteriormente a execução ou investigação das condutas anticoncorrenciais. Todavia, por ocasião da retomada das atividades de aplicação, a parte requerente deverá prontamente notificar a parte requerida a respeito de tal intenção e justificativas. Caso a parte requerida decida continuar com a sua própria atividade de aplicação da legislação concorrencial sobre a prática objeto da cooperação, as autoridades de defesa da concorrência deverão, quando apropriado, coordenar as suas respectivas atividades de aplicação e investigações, consoante os critérios e procedimentos estabelecidos no art. $4^{\circ}$ do Acordo EUA/UE $1991^{734}$.

Desta forma, da análise dos acordos celebrados pelo Brasil e o SBDC com os Estados Unidos, a Argentina e a União Europeia em contraposição ao Acordo EUA/UE 1998 é possível depreender que a cortesia positiva foi adotada de forma mais branda nos acordos celebrados pelas autoridades brasileiras, uma vez que estes trouxeram somente um compromisso de consultar previamente a outra parte antes de adotar uma medida executória, enquanto que o Acordo EUA/UE 1998 trouxe maior detalhamento sobre como poderá ocorrer o relacionamento entre as autoridades no bojo de pedidos de cooperação com base na cortesia positiva ${ }^{735}$.

requerente, conforme requerido ou a intervalos razoáveis de tempo, sobre o estado das suas atividades de aplicação e intenções e, quando apropriado, fornecer às autoridades da concorrência da parte requerente informações confidenciais relevantes, caso as mesmas tenham sido obtidas da respectiva fonte; (iv) notificar prontamente as autoridades de concorrência da parte requerente sobre qualquer mudança nas suas intenções com relação à investigação ou execução; (v) usar os seus melhores esforços para completar a sua investigação e obter uma solução ou iniciar procedimento no prazo de seis meses, ou outro momento, conforme acordado entre as autoridades de concorrência das partes, sobre o adiamento ou a suspensão das atividades de execução pelas autoridades de concorrência da parte requerente; (vi) informar detalhadamente as autoridades de concorrência da parte requerente dos resultados da sua investigação, e levar em consideração as opiniões das autoridades de concorrência da parte requerente, antes de celebrar qualquer acordo, iniciar procedimento, proferir decisão ou finalizar a investigação, e (vii) cumprir com qualquer pedido razoável que possa ser feito pelas autoridades de concorrência da parte requerente.

734 “Tal possibilidade de as partes atuarem de forma independente pode novamente levar ao aparecimento de sérias divergências entre elas, retrocedendo ao status quo predominante antes do advento dos acordos bilaterais". (SILVA, Valéria Guimarães de Lima e. Direito antitruste: aspectos internacionais. Curitiba: Juruá, 2007, p. 442).

735 "Se for efetuada comparação entre o tipo de acordo de cooperação celebrado entre EUA e a UE, e o celebrado entre os EUA e o Brasil, verificam-se facilmente as diferenças básicas que refletem o nível de cooperação estabelecido. O conceito de cortesia positiva, por exemplo, é mais extenso no acordo com a UE, representando no acordo com o Brasil apenas o compromisso de consultar previamente a outra parte antes de adotar qualquer medida executória. Isso porque, apesar de os benefícios da cortesia positiva serem indiscutivelmente reconhecidos, é um dos instrumentos que mais despertam receios, pois a sua eficácia seria mais visível em se tratando de agências que tivessem níveis similares de desenvolvimento. Existe também o receio de que alguns países venham a utilizá-lo com outra motivações, e sufoquem a atividade da autoridade da concorrência requisitada. Da mesma forma, no que diz respeito à cooperação nas investigações, pois, 
Disto se conclui que a extensão da cortesia adotada entre as partes dos acordos bilaterais é diretamente proporcional ao grau de confiança desenvolvido pelas respectivas autoridades de defesa da concorrência e ao nível de desenvolvimento da legislação e instituições de defesa da concorrência ${ }^{736}$. De fato, os Estados Unidos e a União Europeia possuem grau de desenvolvimento das respectivas legislações de defesa da concorrência equivalente, além de terem uma tradição cooperativa em matéria concorrencial mais acentuada do que o verificado nas relações estabelecidas pelas autoridades brasileiras. Por tais motivos, é natural que a cortesia estabelecida entre Estados Unidos e União Europeia reflita um maior desenvolvimento e efetividade do que a estabelecida nos acordos celebrados pelo Brasil e o SBDC.

\subsubsection{A busca por informações}

Dos seis acordos bilaterais de cooperação celebrados pelo Brasil e pelo SBDC para a aplicação da legislação de defesa da concorrência, somente o firmado com a União Europeia não conta com disposições sobre a busca por informações no território da outra parte. Conforme descrito no item 3.2.2.2.3 supra, no âmbito de atos de cooperação multijurisdicional esta busca pode ocorrer principalmente por ocasião do deslocamento de colaboradores das autoridades de defesa da concorrência estrangeira para participar de diligências no território da autoridade requerida, como por exemplo, no caso de participação de reuniões ou interrogatórios, bem como no contato - direto ou por meio da

enquanto no acordo com a União Europeia, o governo norte-americano admite que haja o deferimento ou suspensão de uma investigação a favor de medidas de execução da parte requerida, o acordo com o Brasil não dispõe de nenhuma previsão nesse sentido, mas apenas de dispositivos destinados a evitar conflitos de interesses, sem estabelecer maiores compromissos". (SANTOS, Maria Cecília de Andrade. A política da concorrência e a Organização Mundial do Comércio. Revista de Direito Constitucional e Internacional, abr./jun. 2001, ano 9, n. 35, p. 242).

736 “A depender do nível de relação entre os EUA e o país em questão, assim como o grau de desenvolvimento da autoridade da concorrência daquele país, são adotadas diferentes regras em relação ao conceito de cortesia positiva”. (SANTOS, Maria Cecília de Andrade. Sobre a cooperação em matéria de concorrência entre a União Europeia e o Mercosul. Revista do IBRAC - Direito da Concorrência, Consumo e Comércio Internacional. São Paulo, jan. 2001, v. 8, pp. 239-240). De acordo com a mesma autora, “os acordos de cooperação celebrados <pelos Estados Unidos> com Israel, Japão e Brasil não possuem regras referentes à cortesia positiva tão desenvolvidas". A autora destaca ainda o documento Communication from the United States to the Working Group on the Interaction between Trade and Competition Policy, WT/WGTCP/W/116, no qual os Estados Unidos se pronunciaram no sentido de que "positive comity can be a useful tool in some cases, particularly where the respective antitrust agencies have had the opportunity to develop a relationship of sufficient trust and confidence in each other's ability and commitment to enforce its antitrust laws soundly and effectively. Laws and regulations need not to be identical, but a commitment to national treatment in the application of antitrust principles, adequate investigative and remedial powers, and sufficient independence of antitrust authorities are among the necessary underpinnings of na effective positive comity agreement". 
participação da autoridade requerida - com pessoas localizadas no outro território, seja mediante conferências telefônicas ou com o preenchimento de formulários com questionamentos sobre determinado segmento de mercado e/ou a operação pretendida. Note-se que tal busca poderá envolver não somente as partes da operação pretendida, como também terceiras que detenham informações relevantes às análises a serem conduzidas pelas autoridades de defesa da concorrência.

Nos acordos celebrados com os Estados Unidos e a Argentina, a busca por informações no território da outra parte consta dentre as atividades de aplicação dos $\operatorname{acordos}^{737}$. Tal busca de informações poderá contar com a visita de funcionários da autoridade notificante ao território da outra parte durante o curso de procedimentos iniciados com fundamento nas leis de defesa da concorrência das partes ${ }^{738}$. No entanto, estas visitas estão condicionadas ao procedimento de notificações previsto nos acordos e à obtenção do consentimento da parte notificada.

Os acordos celebrados com o Canadá e o Chile contêm disposições semelhantes sobre a busca por informações. De fato, dentre as disposições desses acordos a respeito das notificações entre as partes, constam as atividades que envolvam a busca por informações localizada no território da outra parte. Esta busca poderá ocorrer por meio de visitas por funcionários da outra parte (desde que obtido o consentimento prévio da parte requerida) ou de outra forma, com exceção de contatos telefônicos com pessoa localizada no território da outra parte, quando tal pessoa não esteja sujeita à investigação e o contato tenha por finalidade somente uma resposta verbal voluntária ${ }^{739}$.

Já no acordo com o Peru, as partes se comprometeram a realizar, mediante solicitação da outra parte e em conformidade com as respectivas leis de defesa da concorrência, requerimentos de informações a agentes econômicos que se encontrem em seus respectivos territórios, exceto quando tal atividade for contrária aos seus interesses ou afetar atividade de aplicação em curso ${ }^{740}$.

Quando tiver lugar no território nacional, a busca por informações acordada pelas autoridades brasileiras poderá ter que cumprir com a Competência Judiciária Internacional brasileira, quando aplicável. De fato, conforme discutido no item 2.1.3, supra, a cooperação administrativa internacional tem por objeto ato de natureza administrativa ou judicial, sem conteúdo jurisdicional, com efeitos meramente administrativos, não

\footnotetext{
${ }^{737}$ Cf. o art. 2.2 dos acordos com os Estados Unidos e a Argentina.

${ }^{738}$ Cf. o art. 2.3 dos acordos celebrados com os Estados Unidos e a Argentina.

${ }^{739}$ Cf. o art. 2.1.e os acordos celebrados com o Chile e o Canadá.

${ }^{740} \mathrm{Cf}$. art. $6^{\circ}$ do acordo celebrado com o Peru.
} 
oferecendo risco de ofensa à soberania, uma vez que tais efeitos não estão aptos a gerar coisa julgada ou exequibilidade ${ }^{741}$. Desta forma, a cooperação administrativa internacional não reclama necessariamente a atuação de órgão judicial nacional, uma vez que não implica na realização de atos jurisdicionais no território nacional. Enquanto as características de cooperação administrativa internacional forem preservadas, portanto, as autoridades brasileiras estão livres para executar os pedidos de busca por informações que lhe forem endereçados pelas suas congêneres estrangeiras.

Destaca-se que não se deve confundir a busca por informações no território brasileiro com o sequestro de bens no território nacional, procedimento que invocaria a atuação de autoridade judiciária brasileira. Nestes casos, a jurisprudência é farta no sentido de que a simples cooperação administrativa internacional não é instrumento legítimo para determinar a apreensão de provas no território brasileiro em razão de pedido de autoridades estrangeiras, devendo as regras de cooperação judiciária ser observadas pela autoridade requerente $^{742}$. Especial referência se faz aos casos de quebra de sigilo bancário e obtenção de dados e registros telefônicos, cujo sigilo é garantido pela legislação brasileira e sua divulgação depende de decisão fundamentada de autoridades judiciária ${ }^{743}$.

Desta forma, quando em determinado caso se faça necessária a atuação de órgão judiciário nacional, em razão da natureza jurisdicional da cooperação requerida, as autoridades administrativas envolvidas deverão buscar na legislação pátria as regras norteadoras da cooperação jurisdicional internacional e respeitar as competências definidas em lei. Nesse quesito, destaca-se a modalidade de cooperação do auxílio direto, descrito no item 2.1.4, supra, pela qual a autoridade receptora do pedido de cooperação tem a prerrogativa de pleitear perante as autoridades nacionais competentes o cumprimento do pedido de cooperação, na medida em que tal medida esteja dentro do âmbito das suas atribuições legais $^{744}$.

\footnotetext{
${ }^{741}$ Reitera-se que os atos das autoridades administrativas nacionais, em sede de cooperação administrativa internacional, estarão sempre sujeitos a controle jurisdicional interno, não contrariando, portanto, os preceitos da soberania do Estado.

${ }^{742}$ Destaca-se o caso em que as autoridades estrangeiras participam de diligências judiciárias no território nacional. De acordo com a jurisprudência pátria "no plano da cooperação internacional, é possível a participação das autoridades estrangeiras, desde que não haja nenhuma interferência delas no curso das providências tomadas" (Habbeas Corpus n ${ }^{\circ}$ 89171/RJ julgado pelo STF em 24 de março de 2009).

${ }^{743}$ Exemplificativamente, ver Carta Rogatória no 11192 procedente da Holanda, julgada pelo STF em 05 de maio de 2004.

${ }^{744}$ Nesses casos o procedimento de execução é inteiramente nacional, possuindo a única particularidade de ser iniciado por um pedido de entidade estrangeira.
} 


\subsubsection{O compartilhamento e a troca de informações}

Todos os seis acordos celebrados pelo Brasil e o SBDC que versam sobre a aplicação da legislação de defesa da concorrência contêm regras relacionadas ao compartilhamento de informações entre as autoridades envolvidas ${ }^{745}$. Algumas destas disposições tratam sobre a troca de informações confidenciais e o tratamento que deve ser dado a essas informações entre as partes dos acordos. Note-se que o acordo com o Peru esclarece que as informações trocadas entre as autoridades podem incluir informações sobre atividades de aplicação, bem como resoluções, sentenças, relatórios técnicos, orientações, dentre outros ${ }^{746}$.

Os acordos celebrados com os Estados Unidos e a Argentina preveem o compartilhamento das informações que possam facilitar a aplicação efetiva das respectivas leis de concorrência ou que promovam uma compreensão mais acurada das condições econômicas e mercadológicas de importância para as atividades das autoridades concorrenciais $^{747}$. Ademais, o acordo com a Argentina traz previsão da realização de duas reuniões por ano para que as autoridades de defesa da concorrência troquem informações, buscando dessa forma garantir o contínuo fluxo de informações entre as autoridades ${ }^{748}$.

Nos acordos celebrados com o Chile e o Canadá, as partes reconhecem que é do interesse mútuo a cooperação e a troca de informações, quando apropriado e praticável $^{749}$. O acordo firmado com a União Europeia contém disposição semelhante, contudo, limitando a troca de informações aos casos em que tal compartilhamento for apropriado e viável $^{750}$. Adicionalmente, o acordo com o Peru traz disposição equivalente, por meio do qual as partes assumiram o compromisso de trocar informações sobre atividades de aplicação das respectivas leis de defesa da concorrência ${ }^{751}$.

\footnotetext{
${ }^{745}$ A Recomendação ${ }^{\circ} 5$ do CCMR propõe que as informações que já se encontram no domínio público sejam distribuídas de forma mais eficiente.

${ }^{746} \mathrm{Cf}$. art. $5^{\circ}$ do acordo com o Peru.

${ }^{747}$ Cf. art. 3.1 dos acordos celebrados com os Estados Unidos e a Argentina.

748 "O conteúdo do Acordo indica que a cooperação e o processo de troca de informações entre as autoridades brasileiras e argentinas tendem a ser desenvolvidos de forma muito mais estreita, na medida em que prevê que as autoridades concorrenciais desses países se encontrem pelo menos duas vezes ao ano para tal finalidade, podendo inclusive discutir a eventual modificação de suas respectivas políticas públicas conforme gerem implicações à concorrência (art. III, 'c') ou compartilhar informações sobre setores econômicos de interesse comum (art. III, 'b')". (SILVA, Valéria Guimarães de Lima e. Direito antitruste: aspectos internacionais. Curitiba: Juruá, 2007, p. 435).

${ }^{749}$ Cf. o art. 3.1 dos acordos celebrados com o Canadá e o Chile.

${ }^{750}$ Cf. o art. 2.3 do acordo com a União Europeia.

${ }^{751}$ Cf. o art. 3.1 do acordo celebrado com o Peru.
} 
Todavia, em geral os acordos analisados trazem disposições que limitam a troca de informações entre as autoridades envolvidas nos casos em que tal compartilhamento seja contrário à legislação de defesa da concorrência ou interesses da parte fornecedora da informação ${ }^{752}$. Ademais, o acordo firmado com o Peru prevê que a troca de informações também não poderá prejudicar atividade de aplicação em curso $^{753}$.

No que se refere especificamente às informações confidenciais, o acordo com a União Europeia limita a troca de informações àquelas que não sejam confidenciais ${ }^{754}$. Note-se que a recomendação $\mathrm{n}^{\circ} 3$ do CCMR destaca a necessidade de maior clarificação sobre que informações devem ser consideradas como confidenciais pelas autoridades de defesa da concorrência. Dos acordos celebrados pelo Brasil e pelo SBDC, o único a trazer esclarecimento preciso a este respeito é o acordo celebrado com a Argentina, o qual estabeleceu que o grau de confidencialidade das informações deve ser decidido pela parte que as detiver, cabendo exclusivamente a esta verificar a possibilidade e o interesse em fornecê-las ${ }^{755}$.

O acordo com o Peru estabelece, adicionalmente, que para que uma parte possa compartilhar informação confidencial com a outra parte, deverá previamente obter o consentimento expresso do titular da informação ${ }^{756}$. De fato, conforme discutido no item 3.2.1, supra, em alguns $\operatorname{casos}^{757}$ os acordos bilaterais em matéria da concorrência de primeira geração preveem a possibilidade de compartilhamento de informações confidenciais entre as autoridades de defesa da concorrência ${ }^{758}$. Tal disposição, no entanto, poderá ser considerada ineficaz, na medida em que poderá esbarrar em princípios de

\footnotetext{
${ }^{752}$ Cf. o art. 9.1 do acordo celebrado com os Estados Unidos, art. 10.1 do acordo com a Argentina, art. 6.2 dos acordos celebrados com o Chile e o Canadá, art. 6.16 do acordo com a União Europeia e art. $5^{\circ}$ do acordo com o Peru. Nesse sentido, ressalta-se o acordo com a União Europeia, o qual traz uma regra específica no seu art. 2.2 que determina que a cooperação entre as partes está sujeita às respectivas leis, especialmente às que protegem as informações confidenciais e os segredos de negócio.

${ }_{753}$ Cf. o art. $5^{\circ}$ do acordo com o Peru.

${ }^{754} \mathrm{Cf}$. o art. 2.3 do acordo com a União Europeia.

${ }^{755} \mathrm{Cf}$. o art. 10.2 do acordo com a Argentina.

${ }^{756} \mathrm{Cf}$. o art. $8^{\circ}$ do acordo com o Peru.

${ }^{757}$ Tratam tanto dos casos dos acordos de segunda geração que preveem o contínuo compartilhamento de informações confidenciais, como dos acordos de primeira geração que preveem em alguns casos procedimentos específicos para a troca de informações confidenciais entre autoridades nacionais de defesa da concorrência, desde que obtida a anuência prévia da fonte das informações objeto da cooperação. Para maiores informações a respeito, ver item 3.1 supra.

${ }^{758}$ Thorstensen, destaca o acordo celebrado entre Estados Unidos e União Europeia em 1991 que prevê a preservação das regras de confidencialidade. Segundo a autora, os Estados Unidos adotaram em 1994 uma lei que permite a troca de informações confidenciais, desde que resguardadas certas condições (THORSTENSEN, Vera. A OMC - Organização Mundial do Comércio e as negociações sobre investimentos e concorrência. Revista Brasileira Política Intrnacional, 1998, v. 41 (1), p. 78).
} 
proteção do interesse nacional, bem como em disposições de outras legislações proibitivas, exigindo um elevado grau de comprometimento das autoridades ${ }^{759}$.

Nesse mesmo sentido, conforme discutido no item 2.2.2.2.1, supra, o CCMR contém recomendações no sentido de que a renúncia das partes aos direitos sobre a confidencialidade das informações que instruem a revisão do ato de concentração deve ser encorajada, já que poderá ser benéfica à dinâmica da análise coordenada das concentrações multijurisdicionais $^{760}$. Por outro lado, de acordo com o RCMR da OCDE e com os Princípios Orientadores e com as Práticas Recomendadas da ICN, a análise de concentrações multijurisdicionais deve garantir a proteção dos segredos industriais, comerciais e demais informações confidenciais previstas nas legislações nacionais.

Da análise da Lei da Concorrência, do RICADE e da Lei de Acesso à Informação (item 1.1.3.3, supra), os procedimentos de análise de ato de concentração submetidos ao SBDC poderão conter informações submetidas a quatro regimes diferenciados de tratamento de informações, a saber, acesso público, acesso restrito, sigiloso e segredo de justiça. Com exceção das informações de índole pública, o SBDC tem a obrigação de guardar a confidencialidade das informações que lhe são submetidas.

Reitera-se, no entanto, entendimento de que a redação acolhida pelo RICADE não esclarece quem seriam as "pessoas autorizadas pelo CADE" a quem o acesso a tais informações seria facultado, tampouco estabelece os parâmetros que o SBDC deverá utilizar na outorga da autorização para acesso a tais informações. Tal lacuna poderá levar a autoridade de defesa da concorrência brasileira a diferentes interpretações sobre a medida da sua discricionariedade na autorização de terceira pessoa para o acesso à informação confidencial; ou seja, se poderia ou não incluir as autoridades estrangeiras de defesa da concorrência. Todavia, conforme já referido anteriormente, para os fins deste estudo acolhe-se a interpretação mais conservadora, de que é necessário que a parte interessada renuncie à confidencialidade da informação antes de a mesma ser compartilhada com autoridades estrangeiras, seguindo assim com a prática e a interpretação do CADE até o advento da Lei da Concorrência ${ }^{761}$.

\footnotetext{
759 “Os Estados Unidos da América que, privilegiam enfaticamente a cooperação bilateral, para poder se servir de acordos de segunda geração, editou, em 1999, o International Antitrust Enforcement Assistance Act, que autoriza o intercâmbio de informações confidenciais, desde que protegidos os interesses estadunidenses". (OLIVEIRA, Gesner; RODAS, João Grandino. Direito e economia da concorrência. Rio de Janeiro: Renovar, 2004, p. 385).

${ }^{760}$ Recomendação $^{\circ} 2$ do CCMR.

761 Nesse sentido, ver recente manifestação do SBDC: "the Brazilian legal framework provides for confidentiality of commercially sensitive information and of information whose disclosure may jeopardize ongoing investigation efforts. This means that, in the absence of a waiver from the party concerned, access to
} 
A interpretação dos dispositivos anteriormente mencionados é relevante na medida em que estes constituem os limites impostos pelo ordenamento jurídico brasileiro no compartilhamento de informações confidenciais emitidas pelas autoridades brasileiras de defesa da concorrência. Qualquer processo cooperativo que envolva o SBDC deverá, portanto, estar em consonância com o ordenamento jurídico nacional que trata do compartilhamento de informações.

À parte da questão sobre informações que podem ser objeto da cooperação bilateral, os acordos bilaterais celebrados pelo Brasil e o SBDC contêm disposições que regulam o tratamento que deve ser dado pela autoridade receptora às informações recebidas. Nesse sentido, o acordo celebrado com os Estados Unidos estabelece que uma vez transferida qualquer informação em regime de sigilo entre as autoridades de defesa da concorrência envolvidas, a autoridade receptora estará obrigada a manter a confidencialidade sobre a informação recebida ${ }^{762}$. O acordo firmado com o Peru vai mais longe e determina que todas as informações trocadas pelas partes, sejam confidenciais ou não, deverão receber o tratamento de informação confidencial pela outra parte ${ }^{763}$.

Além disso, do total de seis acordos firmados pelo Brasil e o SBDC, três possuem disposições que restringem o uso da informação compartilhada pelas autoridades receptoras. O acordo com a Argentina determina que as informações confidenciais fornecidas por uma parte à outra, no contexto da cooperação e coordenação de atividades previstas no acordo, não serão usadas sem o consentimento da parte provedora das informações, com qualquer outro propósito que não seja a aplicação da lei de defesa da concorrência ${ }^{764}$. Já os acordos firmados com o Canadá e o Chile estabelecem que a decisão de uma parte sobre compartilhar determinada informação com a outra pode depender da

this information is limited to the BCPS $\langle S B D C\rangle$ and to the party providing this information". (ORGANIZAÇÃO PARA A COOPERAÇÃO E DESENVOLVIMENTO ECONÔMICO. Global forum on competition - Improving international co-operation in cartel investigations: contribution from Brazil. Session 2. DAF/COMP/GF/WD(2012)32. Jan. 2012, p. 5. Disponível em: <http://search.oecd.org/official documents/publicdisplaydocumentpdf/?cote=DAF/COMP/GF/WD(2012)32\&docLanguage=En>. Acesso em: 18 nov. 2012).

${ }^{762}$ Cf. art. 9.2 do acordo celebrado com os Estados Unidos e art. 6.4 dos acordos firmados com Canadá e Chile. Note-se que o acordo entre Brasil e Estados Unidos estabelece que cada autoridade de defesa deverá se opor ao máximo possível e de acordo com a legislação que lhe for aplicável, a qualquer pedido de qualquer terceiro interessado para o fornecimento de tais informações confidenciais. Nesse sentido, ver recente manifestação do SBDC: "confidential information obtained from a foreign agency or the defendant, may also serve as evidence within Brazilian proceedings but must be kept confidential also in Brazil. Confidential information is treated as confidential until a final decision is rendered or, depending of its content, may be kept confidential even after a final decision is rendered". (ORGANIZAÇÃO PARA A COOPERAÇÃO E DESENVOLVIMENTO ECONÔMICO. Op. cit., 2012, p. 5).

${ }^{763} \mathrm{Cf}$. o art. $8^{\circ}$ do acordo celebrado com a Argentina.

${ }^{764}$ Cf. o art. 10.3 do acordo celebrado com a Argentina. 
aceitação das garantias dadas pela outra parte com relação ao uso pretendido da informação ${ }^{765}$.

\subsubsection{Coordenação entre autoridades}

Os seis acordos bilaterais celebrados pelo Brasil e pelo SBDC para a aplicação da legislação de defesa da concorrência preveem, em alguma medida, a coordenação entre as atividades das autoridades de defesa da concorrência envolvidas. Nesse sentido, os acordos estabelecem que quando as autoridades da concorrência dos dois países estiverem levando a cabo atividades de aplicação, com respeito a matérias relacionadas, elas deverão considerar a conveniência de coordenação dessas atividades de aplicação, desde que seja apropriada e praticável ${ }^{766}$. O acordo com o Peru esclarece, ainda, que as autoridades poderão optar por não coordenar atividades nos casos em que seus interesses ou atividades de aplicação em curso sejam afetados por tal medida ${ }^{767}$.

Note-se que os acordos não definem com precisão o que seriam tais matérias relacionadas $^{768}$, sendo, no entanto, possível interpretar como aquelas práticas, matérias, atos ou fatos, cuja análise seja de interesse de ambas as jurisdições, consoante a legislação aplicável. Nesse tocante as Práticas Recomendadas pela ICN se referem às "questões de competitividade de preocupação mútua”, conceito que poderá seguir de guia à interpreção dos acordos bilaterais. Não está claro, no entanto, se deve haver uma correspondência absoluta entre o objeto das práticas analisadas pelas autoridades envolvidas, ou se tal relação poderia se dar de forma parcial (ou seja, somente em relação à parte do objeto do procedimento em análise). Além disso, os acordos deixaram de desenvolver de melhor forma, os procedimentos e os mecanismos de que as autoridades de defesa da concorrência poderão fazer uso para promover a coordenação de suas atividades.

Ademais, os acordos celebrados pelo Brasil e o SBDC não contêm nenhuma disposição específica com relação à coordenação das autoridades no estabelecimento de

\footnotetext{
${ }^{765}$ Cf. o art. 6.3 dos acordos com o Canadá e o Chile.

${ }^{766} \mathrm{Cf}$. o art. $5^{\circ}$ do acordo celebrado com os Estados Unidos, o art. 6.1 do acordo com a Argentina, o art. 3.2 dos acordos com o Chile e o Canadá, o art. 2.4 do acordo com a União Europeia e os arts. 3.2 e $6^{\circ}$ do acordo com o Peru. A respeito do acordo com os Estados Unidos, ver LAGARES, Eva Valle. International agreements regarding cooperation in the field of competition: the new strategy of the European Commission. Journal of European Competition Law \& Practice, jan. 2010, p. 2, em que esclarece: "Where both sides are pursuing enforcement activities in the same or related matters, they will endeavor to coordinate their enforcement activities".

${ }^{767} \mathrm{Cf}$. o art. $6^{\circ}$ do acordo celebrado com o Peru.

${ }^{768} \mathrm{Ou}$ "matérias inter-relacionadas", conforme consta nos acordos com os Estados Unidos e Argentina.
} 
restrições (remédios) a serem estabelecidos pelas autoridades de defesa da concorrência ${ }^{769}$, o que estaria em consonância com as recomendações da OCDE e da ICN. De fato, poderia haver dispositivo que previsse a troca de informações e discussões entre as autoridades, com o intuito de buscar a convergência das decisões e das restrições a serem definidas pelas diferentes autoridades envolvidas, viabilizando, assim, a realização da concentração com maior eficiência.

Tendo em vista que a coordenação de atividades é vertente relevante na cooperação entre autoridades em sede do controle de concentrações multijurisdicionais, torna-se conveniente compreender as regras mais avançadas sobre o assunto atualmente conhecidas - as Melhores Práticas EUA/UE ${ }^{770}$. Esse instrumento estabelece regras para a coordenação das atividades de cooperação das autoridades de defesa da concorrência norte-americanas e europeias, quando da análise do mesmo ato de concentração multijurisdicional no bojo do Acordo EUA/UE $1991^{771}$. De todo o modo, tal instrumento expressamente prevê que nenhuma de suas disposições pretende modificar ou criar obrigações, possuindo, portanto, natureza de soft law.

As autoridades norte-americanas e europeias reconhecem, pelas Melhores Práticas EUA/UE, que ao analisar uma mesma operação de concentração deve prevalecer o objetivo de alcançar, dentro do que seja possível, resultados consistentes ou, ao menos, não conflitantes $^{772}$. Contudo, as Melhores Práticas EUA/UE alertam que a coordenação efetiva das suas atividades depende em grande parte da cooperação e da boa vontade das partes da operação de concentração e de terceiros. Essa cooperação refere-se, principalmente, ao compartilhamento de informações confidenciais entre as autoridades, tido como essencial para a efetividade da coordenação entre as autoridades, bem como na contínua informação

\footnotetext{
${ }^{769}$ Note-se que o CADE tem demonstrado preferência na adoção de restrições estruturais, em detrimento das comportamentais (apesar de restrições comportamentais já terem sido adotadas). (REGAZZINI, José Augusto Caleiro. Merger control in Brazil. Competition Law International, out. 2005, n. 22, p. 24). O autor informa ainda que até 2005 o CADE não tinha tentado estabelecer restrições que se relacionassem com bens ou atividades localizados no exterior, apesar de ser teoricamente possível.

770 "The Best practices address issues pertaining to, inter alia, coordination on timing and consistency in the imposition of remedies". (GERADIN, Damien; REYSEN, Marc; HENRY, David. Extraterritoriality, comity and cooperation in EU Competition Law. Cooperation, comity and competition policy. New York: Oxford University Press, 2011, p. 39).

771 "This restatement of best practices sets out the conditions under which trans-Atlantic inter-agency cooperation in merger investigations should be conducted, while at the same time confirming and building upon current practice". (US-EU MERGER WORKING GROUP. Best practices on cooperation in merger investigations, 2011, p. 2. Disponível em: <http://ec.europa.eu/competition/international/bilateral/eu_us_. pdf>. Acesso em: 17 nov. 2012).

772 Item I.1 das Melhores Práticas EUA/UE. (Id., ibid., 2011, p. 2).
} 
pelas partes da operação às autoridades sobre os seus aspectos relevantes - incluindo as terceiras jurisdições que estão ou serão envolvidas na análise da concentração ${ }^{773}$.

As Melhores Práticas EUA/UE esclarecem que as comunicações entre as autoridades norte-americanas e europeias podem variar caso a caso, de acordo com as características de uma operação de concentração em particular ${ }^{774}$. De qualquer forma, o documento recomenda a designação de uma pessoa de contato de cada autoridade de defesa da concorrência que será responsável pela centralização e coordenação das comunicações trocadas.

Um dos aspectos regulados nas Melhores Práticas EUA/UE é a coordenação do momento da execução das etapas de controle de concentração pelas autoridades envolvidas, respeitadas as respectivas legislações de defesa da concorrência, por meio da elaboração de um cronograma do processo conjunto de análise. Nesse diapasão, há recomendação que as autoridades norte-americanas e europeias coordenem a comunicação recíproca sobre desenvolvimentos relevantes ocorridos durante a análise, coordenando as fases das suas análises e realizando reuniões e conferências telefônicas conjuntas com as partes da operação de concentração.

Desta forma, com o objetivo de se alcançar efetiva coordenação no processo decisório, as Melhores Práticas EUA/UE recomendam que as partes do ato de concentração multijurisdicional promovam notificações paralelas às autoridades norteamericanas e europeias, garantindo que a análise do caso ocorra em conjunto. Do contrário, e principalmente caso as partes apenas notifiquem uma das autoridades após as demais autoridades já tiverem chegado a uma decisão, a coordenação restará prejudicada ${ }^{775}$.

No que se refere à busca e ao compartilhamento de informações, as Melhores Práticas EUA/UE incentivam a troca de informações públicas entre as autoridades, bem como daquelas informações confidenciais que sejam permitidas pelos respectivos ordenamentos jurídicos.

Note-se que as Melhores Práticas EUA/UE contemplam não somente a troca de informações procedentes das partes do ato de concentração, mas também das análises

\footnotetext{
${ }^{773}$ Ver item I.4 das Melhores Práticas EUA/UE, no qual consta "the merging parties are encouraged to inform the US agencies and DG Competition of the competition authorities in other jurisdictions that are reviewing or are expected to review the same merger, and DG Competition and the US agencies seek to cooperate with those other authorities pursuant to the relevant OECD Recommendation, bilateral cooperation agreement, and/or the principles developed by the International Competition Network for interagency cooperation". (US-EU MERGER WORKING GROUP. Best practices on cooperation in merger investigations. 2011, pp. 2-3. Disponível em: <http://ec.europa.eu/competition/international/bilateral/ eu_us_.pdf>. Acesso em: 17 nov. 2012).

${ }^{774}$ Item II.5 das Melhores Práticas EUA/UE. (Id., ibid., p. 3).
} 
formadas pelas autoridades nas variadas etapas do processo de controle da concentração, como, por exemplo, a definição dos mercados relevantes de produto e geográfico, prognósticos sobre efeitos competitivos e eficiências, teorias sobre danos concorrenciais, teorias econômicas e provas empíricas necessárias ao teste de tais teorias. As discussões poderão incluir ainda os entendimentos das autoridades quanto às restrições ${ }^{776}$ a serem impostas e aos casos anteriores sobre os temas em pauta.

As Melhores Práticas EUA/UE incentivam, ainda, que as autoridades norteamericanas e europeias coordenem o envio de questionários às partes da operação e terceiros, a fim de acessarem informações relevantes à análise do caso, bem como conduzam apresentações e entrevistas conjuntas com as autoridades envolvidas e apresentem documentos de forma simultânea ${ }^{777}$. Para facilitar tal coordenação, as Melhores Práticas EUA/UE incentivam a outorga de termos de renúncia de confidencialidade pelas partes das operações e por terceiros, de forma a minimizar os custos associados ao procedimento e impulsionar trocas mais completas de informações entre as autoridades, o que deverá acarretar em um processo mais célere de análise e aumentar as possibilidades de as autoridades alcançarem resultados consistentes e não conflitantes.

Finalmente, as Melhores Práticas EUA/UE trazem recomendações sobre como se deverá desenvolver o relacionamento entre as autoridades de defesa da concorrência na coordenação das suas atividades com vistas a chegar a entendimentos consistentes e ou não conflitantes no que se refere às restrições a serem prescritas ao ato de concentração multijurisdicional sob análise. Nesse sentido, esclarecem que as restrições poderão ser as mesmas para ambas as jurisdições ou, no caso de não coincidência, as restrições prescritas por uma das autoridades poderão afetar a jurisdição da outra.

Nos casos em que ambas as autoridades definirem o mercado relevante geográfico como internacional, as restrições estabelecidas pelas diferentes autoridades poderão ser as mesmas. Mesmo nos casos em que o mercado relevante geográfico for estabelecido como nacional ou regional, ou quando o mercado relevante de produto estabelecido não for

\footnotetext{
${ }^{775}$ Itens III.10 a III.12 das Melhores Práticas EUA/UE. (Id., ibid., p. 5).

776 Utiliza-se o termo "restrição" como sinônimo de "remedy", optando, desta forma, pela terminologia adotada pela Lei da Concorrência.

${ }^{777}$ Item IV.13 das Melhores Práticas EUA/UE (US-EU MERGER WORKING GROUP. Best practices on cooperation in merger investigations. 2011, pp. 5-6. Disponível em: <http://ec.europa.eu/competition/ international/bilateral/ eu_us_.pdf>. Acesso em: 17 nov. 2012).
} 
idêntico na análise das autoridades envolvidas, as restrições definidas em uma jurisdição poderão se relacionar, depender ou afetarem as restrições definidas na outra jurisdição ${ }^{778}$.

Por tal motivo, as Melhores Práticas EUA/UE recomendam que as autoridades norte-americanas e europeias se esforcem para alcançar decisões convergentes no que se refere às restrições, de modo a não impor obrigações inconsistentes ou conflitantes às partes da operação ${ }^{779}$. Com tal objetivo, as autoridades devem manter-se informadas a respeito das discussões conduzidas internamente e do relevante desenvolvimento das restrições consideradas para o caso em análise, na medida em que tais discussões possam afetar a análise das demais autoridades. Se conduzida corretamente, a coordenação das autoridades neste assunto poderá culminar em um conjunto de restrições que atendam as expectativas de ambas as jurisdições.

Dentre os instrumentos de soft law publicados por entidades internacionais, destaca-se também, com relação à coordenação entre a condução de atividades de aplicação pelas autoridades de defesa da concorrência, as Práticas Recomendadas da ICN. Esse instrumento clama às autoridades de defesa da concorrência a incitarem e facilitarem a cooperação entre si e com as partes da operação de concentração multijurisdicional, seja por meio de comunicações conjuntas às autoridades envolvidas, como pela outorga voluntária de termos de renúncia dos direitos de confidencialidade.

Além disso, a OCDE emitiu recomendações que podem beneficiar as atividades de coordenação entre as autoridades de defesa da concorrência. Nesse sentido, o CCMR traz recomendações para a adoção de dispositivo que obrigue as partes notificantes de concentração multijurisdicional a informarem, em algum momento do procedimento de análise da concentração, se notificaram ou pretendem notificaralguma outra autoridade de defesa da concorrência sobre o mesmo ato - o que pode beneficiar as iniciativas de coordenação das atividades de aplicação de acordos bilaterais ${ }^{780}$. A legislação brasileira parece estar em conformidade com esta disposição, uma vez que os formulários aprovados pelo CADE para a apresentação de atos de concentração contêm um campo no qual as partes de uma operação devem indicar se a mesma foi ou será notificada a outras autoridades de defesa da concorrência ${ }^{781}$.

\footnotetext{
778 Item V.16 das Melhores Práticas EUA/UE (EUA/UE (US-EU MERGER WORKING GROUP. Best practices on cooperation in merger investigations. 2011, p. 6 . Disponível em: <http://ec.europa.eu/competition/ international/bilateral/ eu_us_.pdf>. Acesso em: 17 nov. 2012)..

${ }^{779}$ Item V.17 das Melhores Práticas EUA/EU (Id., ibid., 2011, p. 6.

${ }^{780}$ Recomendação $\mathrm{n}^{\circ} 4$ do CCMR.

${ }^{781}$ Ver Resolução CADE nº 2/2012, Anexo I, itens III.3 e III.4 e Anexo II, itens III.3 e III.4.
} 
Ademais, o CCMR recomenda a elaboração de uma minuta de formulário de notificação de concentração, o qual solicitaria informações comuns de diversas jurisdições em um formato único, mas que contemplasse a possibilidade de haver anexos nacionais, consoante fosse adequado. Não obstante a possibilidade de tal adoção ocorrer em sede de acordos bilaterais, não se tem notícias de adoção de dispositivos dessa espécie nesse tipo de acordo $^{782}$.

Da análise realizada sobre as Melhores Práticas EUA/UE e dos demais instrumentos de soft law emitidos por entidades internacionais, é possível depreender que os acordos celebrados pelo Brasil e o SBDC estão em estágio muito incipiente de desenvolvimento. De fato, os acordos celebrados somente trazem dispositivos bastante generalistas sobre a intenção de as partes coordenarem as suas atividades, sem, no entanto oferecer definições, procedimentos ou esclarecimentos sobre como as autoridades poderão efetivamente garantir a cooperação pretendida.

Ante o exposto, conclui-se que as autoridades brasileiras poderão inspirar-se nos instrumentos de soft law emanados pelas autoridades internacionais, como a OCDE e a ICN, bem como naqueles adotados pelos Estados Unidos e União Europeia para aprimorar os mecanismos de coordenação que utiliza nos acordos de cooperação bilateral dos quais é parte.

\subsubsection{Outras disposições relevantes}

As principais características dos acordos bilaterais de cooperação celebrados pelo Brasil e SBDC, descritas nos itens 3.3.2 a 3.3.7, supra, são temas recorrentes na grande maioria dos acordos bilaterais celebrados pelos mais variados países, encontrando correspondência, inclusive, em relação ao Acordo EUA/UE 1991. Todavia, alguns destes acordos possuem características próprias, que nem sempre encontram correspondência em outros acordos congêneres.

Um exemplo dessa situação está no acordo celebrado pelo Brasil com a Argentina que estabelece que a parte que investigar uma prática anticompetitiva com base no acordo bilateral celebrado poderá notificar o Uruguai e o Paraguai sobre o resultado das investigações e, na medida do possível, sobre seus progressos parciais, quando

\footnotetext{
${ }^{782}$ Recomendação $n^{\circ} 6$ do CCMR. Note-se que a recomendação $n^{\circ} 7$ constata que o setor privado em muito se beneficiaria se houvesse convergência entre os requerimentos de notificação.
} 
significativos $^{783}$. Tal dispositivo denota uma preocupação do Brasil e da Argentina em aprimorar os laços de cooperação com os outros Estados-Partes do Mercosul.

Ademais, alguns acordos trazem regras sobre a resolução de controvérsias entre as partes dos acordos. Os acordos celebrados com o Canadá e o Chile, por exemplo, determinam que quaisquer dúvidas sobre a interpretação ou aplicação do acordo serão objeto de discussão entre as partes ${ }^{784}$. Já o acordo com o Peru estabelece que a interpretação e a aplicação do acordo deverão ser realizadas pelas partes com boa-fé e levando em conta seu objeto e finalidade, sendo que quaisquer diferenças devem ser solucionadas em comum acordo entre as partes ${ }^{785}$.

Da análise destes dispositivos é possível depreender que os mecanismos de solução de controvérsias entre as partes dos acordos bilaterais celebrados pelo SBDC, quando existentes, são de desenvolvimento incipiente, já que garantem uma livre discricionariedade das partes na resolução das divergências existentes pela negociação. Não há, desta forma, a aferição de poderes a uma terceira parte autônoma e independente que possa decidir efetivamente sobre eventuais controvérsias entre as partes. Isso poderá ser relevante na medida em que discordâncias envolvendo a cooperação e a coordenação em matéria concorrencial, na maioria das vezes, relacionam-se a políticas adotadas pelas partes envolvidas na discussão, as quais, por sua vez, poderão não encontrar estímulos políticos e econômicos para chegar a uma solução negociada em relação à controvérsia posta.

\subsubsection{Considerações gerais sobre os acordos firmados pelas autoridades brasileiras}

Ante a análise das disposições dos seis acordos bilaterais celebrados pelo Brasil e pelo SBDC com a finalidade de aplicação da legislação de defesa da concorrência, é possível depreender que o Brasil encontra-se em patamar muito incipiente no que tange ao alcance disponível aos acordos bilaterais celebrados. Primeiramente, justifica-se tal assertiva pelo fato de o Brasil e o SBDC terem firmado poucos acordos bilaterais, sendo que somente dois contaram com o procedimento de ratificação para que fosse conferida a necessária eficácia e vinculação às suas disposições. De forma geral, portanto, o grau de

\footnotetext{
${ }_{783}$ Cf. o art. 12.2 do acordo celebrado com a Argentina.

${ }^{784}$ Cf. o art. 4.3 dos acordos celebrados com o Canadá e o Chile.

${ }^{785}$ Cf. o art. 10 do acordo celebrado com o Peru.
} 
legalização escolhida pelas autoridades brasileiras é fraco, já que o conjunto de acordos celebrados situa-se no patamar de soft law.

A respeito do âmbito de aplicação dos acordos, destacam-se as deficiências encontradas nas disposições dos acordos celebrados com os Estados Unidos e a Argentina, que não incluíram dentre as concentrações multijurisdicionais, objeto da cooperação pretendida, aquelas que envolvem empresas que não mantêm representação permanente no outro território, mas que, todavia, exploram de alguma maneira dito território (seja, por exemplo, mediante importação ou exportação).

Já em relação às notificações trocadas entre as autoridades de defesa da concorrência, os acordos celebrados pelo Brasil e o SBDC não contêm disposições que especifiquem prazos concretos para a promoção das notificações, com exceção do acordo celebrado com a Argentina. Além disso, nenhum dos acordos bilaterais estabelece prazo para o envio das respostas das autoridades de defesa da concorrência no âmbito de cooperação que tenha sido requerida. A falta de estabelecimento de prazos pode ocasionar a falta de eficiência e rapidez na cooperação entre as autoridades.

Em relação às disposições de cortesia negativa, o único acordo celebrado pelo Brasil e o SBDC que traz maior detalhamento sobre as atividades de aplicação que têm potencialidade de afetar os interesses da outra parte é o acordo celebrado com o Peru. O acolhimento de disposições mais detalhadas a respeito do tema nos demais acordos poderia garantir a efetividade na aplicação da cortesia negativa entre as autoridades envolvidas na cooperação.

No tocante à cortesia positiva, existem vários fatores que poderiam ser aprimorados nos acordos adotados pelo Brasil e pelo SBDC, dentre os quais se destaca a própria extensão do princípio da cortesia positiva e a falta de procedimentos específicos que garantam maior sinergia entre as partes da cooperação. Em relação a este tema, todos os acordos poderiam ser aperfeiçoados de acordo com os instrumentos trazidos pelo Acordo EUA/UE 1998, o qual, apesar de não ser aplicável às concentrações multijurisdicionais, traz dispositivos modernos e de grande valia à efetiva cooperação das partes. Um exemplo desta situação está na possibilidade de haver a suspensão ou deferimento das atividades de aplicação em certas ocasiões, o que muito beneficiaria casos de concentrações multijurisdicionais, as quais, em última análise, podem acarretar em resultados conflitantes se analisadas por diferentes autoridades. Mais do que isso, a cortesia positiva seria garantida somente caso as partes dos acordos assumissem a obrigação efetiva de colocar em prática as suas disposições. A corrente voluntariedade inerente a este tipo de regra, 
acaba muitas vezes por conferir margem muito ampla à discricionariedade das partes e, assim, acarreta em lacuna legislativa que permite a não cooperação pelas partes, sem que sejam apresentados quaisquer fundamentos para tanto.

Quanto à busca de informações, o ponto mais relevante relaciona-se às medidas de execução levadas a cabo no território da outra parte, as quais podem estar submetidas às autoridades judiciárias competentes. Desta forma, as autoridades devem ter especial atenção às legislações nacionais que venham a ser aplicáveis a cada caso, de modo a garantir a efetividade da pretensão de cooperação e a correta utilização dos instrumentos de cooperação disponíveis no ordenamento jurídico do território a que se busca cooperação.

Em relação ao compartilhamento de informações, os acordos celebrados pelo Brasil e pelo SBDC, apesar de não constituírem acordos de segunda geração, estão em conformidade com as recomendações da OCDE e ICN, as quais propugnam pela segurança no manuseio de informações confidenciais e pela conformidade de atividades das autoridades de defesa da concorrência com as legislações nacionais que venham a ser aplicáveis. Nesse quesito entende-se que o CADE deveria esclarecer sobre os limites da sua regulamentação em relação às terceiras pessoas a quem pode autorizar o acesso a informações confidenciais e a definição de critérios que deverá utilizar para tanto, a fim de garantir maior segurança jurídica às partes das operações de concentração e às autoridades estrangeiras quanto às expectativas de recebimento de informações das autoridades brasileiras. Por outro lado, este Conselho poderia disponibilizar modelos de termos de renúncia sobre confidencialidade de informações às partes das operações que devam lhe ser submetidas, de modo que possam conferir à autoridade brasileira consentimento para a cooperação internacional com as suas congêneres estrangeiras.

Por fim, no tocante à coordenação das atividades das autoridades brasileiras com as estrangeiras, entende-se que os acordos de cooperação deveriam conter definição mais precisa sobre quais seriam as "matérias relacionadas" (ou inter-relacionadas) que devem dar azo à coordenação entre as autoridades. Mais do que isto, os acordos celebrados pelo Brasil e o SBDC têm muito espaço para evolução no que tange ao estabelecimento de instrumentos efetivos, procedimentos e mecanismos para a promoção da coordenação das atividades em todas as fases das análises conduzidas, o que poderia ocorrer no caso de as autoridades se inspirarem nas Melhores Práticas EUA/UE para a adoção de disposições mais efetivas à coordenação ${ }^{786}$.

786 "Now that over 100 jurisdictions have merger laws, it is particularly important that agencies seek to ensure that their processes do not create conflicts or impose inconsistent demands for parties that are before 
Adicionalmente, os termos dos acordos celebrados, parecem não cumprir com todas as recomendações sobre melhoras práticas divulgadas pela OCDE e pela ICN. É o caso, por exemplo, da recomendação da ICN sobre a participação das partes do ato de concentração nos procedimentos de coordenação por meio da constante comunicação com as respectivas autoridades da concorrência em relação ao momento de notificação, bem como em relação à outorga voluntária de termos de renúncia dos direitos de confidencialidade relevantes para a boa condução do procedimento cooperativo, que encontram escassa previsão nos acordos firmados ${ }^{787}$.

Ademais, os acordos analisados não contêm nenhuma disposição referente à coordenação no estabelecimento das restrições (ou remédios) pelas autoridades de defesa da concorrência, o que estaria em consonância com as recomendações da OCDE e da ICN, bem como com as Melhores Práticas EUA/UE. De fato, poderia haver dispositivo que previsse maior e mais efetiva troca de informações e coordenação entre as autoridades, com o intuito de buscar a convergência das decisões e das restrições a serem definidas pelas diferentes autoridades envolvidas, viabilizando, assim, a realização da concentração com maior eficiência no plano internacional.

Finalmente, os acordos celebrados poderiam ter acolhido instrumentos mais efetivos quanto à resolução de controvérsias na aplicação e interpretação dos seus dispositivos. Os únicos acordos celebrados pelo Brasil e o SBDC que contêm disposições nesse sentido trazem regras bastante fracas para a resolução de controvérsias, acolhendo somente procedimentos de negociação que, por sua vez, poderão não ser úteis no caso concreto, em razão de eventuais discordâncias entre as partes do acordo quanto às políticas e aos interesses públicos relevantes ao caso.

Após a análise dos termos dos acordos bilaterais de cooperação para aplicação das legislações de defesa da concorrência celebrados pelo Brasil e pelo SBDC, importa a análise da aplicação prática dos referidos acordos bilaterais, tanto pelas autoridades brasileiras, quanto pelas autoridades estrangeiras, de modo que seja possível identificar as principais problemáticas identificadas pela experiência internacional e se cogitar, assim, as possíveis soluções disponíveis à comunidade internacional.

more than one agency". (ORGANIZAÇÃO PARA A COOPERAÇÃO E DESENVOLVIMENTO ECONÔMICO. Global forum on competition - Roundtable on cross-border merger control: challenges for developing and emerging economies: contribution from United States. DAF/COMP/GF/WD(2011)29. Session 1. Fev. 2011, p. 3. Disponível em: <http://www.ftc.gov/bc/international/docs/1102crossbordermerger control.pdf>. Acesso em: 01 dez. 2012). 


\subsection{APLICAÇÃO PRÁTICA DOS ACORDOS EM VIGOR AOS ATOS DE CONCENTRAÇÃO MULTIJURISDICIONAIS}

A cooperação bilateral em matéria de concorrência tem ocorrido com frequência entre economias mais desenvolvidas, como no caso da cooperação consolidada entre os Estados Unidos e a União Europeia. Outros países, como no caso do Brasil, começam a consolidar os esforços de cooperação, aproveitando a experiência norte-americana e europeia para trilhar o caminho da cooperação em questões de natureza concorrencial.

Note-se que em razão da delimitação deste estudo aos atos de concentração multijurisdicionais, não se pretende descrever a aplicação prática de cooperação entre autoridades de defesa da concorrência nos casos de investigação de condutas anticoncorrenciais - cooperação esta muito recorrente nos casos de cartéis internacionais. As considerações aqui refletidas estão focadas nos casos em que diferentes autoridades de defesa da concorrência trabalharam em cooperação no controle de atos de concentração multijurisdicionais, tendo seus resultados sido reconhecidos pela comunidade internacional.

\subsubsection{Casos envolvendo autoridades brasileiras}

Não seria correto afirmar que as autoridades brasileiras de defesa da concorrência não têm histórico de cooperação em matéria concorrencial no que se refere aos atos de concentração multijurisdicionais que também afetam o território brasileiro. É possível averiguar a prática comum do SBDC em determinar nas suas decisões sobre aprovação ou não de atos de concentração multijurisdicionais que suas contrapartes estrangeiras sejam notificadas sobre a ocorrência de dita concentração, a fim de que averiguem se a operação poderá ou não afetar os seus mercados. Um exemplo dessa situação está na concentração havida entre Compagnie de Saint-Gobain e Owens Corning ${ }^{788}$, na qual o ConselheiroRelator Fernando de Magalhães Furlan recomendou, em vista de grande parte do mercado latino-americano ser abastecido pela Owens Corning, a comunicação da decisão às autoridades de defesa da concorrência dos Estados-Partes do Mercosul ${ }^{789}$.

\footnotetext{
${ }^{787} \mathrm{O}$ RCMR contém recomendações nesse sentido.

788 Ato de Concentração CADE n 08012.001885/2007-11, realizada em 2007 por empresas estrangeiras (uma norte-americana e outra francesa), que fez surtir efeitos no território nacional, em razão de da planta localizada em Capivari/SP. O CADE exerceu a sua competência com base na teoria dos efeitos e aplicou a legislação brasileira, decidindo pela reprovação da operação e determinando o desinvestimento realizado pela Saint-Gobain em Capivari/SP.

${ }^{789}$ Cf. descrito no capítulo 2 deste estudo, na página 171.
} 
Casos de concentrações multijurisdicionais envolvendo a jurisdição brasileira são numerosos $^{790}$. Em 2008, o SBDC analisou a concentração multijurisdicional envolvendo a fusão de duas sociedades norte-americanas a E.I Dupont de Nemours and Company e a Chemtura Corporation (DuPont/Chemtura) ${ }^{791}$. A DuPont opera em mais de 90 países, oferecendo produtos e serviços nos mercados de agricultura, nutrição, eletrônicos, comunicações, segurança e proteção, construção, transportes e vestuário. Já a Chemtura é uma sociedade com atividades globais no mercado de químicos. Ambas as sociedades mantinham atividades no Brasil, à época da apresentação da operação ao CADE, através de subsidiárias integralmente detidas pelas empresas norte-americanas. A notificação ao SBDC ocorreu em 25 de fevereiro de 2008, com fundamento no fato de afetar diretamente o mercado brasileiro.

Na decisão do caso DuPont/Chemtura, o CADE entendeu que qualquer intervenção da autoridade na operação consubstanciaria uma extrapolação dos limites da jurisdição conferida pela legislação brasileira de defesa da concorrência e, assim, aprovou a operação sem restrições. Interessante notar que não obstante o FTC também ter sido notificado sobre esta operação, nenhuma cooperação ou coordenação direta entre as autoridades foi estabelecida $^{792}$.

Ainda no ano de 2008, o SBDC foi notificado sobre outra concentração multijurisdicional, envolvendo desta vez a fusão da Dow Brasil S/A e da Rohm and Haas Química Ltda (Dow/Rohm Haas) ${ }^{793}$. Apesar de as partes notificantes estarem sediadas no Brasil, as suas controladoras eram organizadas e constituídas de acordo com a legislação norte-americana e desenvolviam operações em diversas jurisdições nos mercados químico e petroquímico.

À época em que o CADE analisou a operação Dow/Rohm Haas, a mesma já havida sido submetida e aprovada pelas autoridades da África do Sul, Turquia, Canadá, Taiwan, China, México e União Europeia. Este fato possibilitou que o SBDC considerasse as decisões tomadas nos outros mercados quando da condução da sua análise sobre o caso ${ }^{794}$.

\footnotetext{
${ }_{790}$ Ver casos descritos no item 1.3.1.2.2 deste estudo.

791 Ato de Concentração CADE n ${ }^{\circ}$ 08012.001312/2008-79.

792 ORGANIZAÇÃA PARA A COOPERAÇÃO E DESENVOLVIMENTO ECONÔMICO. Global forum on competition - Roundtable on Cross-Border Merger Control: Challenges for Developing and Emerging Economies: Contribution from Brazil. Session 1. DAF/COMP/GF(2011)13, p. 110. Dez. 2010. Disponível em: 〈http://www.oecd.org/ competition/mergers/50114086.pdf〉. Acesso em: 18 nov. 2012.

${ }^{793}$ Ato de Concentração CADE n ${ }^{\circ}$ 08012.007982/2008-07.

794 "For instance, SEAE decided not to analyze a particular market based mostly on information and conditions imposed by the FTC in its decision (FTC compelled Dow Group to sell its productive assets in this particular market to a competitor). CADE also considered the FTC's decision in its reasoning. In his vote, Commissioner Carlos Emmanuel Joppert Ragazzo justified that a vertical integration analysis of the merger
} 
Na visão do CADE, o fato de ter baseado fases da sua análise e decisão final nas decisões tomadas por autoridades estrangeiras, em especial pelo FTC, torna o caso exemplo de coordenação em concentrações multijurisdicionais ${ }^{795}$. Parece, no entanto, que tal coordenação pode ser tida como espécie de coordenação unilateral por parte das autoridades brasileiras, da qual as autoridades estrangeiras não direcionaram esforços ou tiveram direta participação.

À semelhança do caso Row/Rohm Haas, em 2012 o CADE julgou caso envolvendo a aquisição da Wyeth pela Pfizer Inc. (Wyeth/Pfizer) ${ }^{796}$, decidindo pela aprovação com restrições ${ }^{797}$. A operação, concluída em 2009, produziu efeitos em vários territórios, inclusive o brasileiro, para o qual a norte-americana Wyeth vendia produtos de saúde humana e animal. Durante a análise do caso, a SEAE levou em consideração as decisões das autoridades de defesa da concorrência de outros países, como Estados Unidos, Austrália e México. Note-se que os entendimentos das várias autoridades envolvidas foram divergentes; enquanto Colômbia, Nova Zelândia e Taiwan aprovaram a operação, os Estados Unidos, Canadá, China e México impuseram restrições ${ }^{798}$. No entanto, não foi possível confrontar a análise deste caso com qualquer iniciativa das autoridades brasileiras e suas congêneres estrangeiras na consecução de coordenação ativa durante a análise da operação.

De fato, diferentemente dos casos em que as autoridades brasileiras cooperaram com congêneres estrangeiras em matéria de condutas - mais especificamente nos casos de cartéis internacionais -, nas pesquisas realizadas não foi possível identificar caso de concentração multijurisdicional em que tenha havido esforço efetivo e substancial de cooperação entre as autoridades de defesa da concorrência brasileiras e estrangeiras na análise e controle de concentrações jurisdicionais. Esta constatação é interessante na medida em que é reconhecida a tendência de haver maior possibilidade de sucesso nos

would not be necessary because the conditions imposed by FTC eliminated the Brazilian competition concerns in this regard'. (ORGANIZAÇÃO PARA A COOPERAÇÃO E DESENVOLVIMENTO ECONÔMICO. Global forum on competition - Roundtable on Cross-Border Merger Control: Challenges for Developing and Emerging Economies: Contribution from Brazil. Session 1. DAF/COMP/GF(2011)13, p. 111. Dez. 2010. Disponível em: 〈http://www.oecd.org/competition/mergers/ 50114086.pdf〉. Acesso em: 18 nov. 2012).

${ }^{795}$ Id. Ibid., p. 111.

796 Ato de Concentração CADE nº 08012.001157/2009-71.

797 O CADE determinou a alienação pela Pfizer de ativos de cinco itens veterinários.

${ }^{798}$ Segundo o relator do processo, as restrições mais rígidas ocorreram no exterior. 
casos de cooperação em matéria de concentrações multijurisdicionais do que nos casos de cartéis $^{799}$.

Parte da doutrina entende que em vista da posição do Brasil como país receptor de investimentos, cujos agentes econômicos estão sediados no exterior, as suas decisões contrárias a concentrações multijurisdicionais têm poucas chances de ter influência no processo decisório das autoridades de defesa da concorrência estrangeiras, já que de difícil implementação $^{800}$. Segundo este entendimento, a efetiva cooperação por parte das autoridades brasileiras com as suas congêneres estrangeiras, relacionadas às sedes dos agentes econômicos participantes de operação de concentração multijurisdicional, poderia ser dispensada ou não priorizada por estas. Este poderia se constituir no motivo para não se verificar a efetiva cooperação em matéria de cooperação multijurisdicional das autoridades brasileiras com as estrangeiras. Outro motivo apontado pela doutrina sobre o baixo nível de cooperação bilateral entre países desenvolvidos e em desenvolvimento está no fato de os países desenvolvimentos terem pouco a ganhar em promover a cooperação com países em desenvolvimento ${ }^{801}$.

Entende-se, porém, que o principal motivo para a parca cooperação em matéria de concentração multijurisdicional pelas autoridades brasileiras deve-se ao fato de até recentemente o Brasil ter mantido um sistema de revisão de concentrações a posteriori. Conforme descrito na parte "b" do item 1.1.3.2.2 deste estudo, a Lei da Concorrência, que entrou em vigor recentemente, no ano de 2012, veio alterar o regime de submissão dos atos de concentração às autoridades brasileiras de um sistema de revisão a posteriori para um regime de análise prévio. Note-se que grande parte dos países, com legislações de defesa da concorrência em nível avançado de desenvolvimento, contam já há algum tempo com regimes de análise e controle prévio de concentrações econômicas.

\footnotetext{
799 "Enforcement cooperation tends to be more sucessful in merger control investigations than in cartel investigations. Corporations seeking to merge often have an incentive to grant a waiver in order to ensure a swift investigation and, consequently, timely consummation of their transaction. In contrast, corporations remain reluctant to facilitate agencies' joint cartel investigations, as consenting to the exchange of confidential information would expose them to additional sanctions in another jurisdiction". (BRADFORD, Anu. International antitrust cooperation and the preference for nonbinding regimes. Cooperation, comity and competition policy, New York: Oxford University Press, 2011, p. 323).

800 "São remotas, na prática, as possibilidades de as autoridades brasileiras emitirem decisões muito discrepantes das de outros países nos quais estão sediadas as matrizes das empresas atuantes no Brasil". (NUSDEO, Ana Maria de Oliveira. Defesa da concorrência e globalização econômica. São Paulo: Malheiros, 2002, p. 216).

801 "Developed countries would likely be exposed to numerous requests of enforcement assistance from developing countries, as large developed country cooperation often achieve a high market share in small developing country markets. In contrast, smaller developing-country corporations rarely trigger an antitrust investigation in large developed-country markets". (BRADFORD, Anu. International antitrust cooperation
} 
Tendo em vista que o Brasil manteve até 2012 um sistema de análise que destoava dos demais países em função do momento para a condução da análise das concentrações que lhes eram submetidas, entende-se que o país esteve durante este período em situação de desvantagem para a condução de processos efetivos de cooperação em matéria de concentrações multijurisdicionais. De fato, considerando que uma operação somente era notificada às autoridades brasileiras após a sua conclusão, portanto, em momento em que as autoridades estrangeiras já haviam proferido as respectivas decisões sobre dita operação, conforme o caso Dow/Rom Haas descrito anteriormente, não restavam muitas oportunidades para a efetiva cooperação e coordenação com as autoridades estrangeiras ${ }^{802}$. Talvez seja este o principal motivo de não ser possível identificar casos de concentração multijurisdicionais de relevo, em que as autoridades brasileiras tenham efetivamente cooperado com autoridades estrangeiras durante o processo decisório.

Com a adoção do regime de análise prévia - a priori -, e assim uma melhor sintonia com as legislações estrangeiras de defesa da concorrência, as circunstâncias parecem convergir para que o país passe a usufruir de posição vantajosa para um efetivo desenvolvimento da cooperação entre autoridades brasileiras e estrangeiras ${ }^{803}$. Espera-se, assim, que notícias sobre a cooperação das autoridades brasileiras com estrangeiras nos procedimentos de análise de concentrações multijurisdicionais se intensifiquem com o passar do tempo.

\subsubsection{Casos envolvendo a União Europeia e os Estados Unidos}

A cooperação havida entre autoridades estrangeiras de defesa da concorrência na análise de atos de concentração multijurisdicionais tem se revelado um instrumento

and the preference for nonbinding regimes. Cooperation, comity and competition policy. New York: Oxford University Press, 2011, p. 324).

${ }^{802}$ Tokeshi e Monteiro descrevem o caso ADCO/KONE (Ato de Concentração CADE $\mathrm{n}^{\circ}$ 08012.007603/2003-66 entre AGO Corporation e Kone Corporation) em que as autoridades europeias, brasileira e turca foram chamadas a analisar. $\mathrm{O}$ autor relata que no caso em questão não houve cooperação, $\mathrm{O}$ que acabou prejudicando as consequências gerais das decisões não concertadas entre as agências (TOKESHI, Helcio; MONTEIRO, Carmen Diva. Worldwide mergers: a brazilian perpective. Competition Law International, out. 2005, p. 28).

803 "If, as antecipated, the Brazilian regime moves to a suspensive jurisdiction model, international cooperation will become a central focus for Brazil, so as to ensure that the advantages of the convergence in statutes and procedures does indeed translate into lower burdens to private parties and better competition law enforcement. Multijurisdicional mergers Will provide a healthy incentive for the competition authorities in Brazil to achieve international Standards for merger reviews periods so that their decisions are not unduly constrained by decisions in other jurisdictions, and so that their concerns can be transmitted to and, when appropriate, taken into account in other countries". (Id., ibid., p. 30). 
relevante para jurisdições com elevado grau de complexidade econômica. Os países com maior tradição de cooperação em matéria concorrencial são os Estados Unidos e a União Europeia $^{804}$. Essas jurisdições puderam, desde 1991, quando foi celebrado o primeiro acordo de cooperação em matéria de concorrência, contar com a colaboração da contraparte estrangeira nos procedimentos de revisão de concentrações econômicas envolvendo as duas jurisdições. Diversos são os casos que denotam a aplicação prática dos acordos bilaterais de cooperação entre os Estados Unidos e a União Europeia, conforme se verá a seguir.

Em 27 de maio de 1996 a Comissão Europeia foi notificada sobre a operação de concentração econômica por fusão das empresas suíças Ciba-Geigy Limited e Sandoz Ltd., da qual resultaria uma nova sociedade - a Novartis AG (caso Ciba-Geigy/Sandoz) ${ }^{805}$; sendo que subsequentemente o FTC fora notificado sobre a mesma concentração. Ambas as autoridades envolvidas acabaram por decidir favoravelmente à concentração pretendida, estabelecendo, contudo, restrições em diferentes medidas. Enquanto que no processo conduzido pela União Europeia a Ciba-Geigy e a Sandoz tiveram que se comprometer a conceder às empresas interessadas, por um período de dois anos contados da conclusão da operação, uma licença exclusiva e ilimitada para a produção de metoprena - a qual se relacionava ao mercado de ectoparasiticidas -, a interpretação das autoridades norteamericanas acarretou em uma decisão com exigências substancialmente mais rigorosas, que incluiu a alienação de dois significativos segmentos das sociedades envolvidas e o licenciamento não exclusivo de diversas patentes ${ }^{806}$.

\footnotetext{
804 "It is generally agreed that the most obvious example of bilateralism in the field of competition law is furnished by the EU/US cooperation. This is also the most important example because these two competition law regimes are the world's most advance and most influential'. (DABBAH, Maher M. Future directions in bilateral cooperation: a policy perspective. Cooperation, comity and competition policy. New York: Oxford University Press, 2011, p. 290). Ademais, "as mergers reviewed by the U.S. agencies increasingly involve non-U.S. parties, U.S. parties with assets located abroad, relevant evidence located abroad, and/or parallel review in other jurisdictions, the United States antitrust agencies often work with their international counterparts to investigate and remedy potentially anticompetitive mergers [...] in 2001, following GE/Honeywell, the European Commission and the U.S. agencies formed a bilateral working group that concentrated its efforts on several aspects of merger analysis including efficiencies and vertical and conglomerate effects". (ORGANIZAÇÃO PARA A COOPERAÇÃO E DESENVOLVIMENTO ECONÔMICO. Global forum on competition - Roundtable on Cross-Border Merger Control: Challenges for Developing and Emerging Economies: Contribution from United States. DAF/COMP/GF/WD(2011)29. Session 1. Fev. 2011, p. 5. Disponível em: <http://www.ftc.gov/bc/international/docs/1102crossbordermerger control.pdf $>$. Acesso em: $01 \mathrm{dez}$. 2012). Ver ainda BRADFORD, Anu. International antitrust cooperation and the preference for nonbinding regimes. Cooperation, comity and competition policy. New York: Oxford University Press, 2011, p. 323.

${ }^{805}$ No âmbito da União Europeia, UNIÃO EUROPEIA. Caso Ciba-Geigy Limited/Sandoz Ltd. (CibaGeisy/Sandoz), Comissão Europeia, Processo nº M.737, decisão 17 jul 1996, JO L 201, 29 jul 1997.

806 JAEGER JUNIOR, Augusto. Direito Internacional da Concorrência - Entre perspectivas unilaterais, multilaterais, bilaterais e regionais. Curitiba: Juruá, 2008, p. 253; e SILVA, Valéria Guimarães de Lima e.
} 
A decisão do FTC baseou-se, principalmente no entendimento de que a concentração pretendida causaria no mercado de terapêutica genética a redução da concorrência ou a criação de um monopólio, pelo fato de a Ciba-Geigy e a Sandoz deixarem de concorrer entre si. Tal situação, de acordo com o FTC, seria uma violação do art. 7 do Clayton Act. Ademais, com relação ao mercado de produtos para o controle de pulgas, o FTC determinou a alienação de todos os negócios deste setor, relativos aos mercados norte-americano e canadense. Além disso, no tocante ao mercado de herbicidas para milho, o FTC determinou que as empresas se desfizessem de parte dos seus negócios e transferissem tecnologia relacionada à produção da metoprena a uma empresa alemã.

Muito embora os setores identificados pelas autoridades norte-americanas e europeias tenham sido coincidentes no que se refere aos graus de concentração, a Comissão Europeia pareceu minimizar os efeitos da concentração no mercado europeu, enquanto que o FTC os maximizou em demasia ${ }^{807}$. Mesmo considerando que o rigor do FTC tenha sido preferível à flexibilidade europeia, a autoridade norte-americana exerceu a sua competência de forma demasiadamente ampla - ao decidir sobre a destinação de ativos das sociedades que não estavam relacionados diretamente ao mercado norte-americano ${ }^{808}$.

Apesar de não se ter notícias se as autoridades norte-americanas e europeias procuraram cooperar durante os procedimentos de controle da concentração no caso CibaGeisy/Sandoz, a análise das decisões e da postura das autoridades envolvidas é relevante, já que se tratou de caso com expressivas repercussões no cenário internacional, o qual foi submetido à análise dos Estados Unidos e da União Europeia após a celebração do Acordo EUA/UE 1991. Mais ainda, denotou uma diferença do posicionamento norte-americano, usualmente a favor de grandes operações de concentração internacionais ${ }^{809}$.

Direito antitruste: aspectos internacionais. Curitiba: Juruá, 2007, p. 445, cuja autora esclarece que a decisão das autoridades norte-americadas constituiu "uma das maiores alienações já requeridas pelo órgão".

807 “Até mesmo no setor de terapêutica genética, onde não se sabia nem ao menos se as patentes das empresas seriam concedidas e se os inventos produziriam resultados concretos". (Id., ibid., p. 447).

${ }^{808} \mathrm{Na}$ perspectiva de Silva, o FTC poderia ter restringido as importações de produtos entre os estabelecimentos das empresas situados no Canadá para o mercado norte-americano, ao invés de determinar a alienação de ativos situados naquele território. Além disso, a autora entende que o FTC ultrapassou a sua jurisdição ao estabelecer restrições sobre patentes registradas em outros territórios, que não o norteamericano. (Id., ibid., pp. 447-448).

809 "Nas últimas décadas, os tribunais americanos raramente proibiram grandes operações internacionais [...]. Há inegável 'predisposição favorável' tanto da FTC quanto do DOJ à aprovação das concentrações que possam beneficiar os consumidores. Na União Europeia, a questão assume contornos diversos". (FORGIONI, Paula A. Os fundamentos do antitruste. 4. ed. São Paulo: Revista dos Tribunais, 2010, p. 457). 
Outro caso de concentração econômica com efeitos multijurisdicionais destacado pela doutrina é o do Boeing/McDonnell Douglas ${ }^{810}$, em que a Boeing pretendia adquirir a McDonnell Douglas, consoante um acordo firmado entre as empresas em 14 de dezembro de 1996. O caso foi submetido à Comissão Europeia em 18 de fevereiro de 1997, a qual, tendo conhecimento que a operação também fora submetida às autoridades norteamericanas, encaminhou a elas uma notificação datada de 26 de junho de 1997, com base no art. $5^{\circ}$ do Acordo EUA/UE 1991, expressando suas preocupações a respeito da concentração pretendida. É possível depreender, portanto, que durante o processo de análise do caso pelas autoridades norte-americanas e europeias se verificou cooperação entre as autoridades de defesa da concorrência de ambos os países ${ }^{811}$.

No entanto, o processo cooperativo no caso Boeing/McDonnell Douglas não foi desprovido de controvérsias. De fato, não obstante a autoridade europeia ter notificado as autoridades norte-americanas sobre seus receios quanto à concentração pretendida, as autoridades norte-americanas proferiram logo após o recebimento da notificação, em 01 de julho de 1997, decisão aprovando a concentração sem restrições. Subsequentemente, apenas três dias depois, membros consultivos da União Europeia recomendaram que a concentração fosse proibida, ignorando desta forma a decisão proferida pelas autoridades norte-americanas $^{812}$. Somente após intensas negociações, que envolveram inclusive o presidente norte-americano Bill Clinton, e de ameaças de retaliação comercial por parte dos Estados Unidos ${ }^{813}$, a Comissão Europeia acabou por aprovar a concentração, em 30 de julho de 1997, mediante o cumprimento de certas condições pela Boeing.

\footnotetext{
810 No âmbito da União Europeia, UNIÃO EUROPEIA. Caso Boeing Company/McDonnell Douglas (Boeing/McDonnell Douglas), Comissão Europeia, Decisão no 97/816, de 30 jul 1997, JO L 336, 8 dez 1997.

811 SANTOS, Maria Cecília de Andrade. Sobre a cooperação em matéria de concorrência entre a União Europeia e o Mercosul. Revista do IBRAC - Direito da Concorrência, Consumo e Comércio Internacional. São Paulo, jan. 2001, v. 8, p. 177.

${ }^{812}$ Silva destaca que em 10 de julho de 2002 "o então Comissionário da Concorrência Europeu, Karel Van Miert, reiterou que a fusão não seria aprovada por obstruir o comércio no setor, a não ser que a Boeing fizesse condições satisfatórias". Nesse sentido, a autora esclareceu ainda que à época a Comissão não tinha condições de impedir que a fusão ocorresse, em virtude do ordenamento então vigente, mas poderia impor multas de até $10 \%$ do valor total da receita anual da nova empresa (o que acabaria por inviabilizar o negócio em razão dos elevados montantes envolvidos), dentre outras sanções e condições. (SILVA, Valéria Guimarães de Lima e. Direito antitruste: aspectos internacionais. Curitiba: Juruá, 2007, pp. 448-449).

${ }^{813}$ A doutrina destaca a inconsistência da posição norte-americana a respeito das decisões nos casos CibaGeigy/Sandoz e Boeing/McDonnell Douglas. Jaeger Júnior destaca que no caso Boeing/McDonnell Douglas os Estados Unidos "teriam sido novamente incoerentes, uma vez que alegaram que a atuação da Comissão Europeia no caso seria uma interferência inadmissível nos seus assuntos internos, pelo fato de a fusão envolver duas empresas nacionais, como se essa não fosse uma contumaz prática norte-americana, e por terem criado uma situação de quase-monopólio mundial que dificilmente seria aceita pelo seu próprio ordenamento, sem qualquer restrição, diferentemente de como agiu no caso da fusão entre as empresas CibaGeigy e Sandoz. Notadamente não seria aceita pelo Clayton Act, que proíbe qualquer fusão que tenha por efeito a redução substancial da concorrência ou tenda a criar monopólio". (JAEGER JUNIOR, Augusto.
} 
Mesmo havendo divergências entre as autoridades de defesa da concorrência envolvidas, foi possível chegar a resultado convergente nas suas decisões ${ }^{814}$. Em razão de tal resultado foi possível depreender, a princípio, que a utilização de acordos bilaterais em matéria concorrencial se revelou satisfatória no caso Boeing/McDonnell Douglas. No entanto, a doutrina especializada ${ }^{815}$ destaca que os resultados convergentes não foram alcançados em razão da simples cooperação entre as autoridades de defesa envolvidas, mas em função de pressões diplomáticas e comerciais exercidas pelas potências econômicas envolvidas $^{816}$.

De fato, a Boeing é uma empresa norte-americana do setor aeronáutico que compete no mercado de jatos comerciais, dentre outros, com a Airbus, sendo este um consórcio formado por quatro membros com significativa participação governamental dentre os quais se destaca o governo da França e da Espanha. Os interesses econômicos governamentais que cercavam a concentração da Boeing eram, portanto, de fácil percepção. Apesar de as formalidades de cooperação estabelecidas pelo Acordo EUA/UE 1991 terem sido cumpridas pelas autoridades competentes, certo é que não foi possível identificar uma efetiva coordenação entre as autoridades, tendo o princípio da cortesia positiva sido negligenciado por completo - principalmente diante do fato de as autoridades terem tomado decisões rapidamente após recebimento de notícias por parte da outra sobre seus interesses internos relevantes, circundando a concentração pretendida ${ }^{817}$.

O caso Boeing/McDonnell Douglas também revelou as divergências existentes entre os sistemas concorrenciais norte-americano e europeu. Enquanto que as autoridades norte-americanas embasaram sua decisão na capacidade competitiva autônoma da McDonnell Douglas, entendendo que não representava ameaça à atividade da Airbus, a autoridade europeia considerou a possibilidade de a Boeing aumentar a sua posição dominante em decorrência da concentração (se considerado o potencial competitivo complementar da McDonnell Douglas) e, assim, impor obstáculos à concorrência no mercado europeu - consubstanciando desta forma uma análise estruturalista do mercado.

Direito Internacional da Concorrência - Entre perspectivas unilaterais, multilaterais, bilaterais e regionais. Curitiba: Juruá, 2008, p. 254).

${ }^{814}$ Ambas as concentrações também foram submetidas à apreciação das autoridades brasileiras da defesa da concorrência, mas infelizmente não foi possível identificar nesses casos cooperação internacional entre autoridades brasileiras com as estrangeiras.

${ }^{815}$ JAEGER JUNIOR, Augusto. Op. cit., 2008, pp. 254-255; e SILVA, Valéria Guimarães de Lima e. Direito antitruste: aspectos internacionais. Curitiba: Juruá, 2007, pp. 450-451.

${ }^{816}$ NUSDEO, Ana Maria de Oliveira. Defesa da concorrência e globalização econômica. São Paulo: Malheiros, 2002, p. 172.

${ }^{817}$ SILVA, Valéria Guimarães de Lima e. Op. cit., 2007, pp. 454-455. 
Outro caso envolvendo a cooperação bilateral das autoridades norte-americanas e europeias trata da concentração da WorldCom Inc. e a MCI Communications Corporation (caso WorldCom/MCI) ${ }^{818}$. Tal concentração econômica, apesar de ter sido realizada nos Estados Unidos, foi também notificada à União Europeia, à qual coube a análise dos efeitos da concentração econômica no mercado comum europeu ${ }^{819}$. As autoridades norteamericanas e europeias trabalharam em estreita cooperação na análise da concentração econômica, refletindo uma verdadeira rotina diária de trabalho até a efetiva tomada de decisão ${ }^{820}$.

A doutrina ${ }^{821}$ destaca, no entanto, que não obstante a cooperação havida entre as autoridades no caso WorldCom/MCI ter incluído a troca de informações e a realização de reuniões periódicas, as autoridades não chegaram a um consenso a respeito da definição do mercado relevante envolvido na concentração. Isso não impediu, no entanto, que as autoridades envolvidas não chegassem a decisões convergentes em relação à operação pretendida. Denota-se, no entanto, que as autoridades não foram capazes de coordenar as suas atividades de modo que pudessem trabalhar sob os mesmos parâmetros de análise.

Constata-se, porém, que nem todos os casos em que houve cooperação entre Estados Unidos e União Europeia em matéria concorrencial apresentaram resultados convergentes. Nesse sentido, pode-se citar um caso emblemático e recente que ocorreu na cooperação bilateral em matéria de concentração. Trata-se da aquisição por parte da General Electric Company da Honeywell International Inc., ambas empresas fabricantes de componentes aeroespaciais, notificada à autoridade europeia em 5 de fevereiro de 2001 $(\mathrm{GE} / \text { Honeywell })^{822}$. Durante a análise do caso por diversas autoridades de defesa da

${ }^{818}$ No âmbito da União Europeia, UNIÃO EUROPEIA. Caso WorldCom Inc./MCI Communications Corporation (WorldCom/MCI), Comissão Europeia, Decisão nº 287/99, 8 jul 1998, JO L 116, 4 maio 1999.

819 A efetiva cooperação entre as autoridades dos Estados Unidos e União Europeia também pode ser verificada no caso da aquisição da Sprint Corporation pela MCI Worldcom (UNIÃO EUROPEIA. Caso Sprint Corporation/MCI Worldcom (Sprint/MCI), Comissão Europeia, Processo no M.1741, decisão 28 jun 2000, JO L 300, 18 nov 2003).

${ }^{820}$ FOX, Eleanor M. Antitrust without borders: from roots to codes to networks. Cooperation, comity and competition policy. New York: Oxford University Press, 2011, p. 266; e JAEGER JÚNIOR, Augusto. Direito Internacional da Concorrência - Entre perspectivas unilaterais, multilaterais, bilaterais e regionais. Curitiba: Juruá, 2008, p. 249.

821 "A cooperação de ambas as autoridades na análise da operação foi simplificada, pelo assentimento que as referidas empresas, bem como outras terceiras interessadas, deram ao intercâmbio de informações. Embora o exame tenha sido paralelo e as autoridades tenham realizado reuniões e audiências conjuntas, não se chegou à almejada coincidência quanto à definição de mercado relevante. Depois da aprovação da operação por ambas as partes, a cooperação entre elas se manteve na fase de acompanhamento dos compromissos". (OLIVEIRA, Gesner; RODAS, João Grandino. Direito e economia da concorrência. Rio de Janeiro: Renovar, 2004, p. 387).

${ }^{822}$ UNIÃO EUROPEIA. Caso General Electric Company/Honeywell International Inc. (GE/Honeywell), Comissão Europeia, Processo no M.2220, decisão 03 jul 2001, JO L 48, 18 fev 2004. A concentração também fora submetida no Brasil ao controle do SBDC (Ato de Concentração CADE nº 08012.006014/00-18), ver 
concorrência envolvidas, as autoridades norte-americanas e europeias declararam ter trabalhado em cooperação estreita ${ }^{823}$, inclusive na inquirição conjunta de testemunhas e realização de reuniões entre as autoridades envolvidas nas investigações ${ }^{824}$.

A operação GE/Honeywell chegou a ser aprovada em maio de 2001 pelas autoridades de defesa da concorrência norte-americanas e canadenses, mediante o compromisso da Honeywell de vender a sua empresa de fabricação de motores para helicópteros e o licenciamento para terceiro concorrente dos serviços de manutenção e reparo de certos motores por ela fabricados.

Todavia, em 3 de julho de 2001, a Comissão Europeia vetou a fusão pretendida pelas empresas, com o fundamento de que a GE, por si só, mantinha posição dominante no mercado de motores para aviões a jato e para grandes aviões comerciais e regionais ${ }^{825}$. Além disso, a Honeywell era, à época da decisão, o fornecedor líder dos produtos para aviação, inclusive para motores para jatos e sistemas de arranque. Desta forma, no entender da Comissão, da combinação das atividades das duas sociedades envolvidas resultaria a criação de posição dominante nos mercados de fornecimento de produtos e de motores para jatos de empresas, além do reforço da já existente posição dominante da GE. ${ }^{826}$

TOKESHI, Helcio; MONTEIRO, Carmen Diva. Worldwide mergers: a brazilian perpective. Competition Law International, out. 2005, pp. 28-29.

${ }^{823}$ Nesse sentido está a declaração de Mario Monti, o então Comissário europeu responsável pelo tema da concorrência: "A Comissão Europeia e o Departamento da Justiça americano trabalharam em estreita cooperação durante a investigação. É de lamentar que, no final, tivéssemos chegado a conclusões diferentes, mas cada autoridade tem que proceder à sua própria avaliação e o risco de posições diferentes, apesar de ser de lamentar, nunca pode ser completamente excluído. Isto não significa que uma autoridade esteja a efectuar uma análise técnica e que a outra prossiga um objectivo político, tal como alguns pretendem, mas simplesmente que podemos interpretar os factos de forma diferente e prever os efeitos de uma operação também de formas diferentes. A GE/Honeywell constitui um dos raros casos de desacordo entre as autoridades de concorrência transatlânticas. Estou determinado a reforçar a nossa cooperação bilateral no futuro para tentar reduzir ainda mais este risco". (UNIÃO EUROPEIA. A Comissão proíbe a aquisição da Honeywell pela GE. Comunicado de Imprensa $n^{\circ}$ IP/01/939, de 03/07/2001, p. 1. Disponível em: $<\mathrm{http}: / /$ wwweuropa.eu/rapid/pressReleasesAction.do?reference=IP/01/939\&format=HTML\&aged=1\&langua ge=PT\&guiLanguage =en>. Acesso em: 28 ago. 2012).

${ }^{824}$ MAJORAS, Deborah Platt. GE-Honeywell: the U.S. decision. Palestra proferida perante a Antitrust Lae Section - State Bar of Georgia, em 29 de novembro de 2001, pp. 2-4. Disponível em: http://www.justice.gov/atr/public/speeches/9893.htm. Acesso em: 28 ago. 2012; e MARTINEZ, Maria Beatriz. A cooperação internacional na defesa da concorrência: acordos bilaterais e aplicação do princípio da cortesia positiva. Revista do IBRAC - Direito da Concorrência, Consumo e Comércio Internacional. São Paulo, jan. 2004, v. 11, pp. 177 ss, na qual a autora esclarece que representantes do DOJ compareceram aos oral hearings realizados na União Europeia no bojo da operação GE/Honeywell com base do Administrative Arrangements on Attendance (AAA).

825 "A doutrina tem essa reprovação como uma demonstração de emancipação da Comunidade Europeia". (JAEGER JÚNIOR, Augusto. Direito Internacional da Concorrência - Entre perspectivas unilaterais, multilaterais, bilaterais e regionais. Curitiba: Juruá, 2008, p. 255).

${ }^{826}$ Fox e Crane informam que a GE apelou da decisão da Comissão Europeia ao então Tribunal de Primeira Instância (atual Tribunal Geral do Tribunal de Justiça da União Europeia). O Tribunal, no entanto, acabou por manter a decisão da Comissão Europeia. (FOX, Eleanor M.; CRANE, Daniel A. Global issues in antitrust and Competition Law. St. Paul: West, 2010, p. 349). 
Para chegar a esta decisão, a Comissão Europeia utilizou um teste tripartite com o objetivo de avaliar o impacto da operação pretendida sobre os mercados relevantes que haviam sido delimitados ${ }^{827}$, chegando à conclusão de que a aquisição criaria ou fortaleceria a posição dominante dos agentes, podendo obstar uma competição efetiva no mercado comum $^{828}$. As autoridades norte-americanas, por sua vez, pronunciaram-se no sentido de que a decisão europeia baseou-se em conceitos divergentes entre as legislações norteamericana e europeia, que em alguns casos já eram considerados como ultrapassados pela prática dos Estados Unidos ${ }^{829}$.

Não obstante a cooperação bilateral havida entre as autoridades competentes, as decisões emanadas fundamentaram-se essencialmente nas políticas da concorrência adotadas pelos entes correspondentes, consubstanciadas nas respectivas legislações em vigor e nos interesses econômicos subjacentes aos respectivos governos ${ }^{830}$. De fato, os Estados Unidos e a União Europeia adotam enfoques diferenciados sobre os fundamentos da defesa concorrencial. Enquanto que os Estados Unidos sustentam o livre mercado, o seu

\footnotetext{
${ }^{827}$ De acordo com Faria, o teste consistia em avaliar “ $1^{\circ}$ ) se a fusão criaria economias de escala difíceis de igualar por outras empresas; $2^{\circ}$ ) se a empresa fusionada ganharia uma vantagem decisiva sobre os seus concorrentes em função do seu tamanho e recursos financeiros; e $3^{\circ}$ ) se a fusão facilitaria a combinação ou agrupamento de produtos complementares, permitindo à nova empresa expelir os concorrentes do mercado". (FARIA, José Ângelo Estrella. O controle de concentrações de empresas estrangeiras e a Lei no 8.884: a extraterritorialidade revisitada. Juris Síntese, maio/jun. 2009, n. 77, p. 17. Disponível em: <http://online. sintese.com>. Acesso em: 19 ago. 2012).

828 "Tal integração permitiria à entidade resultante da concentração reforçar o poder de mercado das duas empresas a nível dos produtos uma da outra. Teria por efeito excluir concorrentes, eliminando a concorrência nestes mercados e, em última análise, afectando negativamente a qualidade do produto, o serviço e os preços aos consumidores". (UNIÃO EUROPEIA. A Comissão proíbe a aquisição da Honeywell pela GE. Comunicado de Imprensa $\mathrm{n}^{\circ}$ IP/01/939, de 03/07/2001, p. 2. Disponível em: <http://europa.eu/rapid/press ReleasesAction.do?reference=IP/01/939\&format=HTML\&aged=1\&language=PT\&guiLanguage=en $>$. Acesso em: 28 ago. 2012).

${ }^{829}$ Especificamente referindo-se ao entrechment doctrine do caso FTC v. Procter \& Gamble, abandonada em 1982 com o advento da nova edição das Diretrizes de Fusão (cf. RIVERS, Ricky D. General Electric/Honeywell Merger: European Commission Antitrust Decision Strikes a Sour Note. ILSA Journal of International and Comparative Law, 2002/2003, v. 9, p. 528; MAJORAS, Deborah Platt. GE-Honeywell: the U.S. decision. Palestra proferida perante a Antitrust Law Section - State Bar of Georgia, em 29 de novembro de 2001, pp. 4-6 e 13-14. Disponível em: 〈http://www.justice.gov/atr/public/speeches/9893.htm〉. Acesso em 28 ago. 2012; FARIA, José Ângelo Estrella. O controle de concentrações de empresas estrangeiras e a Lei $\mathrm{n}^{\circ}$ 8.884: a extraterritorialidade revisitada. Juris Síntese, maio/jun. 2009, n. 77, p. 17. Disponível em: 〈http://online.sintese.com>. Acesso em: 19 ago. 2012. Esclarece ainda Faria que "outros autores veem a origem do problema no critério excessivamente amplo da 'dimensão comunitária' empregado no Regulamento $\mathrm{n}^{\circ}$ 4.064/89 para definir o âmbito de aplicação do sistema europeu de controle de concentrações. Com efeito, o regime do regulamento europeu foi originalmente concebido para delimitar as competências recíprocas da Comissão Europeia e dos Estados-membros, resolvendo assim também o problema de 'multiple filings' dentro da União Europeia. Contudo, o simples critério do faturamento anual, ainda que preferível a outros critérios alternativos para fins básicos do regulamento, não oferece uma delimitação clara para os casos de transações de efeito global". Ademais, Majoras ainda destaca a diferença conceitual entre posição dominante e poder de mercado entre a análise norte-americana e a europeia.

830 "A presença de relevantes interesses nacionais voltou a se sobrepor aos princípios de cooperação preconizados nos acordos bilaterais de cooperação". (JAEGER JÚNIOR, Augusto. Direito Internacional da
} 
poder autocorretivo e o mecanismo natural da agressividade concorrencial para a seleção das empresas mais eficientes, a União Europeia entende que o equilíbrio das estruturas de mercado deve ser defendido mediante intervenção estatal (quando necessário), uma vez que a concorrência sem limites dos agentes de mercado pode levar à destruição do mercado.

Além disso, durante a análise conduzida pelas autoridades norte-americanas entendeu-se que a concentração GE/Honeywell tratava de fusão envolvendo somente grandes conglomerados que não ofereciam concorrência entre si. Já a União Europeia entendeu que a concentração também causaria a concentração vertical e horizontal em vários setores do mercado relevante ${ }^{831}$.

No bojo das discussões que seguiram as decisões no caso GE/Honeywell, as autoridades dos Estados Unidos justificaram o posicionamento exarado pelas suas autoridades na defesa dos interesses dos consumidores, criticando a decisão europeia que teria se preocupado mais com a proteção de empresas concorrentes do que com os interesses dos consumidores ${ }^{832}$.

Note-se que apesar de as autoridades envolvidas terem declarado que trabalharam em estreita cooperação durante a análise da concentração, a doutrina aponta que na realidade a cooperação havida limitou-se à consulta recíproca na busca de informações e esclarecimentos $^{833}$. Tendo em vista que nenhuma das partes abdicou da discricionariedade na análise da concentração, ambas acabaram por alcançar resultados divergentes.

Apesar de ter sido somente o segundo caso na história da atuação da Comissão Europeia para questões de concentração empresarial em que uma operação realizada por sociedades norte-americanas fora proibida, o resultado antagônico na análise das autoridades envolvidas na cooperação no caso GE/Honeywell causou polêmica na comunidade internacional $^{834}$, uma vez que revelou as ineficiências do sistema de

Concorrência - Entre perspectivas unilaterais, multilaterais, bilaterais e regionais. Curitiba: Juruá, 2008, p. 255).

${ }^{831}$ SILVA, Valéria Guimarães de Lima e. Direito antitruste: aspectos internacionais. Curitiba: Juruá, 2007, p. 462.

832 "Os europeus foram acusados de se valer, para fins protecionistas, de métodos ultrapassados de análise, cuja aplicação havia há muito sido abandonada pelos estadunidenses”. (FORGIONI, Paula A. Os fundamentos do antitruste. 4. ed. São Paulo: Revista dos Tribunais, 2010, p. 458). Ver também OLIVEIRA, Gesner; RODAS, João Grandino. Direito e economia da concorrência. Rio de Janeiro: Renovar, 2004, pp. 386-387.

${ }^{833}$ SILVA, Valéria Guimarães de Lima e. Op. cit, 2007, p. 460.

${ }^{834}$ MAJORAS, Deborah Platt. GE-Honeywell: the U.S. decision. Palestra proferida perante a Antitrust Law Section - State Bar of Georgia, em 29 de novembro de 2001. Disponível em: <http://www.justice.gov/atr/public/speeches/9893.htm>. Acesso em: 28 ago. 2012, p. 1. 
cooperação bilateral $^{835}$. Desta forma, é possível concluir em relação ao caso GE/Honeywell que não obstante as tentativas de cooperação, as autoridades norte-americanas e europeias acabaram por adotar posições antagônicas durante as respectivas análises, o que, por sua vez, revelou profundas divergências econômicas, políticas e legais.

Note-se, entretanto, que não obstante alguns problemas terem sido identificados na cooperação entre as autoridades norte-americanas e europeias, ambas as autoridades persistem nos seus esforços cooperativos. A doutrina relata diversos casos em que a cooperação entre as referidas autoridades foi efetiva e produziu resultados satisfatórios ${ }^{836}$. Apesar das limitações à cooperação havida entre as autoridades nos casos Being/McDonnell Douglas e GE/Honeywell, portanto, e da problemática então revelada, não é possível descartar a cooperação bilateral como instrumento idôneo disponível às autoridades concorrenciais para o alcance de maior eficiência na análise das concentrações multijurisdicionais.

\subsubsection{Comparação na aplicação de acordos bilaterais por terceiros países e pelas autoridades brasileiras}

Conforme se pode depreender da análise dos itens anteriormente apresentados, as autoridades brasileiras não estão no mesmo nível de desenvolvimento das autoridades norte-americanas e europeias quanto à aplicação prática da cooperação e coordenação com outras autoridades em casos de concentrações multijurisdicionais. Enquanto os Estados Unidos e a União Europeia foram por diversas vezes chamados a cooperar uns com os outros, revelando ainda alguns casos de maior expressão para a matéria, as autoridades brasileiras não tiveram a oportunidade de conduzir efetivos procedimentos cooperativos com outras autoridades de defesa da concorrência ${ }^{837}$.

835 "Whenever there is a real conflict, the authorities will likely seek to claim an overriding interest in enforcement and disregard comity". (GERADIN, Damien; REYSEN, Marc; HENRY, David. Extraterritoriality, comity and cooperation in EU Competition Law. Cooperation, comity and competition policy. New York: Oxford University Press, 2011, pp. 33-34).

${ }^{836}$ Galloway descreve casos em que houve efetiva cooperação entre as autoridades norte-americanas e europeias na análise de concentrações multijurisdicionais como, por exemplo, Bayer/Aventis CropScience (2004), Sanofi-Synthélabo/Aventis (2004), Alcan/Pechiney II (2003), Boston Scientific/Guidant (2006), Dow Chemical/Union Carbide (2001) e Alcoa/Reynolds (2000). (GALLOWAY, Jonathan. Convergence in International Merger Control. The competition Law review. Issue 2, jul. 2009, v. V, pp. 187-191); e DABBAH, Maher M. Future directions in bilateral cooperation: a policy perspective. Cooperation, comity and competition policy. New York: Oxford University Press, 2011, pp. 291-192, que destaca os casos Air Liquide/BOC (2000), MCI WorldCom/Sprint (2000), Exxon/Mobil (1999), Allied Signal/Honeywell (1999), AstraZeneca/Novartis (2000) e Oracle/PeopleSoft (2004).

${ }^{837}$ Diferentemente do que já ocorreu no passado em relação às práticas anticoncorrenciais, como no caso de cartéis internacionais. De fato, em casos dessa natureza, as autoridades brasileiras já tiveram oportunidade de 
A principal justificativa para este fato parece estar no regime de análise a posteriori até há pouco tempo vigente no Brasil, o qual foi substituído somente recentemente por um regime de análise a priori, ou seja, de análise prévia à conclusão da operação pelas partes notificantes. Essa diferença no tempo da condução da análise sobre a concentração acarretava em situações que o SBDC somente fosse chamado a pronunciar sobre um caso após as autoridades estrangeiras já tê-lo analisado e decidido a respeito. Não restava, portanto, muito espaço para que o SBDC efetivamente cooperasse e coordenasse a sua atuação com as autoridades estrangeiras. Com a adoção do novo regime prévio, que está pari passu com a tendência internacional na análise de concentrações econômicas, tornamse patentes as oportunidades de desenvolvimento de uma política cooperativa pelas autoridades brasileiras em cooperações multijurisdicionais ${ }^{838}$. Caso aproveitem essa oportunidade, as autoridades brasileiras abrirão portas à cooperação e poderão desenvolver procedimentos em prol da coordenação na condução das suas atividades de análise de concentrações multijurisdicionais com as suas congêneres estrangeiras.

Por outro lado, uma vez conhecida a experiência havida entre Estados Unidos e União Europeia em matéria de análise cooperativa e coordenada de concentrações multijurisdicionais, é possível prever que o SBDC poderá enfrentar dificuldades no que se refere aos casos que envolvem importantes interesses econômicos e industriais das jurisdições envolvidas. De fato, os casos conduzidos pelas autoridades norte-americanas e europeias anteriormente descritos revelam que quando relevantes interesses da indústria e economia nacional ou regional estão envolvidos, a interferência política no processo decisório concorrencial torna-se um fator relevante que não pode ser descartado.

Assim, após analisados os casos mais emblemáticos conhecidos sobre as concentrações multijurisdicionais, que envolveram em regime cooperativo principalmente as autoridades norte-americanas e europeias, é possível concluir que a cooperação tal qual concebida atualmente somente terá efetivo sucesso quando não estiverem envolvidos interesses nacionais ou regionais relevantes. Nestes casos, a cooperação certamente será desconsiderada pelas autoridades envolvidas, as quais não deixarão de lado as respectivas

conduzir relevantes processos cooperativos com outras autoridades, como nos conhecidos casos das Vitaminas e dos Compressores.

838 "Pre-merger control with tight controls on the number of days required for each review step should eliminate the risk of a delayed decision by CADE'. (TOKESHI, Helcio; MONTEIRO, Carmen Diva. Worldwide mergers: a brazilian perspective. Competition Law International, out. 2005, p. 28). Ao comentar sobre a Lei da Concorrência, que à época estava ainda trâmite no Congresso Nacional, o autor esclarece que as suas alterações viriam a aumentar a cooperação com outras autoridades e reduzir os encargos aos casos de concentrações multijurisdicionais. 
discricionariedades na formulação da decisão que entendem como mais adequada ao caso concreto, consoante as respectivas leis e políticas de concorrência ${ }^{839}$.

Como consequência desta constatação, coloca-se um novo problema a ser resolvido pela comunidade internacional: como superar as diferenças entre políticas nacionais e regionais econômicas e industriais na intervenção econômica do Estado em matéria concorrencial, mais especificamente sobre as concentrações multijurisdicionais? Parece que tal problemática é conhecida já há algum tempo pela comunidade internacional, a qual, por sua vez, continua a debater-se na busca por soluções. Enquanto isso, as autoridades de defesa da concorrência devem, sempre que possível, procurar se manter imparciais quando da análise de casos de concentrações econômicas com efeitos em variadas jurisdições e procurar, por todos os meios possíveis, aprimorar os instrumentos que dispõem para a promoção da cooperação e a coordenação das suas atividades com as suas congêneres estrangeiras.

\subsection{COOPERAÇÃO BILATERAL EM MATÉRIA DA CONCORRÊNCIA: PROBLEMAS CONSTATADOS E PERSPECTIVAS}

Conforme discutido ao longo deste terceiro capítulo, o incremento das relações bilaterais de cooperação entre os países depende do grau de desenvolvimento da confiança entre os trabalhos desenvolvidos pelas autoridades de defesa da concorrência. Quanto maior a proximidade e a sinergia entre as autoridades envolvidas na cooperação, melhores serão os resultados alcançados pela cooperação. Por tal motivo, é recorrente que os Estados Unidos e a União Europeia, cujas autoridades de defesa da concorrência possuem longa tradição em procedimentos cooperativos, sejam o exemplo mais proeminente em relação à cooperação em matéria concorrencial $^{840}$.

De forma geral, o objetivo definido pela OCDE de buscar a cooperação e a coordenação nas análises de concentrações multijurisdicionais pelas autoridades da concorrência, parece ter sido abarcado pelos acordos bilaterais celebrados pelos variados Estados de forma bastante tímida, estando disponível amplo espaço para o aprimoramento das disposições nesse sentido - incluindo mecanismos a serem utilizados para tal

\footnotetext{
${ }^{839}$ SILVA, Valéria Guimarães de Lima e. Direito antitruste: aspectos internacionais. Curitiba: Juruá, 2007, p. 465 .

${ }^{840}$ DABBAH, Maher M. Future directions in bilateral cooperation: a policy perspective. Cooperation, comity and competition policy. New York: Oxford University Press, 2011, p. 290.
} 
finalidade $^{841}$. Na maior parte das vezes a cooperação jurídica internacional em matéria concorrencial tem sido empreendida no bojo de instrumentos sem força vinculativa, conhecidos como soft law, sem o acolhimento de regras consistentes para a efetiva cooperação e a coordenação concorrencial no plano internacional $^{842}$.

O grau de cooperação almejado em matéria concorrencial somente poderá ser atingido quando for verificado que as autoridades de defesa da concorrência envolvidas no processo de coordenação possuam irrestrita confiança mútua em relação umas às outras ${ }^{843}$, cuja confiança somente poderá ser construída com a aproximação das autoridades e de seus colaboradores $^{844}$.

De fato, durante a década de 1990, quando o princípio da cortesia passou a ser adotado em diversos acordos bilaterais, acreditava-se que posições divergentes em atos de concentrações multijurisdicionais poderiam ser evitadas ou mitigadas por meio da cooperação bilateral entre as autoridades de defesa da concorrência envolvidas na operação ${ }^{845}$. Entendia-se que em vista da adoção do princípio da cortesia positiva, as partes

\footnotetext{
${ }^{841}$ A experiência entre Estados Unidos e União Europeia demonstra que é possível atingir grau mais elevado de cooperação mediante procedimentos que viabilizem discussões entre as autoridades de defesa da concorrência relativas à definição do mercado relevante, das reparações vislumbradas pelas autoridades (remédios), bem como interpretação de direito estrangeiro. Todavia, cf. lembra Draetta, "these bi-lateral cooperation agreements are certainly beneficial to address specific cross-border antitrust issues, where if applied with good will and good faith, but they are not design to change the legislative framework in which each agency operates. They do not touch on fundamental issues such as jurisdiction and the criteria according to which it should be determined when mergers have a global or multi-regional dimension and involve the agencies of both parties. They have done little or nothing to avoid multiple notifications and multiple decisions on the same global transaction, and it was not even their purpose to do so". (DRAETTA, Ugo. Need for better trans-atlantic co-operation in the field of merger control. International Business Law Journal, 2002, p. 562).

842 "Three reasons occur to me why, in the contemporary world, international implementation of competition policy is limited and weak: The present international system lacks the institutional capacity to implement real cooperation; cooperation requires difficult political choices, not merely technical competence; and there is no concensus about the object of cooperation across a broad range of economic sectors". (STEPHAN, Paul B. The problem with cooperation. Cooperation, comity and competition policy. New York: Oxford University Press, 2011, p. 218).

843 "In order for cooperation between reviewing authorities, it appears necessary for the authorities to have confidence in each other's practices, to have built up a strong working relationship, and for cooperation in a particular case to be "mutually beneficial"' (GALLOWAY, Jonathan. Convergence in international merger control. The competition law review. Issue 2 , jul. 2009, v. V, p. 188).

844 "One way to build such confidence is to encourage the personal contacts between the officers of the different authorities. International for a, such as the meeting organized by ICN and the OECD, are often the only opportunities for the officers of the authorities of developing countries to meet their foreign colleagues. Participation in these meetings should be encouraged as much as possible, even if only from an observer point of view. [...] These contacts will be useful for solving multi-jurisdictional cases in the future". (BOTTA, Marco. The cooperation between the competition authorities of the developing countries: why does it not work? Case study on Argentina and Brazil. The competition Law Review. Issue 2, jul. 2009, v. V, p. 177).

${ }^{845}$ RIVERS, Ricky D. General Electric/Honeywell Merger: European Commission Antitrust Decision Strikes a Sour Note. ILSA Journal of International and Comparative Law, 2002/2003, v. 9, p. 530; MARSDEN, Philip. The curious incident of positive comity - the dog that didn't bark (and the trade dogs that just might bite). Cooperation, comity and competition policy. New York: Oxford University Press, 2011, pp. 303-
} 
envolvidas na cooperação buscariam a resolução mútua de eventuais divergências verificadas.

Deve-se lembrar, no entanto, que os acordos bilaterais de cooperação celebrados entre Estados Unidos e União Europeia não obrigam as partes a tomar decisões sobre a aplicação dos respectivos Direitos da Concorrência baseados na cortesia positiva ou a efetivamente cumprir com os pedidos de cooperação, bem como não estabelecem nenhuma penalidade pelo não cumprimento dos dispositivos sobre cortesia positiva e nem instituem nenhum mecanismo de solução dos conflitos identificados na aplicação das legislações envolvidas $^{846}$. A não obrigatoriedade de tais dispositivos de cortesia positiva abre espaço para que as partes dos acordos de cooperação optem por última instância a decidir sobre os casos de concentração multijurisdicionais, levando em consideração os seus interesses nacionais ou regionais, refletidos nas políticas públicas e legislações de defesa da concorrência $^{847}$.

Mesmo antes do caso GE/Honeywell, primeiro momento em que as autoridades envolvidas na cooperação chegaram a decisões completamente antagônicas, as autoridades norte-americanas e europeias já se demonstravam reticentes a respeito da efetividade do princípio da cortesia positiva na resolução do conflito de jurisdições na análise de atos de concentração multijurisdicionais ${ }^{848}$. Em discurso proferido perante o Comitê Judiciário do

307); e LILLA, Paulo Eduardo. A OMC e a interação entre comércio e política antitruste no âmbito da cooperação internacional: perspectivas para a nova rodada de negociações multilaterais. Revista do IBRAC - Direito da Concorrência, Consumo e Comércio Internacional. São Paulo, jan. 2003, v. 10, pp. 233 ss.

846 "By its very nature, cooperation is discretionary". (MARSDEN, Philip. The curious incident of positive comity - the dog that didn't bark (and the trade dogs that just might bite). Cooperation, comity and competition policy. New York: Oxford University Press, 2011, p. 309). Ver ainda JAEGER JÚNIOR, Augusto. Direito Internacional da Concorrência - Entre perspectivas unilaterais, multilaterais, bilaterais e regionais. Curitiba: Juruá, 2008, p. 252; OLIVEIRA, Gesner; RODAS, João Grandino. Direito e economia da concorrência. Rio de Janeiro: Renovar, 2004, p. 386; e SILVA, Valéria Guimarães de Lima e. Direito antitruste: aspectos internacionais. Curitiba: Juruá, 2007, p. 442, cuja autora esclarece que "a ausência de obrigatoriedade compromete a efetividade dos Acordos [...], pois abre espaço para a prática de atos discricionários contrários aos termos acordados, levando a conflitos positivos de competência entre os dois Estados envolvidos".

${ }^{847}$ Esse é o entendimento de Rivers, para quem a decisão da Comissão Europeia no caso GE/Honeywell foi motivada nos seus interesses de proteger a indústria europeia aeroespacial. Por tal razão, os Estados Unidos não deveriam ter se surpreendido com a decisão da Comissão Europeia em obstar a aquisição da Honeywell pela GE. (RIVERS, Ricky D. General Electric/Honeywell Merger: European Commission Antitrust decision strikes a sour note. ILSA Journal of International and Comparative Law, 2002/2003, v. 9, p. 533).

${ }^{848}$ MARTINEZ, Maria Beatriz. A cooperação internacional na defesa da concorrência: acordos bilaterais e aplicação do princípio da cortesia positiva. Revista do IBRAC - Direito da Concorrência, Consumo e Comércio Internacional. São Paulo, jan. 2004, v. 11, pp. 177 ss; e JAEGER JÚNIOR, Augusto. Direito Internacional da Concorrência - Entre perspectivas unilaterais, multilaterais, bilaterais e regionais. Curitiba: Juruá , 2008, p. 246. Este autor refere que "a doutrina se mantém cética em afirmar que o resultado prático do surgimento desses acordos de cooperação é suficiente para a minimização dos déficits de execução que as legislações de defesa da concorrência apresentam quando deparadas com práticas limitadoras da concorrência promovidas no exterior ou de amplitude internacional”. 
Senado norte-americano ${ }^{849}$, em 4 de maio de 1999, o então presidente do FTC, Robert Pitofsky, destacou que o princípio da cortesia positiva trata de um elemento pequeno e modesto, utilizado em casos fora do comum, para tentar proteger as empresas norteamericanas que realizam negócios no exterior ou empresas estrangeiras que realizam negócios nos Estados Unidos. A doutrina aponta ainda que a cortesia positiva entre as autoridades norte-americanas e europeias não foi observada no período da eclosão das guerras comerciais envolvendo as duas economias ${ }^{850}$.

Com o fracasso vislumbrado na análise da concentração entre GE/Honeywell, as autoridades norte-americanas concluíram que há limites à efetividade da cooperação bilateral em matéria da concorrência ${ }^{851}$. De fato, o próprio princípio da cortesia positiva possui limitações, dentre as quais se destacam (i) a necessidade de que a conduta objeto da cooperação seja recriminada no país em que é executada; (ii) a relevância de que as autoridades de defesa da concorrência engajadas na cooperação possuam confiança mútua nas respectivas atividades para que a iniciativa seja eficaz; (iii) a dificuldade de se coibir práticas originadas em outros países, que não aqueles em regime cooperativo; (iv) a demora na consecução dos procedimentos de cooperação, em especial a resposta da parte requerida; e (v) a falta de transparência ${ }^{852}$ na condução das atividades de aplicação dos acordos bilaterais de cooperação ${ }^{853}$.

Além disso, muitas vezes, a aplicação da cortesia positiva encontra dificuldades de implementação em relação aos atos de concentração multijurisdicionais, diferentemente do que ocorre em sede de práticas anticoncorrenciais. Exemplo desta situação está no fato de o objeto principal do Acordo EUA/UE 1998, que trata com maior profundidade da aplicação da cortesia positiva, ter sua aplicação restrita às práticas concorrenciais ${ }^{854}$. Tal

\footnotetext{
${ }^{849}$ Antitrust, Business Rights and Competition Subcommittee.

850 JAEGER JÚNIOR, Augusto. Direito Internacional da Concorrência - Entre perspectivas unilaterais, multilaterais, bilaterais e regionais. Curitiba: Juruá , 2008, p. 250.

${ }^{851}$ RIVERS, Ricky D. General Electric/Honeywell Merger: European Commission Antitrust decision strikes a sour note. ILSA Journal of International and Comparative Law, 2002/2003, v. 9, p. 533.

${ }^{852}$ Destaca-se aqui a recomendação da OCDE, exarada no RCMR, de que a análise de concentração deve ser efetiva, eficiente e oportuna, devendo os países membros assegurar que as regras, políticas, práticas e procedimentos relacionados à análise da concentração sejam transparentes e disponíveis ao público.

${ }^{853}$ MARTINEZ, Maria Beatriz. A cooperação internacional na defesa da concorrência: acordos bilaterais e aplicação do princípio da cortesia positiva. Revista do IBRAC - Direito da Concorrência, Consumo e Comércio Internacional. São Paulo, jan. 2004, v. 11, p. 177 ss.

${ }^{854} \mathrm{Na}$ opinião de alguns autores, a cortesia positiva do Acordo EUA/UE 1998 deveria ser extendida às concentrações multijurisdicionais. Nesse sentido, ver DRAETTA, Ugo. Need for better trans-atlantic cooperation in the field of merger control. International Business Law Journal, 2002, p. 566, no qual expõe que "building on what already exists, for example, the 1998 agreement between US and EU could be expanded to extend the enhanced 'positive comity' to mergers [...] the result would be an increased attention from both sides of the Atlantic to the principles on non-intervention and proportionality, with the consequent possibility that one of the two authorities would defer to the other the scrutiny over a merger having a global
} 
opção, também refletida em outros acordos de cooperação bilateral, se deve ao fato de as legislações de defesa da concorrência conferirem pouca discricionariedade às autoridades de defesa da concorrência durante os procedimentos de análise de concentrações econômicas ${ }^{855}$.

Da análise dos casos práticos de cooperação multijurisdicional em que houve cooperação entre as autoridades norte-americanas e europeias detalhadas anteriormente no item 3.4.2, depreende-se que, em última análise, as autoridades engajadas em cooperação bilateral acabam por utilizar fundamentos econômicos diferenciados, consubstanciados nos respectivos ordenamentos jurídicos, no processo de análise da concentração. As diferentes legislações de defesa da concorrência são o resultado do sistema jurídico que estão inseridas, portanto, não coincidentes entre si, variando tanto em razão de conceitos fundamentais quanto materiais ${ }^{856}$. Esta situação acarreta dificuldade às autoridades que, em regime cooperativo, procuram coordenar as suas atividades e chegar a decisões convergentes sobre uma mesma operação econômica de concentração multijurisdicional ${ }^{857}$.

Parte da doutrina aponta outra deficiência do sistema formado pelos acordos bilaterais de cooperação, nomeadamente a atribuição do poder de decisão aos órgãos dos Estados cujos interesses relevantes estão em jogo ${ }^{858}$. De fato, as decisões sobre atos de concentração multijurisdicionais de relevo podem afetar de modo favorável ou desfavorável a economia dos países cujas autoridades estão incumbidas de proferir tal

dimension, when the interest of the other party appears to be largely prevailing. This development would bring the present practice more in line with international law".

${ }^{855}$ SILVA, Valéria Guimarães de Lima e. Direito antitruste: aspectos internacionais. Curitiba: Juruá, 2007, p. 465 .

856 "The United States and the EU agree that antitrust laws seek to maximize consumer welfare. However, social considerations, such as promotion of employment or protection of small enterprises, still play a role at the margins of the EU antitrust analysis. The EU also employs its antitrust laws to further European integration [...] this market integration goal hás led to a more interventionist enforcement policy vis a vis vertical agreements, in particular territorial restraints that threaten to partition the common market. The EU is also more skeptical of market Power and hás a lower threshold in bringing cases against dominant companies (see decisions against Microsoft and Intel). Similarly, the EU hás also historically taken a harsher view towards vertical and conglomerate mergers (see GE/Honeywell)". (BRADFORD, Anu. International Antitrust Cooperation and the preference for nonbinding regimes. Cooperation, comity and competition policy. New York: Oxford University Press, 2011, p. 325).

857 "Mesmo que tais distinções não sejam claramente visíveis no texto da lei, no momento de sua aplicação a interpretação que lhes será conferida por cada sistema jurídico nacional pode ser sensivelmente distinta, afastando, outrossim, o entendimento das autoridades nacionais sobre a interpretação de uma dada atividade anticoncorrencial e, consequentemente, a possibilidade de coordenação efetiva de seus respectivos processos e o alcance de conclusões similares". (SILVA, Valéria Guimarães de Lima e. Direito antitruste: aspectos internacionais. Curitiba: Juruá, 2007, p. 465).

858 Id., ibid., p. 466; e NUSDEO, Ana Maria de Oliveira. Defesa da concorrência e globalização econômica. São Paulo: Malheiros, 2002, p. 172. Esta autora esclarece que "se houver consenso sobre a necessidade de ajustar a operação para torná-la mais competitiva, ou mesmo desautorizá-la, a cooperação pode ser muito bem sucedida. O mesmo não ocorre quando houver conflito de interesses entre os dois países 
decisão, a qual poderá, em última instância, ser comprometida pela falta de neutralidade dos poderes executivo e judiciários com poderes de decidir sobre a questão. Esse pressuposto acarreta o entendimento de que a cortesia positiva não tem espaço para ser conduzida de forma imparcial, nos casos em que haja conflitos de política concorrencial entre duas jurisdições ${ }^{859}$. Uma das sugestões trazidas pela doutrina para superar esta situação seria a criação de uma autoridade de defesa da concorrência internacional ${ }^{860}$.

Além disso, existe a questão da voluntariedade da cortesia positiva, ou seja, falta de disposição que obrigue as partes de acordo bilateral a cumprirem com os compromissos cooperativos relativos à cortesia positiva ${ }^{861}$. Esta peculiaridade pode ser vista como uma vantagem, na medida em que em não existindo uma efetiva obrigação ao cumprimento da cortesia positiva, os países permanecem livres para proteger os seus próprios interesses. Todavia, tal voluntariedade reflete também uma limitação, já que as partes dos acordos não estão vinculadas às regras de cortesia positiva, tornando, em última análise, ineficaz qualquer das disposições acordadas nesse sentido ${ }^{862}$.

Neste ponto, é fundamental considerar o aspecto político-econômico relacionado às análises de concentrações econômicas envolvendo mais de uma jurisdição ${ }^{863}$. Os casos que

com relação à operação, o que é algo previsível em mercados que envolvam alta tecnologia e concorrência global, nos quais as questões de política industrial interferem mais diretamente na operação".

859 "Assim, a presença de interesses de suma importância para o Estado julgador transforma a análise da cortesia numa análise política, voltada a propiciar, em última instância, benefícios para o próprio país. Nenhum país em sã consciência profere por seus órgãos nacionais uma decisão prejudicial à sua própria economia e benéfica a de seu concorrente, haja vista que, em um mundo marcado pela competição em busca da conquista e ampliação dos mercados através do comércio internacional - fonte primordial das nações para a geração de riquezas - o que está em jogo é a própria sobrevivência do Estado". (SILVA, Valéria Guimarães de Lima e. Direito antitruste: aspectos internacionais. Curitiba: Juruá, 2007, p. 466).

${ }^{860}$ Parte da doutrina refuta essa possibilidade. Nesse sentido, ver Forgioni que esclarece: "na busca dessa 'colaboração', chegou a ir-se mais além, com a defesa da necessidade da criação de órgão supranacional competente para julgar questões internacionais antitruste e ditar as pautas de interpretação a serem seguidas pelos tribunais nacionais [...]. Se por um lado a criação de uma autoridade supranacional pode ser solução viável e útil para países que possuem política antitruste comum (como, p. ex., os países da União Europeia), de outro parece-nos bastante desaconselhável para os chamados países subdesenvolvidos. A adoção de um modelo estrangeiro pode implicar intromissão em política interna, principalmente se estabelecida a submissão das cortes nacionais às linhas determinadas por outra autoridade”. (FORGIONI, Paula A. Os fundamentos do antitruste. 4. ed. Curitiba: Juruá, 2008, pp. 458-460).

861 "The parties to the agreement can, but not necessarily must, work together". (TERHECHTE, Jörg Philipp. International Competition Enforcement Law: between cooperation and convergence. New York: Oxford University Press: Springer, 2011, p. 21).

${ }^{862}$ GUZMAN, Andrew T. Competition law and cooperation: possible strategies. Cooperation, comity and competition policy. New York: Oxford University Press, 2011, p. 356; e MARTINEZ, Maria Beatriz. A cooperação internacional na defesa da concorrência: acordos bilaterais e aplicação do princípio da cortesia positiva. Revista do IBRAC - Direito da Concorrência, Consumo e Comércio Internacional. São Paulo, jan. 2004, v. 11, p. 177 ss. Ver também SILVA, Valéria Guimarães de Lima e. Op. cit., 2007, pp. 465-466, cuja autora conclui serem as decisões da União Europeia e dos Estados Unidos nos casos Ciba-Geisy/Sandoz, Boeing/McDonnell Douglas e GE/Honeywell resultados imediatos da falta de obrigatoriedade das autoridades envolvidas em efetivamente implementar a cortesia positiva no processo de cooperação havido.

${ }^{863}$ Note-se que parte da doutrina discorda dessa posição, entendendo que o protecionismo exarado pelos Estados Unidos e a União Europeia somente tem efeitos marginais e que os conflitos na aplicação das 
envolvem consequências de maior envergadura para a economia dos respectivos países acabam por apresentar um cenário político disposto a exercer pressões em todas as esferas comerciais e econômica, de modo a assegurar o resultado que seja mais favorável à sua economia ${ }^{864}$. Nesse sentido, não é possível identificar que nos dias atuais exista uma internacionalização das políticas concorrenciais dos Estados ${ }^{865}$.

Considerando que no atual cenário econômico internacional a União Europeia talvez exerça o maior contraponto sobre o poderio econômico norte-americano, então ela seria o ente mais favorecido a resistir às pressões políticas norte-americanas na aprovação de concentrações que prejudicassem outros mercados que não o dos Estados Unidos. Todavia, conforme visto anteriormente, houve casos em que nem mesmo a União Europeia foi capaz de tomar uma decisão livre sobre os aspectos concorrenciais envolvendo operação de grande vulto internacional. Quiçá autoridades de outras economias em desenvolvimento ou de menor desenvolvimento relativo tenham sucesso em conter as pressões da superpotência norte-americana ${ }^{866}$.

Em adição à problemática revelada pelas práticas europeia e norte-americana, devese considerar que o Brasil possui algumas tradições inerentes ao seu sistema jurídico e político nacional que podem afetar adversamente as tentativas de cooperação e coordenação das autoridades nacionais de defesa da concorrência. De fato, o SBDC, em

legislações de defesa da concorrência são melhor explicados pelas diferenças existentes sobre os objetivos e fundamentos da legislação de desesa da concorrência. Nesse sentido, ver BRADFORD, Anu. International Antitrust Cooperation and the preference for nonbinding regimes. Cooperation, comity and competition policy. New York: Oxford University Press, pp. 319-320.

864 "O fator político-econômico demonstra, outrossim, ter um peso muito maior na condução das ações estatais do que a abordagem objetiva pela qual as relações internacionais entre os países deveriam ser pautadas". (SILVA, Valéria Guimarães de Lima e. Direito antitruste: aspectos internacionais. Curitiba: Juruá, 2007, p. 467). Ver ainda STEPHAN, Paul B. The problem with cooperation. Cooperation , comity and competition policy. New York: Oxford University Press, 2011, p. 219, que expõe que "cooperation is not technically difficult, but fraught with risks and hard political choices [...] states do not easily give up national champions or open up protected markets to robust competition by foreigners".

865 "Competition politics have not been able to keep pace with the globalization of competition restraints". (TERHECHTE, Jörg Philipp. International Competition Enforcement Law: between cooperation and convergence. New York: Springer, 2011, p. 13).

866 "It is important to recognize the valid and unique needs for developing countries in relation to mergers. It may be appropriate for developing countries in relation to specific sectors for example, to tailor merger rules in such a way that they are able to co-exist with other policy objectives without compromising fundamental competition policies [...]. Developing economies, which usually present a small part of foreign TNC's total world operations, cannot always make a credible threat to prohibit such mergers. Attempts by competition authorities of developing economies to place significant restrictions on the mergers of TNCs could result in their exit from the market altogether potentially causing significant detrimental effects to the developing country's welfare". (ORGANIZAÇÃO PARA A COOPERAÇÃO E DESENVOLVIMENTO ECONÔMICO. Global forum on competition - Roundtable on Cross-Border Merger Control: Challenges for Developing and Emerging Economies: Contribution from UNCTAD. DAF/COMP/GF/WD(2011)8. Jan. 2011, p. 3-4. Disponível em: <http://search.oecd.org/official documents/displaydocumentpdf/?cote=DAF/ COMP/GF/WD(2011)8\&docLanguage=En>. Acesso em: 01 dez. 2012). 
manifestação à OCDE exarada em 13 de janeiro de $2012^{867}$, por ocasião da sua participação no Fórum Global de Concorrência, relatou as dificuldades que encontra em razão da burocracia, que torna a cooperação ineficiente e custosa. Para contornar tal problema, o SBDC relata que formou recentemente um grupo para conduzir discussões com outras autoridades governamentais de forma a viabilizar as reformas legislativas que são necessárias para o estabelecimento de uma cooperação mais direta entre as autoridades de defesa da concorrência e, consequentemente, a assunção de obrigações mais amplas no âmbito dos acordos bilaterais de cooperação.

Sobrepondo-se a todos os problemas anteriormente descritos e vislumbrados na execução dos acordos bilaterais de cooperação em matéria de concorrência, existem ainda limitações inerentes à própria alternativa bilateral adotada, designadamente (i) os efeitos dos acordos bilaterais se restringem somente aos países signatários, excluindo os seus efeitos aos demais Estados que porventura sofram com os efeitos das práticas anticoncorrenciais; (ii) por serem negociados de forma bilateral, cada acordo assume características próprias, acarretando na aplicação inconsistente com os demais acordos da espécie e gerando potencial conflito com outros países; (iii) os países devem lidar com diferentes prazos para a análise e decisão dos casos pelas diferentes autoridades de defesa da concorrência, o que acarreta em dificuldades acrescidas na coordenação e cooperação entre as autoridades; e (iv) a cooperação bilateral e regional não possui os mecanismos necessários para enfrentar os obstáculos internacionais impostos pela atuação das empresas multijurisdicionais ${ }^{868}$.

Alguns autores defendem que ante a insuficiência dos acordos de cooperação bilateral em resolver problemas advindos da aplicação extraterritorial das legislações nacionais da concorrência, identificada em casos que envolvem as autoridades norteamericanas e europeias ${ }^{869}$, deveriam os países se engajar na criação de um Direito

\footnotetext{
${ }^{867}$ ORGANIZAÇÃO PARA A COOPERAÇÃO E DESENVOLVIMENTO ECONÔMICO. Global Forum on Competition - Improving International Co-operation in Cartel Investigations: Contribution from Brazil. Session 2. DAF/COMP/GF/WD(2012)32. Jan. 2012, p. 5. Disponível em: <http://search.oecd.org/official documents/publicdisplaydocumentpdf/ ?cote=DAF/COMP/GF/WD(2012)32\&docLanguage=En $>$. Acesso em: 18 nov. 2012.

${ }^{868}$ SILVA, Valéria Guimarães de Lima e. Direito antitruste: aspectos internacionais. Curitiba: Juruá, 2007, p. 468.

${ }^{869}$ Majoras destaca algumas das diferenças existentes entre os sistemas de análise de atos de concentração pelas autoridades norte-americanas e europeias, dentre as quais: (i) o maior número de colaboradores especializados empregados pelas agências norte-americanas; (ii) diferenças nos mecanismos de revisão das decisões das agências; (iii) visões diferenciadas sobre o papel do mercado e a intervenção do Estado na economia. (MAJORAS, Deborah Platt. GE-Honeywell: the U.S. decision. Palestra proferida perante a Antitrust Law Section - State Bar of Georgia em 29 de novembro de 2001. Disponível em: <http://www. justice.gov/atr/public/speeches/9893.htm>. Acesso em: 28 ago. 2012, p. 15-17).
} 
Internacional da Concorrência uniforme, que assegure a neutralidade e acarrete a diminuição da conotação política auferida aos casos de concentração multijurisdicionais, ou de uma entidade supranacional, munido de mecanismos para resolução de eventuais conflitos $^{870}$.

Parte do sucesso desta empreitada, para alguns autores, estaria associada à desvinculação de políticas nacionais de defesa da concorrência do sistema internacional de cooperação a ser criado ${ }^{871}$. A dificuldade estaria, portanto, em se encontrar uma forma de extrair questões de políticas concorrenciais da equação pela aplicação do Direito Internacional da Concorrência. Parte da doutrina e da comunidade do comércio internacional entende que a OMC e a OCDE seriam os locais adequados para esta consolidação dos princípios concorrenciais no âmbito internacional; outra parte, no entanto, considera esses organismos inapropriados e defendem a criação de organismos de cooperação à parte ${ }^{872}$.

Por outro lado, há quem entenda que um consenso internacional a respeito da uniformização do Direito Internacional da Concorrência não é atualmente factível ${ }^{873} \mathrm{e}$, assim, defendem que uma maior harmonização das legislações nacionais sobre a matéria acumulado com avanços na cooperação bilateral entre os países ${ }^{874}$ seria o caminho

\footnotetext{
${ }^{870}$ Rivers defende que a harmonização das legislações nacionais da concorrência e aumento da cooperação entre autoridades da concorrência somente será relevante na medida em que se criar um mecanismo de execução dos acordos de cooperação (RIVERS, Ricky D. General Electric/Honeywell Merger: European Commission Antitrust decision strikes a sour note. ILSA Journal of International and Comparative Law, 2002/2003, v. 9, pp. 525 e 533-534). Ver ainda DRAETTA, Ugo. Need for better trans-atlantic co-operation in the field of merger control. International Business Laws Journal, 2002, pp. 563-564; SILVA, Valéria Guimarães de Lima e. Direito antitruste: aspectos Internacionais. Curitiba: Juruá, 2007, pp. 467-468; e FARIA, José Ângelo Estrella. O controle de concentrações de empresas estrangeiras e a Lei $n^{\circ}$ 8.884: a extraterritorialidade revisitada. Juris Síntese, maio/jun. 2009, n. 77, pp. 17-20. Disponível em: http://online.sintese.com. Acesso em: 19 ago. 2012, que se manifesta no sentido de que "a inadequação dos mecanismos de coordenação existentes e a tendência a que os interesses nacionais pesem mais do que acordos bilaterais de cooperação, têm alimentado os anseios por um organismo internacional capaz de desenvolver padrões uniformes de direito internacional da concorrência [...] basta salientar existirem essencialmente duas opções: ou se criam instâncias internacionais de proteção da concorrência, ou se concebe um sistema de normas internacionais de proteção da concorrência cuja aplicação seria delegada às autoridades e tribunais nacionais".

${ }^{871}$ RIVERS, Ricky D. General Electric/Honeywell Merger: European Commission Antitrust decision strikes a sour note. ILSA Journal on International and Comparative Law, 2002/2003, v. 9, p. 534.

${ }^{872}$ Sobre este tema ver item 2.2.2.1.1 deste estudo. Ademais, ver FARIA, José Ângelo Estrella. O controle de concentrações de empresas estrangeiras e a Lei $\mathrm{n}^{\circ}$ 8.884: a extraterritorialidade revisitada. Juris Síntese, maio/jun. 2009, n. 77, p. 17. Disponível em: http://online.sintese.com. Acesso em: 19 ago. 2012, em que o autor esclarece que "a variedade de propostas é considerável, assim como a documentação produzida pelas diversas rodadas de negociações multilaterais em que se têm considerado, sem grande sucesso visível, as propostas de criação de um regime internacional de proteção de concorrência".

873 BRADFORD, Anu. International Antitrust Cooperation and the Preference for Nonbinding Regimes. Cooperation, comity and competition policy. New York: Oxford University Press, 2011, p. 327.

${ }^{874}$ MAJORAS, Deborah Platt. GE-Honeywell: the U.S. decision. Palestra proferida perante a Antitrust Law Section - State Bar of Georgia em 29 de novembro de 2001. Disponível em: http://www.justice.gov/atr/publc/speeches/9893.htm. Acesso em: 28 ago. 2012; FORGIONI, Paula A. Os
} 
palpável para mitigar os efeitos da aplicação extraterritorial da legislação de defesa da concorrência. Para esta corrente, a cooperação multilateral certamente não ultrapassará os patamares de legalização de soft law em vista das atuais diferenças existentes entre os sistemas jurídicos. Neste sentido, a melhor opção disponível aos Estados seria a constante e gradual melhoria dos mecanismos de cooperação jurídica bilateral e a convergência das políticas de concorrência ${ }^{875}$. Tal convergência é de difícil alcance, uma vez que as legislações das duas maiores jurisdições em matéria concorrencial (Estados Unidos e União Europeia) possuem fundamentos e instrumentos diferenciados em matéria concorrencial e que numerosos países ainda não contam atualmente com legislações nacionais de defesa da concorrência ${ }^{876}$.

De todo o modo, parece ser uníssono o entendimento de que os acordos bilaterais de cooperação em matéria concorrencial se constituem no melhor recurso de curto e médio prazo para mitigar os problemas advindos da aplicação extraterritorial das legislações de defesa da concorrência nos casos de concentração multijurisdicional ${ }^{877}$. De fato, não obstante os problemas e as limitações enfrentados em alguns casos de cooperação havida

fundamentos do antitruste. 4. ed. São Paulo: Revista dos Tribunais, 2010, p. 458; e BRADFORD, Anu. International Antitrust Cooperation and the Preference for Nonbinding Regimes. Cooperation, comity and competition policy. New York: Oxford University Press, 2011, pp. 328-333.

${ }^{875}$ FARIA, José Ấngelo Estrella. O controle de concentrações de empresas estrangeiras e a Lei $n^{\circ}$ 8.884: a extraterritorialidade revisitada. Juris Síntese, maio/jun. 2009, n. 77, pp. 18-21. Disponível em: <http://online.sintese.com>. Acesso em: 19 ago. 2012.

${ }^{876}$ RIVERS, Ricky D. General Electric/Honeywell Merger: European Commission Antitrust decision strikes a sour note. ILSA Journal of International and Comparative Law, 2002/2003, v. 9, pp. 534-535, que destaca que aproximadamente 100 países da OMC não contam com legislação de defesa da concorrência. Essa lacuna legislativa haveria dado azo a uma competição dos Estados Unidos e União Europeia para influenciar os sistemas estrangeiros de defesa da concorrência por meio de cooperação técnica na elaboração das respectivas legislações nacionais e treinamento dos colaboradores das autoridades de defesa da concorrência.

${ }^{877}$ SILVA, Valéria Guimarães de Lima e. Direito antitruste: aspectos internacionais. Curitiba: Juruá, 2007, p. 469; e BRADFORD, Anu. International antitrust cooperation and the preference for nonbinding regimes. Cooperation, comity and competition policy. New York: Oxford University Press, 2011, p. 322. Ver também CARVALHO, Leonardo Arquimino de. Direito Antitruste \& Relações Internacionais: extraterritorialidade e cooperação. Curitiba: Juruá, 2003, p. 188, que defende que "esta forma de acordos bilaterais parece ser a mais adequada para o período atual em que as políticas de concorrência dos mais diversos países tendem à manutenção dos modelos nacionais, com suas formas específicas de conduzir a política antitruste". Ademais, Lagares comenta sobre a escolha da União Europeia sobre a utilização de acordos bilaterais em matéria concorrencial: "An MoU is a classic and efficient means of articulating cooperation between competition authorities. It was not DG Competition's instrument of choice in the past. It is, however, a flexible instrument to articulate cooperation, which can be put in place in a relatively short period of time, provided the Commission remains within the limits of its competences. This is precisely the case of the MoU with the Brazilian competition authorities, which becomes DG Competition's template for the future" (LAGARES, Eva Valle. International agreements regarding cooperation in the field of competition: the new strategy of the European Commission. Journal of European Competition Law \& Practice, jan. 2010, pp. 2-3); e Botta: "If a supranational system of enforcement of competition law is still far from becoming a reality, effective systems of bilateral cooperation seem at the moment to be the more realistic alternative" (BOTTA, Marco. The cooperation between the Competition Authorities of the 
pelas autoridades norte-americanas e europeias em concentrações multijurisdicionais, que foram submetidos ao intenso escrutínio pela doutrina, é possível verificar que a cooperação em diversos outros casos teve sucesso. Seria, deste modo, injusto negar certa efetividade ao sistema de cooperação constituído por meio de acordos bilaterais ${ }^{878}$. Estariam estes, no entanto, longe de constituírem uma solução definitiva para a problemática constatada ${ }^{879}$.

Nesse sentido cumpre considerar que os instrumentos atualmente existentes para mitigar os problemas advindos da aplicação extraterritorial das legislações de defesa da concorrência, inclusive os acordos bilaterais descritos, tratam na sua maior parte de instrumentos de soft law. Não obstante o relativo sucesso verificado na utilização desses instrumentos até o presente momento, existe um reconhecimento geral da doutrina de que certamente em um futuro próximo tais instrumentos não sejam mais suficientes para garantir a demanda da comunidade internacional sobre as concentrações multijurisdicionais ${ }^{880}$. O que há de se esperar, portanto, no desenvolvimento das relações bilaterais em matéria concorrencial?

Nesse sentido, Guzman destaca que a cooperação poderia evoluir para abarcar regras sobre a escolha da lei aplicável aos casos de dimensão internacional, incluída a possibilidade de declinamento de competência de uma jurisdição à outra, em determinados $\operatorname{casos}^{881}$. Todavia, expõe que problemas poderão ser identificados na adoção deste tipo de

Developing Countries: why does it not work? Case study on Argentina and Brazil. The Competition Law Review. Issue 2, jul. 2009, v. V, p. 155).

878 DABBAH, Maher M. Future directions in bilateral cooperation: a policy perspective. Cooperation, comity and competition policy. New York: Oxford University Press, 2011, pp. 293-294.

879 "The achievements in the area of antitrust international co-operation have certainly been impressive compared to the situation which existed tem years ago. But the approach of Governments appears to be mostly re-active, rather then pro-active. The bi-lateral co-operation in force is of the soft type [...] which does not really meet the needs of the international business community". (DRAETTA, Ugo. Need for better trans-atlantic co-operation in the field of merger control. International Business Law Journal, 2002, p. 557).

880 "Such cooperation is problably facilitated by antitrust cooperation agreements, which encourage cooperation above and beyond that indicated by traditional and positive comity; such agreements do not have the force of law within the United States [...] and on the international plane are understood to be closer to 'soft law' than treaties". (SWAINE, Edward T. Cooperation, comity and competition policy: United States. Cooperation, comity and competition policy. New York: Oxford University Press, 2011, p. 20). Ainda, ver Dabbah, que assim expressa: "the limits of the effectiveness of soft law generally suggest that the current wave of successes might become more modest in the future. However, as antitrust constantly evolves based on refinements in economic thinking, perhaps new challanges will sustain the momentum for soft saw international institutions" (DABBAH, Maher M. Op. cit., p. 297; SOKOL, D. Daniel. International Antitrust Institutions. Cooperation, comity and competition policy. New York: Oxford University Press, 2011, p. 213); e Fox, para quem: "cooperation and soft convergence solve only some of the major antitrust problems of the world" (FOX, Eleanor M. Antitrust without borders: from roots to codes to networks. Cooperation. Comity and Competition policy. New York: Oxford University Press, 2011, p. 273).

881 "For example, such a regime could include some rather standard factors for determining the appropriate Law, such as the location of the anticompetitive conduct, the location of the most important effects, or the principle place of the business of the firm engaged in anticompetitive practices. Cooperating states would face decisions about wheter the goal would be to assign jurisdiction to one particular state or several, and 
regramento, tais como os relacionados à sobrerregulamentação ou desregulamentação, o que torna inadequada esta opção de cooperação aos tempos correntes.

Ao se considerar os atos de concentração multijurisdicionais, tem-se que um dos problemas que poderiam ser objeto de maior cooperação entre as autoridades de defesa da concorrência, no âmbito de acordos bilaterais, relaciona-se aos múltiplos requerimentos de notificação prévia das concentrações multijurisdicionais que devem ser apresentados pelas sociedades envolvidas a diversas autoridades. Mais de 50 países exigem a notificação prévia de concentrações, de modo que as suas respectivas autoridades possam emitir uma decisão sobre a viabilidade da operação antes da sua ocorrência. O cumprimento das legislações de defesa da concorrência pelas partes da operação de concentração multijurisdicionais devem, assim, arcar com os custos e o tempo necessários para a finalização de ditas múltiplas notificações.

Seria perfeitamente viável que os Estados acordassem sobre regras mínimas para estabelecimento da obrigação de notificar cada jurisdição (como por exemplo, pelo estabelecimento de determinado nexo causal), afastando a necessidade de as partes notificarem jurisdições nas quais os efeitos esperados não têm capacidade de afetar diversamente a concorrência local. Há notícias de que a ICN tem explorado esse problema, sendo que um dos pontos em discussão seria a viabilidade de se construir um sistema unificado para notificação de múltiplas autoridades a respeito de uma mesma concentração multijurisdicional $^{882}$.

Já a longo prazo é possível vislumbrar que a experiência advinda da efetivação da cooperação bilateral poderá conduzir a comunidade internacional à celebração de acordo multilateral vinculativo em matéria concorrencial, revelando, assim, o sistema internacional de cooperação tão almejado por muitos dos estudiosos da matéria ${ }^{883}$.

despite problems attaching to each factor noted above, some anticompetitive activities could be governed through an agreement on choice of law rules". (GUZMAN, Andrew T. Competition Law and Cooperation: possible strategies. Cooperation, comity and competition policy. New York: Oxford University Press, 2011, p. 358).

882 "So that one document filed in one place can provide all of the necessary preliminary information. This can be done horizontally - by agreement among the jurisdictions". (FOX, Eleanor M. Antitrust without borders: from roots to codes to networks. Cooperation, comity and competition policy. New York: Oxford University Press, 2011, p. 277).

883 Bradford descreve que a cooperação bilateral poderá de fato conduzir a um acordo multilateral vinculativo, mas que não necessariamente este será o desfecho da evolução da matéria, já que os países poderão optar por manter o sistema de cooperação informal por inúmeras razões. A autora defende, inclusive, que a melhor opção para os Estados seria a manutenção do regime de cooperação informal existente ao invés de adotar um sistema de cooperação vinculativo. Reconhece, no entanto, que grande parte da doutrina tem entendimento diverso. (V. BRADFORD, Anu. International Antitrust Cooperation and the preference for nonbinding regimes. Cooperation, comity and competition policy. New York: Oxford University Press, 2011, pp. 333-342). 


\section{CONCLUSÃO}

Em comparação aos tradicionais ramos da Ciência Jurídica, a história do Direito da Concorrência é recente, constituindo-se numa resposta aos acontecimentos que seguiram à Revolução Industrial. O grande marco legislativo na evolução do Direito da Concorrência trata do Sherman Act norte-americano, de 1890. Todavia, sua maior amplitude foi alcançada durante o século 20, devido à interação havida com a Economia e, em que pese a manutenção da função valorativa do Direito, a consequente coerência e segurança jurídica conferida aos jurisdicionados.

Justamente em função do relevante papel desempenhado pelos Estados Unidos no processo de amadurecimento do Direito da Concorrência, o Direito norte-americano passou a influenciar diversas nações no que se refere à promulgação de legislações nacionais de defesa da concorrência. Não obstante a necessária preocupação de se proporcionar a adaptação da experiência norte-americana à realidade local dos países que buscaram inspiração na construção de um sistema jurídico concorrencial, a influência dos Estados Unidos nesta matéria tem lugar até os dias atuais. Esta influência não é, entretanto, absoluta, sendo que o sistema norte-americano guarda algumas particularidades em relação aos sistemas dos demais países, as quais acabam, em última instância, por constituir parte das dificuldades encontradas nas relações internacionais em matéria concorrencial.

A evolução do sistema jurídico brasileiro em matéria concorrencial foi tardia se comparada à realidade norte-americana, principalmente em razão da intervenção direta do Estado na economia brasileira que se prolongou durante grandes períodos. Apesar de algumas Constituições anteriores e leis infraconstitucionais terem tratado dos princípios relacionados ao liberalismo econômico e à manutenção da concorrência no mercado, os dois grandes marcos do sistema jurídico brasileiro são a Constituição Federal de 1988, que elevou pela primeira vez a livre concorrência como princípio econômico constitucional, e a Lei $n^{\circ} 8.884 / 1994$, que veio regular a defesa da concorrência por completo e de forma sistematizada - esta revogada e substituída pela Lei da Concorrência, em vigor desde 29 de maio de 2012.

A Lei da Concorrência regula os atos de concentração, incluindo tanto aqueles de sentido estrito, quanto os de cooperação empresarial, sem, no entanto, diferenciar os de amplitude nacional dos de amplitude multijurisdicional. Atos de concentração multijurisdicionais devem ser entendidos como aqueles que envolvem ou influenciam mais 
de uma jurisdição, seja pela localização das partes da operação, ou simplesmente pelos efeitos surtidos nos diferentes mercados. Ademais, com o advento da Lei da Concorrência, dentre outras modificações, operou-se uma alteração no sistema de notificação das concentrações econômicas às autoridades brasileiras de defesa da concorrência, passando de um sistema de notificação e análise a posteriori, para um sistema de análise a priori, ou seja, anterior à conclusão da operação.

A intensificação da globalização econômica e a atuação multijurisdicional das empresas ocasionaram a elevação das preocupações concorrenciais ao plano internacional e a emersão do Direito Internacional da Concorrência. Desta forma, o Direito Internacional da Concorrência trata do precoce ramo da Ciência Jurídica que visa a regular e mitigar os problemas advindos da aplicação extraterritorial das variadas legislações nacionais de defesa da concorrência e que possui quatro dimensões de regulação, a saber: unilateral, bilateral, regional e multilateral.

Na sua dimensão unilateral, o Direito Internacional da Concorrência centra-se na questão da aplicação extraterritorial das legislações nacionais de defesa da concorrência às práticas ocorridas no exterior. O fundamento geralmente invocado pela doutrina para a aplicação extraterritorial do direito está no caso S. S. Lotus, julgado pela Corte Permanente de Justiça Internacional. Todavia, foi com a evolução da jurisprudência das cortes norteamericanas, em especial com o julgamento do caso Alcoa, que houve a consagração da teoria dos efeitos, a qual se constitui na base universalmente reconhecida para a aplicação extraterritorial unilateral do Direito da Concorrência.

A aplicação extraterritorial da legislação brasileira de defesa da concorrência foi inicialmente acolhida pela Lei $n^{\circ} 8.884 / 1994$, sendo atualmente prevista no art. $2^{\circ}$ da Lei da Concorrência. As decisões do SBDC e a jurisprudência nacional reconhecem a teoria dos efeitos e lhe dão ampla aplicação e eficácia em relação às práticas que provocam efeitos no território brasileiro, ou que tenham potencialidade para tanto.

A adoção de regras sobre a aplicação extraterritorial do Direito da Concorrência, também verificada em outros Estados, acarreta conflitos de competência positivos e negativos e revela algumas limitações. Uma das principais limitações está na dificuldade de se executar no exterior as decisões proferidas por autoridades nacionais, principalmente nos casos em que houver decisões divergentes emanadas por diferentes autoridades de defesa da concorrência sobre uma mesma prática multijurisdicional. No caso das concentrações multijurisdicionais, o efeito imediato da teoria dos efeitos está na necessidade de as partes das transações terem que notificar uma mesma transação a mais 
de uma autoridade de defesa da concorrência, estando, assim, sujeitas a custos elevados e à possibilidade de obterem decisões antagônicas ou divergentes para um mesmo negócio.

O Direito Internacional da Concorrência aponta a cooperação jurídica internacional como solução disponível aos variados Estados para mitigar as dificuldades encontradas na aplicação extraterritorial das legislações nacionais de defesa da concorrência. O entrelaçamento das relações internacionais e a consequente designação da cooperação como um dos principais elementos da identidade dos Estados Constitucionais, causaram a transformação em Estados Constitucionais Cooperativos, sem que, entretanto, tenham prejudicado a soberania de tais Estados.

A cooperação jurídica internacional pode ser de natureza jurisdicional ou administrativa, sendo que a cooperação promovida pelas autoridades de defesa da concorrência encontra ampla guarida na segunda modalidade, uma vez que envolve na maioria dos casos ato de natureza administrativa, sem conteúdo jurisdicional. Destaca-se o auxílio direto como instrumento de cooperação internacional disponível às autoridades de defesa da concorrência para a concretização de atos de cooperação que porventura tenham conteúdo jurisdicional. A cooperação jurídica internacional poderá ser formal ou informal, consoante os procedimentos e as regras para a sua execução estejam ou não institucionalizados por meio de tratado internacional vinculativo.

As formas de manifestação da cooperação jurídica internacional podem ser mais rígidas, como no caso de tratados e convenções, ou mais flexíveis - soft law -, podendo variar inclusive no âmbito destas, em função de três dimensões, nomeadamente obrigação, precisão e delegação. Em relação ao Direito Internacional da Concorrência, a opção política internacional verificada até o momento foi a da adoção de uma legalização de baixo nível, com baixa delegação. A relação entre o Direito Interno e o Direito Internacional foi amplamente transformada pelos eventos que sucederam a II Guerra Mundial e pela aceleração da globalização econômica. O Direito Internacional Contemporâneo é marcado pela transnormatização, pela qual instrumentos de soft law não vinculativos passam a influenciar a produção normativa dos Estados e a aplicação das legislações nacionais existentes.

A comunidade internacional vem reunindo esforços para a construção de um conjunto de regras multilaterais de Direito Internacional da Concorrência; com destaque para as discussões havidas no âmbito da OMC e os esforços para a criação de um Código Concorrencial Internacional. Apesar de haver inúmeras iniciativas das entidades de atuação internacional para a harmonização e a sistematização de um Direito Internacional da 
Concorrência, não é possível concluir que exista um regramento global e universal nesta matéria, não havendo, desta maneira, uma convergência sobre o tema. Ademais, muitos dos trabalhos produzidos por organizações ou redes governamentais não possuem natureza vinculativa, em que pese os membros dos foros internacionais deterem o poder e a competência para adotar e absorver internamente as regras e recomendações fruto do trabalho de tais entidades.

Destacam-se na esfera dos atos de concentração multijurisdicionais o labor da OCDE e o da ICN, do qual resultou a publicação de instrumentos de melhores práticas com regras de estímulo à celebração de acordos bilaterais e multilaterais de cooperação entre os Estados, bem como disposições relacionadas à troca de informações, ao tratamento de informações confidenciais, aos procedimentos e análise de notificações sobre concentração, à coordenação de investigações de concorrência de interesse mútuo e à forma de se evitar inconsistências em relação aos remédios determinados por outras jurisdições sobre a mesma concentração.

No que toca à cooperação regional, o Direito Internacional da Concorrência tem especial relevância, uma vez que não há possibilidade de se conceber o desenvolvimento econômico de uma região, sem que haja uma correspondente proteção da livre iniciativa, da concorrência e dos direitos dos consumidores. É possível verificar avanços na regulação da concorrência pelos blocos econômicos, principalmente no caso da União Europeia. Não somente ela, entretanto, regula a matéria concorrencial, mas outras organizações internacionais e acordos regionais também possuem regras sobre a matéria.

O Mercosul constitui-se num exemplo de organização com histórico na evolução da matéria concorrencial, uma vez que o tema já foi objeto do Tratado de Assunção e de diversas Decisões do CMC, com destaque para a Decisão CMC n 43/2010 que aprovou o Acordo de Defesa da Concorrência do Mercosul. Todavia, o grau de desenvolvimento da matéria concorrencial no Mercosul é bastante incipiente, uma vez que tanto o Tratado de Assunção quanto as Decisões do CMC referem-se tão somente a hipóteses de cooperação entre as autoridades de defesa da concorrência nacionais; não sendo possível, portanto, concluir que no âmbito regional do Mercosul exista um sistema efetivo de defesa da concorrência.

Finalmente, no que se refere à dimensão bilateral do Direito Internacional da Concorrência, cabe ressaltar que os Estados passaram a celebrar acordos bilaterais para a aplicação da legislação de defesa da concorrência a partir da década de 1970, com o principal intuito de minimizar os efeitos advindos da aplicação extraterritorial das variadas 
legislações nacionais. Os acordos mais influentes no panorama internacional sobre a matéria são aqueles celebrados pelos Estados Unidos e União Europeia nos anos de 1991 e 1998, os quais impulsionaram a celebração deste tipo de acordo por numerosos países. Os acordos bilaterais possuem especial relevância nos casos de concentrações multijurisdicionais, uma vez que propulsionam uma análise rápida e completa pelas autoridades de defesa da concorrência, bem como dinamizam os esforços na eventual adoção de decisões convergentes sobre uma mesma operação.

Os acordos bilaterais poderão ser de primeira ou de segunda geração, consoante prevejam ou não a possibilidade de contínuo compartilhamento de informações confidenciais pelas autoridades envolvidas. O objeto deste tipo de acordo poderá ser a cooperação técnica, a cooperação para a aplicação das legislações nacionais de defesa da concorrência ou ambos. Dentre aqueles que preveem a cooperação na aplicação das legislações de defesa da concorrência é possível detectar que possuem conteúdo recorrente, que afetam os atos de concentração multijurisdicionais, a saber, as notificações trocadas entre autoridades, os princípios da cortesia negativa e positiva, a coordenação de atividades e a coleta de provas e troca de informações na outra jurisdição, incluindo a realização de reuniões periódicas para troca de informações e experiências.

O Brasil e o SBDC celebraram 10 acordos bilaterais em matéria concorrencial, sendo que seis têm por objeto a cooperação na aplicação da legislação de defesa da concorrência. Destes, somente os acordos celebrados com os Estados Unidos e a Argentina passaram pelo processo de ratificação envolvendo o Congresso Nacional. Nesse sentido é importante ressaltar que os acordos poderão ter caráter vinculativo, ou não, consoante sejam ratificados pelo procedimento relativo à recepção de tratados internacionais pelo ordenamento interno. Na hipótese de não serem recepcionados pelo ordenamento interno, tais acordos assemelham-se aos instrumentos de soft law, possuindo, assim, uma relação transnormativa com o Direito Interno.

A análise e o controle das concentrações multijurisdicionais constam no âmbito de aplicação de todos os seis acordos celebrados pelo Brasil e o SBDC. Todavia, alguns dos acordos contêm imprecisões sobre as práticas concentracionistas que estariam englobadas no âmbito de aplicação dos acordos, havendo espaço, portanto, para melhorias nesse tocante.

Além disso, os seis acordos celebrados pelo Brasil e pelo SBDC acolhem o princípio da cortesia negativa e, destes, somente três possuem regras de cortesia positiva. Além da voluntariedade na aplicação da cortesia positiva, tradicional nos acordos desta 
natureza, que acaba por mitigar a eficácia das iniciativas de cooperação, da análise realizada sobre os termos da cortesia positiva adotada é possível depreender que existem amplas possibilidades para o desenvolvimento do instituto nos acordos celebrados pelo Brasil e pelo SBDC.

No que se refere à busca de informações, as autoridades brasileiras devem ter cautela durante o exercício das atividades cooperativas, de modo que não transgridam os requisitos legalmente estabelecidos para a cooperação de conteúdo jurisdicional. Já em relação à troca de informações, a atenção deve voltar-se aos dispositivos das legislações nacionais, em especial da Lei de Acesso à Informação e a Lei da Concorrência, bem como das demais resoluções do $\mathrm{CADE}$, a fim de identificar as informações que são passíveis de compartilhamento com autoridades estrangeiras, em especial quanto às informações confidenciais.

O Brasil encontra-se em patamar muito incipiente no que tange aos acordos bilaterais de cooperação para a aplicação da legislação de defesa da concorrência. Isso se deve ao fato de o Brasil e o SBDC terem celebrado poucos acordos, na sua maioria com baixo grau de legalização. Além disso, os acordos analisados não contemplam todas as recomendações sobre melhores práticas divulgadas pela OCDE e pela ICN, ou, quando as consideram, o fazem de forma bastante tímida. Há muito espaço para o avanço e o desenvolvimento das matérias relativas aos acordos celebrados pelo Brasil e pelo SBDC, o que deverá ocorrer com o aumento do grau de confiança mútua entre as autoridades de defesa da concorrência envolvidas.

Não obstante as limitações identificadas, as autoridades brasileiras têm demonstrado um espírito cooperativo apurado nos casos de concentração multijurisdicional que lhe são submetidos. No entanto, até o momento não foi possível identificar um caso de concentração multijurisdicional em que tenha ocorrido efetiva cooperação e coordenação das autoridades brasileiras com suas congêneres estrangeiras durante a análise de concentração submetida a mais de uma autoridade. Isto se deve principalmente ao fato de até recentemente o sistema jurídico nacional contar com um padrão de notificação de notificações a posteriori, ou seja, após a conclusão da operação pelas partes. Havia, portanto, dificuldade para a promoção da cooperação entre as autoridades brasileiras e as estrangeiras, as quais, na sua maioria, adotam sistemas de análise a priori, o que acarretava em momentos distintos da análise das concentrações multijurisdicionais. Com a modificação do sistema nacional para um sistema de análise prévia, o SBDC está em 
posição de vantagem para incrementar as suas atividades de cooperação no âmbito de concentrações multijurisdicionais.

Em relação à análise dos casos dos países com grande tradição de cooperação, nomeadamente os Estados Unidos e a União Europeia, cujo histórico de cooperação sobre casos de concentrações multijurisdicionais é elevado, depreende-se que em certas e determinadas ocasiões a simples voluntariedade das autoridades em cooperar e coordenar suas atividades de análise não foi suficiente para o alcance de decisões concertadas. Tais casos revelaram profundas divergências quanto ao sistema concorrencial adotado por cada sistema jurídico, bem como a fragilidade do atual sistema de cooperação bilateral voluntária, que pode ser afastado em razão de pressões políticas e econômicas.

A doutrina especializada centra seus esforços no sentido de identificar o futuro do Direito Internacional da Concorrência, em especial se a cooperação bilateral servirá como um passo na evolução das iniciativas internacionais, com o objetivo de se chegar a um sistema multilateral de cooperação em matéria concorrencial, ou se a adesão generalizada pelos países ao método bilateral de cooperação é indicativo da efetiva e final intenção da comunidade internacional nesta matéria. Seja como for, há demasiado espaço para a evolução da matéria, o amadurecimento das discussões e a adoção de instrumentos que sejam eficazes e eficientes na cooperação jurídica internacional pelas autoridades de defesa da concorrência na análise dos atos de concentração multijurisdicionais. 


\section{BIBLIOGRAFIA}

\section{Referências Bibliográficas}

ABBOT, Keneth W. The Many Faces of International Legalization. American Society of International Law, 1998.

ACCIOLY, Elizabeth. Mercosul e União Europeia: estrutura jurídico-institucional. 4. ed. Curitiba: Juruá, 2010.

ACCIOLY, Hildebrando; NASCIMENTO E SILVA, G. E. do; CASELLA, Paulo Borba. Manual de Direito Internacional Público. 17. ed. São Paulo: Saraiva, 2009.

ALMEIDA, José Gabriel Assis de. A aplicação extra-territorial do direito da concorrência brasileiro. Arché: Interdisciplinar. Rio de Janeiro, 2001, v. 10, n. 29. pp. 63-79.

AMARAL JÚNIOR, Alberto. Introdução ao Direito Internacional Público. São Paulo: Atlas, 2008.

ANDERS, Eduardo Caminati; PAGOTTO, Leopoldo; BAGNOLI, Vicente (coords.). Comentários à Nova Lei de Defesa da Concorrência. Rio de Janeiro: Forense; São Paulo: Método, 2012.

ARAÚJO, Leandro Rocha de. Associação Latino-Americana de Integração (ALADI). Blocos Econômicos e Integração na América Latina, África e Ásia. Curitiba: Juruá, 2008. pp. 113-136.

ARAÚJO, Nádia de. Cooperação Jurídica Internacional no Superior Tribunal de Justiça. Comentários à Resolução no 9/2005. Rio de Janeiro: Renovar, 2010.

BAPTISTA, Luiz Olavo. Inserção dos Tratados no Direito Brasileiro. Revista de Informação Legislativa. Brasília, out/dez. 1996, n. 132.

BOTTA, Marco. Multi-jurisdiction mergers and acquisitions in an era of globalization: the Telecom Italia-Telefônica case. Global Antitrust Review, Issue 1, 2008. pp. 97-116.

. The Cooperation between the Competition Authorities of the Developing Countries: Why does it not Work? Case Study on Argentina and Brazil. The Competition Law Review. Issue 2, jul. 2009, v. V. pp 153-178.

BRADFORD, Anu. International Antitrust Cooperation and the Preference for Nonbinding Regimes. Cooperation, Comity and Competition Policy. New York: Oxford University Press, 2011. pp. 319-344.

International Antitrust Negotiations and the False Hope of WTO. Harvard International Law Journal, verão 2007, v. 48, n. 2. pp. 383-439. 
CARVALHO, Leonardo Arquimino de. Direito Antitruste \& Relações Internacionais: extraterritorialidade e cooperação. Curitiba: Juruá, 2003.

CARVALHO RAMOS, André de; CUNHA, Ricardo Thomazinho da. A defesa da concorrência em caráter global: utopia ou necessidade. In: CASELLA, Paulo Borba (org.). Guerra comercial ou integração econômica mundial. São Paulo: LTr, 1998, v. 1. pp. 810-837.

CASELLA, Paulo Borba. Direito da concorrência na UE e no Mercosul. In: BAPTISTA, Luiz Olavo; MERCADANTE, Araminta de Azevedo; CASELLA, Paulo Borba (orgs.). Mercosul: das negociações à implantação. 2. ed. São Paulo: LTr, 1998. pp. 306-352.

Extraterritorialidade e proteção da livre-concorrência. Revista da Faculdade de Direito da Universidade de São Paulo. São Paulo: USP, 2001, v. 96. pp. 501-519.

; SANCHEZ, Rodrigo Elian. Cooperação judiciária internacional. Rio de Janeiro: Renovar, 2002.

CELLI JÚNIOR, Humberto. Regras de concorrência no Direito Internacional Moderno. Porto Alegre: Livraria do Advogado, 1999.

CONSIDERA, Claudio Monteiro; TEIXEIRA, Cleveland Prates. Brazil's Recent Experience in International Cooperation. 1996. Disponível em: <http://www.seae. fazenda.gov.br/central_documentos/textos_artigos/1996-1/3-international-cooperation>. Acesso em: 01 dez. 2012.

CRANE, Daniel A. Substance, procedure and institutions in the International Harmonization of Competition Policy. Chicago Journal of International Law, 20092010, v. 10, n. 1. pp. 143-159.

CUNHA, Ricardo Thomazino da. Direito de defesa da concorrência: Mercosul e União Europeia. Barueri, SP: Manole, 2003.

DABBAH, Maher M. Future directions in bilateral cooperation: a policy perspective. Cooperation, Comity and Competition Policy. New York: Oxford University Press, 2011. pp. 287-300.

DAVID, René. Os grandes sistemas do Direito contemporâneo. Trad. de Hermínio A. Carvalho. 3. ed. São Paulo: Martins Fontes, 1996.

DRAETTA, Ugo. Need For Better Trans-atlantic Co-operation in the Field of Merger Control. International Business Law Journal, 2002. pp. 557-568.

FARIA, José Ângelo Estrella. Aplicação extraterritorial do Direito da Concorrência. Revista de Informação Legislativa. Brasília, jan./mar. 1990, n. 105. pp. 19-46.

O controle de concentrações de empresas estrangeiras e a Lei n. 8.884: a extraterritorialidade revisitada. Juris Síntese, maio/jun. 2009, n. 77. Disponível em: <http://online.sintese.com>. Acesso em: 19 ago. 2012. 
FARINA, Elizabeth M. M. Q.; ARAÚJO, Patricia Agra. Brazilian Competition Policy in a Global Perspective. Competition Law International, out. 2005.

FONSECA, João Bosco Leopoldino. Lei de Proteção da Concorrência. 3. ed. São Paulo: Forense, 2007.

FORGIONI, Paula A. Os fundamentos do antitruste. 4. ed. São Paulo: Revista dos Tribunais, 2010.

FOX, Eleanor M. Antitrust without borders: from roots to codes to networks. Cooperation, Comity and Competition Policy. New York: Oxford Press, 2011. pp. 265286.

West, 2010.

; CRANE, Daniel A. Global issues in antitrust and competition law. St Paul:

GABAN, Eduardo Molan; DOMINGUES, Juliana Oliveira. Direito antitruste. 3. ed. São Paulo: Saraiva, 2012.

GALLOWAY, Jonathan. Convergence in international merger control. The competition law review. Issue 2, jul. 2009, v. V. pp 179-192.

GERADIN, Damien; REYSEN, Marc; HENRY, David. Extraterritoriality, Comity and Cooperation in EU Competition Law. Cooperation, Comity and Competition Policy. New York: Oxford University Press, 2011. pp. 21-44.

GINSBURG, Douglas H.; FRASER, Eric M. The role of economic Analysis in competition law. Getting the balance right: intellectual property, competition law and economics in Asia. Hart Publishing, 2010. Disponível em: <http://papers.ssrn.com/sol3/papers. cfm?abstract_id=1610189>. Acesso em: 19 ago. 2012.

GUZMAN, Andrew T. Competition law and cooperation: possible strategies. Cooperation, Comity and Competition Policy. New York: Oxford University Press, 2011. pp. 345-362.

HÄBERLE, Peter. Estado constitucional cooperativo. Trad. de Marcos Augusto Maliska e Elisete Antoniuk. Rio de Janeiro: Renovar, 2007.

JAEGER JÚNIOR, Augusto. Direito Internacional da Concorrência - Entre perspectivas unilaterais, multilaterais, bilaterais e regionais. Curitiba: Juruá, 2008. 2006.

Liberdade de concorrência na União Europeia e no Mercosul. São Paulo: LTr,

KLEIN, Vinícius. O Direito da Concorrência no Mercosul. Núcleo de Pesquisa em Direito Público do Mercosul, 2002. Revista da Faculdade de Direito da Universidade Federal do Paraná. Disponível em: <http://ojs.c3sl.ufpr.br/ojs2/ index.php/direito/article/view File/1754/1451>. Acesso em: 21 out. 2009. 
KWONKA JR, John E.; WHITE, Lawrence J. The Antitrust Revolution: economics, competition and Policy. 5. ed. Nova Iorque: Oxford University Press, 2008.

LAGARES, Eva Valle. International agreements regarding cooperation in the field of competition: the new strategy of the European Commission. Journal of European Competition Law \& Practice, jan. 2010.

LILLA, Paulo Eduardo. A OMC e a interação entre comércio e política antitruste no âmbito da cooperação internacional: perspectivas para a nova rodada e negociações multilaterais. Revista do IBRAC - Direito da Concorrência, Consumo e Comércio Internacional. São Paulo, jan. 2003, v. 10. p. 233 e ss.

MAGALHÃES, José Carlos de. Direito econômico internacional: tendências e perspectivas. Curitiba: Juruá, 2009.

MAJORAS, Deborah Platt. GE-Honeywell: the U.S. decision. Palestra proferida perante a Antitrust Law Section - State Bar of Georgia em 29 de novembro de 2001. Disponível em: <http://www.justice.gov/atr/public/speeches/9893.htm>. Acesso em: 28 ago. 2012.

MARQUES, Frederico do Valle Magalhães. Direito Internacional da Concorrência. Rio de Janeiro: Renovar, 2006.

MARSDEN, Philip. The curious incident of positive comity - The dog that didn't bark (and the trade dogs that just might bite). Cooperation, Comity and Competition Policy. New York: Oxford University Press, 2011. pp. 301-318.

MARTINEZ, Maria Beatriz. A cooperação internacional na defesa da concorrência: acordos bilaterais e aplicação do princípio da cortesia positiva. Revista do IBRAC Direito da Concorrência, Consumo e Comércio Internacional. São Paulo, jan. 2004, v. 11. pp. 177 e ss.

MENEZES, Wagner. Direito Internacional no cenário contemporâneo. Curitiba: Juruá, 2003.

Ordem global e transnormatividade. Ijuí: Ed. Ijuí, 2005.

O Direito Internacional na América Latina. Curitiba: Juruá, 2007.

. Mercado Comum do Sul (Mercosul). Blocos Econômicos e Integração na América Latina, África e Ásia. Curitiba: Juruá, 2008. pp. 137-160.

Derecho Internacional en América Latina. Brasília: FUNAG, 2010.

MONTGOMERY, Neil. As organizações internacionais como sujeitos de direito internacional. Blocos econômicos e integração na América Latina, África e Ásia. Curitiba: Juruá, 2008. pp. 39-72.

MORAIS, Luís Domingos Silva. Empresas comuns (Joint Ventures) no Direito Comunitário da Concorrência. Coimbra: Almedina, 1996. 
NOONAN, Chris. Editorial - Globalisation, International Enforcement and Extraterritoriality. The Competition Law Review. Issue 2, jul. 2009, v. V. pp. 147-151.

NUSDEO, Ana Maria de Oliveira. Defesa da concorrência e globalização econômica. São Paulo: Malheiros, 2002.

OLIVEIRA, Gesner; RODAS, João Grandino. Direito e economia da concorrência. Rio de Janeiro: Renovar, 2004.

PAIS, Sofia Oliveira. O controlo das concentrações de empresas no âmbito do Direito Comunitário da Concorrência. Coimbra: Almedina, 1996.

PINSKI, Lior. Aplicação extraterritorial da Lei Antitruste. Revista de Direito Mercantil. São Paulo: Revista dos Tribunais, 1999, n. 115. pp. 130-141.

REGAZZINI, José Augusto Caleiro. Merger Control in Brazil. Competition Law International, out. 2005, n. 22.

RIVERS, Ricky D. General Electric/Honeywell Merger: European Commission Antitrust Decision Strikes a Sour Note. ILSA Journal of International and Comparative Law, 2002/2003, v. 9. pp. 525-539.

SALOMÃO FILHO, Calixto. O Mercosul como modelo de regulação do mercado. Contratos internacionais. 3. ed. São Paulo: Revista dos Tribunais, 2002. p. 401-426.

Direito Concorrencial - as condutas. São Paulo: Malheiros, 2007.

Direito Concorrencial - as estruturas. 3. ed. São Paulo: Malheiros, 2007.

SANTOS, Maria Cecília de Andrade. A política da concorrência e a Organização Mundial do Comércio. Revista de Direito Constitucional e Internacional, abr./jun 2001, ano 9, n. 35. pp. 228-254.

Sobre a cooperação em matéria de concorrência entre a União Europeia e o Mercosul. Revista do IBRAC - Direito da Concorrência, Consumo e Comércio Internacional. São Paulo, jan. 2001, v. 8. p. 177 e ss.

SEITENFUS, Ricardo; VENTURA, Deisy. Introdução ao Direito Internacional Público. 2. ed. Porto Alegre: Livraria do Advogado, 2001.

SHIEBER, Benjamin M. Abusos do poder econômico: direito e experiência antitruste no Brasil e nos EUA. São Paulo: Revista dos Tribunais, 1966.

SILVA, José Afonso da. Comentário contextual à Constituição. 6. ed. São Paulo: Malheiros, 2009.

Curso de Direito Constitucional positivo. 18. ed. São Paulo: Malheiros, 2000.

SILVA, Ricardo Perlingeiro Mendes da. Anotações sobre o anteprojeto de lei de cooperação jurídica internacional. Revista de Processo, Nov. 2005, n. 129. pp. 133-160. 
Cooperação jurídica internacional e auxílio direto. O Direito Internacional Contemporâneo - Estudos em Homenagem ao Professor Jacob Dolinger. Rio de Janeiro: Renovar, 2006. pp. 797-809.

SILVA, Valéria Guimarães de Lima e. Direito antitruste: aspectos internacionais. Curitiba: Juruá, 2007.

SLAUGHTER, Anne-Marie. Sovereignty and power in a Networked World Order. Stanford Journal of International Law, 2004, n. 40.

SOKOL, D. Daniel. International antitrust institutions. Cooperation, Comity and Competition Policy. New York: Oxford University Press, 2011. pp. 187-213.

STEPHAN, Paul B. The problem with cooperation. Cooperation, Comity and Competition Policy. New York: Oxford University Press, 2011. pp. 217-227.

SWAINE, Edward T. Cooperation, Comity and Competition Policy: United States. In: Cooperation, Comity and Competition Policy. New York: Oxford University Press, 2011. pp. 3-20.

TAUFICK, Roberto Domingos. Nova lei antitruste brasileira. Rio de Janeiro: Forense; São Paulo: Método, 2012.

TAVARES DE ARAÚJO JR., José. Política de concorrência no Mercosul: uma agenda mínima. Ago. 2001. Disponível em: <http://www.sedi.oas.org/DTTC/TRADE/ PUB/STAFF_ARTICLE/tav01_conc_agenda.asp>. Acesso em: 22 out. 2009.

TERHECHTE, Jörg Philipp. International competition enforcement law: between cooperation and convergence. New York: Springer, 2011.

THORSTENSEN, Vera. A OMC - Organização Mundial do Comércio e as negociações sobre investimentos e concorrência. Revista Brasileira Política Internacional, 1998, v. 41 (1). pp. 57-89.

TOKESHI, Helcio; MONTEIRO, Carmen Diva. Worldwide mergers: a brazilian perpective. Competition Law International, out. 2005.

TRINDADE, Antônio Augusto Cançado. O direito internacional em transformação: Ensaios, 1976-2001. Rio de Janeiro: Renovar, 2002.

VAZ, Isabel. Legislação de defesa da concorrência e extraterritorialidade. Revista do Instituto Brasileiro de Estudos das Relações de Concorrência e de Consumo IBRAC. São Paulo, 1997, v. 4, n. 6. pp. 263-274.

VERGUEIRO, Luiz Fabricio Thaumaturgo. Implementação da cooperação jurídica internacional vertical. Doutorado em Direito (Tese) - Faculdade de Direito da Universidade de São Paulo. São Paulo, 2012.

WHISH, Richard. Competition Law. 6. ed. New York: Oxford University Press, 2009. 


\section{Documentos oficiais/publicações}

INTERNATIONAL COMPETITION NETWORK. Guiding principles for merger notification and review. Disponível em: http://www.internationalcompetition network.org/uploads/library/doc591.pdf. Acesso em: 08 jul. 2010).

International competition network's framework for merger review cooperation. Japan Fair Trade Commission, março, 2012. Disponível em: http://www.jftc.go.jp/en/policy_enforcement/speeches/pdf/1Framework\%20for\%20Merger \%20Review\%20Cooperation.pdf. Acesso em: 01 dez. 2012.

Recommended practices for merger notification procedures. Jun. 2005. Disponível em: http://www.internationalcompetitionnetwork.org/uploads/library/doc588. pdf. Acesso em: 08 jul. 2010.

Waivers of confidentiality in mergers investigations. Disponível em: http://www.internationalcompetitionnetwork.org/uploads/library/doc330.pdf. Acesso em: 08 jul. 2010.

MERGERMARKET; MERRILL DATASITE. The future of M\&A. 2011. Disponível em: <http://www.datasite.com>. Acesso em: 15 fev. 2011.

ORGANIZAÇÃO PARA A COOPERAÇÃO E DESENVOLVIMENTO ECONÔMICO. IDB - Inter-american Development Bank. Lei e Política de Concorrência no Brasil: uma revisão pelos pares. Paris: OCDE, 2010. Disponível em: http://www.oecd.org/ daf/competition/45154401.pdf. Acesso em: 11 ago. 2012.

ORGANIZAÇÃO PARA A COOPERAÇÃO E DESENVOLVIMENTO ECONÔMICO. Global Forum on Competition - Improving International Co-operation in Cartel Investigations: Contribution from Brazil. Session 2. DAF/COMP/GF/WD(2012)32. Jan. 2012. Disponível em: http://search.oecd.org/officialdocuments/publicdisplaydocumentpdf/ ?cote=DAF/COMP/GF/WD(2012)32\&docLanguage=En. Acesso em: 18 nov. 2012.

Global Forum on Competition - Roundtable on Cross-Border Merger Control: Challenges for Developing and Emerging Economies: Contribution from Brazil. Session 1. DAF/COMP/GF(2011)13, p. 107-111. Dez. 2010. Disponível em: http://www.oecd.org/ competition/mergers/50114086.pdf. Acesso em: 18 nov. 2012.

Global Forum on Competition - Roundtable on Cross-Border Merger Control: Challenges for Developing and Emerging Economies: Contribution from UNCTAD. DAF/COMP/GF/WD(2011)8. Jan. 2011. Disponível em: http://search.oecd.org/official documents/displaydocumentpdf/?cote=DAF/COMP/GF/WD(2011)8\&docLanguage=En. Acesso em: 01 dez. 2012.

Global Forum on Competition - Roundtable on Cross-Border Merger Control: Challenges for Developing and Emerging Economies: Contribution from United States. DAF/COMP/GF/WD(2011)29. Session 1. Fev. 2011. Disponível em: http://www.ftc.gov/ bc/international/docs/1102crossbordermergercontrol.pdf. Acesso em: 01 dez. 2012. 
Merger Cases in the Real World - A study of Merger Control Procedures. Paris: OCDE, 1994. Disponível em: http://www.oecd.org/dataoecd/4/40/31587583.pdf. Acesso em: 09 jul. 2010.

Recommendations \& Best Practices. Recommendation of the Council on Merger Review. Paris: OCDE, 2005. Disponível em: http://www.oecd.org/document/44/ 0,3343,en_2649_34715_44940780_1_1_1_1,00.html. Acesso em: 09 jul. 2010.

Recommendation concerning co-operation between member countries on anticompetitive practices affecting international trade. Paris: OCDE, 1995. Disponível em: http://www.oecd.org/dataoecd/60/42/21570317.pdf. Acesso em: 09 jul. 2010.

UNCTAD. Report of the Sixth United Nations Conference to Review All Aspects of the Set of Multilaterally Agreed Equitable Principles and Rules for the Control of Restrictive Business Practices. Disponível em: http://unctad.org/en/docs/ tdrbpconf7d11_en.pdf. Acesso em: 04 nov. 2012.

UNIÃO EUROPEIA. A Comissão proíbe a aquisição da Honeywell pela GE. Comunicado de Imprensa $\mathrm{n}^{\mathrm{o}}$ IP/01/939 de 03/07/2001. Disponível em: $<$ http://europa.eu/rapid/pressReleasesAction.do?reference=IP/01/939\&format=HTML\&ag ed=1\&language $=P T \&$ guiLanguage $=e n>$. Acesso em: 28 ago. 2012.

International co-operation in antitrust matters: making the point in the wake of the Boeing/MDD proceedings. Disponível em: <http://ec.europa.eu/competition/ speeches/text/sp1998_004_en.html>. Acesso em: 04 nov. 2012.

US-EU MERGER WORKING GROUP. Best Practices on Cooperation in Merger Investigations. 2011. Disponível em: http://ec.europa.eu/competition/international/ bilateral/eu_us.pdf. Acesso em: 17 nov. 2012).

\section{Obras Consultadas}

ABADE, Denise Neves. Direitos fundamentais na cooperação jurídica internacional. São Paulo: Saraiva, 2013.

ARAÚJO, Nádia de. A importância da cooperação jurídica internacional para a atuação do Estado brasileiro no plano interno e internacional. Direito Internacional: homenagem a Adherbal Meira Mattos. São Paulo: Quartier Latin, 2009. pp. 98-114.

BARBOSA, Denis Borges. A aplicação da lei brasileira no direito internacional da concorrência. 1980. Disponível em: <http://denisbarbosa.addr.com/55.doc>. Acesso em: 20 out. 2009.

CAMPELLO, Dyle. O Direito da Concorrência no Direito Comunitário Europeu: uma Contribuição ao Mercosul. Rio de Janeiro: Renovar, 2001.

CARVALHO, Vinícius Marques de; MARTINS, Amanda Athayde Linhares; FONTANA, Bernardo Becker. Cartéis Internacionais e Defesa da Concorrência no Brasil. Revista do 
IBRAC - Direito da Concorrência, Consumo e Comércio Internacional. São Paulo, jul. 2011, v. 20. p. 137 e ss.

CASELLA, Paulo Borba. Soberania e aplicação do direito da concorrência na CE e no Mercosul. Revista de Informação Legislativa. Brasília: Senado Federal, jan./mar. 1994, ano 31, n. 121. pp. 117-143. Disponível em: <http://www2.senado.gov.br/bdsf/item/ id/176228>. Acesso em: 27 out. 2012.

FRANCESCHINI, José Inácio Gonzaga. Direito da concorrência - Case law. São Paulo: Singular, 2000.

GRINBERG, Mauro. A concorrência entre empresas perante o Mercosul: enfoque específico sobre Brasil e Argentina face à legislação antitruste. Revista de Direito Mercantil, Industrial, Econômico e Financeiro. Jan./mar. 1993, ano XXXII, n. 89. pp. 56-64.

JACKSON, Vicki C. Constitutional comparisons: convergence, resistance, engagement. Harvard Law Review, 2005-2006, v. 119.

JAEGER JÚNIOR, Augusto. Direito Internacional da Concorrência. In: GUERRA, Sidney (coord.). Tratado de Direito Internacional. Rio de Janeiro: Freitas Bastos, 2008. pp. 423456.

MADRUGA FILHO, Antenor P. O Brasil e a Jurisprudência do STF na Idade Média da cooperação jurídica internacional. Revista Brasileira de Ciências Criminais, maio/jun. 2005, v. 54. pp. 291-311.

MAGALHÃES, José Carlos de; SAMPAIO, Onofre Carlos de Arruda. A concentração de empresas e a competência do CADE. Revista de Direito Mercantil, Industrial, Econômico e Financeiro. São Paulo: Malheiros, jan./mar. 1999, ano 37, v. 113. pp. 30-44.

MATEUS, Abel M. Sobre os fundamentos do direito e economia da concorrência. Revista da Ordem dos Advogados Portugueses. Lisboa: Guerra, dez. 2006, ano 66. pp. 10671099.

MEIRELLES, Elizabeth. Comunidade Andina. Blocos Econômicos e Integração na América Latina, África e Ásia. Curitiba: Juruá, 2008. pp. 161-176.

MENEZES, Wagner (org.). Direito Internacional em expansão. $10^{\circ}$ Congresso Brasileiro de Direito Internacional. Anais... Belo Horizonte: Arrais, 2012, v. II.

MERCADANTE, Araminta de Azevedo; CELLI JR., Umberto; ARAÚJO, Leandro Rocha de (coords.). Blocos econômicos e integração na América Latina, África e Ásia. Curitiba: Juruá, 2008.

OLIVEIRA, Amanda Flavio de. O direito da concorrência e o Poder Judiciário. São Paulo: Forense, 2002.

OLIVEIRA, Luiz Philipe Ferreira de. A cooperação jurídica em matéria internacional e a atuação brasileira. Direito Internacional em expansão. Belo Horizonte: Arraes, 2012, v. II. pp. 97-107. 
PINHEIRO, Luís de Lima. Direito Comercial Internacional. Coimbra: Almedina, 2005.

POSSAS, Mário (coord.). Ensaios sobre economia e Direito da Concorrência. São Paulo: Singular, 2002.

RODAS, José Grandino. Antitrust and the Judiciary: the experience from Brazil. O Direito Internacional Contemporâneo - Estudos em homenagem ao professor Jacob Dolinger. Rio de Janeiro: Renovar, 2006. pp. 535-547.

SERENS, M. Nogueira; MAIA, Pedro. Legislação comunitária nacional de defesa da concorrência. Coimbra: Almedina, 1994.

SEVERINO, Antônio Joaquim. Metodologia do trabalho científico. 23. ed. São Paulo: Cortez, 2007.

TIBÚRCIO, Carmen; BARROSO, Luís Roberto (orgs.). O Direito Internacional contemporâneo: estudos em homenagem ao Professor Jacob Dolinger. Rio de Janeiro: Renovar, 2006.

TIMM, Luciano Benetti. Jurisdiction, Cooperation, Comity and Competition Policy in Brazilian International Antitrust Law. Cooperation, Comity and Competition Policy. New York: Oxford University Press, 2011. pp. 63-82.

\section{Sítios na Internet}

CADE. Disponível em: http://www.cade.gov.br. Acesso em: 02 dez. 2012.

FTC - FEDERAL TRADE COMMISSION. Disponível em: http://www.ftc.gov/. Acesso em: 01 dez. 2012.

ICN - INTERNATIONAL COMPETITION NETWORK. Disponível em: http://www. internationalcompetitionnetwork.org/. Acesso em: 01 dez. 2012.

JUSTIA - US SUPREME COURT CENTER. Disponível em: http://supreme.justia.com/. Acesso em: 10 jul. 2011.

MERCOSUL - MERCADO COMUM DO SUL. Disponível em: http://www.mercosur.int/. Acesso em: 02 dez. 2012.

OCDE - ORGANIZAÇÃO PARA A COOPERAÇÃO E DESENVOLVIMENTO ECONÔMICO. Disponível em: http://www.oecd.org/. Acesso em: 01 dez. 2012.

OMC - ORGANIZAÇÃO MUNDIAL DO COMÉRCIO. Disponível em: http://www.wto.org/. Acesso em: 01 dez. 2012.

ONU - ORGANIZAÇÃO DAS NAÇÕES UNIDAS. Disponível em: http://www.un.org/. Acesso em: 01 dez. 2012.

OPEN JURIST. Disponível em: http://openjurist.org/. Acesso em: 10 jul. 2011. 
Laker Airways Ltd. v. Sabena Belgian World Airways, 731 F. 2d 909 (DC Cir. 1984). Disponível em: http://openjurist.org/731/f2d/909/laker-airways-limited-v-sabenabelgian-world-airlines-klm-laker-airways-limited. Acesso em: 10 jul. 2011.

UNCTAD - CONFERÊNCIA DAS NAÇÕES UNIDAS PARA O COMÉRCIO E O DESENVOLVIMENTO. Disponível em: http://unctad.org/en/Pages/Home.aspx. Acesso em: 01 dez. 2012.

UNIÃO EUROPEIA. Disponível em: http://europa.eu/. Acesso em: 01 dez. 2012.

WORLD COURTS. Case Law of International Judicial and Quasi-Judicial Bodies. Disponível em: http://www.worldcourts.com/. Acesso em: 11 jul. 2011.

\section{Lista de Casos}

CORTE PERMANENTE DE JUSTIÇA INTERNACIONAL. Caso S. S. Lotus. França $v$. Turquia, Recueil dês Arrêts, série A, n. 10, 1927. Disponível em: <http://www.worldcourts.com/pcij/eng/decisions/1927.09.07_lotus.htm>. Acesso em: 11 jul. 2011.

ESTADOS UNIDOS DA AMÉRICA DO NORTE. Caso American Banana Co. v. United Fruit Co, Suprema Corte, 213 U.S. 347 (1909). Disponível em: <http://supreme.justia.com/ us/213/347/case.html>. Acesso em: 10 jul. 2011. $\overline{\text { U.S. } 690}$ (1962).

Caso Continental Ore Co. v. Union Carbide and Carbon Corp, Suprema Corte, 370

Caso Estados Unidos v. Aluminium Corp. of America et. al. (Alcoa), Corte do Segundo Distrito, n. $144 \quad 148 \quad$ F.2d $416 \quad$ (1945). Disponível em: <http://myweb.clemson.edu/ maloney/424/alcoa.pdf>. Acesso em: 10 jul. 2011.

Caso Estados Unidos v. Imperial Chemical Industries, Ltd., Corte Distrital de Nova Iorque, 100, F. Supp. 504 (S.D. N.Y. 1951).

. Caso Estados Unidos v. Sisal Sales Corp, Suprema Corte, 274 U.S. 268 (1927). Disponível em: <http://supreme.justia.com/us/274/268/>. Acesso em: 10 jul. 2011.

Caso Estados Unidos v. The Watchmakers of Switzerland Information Center, Corte Distrital de Nova Iorque, 133, F. Supp. 40 (S.D. N.Y. 1955).

(1993).

Caso Hartford Fire Insurance Co. v. California, Suprema Corte, 113 S.Ct. 2891

Caso Laker Airways Ltd. v. Sabena Belgian World Airways, Corte Distrito de Columbia, 731 F. 2d 909 (DC Cir. 1984). Disponível em: <http://openjurist.org/731/f2d/909/laker-airways-limited-v-sabena-belgian-world-airlinesklm-laker-airways-limited>. Acesso em: 10 jul. 2011.

Caso Mannington Mills, Inc. v. Congoleum Corp, Corte do Terceiro Distrito, 595 F. 2d 1287 (3rd Circ 1979). Disponível em: <http://law.justia.com/cases/federal/appellatecourts/F2/595/1287/324597/>. Acesso em: 10 jul. 2011. 
Caso Timberlane Lumber Co. v. Bank of America, Corte do Nono Distrito, 549 F. 2d 597 (9th Cir. 1976). Disponível em: <http://openjurist.org/749/f2d/1378/timberlanelumber-company-v-bank-of-america-national-trust-and-savings -association>. Acesso em: 10 jul. 2011.

ORGANIZAÇÃO MUNDIAL DO COMÉRCIO. Caso Japan - Measures Affecting Consumer Photographic Film and Paper, Estados Unidos v. Japão, Relatório do painel, WR/DS44/R, 31 de março de 1998.

REPÚBLICA FEDERATIVA DO BRASIL. Caso 3M Company/Grafoplast S.p.A., CADE, Ato de Concentração CADE nº 8012.011065/2008-19.

- Caso AGO Corporation e Kone Corporation (ADCO/KONE), CADE, Ato de Concentração CADE nº 08012.007603/2003-66.

. Caso Aticus Corporation/Texas International Inc., CADE, Ato de Concentração CADE n 132/1997.

Caso Carlyle Group Co-Invest GP Limited/Qinetiq Group Plc., CADE, Ato de Concentração CADE nº 08012.009254/2002-36.

. Caso Compagnie de Saint-Gobain/Owens Corning, CADE, Ato de Concentração CADE $n^{\circ} 08012.001885 / 2007-11$.

. Caso do Cartel das Vitaminas. CADE. Processo administrativo CADE $\mathrm{n}^{\circ}$ 08012.004599/1999-18.

Caso Dow Brasil S/A e da Rohm and Haas Química Ltda. (Dow/Rohm Haas), CADE, Ato de Concentração CADE nº 08012.007982/2008-07.

Caso Eaton s.a.m Monaco/Borg Warner Transmissions Systems Inc. (Eaton Monaco/Borg Warner), CADE, Ato de Concentração CADE nº 08012.009358/2006-74.

- Caso E.I Dupont de Nemours and Company/Chemtura Corporation (DuPont/Chemtura), CADE, Ato de Concentração CADE nº 08012.001312/2008-79.

- Caso General Electric Company/Alstom France S.A., CADE, Ato de Concentração CADE nº 08012.005572/99-99.

Caso General Electric Company/Alstom France S.A., Superior Tribunal de Justiça, Recurso Especial no 615.628-DF julgado em 21 de junho de 2009 (Rel. Ministro Herman Benjamin).

Caso General Electric Company/Honeywell International Inc. (GE/Honeywell), CADE, Ato de Concentração CADE nº 08012.006014/00-18. 120/1997.

Caso Henkel KGaA/Loctite Corporation, CADE, Ato de Concentração CADE $n^{\circ}$ 
Caso MCI Worldcom Inc./Sprint Corporation, CADE, Ato de Concentração CADE no 53500.005134/1999.

. Caso Nalco Chemical Company/Exxon Corporation, CADE, Ato de Concentração CADE $n^{\circ} 28 / 1995$

Caso NSK Ltd./NSK Torrignton Co. Ltd., CADE, Ato de Concentração CADE $n^{\circ}$ 08012.005749/2003-77.

Caso Schwinn GT Corp./Pacific Cycle, LLC., CADE, Ato de Concentração CADE $\left.n^{\circ} 08012.006025 / 2001-89\right)$.

. Caso Toshiba Medical Visualization Systems Europe Limited e Barco NV, CADE, Ato de Concentração CADE nº 08012.011733/2008-16.

. Caso Wyeth/Pfizer Inc. (Wyeth/Pfizer), CADE, Ato de Concentração CADE $n^{\circ}$ 08012.001157/2009-71.

UNIÃO EUROPEIA. Caso A. Ahlström Oy v Comissão Europeia (Wood Pulp), casos n. C-89, 104, 114, 116, 117 e 125-9/85, Tribunal de Justiça da União Europeia, j. 27 set. 1988 .

. Caso Boeing Company/McDonnell Douglas (Boeing/McDonnell Douglas), Comissão Europeia, Decisão no 97/816, de 30 jul 1997, JO L 336, 8 dez 1997.

Caso Boeing Company/Aerospatiale SNI, Alenia-Aeritalia e Selenia SpA (Aerospatiale-Alenia/de Havilland), Comissão Europeia, Processo $n^{\circ}$ IV/M.053, decisão em 2 out 1991, JO L 334, 05 dez 1991.

Caso Ciba-Geigy Limited/Sandoz Ltd. (Ciba-Geisy/Sandoz), Comissão Europeia, Processo nº M.737, decisão 17 jul 1996, JO L 201, 29 jul 1997.

Caso General Electric Company/Honeywell International Inc. (GE/Honeywell), Comissão Europeia, Processo n ${ }^{\circ}$ M.2220, decisão 03 jul 2001, JO L 48, 18 fev 2004.

Caso Sprint Corporation/MCI Worldcom (Sprint/MCI), Comissão Europeia, Processo nº M.1741, decisão 28 jun 2000, JO L 300, 18 nov 2003.

Caso WorldCom Inc./MCI Communications Corporation (WorldCom/MCI), Comissão Europeia, Decisão no 287/99, 8 jul 1998, JO L 116, 4 maio 1999. 
ANEXOS 
ANEXO A

\section{ACORDOS BILATERAIS CELEBRADOS ENTRE ESTADOS UNIDOS E A UNIÃO EUROPEIA}

\begin{tabular}{|c|c|c|}
\hline $\begin{array}{l}\text { País/BLOCO } \\
\text { DATa }\end{array}$ & $\begin{array}{c}\text { ESTADOS UNIDOS X UE } \\
21 / 09 / 1991\end{array}$ & $\begin{array}{l}\text { ESTADOS UNIDOS X UE } \\
04 / 06 / 1998\end{array}$ \\
\hline NOME & $\begin{array}{l}\text { Agreement between the Government of the } \\
\text { United States of America and the Commission of } \\
\text { the European Communities regarding the } \\
\text { Application of their Competition Laws }\end{array}$ & $\begin{array}{l}\text { Agreement between the European Communities } \\
\text { and the Government of the United States of } \\
\text { America on the Application of Positive Comity } \\
\text { Principles in the Enforcement of their Competition } \\
\text { Laws }\end{array}$ \\
\hline PARTES & $\begin{array}{l}\text { Governo dos Estados Unidos da América e } \\
\text { União Europeia }\end{array}$ & $\begin{array}{l}\text { Governo dos Estados Unidos da América e União } \\
\text { Europeia }\end{array}$ \\
\hline $\begin{array}{l}\text { RECEPÇÃO NO } \\
\text { ORDENAMENTO }\end{array}$ & $\begin{array}{l}\text { UE: Decisão do Conselho e da Comissão de } 10 \\
\text { de abril de } 1995 \text { (95/145/EC, ECSC) }\end{array}$ & UE: OJ L 173 de 18/06/1998. \\
\hline TIPO & \begin{tabular}{|llllll}
$\begin{array}{l}\text { Cooperação } \\
\text { concorrência }\end{array}$ & de & aplicação & das & leis & de \\
\end{tabular} & Cortesia Positiva (práticas anticoncorrenciais) \\
\hline NATUREZA & Formal (tratado internacional) & Formal (tratado internacional) \\
\hline $\begin{array}{l}\text { ÂMBITO DE } \\
\text { APLICAÇÃO } \\
\text { (ATOS DE } \\
\text { CONCENTRA- } \\
\text { ÇÃO) }\end{array}$ & $\begin{array}{l}\text { Art. 1.2.A - definição de "leis da concorrência" } \\
\text { incluem regras de controle de concentração } \\
\text { econômica. } \\
\text { Art. 1.2.C - "atividades de aplicação" significa } \\
\text { qualquer aplicação de leis da concorrência por } \\
\text { meio de investigação ou procedimento } \\
\text { conduzido por autoridade de defesa da } \\
\text { concorrência. } \\
\text { Art. } 2.2 \text { - dentre atividades de aplicação constam } \\
\text { (c) as concentrações econômicas em que uma ou } \\
\text { mais partes da operação, ou sociedade } \\
\text { controlando tais partes, seja sociedade } \\
\text { constituída ou organizada de acordo com as leis } \\
\text { da outra parte do acordo, ou dos seus Estados ou } \\
\text { Estados-Membros; (d) envolvam conduta que se } \\
\text { entenda estar submetida à análise da outra parte; } \\
\text { e (e) envolva vias de reparação que possam } \\
\text { significativamente se relacionar, requerer ou } \\
\text { proibir conduta no território da outra parte. }\end{array}$ & $\begin{array}{l}\text { Art. } 1.1-\text { o acordo aplica-se às práticas } \\
\text { anticoncorrenciais que ocorram no território de } \\
\text { uma das partes e tenham efeitos no território da } \\
\text { outra parte e que sejam incriminadas no território } \\
\text { onde sejam praticadas. } \\
\text { Art. } 2, \mathrm{n}^{\circ} 4 \text { - aplica-se tão somente às práticas } \\
\text { anticoncorrenciais, excluindo expressamente do } \\
\text { seu âmbito de aplicação os procedimentos de } \\
\text { controle de atos de concentração. }\end{array}$ \\
\hline $\begin{array}{l}\text { NOTIFICAÇãO } \\
\text { ENTRE } \\
\text { AUTORIDADES }\end{array}$ & $\begin{array}{l}\text { Art.2.3 - regras sobre quando as notificações } \\
\text { relacionadas a atos de concentração devem se } \\
\text { realizar. } \\
\text { Art. } 2.6 \text { - as notificações devem incluir } \\
\text { informações suficientes que permitam uma } \\
\text { avaliação inicial pela parte recipiente sobre } \\
\text { qualquer efeito sobre seus interesses. } \\
\text { Art. } 10 \text { - as comunicações trocadas com base no } \\
\text { acordo o poderão ser através de contato verbal, } \\
\text { telefônico, escrito ou via fax. Já as notificações } \\
\text { relacionadas à cortesia positiva e negativa } \\
\text { deverão ser realizadas por escrito através de vias } \\
\text { diplomáticas. }\end{array}$ & - \\
\hline $\begin{array}{l}\text { CORTESIA } \\
\text { NeGATIVA }\end{array}$ & $\begin{array}{l}\text { Art. } 2.1 \text { - as partes devem notificar uma à outra } \\
\text { sempre que a autoridade de defesa da } \\
\text { concorrência tomar conhecimento que suas } \\
\text { atividades de aplicação possam afetar interesses } \\
\text { importantes da outra parte. } \\
\text { Art. 5.1 - as partes tomarão as medidas } \\
\text { necessárias para coibir práticas que possam } \\
\text { violar a legislação concorrencial e forem } \\
\text { contrárias aos interesses relevantes da outra } \\
\text { parte. }\end{array}$ & - \\
\hline
\end{tabular}




\begin{tabular}{|c|c|c|}
\hline $\begin{array}{l}\text { País/Bloco } \\
\text { DATa }\end{array}$ & $\begin{array}{c}\text { ESTADOS UNIDOS X UE } \\
21 / 09 / 1991\end{array}$ & $\begin{array}{c}\text { ESTADOS UNIDOS X UE } \\
04 / 06 / 1998\end{array}$ \\
\hline $\begin{array}{l}\text { CORTESIA } \\
\text { Positiva }\end{array}$ & $\begin{array}{l}\text { Art. 5.2 - uma parte poderá notificar a outra para } \\
\text { que inicie atividades de aplicação contra práticas } \\
\text { que ocorram no território da outra parte que } \\
\text { possam afetar seus interesses relevantes. A } \\
\text { notificação deverá conter informações } \\
\text { detalhadas e oferta de maiores informações e } \\
\text { outras formas que cooperação que possam } \\
\text { auxiliar a outra parte. } \\
\text { Art. } 5.3 \text { - a parte notificada decidirá se iniciará } \\
\text { ou expandirá ou não as atividades de aplicação } \\
\text { relacionadas e comunicará a parte requerente da } \\
\text { sua decisão. A parte requerida deverá notificar a } \\
\text { requerente sobre os resultados das atividades de } \\
\text { aplicação e, quando possível, dos } \\
\text { desenvolvimentos internos. } \\
\text { Art. 5.4 - a cortesia positiva é facultativa: } \\
\text { nenhuma disposição do art. } 5 \text { limitará a } \\
\text { discricionariedade da parte requerida sobre } \\
\text { iniciar ou não atividades de aplicação sobre a } \\
\text { prática objeto da notificação ou obstará que a } \\
\text { parte requerente conduza atividades de aplicação } \\
\text { sobre tais práticas. }\end{array}$ & $\begin{array}{l}\text { Art. } 3 \text { - qualquer parte por requerer às autoridades } \\
\text { de defesa da concorrência da outra que iniciem } \\
\text { investigações e deem resolução às atividades } \\
\text { anticoncorrenciais de acordo com a legislação de } \\
\text { defesa da concorrência da parte requerida. Tal } \\
\text { solicitação pode ocorrer mesmo que a prática } \\
\text { objeto do requerimento não seja repreendida pela } \\
\text { legislação de defesa da concorrência da parte } \\
\text { requerente ou no caso de as autoridades da parte } \\
\text { requerente não tenham iniciado ainda } \\
\text { procedimentos para repreender tal prática, nos } \\
\text { auspícios da sua respectiva legislação. } \\
\text { Art. } 4 \text { - possibilidade de as autoridades de defesa } \\
\text { da concorrência acordarem a suspensão ou } \\
\text { deferimento das atividades de aplicação da parte } \\
\text { requerente, durante o período em que a parte } \\
\text { requerida estiver em processo de execução das } \\
\text { atividades de aplicação requeridas pela } \\
\text { cooperação. Este dispositivo estabelece critérios } \\
\text { objetivos a serem observados pelas partes na } \\
\text { hipótese de suspensão ou deferimento das } \\
\text { atividades de aplicação. O parágrafo } 4 \text { do art. } 4 \\
\text { expressamente prevê que as autoridades de defesa } \\
\text { da concorrência que tiverem optado por diferir ou } \\
\text { suspender as suas medidas de execução poderão } \\
\text { tomar ou retomar posteriormente a execução ou } \\
\text { investigação das condutas anticoncorrenciais }\end{array}$ \\
\hline REt & $\begin{array}{l}\text { Art. } 3.2 \text { - servidores das autoridades se reunião } \\
\text { duas vezes ao ano para troca de informações e } \\
\text { discussões relacionadas às suas atividades. } \\
\text { Art. } 3.3 \text { - troca de informações que forem } \\
\text { levadas a conhecimento da autoridade sobre } \\
\text { práticas anticoncorrenciais que possam ser } \\
\text { relevantes ou garantam atividades de aplicação } \\
\text { pelas outras autoridades. } \\
\text { Art. } 3.4 \text { - possibilidade de uma parte pedir à } \\
\text { outra a entrega de informações. }\end{array}$ & - \\
\hline $\begin{array}{l}\text { TROCA E } \\
\text { COMPARTILHA- } \\
\text { MENTO DE } \\
\text { INFORMAÇÕES } \\
\quad(\text { GERAL) }\end{array}$ & $\begin{array}{l}\text { Art. } 3.1 \text { - previsão de troca de informações que } \\
\text { facilitem a aplicação das respectivas leis da } \\
\text { concorrência e promovam melhor entendimento } \\
\text { entre as partes das condições econômicas e } \\
\text { teorias relevantes às atividades de aplicação e } \\
\text { intervenções das autoridades. }\end{array}$ & $\begin{array}{l}\text { Art. } 5 \text { - as informações compartilhadas devem ser } \\
\text { utilizadas somente para os propósitos subjacentes } \\
\text { ao compartilhamento em questão, a não ser que } \\
\text { seja autorizado uso diverso pela parte que } \\
\text { disponibilizou a informação e, nos casos de } \\
\text { informação confidencial, a fonte da mesma. }\end{array}$ \\
\hline $\begin{array}{c}\text { TROCA E } \\
\text { COMPARTILHA- } \\
\text { MENTO DE } \\
\text { INFORMAÇÕES } \\
\text { CONFIDENCIAIS }\end{array}$ & $\begin{array}{l}\text { Art. 8.1 - nenhuma parte está obrigada a fornecer } \\
\text { informações à outra parte em violação de lei } \\
\text { aplicável ou cujo compartilhamento seja } \\
\text { contrário aos interesses relevantes da parte } \\
\text { detentora da informação. } \\
\text { Art. } 8.2 \text { - as partes concordam em, na medida do } \\
\text { possível, manter a confidencialidade de qualquer } \\
\text { informação confidencial compartilhada e se opor } \\
\text { à sua divulgação a terceiros não autorizados pela } \\
\text { parte provedora da informação. }\end{array}$ & - \\
\hline
\end{tabular}




\begin{tabular}{|c|c|c|}
\hline $\begin{array}{c}\text { País/Bloco } \\
\text { DAta }\end{array}$ & $\begin{array}{c}\text { ESTADOS UNIDOS X UE } \\
21 / 09 / 1991\end{array}$ & $\begin{array}{c}\text { ESTADOS UNIDOS X UE } \\
04 / 06 / 1998\end{array}$ \\
\hline $\begin{array}{c}\text { COORDENA- } \\
\text { ÇÃO ENTRE } \\
\text { AUTORIDADES }\end{array}$ & $\begin{array}{l}\text { Art. 4.1 - as autoridades proverão assistência } \\
\text { umas às outras nas suas atividades de aplicação, } \\
\text { consoante sejam compatíveis com a suas } \\
\text { legislações e interesses, e dentro das suas } \\
\text { possibilidades razoáveis. } \\
\text { Art. } 4.2 \text { - coordenação de esforços em casos de } \\
\text { matérias inter-relacionadas. As partes deverão } \\
\text { levar em consideração certos fatores: (a) uso } \\
\text { mais eficientes dos recursos das autoridades nas } \\
\text { atividades de aplicação; (b) habilidade da } \\
\text { autoridade em conseguir as informações para } \\
\text { condução das atividades de aplicação; (c) os } \\
\text { efeitos que tal coordenação poderá causar na } \\
\text { condução das atividades de aplicação; e (d) a } \\
\text { possibilidade de redução de custos das pessoas } \\
\text { envolvidas nas atividades de aplicação. } \\
\text { Art. } 4.4 \text { - as partes poderão a qualquer momento } \\
\text { interromper as atividades de coordenação } \\
\text { mediante notificação a ser enviada à outra parte. } \\
\text { Art. 6.3 - estabelece fatores a serem } \\
\text { considerados pelas partes nas atividades de } \\
\text { cooperação, dentre as quais se destaca a } \\
\text { relevância, o impacto e os efeitos das atividades } \\
\text { anticoncorrenciais nos territórios das partes do } \\
\text { acordo. }\end{array}$ & - \\
\hline OBSERVAÇÕES & $\begin{array}{l}\text { Art. } 6 \text { - as partes devem sempre levar em } \\
\text { consideração os interesses relevantes da outra } \\
\text { parte na condução de qualquer atividade de } \\
\text { aplicação. Este artigo estabelece parâmetros para } \\
\text { identificação dos "interesses relevantes" da outra } \\
\text { parte. }\end{array}$ & $\begin{array}{l}\text { Art. } 6 \text { - o acordo complementa e deve ser } \\
\text { interpretado de acordo com o acordo de 1991, o } \\
\text { qual permanece em vigor. }\end{array}$ \\
\hline
\end{tabular}




\section{ANEXO B \\ DECISÕES CMC/MERCOSUL RELEVANTES EM MATÉRIA DE COOPERAÇÃO}

\begin{tabular}{|c|c|c|c|}
\hline BLOCO & $\begin{array}{l}\text { MERCOSUL n' 04/2004 } \\
\text { 07/07/2004 }\end{array}$ & $\begin{array}{l}\text { MERCOSUL n' } 15 / 2006 \\
20 / 07 / 2006\end{array}$ & $\begin{array}{c}\text { MERCOSUL no 43/2010 } \\
16 / 12 / 2010\end{array}$ \\
\hline NoME & $\begin{array}{l}\text { Mercosul/CMC/DEC } \mathrm{n}^{\circ} \text { 04/2004 - Entendimento sobre } \\
\text { Cooperação entre Autoridades de Defesa da } \\
\text { Concorrência dos Estados-Partes do Mercosul para a } \\
\text { Aplicação de suas Leis Nacionais de Concorrência }\end{array}$ & $\begin{array}{l}\text { Mercosul/CMC/DEC. } \mathrm{n}^{\circ} 15 / 2006 \text { - Entendimento } \\
\text { sobre Cooperação entre as Autoridades de Defesa de } \\
\text { Concorrência dos Estados-Partes do Mercosul para o } \\
\text { Controle de Concentrações Econômicas de âmbito } \\
\text { regional }\end{array}$ & $\begin{array}{l}\text { Mercosul/CMC/DEC n } n^{\circ} 43 / 2010 \text { - Acordo de Defesa da } \\
\text { Concorrência do Mercosul }\end{array}$ \\
\hline PARTES & Conselho do Mercado Comum & Conselho do Mercado Comum & Conselho do Mercado Comum \\
\hline $\begin{array}{l}\text { INTERNALIZA- } \\
\text { ÇÃO NO BRASIL }\end{array}$ & $\begin{array}{l}\text { Portaria Conjunta CADE/SDE/SEAE nº 148, de } 13 \text { de } \\
\text { novembro de } 2009\end{array}$ & $\begin{array}{l}\text { Portaria Conjunta CADE/SDE/SEAE n }{ }^{\circ} 148 \text {, de } 13 \text { de } \\
\text { novembro de } 2009\end{array}$ & $\begin{array}{l}\text { O Acordo ainda não foi incorporado pelos ordenamentos } \\
\text { jurídicos dos Estados-Partes. Não foi possível localizar a } \\
\text { proposição legislativa do Acordo de Defesa da Concorrência } \\
\text { do Mercosul de } 2010 \text { junto ao Congresso Nacional. Tendo } \\
\text { em vista que esta decisão do CMC revogou o Protocolo de } \\
\text { Fortaleza, o qual havia sido incorporado no Brasil através do } \\
\text { Decreto no } 3.602 \text {, de } 18 \text { de setembro de } 2000 \text {, entende-se } \\
\text { necessária a proposição legislativa para que surta os devidos } \\
\text { efeitos no território nacional }\end{array}$ \\
\hline TIPO & $\begin{array}{l}\text { Cooperação de aplicação das leis de concorrência e } \\
\text { cooperação técnica }\end{array}$ & $\begin{array}{l}\text { Cooperação de aplicação das leis de concorrência e } \\
\text { cooperação técnica }\end{array}$ & $\begin{array}{l}\text { Cooperação de aplicação das leis de concorrência e } \\
\text { cooperação técnica }\end{array}$ \\
\hline NATUREZA & Formal (tratado internacional) & Formal (tratado internacional) & Informal (tratado internacional não internalizado | soft law) \\
\hline
\end{tabular}




\begin{tabular}{|c|c|c|c|}
\hline BLOCO & $\begin{array}{c}\text { MERCOSUL n' 04/2004 } \\
\text { 07/07/2004 }\end{array}$ & $\begin{array}{c}\text { MERCOSUL no }^{0} 15 / 2006 \\
20 / 07 / 2006\end{array}$ & $\begin{array}{c}\text { MERCOSUL no }^{0} 43 / 2010 \\
16 / 12 / 2010\end{array}$ \\
\hline $\begin{array}{c}\text { ÂMBITO DE } \\
\text { APLICAÇÃO } \\
\text { (ATOS DE } \\
\text { CONCENTRAÇÃO) }\end{array}$ & $\begin{array}{l}\text { Art. } 2.2 \text { - "atividades de aplicação" compreendem } \\
\text { quaisquer investigações ou procedimento conduzido } \\
\text { por uma autoridade no marco da sua legislação de } \\
\text { defesa da concorrência, inclusive aquelas que } \\
\text { envolvam fusões ou aquisições em uma ou mais partes } \\
\text { da transação, ou uma empresa que controle uma ou } \\
\text { mais partes da transação, seja uma empresa constituída } \\
\text { ou organizada segundo as leis da outra parte, bem } \\
\text { como no caso de busca de informações localizadas no } \\
\text { território de outra parte - dentre outras hipóteses. } \\
\text { Envolvem atos de concentrações apresentados perante } \\
\text { uma das autoridades que em que estejam envolvidas } \\
\text { empresas constituídas e organizadas no território de } \\
\text { outra parte. Não abrange, a princípio, preocupação em } \\
\text { relação aos atos de concentrações que possam afetar o } \\
\text { mercado nacional dos outros Estados-Partes, quando } \\
\text { promovidos por empresas que não tenham sido lá } \\
\text { constituídas ou organizadas, tampouco o mercado do } \\
\text { Mercosul como um todo. }\end{array}$ & $\begin{array}{l}\text { Art. } 1 \text { - cooperação entre as autoridades de defesa da } \\
\text { concorrência dos Estados-Partes em relação ao } \\
\text { controle de concentrações econômicas conduzidas por } \\
\text { qualquer dos Estados Partes, mas englobam não } \\
\text { somente as concentrações que surtam efeitos nos } \\
\text { territórios de mais de um Estado-Parte, } \\
\text { individualmente considerado, como aquelas que } \\
\text { afetem o território do Mercosul como um todo. Inclui } \\
\text { não somente as concentrações que envolvam empresas } \\
\text { constituídas e organizadas em outros Estados-Partes, } \\
\text { mas também aquelas que surtam efeitos nos territórios } \\
\text { dos outros Estados-Partes. Esta alteração no âmbito de } \\
\text { aplicação das regras de cooperação, em relação à } \\
\text { decisão anterior, parece, desta forma, estar acertada } \\
\text { com a teoria dos efeitos. } \\
\text { Art. 4.1 - a cooperação pretendida refere-se à análise e } \\
\text { apreciação dos atos de concentração econômica. }\end{array}$ & $\begin{array}{l}\text { Art. 1 - objetivos (i) a promoção e da cooperação e da } \\
\text { coordenação entre os Estados-Partes no tocante à aplicação } \\
\text { das leis nacionais de concorrência no âmbito do Mercosul; } \\
\text { (ii) prover assistência mútua em qualquer matéria relativa à } \\
\text { política de concorrência que considerem necessária; (iii) } \\
\text { assegurar a consideração cuidadosa pelos Estados-Partes de } \\
\text { seus relevantes interesses recíprocos, na aplicação das } \\
\text { respectivas leis de concorrência; e (iv) eliminar práticas } \\
\text { anticompetitivas por meio da aplicação das respectivas leis } \\
\text { de concorrência. } \\
\text { Art. 2.d - menção expressa às concentrações econômicas, } \\
\text { conforme venham a ser definidas nas legislações nacionais } \\
\text { de defesa da concorrência dos Estados Parte. }\end{array}$ \\
\hline $\begin{array}{l}\text { COOPERAÇão } \\
\text { TÉCNICA }\end{array}$ & $\begin{array}{l}\text { Art. } 7 \text { - as partes reconhecem a relevância das } \\
\text { autoridades trabalharem conjuntamente na cooperação } \\
\text { técnica, a qual incluirá intercâmbio de informações e } \\
\text { de funcionários, para fins de treinamento, a realização } \\
\text { de conferências ou cursos de treinamento dentre outras } \\
\text { iniciativas. }\end{array}$ & $\begin{array}{l}\text { Art. } 7 \text { - as partes reconhecem a relevância das } \\
\text { autoridades trabalharem conjuntamente na cooperação } \\
\text { técnica, a qual incluirá intercâmbio de informações e } \\
\text { de funcionários, para fins de treinamento, a realização } \\
\text { de conferências ou cursos de treinamento dentre outras } \\
\text { iniciativas. }\end{array}$ & $\begin{array}{l}\text { Art. } 16 \text { - partes reconhecem cooperação técnica, } \\
\text { comprometendo-se a promover troca de conhecimentos e } \\
\text { informações, funcionários, realização de conferências e } \\
\text { cursos, dentre outros. }\end{array}$ \\
\hline $\begin{array}{l}\text { NOTIFICAÇÃO } \\
\text { ENTRE } \\
\text { AUTORIDADES }\end{array}$ & $\begin{array}{l}\text { Art.2.1 - Notificações devem indicar natureza das } \\
\text { práticas sujeitas à investigação e os instrumentos } \\
\text { legais pertinentes. No caso do Brasil, notificação deve } \\
\text { ser realizada em } 15 \text { dias a partir da publicação da } \\
\text { decisão que instaurar processo administrativo ou } \\
\text { investigação preliminar (condutas anticoncorrenciais) } \\
\text { ou da publicação que informa a notificação ao SBDC } \\
\text { de uma operação (atos de concentração). } \\
\text { Art. } 11 \text { - sistema de notificações diretas entre as } \\
\text { autoridades nacionais de defesa da concorrência, sem } \\
\text { prejuízo de que seja utilizado o canal diplomático por } \\
\text { solicitação de uma das partes. }\end{array}$ & 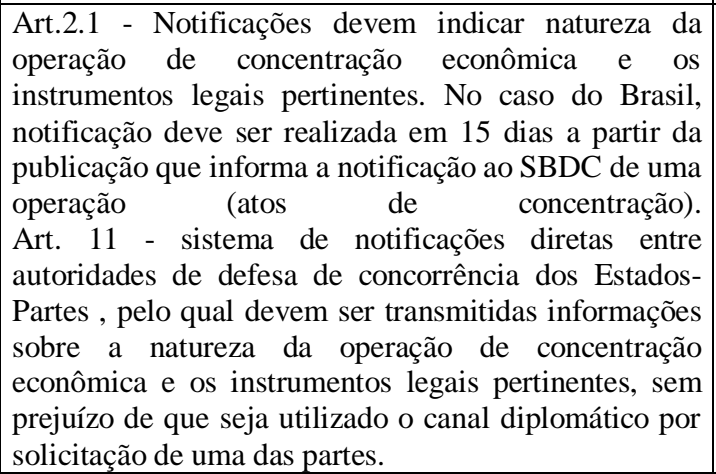 & $\begin{array}{l}\text { Art. } 6 \text { e } 13 \text { - as consultas a serem analisadas por autoridades } \\
\text { de defesa da concorrência de outro Estado-Parte devem ser } \\
\text { submetidas ao Comitê Técnico no } 5 \text {, para que este as } \\
\text { redirecione, independente de notificação prévia. A } \\
\text { autoridade que emitir tal decisão tem a obrigação de } \\
\text { informar a autoridade consultada sobre o teor da sua decisão } \\
\text { final, acompanhada das razões técnicas que a embasaram, } \\
\text { uma vez prolatada. }\end{array}$ \\
\hline
\end{tabular}




\begin{tabular}{|c|c|c|c|}
\hline BLOCO & $\begin{array}{c}\text { MERCOSUL no 04/2004 }^{0} \\
07 / 07 / 2004\end{array}$ & $\begin{array}{c}\text { MERCOSUL n }^{0} 15 / 2006 \\
20 / 07 / 2006\end{array}$ & $\begin{array}{c}\text { MERCOSUL no }^{\circ} 43 / 2010 \\
16 / 12 / 2010\end{array}$ \\
\hline $\begin{array}{l}\text { CORTESIA } \\
\text { NEGATIVA }\end{array}$ & $\begin{array}{l}\text { Art. } 6 \text { - os Estados-Partes deverão, na medida em que } \\
\text { seja admissível pela sua respectiva legislação nacional } \\
\text { e compatível com seus interesses fundamentais, } \\
\text { assegurar a consideração dos interesses fundamentais } \\
\text { das outras partes. }\end{array}$ & $\begin{array}{l}\text { Art. } 6 \text { - cada Estado-Parte deverá, na medida do } \\
\text { permitido pela respectiva legislação nacional e que } \\
\text { seja compatível com seus interesses fundamentais, } \\
\text { assegurar a consideração dos interesses fundamentais } \\
\text { dos demais Estados-Partes em todas as atividades de } \\
\text { aplicação, inclusive na apreciação do mérito. }\end{array}$ & $\begin{array}{l}\text { Art. } 20,21,22 \text { e } 23 \text { - acolhimento do princípio da cortesia } \\
\text { negativa ao estabelecer a obrigação de cada Estado-Parte, } \\
\text { dentro das suas possibilidades, em notificar os demais } \\
\text { Estados-Partes a respeito de qualquer ação de aplicação ou } \\
\text { execução que verse sobre matéria da concorrência, que de } \\
\text { uma forma ou outra seja do interesse da outra parte. Tal } \\
\text { notificação deve se dar na fase inicial dos processos e deverá } \\
\text { ser submetida através do Comitê Técnico n }{ }^{\circ} 5 \text {. }\end{array}$ \\
\hline $\begin{array}{l}\text { CORTESIA } \\
\text { Positiva }\end{array}$ & $\begin{array}{l}\text { Art. } 4.3 \text { - uma parte pode solicitar outra parte que } \\
\text { inicie procedimentos de cooperação quando perceber } \\
\text { que estão sendo levadas a cabo no território da outra } \\
\text { parte práticas que afetem adversamente os seus } \\
\text { interesses fundamentais. Solicitação deve conter } \\
\text { natureza das práticas e efeitos adversos sobre seus } \\
\text { interesses fundamentais, bem como incluir } \\
\text { informações que estejam em condição de serem } \\
\text { fornecidas. } \\
\text { Art. } 4.4 \text { - as autoridades deverão decidir que iniciarão } \\
\text { as atividades de aplicação solicitadas e comunicarão a } \\
\text { parte requerente da sua decisão. Também deverá } \\
\text { comunicar os resultados da investigação e progressos } \\
\text { significativos. } \\
\text { Art. } 4.5 \text { - a discricionariedade das autoridades não é } \\
\text { limitada pela Decisão, significando que as autoridades } \\
\text { mantêm livres para executar suas atividades consoante } \\
\text { as respectivas legislações. }\end{array}$ & $\begin{array}{l}\text { Art. 4.3 e } 4.4 \text { - na eventualidade de um Estado-Parte } \\
\text { entender que estão sendo levadas a cabo atividades de } \\
\text { aplicação em outro Estado-Parte, ele poderá solicitar } \\
\text { que as autoridades de defesa da concorrência do } \\
\text { Estado requerido que inicie os procedimentos de } \\
\text { cooperação previstos na decisão. A notificação, neste } \\
\text { caso, deverá indicar os possíveis efeitos adversos de } \\
\text { tal concentração econômica em relação a seus } \\
\text { interesses fundamentais e incluir o oferecimento de } \\
\text { informação e cooperação que tiver condições de } \\
\text { fornecer. Uma vez recebida a solicitação de } \\
\text { cooperação de outro Estado-Parte, a autoridade de } \\
\text { defesa da concorrência deverá avaliar se iniciará o } \\
\text { procedimento de cooperação e informar prontamente o } \\
\text { Estado solicitante sobre a sua decisão e sobre o } \\
\text { andamento e sobre eventuais medidas tomadas no } \\
\text { decorrer da atividade de aplicação que se relacione } \\
\text { com o mérito da operação. } \\
\text { Art. 4.5 - a discricionariedade das autoridades não é } \\
\text { limitada pela Decisão, significando que as autoridades } \\
\text { mantém livres para executar suas atividades consoante } \\
\text { as respectivas legislações. }\end{array}$ & $\begin{array}{l}\text { Art. } 5 \text { - sistema de consultas entre autoridades da } \\
\text { concorrência. Autoridades devem envidar seus melhores } \\
\text { esforços para responder as consultas no prazo de } 90 \text { dias do } \\
\text { recebimento. } \\
\text { Art. } 7 \text { - consultas podem tomar lugar quando uma parte } \\
\text { acredita que práticas ou concentrações econômicas ocorridas } \\
\text { no território de outra parte afetem seus interesses. } \\
\text { Art. } 8 \text { e } 12 \text { - autoridades permanecem livres para conduzir } \\
\text { suas atividades consoante respectivas legislações nacionais. } \\
\text { Art. } 9 \text {. - a autoridade consultada deve levar em consideração } \\
\text { os interesses da parte solicitante. } \\
\text { Art. } 10 \text { - autoridade consultada pode iniciar ou ampliar } \\
\text { atividades de aplicação consoante consulta recebida. } \\
\text { Art. } 11 \text { - a autoridade solicitada deve comunicar a solicitante } \\
\text { sobre medidas que venham a ser iniciadas, bem como sobre } \\
\text { o andamento de eventuais procedimentos relacionados à } \\
\text { consulta. } \\
\text { Art. } 13 \text { - consultas são conduzidas por intermédio do Comitê } \\
\text { Técnico n } 5 \text {. }\end{array}$ \\
\hline REUNIÕES & $\begin{array}{l}\text { Art. } 8 \text { - os funcionários das autoridades de defesa da } \\
\text { concorrência deverão se reunir periodicamente para } \\
\text { trocar informações sobre os esforços e prioridades na } \\
\text { aplicação das respectivas legislaçôes. }\end{array}$ & $\begin{array}{l}\text { Art. } 8 \text { - os funcionários das autoridades de defesa da } \\
\text { concorrência deverão se reunir periodicamente para } \\
\text { trocar informações sobre os esforços e prioridades na } \\
\text { aplicação das respectivas legislaçôes. }\end{array}$ & - \\
\hline $\begin{array}{l}\text { TROCA E } \\
\text { COMPARTILHA- } \\
\text { MENTO DE } \\
\text { INFORMAÇÕES } \\
\text { (GERAL) } \\
\end{array}$ & - & - & $\begin{array}{l}\text { Art. } 18 \text { e } 19 \text { - previsão de troca de informações entre } \\
\text { autoridades, dentre as quais informações sobre casos de } \\
\text { interesse, legislação e doutrina, jurisprudência, estudos } \\
\text { dentre outros. }\end{array}$ \\
\hline
\end{tabular}




\begin{tabular}{|c|c|c|c|}
\hline BLOCO & $\begin{array}{c}\text { MERCOSUL no }^{0} \text { 04/2004 } \\
\text { 07/07/2004 }\end{array}$ & $\begin{array}{c}\text { MERCOSUL n } \mathbf{n}^{0} 15 / 2006 \\
20 / 07 / 2006\end{array}$ & $\begin{array}{c}\text { MERCOSUL no }^{0} 43 / 2010 \\
16 / 12 / 2010\end{array}$ \\
\hline $\begin{array}{c}\text { TROCA E } \\
\text { COMPARTILHA- } \\
\text { MENTO DE } \\
\text { INFORMAÇÕES } \\
\text { CONFIDENCIAIS }\end{array}$ & $\begin{array}{l}\text { Art. } 9 \text { - nenhuma parte está obrigada a fornecer } \\
\text { informações às demais partes, se o provimento de tal } \\
\text { informação for proibido de acordo com a sua lei } \\
\text { nacional ou for incompatível com seus interesses } \\
\text { fundamentais. Todavia, as partes têm o dever manter a } \\
\text { confidencialidade com respeito às informações } \\
\text { fornecidas em confidencialidade por outra parte, não } \\
\text { podendo fornecê-la a terceiros. }\end{array}$ & $\begin{array}{l}\text { Art. } 9 \text { - nenhum Estado-Parte está obrigado a fornecer } \\
\text { informações a outro Estado, caso a entrega de tal } \\
\text { informação seja proibida de acordo com a legislação } \\
\text { nacional ou for incompatível com seus interesses } \\
\text { fundamentais. Por outro lado, cada Estado-Parte deve } \\
\text { manter a confidencialidade sobre as informações que } \\
\text { lhe forem fornecidas nesta qualidade, não lhe sendo } \\
\text { possível disponibilizar tal informação confidencial a } \\
\text { terceiros, sem que antes seja obtida anuência prévia do } \\
\text { Estado ofertante. }\end{array}$ & $\begin{array}{l}\text { Art. } 24 \text { - nenhum Estado-Parte está obrigado a fornecer aos } \\
\text { demais ou ao Comitê Técnico informações ou dados } \\
\text { confidenciais, em razão das respectivas legislações nacionais } \\
\text { da concorrência, ou por incompatibilidade com seus } \\
\text { interesses relevantes ou políticas governamentais. } \\
\text { Art. } 25 \text { - saldo disposição em contrário, todas as opiniões } \\
\text { apresentadas pelas partes devem ser consideradas como } \\
\text { confidenciais. } \\
\text { Art. } 26 \text { - as informações fornecidas devem ser utilizadas } \\
\text { para a finalidade para a qual foram compartilhadas. O uso de } \\
\text { tais informações para outras finalidade somente é permitido } \\
\text { após obtido o consentimento da parte provedora da } \\
\text { informação. }\end{array}$ \\
\hline $\begin{array}{c}\text { COORDENAÇÃO } \\
\text { ENTRE } \\
\text { AUTORIDADES }\end{array}$ & $\begin{array}{l}\text { Art. } 2.3 \text { - uma parte pode autorizar aos funcionários da } \\
\text { outra parte que visitem seu território no curso das } \\
\text { investigações. } \\
\text { Art. } 5 \text { - as autoridades nacionais de defesa da } \\
\text { concorrência poderão coordenar as respectivas } \\
\text { atividades de aplicação com relação a matérias inter- } \\
\text { relacionadas ou conexas, quando assim julgarem } \\
\text { conveniente. }\end{array}$ & $\begin{array}{l}\text { Art. } 5 \text { - quando autoridades de defesa da concorrência } \\
\text { de dois ou mais Estados-Partes estiverem realizando } \\
\text { atividades de aplicação sobre concentrações } \\
\text { econômicas inter-relacionadas ou conexas, deverão } \\
\text { considerar a conveniência de promover a coordenação } \\
\text { das respectivas atividades, levando em consideração } \\
\text { os interesses dos demais Estados-Partes. }\end{array}$ & $\begin{array}{l}\text { Art. } 14 \text { e } 15 \text { - procedimento para coordenação das atividades } \\
\text { das autoridades de defesa da concorrência nacionais na } \\
\text { aplicação das respectivas legislações de concorrência aos } \\
\text { casos que envolvam mais de uma jurisdição. As autoridades } \\
\text { envolvidas na apreciação de um mesmo casos devem reunir } \\
\text { esforços para não chegarem a decisões contraditórias. } \\
\text { Apesar dos Estados-Partes deverem envidar os seus } \\
\text { melhores esforços para não proferirem decisões } \\
\text { contraditórias através da coordenação das suas atividades, } \\
\text { cada autoridade da concorrência permanece livre para emitir } \\
\text { a decisão que considere mais adequada, de acordo com a } \\
\text { respectiva legislação. }\end{array}$ \\
\hline OBSERVAÇÕES & - & - & 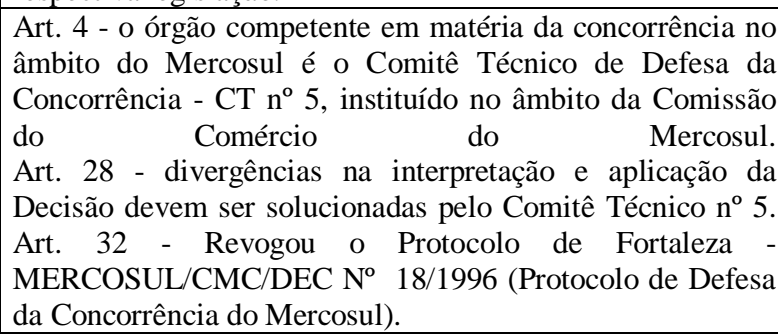 \\
\hline
\end{tabular}


ANEXO C

SUMÁRIO DOS ACORDOS CELEBRADOS PELO BRASIL E SBDC

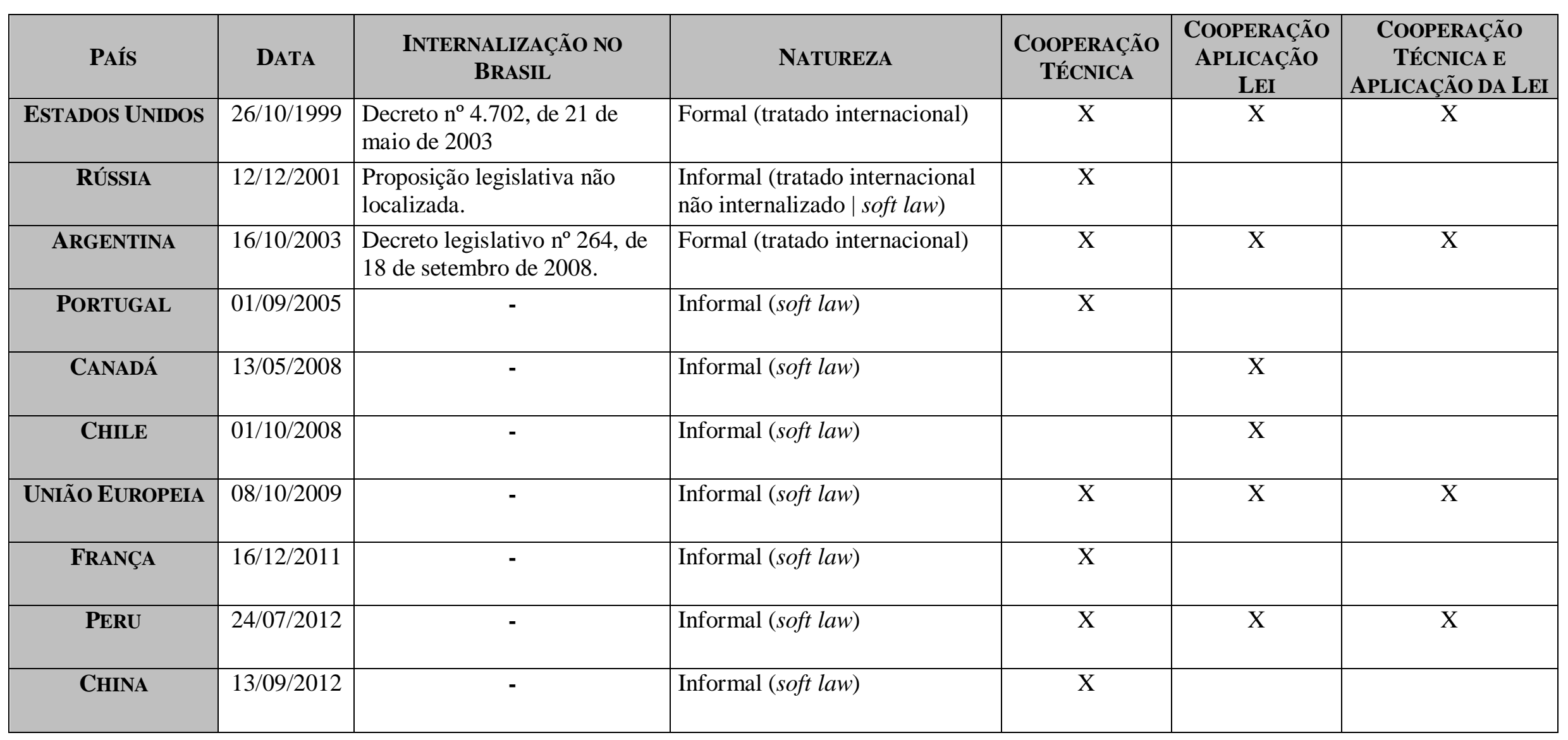




\section{ANEXO D}

ACORDOS CELEBRADOS PELO BRASIL E SBDC COM DISPOSIÇÕES DE COOPERAÇÃO TÉCNICA

\begin{tabular}{|c|c|c|c|c|}
\hline PAÍS & ESTADOS UNIDOS & RÚSSIA & ARGENTINA & Portugal \\
\hline$\overline{\text { DATA }}$ & $26 / 10 / 1999$ & $12 / 12 / 2001$ & $16 / 10 / 2003$ & $01 / 09 / 2005$ \\
\hline NoME & $\begin{array}{l}\text { Acordo entre o Governo da República } \\
\text { Federativa do Brasil e o Governo dos } \\
\text { Estados Unidos da América Relativo à } \\
\text { Cooperação entre suas Autoridades de } \\
\text { Defesa da Concorrência na Aplicação de } \\
\text { suas Leis de Concorrência }\end{array}$ & $\begin{array}{l}\text { Acordo entre o Governo da República } \\
\text { Federativa do Brasil e o Governo da } \\
\text { Federação da Rússia sobre Cooperação } \\
\text { na Área da Política de Concorrência }\end{array}$ & $\begin{array}{l}\text { Acordo de Cooperação entre República } \\
\text { Federativa do Brasil e a República } \\
\text { Argentina relativo à Cooperação entre } \\
\text { suas Autoridades de Defesa da } \\
\text { Concorrência na aplicação de suas leis } \\
\text { de concorrência }\end{array}$ & $\begin{array}{l}\text { Protocolo } \mathrm{n}^{\circ} 001 / 2005 \text { de Cooperação } \\
\text { Técnica que entre si celebram o Conselho } \\
\text { Administrativo de Defesa Econômica - } \\
\text { CADE, a Secretaria de Direito Econômico } \\
\text { do Ministério da Justiça, a Secretaria de } \\
\text { Acompanhamento Econômico do Ministério } \\
\text { da Fazenda e a Autoridade da Concorrência } \\
\text { de Portugal }\end{array}$ \\
\hline PARTES & $\begin{array}{l}\text { República Federativa do Brasil e } \\
\text { Estados Unidos da América }\end{array}$ & $\begin{array}{lllll}\text { República Federativa } & \text { do } & \text { Brasil } & \text { e } \\
\text { Federação da Rússia } & & & \end{array}$ & \begin{tabular}{|lllll} 
República Federativa & do & Brasil & $\mathrm{e}$ \\
República Argentina & & & \\
\end{tabular} & $\begin{array}{l}\text { CADE, SDE, SEAE e Autoridade da } \\
\text { Concorrência (Portugal) }\end{array}$ \\
\hline $\begin{array}{l}\text { INTERNALIZAÇÃO } \\
\text { NO BRASIL }\end{array}$ & Decreto $^{\circ} 4.702$, de 21 de maio de 2003 & Proposição legislativa não localizada. & $\begin{array}{l}\text { Decreto legislativo } \mathrm{n}^{\circ} \text { 264, de } 18 \text { de } \\
\text { setembro de } 2008 .\end{array}$ & - \\
\hline TIPO & $\begin{array}{l}\text { Cooperação de aplicação das leis de } \\
\text { concorrência e cooperação técnica }\end{array}$ & Cooperação técnica & $\begin{array}{l}\text { Cooperação de aplicação das leis de } \\
\text { concorrência e cooperação técnica }\end{array}$ & Cooperação técnica \\
\hline NATUREZA & Formal (tratado internacional) & $\begin{array}{l}\text { Informal (tratado internacional não } \\
\text { internalizado } \mid \text { soft law) }\end{array}$ & Formal (tratado internacional) & Informal (soft law) \\
\hline
\end{tabular}




\begin{tabular}{|c|c|c|c|c|}
\hline PAís & ESTADOS UNIDOS & RÚSSIA & ARGENTINA & Portugal \\
\hline $\begin{array}{c}\text { COOPERAÇão } \\
\text { TÉCNICA }\end{array}$ & $\begin{array}{l}\text { Art. } 7 \text { - previsão de atividades de } \\
\text { cooperação técnica, incluindo (i) troca } \\
\text { de informações; (ii) intercâmbio de } \\
\text { funcionários para fins de treinamento; } \\
\text { (iii) participação em conferências e } \\
\text { cursos de treinamento, dentre outros. }\end{array}$ & $\begin{array}{l}\text { Art. } 3 \text { - a cooperação entre as partes tem } \\
\text { por objetivo: (i) o aperfeiçoamento das } \\
\text { bases jurídicas da política da } \\
\text { concorrência; (ii) realização de medidas } \\
\text { práticas para regulação antimonopolista } \\
\text { e desenvolvimento de ambiente } \\
\text { concorrencial; (iii) troca de experiência } \\
\text { no campo de revelação de casos de } \\
\text { natureza concorrencial; (iv) troca de } \\
\text { experiências; (v) criação de condições } \\
\text { favoráveis ao funcionamento eficaz dos } \\
\text { mercados de mercadorias e valores; e } \\
\text { (vi) desenvolvimento de base científica e } \\
\text { metodológica para pesquisas no campo } \\
\text { do direito concorrencial. } \\
\text { Art. } 4 \text { - A cooperação técnica envolverá } \\
\text { o (i) intercâmbio de atos normativos } \\
\text { jurídicos, materiais informativos, } \\
\text { metodológicos; (ii) a prestação de ajuda } \\
\text { metodológica, intercâmbio de resultados } \\
\text { de pesquisas e promoção de consultas; } \\
\text { (iii) convite para especialistas } \\
\text { participarem em processo de ensino e } \\
\text { estágios para troca de experiências; e } \\
\text { (iv) organização de simpósios, } \\
\text { conferências e seminários bilaterais. }\end{array}$ & $\begin{array}{l}\text { Art. } 8 \text { - previsão de atividades de } \\
\text { cooperação técnica, incluindo (i) troca } \\
\text { de informações; (ii) intercâmbio de } \\
\text { funcionários para fins de treinamento; } \\
\text { (iii) participação em conferências e } \\
\text { cursos de treinamento, dentre outros. }\end{array}$ & $\begin{array}{l}\text { Art. 1.1 - o Protocolo contempla (i) a } \\
\text { realização de programas de intercâmbio para } \\
\text { troca de experiências entre as partes; (ii) a } \\
\text { realização de eventos; (iii) consultas mútuas } \\
\text { sobre temas relevantes; (iv) intercâmbio de } \\
\text { publicações; (v) troca de informações e } \\
\text { documentação, dentre outras atividades } \\
\text { Art. } 2.1 \text { - partes comprometem-se a colocar } \\
\text { à disposição umas às outras o acervo de } \\
\text { decisões e notas técnicas. } \\
\text { Art. } 2.2 \text { - fornecer informações, ressalvados } \\
\text { os casos em que a divulgação de tal } \\
\text { informação seja legalmente proibida. } \\
\text { Art. 8.2 - partes devem manter } \\
\text { confidencialidade de informações até que } \\
\text { matéria em questão seja julgada. }\end{array}$ \\
\hline $\begin{array}{c}\text { Reuniões } \\
\text { PERIódicas }\end{array}$ & $\begin{array}{l}\text { Art. } 8 \text { - funcionários das autoridades se } \\
\text { encontrarão periodicamente para trocar } \\
\text { informações sobre seus esforços e } \\
\text { prioridades. }\end{array}$ & - & $\begin{array}{l}\text { Art. } 9 \text { - funcionários das autoridades se } \\
\text { encontrarão periodicamente para trocar } \\
\text { informações sobre seus esforços e } \\
\text { prioridades. }\end{array}$ & \\
\hline
\end{tabular}




\begin{tabular}{|c|c|c|c|c|}
\hline País & ESTADOS UNIDOS & $\begin{array}{l}\text { RúsSIA } \\
\end{array}$ & ARGENTINA & Portugal \\
\hline OBSERVaÇões & $\begin{array}{l}\text { Acordo contém dispositivos sobre } \\
\text { cooperação na aplicação das respectivas } \\
\text { leis de concorrência. }\end{array}$ & $\begin{array}{l}\text { Art. } 6^{\circ}-\text { divergências sobre } \\
\text { interpretação/execução do acordo serão } \\
\text { objeto de negociação entre as partes. } \\
\text { Art. } 7^{\circ} \text { - previsão de consultas periódicas } \\
\text { para averiguar implementação do } \\
\text { Acordo. } \\
\text { Art. } 5^{\circ} \text { - cooperação será efetuada com } \\
\text { base em programas bianuais. } \\
\text { 21/09/2011 - assinatura do Programa } \\
\text { sobre Cooperação entre o CADE, a } \\
\text { SDE, a SEAE do Governo da República } \\
\text { Federativa do Brasil e o Serviço Federal } \\
\text { Antimonopólio da Federação da Rússia } \\
\text { para o biênio 2012-2013 (último } \\
\text { programa estabelecido). Este programa } \\
\text { contém regras pormenorizadas sobre os } \\
\text { mecanismos de cooperação, incluindo } \\
\text { prazos para a realização das trocas de } \\
\text { informações, tratamento confidencial } \\
\text { das informações compartilhadas dentre } \\
\text { outros. }\end{array}$ & $\begin{array}{l}\text { Acordo contém dispositivos sobre } \\
\text { cooperação na aplicação das respectivas } \\
\text { leis de concorrencia. }\end{array}$ & $\begin{array}{l}\text { Art. } 8.1 \text { - documentos e/ou correspondências } \\
\text { trocados devem ser encaminhados mediante } \\
\text { correspondência oficial. } \\
\text { Art. } 9.1 \text { - dúvidas e controvérsias sobre } \\
\text { aplicação ou interpretação do Protocolo } \\
\text { serão dirimidas por via diplomática. } \\
\text { Em 14/01/2010 a Autoridade da } \\
\text { Concorrência de Portugal, CADE, SDE e } \\
\text { SEAE formalizaram o Protocolo de } \\
\text { Cooperação Técnica entre Sistema } \\
\text { Brasileiro de Defesa da Concorrência e } \\
\text { Autoridade da Concorrência de Portugal, o } \\
\text { qual reflete em geral os termos do Protocolo } \\
\text { anterior, mas inclui regras sobre cortesia } \\
\text { negativa (art. 2.4) e positiva (Art. 2.5), sem } \\
\text { no entanto trazer regulação pormenorizada } \\
\text { sobre o tema. }\end{array}$ \\
\hline
\end{tabular}




\begin{tabular}{|c|c|c|c|c|}
\hline PAís & UNIÃO EUROPEIA & FranÇA & PERU & China \\
\hline DATA & 08/10/2009 & $16 / 12 / 2011$ & $24 / 07 / 2012$ & $13 / 09 / 2012$ \\
\hline NOME & \begin{tabular}{|llll}
$\begin{array}{l}\text { Memorando } \\
\text { Cooperação }\end{array}$ & de & Entendimento de \\
\end{tabular} & $\begin{array}{l}\text { Acordo de Cooperação Técnica que } \\
\text { entre si celebram o CADE e a Autorité } \\
\text { de La Concurrence }\end{array}$ & $\begin{array}{l}\text { Acordo de Cooperação entre o Instituto } \\
\text { Nacional de Defesa da Concorrência e } \\
\text { da Proteção da Propriedade Intelectual } \\
\text { (INDECOPI) e o o conselho } \\
\text { Administrativo de Defesa Econômica } \\
\end{array}$ & $\begin{array}{l}\text { Memorando de Entendimento de } \\
\text { Cooperação sobre Concorrência entre o } \\
\text { Ministério da Indústria e Comércio do } \\
\text { Governo da República Popular da China e o } \\
\text { CADE }\end{array}$ \\
\hline Partes & $\begin{array}{l}\text { Diretório-Geral de Concorrência da } \\
\text { Comissão Europeia (DG Competition), } \\
\text { C ADE, SDE e SEAE }\end{array}$ & $\begin{array}{l}\text { Autorité de La Concurrence (França) e } \\
\text { CADE }\end{array}$ & 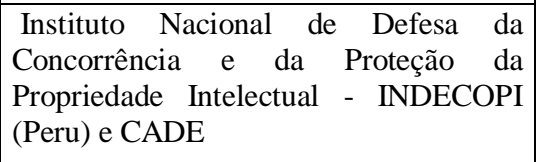 & $\begin{array}{l}\text { Ministério da Indústria e Comércio (China) } \\
\text { e o CADE }\end{array}$ \\
\hline $\begin{array}{l}\text { INTERNALIZAÇÃo } \\
\text { NO BRASIL }\end{array}$ & - & - & - & - \\
\hline TIPO & $\begin{array}{l}\text { Cooperação de aplicação das leis de } \\
\text { concorrência e cooperação técnica }\end{array}$ & Cooperação técnica & $\begin{array}{l}\text { Cooperação de aplicação das leis de } \\
\text { concorrência e cooperação técnica }\end{array}$ & Cooperação técnica \\
\hline NATUREZA & Informal (soft law) & Informal (soft law) & Informal (soft law) & \begin{tabular}{|l|l} 
Informal (soft law) \\
\end{tabular} \\
\hline $\begin{array}{l}\text { COOPERAÇÃo } \\
\text { TÉCNICA }\end{array}$ & $\begin{array}{l}\text { Art. } 2.5 \text { - previsão de fornecimento de } \\
\text { assistência técnica recíproca para a } \\
\text { implementação de leis e políticas da } \\
\text { concorrência, que poderão incluir (i) } \\
\text { intercâmbio de servidores; (ii) } \\
\text { realização de eventos; (iii) intercâmbio } \\
\text { de publicações e outros documentos } \\
\text { públicos. }\end{array}$ & $\begin{array}{l}\text { Art. 1.1 - objeto do acordo é a } \\
\text { cooperação técnica entre as partes em } \\
\text { matéria concorrencial. } \\
\text { Art. 1.2 - a cooperação poderá incluir (i) } \\
\text { programas de intercâmbio para troca de } \\
\text { experiências; (ii) realização de eventos; } \\
\text { (iii) consultas recíprocas sobre a matéria } \\
\text { concorrencial; (iv) incentivo à } \\
\text { publicação de artigos técnicos; (v) troca } \\
\text { de informações sobre atividades e } \\
\text { resultados da aplicação da legislação da } \\
\text { concorrência (decisões, estudos, } \\
\text { legislações, etc.), respeitadas normas } \\
\text { sobre confidencialidade de informações, } \\
\text { segredo de negócios, profissional e } \\
\text { proteção de dados pessoais. } \\
\text { Art. 2.1 - partes deverão disponibilizar } \\
\text { acervo não confidencial de decisões, } \\
\text { responder aos pedidos de informações e } \\
\text { indicar representante como ponto de } \\
\text { contato para facilitar comunicações } \\
\text { entre as partes e implementação do } \\
\text { acordo. }\end{array}$ & $\begin{array}{l}\text { Art. } 3.3 \text { - partes assumem compromisso } \\
\text { de realizar atividades de assistência } \\
\text { técnica, tais como conferências, } \\
\text { seminários, cursos, oficinas, visitas, } \\
\text { estágio dentre outros. } \\
\text { Art. } 7 \text { - assistência técnica com } \\
\text { finalidade de cada parte aproveitar as } \\
\text { experiências da outra parte. }\end{array}$ & $\begin{array}{l}\text { Art. 1 - objetivo principal da cooperação } \\
\text { técnica é a troca de informações e atividades } \\
\text { de treinamento técnico. } \\
\text { Art. } 2 \text { - a cooperação técnica abrangerá (i) } \\
\text { troca de informações sobre políticas, leis, } \\
\text { casos e outras, desde que autorizado pela } \\
\text { legislação nacional; (ii) realização de } \\
\text { eventos e cursos; (iii) visitas de delegações, } \\
\text { dentro outros. } \\
\text { Art. } 5 \text { - partes não estão obrigadas a } \\
\text { fornecer informações, cuja divulgação seja } \\
\text { proibida por lei ou afetem os interesses da } \\
\text { parte provedora da informação. Informações } \\
\text { trocadas devem ser mantidas em } \\
\text { confidencialidade pela receptora. }\end{array}$ \\
\hline
\end{tabular}




\begin{tabular}{|c|c|c|c|c|}
\hline PAís & UNIÃO EUROPEIA & FranÇA & Peru & ChINA \\
\hline $\begin{array}{l}\text { REuniões } \\
\text { PERIódicas }\end{array}$ & $\begin{array}{l}\text { Art. } 5.12 \text { e } 5.13 \text { - encontros periódicos } \\
\text { para debate de assuntos atuais, } \\
\text { experiências e novos desenvolvimentos } \\
\text { relacionados à matéria concorrencial, } \\
\text { trocar informações, experiências e } \\
\text { pontos de vista sobre setores da } \\
\text { economia, iniciativas multilaterais } \\
\text { dentre outros. Partes aproveitarão } \\
\text { oportunidades de encontro oferecidas } \\
\text { em fóruns já em andamento dos quais } \\
\text { ambas participem. }\end{array}$ & - & $\begin{array}{l}\text { Art. } 7^{\circ}-\text { partes poderão reunir-se } \\
\text { periodicamente para trocar e e } \\
\text { compartilhar informações e experiências } \\
\text { relacionadas à matéria concorrencial. }\end{array}$ & $\begin{array}{l}\text { Art. } 3.3 \text { - as partes realização encontros } \\
\text { preferencialmente uma vez ao ano, } \\
\text { alternando-se as sedes. }\end{array}$ \\
\hline OBSERVAÇÕES & $\begin{array}{l}\text { Acordo contém dispositivos sobre } \\
\text { cooperação na aplicação das respectivas } \\
\text { leis de concorrência. }\end{array}$ & $\begin{array}{l}\text { Art. } 1.4 \text { - comunicações poderão ser } \\
\text { realizadas por qualquer mero, } \\
\text { preferencialmente por meio eletrônico } \\
\text { ou conferências telefônicas. }\end{array}$ & $\begin{array}{l}\text { Acordo contém dispositivos sobre } \\
\text { cooperação na aplicação das respectivas } \\
\text { leis de concorrência. }\end{array}$ & $\begin{array}{l}\text { Art. } 3.1 \text { - partes estabelecem ponto de } \\
\text { contato para implementação do acordo que, } \\
\text { no caso brasileiro, está na Assessoria } \\
\text { Internacional do CADE. } \\
\text { Art. } 3.2 \text { - partes devem estabelecer projetos } \\
\text { específicos para implementação do acordo. } \\
\text { Art. 6 - controvérsias e disputas devem ser } \\
\text { resolvidas através de consultas e } \\
\text { negociações diretas. }\end{array}$ \\
\hline
\end{tabular}


ANEXO E

\section{ACORDOS CELEBRADOS PELO BRASIL E SBDC COM DISPOSIÇÕES DE COOPERAÇÃO NA APLICAÇÃO DAS LEIS DE DEFESA DA CONCORRÊNCIA}

\begin{tabular}{|c|c|c|c|}
\hline País & ESTADOS UNIDOS & ARGENTINA & CANADÁ \\
\hline DATA & $26 / 10 / 1999$ & $16 / 10 / 2003$ & $13 / 05 / 2008$ \\
\hline NOME & $\begin{array}{l}\text { Acordo entre o Governo da República Federativa do } \\
\text { Brasil e o Governo dos Estados Unidos da América } \\
\text { Relativo à Cooperação entre suas Autoridades de } \\
\text { Defesa da Concorrência na Aplicação de suas Leis de } \\
\text { Concorrência }\end{array}$ & $\begin{array}{l}\text { Acordo de Cooperação entre República Federativa do } \\
\text { Brasil e a República Argentina relativo à Cooperação } \\
\text { entre suas Autoridades de Defesa da Concorrência na } \\
\text { aplicação de suas leis de concorrência }\end{array}$ & $\begin{array}{l}\text { Entendimento de Cooperação entre o Conselho da } \\
\text { Concorrência, a agência de defesa da concorrência do } \\
\text { Governo do Canadá e o CADE, a SDE, a SEAE do } \\
\text { Governo da República Federativa do Brasil acerca da } \\
\text { Aplicação de suas respectivas Normas de Defesa da } \\
\text { Concorrência }\end{array}$ \\
\hline PARTES & $\begin{array}{l}\text { República Federativa do Brasil e Estados Unidos da } \\
\text { América }\end{array}$ & República Federativa do Brasil e República Argentina & Defesa da Concorrência do Canadá, CADE, SDE e SEAE \\
\hline $\begin{array}{l}\text { INTERNALIZAÇã } \\
\text { O NO BRASIL }\end{array}$ & Decreto $^{\circ} 4.702$, de 21 de maio de 2003 & Decreto legislativo ${ }^{\circ} 264$, de 18 de setembro de 2008. & - \\
\hline TIPO & $\begin{array}{l}\text { Cooperação de aplicação das leis de concorrência e } \\
\text { cooperação técnica }\end{array}$ & $\begin{array}{l}\text { Cooperação de aplicação das leis de concorrência e } \\
\text { cooperação técnica }\end{array}$ & $\begin{array}{l}\text { Cooperação de aplicação das leis de concorrência e } \\
\text { cooperação técnica }\end{array}$ \\
\hline NATUREZA & Formal (tratado internacional) & Formal (tratado internacional) & Informal (soft law) \\
\hline $\begin{array}{c}\text { ÂMBITO DE } \\
\text { APLICAÇÃo } \\
\text { (ATOS DE } \\
\text { CONCENTRAÇÃo) }\end{array}$ & $\begin{array}{l}\text { Art. 1.2 - "atividade de aplicação" consiste em } \\
\text { qualquer investigação ou procedimento conduzido por } \\
\text { uma das autoridades da concorrência envolvidas, ao } \\
\text { amparo da respectiva lei de concorrência. } \\
\text { Art. } 2.2 \text { - esclarece quais atividades de aplicação } \\
\text { deverão ser notificadas por uma autoridade da } \\
\text { concorrência à outra, dentre as quais destacamos as } \\
\text { atividades que (i) "envolvam fusões ou aquisições nas } \\
\text { quais uma ou mais das partes da transação, ou uma } \\
\text { empresa que controle uma ou mais das partes da } \\
\text { transação, for uma empresa constituída ou organizada } \\
\text { sob as leis da outra Parte, ou de um de seus estados"; e } \\
\text { (ii) "envolvam a busca de informações localizadas no } \\
\text { território da outra Parte". }\end{array}$ & $\begin{array}{l}\text { Art. 1.2.d - "atividades de aplicação" consistem em } \\
\text { qualquer investigação, incluído o exame de atos de } \\
\text { concentração, bem como qualquer outro procedimento } \\
\text { conduzido por uma parte, nos termos de suas leis de } \\
\text { defesa da concorrência. } \\
\text { Art. } 2.2 \text { - As atividades de aplicação a serem } \\
\text { notificadas em conformidade com este artigo são } \\
\text { aquelas que: a) sejam relevantes para as atividades da } \\
\text { outra parte na aplicação de suas leis; (...) (c) envolvam } \\
\text { atos de concentração, nos quais uma ou mais das } \\
\text { partes envolvidas, ou uma empresa que controle um ou } \\
\text { mais dos partícipes da operação, seja uma empresa } \\
\text { constituída ou organizada sob as leis da outra parte, ou } \\
\text { de uma de suas unidades subnacionais; (...) e e) } \\
\text { envolvam a busca de informações localizadas no } \\
\text { território da outra Parte. }\end{array}$ & $\begin{array}{l}\text { Art. 1.2.b - "atividade de aplicação" consiste em qualquer } \\
\text { investigação ou procedimento conduzido por uma parte } \\
\text { em relação à respectiva lei de defesa da concorrência. } \\
\text { Art. 2.1 - notificações entre as partes devem incluir as } \\
\text { atividades que (...) (c) envolvam concentrações } \\
\text { econômicas nas quais uma ou mais partes da operação } \\
\text { mantenha atividade econômica no território da outra parte } \\
\text { ou esteja sob controle de entidade que seja constituída ou } \\
\text { organizada de acordo com as leis do território da outra } \\
\text { parte; (d) envolvam penalidades ou restrições que } \\
\text { expressamente requeiram ou proíbam conduta naquele } \\
\text { território; e (e) envolvam a busca de informações } \\
\text { localizada no território da outra parte. }\end{array}$ \\
\hline
\end{tabular}




\begin{tabular}{|c|c|c|c|}
\hline PAí́S & ESTADOS UNIDOS & ARGENTINA & CANADÁ \\
\hline $\begin{array}{l}\text { NOTIFICAÇÃO } \\
\text { ENTRE } \\
\text { AUTORIDADES }\end{array}$ & $\begin{array}{l}\text { Art. } 2.1 \text { - estabelece as hipóteses e os procedimentos } \\
\text { de notificação, as quais se relacionam às atividades de } \\
\text { aplicação. Notificações devem conter natureza das } \\
\text { práticas objeto da cooperação e os dispositivos legais } \\
\text { pertinentes, devendo ser realizadas tão logo quanto } \\
\text { possível. } \\
\text { Artigo } 11 \text { - As notificações serão efetuadas por } \\
\text { comunicação direta entre as autoridades de defesa da } \\
\text { concorrência das partes. Os pedidos de consultas e as } \\
\text { notificações previstos nos artigos } 2,4.2 \text { e } 6.2 \text { deverão, } \\
\text { entretanto, ser confirmados prontamente, por escrito, } \\
\text { por meio dos canais diplomáticos costumeiros e } \\
\text { deverão fazer referência às comunicações iniciais entre } \\
\text { as autoridades, repetindo a informação já fornecida na } \\
\text { primeira comunicação. }\end{array}$ & $\begin{array}{l}\text { Artigo 2.1 - Cada parte deverá notificar a outra parte } \\
\text { no tocante às atividades de aplicação. As notificações } \\
\text { deverão identificar a natureza das práticas sob } \\
\text { investigação e os dispositivos legais pertinentes e } \\
\text { deverão ser efetuadas nos prazos estabelecidos no } \\
\text { acordo. No caso do Brasil, a notificação sobre atos de } \\
\text { concentração deverá ser promovida em } 15 \text { dias a } \\
\text { contar da publicação que informa a notificação do ato } \\
\text { ao SBDC. } \\
\text { Artigo } 12.1 \text { - As notificações previstas no Artigo } 2 \text { do } \\
\text { acordo, bem como quaisquer outras comunicações } \\
\text { dele decorrentes, poderão ser efetuadas por } \\
\text { comunicação direta entre as autoridades. Os pedidos } \\
\text { de consultas previstos nos artigos } 5.2 \text { e } 7.2 \text { deverão, } \\
\text { entretanto, ser confirmados prontamente, por escrito, } \\
\text { por meio dos canais diplomáticos costumeiros e } \\
\text { deverão fazer referência às comunicações iniciais entre } \\
\text { as autoridades, repetindo a informação já fornecida na } \\
\text { primeira comunicação. }\end{array}$ & $\begin{array}{l}\text { Art. } 2.1 \text { - as partes devem notificar umas às outras sobre as } \\
\text { atividades de aplicação que possam afetar os interesses da } \\
\text { outra parte. } \\
\text { Art. } 2.2 \text { - as notificações devem ser promovidas tão logo } \\
\text { que se torne evidente que as circunstâncias a serem } \\
\text { notificadas estão presentes. } \\
\text { Art. } 2.3 \text { - uma vez que uma matéria tenha sido notificada, } \\
\text { notificações subsequentes em relação a tal matéria não } \\
\text { necessitam de ser realizadas, a não ser que a parte } \\
\text { notificante tome conhecimento de novas questões } \\
\text { relacionadas aos interesses da outra parte ou caso a outra } \\
\text { parte assim o requeira. } \\
\text { Art. } 2.4 \text { - as notificações devem incluir a natureza da } \\
\text { atividade sob investigação e os dispositivos legais } \\
\text { aplicáveis, devendo ser suficientemente detalhadas de } \\
\text { modo a proporcionar a parte notificada uma avaliação } \\
\text { inicial sobre os efeitos da atividade nos seus interesses de } \\
\text { aplicação a legislação de defesa da concorrência. } \\
\text { Art. } 7 \text { - as notificações serão efetuadas por comunicação } \\
\text { direta entre as partes. Cada parte deve indicar um ponto de } \\
\text { contato para as finalidades do acordo. }\end{array}$ \\
\hline $\begin{array}{l}\text { CORTESIA } \\
\text { NEGATIVA }\end{array}$ & $\begin{array}{l}\text { Art. } 6.1 \text { - as partes assumem a obrigação de considerar } \\
\text { os importantes interesses da outra parte em todas as } \\
\text { fases das atividades de aplicação, na medida em que } \\
\text { houver compatibilidade com as respectivas legislações } \\
\text { e próprios interesses importantes. Tal consideração } \\
\text { deverá ocorrer inclusive nas decisões sobre a iniciação } \\
\text { de investigação ou procedimento, amplitude de } \\
\text { investigação ou procedimento e natureza das medidas } \\
\text { legais ou penalidades propostas em cada caso. }\end{array}$ & $\begin{array}{l}\text { Artigo 7.1 - Cada parte deverá, ao amparo de suas leis } \\
\text { e na medida em que for compatível com seus próprios } \\
\text { importantes interesses, assegurar cuidadosa } \\
\text { consideração aos importantes interesses da outra Parte. }\end{array}$ & $\begin{array}{l}\text { Art. } 4.1 \text { - reconhecimento do interesse das partes em } \\
\text { minimizar efeitos potencialmente adversos relacionados às } \\
\text { atividades de aplicação de uma parte sobre os interesses da } \\
\text { outra parte. } \\
\text { Art. } 4.2 \text { - previsão de notificação de uma parte à outra } \\
\text { sobre possibilidade que seus interesses importantes sejam } \\
\text { afetados pela aplicação da legislação da concorrência da } \\
\text { outra parte. Parte requerida deverá se esforçar para } \\
\text { oferecer oportunidade de discussão e atualizar a requerente } \\
\text { sobre desenvolvimentos significativos relacionados a tais } \\
\text { interesses. }\end{array}$ \\
\hline
\end{tabular}




\begin{tabular}{|c|c|c|c|}
\hline PAís & ESTADOS UNIDOS & ARGENTINA & CANADÁ \\
\hline $\begin{array}{l}\text { CORTESIA } \\
\text { Positiva }\end{array}$ & $\begin{array}{l}\text { Art. } 4.2 \text { - se uma Parte acreditar que práticas } \\
\text { anticompetitivas realizadas no território da outra Parte } \\
\text { afetam adversamente seus importantes interesses, a } \\
\text { primeira Parte poderá, após consulta prévia à outra } \\
\text { Parte, solicitar que as autoridades de defesa da } \\
\text { concorrência daquela outra Parte iniciem atividades de } \\
\text { aplicação apropriadas. O pedido deverá ser detalhado, } \\
\text { indicando a natureza da prática objeto da cooperação e } \\
\text { efeitos nos interesses relevantes da parte requerente, } \\
\text { bem como a oferta de informações e cooperações } \\
\text { adicionais que forem possíveis. } \\
\text { Art. } 4.3 \text { - Autoridades requeridas decidirão se } \\
\text { iniciarão ou ampliarão atividades de aplicação em } \\
\text { curso em função do pedido de cooperação e } \\
\text { informarão a parte requerente sobre a sua decisão. Se } \\
\text { atividades forem iniciadas ou ampliadas, a autoridade } \\
\text { requerida deverá comunicar a requerente os seus } \\
\text { resultados e progressos parciais significativos. } \\
\text { Art. } 4.4 \text { - a discricionariedade das autoridades não é } \\
\text { limitada pelo acordo, as quais permanecem livres para, } \\
\text { de acordo com as respectivas atribuições legais, a } \\
\text { conduzir suas atividades livremente. }\end{array}$ & $\begin{array}{l}\text { Art. 5.2 - Se uma parte acreditar que práticas } \\
\text { anticompetitivas realizadas no território da outra parte } \\
\text { afetam adversamente seus importantes interesses, a } \\
\text { primeira parte poderá, após consulta prévia à outra } \\
\text { parte, solicitar às autoridades de defesa da } \\
\text { concorrência daquela outra parte que iniciem as } \\
\text { atividades de aplicação apropriadas. O pedido deverá } \\
\text { ser o mais específico possível acerca da natureza das } \\
\text { práticas anticompetitivas e de seu efeito nos } \\
\text { importantes interesses da parte solicitante, e deverá } \\
\text { incluir oferta de informação e cooperação adicionais } \\
\text { que forem possíveis. } \\
\text { Artigo 5.3 - As autoridades requeridas considerarão se } \\
\text { iniciarão ou ampliarão atividades de aplicação em } \\
\text { curso em função do pedido de cooperação e } \\
\text { informarão parte requerente de sua decisão. Se } \\
\text { atividades forem iniciadas ou ampliadas, a autoridade } \\
\text { requerida deverá comunicar a requerente os seus } \\
\text { resultados e progressos parciais significativos. } \\
\text { Artigo 5.4 - a discricionariedade das autoridades não é } \\
\text { limitada pelo acordo, as quais permanecem livres para, } \\
\text { de acordo com as respectivas atribuições legais, a } \\
\text { conduzir suas atividades livremente. }\end{array}$ & - \\
\hline $\begin{array}{c}\text { BUSCA POR } \\
\text { INFORMAÇÕES }\end{array}$ & $\begin{array}{l}\text { Art. 2.2.e - As atividades de aplicação a serem } \\
\text { notificadas incluem aquelas que envolvam a busca de } \\
\text { informações localizadas no território da outra parte. } \\
\text { Art. 2.3 - As partes autorizam a visita de funcionários } \\
\text { da outra parte aos seus respectivos territórios durante o } \\
\text { curso de investigações ao amparo da legislação } \\
\text { concorrencial aplicável. Tais visitas estão } \\
\text { condicionadas à notificação e ao consentimento da } \\
\text { parte notificada. }\end{array}$ & $\begin{array}{l}\text { Art. 2.2.e - As atividades de aplicação a serem } \\
\text { notificadas incluem aquelas que envolvam a busca de } \\
\text { informações localizadas no território da outra parte. } \\
\text { Art. 2.3 - As partes autorizam a visita de funcionários } \\
\text { da outra parte aos seus respectivos territórios durante o } \\
\text { curso de investigações ao amparo da legislação } \\
\text { concorrencial aplicável. Tais visitas estão } \\
\text { condicionadas à notificação e ao consentimento da } \\
\text { parte notificada. }\end{array}$ & $\begin{array}{l}\text { Art. 2.1.e - notificações entre as partes devem incluir as } \\
\text { atividades que envolvam a busca de informações } \\
\text { localizada no território da outra parte. A busca de } \\
\text { informações poderá ocorrer através de visitas por } \\
\text { funcionários da outra parte (desde que obtido o } \\
\text { consentimento prévio da parte requerida) ou de outra } \\
\text { forma, com exceção de contatos telefônicos com pessoa } \\
\text { localizada no território da outra parte quando tal pessoa } \\
\text { não esteja sujeita à investigação e o contato tenha por } \\
\text { finalidade somente uma resposta verbal voluntária. }\end{array}$ \\
\hline
\end{tabular}




\begin{tabular}{|c|c|c|c|}
\hline PAÍS & ESTADOS UNIDOS & ARGENTINA & CANADÁ \\
\hline $\begin{array}{l}\text { TROCA E } \\
\text { COMPARTILHA- } \\
\text { MENTO DE } \\
\text { INFORMAÇÕES } \\
\text { (GERAL) }\end{array}$ & $\begin{array}{l}\text { Art. } 3.1 \text { - partes reconhecem o interesse de cooperar na } \\
\text { aplicação das respectivas leis da concorrência e } \\
\text { compartilhar informações para tal finalidade, na } \\
\text { medida em que seja compatível com suas leis e } \\
\text { importantes interesses e dentro dos recursos } \\
\text { razoavelmente disponíveis. }\end{array}$ & $\begin{array}{l}\text { Art. } 3.1 \text { - As partes acordam ser de interesse comum o } \\
\text { compartilhamento das informações que: a) possam } \\
\text { facilitar a aplicação efetiva das respectivas leis de } \\
\text { concorrência; ou, b) promovam uma compreensão } \\
\text { mais acurada das condições econômicas e } \\
\text { mercadológicas de importância para as atividades das } \\
\text { autoridades concorrenciais. } \\
\text { Art. } 3.2 \text { - As partes se reunirão ao menos duas vezes } \\
\text { ao ano para trocar informações sobre atividades de } \\
\text { aplicação desenvolvidas, setores econômicos de } \\
\text { interesse comum, dentre outros. } \\
\text { Art. } 4.1 \text { - As partes concordam que é de interesse } \\
\text { comum cooperar para a identificação de práticas } \\
\text { anticompetitivas e para a aplicação de suas leis de } \\
\text { concorrência, além de compartilhar informações que } \\
\text { irão facilitar a efetiva aplicação dessas leis e promover } \\
\text { o melhor entendimento das políticas e atividades de } \\
\text { cada uma delas na aplicação das leis de concorrência, } \\
\text { na medida em que sejam compatíveis com suas leis e } \\
\text { importantes interesses, e dentro de seus recursos } \\
\text { razoavelmente disponíveis. }\end{array}$ & $\begin{array}{l}\text { Art. } 3.1 \text { - as partes reconhecem que é do interesse mútuo a } \\
\text { cooperação e a troca de informações, quando apropriado e } \\
\text { praticável. }\end{array}$ \\
\hline $\begin{array}{c}\text { TROCA E } \\
\text { COMPARTILHA- } \\
\text { MENTO DE } \\
\text { INFORMAÇÕES } \\
\text { CONFIDENCIAIS }\end{array}$ & $\begin{array}{l}\text { Art. 9.1 - nenhuma autoridade da concorrência dos } \\
\text { países signatários será obrigada a fornecer } \\
\text { informações às outras autoridades, caso o } \\
\text { fornecimento de tal informação seja proibido segundo } \\
\text { a legislação aplicável do Estado que detém tais } \\
\text { informações ou seja incompatível com os seus } \\
\text { interesses. } \\
\text { Art. } 9.2 \text { - uma vez transferida qualquer informação em } \\
\text { regime de sigilo entre as autoridades de defesa da } \\
\text { concorrência envolvidas, a autoridade receptora estará } \\
\text { obrigada a manter a confidencialidade sobre a } \\
\text { informação recebida. }\end{array}$ & $\begin{array}{l}\text { Art. 10.1 - nenhuma autoridade da concorrência dos } \\
\text { países signatários será obrigada a fornecer } \\
\text { informações às outras autoridades, caso o } \\
\text { fornecimento de tal informação seja proibido segundo } \\
\text { a legislação aplicável do Estado que detém tais } \\
\text { informações ou seja incompatível com os seus } \\
\text { interesses. } \\
\text { Art. } 10.2 \text { - O grau de confidencialidade das } \\
\text { informações será decidido pela parte que as detiver, } \\
\text { cabendo exclusivamente a esta verificar a } \\
\text { possibilidade e o interesse em fornecê-las. } \\
\text { Art. } 10.3 \text { - As informações confidenciais fornecidas } \\
\text { por uma Parte à outra, no contexto da cooperação e } \\
\text { coordenação de atividades previstas no acordo, não } \\
\text { serão usados sem o consentimento da parte provedora } \\
\text { das informações, com qualquer outro propósito que } \\
\text { não a aplicação da lei de defesa da concorrência. }\end{array}$ & $\begin{array}{l}\text { Art. 6.2 - nenhuma parte será obrigada a fornecer } \\
\text { informações à outra parte, caso o fornecimento de tal } \\
\text { informação seja proibido segundo a legislação aplicável do } \\
\text { Estado que detém tais informações ou seja incompatível } \\
\text { com os seus interesses. } \\
\text { Art. } 6.3 \text { - a decisão de uma parte sobre compartilhar } \\
\text { determinada informação à outra pode depender da } \\
\text { aceitação das garantias dadas pela outra parte com relação } \\
\text { aos fins que a informação será utilizada. } \\
\text { Art. } 6.4 \text { - uma vez transferida qualquer informação em } \\
\text { regime de sigilo entre as autoridades de defesa da } \\
\text { concorrência envolvidas, a autoridade receptora estará } \\
\text { obrigada a manter a confidencialidade sobre a informação } \\
\text { recebida, exceto se a parte provedora da informação } \\
\text { consinta por escrito com a divulgação de tal informação. }\end{array}$ \\
\hline
\end{tabular}


PAÍS

COORDEnaÇão

ENTRE

AUTORIDADES

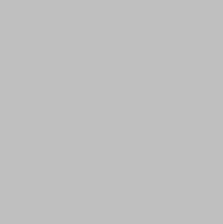

OBSERVAÇões

\section{ESTADOS UNIDOS}

Art. 5 - quando as autoridades da concorrência dos dois países estiverem levando a cabo atividades de aplicação, com respeito à matéria inter-relacionada, elas deverão considerar a conveniência de coordenação dessas atividades de aplicação. Note-se que o acordo não define com precisão o que seriam tais matérias inter-relacionadas, sendo possíve interpretar como aquelas matérias, atos ou fatos, cuja análise seja de interesse de ambas as jurisdições, consoante a legislação aplicável.

Art. 6.2 - previsão sobre procedimentos de consultas
entre as partes.

\section{ARgentina}

Art. 6.1 - Quando as autoridades das duas partes Art. 3.2 - quando as partes estiverem conduzindo estiverem implementando atividades de aplicação no atividades de aplicação com relação aos mesmos assuntos tocante às matérias inter-relacionadas, elas ou assuntos relacionados, elas envidarão esforços para considerarão a conveniência de coordenação dessas coordenar as suas atividades de aplicação, quando atividades de aplicação. apropriado e praticável. Art. 7.2 - previs

Vinculação: Art. 11 - Nada neste Acordo exigirá que uma Parte tome qualquer medida, ou abstenha-se de agir de uma maneira que não esteja em conformidade com suas leis existentes, ou que exija qualquer mudança nas leis das Partes ou de suas respectivas unidades constitutivas do Estado federal.

Países do Mercosul: Art. 12.2 - A parte que investigar uma prática anticompetitiva com base no acordo poderá notificar o Uruguai e o Paraguai sobre resultado das investigações e, na medida do possíve sobre seus progressos parciais, quando significativos.
Art. 3.3 - as partes concordam que é do mútuo interesse trabalharem juntas em iniciativas de assistência técnica relacionadas ao direito e à política da concorrência. Tais iniciativas poderão incluir formas de cooperação técnica conforme as partes decidirem ser apropriadas ao caso. Art. 4.3 - quaisquer dúvidas sobre a interpretação ou aplicação do acordo serão objeto de discussão entre as partes.

Art. 5 - As partes se reunirão periodicamente, conforme seja necessário para troca de informações sobre atividades de aplicação e setores econômicos de interesse comum, dentre outros. 


\begin{tabular}{|c|c|c|c|}
\hline PAÍS & CHILE & UNIÃO EUROPEIA & PERU \\
\hline DATA & $01 / 10 / 2008$ & $08 / 10 / 2009$ & $24 / 07 / 2012$ \\
\hline NOME & $\begin{array}{l}\text { Entendimento de Cooperação entre Fiscalía Nacional } \\
\text { Económica do Chile e o CADE, a SDE e a SEAE do } \\
\text { Governo da República Federativa do Brasil, acerca da } \\
\text { Aplicação de suas respectivas Normas de Defesa da } \\
\text { Concorrência }\end{array}$ & Memorando de Entendimento de Cooperação & $\begin{array}{l}\text { Acordo de Cooperação entre o Instituto Nacional de } \\
\text { Defesa da Concorrência e da Proteção da Propriedade } \\
\text { Intelectual (INDECOPI) e o Conselho Administrativo de } \\
\text { Defesa Econômica }\end{array}$ \\
\hline PARTES & $\begin{array}{l}\text { Fiscalia Nacional Económica (Chile), CADE, SDE e } \\
\text { SEAE }\end{array}$ & $\begin{array}{l}\text { Diretório-Geral de Concorrência da Comissão } \\
\text { Europeia (DG Competition), C ADE, SDE e SEAE }\end{array}$ & $\begin{array}{l}\text { Instituto Nacional de Defesa da Concorrência e da } \\
\text { Proteção da Propriedade Intelectual - INDECOPI (Peru) e } \\
\text { CADE }\end{array}$ \\
\hline $\begin{array}{l}\text { INTERNALIZAÇã } \\
\text { O NO BRASIL }\end{array}$ & - & - & - \\
\hline TIPO & Cooperação de aplicação das leis de concorrência & $\begin{array}{l}\text { Cooperação de aplicação das leis de concorrência e } \\
\text { cooperação técnica }\end{array}$ & $\begin{array}{l}\text { Cooperação de aplicação das leis de concorrência e } \\
\text { cooperação técnica }\end{array}$ \\
\hline NATUREZA & Informal (soft law) & Informal (soft law) & Informal (soft law) \\
\hline $\begin{array}{c}\text { ÂMBITO DE } \\
\text { APLICAÇÃO } \\
\text { (ATOS DE } \\
\text { CONCENTRAÇÃO) }\end{array}$ & $\begin{array}{l}\text { Art. 1.2.b - "atividade de aplicação" consiste em } \\
\text { qualquer investigação ou procedimento conduzido por } \\
\text { uma parte em relação à respectiva lei de defesa da } \\
\text { concorrência. } \\
\text { Art. } 2.1 \text { - notificações entre as partes devem incluir as } \\
\text { atividades que (...) (c) envolvam concentrações } \\
\text { econômicas nas quais uma ou mais partes da operação } \\
\text { mantenha atividade econômica no território da outra } \\
\text { parte ou esteja sob controle de entidade que seja } \\
\text { constituída ou organizada de acordo com as leis do } \\
\text { território da outra parte; (d) envolvam penalidades ou } \\
\text { restrições que expressamente requeiram ou próbam } \\
\text { conduta naquele território; e (e) envolvam a busca de } \\
\text { informações localizada no território da outra parte. }\end{array}$ & $\begin{array}{llll}\text { Art. } 1.1-\text { promover e fortalecer cooperação } \\
\text { coordenação entre as partes. }\end{array}$ & $\begin{array}{l}\text { Art. } 1.2 \text { - dentre as atividades de aplicação, há menção às } \\
\text { concentrações econômicas. } \\
\text { Art. } 5 . b \text { - dentre as atividades de aplicação mencionadas } \\
\text { constam os procedimentos realizados pelas partes para } \\
\text { determinar sanções, remédios ou autorizações previstas } \\
\text { nas respectivas leis de defesa da concorrência. } \\
\text { Art. } 6 \text { - dentre as atividades de aplicação das leis da } \\
\text { concorrência, constam (b) operações de concentração que } \\
\text { tenham sido ou que venham a ser realizadas total ou } \\
\text { parcialmente no território da outra parte, que possam ter } \\
\text { efeitos total ou parcialmente no território da outra parte ou } \\
\text { que possam estar sujeitas à aplicação da lei de defesa da } \\
\text { concorrência da outra parte; (c) envolvam um ou mais } \\
\text { agentes econômicos que realizem alguma atividade } \\
\text { econômica no território da outra parte ou que são } \\
\text { vinculados a um ou mais agentes econômicos que realizem } \\
\text { alguma atividade econômica no território da outra parte. }\end{array}$ \\
\hline
\end{tabular}




\begin{tabular}{|c|c|c|c|}
\hline PAís & CHILE & UNIÃO EUROPEIA & Peru \\
\hline $\begin{array}{l}\text { NOTIFICAÇÃo } \\
\text { ENTRE } \\
\text { AUTORIDADES }\end{array}$ & $\begin{array}{l}\text { Art. } 2.1 \text { - as partes devem notificar umas às outras } \\
\text { sobre as atividades de aplicação que possam afetar os } \\
\text { interesses da outra parte. } \\
\text { Art. } 2.2 \text { - as notificações devem ser promovidas tão } \\
\text { logo que se torne evidente que as circunstâncias a } \\
\text { serem notificadas estão presentes (por escrito e via e- } \\
\text { mail ao Presidente da autoridade). } \\
\text { Art. } 2.3 \text { - uma vez que uma matéria tenha sido } \\
\text { notificada, notificações subsequentes em relação a tal } \\
\text { matéria não necessitam de ser realizadas, a não ser que } \\
\text { a parte notificante tome conhecimento de novas } \\
\text { questões relacionadas aos interesses da outra parte ou } \\
\text { caso a outra parte assim o requeira. } \\
\text { Art. } 2.4 \text { - as notificações devem incluir a natureza da } \\
\text { atividade sob investigação e os dispositivos legais } \\
\text { aplicáveis, devendo ser suficientemente detalhadas de } \\
\text { modo a proporcionar a parte notificada uma avaliação } \\
\text { inicial sobre os efeitos da atividade nos seus interesses } \\
\text { de aplicação a legislação de defesa da concorrência. } \\
\text { Art. } 7 \text { - as notificações serão efetuadas por } \\
\text { comunicação direta entre as partes. O ponto de contato } \\
\text { para as finalidades do acordo será o Presidente da } \\
\text { respectiva autoridade. }\end{array}$ & $\begin{array}{l}\text { Art. } 7.17 \text { - cada parte deverá designar um contato } \\
\text { central para receber as informações compartilhadas. A } \\
\text { língua oficial das comunicações é a língua inglesa. }\end{array}$ & $\begin{array}{l}\text { Art. } 6 \text { - as notificações trocadas devem conter } \\
\text { detalhamento da prática objeto da cooperação e os agentes } \\
\text { econômicos envolvidos, assim como todos os outros } \\
\text { detalhes necessários para que a parte notificada possa } \\
\text { determinar preliminarmente as implicações desta } \\
\text { informação sobre suas atividades de aplicação. A } \\
\text { notificação deve ser feita o mais breve possível e não será } \\
\text { necessário fazer notificações adicionais sobre a mesma } \\
\text { atividade de aplicação, exceto que a parte notificada } \\
\text { solicite informações adicionais ou que a parte notificante } \\
\text { tome conhecimento de novas circunstâncias que possam } \\
\text { afetar os interesses da outra parte. } \\
\text { Art. } 9 \text { - as partes definem quem são os coordenadores do } \\
\text { acordo, que no caso do Brasil é o Presidente do CADE. }\end{array}$ \\
\hline $\begin{array}{l}\text { CORTESIA } \\
\text { NEGATIVA }\end{array}$ & $\begin{array}{l}\text { Art. } 4.1 \text { - reconhecimento do interesse das partes em } \\
\text { minimizar efeitos potencialmente adversos } \\
\text { relacionados às atividades de aplicação de uma parte } \\
\text { sobre os interesses da outra parte. } \\
\text { Art. } 4.2 \text { - previsão de notificação de uma parte à outra } \\
\text { sobre possibilidade que seus interesses importantes } \\
\text { sejam afetados pela aplicação da legislação da } \\
\text { concorrência da outra parte. Parte requerida deverá se } \\
\text { esforçar para oferecer oportunidade de discussão e } \\
\text { atualizar a requerente sobre desenvolvimentos } \\
\text { significativos relacionados a tais interesses. }\end{array}$ & $\begin{array}{l}\text { Art. } 4.9 \text { - reconhecimento do interesse das partes em } \\
\text { minimizar efeitos potencialmente adversos } \\
\text { relacionados às atividades de aplicação de uma parte } \\
\text { sobre os interesses da outra parte. } \\
\text { Art. } 4.10 \text { - previsão de notificação de uma parte à } \\
\text { outra sobre possibilidade que seus interesses } \\
\text { importantes sejam afetados pela aplicação da } \\
\text { legislação da concorrência da outra parte. Parte } \\
\text { requerida deverá se esforçar para oferecer } \\
\text { oportunidade de discussão e atualizar a requerente } \\
\text { sobre desenvolvimentos significativos relacionados a } \\
\text { tais interesses. }\end{array}$ & $\begin{array}{l}\text { Art. } 6 \text { - as partes se comprometem a notificar umas a } \\
\text { outras sobre atividades de aplicação que possam afetar os } \\
\text { interesses da outra parte, exceto quando tal notificação for } \\
\text { contrária aos seus interesses ou afetar atividade de } \\
\text { aplicação em curso. Este dispositivo traz um detalhamento } \\
\text { sobre as atividades de aplicação que poderão afetar os } \\
\text { interesses da outra parte, dentre os quais se incluem (b) } \\
\text { operações de concentração que tenham sido ou que } \\
\text { venham a ser realizadas total ou parcialmente no território } \\
\text { da outra parte, que possam ter efeitos total ou parcialmente } \\
\text { no território da outra parte ou que possam estar sujeitas à } \\
\text { aplicação da lei de defesa da concorrência da outra parte; } \\
\text { (c) envolvam um ou mais agentes econômicos que } \\
\text { realizem alguma atividade econômica no território da } \\
\text { outra parte ou que são vinculados a um ou mais agentes } \\
\text { econômicos que realizem alguma atividade econômica no } \\
\text { território da outra parte. }\end{array}$ \\
\hline
\end{tabular}




\begin{tabular}{|c|c|c|c|}
\hline PAí́S & Chile & UNIÃo EUROPEIA & Peru \\
\hline $\begin{array}{l}\text { CORTESIA } \\
\text { Positiva }\end{array}$ & - & $\begin{array}{l}\text { Art. 3.6 - se uma parte acredita que práticas } \\
\text { anticoncorrenciais realizadas na jurisdição da outra } \\
\text { parte afetem adversamente seus importantes interesses, } \\
\text { poderá solicitar a outra parte que inicie medidas } \\
\text { apropriadas de implementação das suas leis. } \\
\text { Art. } 3.7 \text { - a parte requerida irá considerar se iniciará ou } \\
\text { ampliará atividades de aplicação em curso sobre a } \\
\text { prática objeto do pedido de cooperação. } \\
\text { Art. 3.8 - a discricionariedade das autoridades não é } \\
\text { limitada pelo acordo, as quais permanecem livres para, } \\
\text { de acordo com as respectivas atribuições legais, a } \\
\text { conduzir suas atividades livremente. }\end{array}$ & - \\
\hline $\begin{array}{c}\text { BUSCA POR } \\
\text { INFORMAÇÕES }\end{array}$ & $\begin{array}{l}\text { Art. } 2.1 \text { e - notificações entre as partes devem incluir } \\
\text { as atividades que envolvam a busca de informações } \\
\text { localizada no território da outra parte. A busca de } \\
\text { informações poderá ocorrer através de visitas por } \\
\text { funcionários da outra parte (desde que obtido o } \\
\text { consentimento prévio da parte requerida) ou de outra } \\
\text { forma, com exceção de contatos telefônicos com } \\
\text { pessoa localizada no território da outra parte quando } \\
\text { tal pessoa não esteja sujeita à investigação e o contato } \\
\text { tenha por finalidade somente uma resposta verbal } \\
\text { voluntária. }\end{array}$ & - & $\begin{array}{l}\text { Art. } 6 \text { - as partes de comprometem a realizar, mediante } \\
\text { solicitação da outra parte e em conformidade com as } \\
\text { respectivas leis de defesa da concorrência, requerimentos } \\
\text { de informações a agentes econômicos que se encontrem } \\
\text { em seus respectivos territórios, exceto quando tal } \\
\text { execução for contrário aos seus interesses ou afetar } \\
\text { atividade de aplicação em curso. }\end{array}$ \\
\hline $\begin{array}{c}\text { TROCA E } \\
\text { COMPARTILHA- } \\
\text { MENTO DE } \\
\text { INFORMAÇÕES } \\
\text { (GERAL) }\end{array}$ & $\begin{array}{l}\text { Art. } 3.1 \text { - as partes reconhecem que é do interesse } \\
\text { mútuo a cooperação e a troca de informações, quando } \\
\text { apropriado e praticável. }\end{array}$ & $\begin{array}{l}\text { Art. } 2.3 \text { - partes reconhecem o interesse mútuo em } \\
\text { trocar informações não confidenciais, experiências e } \\
\text { pontos de vista sobre investigações sobre casos e } \\
\text { assuntos de política da concorrência, no que for } \\
\text { apropriado e viável. } \\
\text { Art. } 6.16 \text { - a nenhuma parte é exigido que comunique } \\
\text { qualquer informação à outra parte, se tal comunicação } \\
\text { for proibida pelas leis e regulamentos ou contrária aos } \\
\text { interesses da parte que detém a informação. }\end{array}$ & $\begin{array}{l}\text { Art. } 3.1 \text { - as partes assumem o compromisso de trocar } \\
\text { informações sobre atividades de aplicação das respectivas } \\
\text { leis de defesa da concorrência. } \\
\text { Art. } 5 \text { - as partes se comprometem a trocar informações e } \\
\text { responder consultas sobre atividades de aplicação, desde } \\
\text { que não seja contrário aos seus interesses e não prejudique } \\
\text { atividade de aplicação em curso. Tais informações podem } \\
\text { incluir informações sobre atividades de aplicação, bem } \\
\text { como resoluções, sentenças, relatórios técnicos, } \\
\text { orientações dentre outros. } \\
\text { Art. } 8 \text { - as informações trocadas pelas partes, sejam } \\
\text { confidenciais ou não, deverão receber o tratamento de } \\
\text { informação confidencial pela outra parte. }\end{array}$ \\
\hline
\end{tabular}




\begin{tabular}{|c|c|c|c|}
\hline PAÍS & CHILE & UNIÃO EUROPEIA & Peru \\
\hline $\begin{array}{l}\text { TROCA E } \\
\text { COMPARTILHA- } \\
\text { MENTO DE } \\
\text { INFORMAÇÕES } \\
\text { CONFIDENCIAIS }\end{array}$ & $\begin{array}{l}\text { Art. } 6.2 \text { - nenhuma parte será obrigada a fornecer } \\
\text { informações à outra parte, caso o fornecimento de tal } \\
\text { informação seja proibido segundo a legislação } \\
\text { aplicável do Estado que detém tais informações ou } \\
\text { seja incompatível com os seus interesses. } \\
\text { Art. } 6.3 \text { - a decisão de uma parte sobre compartilhar } \\
\text { determinada informação à outra pode depender da } \\
\text { aceitação das garantias dadas pela outra parte com } \\
\text { relação aos fins que a informação será utilizada. } \\
\text { Art. } 6.4 \text { - uma vez transferida qualquer informação em } \\
\text { regime de sigilo entre as autoridades de defesa da } \\
\text { concorrência envolvidas, a autoridade receptora estará } \\
\text { obrigada a manter a confidencialidade sobre a } \\
\text { informação recebida, exceto se a parte provedora da } \\
\text { informação consinta por escrito com a divulgação de } \\
\text { tal informação. }\end{array}$ & $\begin{array}{l}\text { Art. } 2.2 \text { - a cooperação entre as partes está sujeita às } \\
\text { respectivas leis, especialmente às que protegem as } \\
\text { informações confidenciais e os segredos de negócio. }\end{array}$ & $\begin{array}{l}\text { Art. } 8 \text { - para que uma parte possa compartilhar informação } \\
\text { confidencial com a outra parte, deverá previamente obter o } \\
\text { consentimento expresso do titular da informação. }\end{array}$ \\
\hline $\begin{array}{l}\text { COORDENAÇão } \\
\text { ENTRE } \\
\text { AUTORIDADES }\end{array}$ & $\begin{array}{l}\text { Art. } 3.2 \text { - quando as partes estiverem conduzindo } \\
\text { atividades de aplicação com relação aos mesmos } \\
\text { assuntos ou assuntos relacionados, elas envidarão } \\
\text { esforços para coordenar as suas atividades de } \\
\text { aplicação, quando apropriado e praticável. }\end{array}$ & $\begin{array}{l}\text { Art. } 2.4 \text { - caso as partes busquem realizar medidas de } \\
\text { implementação sobre assuntos semelhantes ou } \\
\text { relacionados, elas se esforçarão para coordenar } \\
\text { medidas de implementação, no que for apropriado e } \\
\text { viável. }\end{array}$ & $\begin{array}{l}\text { Art. } 3.2 \text { - as partes assumem o compromisso de coordenar } \\
\text { e colaborar nas atividades de aplicação das respectivas leis } \\
\text { de defesa da concorrência. } \\
\text { Art. } 6 \text { - quando as partes realizarem atividades de } \\
\text { aplicação que estejam relacionadas, poderão coordenar e } \\
\text { colaborar em suas atividades de aplicação, desde que não } \\
\text { contrarie os seus interesses e não afete nenhuma atividade } \\
\text { de aplicação em curso. }\end{array}$ \\
\hline OBSERVAÇÕES & $\begin{array}{l}\text { Art. } 3.3 \text { - as partes concordam que é do mútuo } \\
\text { interesse trabalharem juntas em iniciativas de } \\
\text { assistência técnica relacionadas ao direito e à política } \\
\text { da concorrência. Tais iniciativas poderão incluir } \\
\text { formas de cooperação técnica conforme as partes } \\
\text { decidirem ser apropriadas ao caso. } \\
\text { Art. } 4.3 \text { - quaisquer dúvidas sobre a interpretação ou } \\
\text { aplicação do acordo serão objeto de discussão entre as } \\
\text { partes. } \\
\text { Art. } 5^{\circ} \text { - As partes se reunirão periodicamente, } \\
\text { conforme seja necessário para troca de informações } \\
\text { sobre atividades de aplicação e setores econômicos de } \\
\text { interesse comum, dentre outros. }\end{array}$ & $\begin{array}{l}\text { Art. } 8.20 \text { - as disposições do acordo não estão } \\
\text { destinadas a criar direitos ou obrigações de direito } \\
\text { internacional. }\end{array}$ & $\begin{array}{l}\text { Art. } 10 \text { - a interpretação e a aplicação do acordo deverão } \\
\text { ser realizadas pelas partes com boa-fé e levando em conta } \\
\text { seu objeto e finalidade. Quaisquer diferenças deverão ser } \\
\text { solucionadas em comum acordo entre as partes. }\end{array}$ \\
\hline
\end{tabular}

